
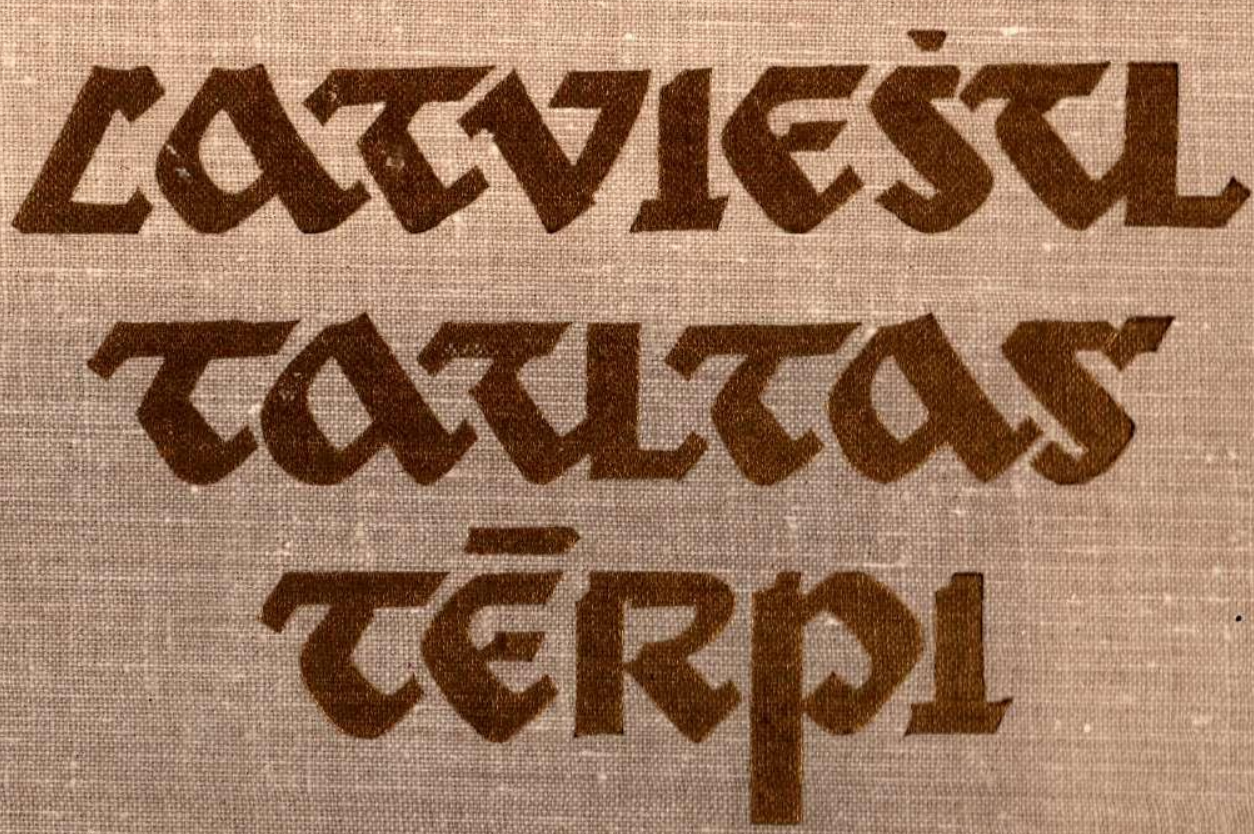


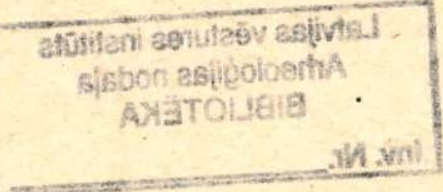




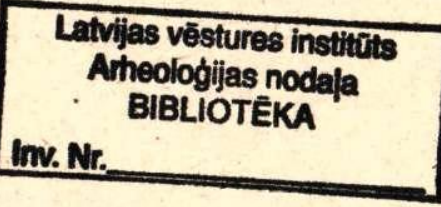

\title{
ARHEOLOĢIJA UN ETNOGRĀFIJA
}

\author{
RAKSTU KRĀJUMS
}

\section{VII}




\section{SLAVA \\ LATVIEŠU \\ TAUTAS TERPI}




\section{MĀKSLINIEKS J. RIEKSTINS}

Publicēts saskañā ar Latvijas PSR ZA Redakciju un izdevumu padomes 1965. gada 25. februāra lēmumu 


\section{PRIEKŠVĀRDS}

Apğērbs līdzās mājoklim un pārtikai pieder pie svarīgākajiem cilvēku eksistences nepieciešamajiem priekšnoteikumiem visās sabiedriski ekonomiskajās formācijās. Tâpēc apgèerba vēsture ir svarīga tautas kultūras vēstures sastāvdaḷ. Ja savas attīstības sākumā apgeērbs kalpoja galvenokārt aizsardzībai pret nelabvēlīgu klimatisko apstākḷu ietekmi, tad vềāk apgèrbam valkātājs bija jāizrotā un ar formu, krāsām, ornamentu jāparāda vai nu valkātāja piederíba pie kādas no pirmajām etniskās kopības un sabiedriskās organizācijas formām, vai arī atškirīība no tām. Pamatvilcienos latviešu tautas apgèerbs no dzimšu un cilšu apgèreiem izveidojās līdz ar latviešu tautības elementu konsolidācijas sākumiem, tālāk attīstoties gadsimtiem ilgajā feodālisma laikmetā ražošanas veida, klimatisko apstāklu, tautas nodarbošanăs, tautas kultūras un vēsturi sko apstāklu ietekmē. Latviešu tautas apg̉ērba formā, krāsās, ornamentā, rotās atspogulojas tautas dail̨rade, gadsimtos veidojusies tautas mākslinieciskā gaume, kas spilgtāk nekā citas materiālās kultūras parādības atspogulo tautas kultūras specifiku. Lai gan apgèerbs, tāpat kā citi materiālās kultūras veidi, līdz ar sabiedrības attīstibu pastāvīgi izmainās, daudzi tautas apgèrè elementi parāda lielu noturībur. Latviešu tautas apḡērbā atspogulojas ne tikai tie etniskie komponenti, no kuriem savā laikā veidojās latviešu tautība, bet atainojas arī kultūras sakari ar kaimiṇu tautām, sevišḳi ar lietuviešiem un slāvu tautām. Sarežğìtā latviešu etniskā vēsture veicinā ja vairāku tautas tērpu lokālu variantu izveidošanos, no kuriem katrs dalās vēl sīkākās grupās, kas bieži vien raksturīgas atsevišḳiem pagastiem un pat ciemiem. Tảpēc tautas apg̉ērbs, būdams tautas kultūras vēstures neatnemama sastāvdaḷ, vienlaikus ir arī vērtīgs a vots tautas nodarbošanās veidu, sociālo attiecību, g̀imenes dzīves, tradīciju, tautas estētiskā ideāla, tautas etnoğenèzes un etniskās vēstures un kultūras sakaru pētī jumiem.

Padomju Savienībā, tautas demokrātijas zemēs un visā pasaulē jaunās demokrātiskâs kultūras celtniecības pamatos tiek guldīts agrāko laikmetu kultūras mantojums, jaunā kultūra veidota uz vēsturiskiem pamatiem un agrāko paaudžu radītās kultüras progresīvajiem, demokrātiskajiem elementiem. Latviešu tautas demokrātiskā kultura ievērojamus sasniegumus guvusi daudzās nozarēs, taču viens no spilgtākajiem tås izpausmes veidiem, bez šaubām, ir tautas tērpi. Tautas apg̉ērba pētī̌sana bija un paliks viens no centrāla jiem padomju un ārzemju etnogrāfijas zinātnes uzdevumiem tautu kultūras sakaru, etniskās vēstures un tautas daiḷades attīstības problềmu risināšanā ${ }^{1}$.

Pirmskapitālistiskajā šḳiru sabiedrībā valdošā škira apgēēbu, modi plaši izmantoja savas kundzības nostiprināšanai. Apğērba materiāls, forma un pat atseviškịe aptềrba gabali un rotas bija šḳiras vai pat kārtas pazīme, kas strādājošo apspiesto

I Sạ sakarã minami padomju un tautas demokrātijas valstu etnogrāfu pētījumi: Эстонская народініі олежла XIX и начала XX века. Таллин, 1960; В. А. Б ел и ц е р. Народная одежда удмуртов. M. $1001 /$ Г. С. М а сло в а. Народный орнамент верхневолжских карел. M., 1951; Volkstrachten ii der tochechoslowakei. Prag, 1956; Н. Г а ген-Т о р н. Болгарская одежда. М.-Л., 1958; роlu labian lerpu petijumiem veltita sērija: Atlas polskich strojów ludowych, 1951-1957; Научная пробАенатика секінї VII международного конгресса антропологических и этнографических наук. „Севегекан этеорафия», 1963, IV, 176.-179. lpp.; sociālistisko zemju etnogrāfu starptautiskajā

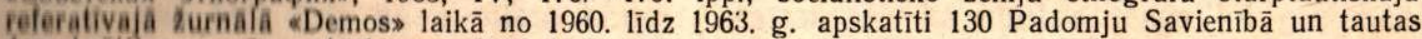
demokirälijas zemès apgěrbiem veltîti darbi. 
šḳiru atškịira no nestrādājošās apspiedējas škiras. Sevišḳi spltgti tas izpaudās Latvijā feodālisma periodā, kur pastāvošās sociālās pretrunas starp muižniekiem un zemniekiem tika pastiprinātas vēl ar nacionālajām pretrunām. Muižnieki, mācītāji un birğeli rūpigi raudzijās, lai zemnieki ievērotu ap geērba noteikumus un nestaigātu «kungu» drēbēs. Latviešu tautas apgēēbs gadsimtiem ilgi bija apspiestās, ekspluatētās un nicinātās zemnieku šḳiras apğērbs, kuru valkāja vairāk nekā $95 \%$ Latvijas iedzīvotāju. Tautas apgèrēbs bija pierādījums latviešu zemnieku sociālajai un politiskajai beztiesībai viṇu gadsimtiem ilgajā cinnā par sociālo taisnību un politiskajām tiesībām. Tāpēc saprotams, ka topošās latviešu lauku buržuāzijas pārstāvji un viṇu līdzskrējēji feodālisma sairšanas periodã līdz ar kārtu tērpu kundzības samazināšanos un modes demokratizācijas sākumiem Eiropā pēc Franču buržuāziskās revolūcijas kā pirmie atteicās no tradicionālā latviešu tautas apgēerba un savā apgeērbā sāka atdarināt vācu muižniekus un birģelus. Turpretī latviešu tautas lielākā dala, darba zemnieki, kalpi līdz pat 20. gs. sākumam bija latviešu tautas apğèrbu tradīciju glabātāji. Tas neliedza latviešu buržuāzijai tautas apgèēbu kā spilgtu tautas mākslas paraugu plaši izmantot pierādijjumam par latviešu tautas augsto kultūru cīnā pret vācu buržuāziju, cīṇā par vietējās buržuāzijas līdztiesību un vēlāko kundzību Latvijas kapitālistiskajā saimniecībā un sabiedrībā, izmantot šḳiru miera nostiprināšanai un buržuāziskā nacionālisma izplatišanai. Iztēlojot latviešu turīgo zemniecību par tautas apg̀ērba vienīgo veidotāju, bet tautas apgèerbu - par «tautas gara» izpausmes pierādījumu, izcelot tikai greznākos goda tērpus un apskatot tautas apgérbus atrauti no latviešu kaimiṇu tautu tēr piem utt., latviešu buržuāzija, it seviški buržuāziskās Latvijas laika t. s. "tīās latviešu kultūras meklētāji», tautas apg̛ērbu savā literatūrā apvijuši ar veselu viltojumu mudžekli.

Latviešu padomju etnogrāfu uzdevums ir atmaskot minētos viltojumus, zinātniski izskaidrot tautas tērpa izcelšanās un attīstības celus, atklāt kultūras sakarus, . visu to pozitīvo, ko latviešu tauta gadu tūkstošu gaitā ir ieguldījusi tautas tērpos, un nodot te ieguldīto pozitīvo kultūras mantojumu latviešu sociālistiskās nācijas rīcībã izmantošanai jaunās kultū ras celtniecībā.

Pirmais etnogrăfu pasākums šajā virzienā ir šì $M$. Slavas monogrāfija.

Izmantojot mūsu un kaimiṇu republiku muzeju, arhīvu, publicēto avotu un literatūras materiālus, balstoties uz vēsturiskā materiālisma metodolog̣iju, autore izseko latviešu tautas goda un darba apğērba attīstībai feodālisma sairšanas un kapitālisma laikmetā, sevišḳu vērību piegriežot kultūras sakariem un kultūras mijiedarbībai ar latviešu kaimiṇu tautām. Darbā atspogulota likumsakarīgā tautas apgèēbu nomaiṇa ar t. s. modes apgèrể 19. gs. otrajā pusē, kā arī latviešu buržuāzijas mēg̀inājumi izmantot tautas apgēērbu savu šḳiras mērḳu sasniegšanai.

Padomju Latvijā pēc kapitālistiskās iekārtas likvidēšanas radīti apstākḷi, lai tautas apg̣ērbs ieñemtu to goda vietu, kāda tam pienākas. Padomju Latvijā latviešu tautas goda apgères kluvis par iecienìtu reprezentācijas tērpu. Tautas goda tērpos Latvijas darbaḷaudis atzīmē Lielās Oktobra sociālistiskās revolūcijas un Pirmã Maija svētkus, republikas jubilejas dienas, PadomjuLatvijas dziesmu un deju svētkus, sagaida ārzemju cieminus. Tautas goda tērpi kḷvuši par iecienītāko visu tautas mākslinieciskās pašdarbības kolektivu apġērbu.

Latvijas darbalaužu mūsdie nu apgèrēbā izplatās latviešu tautas apgèēba elementi. Plašu pieprasijjumu guvuši rūpniecības ražotie audumi ar tautas ornamentiem.

Tautaș apḡērbs ir neatṇemama latviešu tautas kultūras mantojuma sastāvdala, neizsmeḷma tautas kultūras dārgumu krātuve mūsu padomju kultūras bagātināšanai un tālākai attīstībai.

\section{H. STRODS,}

Latvijas PSR ZA Vēstures institūta arheologíijas un etnogräfijas sektora vaditājs 


\section{IEVADS}

Apgèerbs, tāpat kā uzturs un dzĩvoklis, ir cilvêku eksistences nepieciešama sastāvdal̨a, tāpēc arì tã attīstība cieši saistīta ar cilvēces attīstības procesiem. Apḡērba izveidi nosaka ražošanas veids, kả arī geogrāfiskie un klimatiskie apstāklı, kådos dzīvo attiecīgā laužu grupa. Tautas apgèrēbs lídz ar tā rotājumu neattīstās vis izolēti, bet rodas to dažādo etnisko grupu mijiedarbības procesā, kas veido tautu.

Zināmā mērā apgeērbs atspoguḷo vecuma un nociālâs atškirīibas, kầ arī valkātāju etnisko piederibu, pie kam nacionālā gaume un tradīcijas visspilgtăk izpaužas apg̉ērba rotājumā.

Ápgèerba raksturu sabiedrības attīstības procesầ ietekmē cilvēka stāvoklis sabiedrībā un g̀imenè. Tä rodas atšḳirības vīriešu un sieviešu apEêrbă, jaunavu un precētu sieviešu apg̀ērbā, rodas avêtku jeb goda apḡērbs, kāzu un bēru u. c. aptêrbl. Sabiedriskā darba diferenciācijas procesā izveidojas dažādi profesionālā apgēēba veidi.

Tautibu konsolidēšanās procesā izveidojas lautas tērps, kas atspogulo tautas kultūras speciliku un māksliniecisko gaumi. Tas saglabājas arì iekiojošos vêsturiskajos laikos. Tã, piemẽram, dandzveidigie latviešu tautas tērpi saglabājušies Halvenajâs iezīmēs latviešu zemnieku vidū pat līdz 20. ถู่, sakumam.

Sajâ darbā centāmies parādīt latviešu zemnleku apgèrrba attīstību klaušu saimniecības saIศuma posmã (18. gs. beigas - 19. gs. sākums), analizéjot gan tautas tẽrpa formas, gan rotājumu in Kirâsu ziedu. Tautas tērps šajā posmā ir apspiesiă un ekspluatētās darba zemniecības apgēèrbs, bet lidz kapitālisma straujas attīstības posmam 10. ํㅐ otrajă pusē darba zemniecība bija galvenā latvlesu tautas kultūras veidotāja.

Klailiu saimniecības sairuma posmā Latvija bija vel leodäli dzimtbūtnieciska zeme, kurā galVenaí razolanas lïdzeklis - zeme - piederēja iniizniekiem, bet tiešie ražotāji - latviešu zemileki - bija paklauti smagam feodālās ekspluatāejjạ jôgam. Saja laikă muižniecība un samērā neliélai pilsêtu ledzivotāju slānis pārstāvēja vācu eada|ı kultâru, kas bija līdz nāvei nīsto kungu hisitara.
Lai arī Latvijas teritorijas lielākajā daḷā 19. gs. sākumā dzimtbūšana tika atcelta, feodālās attiecības joprojām saglabājās, vienīgi zināmā mērā tika samazināta galvenā feodālās sabiedrības ražotāja - zemnieka atkarība no muižnieka. «Šai periodā pastiprinājās zemnieku diferenciācija, spilgtāk iezīmêjās robežas, kas škīira dažādas zemnieku kategorijas, kaut gan par pilnīgu interešu pretiškīibu starp saimniekiem, no vienas, un kalpiem un valiniekiem, no otras puses, vēl agri runāt, jo visām šìm zemnieku kategorijām bija viens kopējs ienaidnieks - muižnieks. Muižnieku jūgs ievērojamā mērā pielīdzināja zemnieka-saimnieka stāvokli kalpa stāvoklim.»1 Tāpēc arī zemnieku apgèrbs šai laikā vēl nerāda tik krasas atšḳirības kalpu un saimnieku starpā, kä tas ir 19. gs. 70.80. gados, kad sakarā ar pārmainām ražošanas spēkos un attiecībās samērā strauji izmainās arī apg̛ērbs. Turīgākie zemnieki visvisādi, arī apgèrbā, centās atdarināt gan muižniekus, gan vācu birğelus. Seno tradīciju glabātāja un kopēja 19. gs. otrajā pusē ir vēl vidējā zemniecība. ${ }^{2}$

Tautas apgèerba attīstību un tālāku izveidošanos feodālisma sairuma un kapitālisma nostiprināšanās apstākḷ nos noteica lēnā naudas-preču saimniecības attīstība. Atsevišķi apgērba elementi saglabājās cauri gadsimtiem maz izmainītās formâs, kamēr citi parādījušies tikai jaunākā laikā.

Analizējot materiālu, kas attiecināms uz monogrāfijā apskatāmo posmu (18.-19. gs.), nereti, lai noskaidrotu kädas parädỉbas izcelšanās iemeslus un attīstības gaitu, bija nepieciešami gan ekskursi tālākā pagātnē, gan, otrādi, izsekojums to attīstībai vēlakajā laikā. Tautas tērpa izveide tiks izsekota līdz mūsu dienäm, bet t. s. modes apgēerbu formas, kuras, sākot ar 19. gs. 80. gadiem, gandrīz visä Latvijā ir kluvušas par valdošajām arī lauku sētās, netiks apskatītas. S̄ādu temata ierobežojumu zināmā mērā izraisa apstāklis, ka apgērbs kā vēstures avots atspogulo ne tikai sava laika ražošanas spēku un ražošanas attiecību līmeni, bet rāda arī zināmas lokālas atškirīibas, kas saglabājas loti ilgi un ir visai nozīmīgas etniskās vēstures pētīšanai. Tā kā tautas tērps kā etniskās vēstures avots līdzšinējos publicējumos par apgeērbiem nav 
apskatīts, tad šim jautājumam monogrāfijā būs ierādīta samērā plaša vieta.

Tautas tērpam ir nozīme ne tikai kā vēstures avotam, bet tas ir arī augstvērtīgs tautas mākslas veidojums. Tādējādi tam ir ne tikai zinātniski teorētiska, bet arī liela praktiska vērtība, jo, atklājot citu tautu kultūru ietekmi un plašām tautas masām nododot vērtīgo tautas mākslas objektu atlasi, tiks veicināts nacionālo tautas mākslu tuvināšanās un savstarpējas bagātināšanās process. Izsekojot tautas tērpu vēsturiskajai attīstības gaitai un kultūras sakaru mijiedarbības procesam, iespējams ne tikai atklāt jebkuras tautas tērpam piemītošās iekšējās specifikas īpatnības, bet arī saskatīt vispārējās kopējās tērpa attīstības likumsakarības, atsegt internacionālās, visu tautu tērpiem kopējās attīstības iezīmes.

Tērpu augstvērtīgais mākslinieciskais noformējums darbaḷaužu mākslinieciskās gaumes un estētiskās kultūras audzināšanā var noderēt kā neizsmeḷams avots mākslinieciskās pašdarbības un lietišḳās mākslas meistaru jaunradei, jo «...skaistais ir jāsaglabā, jāṇem kā paraugs, jāa vadās no tā, pat ja tas ir «vecs». Kādēl mums jānovēršas no patiesi skaistā, jāatsakās no tā kā no izejpunkta tâlākai attīstībai tikai tāeēl, ka tas ir «vecs»? Kādēl jāliecas tikai jaunā priekšā kā dieva priekšā, kuram jāpakḷaujas tikai tādēl, ka

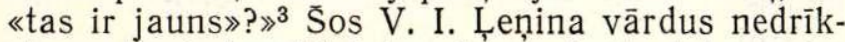
stam aizmirst, veidojot padomju tautu internacionālo kultūru.

PSKP XXII kongresā pieṇemtā Komunistiskās partijas Programma, rezumējot mūsu valsts sasniegumus un nospraužot tālākos uzdevumus, jautājumā par sadarbību kultūras laukā izvirza svarīgu uzdevumu: "Pastāvīgi attīstīt visus sociālistisko zemju tautu kultūras sadarbības un saskares veidus, savstarpēju apmaiṇu ar kultūras sasniegumiem, stimulēt zinātnes, literatūras un mākslas darbinieku kopēju radošu darbu; aktīvi veicināt nacionālo kultūru savstarpējo bagātināšanos un sociālistisko nāciju dzīves veida un garīgās struk- tūras tuvināšanos.» ${ }^{4}$ Arī latviešu tautas tērps var dot savu ieguldījumu nacionālo kultūru bagātināšanas jomā un veicināt tautu draudzības tālāku nostiprināšanos. Bet, apgūstot kultūras mantojumu, jāprot pareizi novērtēt tā kultūrvēsturiskā nozīme. Komunistiskās celtniecības periodā jāseko partijas izvirzītajam uzdevumam: «...stiprināt tautu draudzību kā vienu no svarīgākajiem sociālisma iekarojumiem, nesamierināmi cīnīties pret nacionālisma un šovinisma izpausmēm un paliekām, pret nacionālās aprobežotības un pārākuma tendencēm, tendencēm idealizēt pagātni un notušèt sociālās pretrunas tautu vēsturē, pret paražām un tikumiem, kas kavē komunistisko celtniecību.» ${ }^{5}$ Attiecībā uz latviešu tautas kultūras mantojumu jāsaka, ka tautas tērpi ir tā kultūras mantojuma dala, kuras pētīšana prasa stingru pārvērtējumu. Buržuāziskās Latvijas laika un it īpaši fašistiskās diktatūras laika publicējumi ir nacionālistiski tendenciozi, tie nemaz neparāda kultūrvēsturiskos sakarus ar kaiminu tautām un neraksturo sociālos grupējumus, kuri atspogulojas apgēêāa

Sistematizējot materiālus par latviešu zemnieku apğērbu, parādot tā galvenos elementus, izdalījām atsevišḳi apgèreba kompleksus līdz ar to lokālajiem variantiem. Mēgoinājām arī noteikt atsevišḳu apgèēba dal̨u vai variantu eksistēšanas vidi un laiku, lai konstatētu apgēēba attīstības gaitu. Monogrāfijā apskatīta arī apgèērbu pagatavošanas tehnika un piegriezums. Aplūkojot apgèrba izveidi, tā atsevišķās dalas salīdzinātas ar kaimiṇtautu - slāvu tautu, lietuviešu, igauṇu tērpa attiecīgajām dạ̄ām. Lai gan latviešu tauta vēsturiski saistīta arī ar vācu un zviedru tautām, salīdzinājumi ar šo tautu tērpiem nebūs visai plaši, jo šīm tautām latviešu tautas tērpa attīstībā nebija būtiskas nozìmes.

Monogrāfijas uzrakstīšanai izmantoti ekspedī. ciju, komandējumu un arhīvu materiāli, muzeju kolekcijas un speciālā literatūra. Bez etnogrāfiskās pamatliteratūras izmantoti arī atsevišḳi darbi vēsturē, ekonomikā un filozofijā. 


\section{AVOTU UN LITERATUTRAS APSKATS}

Avoti par tautas tērpiem iedalāmi trīs grupās: 1) paši apgèërba gabali, 2) ikonogrāfiskais matefiâls, 3) rakstìtie avoti.

Visu šo trīs avotu grupu materiāli galvenokārt atrodami Latvijas PSR muzejos. Visbagātākā tautas têrpu «krātuve» ir Latvijas PSR Vēstures muzeja Etnogrāfijas nodalas apḡērbu kolekcija, kurā if ap 17000 dažādu apgēerba gabalu. ${ }^{6}$

Pêc lietošanas laika kolekcijas priekšmeti attieeas galvenokārt uz 19. gs. pirmo pusi, un tikai da21 no tiem - uz 18. gs. ${ }^{7}$ Apgèērbu kolekcijā sastopami têrpi gandrīz no visiem Latvijas novadiem. Sevišķi bagätīgi kolekcijā pārstāvēts sieviešu apterbs, $\operatorname{tanī~ir~daudz~kreklu,~brunču,~vainagu,~vil-~}$ lalou, pirkstaiṇu, dūraiṇu, zeķu. Diemžēl, izṇemot đazus pilsētnieciski darinătus tērpus no pašaustas drânas ar pirktu lenšu un samta izgreznojumiem, mizeja krājuma tērpi neḷauj secināt, kādas izmalọas notikušas apgèērbā 19. gs. otrajā pusē.

Vertiga ir arī muzeja rotaslietu kolekcija metala (sudraba un bronzas) saktas, sprādzes, kafiili, gredzeni.

Miizeja bagātās etnogrāfiskās kolekcijas vērUibi hlipfi mazina zinātnisko aprakstu trūkums. Ia dazreiz lidzäs inventāra numuram uzrādīts arī apvidis, no kurienes priekšmets nācis, tad loti foil atzimets, piemêram, apğērba valkāšanas laiks, valkatăja sociălais stāvoklis un attiecīgā priekš-

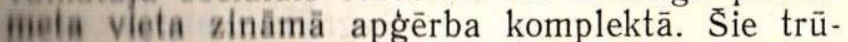
liimi mazina materiāla zinātnisko nozīmi apg̛ēerba pelinlecibă. Tảdă veidā ar raksturīgo priekšmetislimiia novirai savăktas skaistākās atseviškās apGe hỉ dalas un greznākie apg̉ērbu komplekti, kas ienai neraksturo darba cilvêku, turpretim darba IEfii vinipar tav văkti.

Alliẹila aptererba kompleksa valkāšanas laiku imenenifaic a centämies noteikt pēc auduma

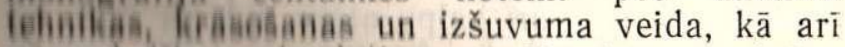
pee ralailico avolii datiem, zīmējumiem un ziṇām, lio dazkart mntedza vecâkăs paaudzes teicēji un analogéski materiali cilu tautu apgèrbos. S̄ai saliara neviślşi nozimiggas izrädijušās etnogrāfiskajās cliupedicijâs un komandejumos laikā no 1951. lỉdz 1062. gadam legutâs pârbaudes ziṇas (1. att.).
Latvijas PSR Vēstures muzeja arhīvā atrodami apraksti, zīmējumi, skicējumi, fotouznēmumi, kas savākti buržuāziskās Latvijas laikā rīkotajās ekspedīcijās. ${ }^{8}$ Savāktais materiāls atspogulo buržuā. ziskās etnogrāfijas metodoloğijas trūkumus. Materiālu lielākā dala vākta laikā no 1924. līdz 1930. g. (2. att.), bet šā laika posma apgēerbi fiksēti loti retos gadījumos. ${ }^{9}$ Ekspedīcijas dalîbnieki vākuši materiālus par 19. gs. valkăto apg̛ērbu, pie kam dati savākti par atseviškiem apgērba gabaliem, kamēr par pārējām apgèērba sastāvdalăm, kādas valkātas vienlaikus ar fiksēto apgèerba dalı, ziṇu nav nekādu. Tāpēc, lai šodien precīzi sastādỉtu atseviškus apgererba komplektus, jāsastopas ar lielām grūtībām. Materiālam pievienotajos aprakstos nav norādīta apgēerba valkātāja piederība pie tā vai cita zemnieku släña. Savukārt, ja reizumis arī aprakstīti vesela novada apgèerbi, tad nav noteikts to eksistēšanas laiks. Sistemātiski fiksēti atseviški skaisti priekšmeti bez jebkäda kopsakara ar apkărtējo vidi. Tāpat arī daudzās no privātpersonām iepirktās muzeja kolekcijas nav zinātniski dokumentētas. ${ }^{10}$

Materiāli par latviešu zemnieku apǵērbiem glabājas arī Lenningradā PSRS Tautu etnogrāfijas muzejā. Šie fondi galvenokārt komplektējas no Daškova Etnogrāfijas muzeja eksponātiem, kas vākti Viskrievijas I etnogrāfiskajai izstādei Maskavā 1867. g. Kolekcijā esošie latviešu tērpi ir vienādi ar mūsu republikas muzejos rodamajiem tērpiem, tāpēc pirmējie izmantoti tikai salīdzināšanai. Vērtīgāki ir Dienvidkurzemes vīriešu un sieviešu apgēerbu attēli, kurus Daškova muzejam dāvinājuši Fr. Brīvzemnieks un V. Sizovs; Ludzas apriṇka mežzinis N. Lilje dāvinājis Ludzas apriṇka apgēēbu komplektus un fotoattēlus. ${ }^{11}$

Samērā plašas apğērbu kolekcijas glabājas arī dažos Latvijas PSR novadpētniecības muzejos.

Bagātākie novadpētniecības muzeji ${ }^{12}$ ir Liepājā, Ventspilī, Madonā un Jēkabpilī, pie kam pilnīgākās apgèēba kolekcijas glabājas Liepājas novadpētniecības muzejā; diemžēl arī šiem materiāliem trūkst zinātnisko aprakstu.

Latvijas PSR ZA Valodas un literatūras institūta Folkloras sektora arhīvā glabājas galveno- 


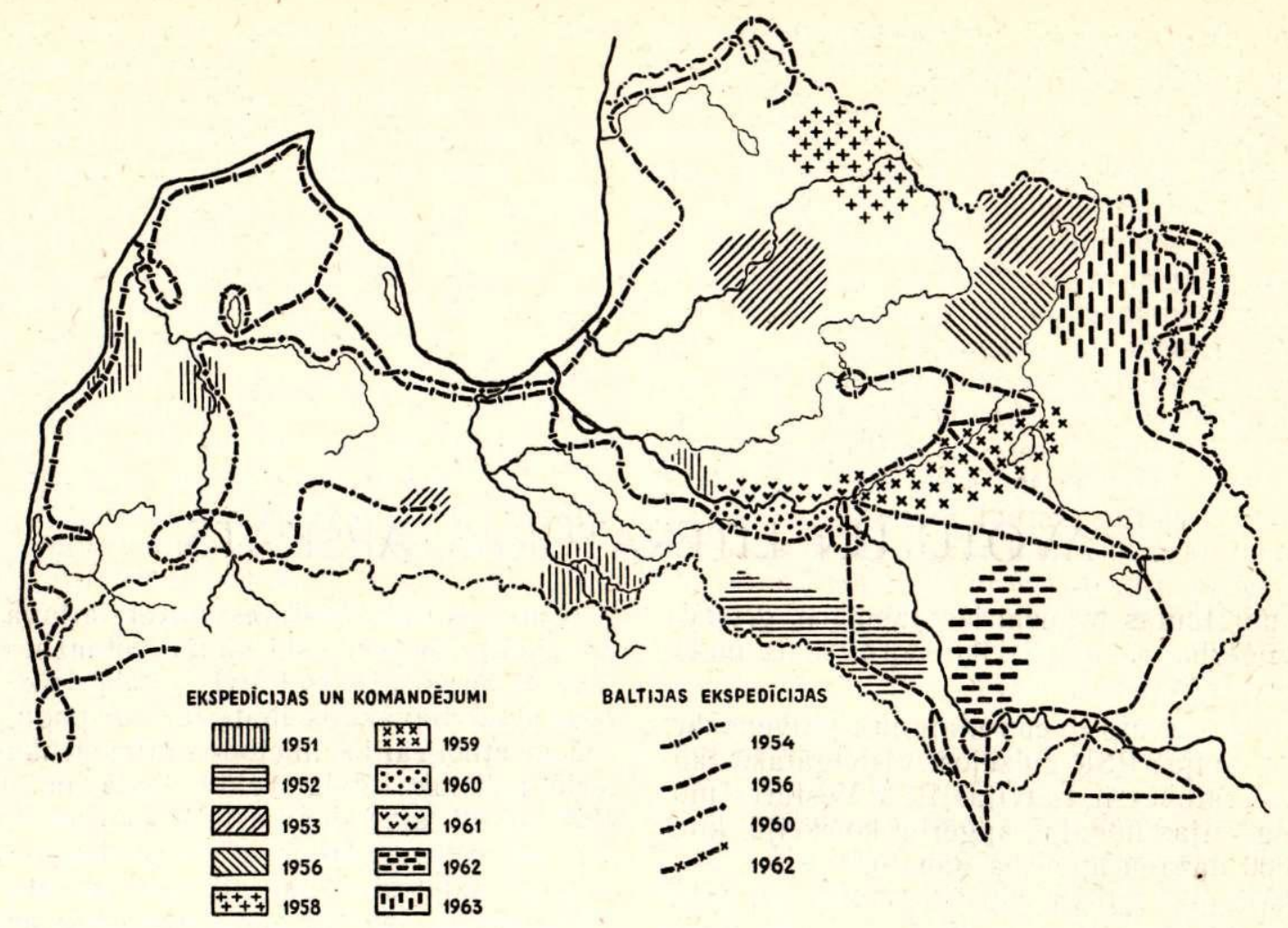

1. att. Vietas, kur laikā no 1951. līdz 1963. gadam materiālus vākusi M. Slava.

kārt folkloras materiāli, kas savākti zinātniskajās ekspedīcijās, sākot ar 1924. g. Te sastopami interesanti apraksti par krāsošanas paṇēmieniem ar augu krāsām, par paradumiem, kas saistīti ar apgèerba darināšanu un valkāšanu u. tml. ${ }^{13}$

Interesants, bet lïdz šim maz apzināts avots apgēērbu pētniecībā ir pagasta tiesu protokoli. ${ }^{14} \mathrm{Te}$ tiesu procesu atreferējumos ir uzskaitîti atsevišḳi apgèēbu gabali. Parasti protokolos fiksētas kalpu sūdzības pret saimniekiem par neizmaksātu algu vai amatnieku (skroderu) sūdzības par nesamaksātu darbu. Ziṇas par apgēerbu krājumu, kas piederējis vienam cilvēkam, atrodamas arī mirušo personu mantu sarakstos. Diemžēl, norādijjumus par mirušo sociālo stāvokli sarakstos atrodam tikai atseviškos gadijjumos, tāpēc nereti mirušã atstātā manta ir vienīgais norādijums, vai mirušais bijis bagāts vai piederējis pie nabadzịgiem laudỉm. Protams, šie materiāli turpat vai nekā nedod apgēèrbu piegriezuma un rotājuma noteikšanai, tomēr pēc tiem iespējams spriest par atsevišķu apǵērba gabalu valkāšanas laiku un vietējo terminoloğiju.

Zemnieku apg̀ērbs ir aprakstīts arī bēgḷ «patentos»,15 kur muižnieki ziṇo par izbēgušiem zemniekiem un apraksta to pazī̌anas zïmes. Aprakstot apgeērbu, vispirms norädīts, vai bēglis gêerbies zemnieku drēbēs vai arī pēc muižu laužu parauga. Seviški precīzi aprakstīts matu kārtojums.

Lìdzīgas zinas publicētas Rịgas Sludinājumu pielikumā. ${ }^{16}$ Materiālus par apgèrōbu varam at- rast arī nedaudzās publicētās draudžu hronikās par dažām Kurzemes un Zemgales draudzēm laikā no 18 . gs. beigām līdz 19 . gs. sākumam. ${ }^{17}$ Hronikās măcitāji pierakstījuši ziñas par aizbēgušo zemnieku apgèerbu. Arī draudžu hronikas vienīgi fiksē, kāds apgèrbs zemniekam piederējis un kā tas ticis valkāts. Draudžu hronikās atrodami norādījumi par tām atškirīīām apgèēbā, kam pamatā ir valkātāja sociālais stāvoklis, jo, pieminot apgèrrbu, hronikās vienmēr norādìts, kam tas piederējis - saimniekam vai kalpam.

PSRS Ģeogrāfijas biedrības zinātniskajā arhīvā Leñingradā glabājas J. Šegrēna 1846. g. ekspedīcijầ Kurzemê, Vidzemē un Bauskas apkārtnē fiksētie mākslinieka A. Pecolda akvareli. Biedrības uzdevumā J. Šegrēns Latvijā pētīja lībiešu un t. s. krieviṇu skaitlisko sastāvu, valodu un dzīves veidu. ${ }^{18}$ Zīmējumos galvenokārt redzami antropolog̀iskie tipi, apğèrbi un sadzīves ainas. Tas ir vērtīgs salīdzināmais materiāls par lībiešu un latviešu apg̉ērbu konsolidēšanās procesu 19. gs.

Şajā pašā arhīvā glabājas arī J. Kalēja-Kuzṇecova 1869. g. Latgales ekspedīcijas piezìmes, ${ }^{19} \mathrm{kur}$ dažkārt fiksētas arī kalpu algas, lìdz ar līgto apgèrbu, kā arī sniegts Andrupenes tirgū redzēto apgēērbu apraksts.

No arhīvu materiāliem latviešu zemnieku apgèrea pētīšanā nozīmīgākie ir J. Broces (1742.1823.) un Rīgas ārsta O. Hūna (1764.-1823.) rokraksti. 
J. Broces plašākais darbs (10 sējumi «in folio») «Monumente $\ldots{ }^{20}$ ir vērtīgs avots latviešu tautas dzīves veida, apǵērba, darba rīku un sadzīves pētniekam. Autors, Rīgas k̦eizariskā liceja konrektors, bijis liels senatnes cienītājs un vācis materiālus galvenokārt par Vidzemes vēsturi. Zīmējumi darināti laikā no 1771. līdz 1818. g. J. Broce fiksējis ne tikai interesantākos Rịgā redzētos apgèēbus, bet, celodams pa dažãdiem Latvijas apvidiem, uzzìmējis arī tur redzētos. Bez tam J. Broces materiālos atrodami arī dažādi gleznu u. tml. materiālu pārzìmējumi. Par latviešu apg̣ērbiem daudz materiāla sniedz «Monumente...» III sējums ar 211 zìmējumiem. (Visā Broces darbā ir 253 speciāli apgèērbu zìmējumi.) Gandrīz pie katra zìmējuma minēta apgeērba valkātāja tautība, sabiedriskais stāvoklis, kā arī norādīts apvidus, kur ap. geērbs valkāts. Tāpat pievienoti arī apğērba apraksti. Dala no šiem zìmējumiem publicēta jau agrāk, bet dala no tiem pirmoreiz izmantota šai darbā. Visvairāk materiāla J. Broce sniedz par Vidzemi, turklāt par vīriešu apgēerbiem J. Broces krăjumi ir gandrīz vai vienīgais un plašākais avots. Materiāla no pārējām Latvijas dalām J. Brocem ir maz (3. att.). J. Broces zīmējumi izpildîti akvarelu tehnikā un samērā precīzi atspogulo apgèrba formas un krāsu kolorītu. Precĩzie J. Broces apraksti visumā neizraisa iebildumus, ipaši tur, kur autors apraksta paša redzēto. Vienīgi, aprakstot citu fiksētos un paša pārzìmētos materiālus, dažkārt jūtamas neprecizitātes. Tā. piemēram, apstrīdams liekas J. Broces apraksts, kas pievienots t. s. vidzemnieku kāzu skatam (Monumente..., III. 10. lpp., kādas lielas gleznas J. Broces pārzīmēts fragments) vai Piebalgas sieviešu apğērbu zīmējumam (par pēdējo skat. šì darba 52. lpp.). Käzu skata aprakstā J. Broce norāda, ka apvidus, no kura esot gleznas kopijā redzamie apǵērbi, bez šaubām, esot igaunisks. ${ }^{21}$ Pēc mūsu domām kā aprakstā sniegtais apḡērba dalu raksturojums, tā arī paši attēlā redzamie apġērbi nebūt nerāda kaut ko tikai igauñiem vien raksturīgu, bet rāda gan vai nu tầdas apgèerba ipatnības, kas ir kopējas kā igauniem, tā latviešiem, vai arī tādas, kas raksturīgākkas latviešiem. Liekas, ka tāpēc arī igauñu zinātnieki savos pēdèjos publicējumos neievieto un nepiemin šo J. Broces zỉmējumu. ${ }^{22}$ Līgavu ar aizklāto seju nevar uzskatīt tikai par igauṇu kàzu ceremonijā raksturīgu parādību, jo paradums aizklāt līgavai seju plaši pazīstams arī citām tautām un arī latviešiem, lai gan ne tik plaši. Par to ziñas sniedz tautasdziesmas un Kr. Barona apraksts «Seno latviešu precību un kāzu paražas» («Latvju Dainas», III, 1). ${ }^{23}$ Zināmā mērā šai sakarā minama arī Alsungas ligavu galvas rota - linkainis, kas dạēji aizsedz

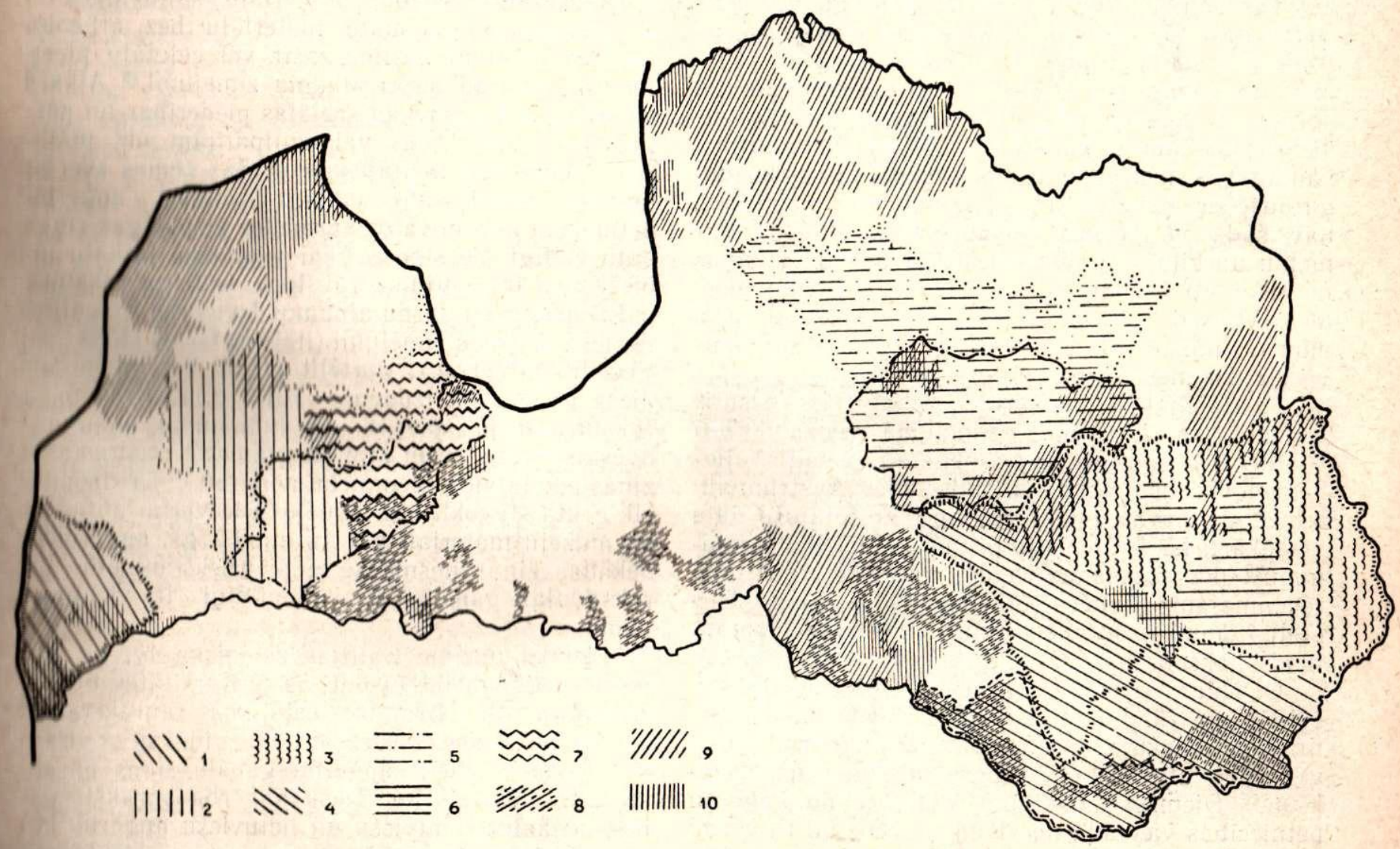

2. att. Latvijas PSR Vēstures muzeja (bij. CVVM) rīkotās ekspedīcijas:

I =1924. g.; $2-1925$. g.; $3-1926$. g.; $4-1927$. g.; 5 - 1928. g.; 6 - 1929. g.; 7 - 1930. g.; 8 - 1937. g.; 9 - pẽ̃ 1945. g.; $10-$ pārējās (atsevišķi izbraucieni u. tml.). 


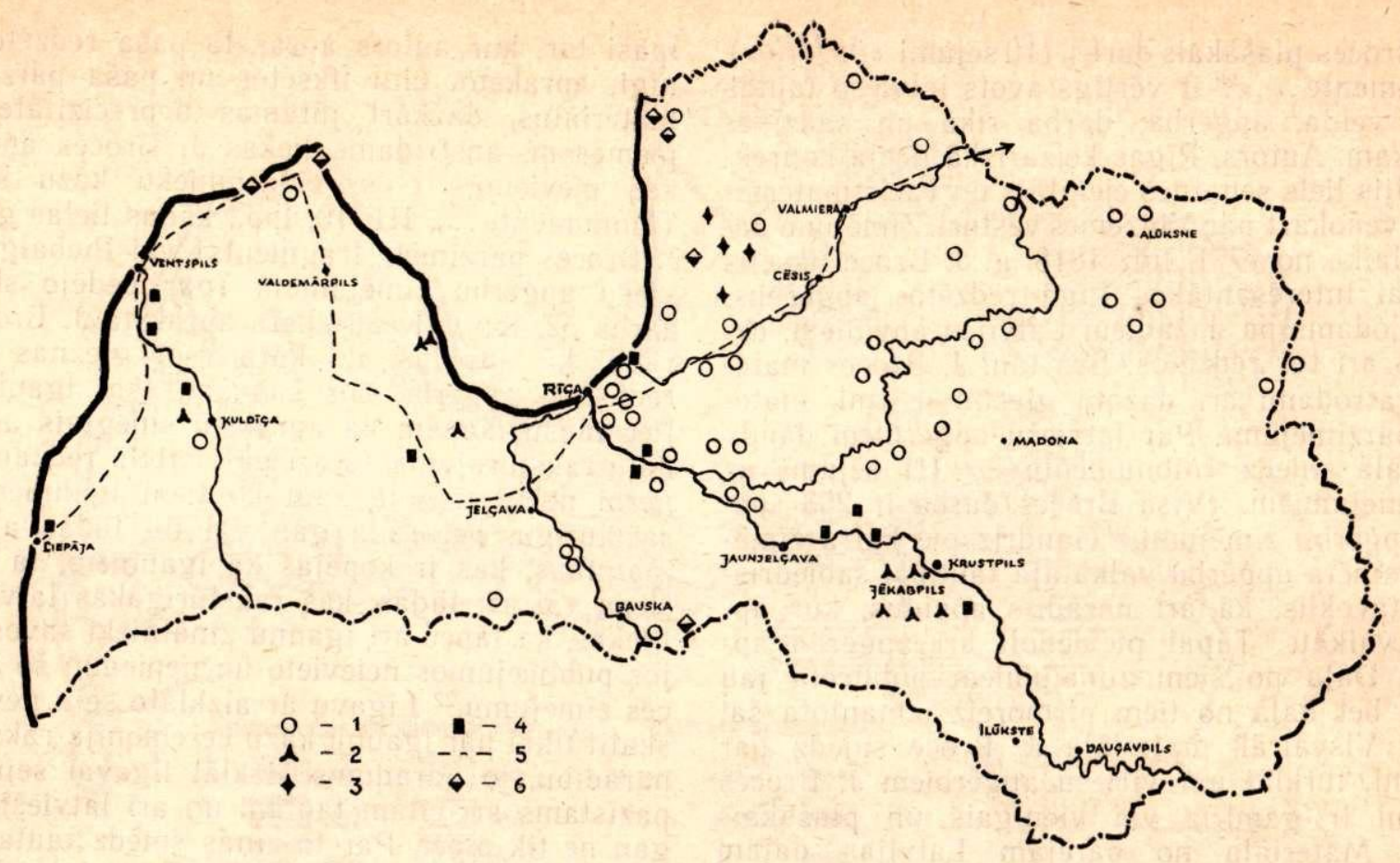

3. att. Latviešu apgēērba zīmējumi 18. gs. un 19. gs. pirmās puses autoru darbos:

1 - J. Broces; 2 - O. Hûna; $3-$ H. Brīgenas; $4-$ F. Kruzes; $5-$ J. Kola: 6 - A. Pecolda.

līgavas seju un pilnīgi nosedz vainagu. Kā autveida galvassegas veids «linkainis» pazīstams arī Vidzemē, lai gan par tā valkāšanas veidu vairs nav saglabājušās atmiñas. Kāzinieču vainagu forma un to rotājums (liekas, ar metāla spīguliem) pazīstams Vidzemē (Piebalgas un Jumurdas vainags), kamēr igaunu sieviešu galvassegas mugurpusē ir sašaurinātas. ${ }^{24}$ Zīmējumā kāziniecēm nav šãda mugurpusē sašaurināta vainaga. Par melnu un zilu vainagu valkāšanu Latvijā ir zinas ne tikai no Piebalgas, bet arī no Austrumvidzemes. Vien̄igi vainagi zīmējumā ir augstāki nekā mums zināmie latviešu vainagi, bet tos platākus varēja uzzīmēt gleznas autors.

Savdabīgākais apgēerba gabals ir nešūtie brunči, kas J. Broces zīmējumā redzami loti skaidri. Lai gan līdz mūsu dienām nav saglabājies neviens brunču variants, tad tomēr Austrumvidzemes "prošava» (skat. 48. lpp.) ar rotājošo dalı visapkārt, kā arī nešūtie brunči ar vertikālo rotājumu ${ }^{25}$ pēc rotāšanas veida ir tuvāki zīmējumā redzamajam brunču rotāšanas principam. Turpretī igaunu nešūtajiem brunčiem vienmēr rotāta tikai apakšejēā mala. ${ }^{26}$

O. Hūna darbs (rokrakstā) attiecas uz 18. gs. beigām un 19. gs. sākumu. Tas sniedz daudz vērtĩgu statistisku ziṇu. Ilustratīvais materiāls galvenokārt attiecas uz Augšzemi un Ziemelkurzemi. ${ }^{27}$ Diemžēl, zìmējumu kvalitāte no apǵērbu pētniecības viedokḷa ne vienmēr vienāda. Precīzāk uzzīmēti ir Augšzemes apḡērbi, bet zīmējumi, kur parādīts Kurzemes apğērbs, dažkārt pat nav izprotami.
Apskatāmā perioda materiālu salīdzināšanai ar iepriekšējo gadsimtu materiālu bez arheolog̀iskām liecîbām nozīmīgas ir vēl ceḷtāju piezīmes un dažādu tērpu albumu zīmējumi. ${ }^{28}$ Atkarā no ceḷtāju-ārzemnieku sociālās piederības un personīgām simpātijām vai antipātijām šie materiāli iepazīstina lasītājus ar svešas zemes «vergu tautas» nekulturālo dzīvi. Protams, apgēerbu pētniekam meklēt šajos aprakstos vispusīgas ziṇas būtu veltīgi, tie sniedz tikai vispārīgu ieskatu un bieži vien ir gadījuma rakstura. Lìdzīga rakstura ir Eiropas tautu têrpu albumos ievietotie Livonijas sieviešu apgèēbu zīmējumi (itāliešu Grasi (1585. g.), Večellio (1590. g.), Bertelli (1596. g.) un holandieša Breina (4. izdevums 1610. g.)). Tāda paša rakstura ir pārējās 16. gs. humānistu ideju apdvestās, vēstures un atminu grāmatās sastopamās zinas par latviešu zemnieku apgèēbu. ${ }^{29}$ Tās liecina, cik grūtā stāvoklī bija nonākusi latviešu tauta. Tã kā muzeju materiāli par 16. un 17. gs. apgēerbiem nekädas ziñas nesniedz, tad iepriekš minētie apraksti, lai gan ir visai nepilnīgi, ir vienīgais avots.

Lielāka nozīme Baltijas zemnieku 17. gs. apgèerba pētišanā ir Dusburgas universitātes tiesību profesora J. Branda celojuma aprakstam. ${ }^{30}$ J. Brands sniedz Kurzemē un Vidzemē redzèto vīriešu un sieviešu apgèèrbu gabalu sīkus aprakstus. Izsmelošais lietuviešu apḡērba apraksts palīdz noskaidrot latviešu un lietuviešu apgēēbu kopējo izcelšanos. Jāpiezīmē, ka par nešūtajiem brunčiem šis ir vienīgais nepārprotamais materiāls. 
Citāda rakstura ziṇas par latviešu apgèērbu, salídzinot to ar igaunu apgèrbu, sniedz A. Hupels $(1737 .-1819 .)^{31}$, kas, darbodamies Rīgā un Igaunijā, labi novêrojis tur redzēto. Labāk aprakstīti igaunu apgểrbi lídz ar tā laika cenām un raksturịgākăm atškirībăm atseviškos apgabalos. Apgerbu petniecibai svarīgākā ir darba otrā dala.

Burzuäziskais apgaismotājs un publicists Garlibs Merḳelis (1769.-1850.) savā darbā ¿Latvieši, sevišḳi Vidzemē, filozofiskā gadsimta beigâs» lîdzās smagā dzimtbūšanas jūga raksturojumam skar arī latviešu sadzivi un apraksta vinuu apgēerrbu. Vērtīgākie ir G. Merḳeḷa norādījumi par apgēerbu atšḳirībām dažādos novados. Ziñas par apgërbu atrodam arì citos G. Merḳela darbos..$^{32}$

P. Drahenielss (1795.-1879.) savās atmiṇās (lai gan tās publicētas 19. gs. 80. gados, tomēr attiecināmas uz gadsimta sākumu), starp citu, min arī Kurzemes latviešu tērpu, norādot, ka gandrīz vai katras muižas zemnieki valkā savu īpašu tễrpu. Lỉdz ar zemnieku brīvlaišanu, kad viṇi uzsākuši celot no viena apgabala uz citu, izzuduši arī šie nacionālie tērpi («Nationaltrachten»), un têrpi visā zemē kḷūstot vienveidīgāki. Autors turpat piezīmē, ka «nacionālais tērps» gan nebūšot visai pareizs apzīmējums, jo mazajā Kurzemē pastāvējuši vismaz divdesmit dažādi tērpu veidi, pie kam Ventspils un Kuldīgas apkārtnē tie saglabājušies vēl tagad (19. gs. vidū)..$^{33}$

1799.-1800. g. savu trīssējumu «Dzīves stāstu» laidis klajā aktieris un dzejnieks J. Brandess, kas kādu savas dēkainās dzìves laiku uzturējies arī Latvijā. «Dzīves stāsta» 2. un 3. sējumā J. Brandess apraksta arī Kurzemes un Rīgas apkārtnes latviešu tērpus. ${ }^{34}$

Ap šo pašu laiku publicēts arī «Kurzemes apraksts» līdz ar iedzīvotāju apg̉ērba sīku apskatu. Te atzīmēts, ka zemnieku ietērpj viṇa lauka lini un ganāmpulku vilna un tikai pilsētu tuvumā zem. nieks tiekot pavedināts atdarināt pilsētnieku apGẻrbu un izmantot svešas preces. Dažādo Kurzemes apvidu tērpi cits no cita tik stipri atškiroties, ka esot visai grūti runāt par kādu noteiktu nacionâlu tērpu. ${ }^{35}$

Labs palīgs zemnieku apgèērbu pētī̌sanai ir zīmêjumi uz attiecīgā laika ğeogrāfiskajām kartēm. Karšu skicējumi dažreiz gan ir visai naivi, tomēr aptěrrbs fiksēts samērā precīzi (4. att.).

No 19. gs. celojumu aprakstiem materiālus par latviešu apğēerbiem atrodam J. Kola (1808.-1878.) aprakstā. ${ }^{36}$ Darbam pievienotas arī 2 tabulas ar lîtviešu un igaunu apgèēbu zīmējumiem. Savā aprakstâ J. Kols kritiski novērtē iepriekšējo autoru materiălus, jo tie neesot saskatijuši katras tautas terpa savdabīgo skaistumu. J. Kols pirmais atzimēe Kurzemes sieviešu apgeērbu līdzību ar igauṇu sieviehu apł́ērbu un augstu novērtē latviešu prasmi Gatavot apgēerbu mājas apstāklos. Ar lielu siltumu J. Kols apraksta kāzu paražas, izdāvājamo cimdu đaiidzumu pat pārspīlējot.

Aptèrbu pētniecībā nozīmīgas ir arheologa
F. Kruzes darba «Necrolivonica» ${ }^{37}$ pielikumā ievietotās krāsạinās Kurzemes un Aizkraukles apg̉ērbu zīmējumu tabulas. (Jāpiezīmē, ka F. Kruzes zīmētais Kurzemes apgèrbs pilnīgi saskan ar P. Drahenfelsa aprakstu.) Lai raksturotu apgèerbu pēc arheoloğiskiem izrakumiem, autors uz vietām vācis arī etnogrāfiskus materiālus. Tur, kur F. Kruze tikai apraksta etnogrāfisko materiālu vai salīdzina to ar arheologisko, labi parādìta latviešu un igaunu sieviešu apgēerbu lïdzība un atškirīība; diemžêl, jautājumā par latviešu apgēēba vecumu autors nonāk pie kurioziem secinājumiem par tā līdzību ar seno romiešu un griekุu apgērbiem.

19. gs. otrajā pusē līdz ar latviešu buržuāziskās nācijas veidošanos sistemātiskāku etnogrāfisko materiālu vākšanu, krāšanu un zināmu pētniecības darbu sāka latviešu buržuāziskā inteligence, jo etnogrāfiskie materiāli apspiestās lat-
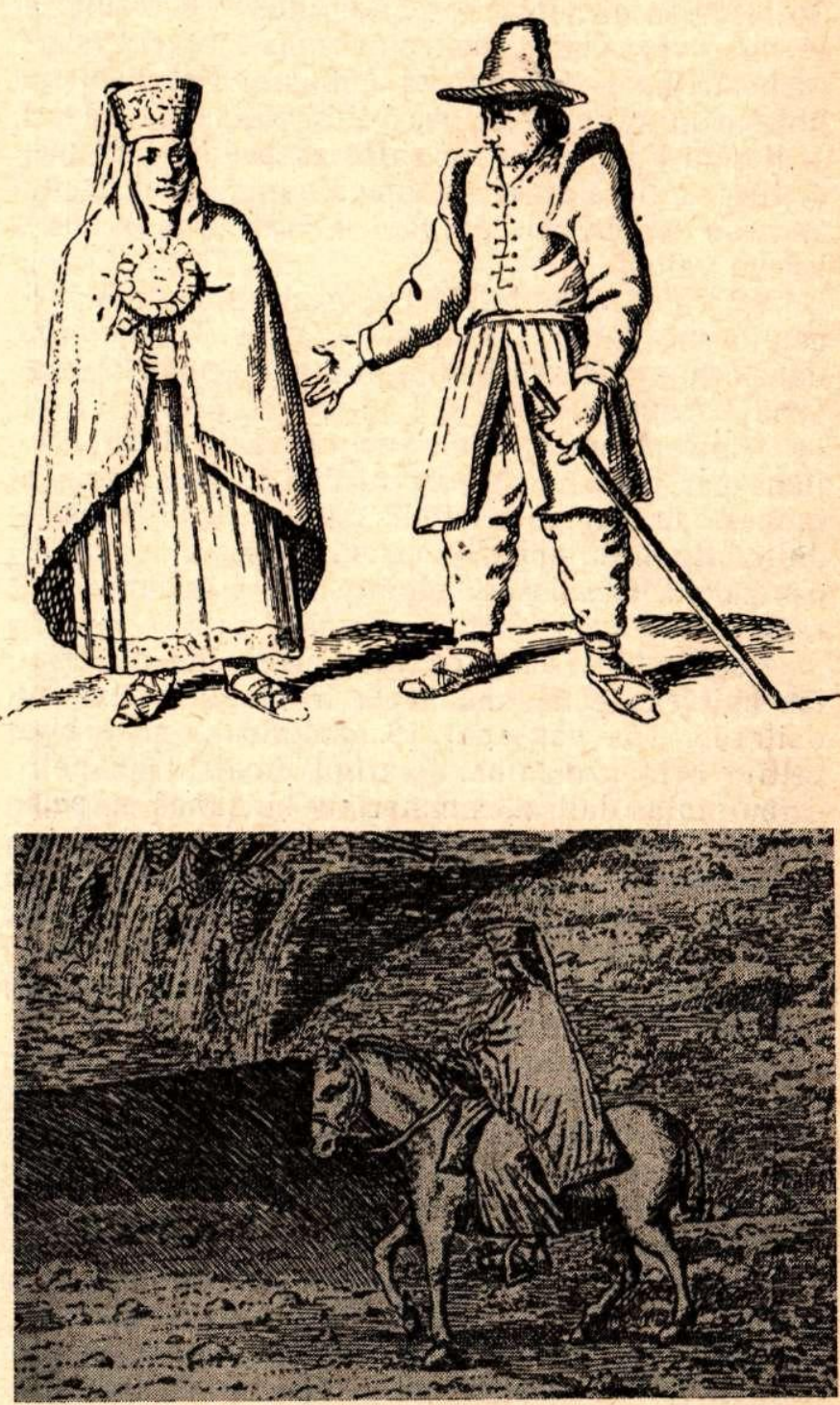

4. att. 18. gs. latviešu zemnieku têrpi (detala Barnikela kartē, 1747. g.) 
viešu nācijas buržuāzijai deva pamatojumu cīṇā par latviešu tautas, t. i., par latviešu lauku buržuāzijas līdztiesību. Sevišḳi lielu vērību latviešu tautas senatnes pētîšanai veltīja progresĩvās buržuāziskās nacionāli liberālās jaunlatviešu kustības pārstāvji.

Lieli nopelni latviešu tautas dzives pētīšanā pieder Krievu Ģeogrāfijas biedrībai, kā arī Maskavas Dabaszinātṇu, antropolog̣ijas un etnogrāfijas draugu biedrībai. To darbā, organizēdami folkloras un etnogrāfijas materiālu vākšanu, piedalījās arī latviešu buržuāziskās inteliğences pārstāvji (J. Kalējs-Kuzṇecovs, Fr. Brīvzemnieks u. c.).

Maskavas Dabaszinâtnuu, antropolog̣ijas un etnogrāfijas draugu biedrîbai ierosinot, 1868. g. tika nodibināta Rịgas Latviešu biedrības Zinību komisija, kas sāka vākt materiālus Latviešu etnogrāfiskā muzeja dibināšanai. Pirmo savākto priekšmetu vidū bija arī vairāki apg̀ērba gabali. Šo biedrību darbības izraisītās intereses rezultātā 19. gs. vidū tika rīkotas pirmās etnogrăfiskās ekspedīcijas - jau minētā J. Segrēna ekspedīcija lībiešu un krieviṇu dzìves veida pētī̌sanai, kā arī J. Kalēja-Kuznecova Latgales ekspedīcija. Ekspedīciju rezultātā atseviški zìmējumi un apraksti par latviešu apgēerbiem parādās vairākos izdevumos krievu valodā.

Vērtīgāki materiāli par apg̉ērbu sniegti A. Sementovska darba $\bar{a}^{38}$ : te minētās atsevišḳu apgiērbu dalu cenas dod svarīgu liecību par zemnieku materiālo stāvokli.

«Antropoloğisku un etnogräfisku rakstu krājumā par Krieviju» ${ }^{39}$ ievietoti divi Ludzas apriṇka latvieša un latvietes attēli. Attēlos skaidri parā. ditas latgaliešu apgēerba atsevišḳas detaḷas, villaines raksti. Grāmatas beigās sniegts apḡèrba apraksts.

Bagāts tautas dzīves, tās garīgās un materiālās kultūras pētišanas avots ir tautas mutvārdu daiḷrade. Tās vākšanai 19 . gs. otrajā pusē bija veltîta liela uzmanība. Svarigu atbalstu un palīdzību tautas daiḷrades materiālu krāšanas un pētīšanas darbiniekiem sniedza krievu zinātnieki. Tautasdziesmas - «Latvju Dainas», kuras krāja un sistematizēja Kr. Barons, izdeva Pēterburgas Zinātnu akadēmija (I - Jelgavā, 1894.; II-VI Pēterburgā, 1903.-1915.). «Latvju Dainās» sniegti arī plaši latviešu paražu apskati.

Svarīga nozīme latviešu etnogrāfisko materiālu vākšanā bija Pēterburgas filologa E. Voltera vadībā sastādìtajai programmai ${ }^{40}$ S̄î programma bija neatsverams palīgs pirmo etnogrāfisko kolekciju un apḡērbu materiālu vācējiem.

Sakarā ar X arheologu kongresu Rīgā tika noorganizēta pirmā latviešu etnogrāfiskā izstāde. Eksponātu vākšanai RLB Zinību komisija bija organizējusi vairākas ekspedīcijas, kurās dažādu novadu latviešu apgeērbus zīmēja arī mākslinieks J. Krēsliṇš. No zīmējumiem saglabājusies niecīga dala. Zìmējumi, kurus J. Krēsliṇš veicis uz vietas, tieši vācot materiālus, ir vērtīgs avots, jo pareizi atspogulo tā laika apgēèrbus. Turpretim zīmējumi, kurus J. Krēsliṇš 1896. g. izstādes vajadzỉbām zìmējis pèc J. Broces materiāliem, ir mazvērtīgi, jo tajes daudz paša zīmētāja izdomãjumu. ${ }^{41}$

Sākot ar 19. gs. 70. gadiem, latviešu buržuāzija, nostiprinājusi savas pozīcijas, arvien plašāk sāka izmantot presi šauri škiriskām interesēm. Latviešu tautas «mūžĩgās vienìbas» un škiru «mierīgas līdzās pastāvēšanas» propagandai tika iz. mantoti latviešu tautas tērpi. ${ }^{42}$ Piemēram, 80 . gadu beigās notika veseli disputi par to, kãdos têrpos jāierodas nākošajos dziesmu svētkos. ${ }^{43}$

19. gs. beigās rakstus par latviešu apgèēbu iespieda arī citas latviešu buržuāziskās avīzes un žurnāli - «Baltijas Vēstnesis», «Latviešu Avīzes», literatūras un mākslas žurnāls "Austrums», kā arī RLB Zinību komisijas rakstu krājumi.

Uz augošãs latviešu buržuāzijas cīṇu par savu vietu nevarēja mierīgi noskatīties vācieši. Tāpēc etnogrāfiskos materiālus rosīgi vākt uzsāka arī muižnieku ideologi. Baltijas vāciešu vēsturnieku un etnogrāfu mērḳis nebija dziḷi un vispusīgi pētīt latviešu tautas kultūru; vini centās ar pašas latviešu tautas radītajiem vēstures avotiem pierādīt, ka latviešiem kultūru atnesuši vācieši.

Pie vācu autoru nozīmīgākajiem etnogrāfiskajiem pētījumiem (19. gs. beigās -20 . gs. sākumā) pieder A. Bīlenšteina darbs «Die Holzbauten und Holzgeräte der Letten».44 Autors aplüko apgēēba materiālu apstrādāšanas rīkus un tehniku, bet par apḡērbu formām nerunā. A. Bīlenšteins kā tipisks vācu kultūras pārākuma paudējs izskaidro audumu izstrādāšanas tehnikas attīstíbu ar aizguvumiem no citām tautām un visupirmām kārtām - no vāciešiem. Ar tādu pašu tendenci vēlākajos gados uzrakstīta $M$. Bỉlenšteinas grāmata par krāsošanu ar augu krāsām un škiedru apstrādāšanu. ${ }^{45}$ Jāpiezīmē, ka $M$. Bīlenšteinas darbā daudz laba faktu materiāla.

Salīdzināmos materiālus par zviedru, igauṇu, lïbiešu un daḷēji arī par latviešu apgèèrbiem publicējis somu etnogrāfs A. Heikels. ${ }^{46} \mathrm{P}$ ar latviešu ap. gèrêu A. Heikels devis materiālus vienīgi no Bārtas, Rucavas un Alsungas novadiem. Speciāla nodaḷ A. Heikela grāmatā veltīta lỉbiešu apgeērbam. Grāmata savā laikā, bez šaubām, izraisîja lielu interesi, jo tanī apkopots plašs faktu materiāls, kura lielāko daḷ savācis pats autors un kas publicēti pirmo reizi. S̄ì krājuma nozīme ar laiku gan stipri samazinājusies, jo vēlākajos gados savāktie materiāli par latviešu apgēerbu tālu pārsniedz A. Heikela tomēr visai fragmentārās ziṇas.

Buržuāziskās diktatūras gados turpinājās etnogrāfisko materiālu vākšana un apkopošana. Daudı tika rakstīts par dažādām paražām, tautas celtniecību, apgēerbiem un citām materiālās kultūras nozarēm; plaši tika aprakstīta priekšmetu forma, materiāls, rotājums u. c. bez dzil̄ākas analīzes un plašāka salīdzināmā materiāla. Tika izdoti arī atseviški darbi par latviešu tautas apg̉ērbu. Tajos ir bagāts faktu materiāls, bet trūkst šo faktu zinātniska izvērtējuma. Autori galveno uzmanību vel- 
tījuši atsevišķu apgēēba daḷ aprakstiem, krâsu bagātībai un rotājumiem, pilnīgi ignorējot piegriezumu. Izdalot apg̣ērbu kompleksus, šie pētnieki nemēgeināja saistît tos ar noteiktiem vēstures periodiem, ne arỉ precizēt valkātāja šḳirisko piederỉbu. Săds vêrtêjums izriet no buržuẳiskajā etnogrâfijă pieṇemtās teorijas par «latviešu tautas konservativo» raksturu, kuru gan pilnībā atspēko fakitu materiāls. Tā kã šie izdevumi tematiski saisiii ar mûsu monogrāfiju, nepieciešams îsumā apskatit vismaz galvenos no tiem.

Plašakais reprezentatīva rakstura darbs ir *Latvju Raksti». ${ }^{77}$ Tas izdots trīs greznos sējumos ar kräsainiem ornamentu zìmējumiem uz atsevišKâm lapăm un atsevišḳu rajonu (Krustpils, Piebalgas, Cesvaines, Tirzas, Laudonas un Alsungas) etnogräfiskiem aprakstiem, kas pauž buržuāzisko nacionălismu un slavina «latvisko kultūru». Lielais vairums krāsaino zīmējumu izgatavots pēc Valsts vēstures muzeja materiāliem, labā poligrāliskia tehnikā. Diemžēl, krāsu gamma ir pārāk spilgta, tātad nav visai precīza. Tāpat atsevišḳu apvidu apraksti ñemti galvenokārt no muzeja arhivva, bez analīzes un cita salīdzināmā materiâla, Labākie ir K. Pāvuliṇas apraksti: tiem izmantoti autores pašas vāktie lauku materiāli. ${ }^{48}$ Tendenciozi un pretrunīgi ir M. Silina un R. Zarina raksti.49

Apraksti «Latvju Rakstos» doti latviešu un francu valodās, lai izdevumu varētu lietot ne vien Latvijă, bet arī ārzemēs. Izdevuma nolūks bija pieradit latviešu kultūras senumu, lai dotu tiesības latviešu nacionālistiskajai buržuāzijai ieṇemt Bavu vietu blakus citu tautu buržuāzijai.

Tâdă pašã nolūkā tika izdoti Valsts vēstures mizeja krājumi ${ }^{50}$ Pirmā krājuma priekšvārdā redaktors $M$. Siliṇš norāda, ka šîs publikācijas neplecię̧amas reprezentācijai ārzemēs. ${ }^{51}$ Krājumos aitêtvêrtigas kvalitātes krāsainas ilustrācijas. Materiâlu analizi un darināšanas tehniku aprakstu aniedzis J. Niedre.

Krajumu ievados vērojams mēğinājums izlialidrot atsevišķo novadu îpatnību izcelšanos un ineeli điifi latvisko Lātavu» (Krustpils novadu ar İii plegulošajăm Vidzemes, Latgales, Augšzemes iii Cemgales da|ām), kur esot labākie raksti, atlisilika tehnika un stingrākie kompozīcijas likumi iii liir latvieši neesot sajaukušies ar citām tautain 'Saprotams, ka šãda nostāja ir tendencioza iiin fiezinâtniska.

llisitrativais materiāls rodams latviešu Dziesmu viliii biedribas izdotajās tautas tērpu lapās ar Divivisa aprakstiem. ${ }^{3}$ Aprakstos autors cenšas iư Cingerakius norădijumus par tautas tērpu darifí (ii) aiti oblehtivismam, bez tam latviešu tautas ficii ationibu tas saista vienigi ar tehnikas, konfirif ar Rletimeiropas tehnikas attīstību.

Pâ pirmo mę̧inājumu apkopot visu uzkrājumatertalu un lzsekot tă attīstībai no vissenāajiem laikiem lidz 20, gs. var uzskatīt K. Straubefen falistu dLatviešu têrps un viña raksta orna- mentika» (1930. g.). ${ }^{54}$ Raksta pamatā plašs faktu materiāls, tomēr dažas koncepcijas arī šai citādi vērtīgajā darbā nav pareizas un pieñemamas (par tām būs runa tālāk).

Lìdzīga rakstura ir kolektīvais darbs «Latviešu tautas tērpi». ${ }^{55}$ Darbā galvenā vērība veltîta esošā materiāla apskatam un tikai retos gadijjumos sniegta tā analīze. Sīkāk iztirzāts arheologiskais materiāls. Neiedziḷinoties darba sīkākā analīzê, minēsim dažas raksturīgākās kḷūdas darba teorētiskajā nostādnē. Jau ievada daḷā autori izklāsta savu tendenciozo nostāju tautas tērpu pētniecības jautājumos, deklarēdami, ka šā izdevuma nolūks ir atdzìvināt tautas tẽrpus kā «senā latvieša îpatnējā gara un rakstura lieciniekus». ${ }^{56}$ Skaidrs, ka šis darbs, tāpat kā pārējie tolaik iznākušie darbi, bija atbilde uz «vadoña» aicinājumu meklēt «latviešu ipatnējo garu». Noliedzot latviešu tautas vēsturiskos kultūras sakarus ar kaimiṇu tautām un falsificējot vēstures avotus, autori centās pierādīt visas tautas «vienotību» un «konservatīvo» raksturu.

Autoru izvirzītā doma, ka «latviešu tautas konservatīvisma dēl tautas tērpā līdz mūsu dienām ir uzglabājušās daudz loti senas, vēl aizvēsturiskas tradīcijas», ${ }^{57}$ neiztur kritiku, jo tās pamatā nezinātniska, ideālistiska pieeja vēstures procesam, kuru nosakot mistiskais "nemainigais tautas gars».

Tautas tērpu popularizēšanai fašistiskās varas gados tika izdota grāmata «Novadu tērpi» ${ }^{58}$ ar sīkiem tehniskiem zīmējumiem un norādījumiem par tērpu izgatavošanu pēc muzeja materiāliem.

Samērā plaši raksti par apgēerbu ir «Latviešu tautas dainuı» atsevišku nodal̨u ievados. ${ }^{59} \mathrm{Te}$ arī ievietots vienīgais plašākais raksts par vīriešu apgeērbiem. ${ }^{60}$ Raksta autors, analizējot apgèēba attīstību, noteicošu vietu piešḳir dažădiem Rietumeiropas modes strāvojumiem, ignorējot konkrētus vēsturiskus apstāklus; tomēr pagrūti iedomăties, ka dzimtcilvēkiem būtu bijusi iespēja izsekot jaunākām modes parādībām.

Vairāki îsāki rakstiṇi ar tautas tērpu materiālu publikācijas ${ }^{61}$ vai arī pareiza tautas tërpa propagandas $^{62}$ raksturu ievietoti periodiskajos izdevumos. Atsevišḳi minams E. Elksnites pētijums par Rucavas krekliem, kurā sakopota bagāta vietējā terminoloğija un vērojams mēǵinājums sniegt kreklu attīstỉbas analīzi.63

Latviešu kultūras krīze buržuāziskās kundzības periodā Latvijā atbalsojās arī lietiškajāā mākslā. No Rietumiem ievazātie bezgaumìgie naturālie ziedu u. c. motĩvi bija izskauduši latviešu tautas mākslas veselīgos pamatus. Tāpēc kaut ìsumā jāapskata arī publicêjumi par tautas tērpa ornamentiku, jo lielākā daḷa ornamentu analizēti, balstoties tieši uz apgèēbā sastopamā rotājuma.

Viens no pirmajiem, kas uzsāka cīnu pret banalitāti un bezgaumību lietišḳajā mākslā, ir mākslinieks J. Madernieks, kas savus ornamentu zimèjumus publicēja dažādos žurnālos un atsevišḳās grầmatās. ${ }^{64} \mathrm{~J}$. Madernieka zīmêjumi pēc stila un krāsu zieda ir samērā sveši latvieśu ornamentı 
tradicijâm, tomêr bezgaumìgo «jugendstila» izšuvumu izskaušanā tiem bija liela nozīme.

Latviešu tautas mākslas ornamentu propagandēšanas darbu turpināja J. Sudmalis, sastādīdams albumu «Latvju Raksti».65 Darba vērtību tomēr zināmā mērā mazina tas, ka visi, arī tekstīliju un adijumu ornamenti zīmēti, neievērojot izšūšanas un adīšanas tehniku īpatnības. Rezultātā plaši iz. platījās izšuvumi, kuru ornaments uz auduma bija uzzìmēts taisnām kontūrām ar zīmuli un pēc tam izšūts.

Ornamentam un kompozīcijai veltīts E. Brastina darbs divos sējumos. ${ }^{66}$ Pirmajā sējumā doti atsevišku ornamentu elementu apraksti, lìdz ar mitologijā balstītu skaidrojumu, bet otrajā analizēta rakstu kompozīcija. E. Brastinš kā reakcionārās nacionālistiskās buržuāzijas interešu paudējs klaji parāda savu naidīgo nostāju pret latviešu kaiminiem - austrumslāviem, nereti aizrunājoties lìdz acìm redzamam absurdam. Piemēram, meklējot latviešu ornamenta atškirīibu no krievu ornamenta, E. Brastinš apgalvo, ka krievu iespaids lielā mērā pazeminājis latvisko formu cēlumu. ${ }^{67}$ Protams, ka ar šādu šovinistisku «tîri latvisko» formu meklēšanu autors cenšas noklusēt krievu un latviešu kultūras sakarus un mazināt to ietekmi, lai gan tiem no seniem laikiem ir bijusi liela nozīme abu tautu mākslā.

Latviešu tautas kultūras "pārākumu» pār kaimiṇu - «svešajām kultūrām», tās saistību ar Rietumeiropas un Skandināvijas kultūru savos rakstos turpina propagandēt emigrējušie buržuāziskie nacionālisti. Saprotams, ka, dzīvojot atrauti no latviešu tautas un kultūras, emigranti nevar sniegt jaunus, kaut cik nopietnus pétijumus latviešu materiālās un garīgās kultūras jautājumos, tāpēc ar buržuāziskās Latvijas laika izdevumu atkārtotu iespiešanu tie mēg̣ina mākslīgi saglabāt «tīri» latviskās kultūras paliekas pa visu pasauli izkaisīto emigrantu vidū. Piemēram, lai gan "Latvju rakstu» I sējuma ${ }^{68}$ ievadā norādìts, ka krājumā ievietoti jauni materiāli un atziñas, tomēr, atskaitot dažas piezīmes par tautas tērpu atdarināšanu un dažus nepublicētus fotoattēlus, tālāk par atseviškiem fragmentiem no 1939. g. izdotā darba «Novadu tērpi» tie nesniedzas. Emigranti gan mēgina îsumā apskatīt latviešu tautas tērpa vềsturi, kā arī izskaidrot tautasdziesmās apdziedātās apğērba dalas, tomēr jaunus secinājumus nav spêjigi dot. ${ }^{69}$

Pamatojoties uz buržuāziskās etnogrāfijas koncepcijām, emigrantu rakstos atkārtoti pausti nepieñemami uzskati, ka latviešu tautas têrpa attīstība izbeidzoties ar 17. gs. Tomēr, salïdzinot J. Broces 18. gs. zīmējumus ar muzeja apgērbu kolekcijām (kas attiecināmas uz 19. gs.), redzam, ka izmainījušies gan atseviški apg̀ērba gabali, gan veseli apğērbu kompleksi (skat. tālāk, 2. un 3. nod.), sevišḳi skaidri tas vērojams Lielvārdes un Piebalgas novada tērpos. Iztirzājot atsevišḳu apgèrba gabalu attīstību, emigrantu rakstos vienmệr vērojama cenšanās parādìt šo apgèrerbu gabalı saistību ar Rietumeiropas un Skandināvijas apgēerbiem, ignorējot vistuvāko kaiminu - lietuviešu, igauṇu, slāvu un lībiešu ietekmi, lai gan tieši tie ekonomisko un kultūras sakaru ciešās mijiedarbības rezultātā atstājuši vismanāmākās pēdas latviešu kultūras attīstībā. Tātad autori pauž padomju historiogrāfijā jau daudzkārt kritizēto un atmesto varjagu teoriju. ${ }^{70}$

Jau agrākajos buržuāzișko nacionālistu darbos izvirzito teoriju par Krustpils novada tautas tērpa «skaidrỉbu» emigrantu «teorētiki» pieñem bez korektīvām, nemaz tuvāk nepaskaidrojot, kāpēc (nostājas antivēsturiskā būtība būs pārầdíta tālāk).

Saàdu teorētisku kḷūdu dēl autori materiālu izklāstā nonāk pretrunā ar saviem apgalvojumiem. ${ }^{71}$ No vienas puses, paužot latviešu emigrantu reakcionārās intereses un sludinot «tīri latvisko» un «konservatīvo» kultūru, tie, no otras puses, savos darbos atspogulo arī 20. gs. pirmajā pusē Eiropā valdošās etnogrāfiskās teorijas, kuru pamatā bija kultūras pārmantošanas idejas (un nevis mijiedarbība), pie kam kā centru, no kurienes šì kultūra ieplūda Latvijā, minot gan Skandināviju, gan Rietumeiropu.

Emigrantu izdotajā latviešu tautasdziesmu krājumā ir publicēti arī J. Straubęrga raksti par latviešu rotām un rotkalu amatu. ${ }^{72}$ Minētā raksta sastādīšanai izmantoti J. Strauberga jau 1938. un 1939. g. publicētie raksti. ${ }^{73}$

Nobeidzot priekšpadomju laika literatūras apskatu, jāsaka, ka tajā atspogulojas latviešu buržuāziskâs historiogrāfijas trī̄s attīstības posmi. ${ }^{74}$

Pirmais posms aptver laiku apmēram no 19. gs. 80. gadiem līdz pirmajam pasaules karam un Lielajai Oktobra sociālistiskajai revolūcijai. Lai gan šajā laikā presē notiek diskusijas par tautas têrpu izmantošanu svētku gadijjumos, latviešu tautības autoriem plašāku pētījumu par apḡērbiem vēl nav. Pētijumi par apgeērbiem šajā laikā pieder sveštautiešiem.

Otrajā posmā - no 1920. g. līdz 1934. g. 15. maija apvērsumam - Latvijas buržuāziskās republikas gados, kad buržuāzija bija kluvusi par galveno polítisko spēku Latvijā un centās nostiprināt savu varu, tautas apgèēbam kā greznākajam kultūras mantojuma objektam bija nozimmiga vieta latviešu kultūras augstā attīstības līmeña «pierādīšanā». Sajā laikā galvenokārt reprezentêšanās nolūkos tiek izdoti kapitāli darbi, kuros sakopoti materiāli par apg̛ērbu, tā ornamentiku un latviskā stila jautājumiem.

Trešajā posmā - no 1934. g. 15. maija fašistiskā apvērsuma līdz padomju varas uzvarai Latvijā 1940. g. - galvenā vērība tiek pievērsta fašistiskās diktatūras un «vadona kulta» attaisnošanai. Notiek pastiprināta materiālu vākšana un publicēšana, it īpaši par Zemgales tautas tērpiem. Tiek izdoti plaši tehniskie apraksti par tautas tērpu darināšanu, lai ar tautas tērpa palīdzību propagandētu «tautas vienotības» idejas.

Padomju etnogrāfija, balstoties uz vēsturiskā materiālisma metodologijas, tautas kultūras 
daudzveidību aplūko ciešā saistībā ar tautas sociālekonomisko attīstību. Tāpēc arī jebkuru jautājumu padomju etnogrāfi pēta kompleksi, t. i., atsevišḳu parādību izskaidrojumā par salīdzināmo materiâlu sava viedokla pierādīšanai izmantojot citu zinātṇu disciplīnas un avotu liecības.

Būtiski izmainījušās materiālu vākšanas metodes, to pamatā ir marksistiski leṇiniskā metodologija. Saskañā ar to visas parādìbas tiek fiksētas stingrā vēsturiskā secībā, savstarpēji saistītas, katru priekšmetu uzskatot par cilvēka darba rezultätu.

Ievērojot šos principus, etnogrāfu ekspedīcijas tiek rūpīgi sagatavotas un to dalībnieki văc tematiski noteiktus materiālus, tā nodrošinot dzilāku pētāmā jautājuma izpratni, savāktā materiāla pilnvērtību un jau materiālu vākšanas gaitā veicot dalu pètniecíbas darba.

Visplašāko etnogrāfisko materiālu vākšanas, kârtošanas un publicēšanas darbu Padomju Latvijā veic Latvijas PSR Zinātnu akadēmijas Vēstures institūta Etnogrāfijas sektors. Materiālu vākšana tika uzsākta tūlìt pēc Latvijas PSR Zinātñu akadēmijas nodibināšanas: 1946. g. pie ZA Vēstures un materiālās kultūras institūta tika nodibināta etnogrāfu grupa (kopš 1956. g. Etnogrāfijas sektors darbojas Latvijas PSR ZA Vēstures institūta sastāvā). Tomēr pagāja zināms laiks, līdz uzkrājās pieredze, izveidojās etnogrāfu kadri un bija iespējams apkopot un publicēt plašākus ekspedīciju materiālus un apcerējumus. Temats par apg̉ērbiem jau kopš pirmajām institūta dibināšanas dienām bija izvirzìts par vienu no galvenaiiem, tāpēc arī par to savākts visvairāk materiālu. Savākto materiālu lielākā dala $(60 \%)$ atspoguḷo izmaiñas, kādas notikušas apğērbos padomju varas laikā. $25 \%$ materiāla attiecināmi uz buržuāziskās Latvijas gadiem un $15 \%$ - uz agrākajiem posmiem. ${ }^{75}$

Latvijas PSR ZA Vēstures institūta Etnogrāfijas sektora vāktie materiāli sakopoti sektora arhīvă. Te līdz 1962. g. glabājās arī neliela apgèreu kolekcija no Augšzemes, Latgales un Piebalgas; ši kolekcija tagad atrodas Etnogrāfiskā brivdabas muzeja fondos.

Lìdztekus Latvijas PSR ZA rīkotajām ekspedīeijäm Latvijas teritorijā, sākot ar 1952. g., darbojas PSRS Zinātṇu akadēmijas Etnogrăfijas instilâta organizētā Baltijas kompleksầ ekspedīija, luiras sastāvā piedalās arī Latvijas PSR Zinātṇu àkadēmijas pārstāvji. ${ }^{76}$ Baltijas kompleksajā ekspedícijā etnogräfiskais materiāls tika vākts visās iijâs Baltijas republikās pēc vienota plāna, lepiriekš nosakot rajonus, kuru pētišanā būtu ieinteresetas visas republikas. S̄āda ekspedīcijas darba lioordinăcija lauj dziḷāk un vispusīgāk pētît tauIas materiālās kultūras parādības ne tikai vienas atieviškas zemes robežās. Ekspedīcijās savāktais nalidzinămais materiāls noder pētniecības darbā dailakiem un vispusīgākiem secinājumiem. Balti1 î̉ Kompleksās ekspedīcijas materiāli tika vākti par zemnieku dzīvojamām ēkām, lauksaimniecības darba rīkiem un apgèrbiem. ${ }^{77}$

Padomju varas gados etnogrāfijas pētniecības darba pamatā ir stingrs zinātniskums, un etnogrāfu darbam nodrošinātas visas iespêjas tālākai attīstībai.

Pirmais latviešu padomju etnogrāfu darbs ir «Latvju Raksti» ${ }^{78}$ : tas aptver 3 mapes ar krāsainu rakstu attēliem un atsevišǩ apgēerba dalu aprakstiem. Te izmantotas kapitălajā izdevumā «Latvju Raksti» (1924.-1931.), kā arī citos izdevumos (piemēram, K. Klaustiña un J. Endzelina LTD pielikumu) klišejas. Vērtīgākie ir atsevišķo apg̀ērba dalu apraksti, kuros J. Niedre it ipaši pasvītro zemniecības sociālās neviengabalainības atspogulojumu apgèerbā.

Kã faktu materiāli nozīmīgi ir bij. Valsts vēsturiskā muzeja publicējumi par Rỉgas un Latgales novadu têrpiem. ${ }^{79}$ So izdevumu teksts nepārsniedz tehnisko aprakstu robežas. Līdzīga rakstura ir krāsainie tautas tērpu bukletiṇi («plēšiñas») ar konspektīviem tekstiem; tos sakărtojuši izdošanai Rịgas Lietišķās mākslas vidusskolas pedagogi un audzēkni. ${ }^{80}$

Neliels raksts par latviešu zemnieku apgērbu bij. Neretas un Aknistes rajonos ievietots PSRS ZA Etnogrāfijas institūta krājumā par Baltijas ekspedīcijas materiāliem. ${ }^{81}$ Raksti par tautas tērpiem ievietoti arī vēl dažos citos izdevumos. ${ }^{82}$

Ievērojama nozīme latviešu tautas tērpu attīstības pētniecībā ir arheolog̀es A. Zariṇas pētījumiem par latgalu apgērbiem. Balstoties uz arheoloǵisko izrakumu materiāliem, iespējams arī etnogrā́fiskajā materiālā izsekot zināmai attīstības linijai. ${ }^{83}$

Lai gan pētījumi par mājaušanu Vidzemēê ${ }^{84}$ hronologiski skar jaunāku periodu - 19. gs. otro pusi un 20. gs. sākumu, bet, tā kā tajos apskatīta aušanas attīstība un apgēēbu audumi arī iepriekšèjos periodos, tie ir nozīmīgi šĩs monogrāfijas temata risināšanai.

Nozīmīgu darbu Jēkabpils rajona iedzìvotāju apgèerba attīstības pētniecībā veikusi L. Terentjeva, kas monogrāfijā «Kolhozu zemniecība Latvijā» izsekojusi zemnieku apgèērba attīstībai vēlā feodālisma, kapitãlisma un sociālisma posmā Jẽkabpils rajonā ${ }^{85}$ Autorei labi izdevies atklāt sociālās diferencēšanās atspogulojumu buržuāziskās Latvijas laika zemnieku apgērbā, un par šo posmu tas ir pirmais pétijums Padomju Latvijas etnogrāfiskajā literatūrā.

Par krievu iedzīvotāju - vecticībnieku apgèerbu Latgalē jaunus materiālus publicējusi N. Lebedeva, ${ }^{86}$ labi parādot nodarbošanās veida un tradīciju nozìmi apgèrbu izveidē.

Tātad visi lĩdzśinējie pētījumi par latviešu zemnieku apgēerbiem galvenokārt skar tikai atsevišķas jautājuma puses. Mūsu uzdevums bija no marksistiskās metodoloğijas viedokḷa novērtēt buržuāzisko autoru uzskatus un, pamatojoties uz jauniem materiāliem, sniegt secinājimus apgēēba attīstības un kultūrvēsturisko sakaru jomā. 


\section{APG̣ĒRBA RAKSTUROJUMS LİDZ 18. GS. VIDUM}

Latviešu apgêerba vēsturiskās attīstības raksturojumu sāksim ar mūsu ēras pirmajiem gadsimtiem, kad katrai cilšu grupai - kuršiem, latgaliem, zemgaḷiem un sē|iem - bija savas apbedīšanas parażas, savdabigas rotaslietas un lïdz ar to laikam arī dažã zināa atškirĩgi apgēērbi ${ }^{87}$

Senākas ziṇas par apgēerbiem sniedz arheologiskie izrakumi. Pēc atrastajām senlietām un audumu fragmentiem iespējams rekonstruēt tērpus, kas valkāti no 7 . lìdz 13. gs. Tuvāk neiedzilinoties arheologiskā materiāla analīzē, ${ }^{88}$ zināmi ekskursi pagātnē tomēr nepieciešami, jo daudzas 18. gs. apgērba dalas savas pirmatnējās formas ieguvušas vêl laikā lidz 12. gs.

Ģeogrāfiskie un klimatiskie apstākli, kas stipri ietekmẽ iedzīvotāju apḡērba izveidi, Latvijas PSR teritorijā kopš tā laika, par kuru ir pirmās ziñas, kas lauj spriest par iedzīvotāju apgēerbu, nav tik stipri izmainījušies, lai nestu sev lỉdz radikālas izmainas apgēêrbā. Tāpēc jāpieṇem, ka to laiku Latvijas, PSR teritorijas apdzīvotāju, tāpat kā visu mērenās klimata joslas apdzīvotāju apgērba sastāvdalas visumā palikušas tās pašas, kādas tās ir mūsu apskatāmajā laika posmā. Bez tam arī tehnika un virsbūves elementi pirmskapitālistiskajās formācijās visumā attīstās lēnām, un arī tas runā par labu apstāklim, ka apgēerba sastāydalas kopš 12.-13. gs. lïdz 18. gs, nav stipri izmainījušăs.

$\mathrm{Par}$ senākiem apgēerba auduma fragmentiem var uzskatît atradumus no mūsu ēras 2 . lỉdz 4 . gs. ${ }^{89}$ Tomēr šo atradumu skaits ir tik niecīgs, ka apgêrbu nav iespējams rekonstruēt. Par pārejas periodu uz šķiru sabiedrïbu (5.--9. gs.) atradumi ir jau daudz bagātāki; pêc tiem iespējams spriest par apgērbu, kāds tolaik valkâts. Sievietes apgērbs sastāvējis no linu krekla, vilnas vai pusvilnas brunčiem (šūtiem vai nešūtiem), plecu segas - villaines, ${ }^{90}$ galvassegas un apaviem. Vïriešu tērps sastāvējis no linu krekla, vilnas vai pusvilnas svārkiem, kas bijuši sajozti ar jostu, no vilnas, pusvilnas vai linu biksēm, cepures ar bronzas spirālēm, autiem un apaviem. ${ }^{91}$ Atrastie apgêrba dalu fragmenti ar bagātu metāla rotājumu, rotaslietas un cits kapu inventārs liecina par sociālo nevienlídzỉbu un škiru attiecību sākumiem. ${ }^{92}$ Šim posmam raksturigi cieši sakari ar kaiminu zemēm un ciltîm. Latgalè nostiprinājās sakari ar austrumu kaiminiem slāviem, bet kuršu un zemgalu teritorijā izdarîtie arheoloğiskie izrakumi liecina par sakariem ar Gotlandes salas iedzīvotājiem un skandināviem ${ }^{93}$

Nākošajam periodam (10.-12. gs.) raksturīga ražošanas spēku tālāka attīstība, feodālo attiecību rašanās un škiriru sabiedrības tālāka veidošanās. Straujas attīstības process nesa sev līdz tālāku sociālo diferenciāciju. ${ }^{94}$ Augstāko slāṇu pārstāvju apbedījumos pieaug rotaslietu daudzums un villainu rotājumu bagātība, turpretim lielākās dalas kapu inventārs satur tikai pašus nepieciešamākos apgēerba gabalus un saktas apg̛ērbu sastiprināšanai. ${ }^{95}$ Vairums no šā laika rotaslietām izgatavotas uz vietas, bet dala ievesta no dienvidiem un austrumiem un liecina par kultūras sakaru tālāku attīstību. ${ }^{96}$

Atrastie linu auduma fragmenti vēl nedod iespēju runāt par kreklu piegriezumu, ${ }^{97}$ bet, spriežot pēc mūsu rīcíbā esošajiem vecākajiem 18.-19. gs. kreklu paraugiem, jādomā, ka 12. gs. Baltijā, tai skaită arī Latvijā, valkāts tunikveida krekls bez uzplečiem ar taisni piegrieztām krekla piedurknëm, bez aprocēm. Piedurknes pie delnas locītavām saturēja rokas. sprādzes. ${ }^{98}$ Dažos kapos atrastas krekla apkakles paliekas, ${ }^{99}$ bet biežie kaklarotu atradumi un kreklu valkāšanas veids vedina domāt, ka plašẩ bijuši izplatīti krekli bez apkaklēm.

Pēc arheolog̣iskajiem materiāliem grūti noteikt, kāds bijis gurnu apgèrbs 12. gs. Latvijas PSR Vēstures muzeja arheolog̣ijas nodalas fondios rekonstrukcijām (jāpiezīmē, ka šîs rekonstrukcijas izdarītas 30 . gados) brunči ir šũti, ar celu apaudu apakšmalā ${ }^{100}$, citās rekonstrukcijās tie rotāti metāla gredzentiniiem, ko vềlāk nomainīja izšuvumti.101 Saskañā ar arheologu norädījumiem, ka brunči bijuši šūti, - tas gan netiek pierādīts ar konkrètu materiālu, t. i., šūtām vīlēm, - pielaujams, ka jau 12. gs bijuši pazisstami šūti brunči, ${ }^{102}$ kas nomainīja nešuto apgēerbu, tāpat kā mūsu kaiminiem iguniem. ${ }^{103}$ Loti maz materiāla ir par víriešu apgèrbu. Pēc prof. H. Mooras domām kā Baltijas, tā Krievzemes tautu vīriešu apgèrbs acīm redzot sastāvējis no linu krekla un biksēm, audekla svārkiem (kaftana) un ādas vai lūku apaviem. ${ }^{104}$

Sieviešu apǵērbā plecu sega - villaine šai laikā (10.12. gs.) jau loti bagāti rotāta, pie kam rotâjums ir visai sarežgìitas kompozīcijas. ${ }^{105}$ Tã kā villainu darināšana bija saistìta ar lielu materiālo vērtību un laika ieguldijjumu, tad bagāti rotātās villaines liecina par to valkătāju piederību pie turīgāko slāṇu pārstāvjiem. Virrieši valkājuši vilnas auduma svārkus, kas pie kakla dažkārt rotāti ar bronzas spirālēm un uz krūtīm sasprausti ar saktu, ${ }^{106}$ ap vidu svārkus saturēja josta. Latgalu vîriešu apgêrérba sastāvdala ir rokauti. ${ }^{107}$ Rokauti atrasti samērā reti un tikai bagātajos kapos, turklāt nav sastopami pēc vācu iebrukuma, tāpēc jādomā, ka tos valkājuši latgalu feodālās virsotnes pārstāvji..108

Sieviešu ġimenes stâvokḷa un vecuma raksturotāja ir galvassega. Jaunavu galvas rota bija vainags, bet precētu sievu - galvas auts vai cepure. Arheologiskajā materiālā vispirms konstatēts metāla vainags. Nedaudzie 6 . gs. bronzas lentes vainagi atrasti zemgalu kapulaukos. ${ }^{109}$ Senākais konstatētais vainaga veids ir posmos savērtu bronzas vijinu vainags, kas saglabājās līdz 13. gs.; 9. gs. pie latgalu vainagiem sāk parädīities dažādi piekarini, važinas un lentes, kas konstatēti arī 13. gs. auduma vainagiem. ${ }^{110}$ Zemgaliem un kuršiem vainagi ar piekariniem nav raksturigi. ${ }^{111}$ Auduma vainagi, kas rotāti ar uzšūtiem bronzas rinkīšiem un stikla krellītem, maz atškiras no 18. gs. tautas tērpa vainagiem un liecina par visai senu tradīciju. Bez metāla un auduma vainagiem 12. gs. pazīstami arî no zirgu astriem pīti vainagi, ${ }^{112}$ kas pēc materiāla sakrīt ar 18. gs. Rūjienas vainagu, bet pēc formas atbilst 19. gs. sākuma Vidzemes sienamajiem vainagiem. ${ }^{113}$

Jaunavas vainagu, kā arī sievas galvas autu lika galvā godos. Sievas gandrīz nekad nestaigãja ar nesegtu galvu. Ikdienā valkātā galvassega, liekas, būs bijusi lakatveida un, saprotams, ne tik grezna, kāds bija galvas auts. Galvas auti arheoloğisko izrakumu materiālā vềl nav konstatēti, bet, spriežot pēc 18. gs. materiāliem ${ }^{114}$ un igaunu etnogrāfiskās literatūras datiem, ${ }^{115}$ tie droši vien būs valkāti. Arī 17. gs. 
rakstītie avoti kā sievu raksturīgāko galvassegu min galvas autu. ${ }^{116}$

Zinämas grūtības rada vīriešu galvassegu formu noteikšana, bet atrastās spirālītes un ādas sloksnīšu fragmenti vedina domāt, ka vīriešiem bijušas apalas, ar metālu rotātas cepures. ${ }^{117}$

Kãjas kã vīrieši, tã sievietes aptina ar autiem, ${ }^{118}$ virs kuriem vilka rotātus âdas apavus. ${ }^{119}$ Lai gan arheologiskajā materiālā konstatēti arī ādas apavu fragmenti, galvenokārt seno pilskalnu vietās, tomēr liekas, ka zemnieku parastäkais apavu veids bũs bijušas lūku vīzes, kas, saprotams, nevarēja saglabăties. ${ }^{120}$

Visu šo tērpa komplektu vēl papildināja valkātāja turỉbai atbilstošas rotaslietas, kas arheologiskajā materiālā sastopamas lielā vairumā.

Vācu agresija Baltijas jūras austrumu piekrastē 13. gs. uz ilgu laiku pärtrauca latviešu tautas dabisko attīstības gaitu. Iebrucēju uzvaras rezultātā feodālisms Latvijā attīsiijâs savdabīgi, jo škiru cīnu šeit saasināja nacionālās pretfunas. ${ }^{121}$ Svešzemnieku jūgā izzūd greznie metāla rotājumi in lielais rotaslietu skaits arī bagāto iedzīvotãju kapos, bet apgèrba materiāls un formas šai laikā izmainās visai maz.

Latvijas iedzīvotāju un to kaimiṇu kopējās cīnas pret vâcu iebrucējiem 13. gs, veicinäja to saliedēšanos un zinămä mểrâ paātrināja latviešu tautības veidošanās procesu. Tomēr feodālā sadrumstalotība, kas turpinājās pêc vãcu iekarotāju lebrukšanas, väjie ekonomiskie un kultūras sakari, ekonomisko un kultūras centru un plašākas tirdzniecības gausā attistības gaita bija par cēloni tam, ka latviešu tautības izveidošanās ieilga uz vairākiem gadsimtiem. ${ }^{122}$

Zinas par Livonijas ${ }^{123}$ zemnieku apgèrbu no 13 . lïdz 16. gs. ir visai niecígas. Arheologiskajā materiālā var gan izsekot rotaslietu formu tālākajai attīstîbai, jo tãs vēl samērä lielos daudzumos sastopamas arī 14. gs. kapos. Nedaudzie rakstîtie avoti un etnogrāfiskais materiāls dod samērā trūeigu ainu par šä laika apgèrbiem, it ipaši par vĩriešu apherbu.

Runājot par feodālismam raksturīgajām šḳirām - zemniekiem un feodāliem Latvijāa, vienmêr jāsaduras ar nacionâlo jautājumu. Tã kā apspiesto zemieku šḳiru veidoja latviể (un igauni), tad uz škiru pretrunu bãzes, kādas pastāvêja starp feodā|liem un zemniekiem, izauga nacionāläs pretfiinas. Par šo pretrunu aso raksturu liecina kaut vai tāds timies fakts, ka ar laiku visus brīvos cilvēkus pat oficiälajos delicimentos sauca par vāciešiem, turpretim nebrīvos dzimthiiiís par neväciem. ${ }^{124}$ Nacionālajäm pretrunäm bija liela nozime Latvijas un Igaunijas vēsturē. ${ }^{125} \mathrm{Ar}$ tām arī zināmā iinçi Izskaldrojama vācu feodālu kultüras niecīgā nozīme lalvies̆u tautas kultüras izveidē; šì kultūra latviešiem nebija ileอemama, jo bija ienīsto «kungu kultūra». Daudz nozīmīGaki vieta latviešu tautas tērpa izveides procesã bija etniskā nătava Izmainåm un kultūras sakariem ar kaiminu tautām. Garajes un smagajos vācu feodālu kundzības un feodâlās Aâriminatalotibas gadsimtos latviešu etniskajā sastāvā notika liẹali pârmainas. Jau līdz 13. gs. Latvijā dzīvojošo cilšu aivlenibu saplušanas procesam lìdztekus bija vērojama arī citu hintibi grupu ieklaušanās latviešu tautībā. Latviešu etnisnie hastava ieplüda pie somugriem piederīgie libieši, kas Wyoja Kurzemes ziemelu un Vidzemes rietumu dalā. Latvis:ii taitibố leplûda arî krievu, lietuviešu, igaunu un citu (ojichi elementi, kas kopă ar bijušajām Latvijā dzīvojošām (i) Grupâm lzveidoja vienotu latviešu tautîbu ar kopēju iviliiflii un valodu. Protams, visi šie procesi savu ietekmi

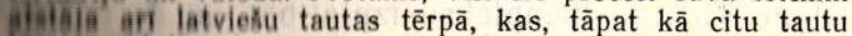
iliê velifalies tautas konsolidācijas procesā. Tautas tērpā

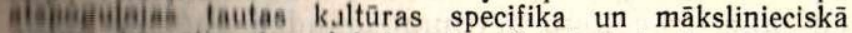
-

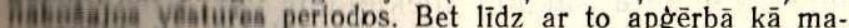

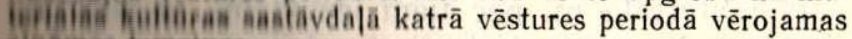

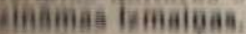

Baineta labir priekbstatu par 13.-18. gs. Livonijas zem-

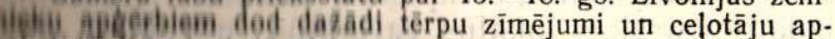

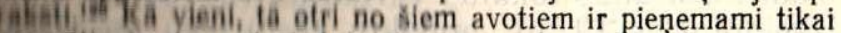

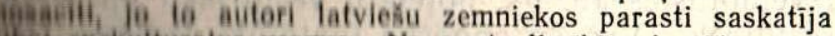

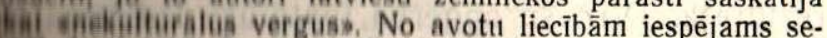

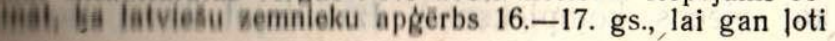

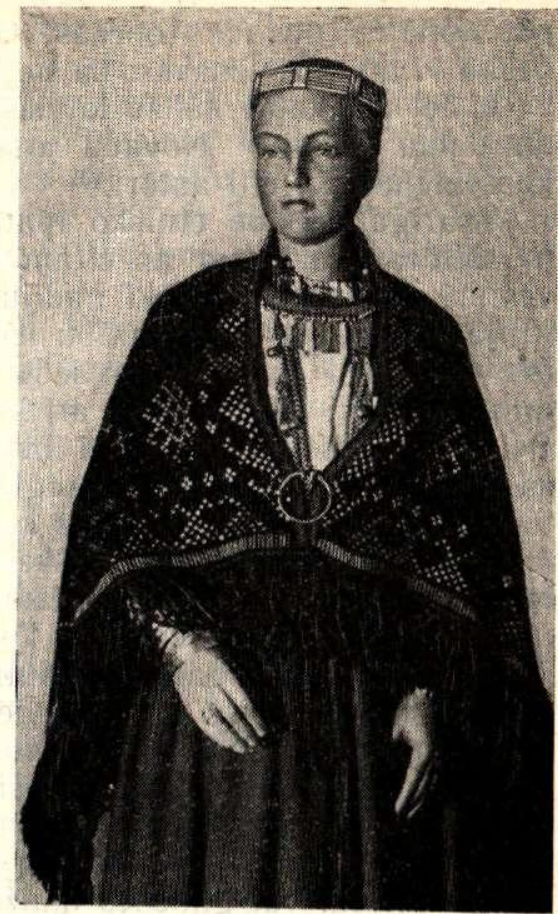

5. att. 12. gs, latgalu sievietes têrpa rekonstrukcija Latvijas PSR Vēstures muzejā.

trūcīgs rotājuma ziñā, sastāv no tiem pašiem apgērba gabaliem, kādi konstatējami arheoloğiskajos izrakumos.

Te jāpiebilst, ka minētie zīmêjumi reproducēšanas nolū. kos tikuši vairākkārt pārzīmēti; pārzīmēšanu izdarījuši cilvēki, kas paši šos tērpus nekad nav redzējuši, tāpēc arī dala detalu ir tā pãrveidota un stilizēta, ka rodas grūtības tâs pareizi interpretēt. ${ }^{127} \mathrm{Ar}$ to zināmā mērã izskaidrojama parādība, ka minētie zīmējumi nesaskan ar tã laika celotāju aprakstiem, proti, zīmējumos apgèerbi ir loti grezni un bagātīgi rotāti, turpretim. spriežot pēc aprakstiem, tie ir loti trūcīgi. Jautäjumu palīdz noskaidrot arheologiskais materiāls. Kä rāda vēstures dati, feodālo karu izpostîtajā un iebrucēju izlaupītajā zemē 13.-15. gs. bieži plosījās bads un mēris, kam nenoliedzami sekoja pagrimums; par to liecina arī arheoloğiskie atradumi: kapu inventärä vairs nav konstatējamas skaistas formas rotaslietas; ${ }^{128}$ rotaslietu forma degenerējas, rotas klūst neglítas, mazvērtígas; sudrabs pamazām no lietošanas izzüd, un arī amatniecības progress nav vērojams. ${ }^{129}$

Tãpēc apšaubāmi ir buržuāzisko autoru vērtêjumi, kas mēginināja pierādīt, ka zīmējumos parādītie apgèerbi liecinot par latviešu tā laika turïbu un ka aprakstos minētā «nabadzíba daudzreiz ir bijusi pärspilēta». ${ }^{130}$ Jāpiezīmē, ka feodālisma posmä, tāpat kã vēlāk, neskatoties uz vispärējo grūto stā. vokli, latviešu turības pakāpe nebūt nebija vienāda, jo līdzās turīgajiem saimniekiem bija arī nabadzīgie, kuriem, kā to norẩda laikabiedri, dažkārt pat nebijis krekla.

Tā kā latviešu zemnieki kā dzimtcilvēki bija piesaistīti zināmam apvidum un, pastāvot naturālajai saimniecībai, visu dzivei nepieciešamo izgatavoja no vietējā izejmateriāla ar primitiviem darba rīkiem, tad šādu apstāklu rezultātā izveidojās savdabīgi etnogräfiski novadi, kas saglabājās līdz 19. gs. vidum, kad sakarā ar kapitālisma straujāku attīstību un vietējā tirgus paplašināšanos radās priekšnoteikumi etnogrāfisko novadu saplūšanai. Tomēr atsevišḳos gadijumos novadu ipatnības saglabājās pat lìdz 20. gs.

Katra šāda novada iedzīvotājiem bija izveidojušies savi darba pañëmieni, iecienitas rakstu kompozīcijas un arī krāsu salikums, kas veidojās un 
papildinājās novada robežās. G. Merkelis savã darbā «Latvieši» izsakās, ka ne tikai katrā apgabalā, bet pat katrā muižā latvieši izturas, geērbjas un domā citādi. ${ }^{131}$ Novadu atšḳirīgās îpatnības konstatējuši arī citi autori. ${ }^{132}$

Svarīga nozīme etnisko īpatnību izveidošanā ir kultūras sakariem ar citām tautām. Latvijas vēsturē ir zināmi vairāki gadījumi, kad tās teritorijā nometināti citu tautību iedzīvotāji, kas vēlāk saplūduši ar vietējiem iedzīvotājiem; līdz ar to savstarpēji asimilējušās arī kultūras îpatnības. Bet šāda procesa rezultātā nebūt nerodas kaut kāda jauna kultūra. Tauta saglabā savas īpatnības un papildina tās ar otras kultūras labākajām formām. Tā, piemēram, Bauskas apkārtnē novietoto «krievinuı» ietekme manāma ipatnējā ornamenta izveidē Zemgales tērpu kompleksā. ${ }^{133}$

Vidzemē un Latgalē sveštautiešu grupas (piemēram, igauṇi, leiši, poḷi) novietotas pēc lieliem kariem un epidēmijām; tāpat no vienas vietas uz otru pārvietoti arī paši latvieši ${ }^{134}$ G. Merḳelis, piemēram, min gadījumus, kad muižnieku sapulce nolēmusi, ka tajos novados, kur vairāk laužu, atsevišḳi cilvēki vai ǵimenes muižniekiem jāpārdod citiem muižniekiem, kuru ļaudis iznīkuši vai gājuši bojā karā. ${ }^{135}$

Neskatoties uz katram novadam raksturīgām atškirībām, latviešu tautas tērpus var iedalīt piecos'lielos tērpu kompleksos - Vidzemes, Latgales, Augšzemes, Zemgales un Kurzemes. Tērpu kompleksu nosaukumi nav saistāmi ar administratīvo iedalijjumu. Katram kompleksam raksturīgs vairāk vai mazāk vienveidīgs apg̀ērba piegriezums, krāsu zieds un apgèrèba rotāšanas principi.

Jautājumam par apgèērba lokālajiem kompleksiem ir sava vēsture. Kă jau iepriekš tika norādīts, 18. gs. autori, kā arī vēlākie pētnieki pievērsuši lielu vērību tautas tērpu nevienveidībai. Buržuāziskie etnogrāfi, aprakstot latviešu tautas tērpus, to klasificēšanai ieteica dažādas shēmas un sastādīja pat «etnogrãfiskas kartes». Balstoties galvenokārt uz rotājuma ornamenta, tika izdalīti $15-29$ apgèrerbu novadi, kas it kā esot raksturīgi noteiktiem apvidiem.

Etnogrāfiskās apgèerbu kartes pirmo reizi publicētas 1926. g. krâjuma «Latvju Raksti» I un II sējumā. Latvijas PSR Vēstures muzejā glabājas J. Jaunzema un $M$. Siliṇa sastādītās kartes; diemžèl, autori nepaskaidro karšu sastādīšanas principus.

M. Siliṇš savā apgèerbu kartê-136 izdala 23 apgabalus, nosaucot tos visai dīvaini - par Kiūliem, Kauḷiem, Augšgaḷiem u. tml., jo pēc $M$. Silina domām Latvijā agrāk esot dzīvojušas tādas ciltis kā latga|i, malēnieši, kūụi, augšga|i, zemgaḷi, kurši, tāmnieki un ventiṇi. ${ }^{137}$ Tātad $M$. Siliňš, sastādot savu apgèrbu karti, par pamatu neemis it kā teritorijas apdzìvotāju dalījumu ciltīs. Dīvainoș cilšu nosaukumus autors nepaskaidro. Pēc
M. Silina domām latviešu raksturīgākās īpatnības vistīrākā veidā saglabājušās Lātavā, kuras centrs esot Krustpils novads (Ungurmuižas, Vīpes un Krustpils pag., kā arī dala no Lìvānu pag.), jo te latvieši neesot sajaukušies ar citām tautãm. ${ }^{138}$ Sāda tautas tërpa analīze ir nepareiza un ir pretrunā kā ar vēstures faktiem, tā arī ar materiālu, ko sniedz paši tautas tērpi. Apgalvot, ka t. s. Lātavā nav notikusi tautu sajaukšanās, ir diezgan pārdroši, vēl jo vairāk tāpēc, ka pa šo rajonu gājuši senie satiksmes ceḷi uz citām zemēm. Bez tam zināms, ka pēc Ziemeḷu kara Vidzemē un tātad arī Krustpils apkārtnē sākās bads, kā rezultātā aizgāja bojā daudz zemnieku. Bojā gājušo vietā muižnieki iepirka zemniekus citos Latvijas rajonos. Beidzot, Krustpils tipa villainē, kuru M. Silinš uzlūko par raksturīgāko latviešu mākslas paraugu, vērojama samērā jauna tehnika, kas parầās Latvijā tikai 17. gs. ${ }^{139}$ Tāpat arī Krustpils krekla piegriezums ir jaunāks par Kurzemes kreklu piegriezumu, un bez tam pirmajam ir daudz kopēja ar slāvu kreklu piegriezumu (par to sīkāk 2. nodalāā). Tāpat, liekas, ka nav nekāda pamata izcelt Krustpils tērpu kā pilnīgāko un skaistāko, jo, objektīvi vērtējot, katra novada tērpā ir savs savdabigs skaistums.

Zīmīgi, ka J. Jaunzems savā kartē no pierobežas apgabaliem izdala tikai rajonus, kas robežojas ar KPFSR un Baltkrievijas PSR, un nosauc tos vienkärši par pierobežas apgabalu. Gar Lietuvas un Igaunijas robežu J. Jaunzems šādu «pierobežas apgabalu» neizdala. Tas liecina, ka autors neatzīst kultūras sakaru mijiedarbību, jo citādi nav saprotams, kāpēc šādi pierobežas apgabali nav izdalīti arī gar citām robežām. Iespējams, ka J. Jaunzems, sastādot savu etnogrāfisko karti, ir turējis prātā tikai vienu materiālās kultūras nozari - apgèērbu, jo attiecībā uz celtniecības, darba rīku vai apgēerbu materiālu šāda pierobežas zona neizdalās. Bez tam karte nav datēta.

J. Niedre, sastādot etnogrāfisko karti, gandrīz visu Latvijas dienvidaustrumu dalu ietver vienā apgabalā, kuru dala Krustpils, Lielvārdes un Piebalgas novadā. ${ }^{140}$ Liekas, ka šăda dalījuma pamatả ir izšūtās Austrumlatvijas villaines, bet arī tās neatspogulo visu apgèēba dalu ipatnïbas.

Pēc mūsu domām pareizāk būtu, pamatojoties uz vēsturisko apstākḷ un etnogrāfiskā materiāla pētījumiem, apvienot tērpus piecos kompleksos, vēl jo vairāk tāpềc, ka kompleksu izplatības teritorijas zināmā mērā sakrīt ar seno cilšu apvienību teritorijām. Tas, ka kompleksu izplatības un šo teritoriju robežas zināmā mērā sakrīt, nav nejaušība, jo, kā rāda arheologu pētījumi, daudzu apğērba dalu un ornamenta sākumi meklējami jau arheolog̀iskajā materiālā un pēc tiem iespējams skaidri izšḳirt katrai cilšu apvienībai raksturīgās iezīmes.

Šo piecu pamatkompleksu ietvaros iespējams izdalīt vairākus lokālus variantus (novadus), kas izveidojušies 19. gs. noteiktu vēsturisku apstākḷ rezultātā. (Vīriešu apg̀ērba îpatnības izdalītas tikai piecos kompleksos.) Izveidojot kompleksus, 
ñemtas vērā visas apgèrba dalu îpatnības, kā piegriezums, tā arī ornaments; lielāka nozīme šai zinā ir krekla ipatnībām, jo te saglabājušies senā. kie elementi. Par pamatu tērpa rotājuma analīzei nemts goda apgèrbs, jo tā rotājums ir visbagātākais.

Pêtot latviešu tautas tērpu kompleksus, ne vienmêr iespējams noskaidrot atsevišḳu elementu izcelsanos. Daudzas tautas tērpa elementu izmaiñas ir Jaunāka gājuma un saistîtas ar pilsētas kultūfas izplatī̌sanos lauku sētās, bet daudzas īpatnības sniedzas tālā pagātnē, un to sākumi meklējami jau cilšu īpatnībās. Tas nenozīmē, ka ekonomiskie un vêsturiskie apstākḷi nebūtu ietekmējuši apgēerba izmainas; šai sakarā jāpiezīmē, ka jāatšḳir šo izmainu pārejošā, nepastāvīgā dala no paliekošās, raksturīgās. Tā, piemēram, ar metālu rotātas villaines pazīstamas jau kopš 7. gs., bet ir zināms, ka ekonomisku un vēsturisku apstākḷ maiṇas rezultātā 13. un 14. gs. metāla rotājumu pakāpeniski nomaina stikla zīlīšu rotājums, kuru savukārt 16 . un 17. gs. sakarā ar izšǔšanas mākas straujāku attīstību un latviešu tuvināšanos citām tautām nomaina krāsains izšuvums. Izšūšanas tehnikas săkumi saskatāmi jau 12. gs. villainēs. ${ }^{141}$ Tādējādi, izmainoties rotājumam, latviešu villaines savas raksturīgās îpatnējās formas tomēr saglabāja.
Vidzemes tērpu komplekss aptver teritoriju, kur senatnē dzīvojuši latgaḷi un lïbieši; tās robežas dalēji sakrīt ar Vidzemes 20. gs. administratīvā dalījuma robežām. Vidzemes tautas tērpu kompleksā atspoguḷojas arī kultūras mijiedarbība ar kaimiṇiem igauniem, jo ar tiem šîs teritorijas iedzivvotāji vairākus gadsimtus bija polïtiski un ekonomiski saistīti.

Vidzemes tērpu kompleksā iespējams izdalīt 6 variantus - Rietumvidzemes, Ziemelvidzemes, Piebalgas, Lielvārdes, Krustpils un Austrumvidzemes. Krustpils tērpā, tā kā novada ${ }^{142}$ centrs Krustpils - atrodas uz Latgales robežas un vairākus gadsimtus bija administratīvi saistīts ar Latgali, ir daudz Latgales tērpu kompleksam raksturīgu iezīmju, tāpēc dažkārt tas tiek pieskaitīts Latgales tērpiem. ${ }^{143}$

Latgales tērpu komplekss izveidojies teritorijā, kur senāk dzīvojuši latgaḷi. Atšḳirībā no vidzemniekiem, kuru pamats arī galvenokārt veidojies no latgaliiem, Latgales kultūru un tātad arī apğērbu stipri ietekmējuši Latgales îpatnējie ekonomiskie, vēsturiskie un ğeogrāfiskie apstākḷi (iedzīvotāju pelnās iešana, jauktais iedzīvotāju sastāvs, zināmā mērā to ietekmējusi arī atškirīgā reliğija).

Latgales kompleksā izšḳirami 2 varianti Dienvidlatgales un Ziemellatgales.

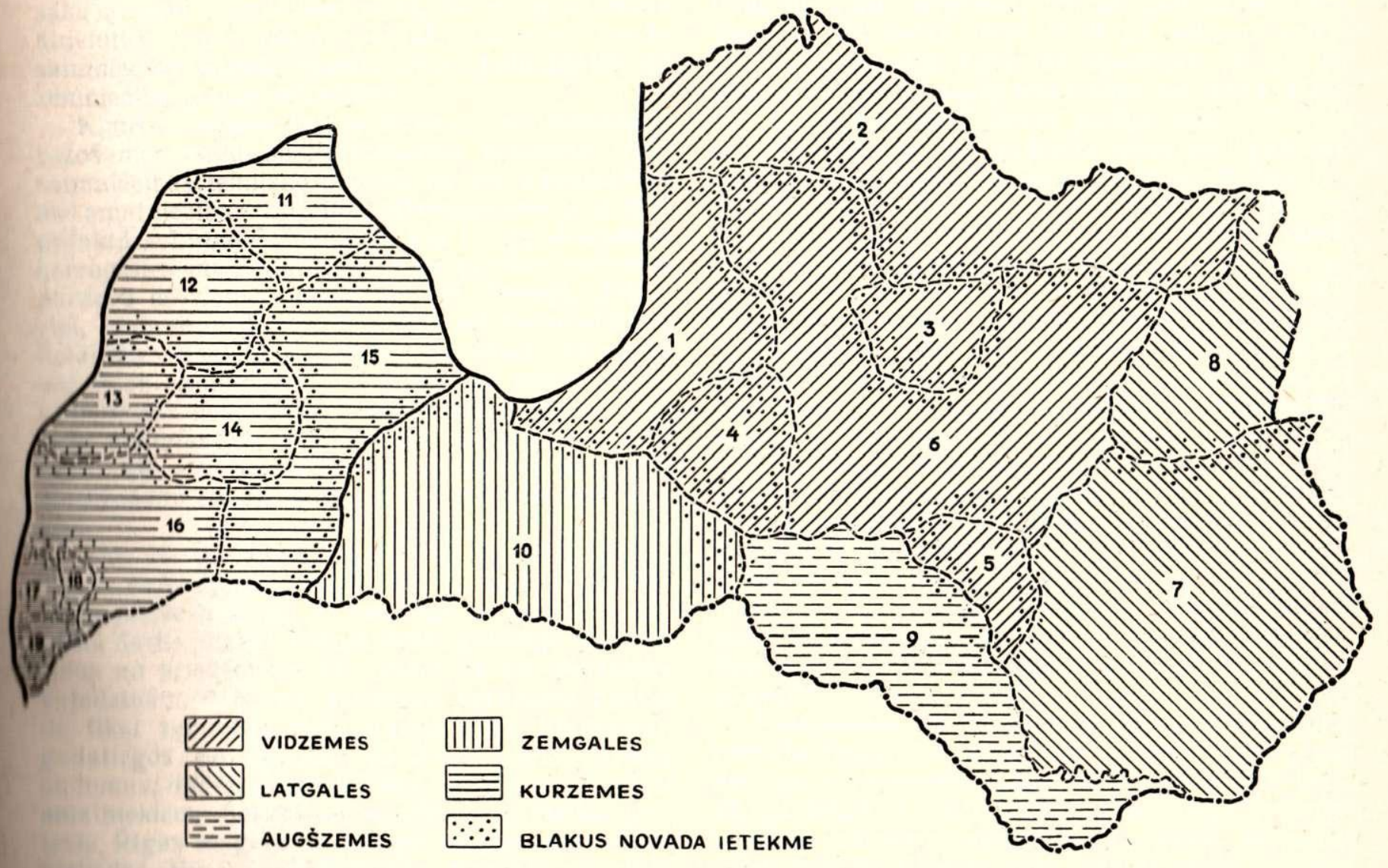

6. att. Latviešu apgeērbu kompleksi un to lokālie varianti 19. gs. sākumā:

L Hieiumvidzemes: 2 - Ziemelvidzemes; 3 - Piebalgas; 4 - Lielvārdes; 5 - Krustpils: 6 - Austrumvidzemes; 7 - Dienvid15 - Austrumkurzemes; 16 - Dienvidkurzemes; (17-19 - Nìcas, Bārtas, Rucavas). 
Augšzemes kompleksa tērpi izplatīti teritorijā, kur senāk dzīvojuši sēḷi. Pēc savām raksturīgākajām iezīmēm tērpu atsevišķas sastāvdalas tuvas Vidzemes, Latgales un dažreiz arī Zemgales kompleksa tērpiem. Tomēr Augšzemes tērpu komplekss izdalāms atsevišḳi, jo kreklu tips ar piešūtiem uzplečiem, kāds izplatîts Augšzemē, nav sastopams iepriekš minētajos kompleksos, izṇemot Lielvārdes novadu.

Zemgales kompleksa tērpi valkāti seno zemgalu apdzìvotajā teritorijā. Zemgales komplekss veidojies īpatnējos vēstures apstākḷos. 13. gs. zemgali, cinṇā ar vācu iebrucējiem cietuši sakāvi, devās uz Lietuvu, bet viṇu zemē ienāca citu novadu iedzīvotāji; starp citu, Zemgalē tika nometināti arì somu voti. Zemgales novada īpatnību veidošanā sava nozīme bijusi arī hercoga Jēkaba manufaktūrām. Tāpat novada iedzīvotāju ciešie sakari ar kaiminiem lietuviešiem veicināja atškirīgu tērpa valkāšanas tradīciju izveidošanos.
Kurzemes kompleksa tērpi izplatīti teritorijā, kur senāk dzīvojuši kurši un lībieši. Kurzemes lībieši asimilācijas procesā savas îpatnības saglabāja daudz ilgāk nekā Vidzemes lỉbieši. Zinămā mêrā tas atspogulojas arī tautas tērpos. Bez tam šo teritoriju nav skāruši tādi postoši kari kā pārējo Latviju, tāpēc arī šeit atsevišķas loti senas tautas tērpu iezīmes saglabājas ilgāk, dažos novados pat līdz 20. gs. vidum. No otras puses, tieši Kurzemes tērpu kompleks̄ā saglabājušies visvecākie apgeērba gabalu rotājumi - zilās mēlenes ar metāla rotājumu un metāla vainadziṇi. Kurzemes kompleksa izplatības robežas gandrìz sakrīt ar buržuāziskajā Latvijā pastāvošajām Kurzemes administratĩvajām robežām. Tērpa kompleksa atšḳirīgas īpatnības ir kreklu rotājums, īpatnējās villaines, metāla jostas, metāla vai zịlu vainagi ar cietu pamatni un spēcīgais krāsu zieds.

Kurzemes tērpu kompleksā 6 varianti: Ziemelkurzemes, Ventspils, Alsungas, Kuldīgas, Austrumkurzemes un Dienvidkurzemes. 


\section{APG̣ERBA MATERIĀLS, VEIDI UN VALKĀŠANAS TRADİCIJAS}

Lai gan 18. gs. beigās un 19. gs. sākumā Latvija vēl bija feodāli dzimtbūtnieciska zeme, tomēr šai laikā muižu saimniecībās arvien vairāk iespiedās preču-naudas attiecības. Muižnieki centās klaušu saimniecības produktu lielāko dal̨u pārvērst precēs, ko pārdeva vai nu vietējā tirgū, vai izveda uz ārzemēm. Viskrievijas tirgus izveidošanās zināmā mērā ietekmēja Baltijas muižu saimniecisko attīstību, radot izmaiṇas arī klaušu zemnieku dzīves veidā.

Sākot ar 18. gs. beigām, muižnieki pastiprināti sāka atñemt zemniekiem zemi, lai uz zemniekiem atñemtās zemes rēḳina paplašinātu savu muižu saimniecību. Klaušu apmēri arvien palielinājās, un zemniecība grima nabadzībā.

Klaušu saimniecības sairums un kapitālistiskās ražošanas veida nostiprināšanās veicināja lauksaimniecíbas tehnisko nozaru, kā arī manufaktūru un amatniecības attīstību. Dzimtbūtnieciskā ma. nufaktūra Latvijā izveidojās jau 17. gs. Kurzemes hercogistes manufaktūras savus ražotos audumus părdeva ne vien Vidzemē, bet arī Krievijā, Zviedrijā, Lietuvā un Polijā..$^{144}$ Tomēr šîs manufaktūras lielăkoties pastāvēja samērā îsu laiku un agrāk vai vểāk panīka, jo bija radušās uz vēsturiski un ekonomiski nepietiekami sagatavotas bāzes. Latvijă manufaktūru rūpniecības vēsture praktiski sâkas 18. gs. beigās. ${ }^{145}$ Manufaktūras un preču silkražošana 18. gs. beigās bija izplatītas visā Latvijä.

Lidz 18. gs. vidum un vēl ilgi pēc tam rūpnieeiskâs ražošanas pamatā Latvijā bija zemniekainajamatnieka darbs uz laukiem un cunftu amatilielia darbs pilsētā. Dzimtcilvēki gatavoja dažādus fikiin un priekšmetus kā savām, tā arī muižnieku va)adnbaลm. ${ }^{146}$ Nereti zemnieku ražojumu pietika ie 'lika remnieku pašu vajadzībäm. Sīkražotāji Haidaliriges un pilsētās pārdeva savus ražotos andianai tâdéjâdi konkurējot ar pilsētu cunftes aiiialiilekiem. Sakarā ar cunftes amatnieku proleăii Rigan maêsistrăts 18 . gs. beigās zemniekiem gialiedza Rigas priekšpilsētās tirgoties ar pašu darinatiem audekliem. Par lauku amatnieku kon. lìrene ar pilsêtu amatniekiem liecina arī Kurzeines liercoga 1772 . g. aizliegums lauku amatnie- kiem un zemniekiem pārdot savus darinājumus lielos daudzumos. ${ }^{147}$ Tomēr jāsaka,. ka visumā 18. gs. un 19. gs. pirmajā pusē amatniecība un preču sīkražošana Latvijā bija attīstīta samērā vāji un vēl bija saistīta ar lauksaimniecību.

Viena no svarīgākajām mājamatniecības nozarēm bija vērpšana un aušana. Zemniekiem kā nodevu dala bija jānodod muižai savērpti lini vai noausts audekls. Lìdz ar tirdznieciskās zemkopības attīstību muižnieki pelnas ieguvei sāka izmantot arī mājamatniecības nozares, izdodot zemniecēm linus uz māju vērpšanai vai arī ziemas mënešos sasaucot tās muižā vērpt. ${ }^{148} 19$. gs. sākumā vairākās kroṇa muižās Kurzemē atjaunoja 18. gs. izbeigtās un vakas naudā ieskaitītās vêrpšanas klaušas, kuras zemnieku sievas pildīja mājās. ${ }^{149}$ Dalu savērpto linu un linu audumus muižnieki patērēja savām vajadzībām, bet daḷ pārdeva vietējos tirgos. ${ }^{150}$ Ërtais ūdenscelı̌ - Daugava, kas saistīja Latgali ar Rìgas ostu, deva iespēju Latgales muižniekiem linu škiedras un linsēklas eksportēt uz ārzemēm. ${ }^{151}$ Spriežot pēc $O$. Hūna atzīmēm, pašaustie linu un vilnas audumi nebijuši visai labas kvalitātes; valdošās šḳiras pārstāvji kā pilsētās, tā uz laukiem parasti valkājuši no ārzemēm ievestus linu audumus ${ }^{152}$ vai arī iegādājušies profesionālo audēju ražojumus. ${ }^{153}$ Vilnas audumus muižnieku un pilsētnieku augstāko slānu vajadzībām tāpat ieveda no ārzemēm vai Iekškrievijas guberṇām; tie bija smalkāki un vairāk atbilda augstāko kārtu gaumei. 18. gs. otrajā pusē arvien vairāk samazinājās muižai strādājošo kurpnieku un drēbnieku skaits, jo tie, pieaugot muižnieku dzīves standartam, vairs nespēja apmierināt feodālu prasības. Par modes lietu kluva pilsētā gatavoti uzvalki un apavi. ${ }^{154}$

Neskatoties uz feodālisma laikā valdošo nerakstīto likumu - zemnieku saimniecībām sagādāt sev visu nepieciešamo mājamatniecības ceḷā, 18. gs. beigās Latvijā iezīmējoties naturālās saimniecības sairuma pazīmēm, turīgākie zemnieki vairs neiztika tikai ar savā sētā saražoto un sāka pirkt amatniecības ražojumus. Tas viss saistāms ar zemnieku diferenciācijas pastiprināšanos. Diferenciācija, vismaz Rīgas tuvumā dzīvojošo zem- 


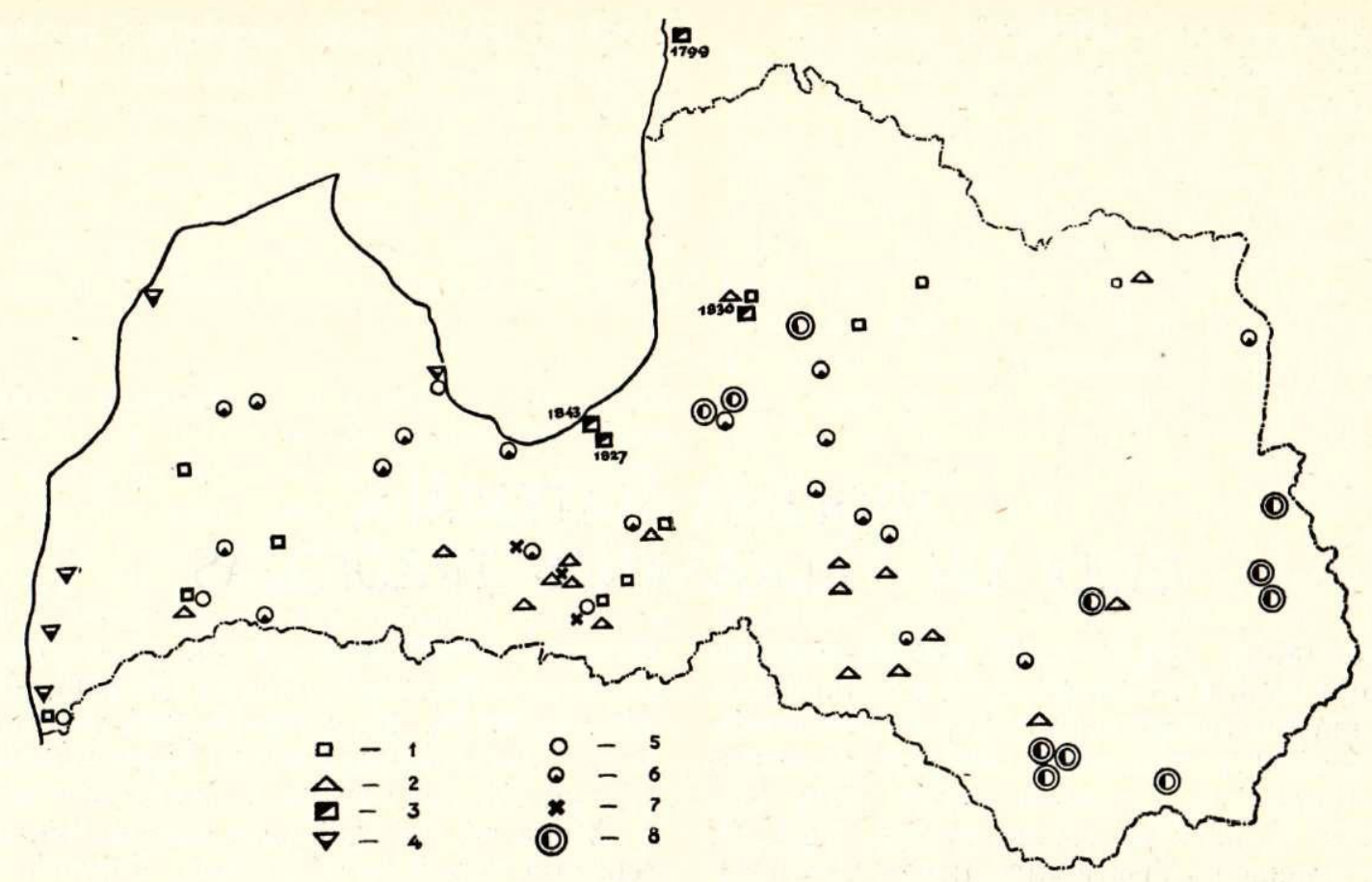

7. att. Manufaktūras un fabrikas 17. gs. - 19. gs. pirmajā pusē:

$I$ - vadmalas austuves; 2 - linu austuves; 3 - kokvilnas apstrādāšanas; 4 - dzintara virpotavas; 5 - veltuves; 6 - stikla cepli; 7 - tapešu audumu darbnĩcas; 8 - ādu apstrādāšana.

nieku vidū, jau bija tik spēcīga, ka turīgākie zemnieki nebija vairs mierā ar pašu mājas sieviešu šūtajām goda drēbēm, bet valkāja jau īpaša skrodera šūtus apgèrēbus. ${ }^{155}$

Svarīga nozīme vērpšanas un aušanas tehnikas tālākajā izveidē bija gan manufaktūru un amatniecības attīstībai, gan arì pilsētu amatniekiem, kas uz laiku strādāja muižās. Lai celtu darba ražigumu, muižnieki ieteica vārpstiṇu nomainīt ar vērpjamo ratiṇu, kas 18 . gs. izplatījās visā Latvijā. ${ }^{156}$

Tirgus ietekmë vispirms muižu amatniekiem, bet pēc tam arī zemnieku sētās parādās platāki aužamie stāvi. ${ }^{157}$ Manufaktūrās austo audumu tehnikas pārveidotā formā ieviesās arī mājrūpniecībā.

19. gs. pirmajā pusē, neraugoties uz prečunaudas saimniecỉbas vēršanos plašumā, zemnieku saimniecību lielākajai daḷai joprojām bija naturāls raksturs: zemnieks pats gatavoja mājās nepieciešamos darba rīkus, bet zemniece pati noauda ikdienai un godiem nepieciešamās drānas. Lauku amatnieku pakalpojumus varēja izmantot tikai zemniecības turīgākā daḷa, kas bija samērā niecīga.

19. gs. 30. gados Latvijā sākās rūpniecības apvērsums. ${ }^{158}$ Pats lielākais ekonomiskais un kultūras centrs bija Rīga, bet arī citās pilsētās bija manufaktūras, kas ražoja apg̀ērba un apavu materiālus. 19. gs. 20. gadu vidū Rìgas kapitālistiskajā rūpniecībā pieauga kokvilnas un vilnas izstrādājumu ražošanas nozime. Tomēr zemnieku saimniecībās tiem vēl būtiskas nozīmes nebija. Arī dzimtbūšanas atcelšana 1817 . un 1819. g. faktiski neiznī- cināja zemnieku atkarību no muižniekiem. Visa zeme, tai skaitā arī tā sauktā zemnieku zeme, palika muižnieku īpašums, un līdz 60. gadiem Latvijā zemnieku-zemes ipašnieku bija loti maz. ${ }^{159}$ Latviešu tauta 19. gs. sākumā joprojām bija darba nomāktie dzimtcilvēki. Klaušu noma un citas dzimtbūtniecisko attiecību paliekas, bet Latgalē arī dzimtbūšanas saglabāšanās un zemnieku vispārējā nabadzība stipri ierobežoja rūpniecības preču pa. tērinu. ${ }^{160}$ Iekšèjā tirgus šaurie ietvari savukārt kavēja kapitālistiskās lielrūpniecības attīstību. ${ }^{161}$ Tikai loti neliela latviešu dạ̣a atradās labākā stāvoklī. Tie bija daži muižu nomnieki, sīki uzñēmēji u. c. kungu labvēlību izpelnījušies muižnieku «rokaspuiši» - krodzinieki, dzirnavnieki u. c. Tomēr arī tie nepiederēja pie kungu kārtas un locīja muguras vācu baronu un citu kungu priekšā. Tā laika ekspluatatoru škiras bija muižnieki un augošā buržuāzija, kas rekrutējās gandrīz vienīgi no vāciešiem. ${ }^{162}$ Vācieši gèrbās pēc tolaik Rietumeiropā valdošās modes, bet to līdzskrējēji - krodzinieki, dzirnavnieki u. c. centās līdzināties kungu kārtai. ${ }^{163}$

Pirmskapitāliśma laikā un vēl 19. gs. pirmajā pusē zemnieki dalījās māju nomniekos jeb saimniekos, kalpos un val̨iniekos. Neraugoties uz pastāvošajām pretrunām, saimniekus un kalpus joprojām vienoja kopējā cīṇa pret muižniekiem. 30 gados loti smags kḷuva vaḷinieku stāvoklis; tie izeju no nabadzības meklēja, dodoties pat ar visām ğimenēm uz pilsētu. Tieši šo valinieku un peḷnās gājēju apgèērbā visātrāk ieviesās jauni ma- 
teriāli un apg̀ērbu formas. Smagais klaušu jūgs ne|āva saimniekiem krasi izdalīties no vispārējās zemnieku masas, jo kā saimnieku, tā kalpu apgèrbu darināja uz vieniem un tiem pašiem aužamajiem stāviem. Turpretim apgèēba krājumu un rotājumu ziṇā kalpu un saimnieku apgêerbi bija jau atšḳirīgi.

Pārejot uz naudas nomu un iepērkot mājas, săkầs straujāka zemnieku diferenciācija. Ja arī tăs rezultātā trūcīgās un daḷēji arī vidējās saimniecības zemnieki apgēēbu materiālu joprojām auda pašu mājās, tad turīgie saimnieki goda tērpiem sāka pirkt fabrikās austus audumus un, cenzdamies atdarināt muižniekus un pilsētu buržuāziju, kā pirmie atteicās no tradicionālajiem tautas tërpiem. ${ }^{164}$

19. gs. otrajā pusē, sevišǩi 70 . un 80 . gados, sakarā ar kapitālisma straujāku attīstību, rūpniecības ražojumu ieviešanos un pilsētas modes ietekmes pastiprināšanos laukos tērpus jau masveidā papildināja ar rūpniecības ražojumiem, līdz beidzot tos nomainīja pēc pilsētas modes šūti apgèrbi. ${ }^{165}$

S̄ā posma arhīvu dokumentos un citos vēstures avotos aizvien biežāk minēti apgērba gabali no pirkta materiāla. Visbiežāk minēti zīda vai kokvilnas galvas lakatinii, ${ }^{166}$ bet 80 . gados vairāk sāk minēt «bukstina drëbes», «pirktos brunčus», «katūna jakas», «muslīna lakatus». ${ }^{167}$ Turīgāko zemnieču apg̀ērbu liela dal̨a darināta no pirkta materiāla. ${ }^{168}$ Turpretim mazturīgāko zemnieku un laukstrādnieku apg̛ērbi gandrīz visi vēl darināti no pašausta materiāla. ${ }^{169}$

Jāatzīmē, ka kapitālisma. attīstība Latvijas lauksaimniecībā norisinājās ne revolucionārā celā, bet pa t. s. prūšu celı. Tūkstošiem zemnieku saimniecības tika izputinātas, daudzus zemniekus muiž. nieki izlika no iekoptām mājām, tās ar visu zemi pievienojot muižām. Zemnieki, kam bija izdevies iekrāt kādu mazumu naudas, bija ieinteresēti iepirkt no muižniekiem zemi. ${ }^{170}$ Saprotams, ka, līdzeklus krājot māju iepirkšanai, zemnieku saimniecībās vēl aizvien bija loti maz liekas naudas pirkto apg̉ērbu iegādei. Tāpēc arī, neskatoties uz kapitālisma straujo attīstību, 19. gs. otrajā pusē lielākā zemnieku dala apg̣ērbu turpina darināt mājās, lai gan piegriezumâ jau šai laikā dominē pilsētu modes.

\section{AUDUMU DARINĀSANA UN APSTRĀDĀS̄ANA}

Galvenais zemnieku apğērba materiāls feodālisma laikmetā ir vilna un lini, kuru apstrādāšana gūlās uz zemnieču pleciem. ${ }^{171}$

Aušana Latvijas PSR teritorijā bija pazīstama jau loti sen; par to liecina arheologiskajos izrakumos atrastās primitīvo aužamo stāvu un vērpjamo skriemeḷu paliekas. Pēc arheolog̀es A. Zariñas atzinuma 19. gs. sākumā izplatītās apgēerba darināšanas tehnikas bijušas pazisstamas jau 13. gs. ${ }^{172}$ Ražošanas spēku un ražošanas attiecỉbu attīstîbas rezultātā horizontālie aužamie stāvi parādījās 12 . gs. latgalu teritorijā. ${ }^{173}$ Tiem bija nozìmīga vieta aušanas tehnikas pilnveidošanā. Horizontālie aužamie stāvi pakāpeniski, vairāku gadsimtu laikā izspieda mazražīgākos vertikālos stāvus. ${ }^{174} 18$. gs. beigâs jau pazīstami uzlaboti horizontālie aužamie stāvi, kuru platums tāpat kā vẻlāk, 19. gs., ir $90-125 \mathrm{~cm} ; 175$ ar nelielām variācijām tie izplatīti visā Latvijā. Apgèērba audumu platumam bija liela nozīme, jo tas zināmā mērā veicināja îpatnēja piegriezuma izveidošanos (tunikveida krekli un brunči no viena auduma gabala).

\section{AUDUMI}

19. gs. sākumā bija pazīstamas šādas apgēērba audumu tehnikas: pamatpinumi - vienkārtnis, triiitis, atlass un daži vinu atvasinājumi, piemēram, ripss. Pašu vienkāršāko no tām - vienkārtni (8. att., 1) - auda ar divām nī̌u kārtām. No vien- kārtṇa audekla darināja kreklus, snātenes, priekš. autus, aubes un rūtainos vilnas brunčus, kā arī vīriešu un sieviešu virsdrēbes, jakas un nieburus.

Vertikāli svītrainos brunčus auda audu ripsā; to auda tāpat kā vienkārtni, tikai velkus savilka retā šḳietā, tāpēc aužot iekšaudi pilnīgi nosedza velkus, audumā veidojot ripsa audumiem raksturī. gas vertikālās līnijas (8. att., 2).

Trinīti auda ar trīs vai četrām nīšu kārtām. Aužot pēc šīs tehnikas, audumā izveidojās diagonālas svītras (8. att., 3), jo aužot raksts ar katru nākošo audu kārtu regulāri pavirzījās tālāk pa vienu diegu. Triniša audumus lietoja villainēm, ñieburiem, jakām un vīriešu biksēm, svārkiem un virsdrēbēm. Pazīstams abpusējais, velku un audu trinìtis. Velku trinītī auduma labajā pusē pārsvarā redzami velki, bet audu trinitim - audi. Abpusējā 4 rūšu trinītī austas villaines no 9. līdz 12 . gs.

Auda arī rakstainā trinītī (8. att., 4) (acainī, krusta trinīīi). No šādā tehnikā austiem audumiem, piemēram, šuva sieviešu kreklu augšdalas Ziemelllatgalē.

Atlasa pinumā (8. att., 6) audu diegs škērso ik trīs velku diegus, vienu izlaižot. Lai dabūtu šādu audumu, velkus vienmēr nem smalkākus par audiem, lai tie virspusē nebūtu redzami. Atlasa pinumā, piemēram, austs Bārtas un Rucavas novadu brunču audums.

Rakstainiem audumiem ar sarežg̀itu diegu pinumu lietotas vairākas nīšu kārtas, kā arī attiecīgi vairākas paminas. Tāds, piemēram, ir drellu raksts Rucavas novada snātenēs. 

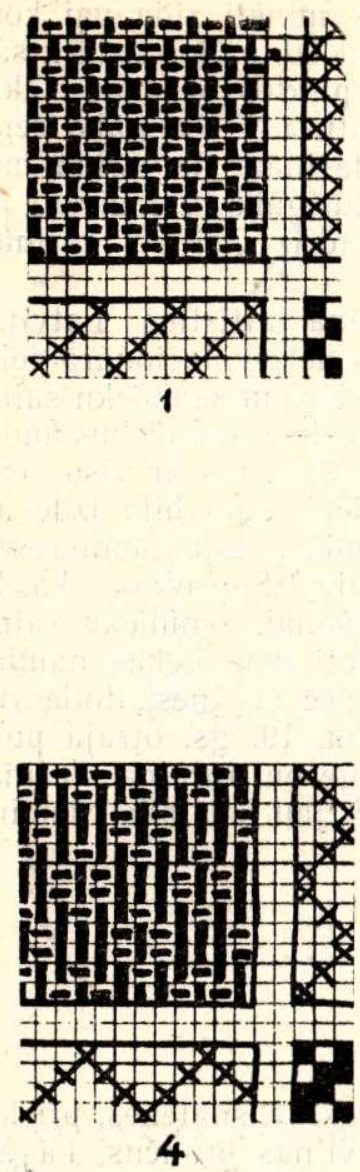

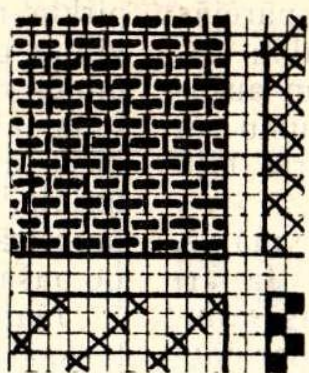

2

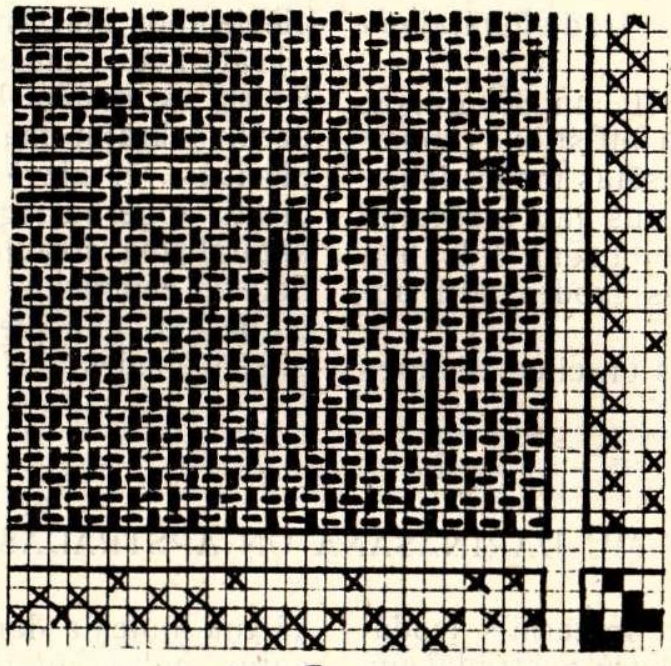

5

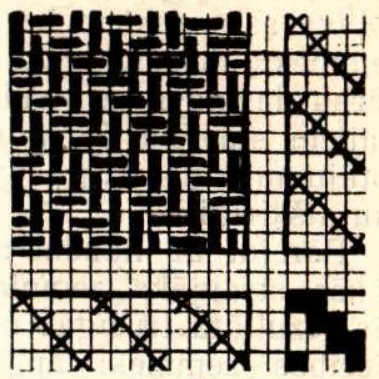

3

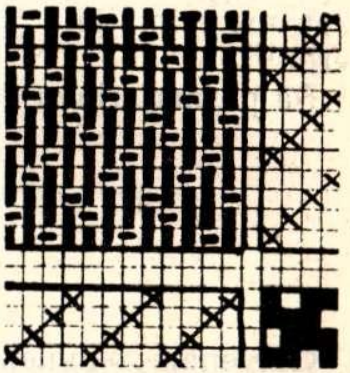

6

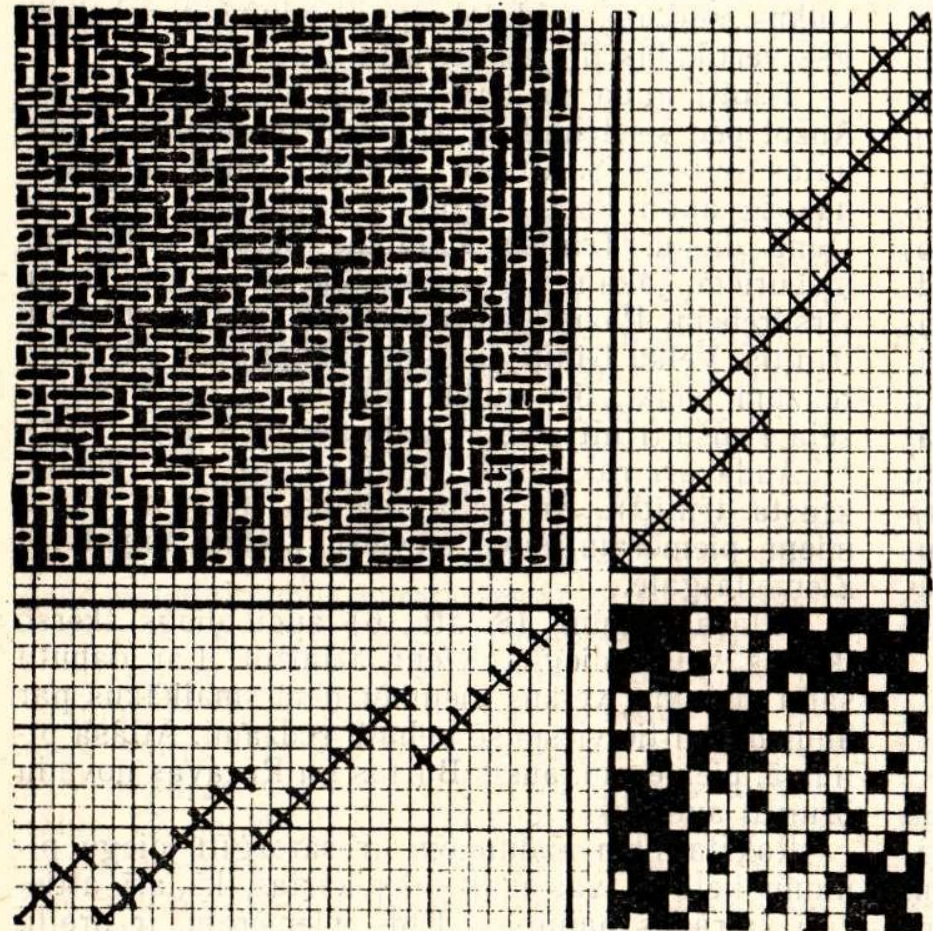

7
8. att. Audumu tehnikas:

1 - vienkārtnis; 2 - vienkārtña ripss; 3 - trinītis: 4 - krusta trinitis; 5 - pubulainais audums; 6 atlass: 7 - atlasa drellis. 
Vienkārtnim un abpusējam trinītim, kur velki un audi virspusē redzami vienādā mērā, lietoti vienādi smalki velki un audi. Tādiem audumiem kā audu ripss, audu trinitis un audu atlass velkiem nēma linu diegus, audiem - vilnu.

Rakstaino audumu krāsaino rakstu parasti ielasīja, un tas ir izšūtā ielocītā raksta priekštecis. Ielasîtā rakstā austi vecākie Ziemeḷlatgales kreklu uzpleči un piedurkṇu augšgali, kā arī Dienvidkurzemes villaines.

Vissarežg̀îtākā ir Zemgales brunču audumu tehnika: tos aužot, rakstu ielasīja ar skalu palīdzību. ${ }^{176}$

Mežg̀iṇveida audumā austas Latgales snātenes. ${ }^{177}$

Savdabīgus brunču rakstus panāca, krāsojot dzijas ar pārsējumiem (Augšzemē) vai sašḳetinot divu krāsu dzijas (Kurzemē).

\section{LINU BALINĀSANA UN VILNAS VELSANA}

Goda apgeērbiem linu audumu vienmēr balināja. Balināšanas process sākās jau ar dzijas balināšanu un mazgāšanu; labākus rezultātus guva, balinot audeklus. Vecākais linu audumu balināšanas veids ir balināšana saulē, audumu samērcot mīkstā $\bar{u}$ denī. ${ }^{178}$ Otrs veids ir balināšana ar sārma palīdzību. Linu vai pakulu audumus parasti vispirms labi izvelēja vai vārīja stiprā sārmā ${ }^{179}$ un slapjus žāvēja saulē (izkarot uz žogiem vai izklā. jot zālē). Kad audekls izžuva, to atkal iemērca un izlika saulē. Šo procesu atkārtoja vairākas reizes gandrīz mēnesi no vietas, kamēr audekls kluva pilnīgi balts. Balināšanas laikā audeklu atstāja ārā kā dienu, tā nakti, jo arī rasa veicināja balinā. šanu.

Izžuvušie linu audumi bija nelīdzeni un cieti, tāpêc, lai tos padarītu piekḷāvīgus un spožus, audumus kūla. Vienkāršākais audekla kulamais darba rīks ir apala koka vāle. Salocitu auduma gabalu uzlika uz koka bluksa un, visu laiku grozot, dauzīja ar vāli. Dažkằrt audumu rullēja uz apaļa gluda koka veltṇa uztīto audumu vāḷāja zem rullējamā dēla, kura apakšpuse varēja būt gluda vai rievaina. Śie audekla un velas apstrādãšanas veidi dažuviet pazīstami vēl šodien. ${ }^{180}$

Vilnas audumus virsdrēbēm un vīriešu svārkiem pēc nonemšanas no aužamiem stāviem vēla. Līdz 19. gs. otrajai pusei audumus vēla ar rokām mājas apstākḷos. Audumu vēla tādēl, lai tas kḷūtu biezāks un mīkstāks. Vēla parasti vasarā, bet, ja bija nepieciešamība velt ziemā, tad rūpējās, lai telpas būtu siltas, jo siltumā audums vêlās labāk. Noteiktas telpas velšanai nebija, parasti vēla pirtī vai citā kādā telpā, vasarā arī upmalā vai skaidienā. ${ }^{181}$ Velšanas laikā bija rūpīgi jāseko, lai saglabātos vajadzīgā temperatūra un audums būtu pietiekami mitrs. Ierīces, uz kurām vēla vadmalu, bija primitīvas un loti dažādas. Viens no vecākajiem velšanas veidiem ir velšana uz kokzaru ecē- šām ${ }^{182}$ vai virvēm, kas krusteniski savilktas liela kubla dibenā. ${ }^{183}$ Pilnīgāks velšanas veids ir vel. šana ar speciāliem rievainiem veltniiem. ${ }^{184}$ Sākot velšanu, audumu vispirms samērcēja karstā sārmā ziepju vai linsēklu novārījumā, pēc tam izlika uz velētavas un pamatīgi izvelēja. Tad nesa istabā un slapjo audumu izklāja uz durvìm vai citas velamās vietas, puiši un meitas sasēdās tam apkārt un sāka ar rokām berzēt audumu, lai tas saveltos. ${ }^{185}$

Pēc velšanas vadmalu. rūpīgi mazgāja un stiepa. Savelto vadmalu satina uz veltna un nolika pie sienas, lai notecētu ūdens, pēc tam to izlika žāvēt ${ }^{186}$ vai -nu ārā, vai maizes krāsnī, lai pūka labāk piegulētu audumam. Izžuvušo vadmalu salocīja negludinātu, gludināja tad, kad sāka šūt. ${ }^{187}$ Kopš 19. gs. vidus vadmalu sāka velt un gludināt dzirnavās, kuras starp Rìgas manufakturām minētas jau 1815. g. ${ }^{188}$

\section{KRĀSOSANA}

Audumu un dziju krāsošanai līdz 19. gs. vidum lietoja gandrīz vienígi augu krāsas. Kurzemes hercogistes krāsotavầ 17. gs. ne tikai krāsoja audumus, bet arī izgatavoja dežādas krāsas no ievestiem krāskokiem. Vienu no pirmajām ieveda indigo krāsu, pernambukkokus un sarkankokus. ${ }^{189}$ Ar ievestiem krāskokiem audumus krāsoja arī 19. gs. pirmās puses manufaktūrās. ${ }^{190}$ Şãdas krāsas pārdotas arī vietējos gadatirgos. ${ }^{191}$

Zemnieku apg̀ērbu krāsošanā, kā liekas, šīm krāsām vēl nebija nekādas lielās nozīmes. Pēc laikabiedru liecībām vēl visu 19. gs. otro pusi plaši izplatīta ir krāsošana ar augu krāsām. ${ }^{192}$ Augus krāsošanai ieguva uz vietas, tāpēc audumu krāsa atseviškos novados lielā mērā bija atkarīga no vietējās augu valsts. Tā ar laiku izveidojās audumu krāsu un rakstu vietējās tradīcijas, kas nezaudēja savu nozìmi arī tad, kad 19. gs. otrajā pusē sāka lietot kịmiskās krāsvielas. ${ }^{193}$

Pēc priekšmetiem, kas saglabājušies no 19. gs. secināms, ka izplatītākās bijušas gaišās krāsas. Ne sievietes, ne vîrieši vienkrāsainus apgēēbus nevalkāja. Tā, piemēram, 19. gs. vidū Krustpils novadā vĩriešu bikses šuva no tãda paša auduma kā sieviešu brunčus, kuru rakstu veidoja raibu kvadrātu un joslu kombinëjums. ${ }^{194}$

Tomēr latviešu (seviški vīriešu) apgèērba pamatdalas un rakstu fons lídz pat 19. gs. galvenokārt bija balts vai gaišpelēks. ${ }^{195}$ Latvietes pazinu. šas 112 dažādu stādu, ko izmantoja krāsošanai. ${ }^{196}$ Viena no iecienītākajām bijusi sarkanā krāsa, jo izplatītais krāsošanas augs - madara (Galium verum) devis labu sarkanu krāsu.

Liekas, ka pareizs ir $M$. Skruzī̌a pienēmums, ka krāsošana sarkanā krāsā latviešiem bijusi pazīstama jau sen. ${ }^{197} \mathrm{Kā}$ zināms, sarkanā krāsa loti daudzām tautām ir viena no iemīḷtākajām ụn senākajām. ${ }^{198}$ 


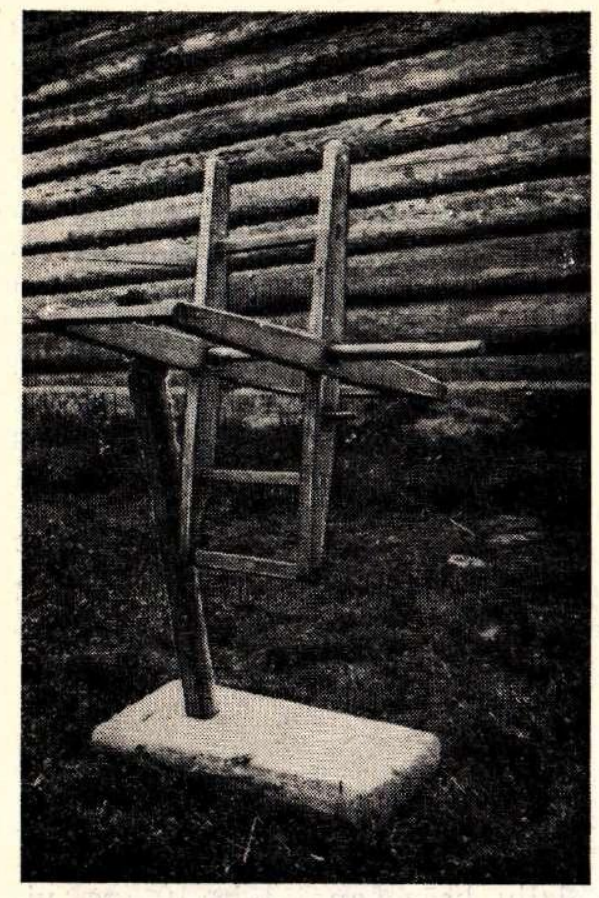

1

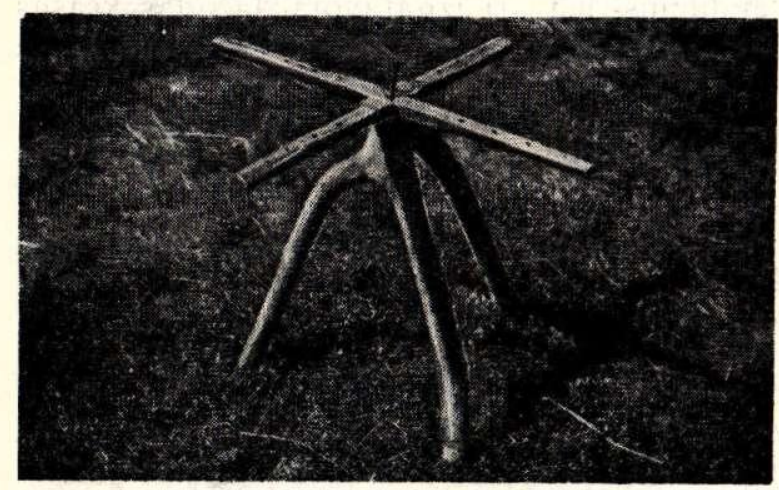

3

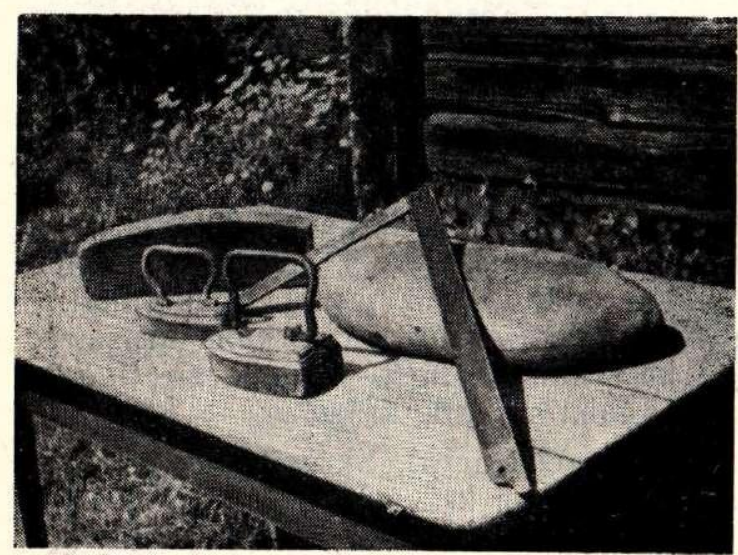

5
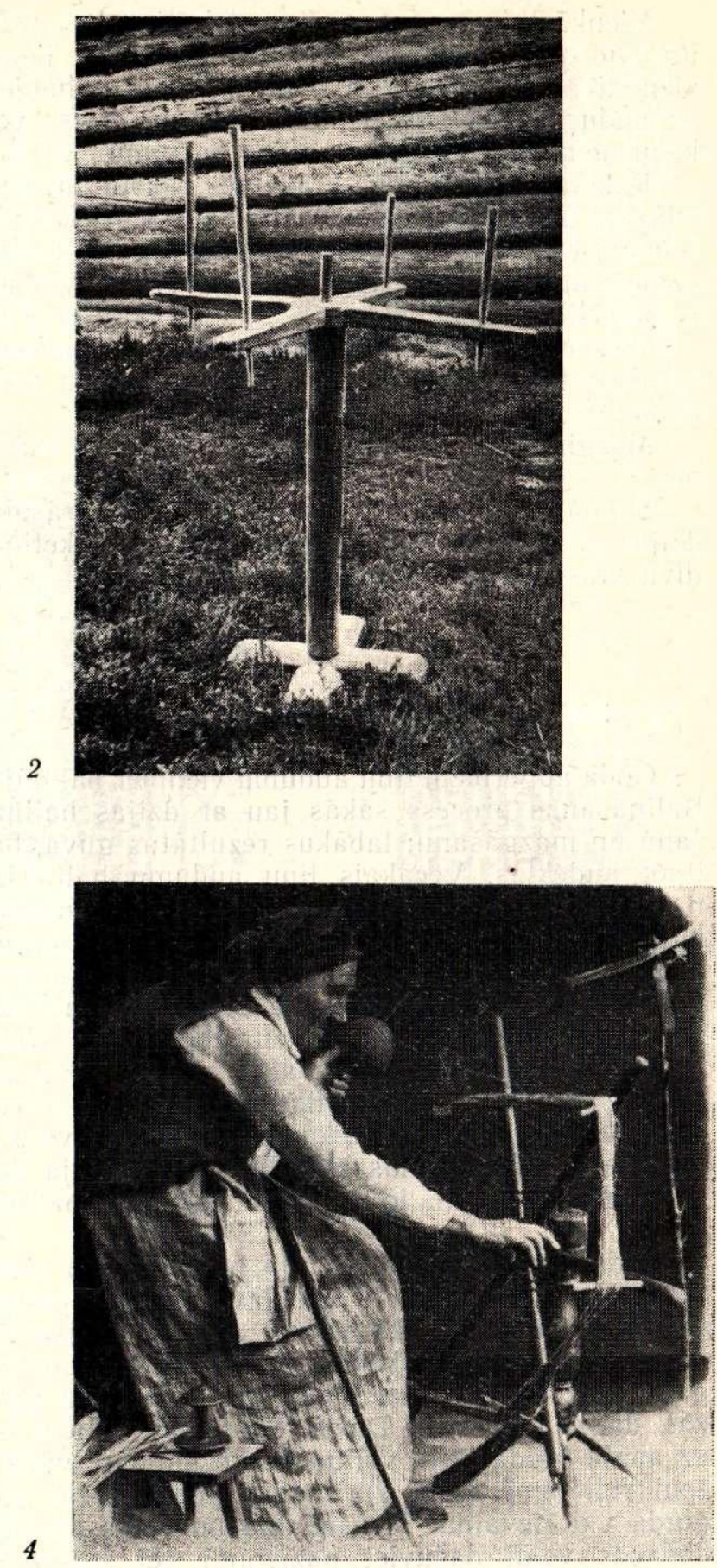

To, ka bāli, bezkrāsaini raksti nav bijuši iecienìti, liecina arī sekojoša latviešu tautasdziesma:

Nesmejat, sveši laudis,

Ka man bāli dzīpariṇi,

Grāvu grāvus izstaigăju,

Maraninu [madaru] meklēdama.

Maza mana roka bija, LTD, 120

Bāli mani dzīpariṇi.

$$
\text { LTD, } 93
$$

Pēdējā divrinde liecina, ka audumu krāsa nereti bija atkarīga ne tikai no vietējās augu valsts 


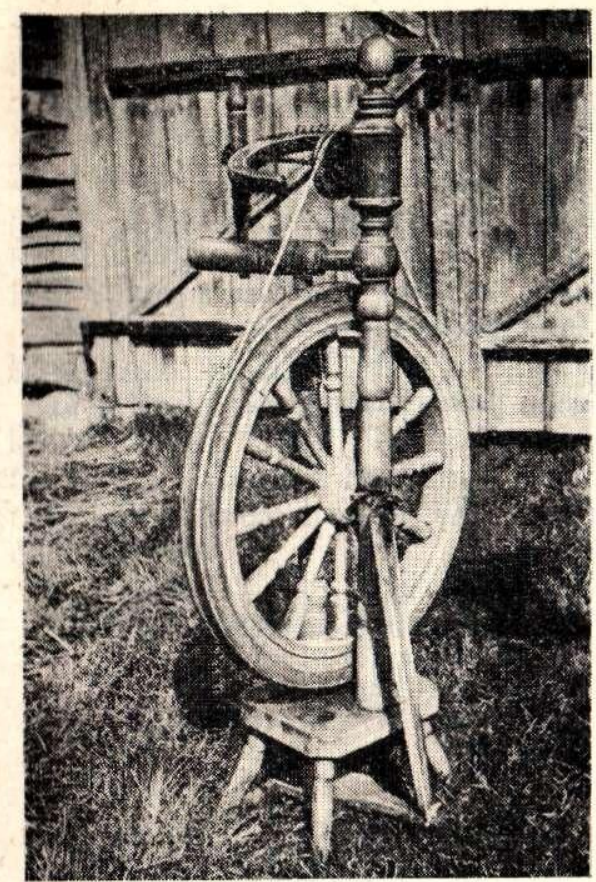

6
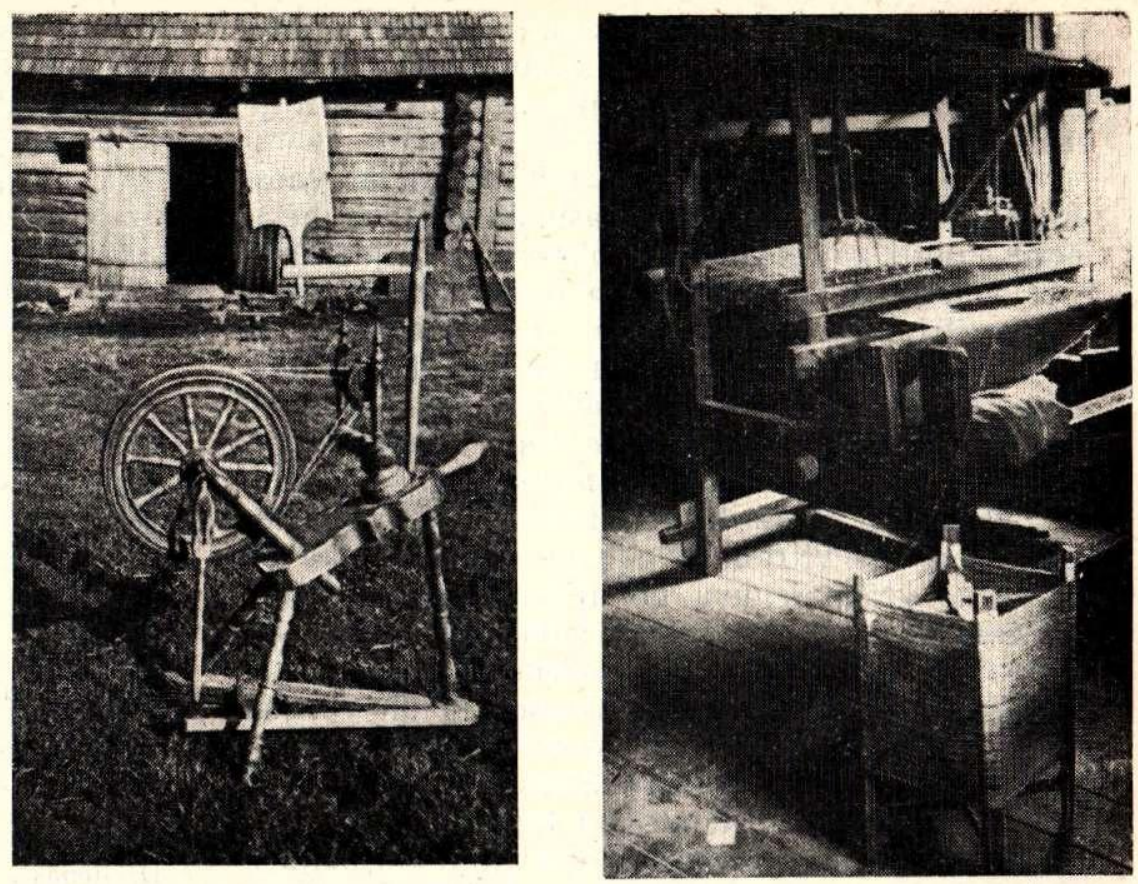

8

y. att. Audumu darināšanas procesam nepieciešamie rỉki:

1-4 - tîtavas; 5 - lauku drēhnieka darha rīki; 6-7 - ratiṇi; 8 - aužamie stāví.

rakstura, bet arī no valkātāja sociālā stāvoḳa, jo valkātājas «maza roka» liecina par valkātājas nabadzību.

Dziju krāsošanu apzīmēja ar vārdiem «tai. sìt»,199 «pervēt», «rakstît», «madarot», «rustēt». 200

Meitas taisa dzīpariṇu,

Es baroju kumelinu.

Meitām skaisti dzīpariṇi,

Man bij labis kumeliṇš.

LD, 7856

Arī krāsošanai kādā vienā noteiktā krāsā ir savs apzīmējums. Tā, piemëram, krāsojot melnā krāsā - «melnoja», zilā «zilināja», tumšbrūnā «bruzenēja», sarkanā vai citā kādā krāsā — «novārīja».201

Sarkanu krāsu, kā jau minēts, ieguva no madaru saknēm. Madaras auga plavās, mālainās zemēs. ${ }^{202}$

Silā iemu, silā teku,

Silā man vajadzēja:

Silä man dzeltes ${ }^{203}$ auga,

Pasilē - madariñas.

LD, 7139

Saknes savāca pavasarī, madaru ziedēšanas laikă, izžāvēja un smalki saberza. Pirms krāsošanas legūto pulveri aplēja ar ūdeni un vārīja. Novârijumu izkāsa un lēja atpakal katlā. Katlā salika dzijas un vārīja uz lēnas uguns. Kad dzija bija nokrāsojusies, katlu no uguns nocēla, laujot dzijai atdzist ūdenī. Pẹc tam dziju iznềma, skaloja un žāvēja.

Par madaru lietošanu sarkanas krāsas iegūšanai stāsta daudzas latviešu tautasdziesmas:

Vai, vedekl', tevis dēl
Madarinas neziedēj':
Pašai virsas villainei
Nav sarkanu dzipariṇu.

RLB ZK RK, VII, 34. 1pp.

Ai sīkās madarinas,

Bēdziet lazdu krūmiṇã:

Lielā pulkā meitas năca,

Visām kalti mugurâ.

F 891,2800

Bez tam sarkanu krāsu ieguva, krāsojot arī ar miltenājiem, alkšṇu lapām, koku mizu skaidinām, bērzu gremzdiem. Alkšnu lapas krāsošanai ievāca pirms Jānu dienas, kamēr lapas vêl jaunas.

Krāsošanai dzeltenā krāsā visbiežāk lietoja bērzu lapas un sīpolu mizas. Bērzu lapas plūca pavasarī, tūlīt pēc izplaukšanas, un izžāvēja. Dzeltenu krāsu ieguva arī, krāsojot ar kazenāju mizām, purenu ziediem, sūnām, kas auga uz akmeniem vai bērzu stumbriem, dzeltenajām pīpenēm, kling̣erītēm, biškrēsliniem, nežāvētām kārklu mizām, rudzu asniem (skat. tab. 30. 1pp.), ko savāca maijā pirms vārpošanas un lietoja kaltētus un nekaltētus, utt. Vecpiebalgā dzelteno krāsu ieguva, krāsojot arī sasmalcinātu kieg̀eḷu novārījumā.

Zalo krāsu ieguva, krāsojot ar sunuburkškiem (Conium maculatum) un kodinot ar alaunu vai arì krāsojot ar kartupeḷu lakstiem (kodinot ar sāli vai 
vara vitriolu), biškrēslinu lapām, bērzu lapām, nokasītām vītolu mizām, brūklenājiem, sūnām, burkānu lakstiem, viršiem, kaṇepju pelavām, cūkpienุu ziediem utt.

Krāsojot ar rudzu asniem un kodinot ar vara vitriolu, ieguva tumši zaḷu krāsu. Ja krāsu gribēja iegūt spilgti zaḷu, dzelteni nokrāsotās dzijas krāsoja vēlreiz ar «zilumzālēm» podos. Zilumzāles (vara vitriolu) aplēja ar stipru sārmu (tādu, kurā ola negrima) un šḳidumā lika dzelteni nokrāsotās dzijas. Kad no podiem nāca nelaba smaka, meitas zināja, ka dzijas nokrāsojušās. S̄ādi krāsotas dzijas bija loti spilgtas un izturīgas pret balěšanu.

Zaḷu krāsu varēja iegūt arī no lēpju lapām, vārot tās ar vara vitriolu.

Brūno krāsu ieguva no alkšṇu mizām. Mizu noplēsa, izkaltēja un savārīja ūdenī, pēc tam šḳidrumu izkāsa. Skidrumam pievienoja alaunu, tad tanī lika krāsojamo dziju vai audeklu un vārīja.

Lai krāsa labāk «piekostos», katlu ar krāsojamo materiālu reizēm lika maizes krāsnī tūlīt pēc maizes iznemšanas un atstāja tur, kamēr krāsns izdzisa. Dažkārt, it īpaši krāsojot vilnu vai dzijas, tās pēc izṇemšanas no krāsošanas šḳīduma sabāza maisā (auduma gabalu tādās reizēs uztina uz apala koka, ap $5 \mathrm{~cm}$ diametrā, aptina ar lupatu, lai audums nenotrieptos) un lika krāsnī uz dēla. Tā krāsojamais gabals tika reizē arī izgludināts. Vilnu pēc krāsošanas dažreiz sutināja garaiṇos virs katla ar vārošu ūdeni vai izkarsēja vasaru karstā saulē, lai dzija būtu mîkstāka un krāsa izturīgāka.

Tumšbrūnu krāsu ieguva, krāsojot ar ozolu mizām, egḷ čiekuriem, akmens sūnām, kartupelu lakstiem (3 kg nežävētu lakstu uz $500 \mathrm{~g}$ vilnas, žāvētu - daudz mazāk). Tumšbrūnu krāsu ieguva, arī krāsojot ar paegḷiem vai ābeḷu lapu, bērzu mizu, arī sarkanā āboliṇa, bērzu pumpuru, kazenāju mizu (ievāca tad, kad ogas jau bija nogatavojušās) novārījumā.

Melno krāsu²04 ieguva, krāsojot ar ozolu mizām. Mizas ievāca pavasarī, izžāvēja un vārīja ūdenī. Novārījumā iegremdēja dzijas, paturēja tur kādu laiku, tad izñēma, nospieda un žãvēja saulē. Atkārtojot šo procesu vairākas reizes, ieguva vēlamo nokrāsu. Līdzīgā veidā melno krāsu ieguva, krāsojot ar melnalkšna un ošu mizām. Krāsojot ar puplakšu lakstiem, dabūja pelēcīgi melnu krāsu.

19. gs. krāsošanai melnā krāsā lietoja arī piḳenes (Aspidum filix), pievienojot vara vitriolu. Pēc krāsošanas ar piķenēm krāsojamo gabalu vajadzēja sautēt. Melnā krāsā ar piḳenēm nokrāsojās vilnas dzijas, bet pelēcīgi zilā - linu dzijas. ${ }^{205}$

Pelēku krāsu ieguva, krāsojot ar mēlenēm vai ievu mizām. Bez tam pelēkas krāsas iegūšanai lietoja arī tos pašus augus, kas deva melno un tumši brūno krāsu, vienīgi krāsvielas niēma mazākās devās.

Zilầs krāsas iegūšanai lietoja indigo, ko arī sauca par zilumzālēm. Šim nolūkam māla podos krāja urīnu. Krāsu sadauzīja smalku un iebēra podâ. Podu nosēja ar vairākām lupatām vai ādu, lai «stiprums nenoietu», un nolika rūgt siltā vietā istabā pie krāsns vai ieraka kūtī aitu mēslos, jo rūgšanas laikā pods stipri smirdēja. ${ }^{206}$ Šis krâso-

\section{Krāsošanai biežāk izmantotie augi}

Z - krāsošanai izmantoja attiecīgā auga ziedus, L lapas (lakstus, skujas), O - ogas, $M$ - mizas, C - čiekurus, $\mathrm{G}$ - gremzdus, $\mathrm{S}$ - sēklas, A - visu augu.

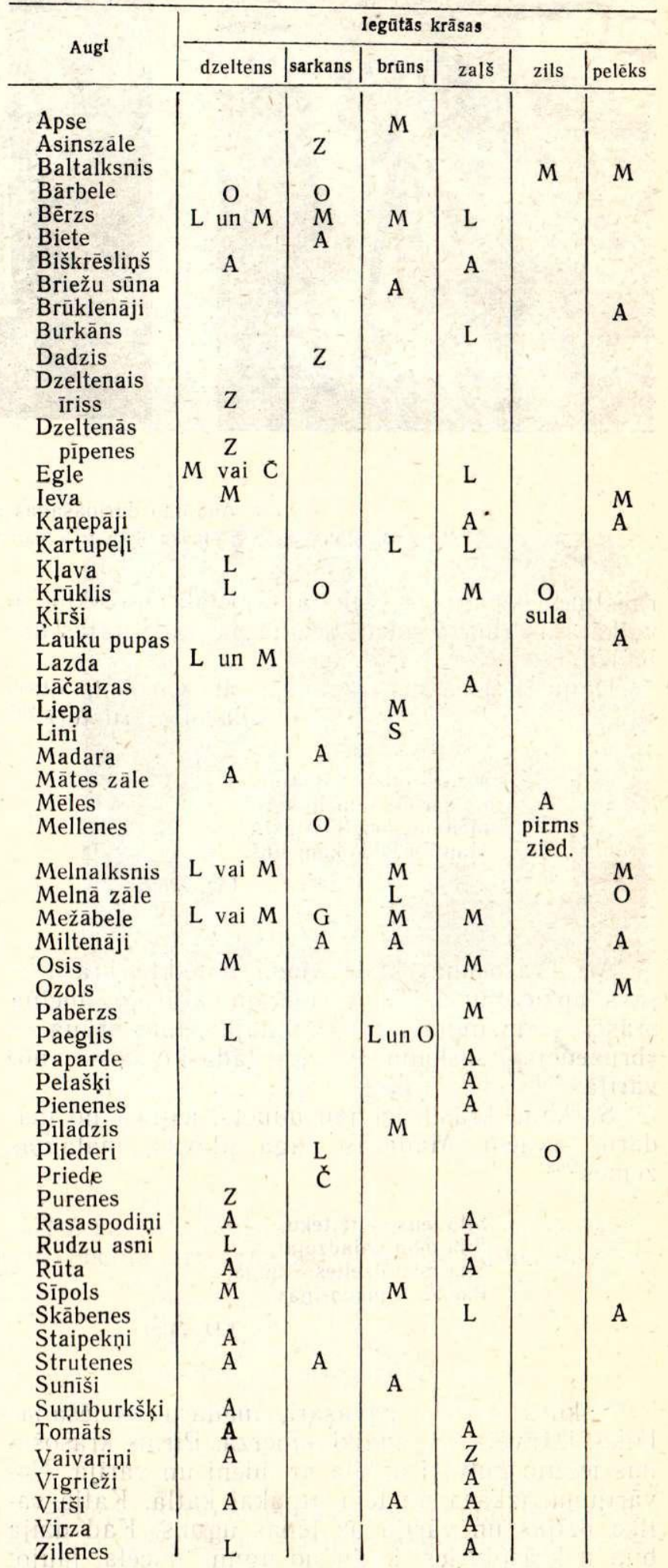


šanas panēmiens šḳidināt indigo rūgstošā urīnā ir vienkäršākais un izplatīts visā Latvijas PSR teritorijā. Bez urīna zilumzālu raudzēšanai izmantoja arī sārmu. Raudzēšanas process ilga no 6 līdz 20 dienām, iegūtā krāsa bija izturīga un nenopluka. Škidrumu krāsošanai varēja izmantot vairākas reizes, tāpēc gandrīz katră mājā glabājās tādi krāsu podi. ${ }^{207}$

Retāk zilās krāsas iegüšanai lietoja skābo kiršu ogas vai apšu mizas. ${ }^{208}$

Tautasdziesmās visbiežāk minēta mẹ|i zilā krāsa. Šādu krāsu ieguva no mēlenēm (Isatis tinctoria, Vaccinum mirtillus), kas Latvijas teritorijā brīvā dabā neaug, bet tiek kultivētas tikai dārzos. ${ }^{209}$

Rasa, rasa, migla, migla,

Tā man žēli padarīja,

Tã noēda mēlu dārzu,

Nava skaistu dzīpariṇu.

LD, 7137

Mêlu adu, mēlu rakstu,

Mēlu liku pūriñă.

Kas kait man nemēlot,

Man māmiṇa mējotãja.

LD, 7181

Mēlu vilku, mēlu sedzu,

Man māmiṇa mēlotãja,

Kur sēdēju, kur stāvēju,

Tur nobira mē|u ziedi.

LD, 7156

Kā rāda tabula (30. Ipp.), vairums augu dod dzeltenos, zalos un brūnos tonus; bez tam reti augi dod oranžsarkanus, violeti sarkanus un zilganpelēkus tonus. Spilgti zilu un sarkanu krāsu, krāsojot ar vietējiem augiem, nav iespējams iegūt, tāpēc arī šìs krāsas nav raksturīgas latviešu tautas tērpu rotājumā.

Jāievēro, ka, mainot kodinātājus, viens un tas pats krāsu augs deva dažādas krāsas un toṇus.
Krāsa mainījās arī atkarā no krāsojamā auga ievākšanas laika (pavasarī, vasarā u. tml.).

19. gs. krāsu nostiprināšanai ${ }^{210}$ lietoja sodu, potašu, alaunu, dzelzs un vara vitriolu; šìs vielas pirka vai nu veikalos, vai no apkārtstaigājošiem tirgotājiem. Senatnē krāsu nostiprināšanai kalpoja gan gaisma, gaiss un üdens, gan arī laiks. Par to liecina tautas dažādie ticêjumi. ${ }^{211}$

Lai nostiprinātu krāsu ar gaismu un gaisa palīdzību, krāsojamo priekšmetu samērcēja krāsojamā škịidumā un žāvēja spilgtā saulē. Atkārtojot to vairāk reižu, ieguva tumšāku un izturīgāku krāsojumu. Protams, krāsošanai bija nepieciešama pieredze. Labai krāsotājai krāsas iznāca spilgtas un noturīgas, un apgèerbs pat pēc ilgas valkāšanas nezaudẽja savu krāsu. ${ }^{212}$

Ar gaismas palīdzību krāsvielas nostiprināja, krāsojot ar t. s. kubla krāsvielām. S̄īs krāsvielas neškīist ūdenī, bet sārmā, jo tiek apstrādātas ar reducētājām vielām, pie kam rezultātā rodas citādas krāsas nekā pati krāsviela; šãdos škịidumos iemērcēja krāsojamo materiālu; ja pēdējo no škīduma izṇēma un atstāja gaisā, tad škiiedrā radās atkal pirmatnējā krāsviela. Ar kublà krāsvielām parasti krāsoja speciāli krāsotāji, it ippaši Latgalẹ.

19. gs. vidū pamazām sāka izplatīties kỉmiskās krāsvielas. Tās pārdeva apkārtceḷojošie tirgotāji, kurus Ventspils apkārtnē sauca par «rāvinātājiem». Sākumā, kamēr zemnieki paši iemācījās lietot jaunās, tā saucamās greznās krāsas, ${ }^{213}$ tirgotāji paši bija arī krāsotāji. 19. gs. beigās krāsošanai lietoja arī krāsaino papīru, it îpaši ja bija jākrāso mazāks daudzums materiāla. ${ }^{214}$

Nobeidzot iso apskatu par kräsošanai lietotajiem augiem, atzīmējams, ka liela nokrāsu dažâ. dība tika panākta ar kodināšanu. Katrā novadā bija savi raksturīgi krāsu salikumi. Mûsu klima. tiskās joslas augu valsts ir nabadzīgāka un nedod tādu toṇu dažãdỉbu kā augu valsts dienvidos. Tomēr, ka arī šĩs nelielās dabas veltes ir tikušas prasmīgi izmantotas, rāda īpatnējais krāsu salikums latviešu tautas tērpā.

\section{APĢERBA ROTĀŠANAS TEHNIKAS UN ŠOSAANA}

Pēc apgèerba materiāla sagatavošanas vajadzēja izvēlēties apg̛ērba rotāšanas veidu, jo apgeerbu rotāja pirms šũšanas. Ar izšuvumiem parasti rotāja tikai goda un ceremoniju apg̀ērbus.

Apskatāmā posma zemnieku apgēerbu rotājumu veids un tehnikas veidojas uz iepriekšējo gadsimtu rotājumu pamata.

Sākot rotājumu veidu analīzi, jāpiezīmē, ka laikā, kad profesionālās mākslas vēl nebija, apgèrbs bija gandrīz vienīgais objekts, kur sieviete - tērpa valkātāja - varēja parādìt savu radošo izdomu. Par pašu ši daiḷrades procesa norises gaitu, atskaitot tautasdziesmas un pašus rotātos apḡērba gabalus, nav saglabājušās ziñas. Tāpat arī nav zināms, vai atsevišḳās vietās bijuši kādi izšūšanas centri, kur apgeērba rotāšana pastāvējusi kā amata veids. Liekas tomēr, ka lielāko dalu rotāto apgèerba gabalu izstrādājušas savām vajadzībām pašas zemnieces. Līdz mūsu dienăm saglabājušies pa lielākai dalai tikai paši skaistākie un greznākie apgèerbu gabali, kas kā mākslas vērtības atspogulo tā laika cilvēku estētisko gaumi.

Latviešu tautas tērpu rotājumiem raksturīgs ir geometriskais raksts, kurš izpildīts, skaitot auduma diegus. Protams, šāds izšūšanas veids bija stipri darbietilpīgs process, tāpēc vienas otras greznās villaines izšǔšanai bija vajadzīgi vairāki gadi. Simtiem tautasdziesmu liecina par lielo čaklumu un smagajiem darba apstākḷiem (pie skala 

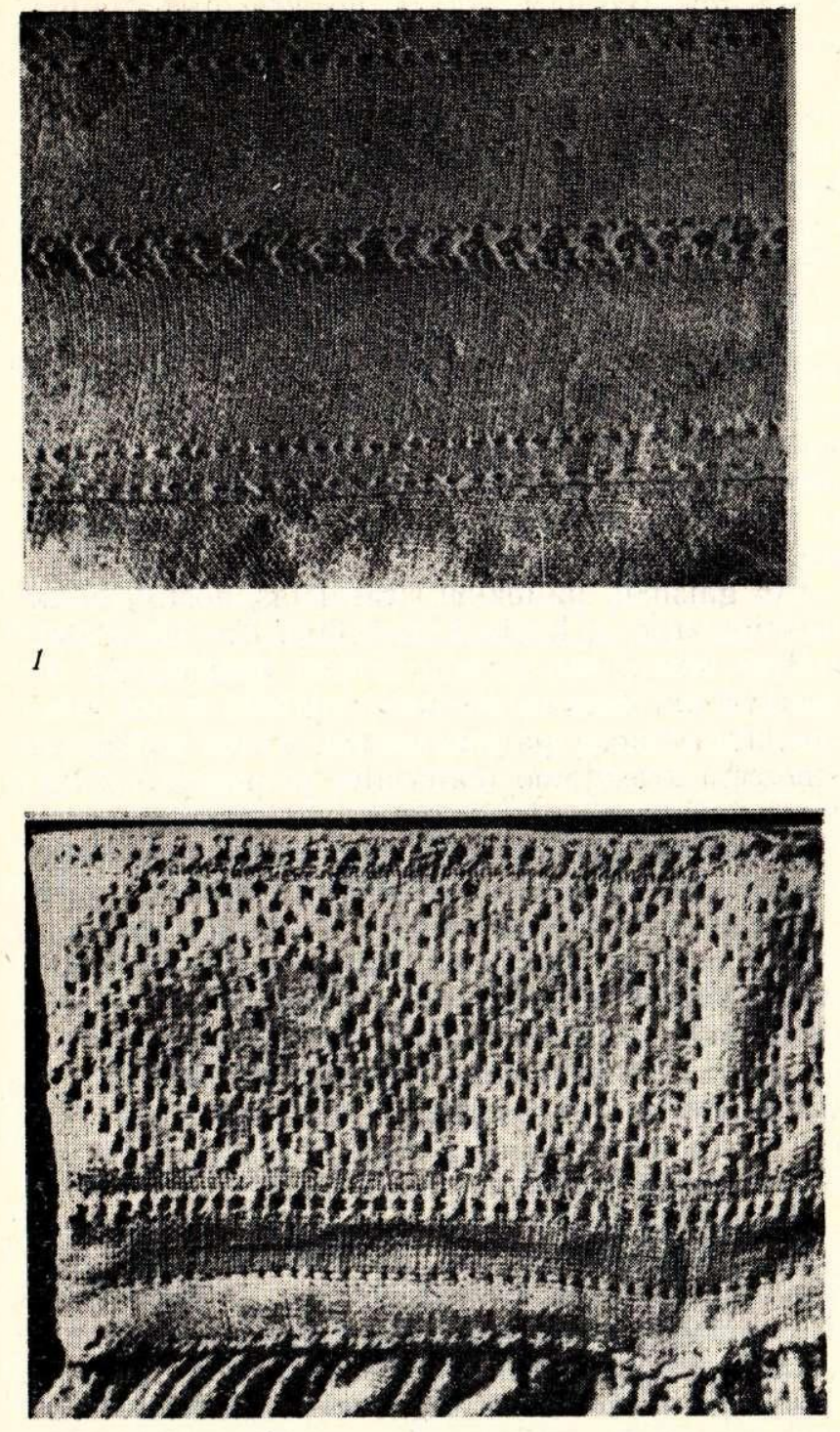

3

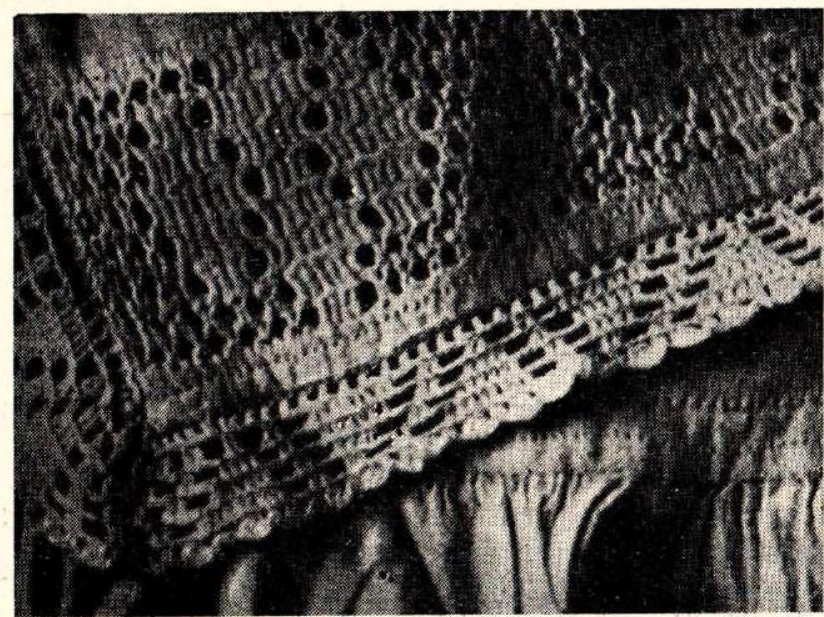

5

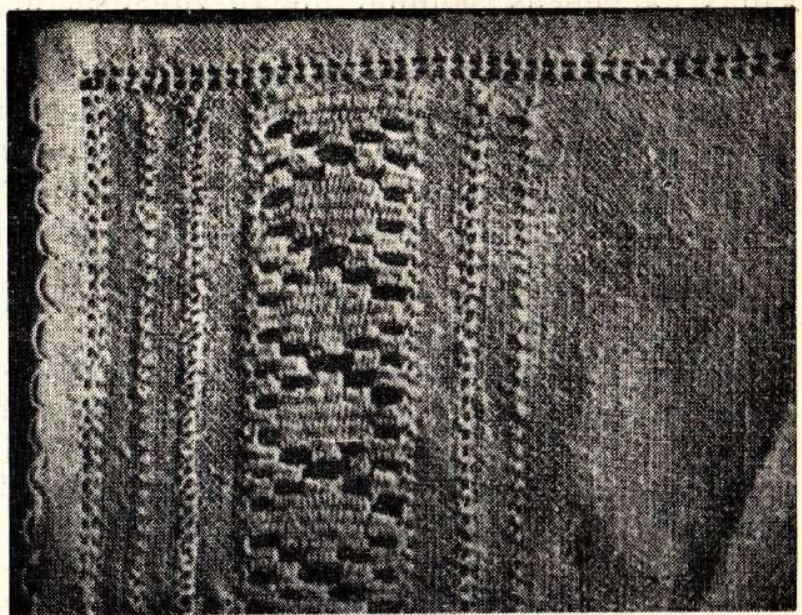

2

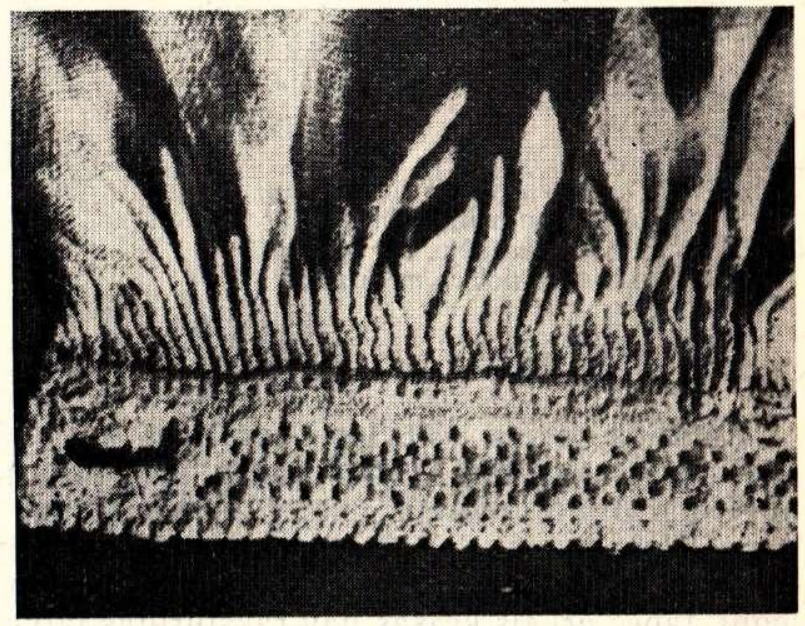

4

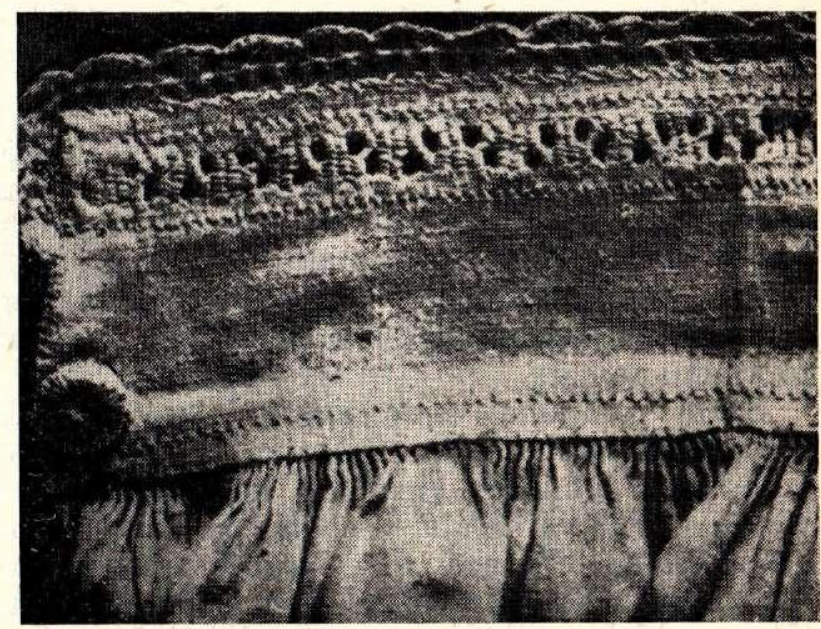

6 


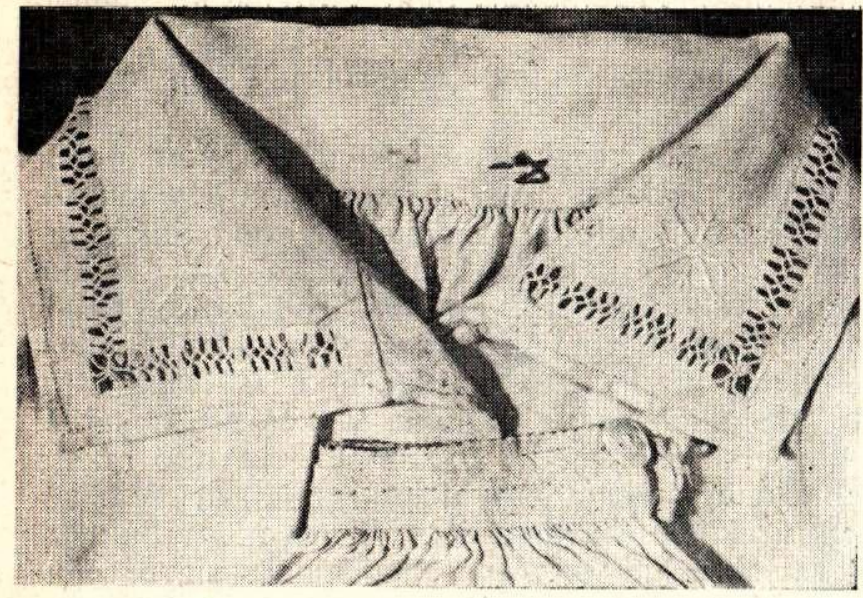

7

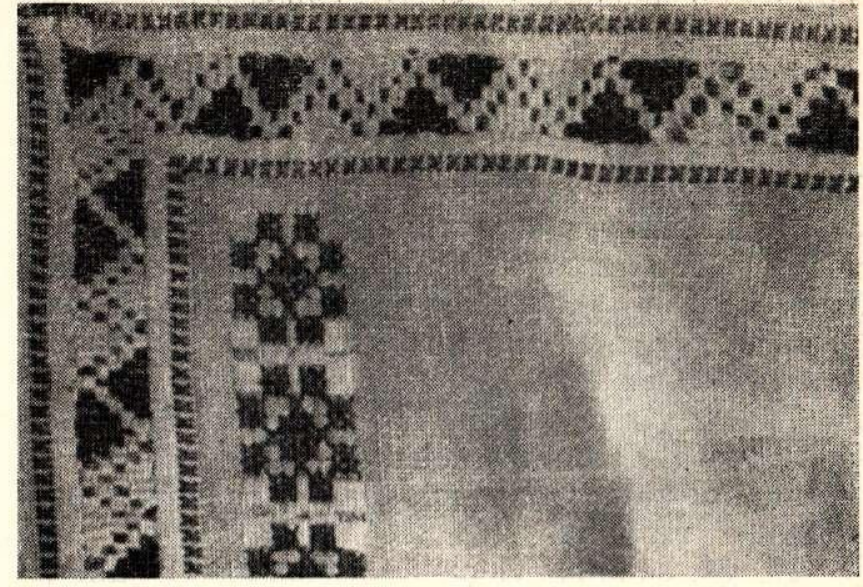

8

10. att. Vienvirziena izvilkuma paraugi:

1 -- Zemgales krekla uzplecis; 2 - Zemgales krekla apkakle; 3 -Ventspils krekla apkakle; 4 - Ventspils krekla aproce; 5 - Lutrinu krekla apkakles raksts; 6 - Lutriṇu krekla aproce; 7 - Talsu krekls; 8 - Augšzemes krekla uzpleča fragments.

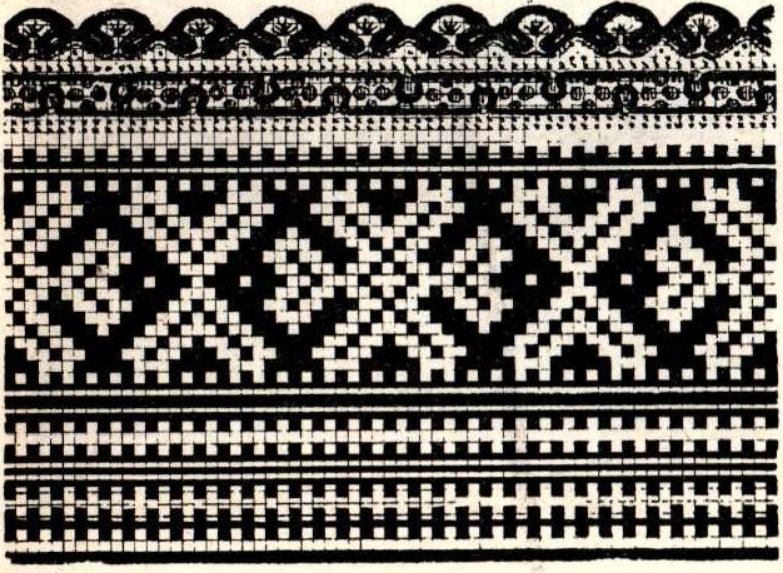

1

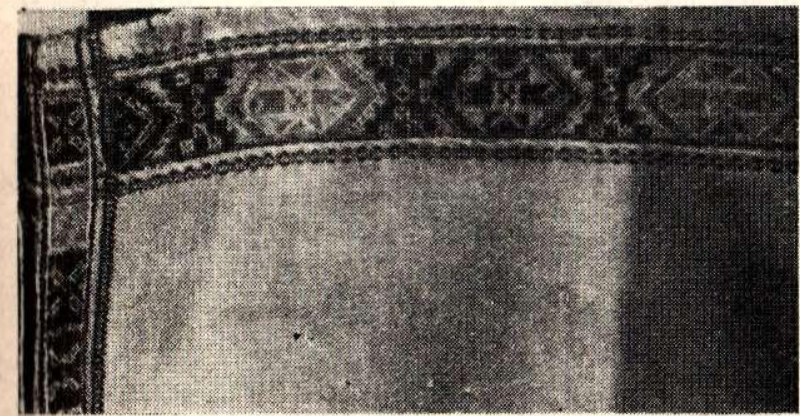

3

11. att. Ielocītā raksta paraugi:

1, 2 - Augšzemes sievu galvas auta noslēguma raksts (ZA Vēstures institūta Etnogrāfijas sektora materiāli); 3,4 - Dienvidkurzemes villaines raksts (Liepājas NM materiāli).

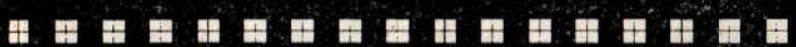

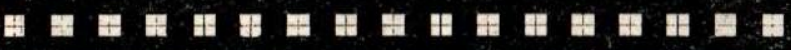

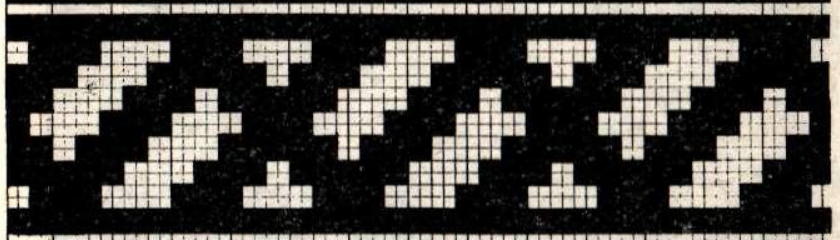

It

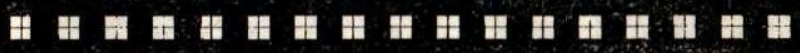

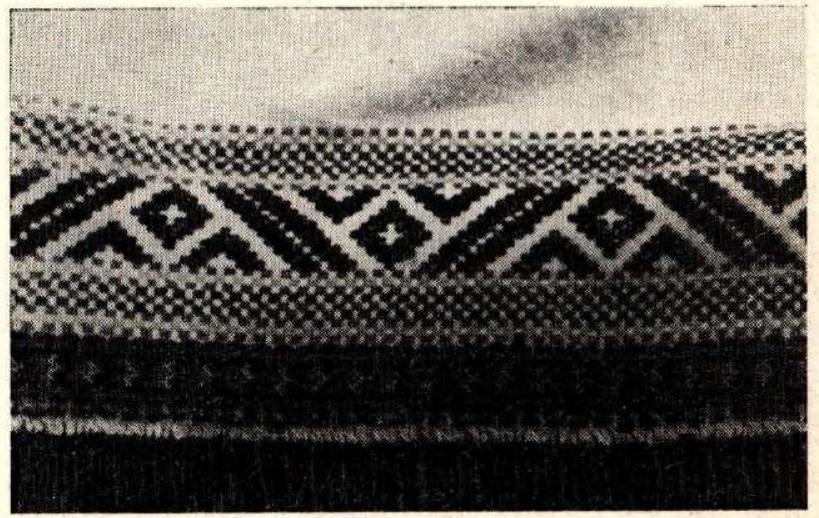


uguns un mēness gaismā), kādos radušies šie mākslas darbi.

Izšūšanas tehniku meitenes parasti mācījās no savām vecmāmulām un mātēm. Jau ganu gaitas sākot, meitenēm bija jāsāk izšūt un adīt pašām nepieciešamos apğērba gabalus. Lai arī izšūšanas tehnika tika mantota no paaudzes uz paaudzi, tomēr tā nepārtraukti attīstījās, gan nesalīdzināmi lēnāk, nekā tas bija 19. gs. otrajā pusē, kad plaši ieviesās dažādas «musturu» grāmatas un darbojās rokdarbu kursi.

Tautas tērpu rotājumā - izšuvumos ir izveidojušies savi tehnikas, kompozicijas un kräsu salikumi, pie kam katram novadam ir raksturigi savi apg̀ērbu rotājumi.

19. gss. sākumā viena no visizplatītākajām izšuvumu tehnikām bija caurās vīles un vienvirziena izvilkums (10. att.); šādās tehnikās daḷēji ir rotāti gandrīz visi sieviešu krekli. Kā galvenais krekla

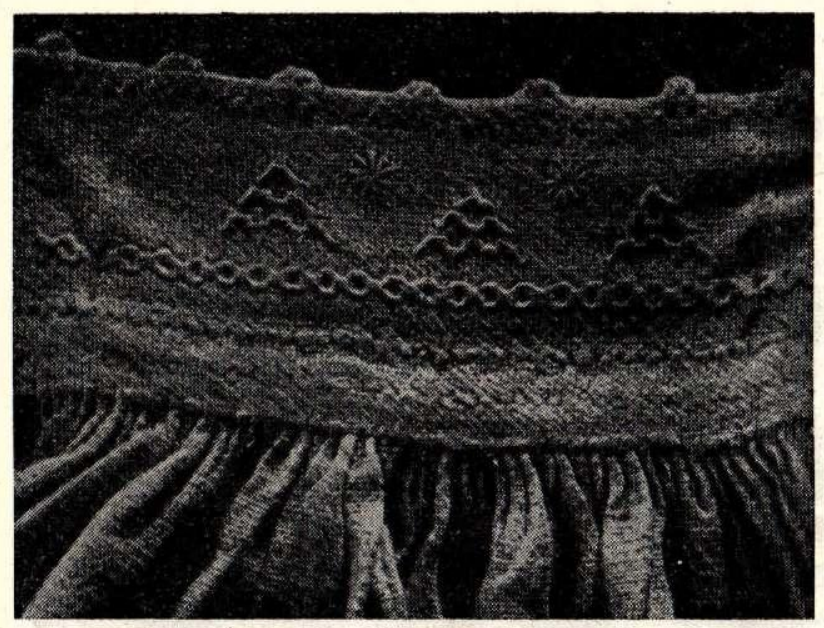

1

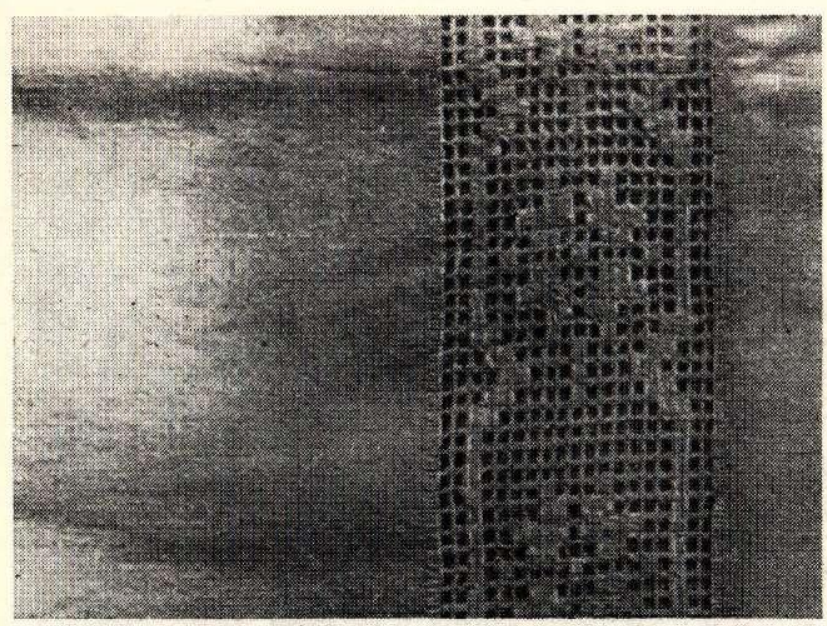

3

12. att. Vìtā raksta un divvirzienu izvilkuma paraugi:

1 - Zemgales krekla aproce; 2 - Rendas krekla aproce; 3, 4 - divvirzienu izvilkums Zemgales krekla rotājumā (Rigas Lietišksās mākslas vidusskolas (turpmāk - RLMV) materiāli). rotājums tas sastopams tikai Vidzemē un Ziemelkurzemē, kamēr pārējos novados ar cauro vīli vai nelielu vienvirziena izvilkumu rotāja vienīgi kreklu krūšu škēlumus.

Viena no vecākajām izšuvumu tehnikām ir «ielocitais raksts», kas, liekas, attīstijies jau tolaik, kad horizontālie aužamie stāvi nomainīja vertikālos un kad katru villaini neauda atseviškii, bet vienos velkos uzreiz vairākas. Tad katras villaines rotāšanai izdevīgāk bija rakstu ielasīt audos, bet velku virzienā vienkāršāk bija izšūt ar adatu, jo raksta ielasišana auduma velkos prasa sarežġitu velku iekārtu. 19. gs. sākumā ielocîto rakstu tehnika raksturīga Latgales un dậjēi arī Augšzemes krekliem, kā arī Dienvidkurzemes villainēm, Bārtas kreklam un Austrumvidzemes sievu cepurëm (11. att.; 29. tab., 4).

No baltajiem izšuvumiem par visvecāko tehniku jāuzskata t. s. vītais dūriens, kas 19. gs. sā-

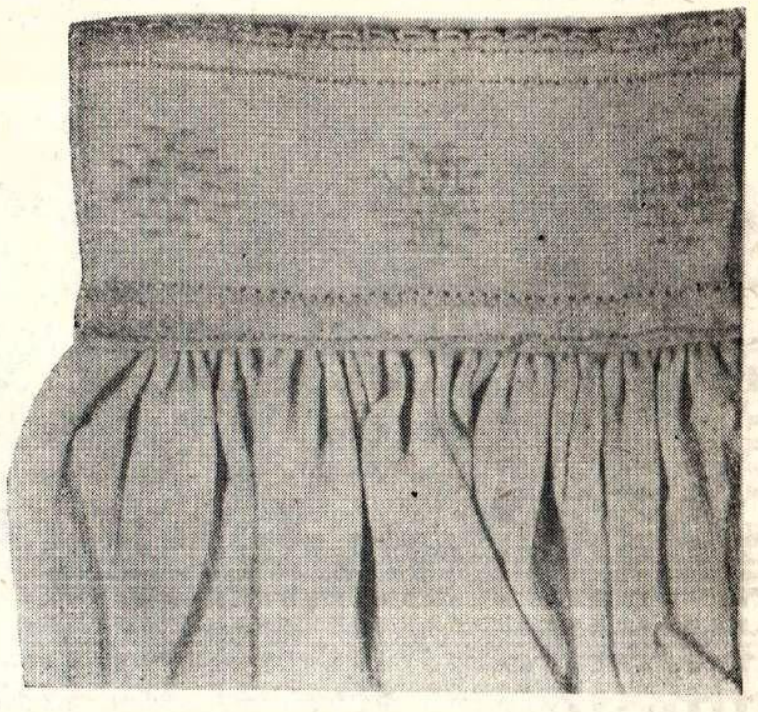

2

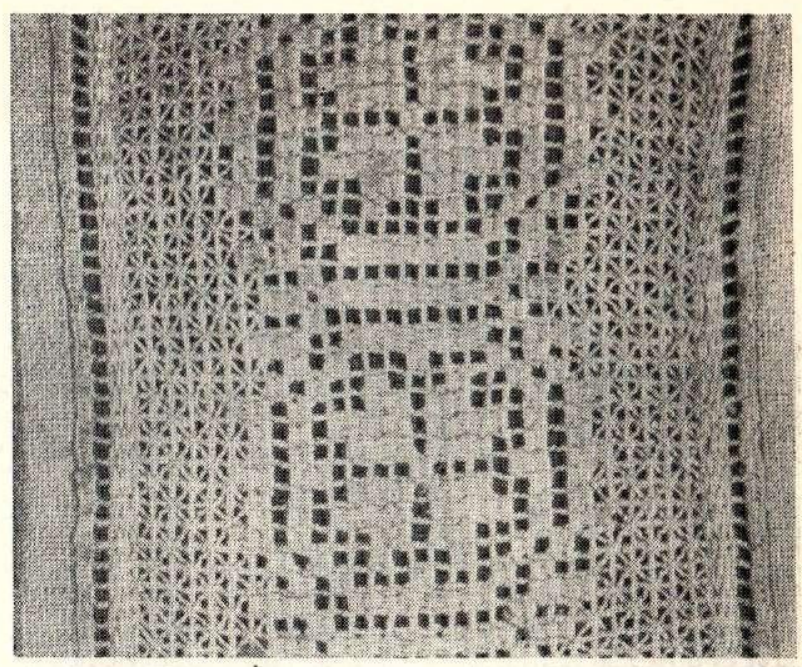

4 

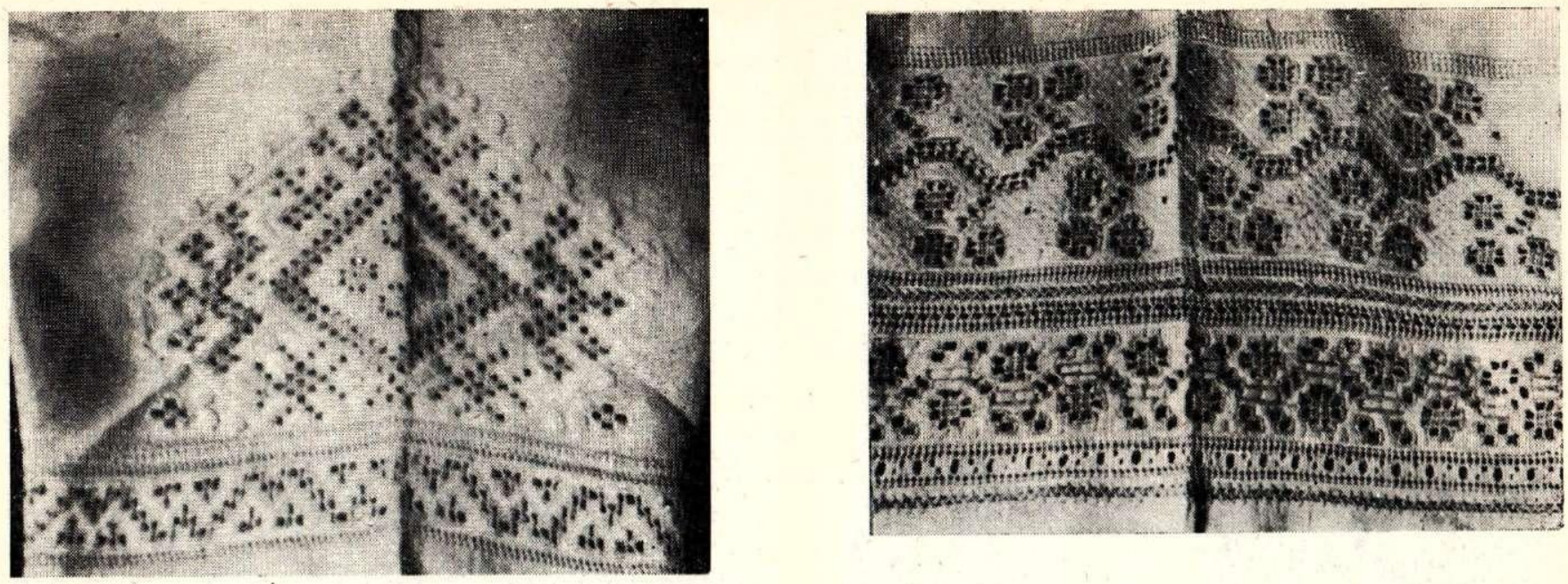

13. att. Grieztā raksta paraugi - Rucavas krekla raksts (Liepājas NM materiāli).

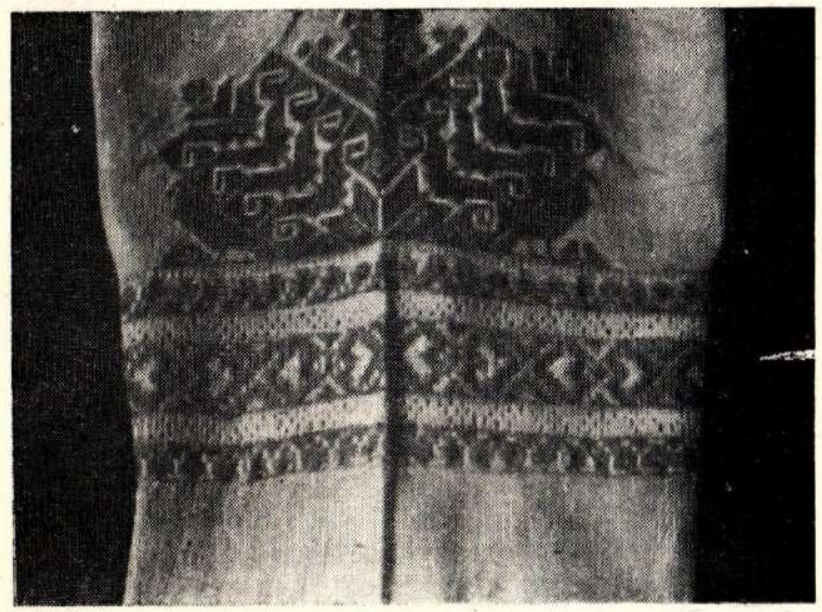

1

14. att. Krâsaino darbu (krustdürienu) paraugi: 1 - Rucavas «krūms»; 2 - Kuldīgas krekla apkakles raksts (RLMV materiāli).

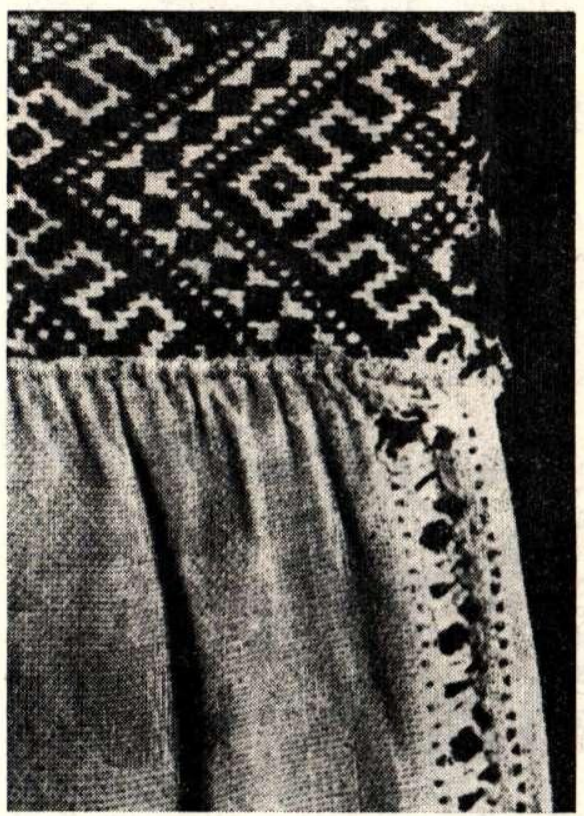

2

kumā saglabājies tikai Alsungas un Kuldīgas kreklos. «Vìtais dūriens» parasti tiek kombinēts ar spodršuvumu un citām balto izšuvumu tehnikām (12. att., 1).

Zemgales kreklu rotājumiem raksturīga divvirzienu izvilkuma tehnika, ${ }^{215}$ kas pārējā Latvijā, atskaitot vienu Alsungas kreklu, ${ }^{216} 19$. gs. citur nav pazīstama (12. att., 3, 4). Jaunākajiem Zem. gales krekliem rotājums izstrādāts spodršuvumā jeb t. s. broderejas tehnikā. Broderejas tehnikā izstrādātas arī 19. gs. vidū Vidzemē izplatītās «torna» cepures. Zemgales kreklam raksts variēts apkakles stūros un aprocēs (12. att., 3). Rotājuma kompozīcija atgädina lietuviešu kreklu rotājumu. ${ }^{2{ }^{7}}$ Sauri lokāla izplatība ir Lielvārdes un Rucavas kreklos (13. att.) sastopamajam «grieztajam» rak. stam, kas pằrējā Latvijā nav pazīstams. ${ }^{218}$ Griez- tais raksts ir Norvēgijas izšuvumos plaši pazīstamais hardangers; ${ }^{219}$ Rucavas kreklos tas ieguvis īpatnēju, tikai Rucavai vien raksturigu kompozīcijas un krāsu salikumu (balts, pelēks; sarkans un balts). Šajā tehnikā izstrādāti arī Ziemeligaunijas un Rietumukrainas krekli. ${ }^{220}$

Jaunākā ir krustdūrienu tehnika, kas visplašāk izmantota Rucavas kreklu krūmu rakstiem (14. att., 1) un dažās Austrumvidzemes un Latgales villainēs.

Krāsainie izšuvumi - svītru dūriens un spodršuvums - viskrāšñākie ir Austrumvidzemes tipa izšūtajās villainēs (skat. 16. tab.) un Vidzemes sievu cepurēs. Krustpils villaines gan pēc kompozīcijas, ${ }^{221}$ krāsu noskaṇas, gan arī pēc izšuvumu tehnikas dažādības ir viens no viskrāšnākajiem un ìpatnējākiem tautas mākslas darinājumiem. 


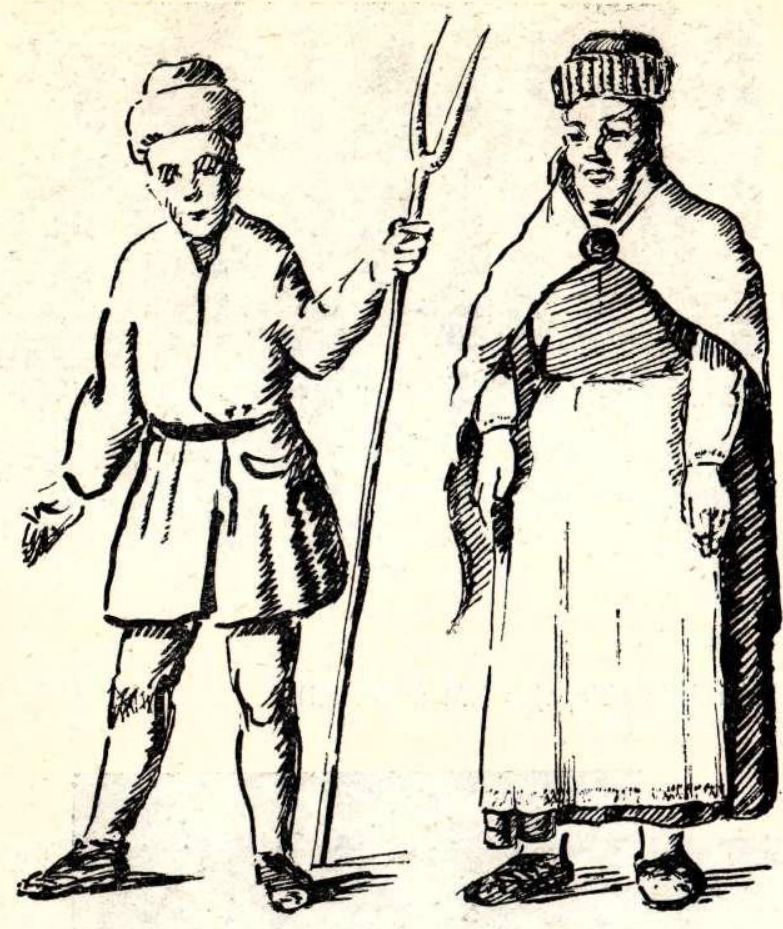

15. att. 17. gs. (1612. g.) Vidzemes sievu cepure (pēc kartes, kas ievietota J. Broces „Monumente“..., III. 83. Ipp.).

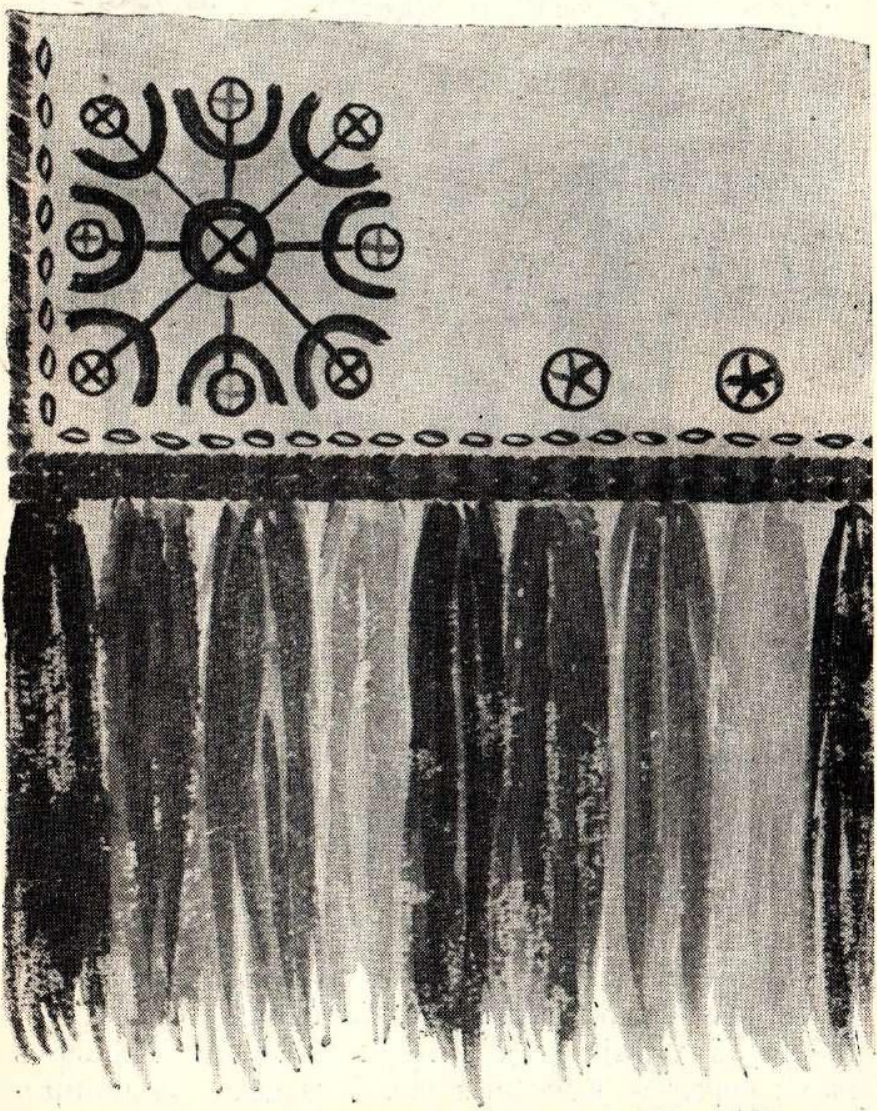

17. att. Talsu villaine (Latvijas PSR Vēstures muzeja materiāli).

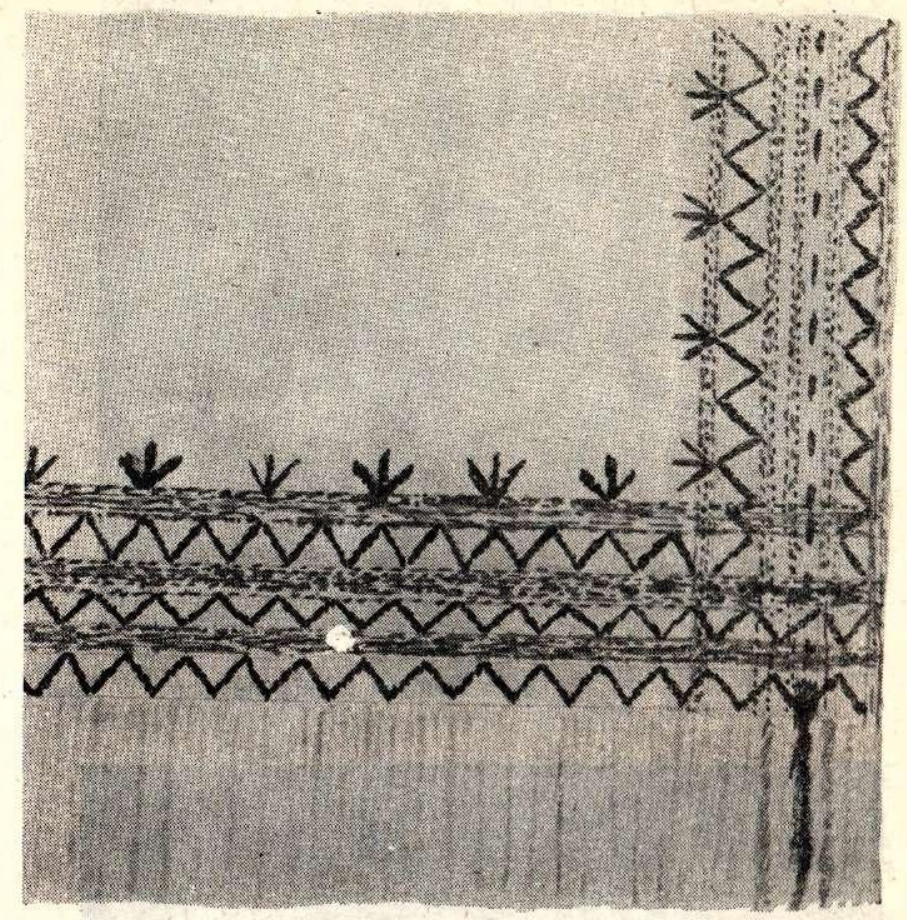

16. att. Ventspils villaine (Latvijas PSR Vēstures muzeja materiāli).
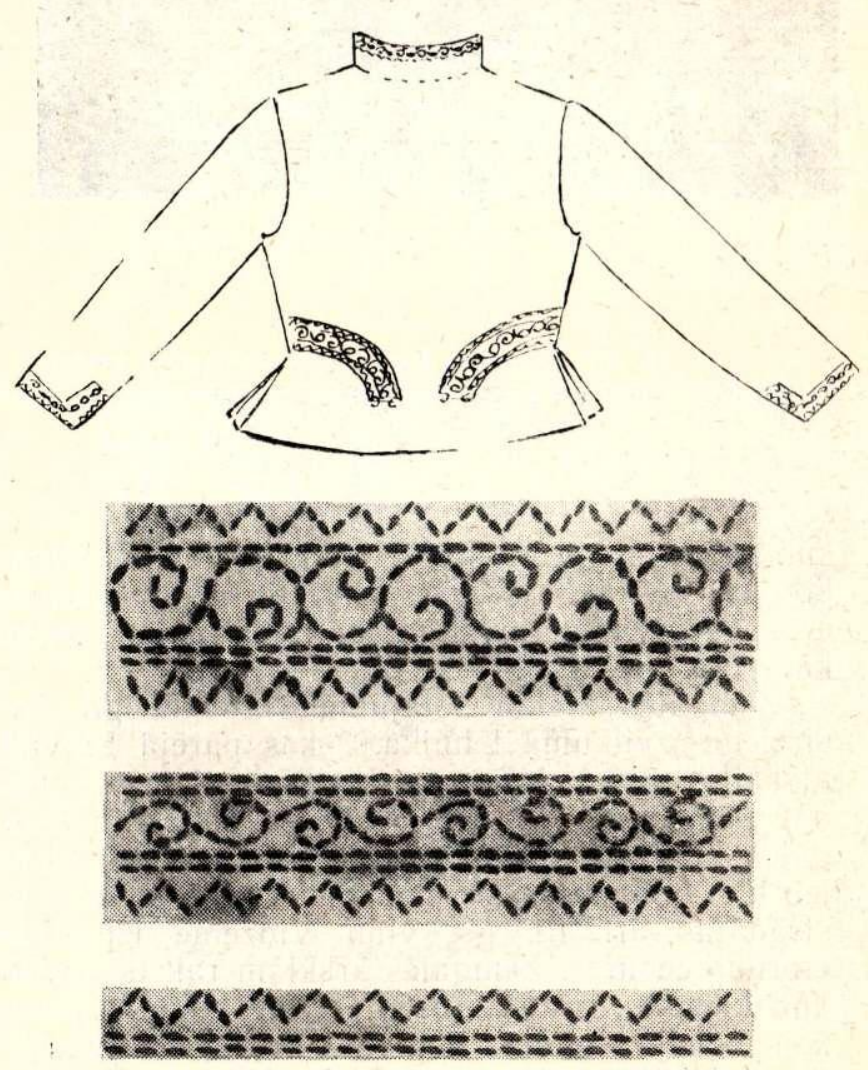

18. att. Mašîndūriens Kurzemes vīriešu svārku rotājumā (Latvijas PSR Vēstures muzeja materiāli). 
Bagātākais raksts izvietots villaines galos trīs joslās, kamēr malās šūtas šaurākas josliṇas. Virs malu joslām centra virzienā šūti izskaṇu raksti «austras koki», kas rada vieglu pāreju no bagāti rotātām malām uz nerotāto vidus dalı. Grezno izšuvumu vēl papildina krāsainie celu audi gar malām, kā arī virs baltām velku bārkstīm šūtās krāsainās, celos austās bārkstis. Šāds kompozīcijas princips rada noslēgtu vienību un labi atbilst villaiṇu valkāšanas veidam. Villaine izšūta dažādās krāsaino darbu tehnikās, kas ar vieglo svītru dūrienu un smagāko spodršuvumu vēl vairāk pasvītro dominējošo saulīšu rakstu. Joslu iežogojumiem raksturīgas vienas no senākajām izšuvumu tehnikām - etnogrāfiskais kātu dūriens un lỉklo. cis. Izšuvumā dominē zalā un dzeltenā krāsa, mazāk - sarkanā un zilā. İpatnējās un uz senu tradiciju pamata dibinātās krāsu mainas rezultātā viens un tas pats saulītes motīvs katrreiz parādās citā krāsu tonī.
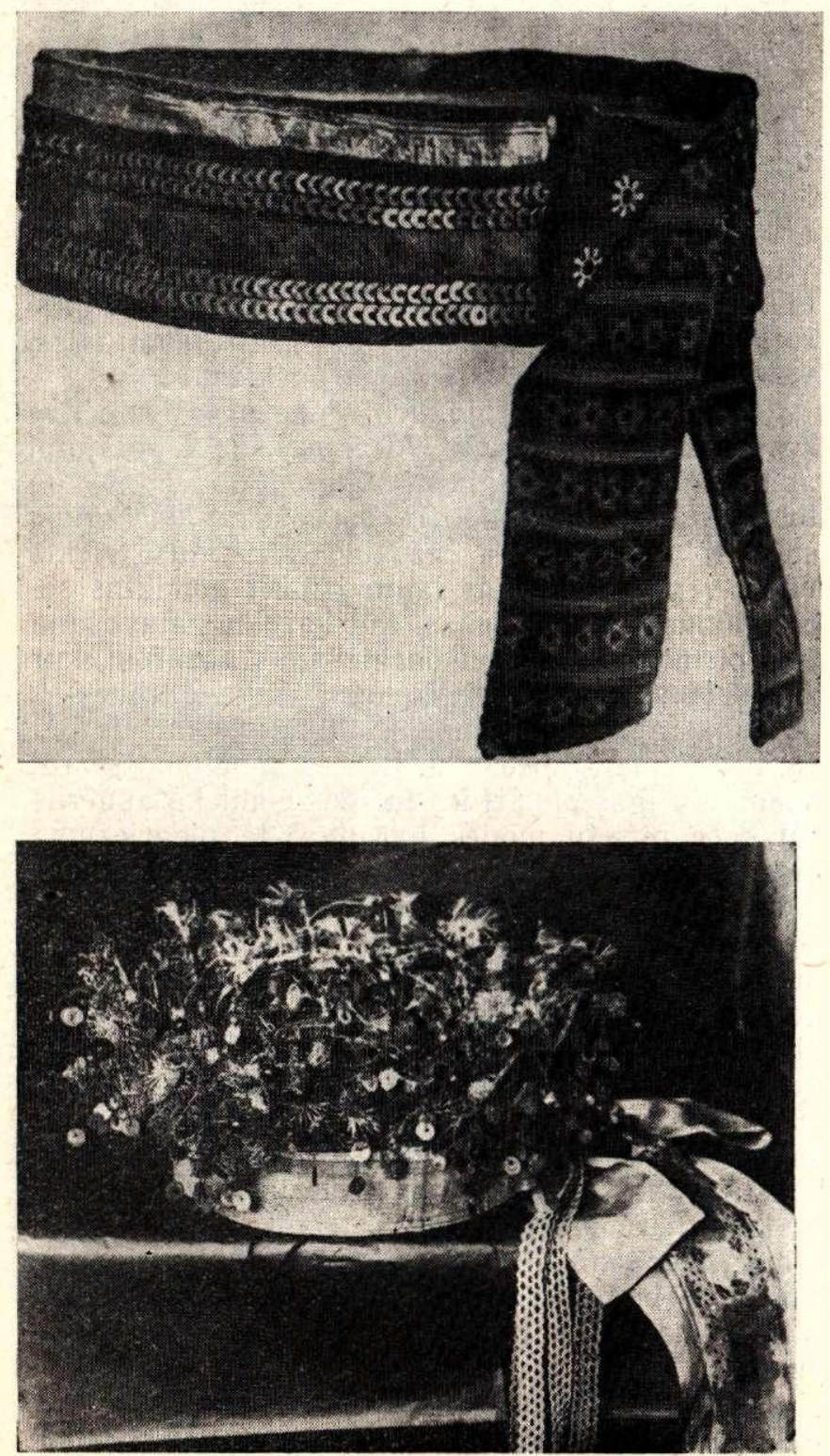
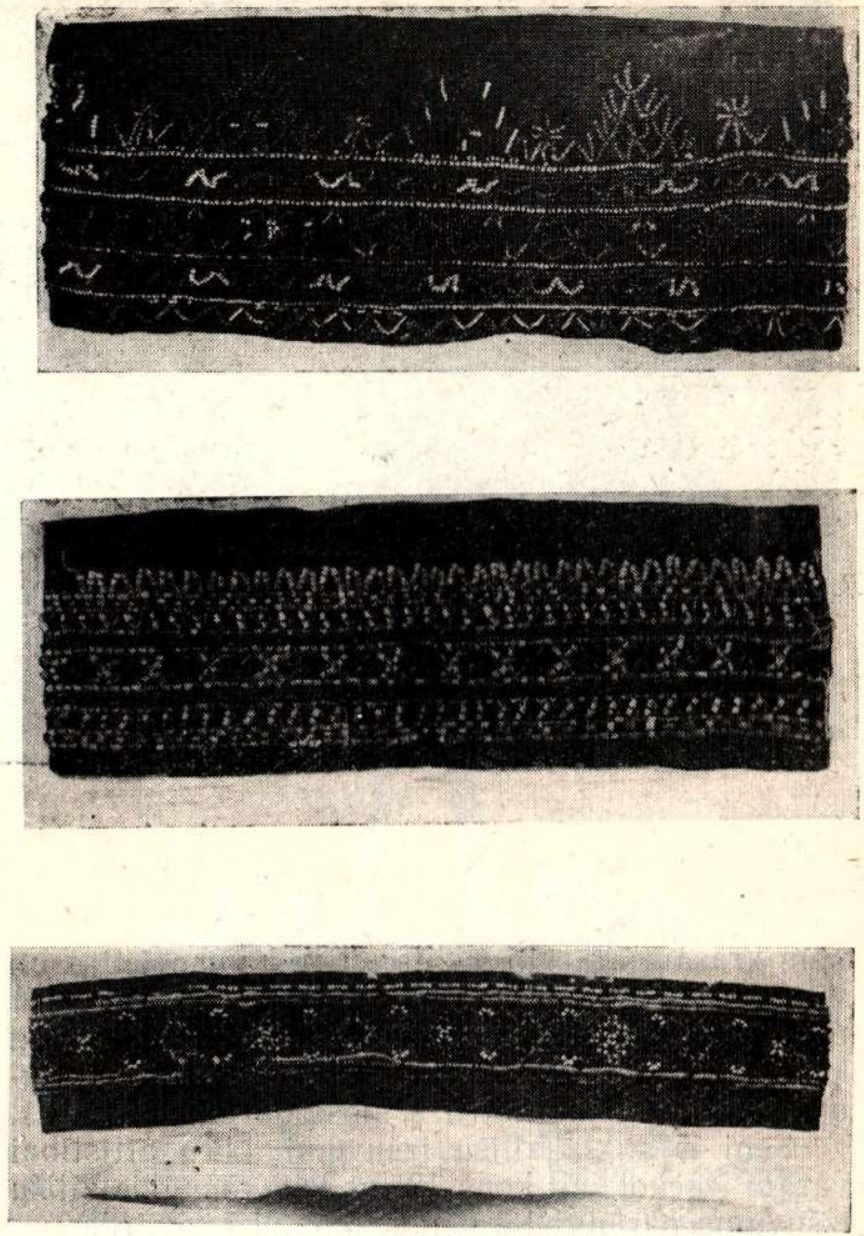

19. att. Zỉlišu un vizulu rotājums vainagos.

Austrumvidzemes villaines kompozicionāli atgādina Krustpils villaines, atšḳirības dažkārt ir tikai joslu proporcijās, bez tam Austrumvidzemes villainu rotājumā nereti parādās brūnā krāsa. ${ }^{222}$

Sievu cepures (Austrumvidzemes, Lielvārdes) ${ }^{223}$ izšūtas dažādās krāsaino darbu tehnikās. Vidzemes vidienas sievu cepures ar îpatnējām vertikālām svītrām cepures malās redzamas jau 17. gs. zīmējumos (15. att.); liekas, ka krāsainās svītras būs bijušas ieaustas. Kompozicionāli Lielvārdes sievu cepures arī ir ieturētas triju joslu dalījumā, tikai šaurākās joslas negrupējas ap platāko, centrālo joslu, bet katra josla parasti mēdz būt citādā platumā (skat. 29. tab.).

Senākais, Vidzemei īpatnējais kreklu rotāšanas veids ir krāsainā izšuvumā darinātas stāvās ap. kakles, ${ }^{224}$ kas 19. gs. sākumā saglabājušās tikai Krustpils, Austrumvidzemes un 18. gs. arī Lielvārdes novadā (skat. 2. tab.). Krāsainie kreklu rotājumi, liekas, ir vecāki. 19. gs. tos nomaina baltie izšuvumi. Turpretim Alsungas un Rucavas kreklu krāsainais izšuvums ir jaunāks; par to liecina no krekliem ar balto rotājumu pārnemtā iz. šūšanas tehnika un kompozīcija, kā arī ar ḳimis- 

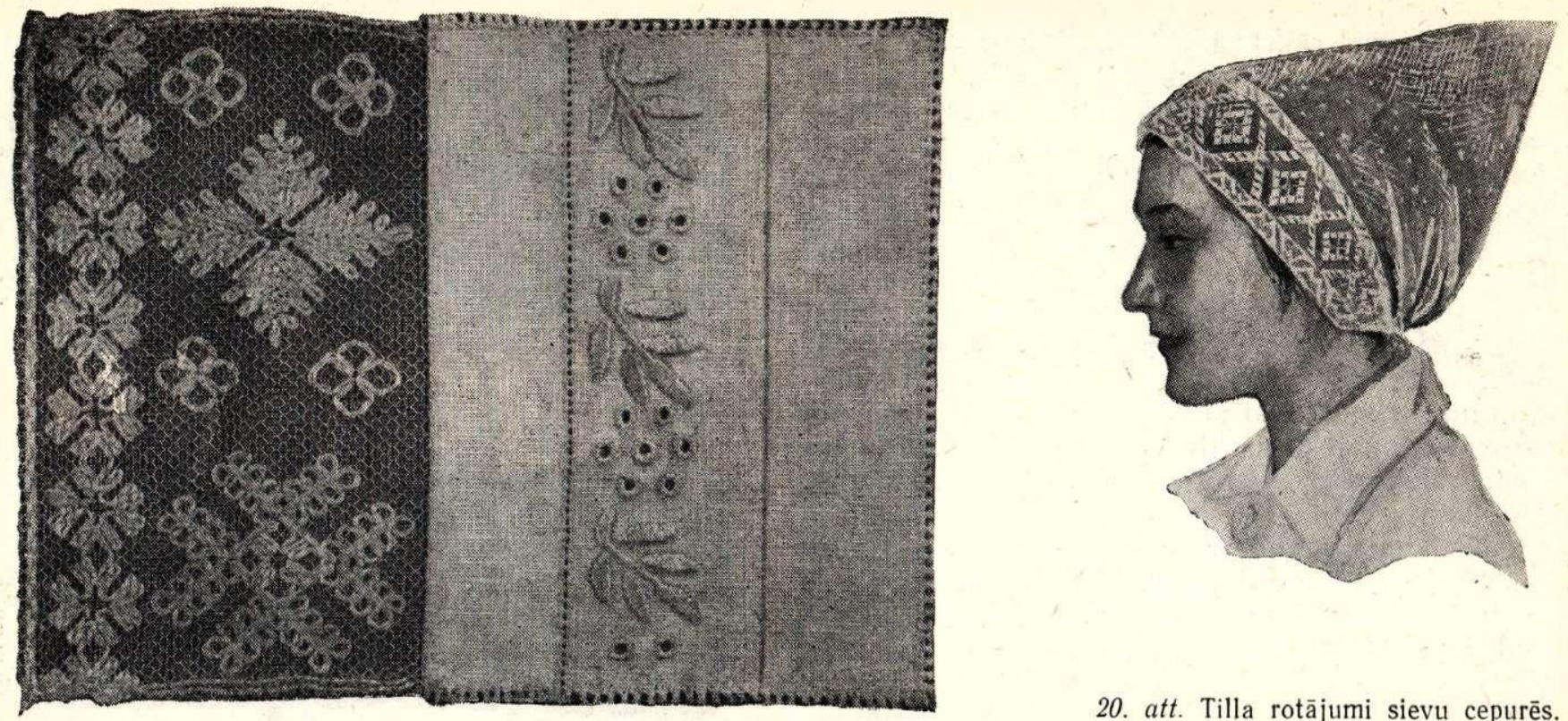

20. att. Tilla rotājumi sievu cepurēs.

kām krāsām krāsotās dzijas. Pēc kompozīcijas un izšuvuma tehnikām vecākās ir Ventspils (16. att.) un Talsu villaines, kuras izstrādātas svītru un ķēžu dūrienāê225 (17. att.). Vīriešu svārku rotājumam parasti izmantoti t. s. mašīndūrieni (18. att.).

Seni ir stikla zīlī̌su izšuvumi, kuru attīstībai varam izsekot jau kopš 12 . gs. ${ }^{226}$ Krāšnākie zîliišu izšuvuma paraugi 18. gs. sastopami Lielvārdes un Talsu novadu vainagos (19. att.), bet 19. gs. zìlu jostās.

Samērā jauna tehnika, kas latviešu tautas mākslā parādās reizē ar baltajām «torṇa» cepurēm, ir tilla izšuvumi, kuru labāko paraugu kompozīcijas veido geometriski raksti, kas vairāk at. bilst latviešu tautas mākslas specifikai (20. att.).

Sākot ar 19. gs. otro pusi un pāreju uz «modes» apgèrēbu, izšuvumiem rotāti apg̀êrbi aizvien vairāk izzūd un 19. gs. beigās sastopami jau vairs tikai retumis. Tomēr senās rotāšanas tradīcijas savu nozīmi nezaudē, bet plašu izplatību gūst jaunos dekoratīvos priekšmetos - dvieḷu galos, galda segās, aizkaros, spilvenos, palagos u. c.

Kā jau minēts, latviešu tautas mākslas izšuvumu senākajam tehniskajam izpildijjumam rak. sturīga ir izšǔšana, skaitot auduma diegus. 19. gs. beigās, kad izšūšanai sāka lietot pirktos kokvilnas audumus, kuriem diegus saskaitît bija visai grūti, izšuvumos ieviešas ar brīvu roku zìmētie ziedu motīvi. ${ }^{227}$ Tautas tērpu rotājumā (izṇemot kreklus Rucavā, kā arī víriešu kreklus Latgalē un Augšzemē) šie motīi neieviešas 228 (21. att.).

Bez izšuvumiem apgēēbu rotāšanai plaši izmantotas apmales, aukliṇas, bārkstis un puški, kas izsekojami pat jau 10.-12. gs. darinājumos. ${ }^{229}$ 18. gs. vilnas aukliṇu rotājumi visplašāk izmantoti vīriešu svārkiem. Ar auklām parasti apšuva jau gatavu sašūtu apg̣ērbu. Auklu rotājums novie- tots gar svārku vai brunču apakšmalu, ap kabatu iegriezumiem, ap apkakli un svārku atlokiem, kā arī piedurkṇu galos; dažkārt ar auklām sedza arī vīles. Auklas piešuva vai nu taisni, vai arī no auklu cilpām veidojot rakstu (22. att.). Auklu rotājumi dažkārt apvienoti ar izšuvumiem (Cesvaines jaka) un dažāda veida puškiem.

Līdzīgi auklu rotājumiem ir apš̉uvumi ar citas krāsas audumu vai ādu. Aitādas kažoku rotājumi ar trušu ādu plaši izplatīti 18. gs. Lielā radniecība to rotājumā vedina domāt, ka kažokus darinājuši speciāli amatnieki - kažoku šuvēji. Mūsu rīcībā vēl nav materiāla, kas lautu izdarît noteiktus secinājumus, bet, kā liekas, tad kažoku gatavošana bija pirmā no apgeērbu darināšanas nozarēm, kur zemnieki izmantoja vietējo amatnieku darbu.

Rīgas apkārtnē zemnieku drēbnieks minēts jau 18. gs. pirmajā pusē. ${ }^{230} \mathrm{~J}$. Broces zìmējumos ${ }^{231}$ redzamais Rīgas apkārtnes turīgo zemnieku apğērbs šūts pēc pilsētu modes parauga; tā piegriezums visai sarežgīts un noteikti prasijjis speciālas amata zināšanas. Tomēr par lauku drēbniekiem kā īpa. šiem apkārtcelojošiem amatniekiem, kas šuva virsdrēbes - svārkus, mētelus, kažokus un vīriešu goda drēbes, varam runāt tikai, sākot ar 19. gs. pirmo pusi. Visus pārējos sieviešu apg̀ērbu gabalus un vîriešu linu auduma darba drēbes turpina šūt pašu māju sievietes. Pēc muzeju fondos eso. šajiem vīriešu svārkiem un sieviešu jakām grūti konstatēt, vai tos šuvuši speciāli drēbnieki vai ne, jo lauku drēbnieku šūšanas tehnika vēl bija uz zema lïmena un tie tāpat kā zemnieces visus šūšanas darbus veica ar rokām. Lauku drēbnieki sāka izmantot šujmašinas tikai 19 . gs. otrajā pusē. ${ }^{232}$

Drēbnieku darba apstākḷi šai laikā nebija spīdoši, jo tumšās un zemās istabas jau dienas laikā 


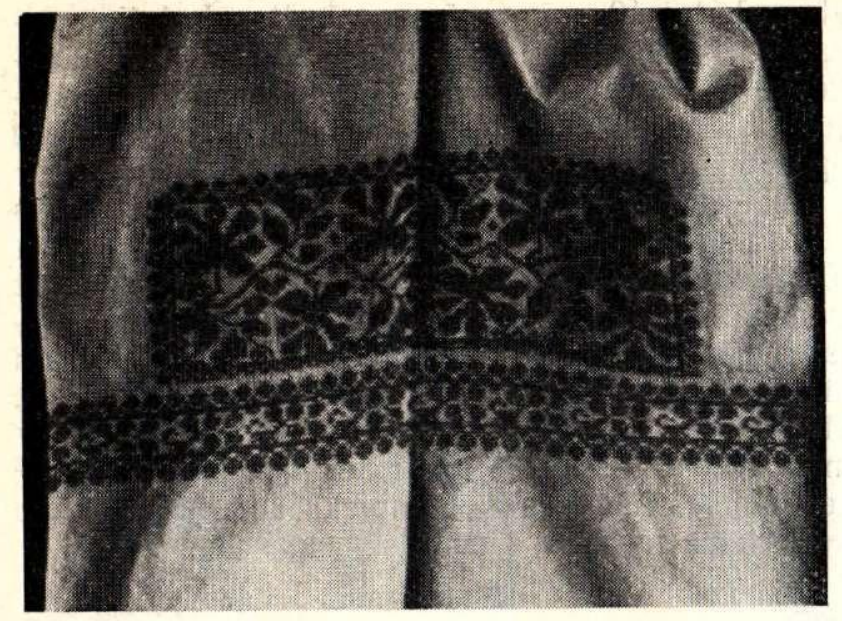

1

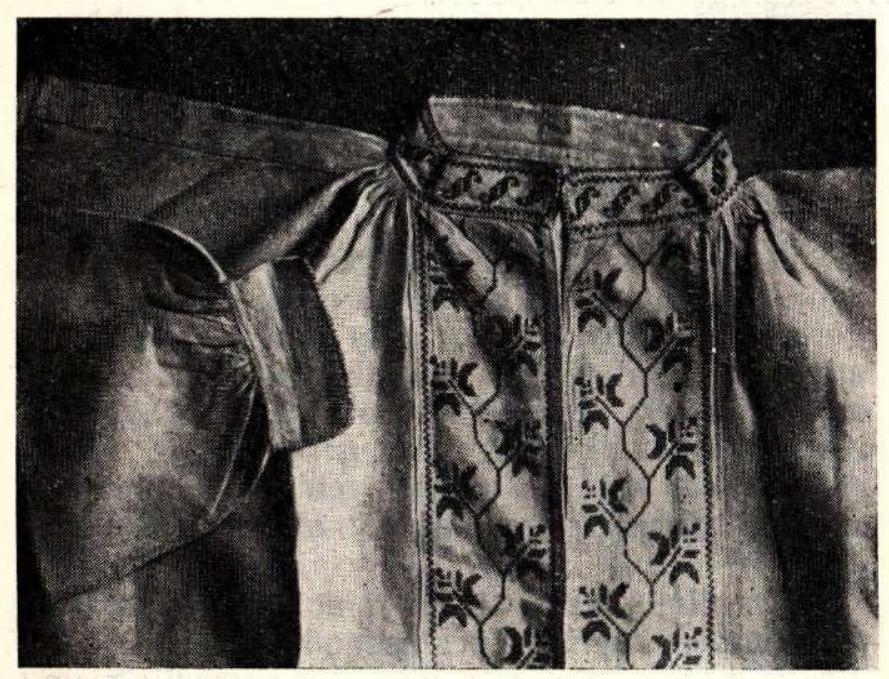

2

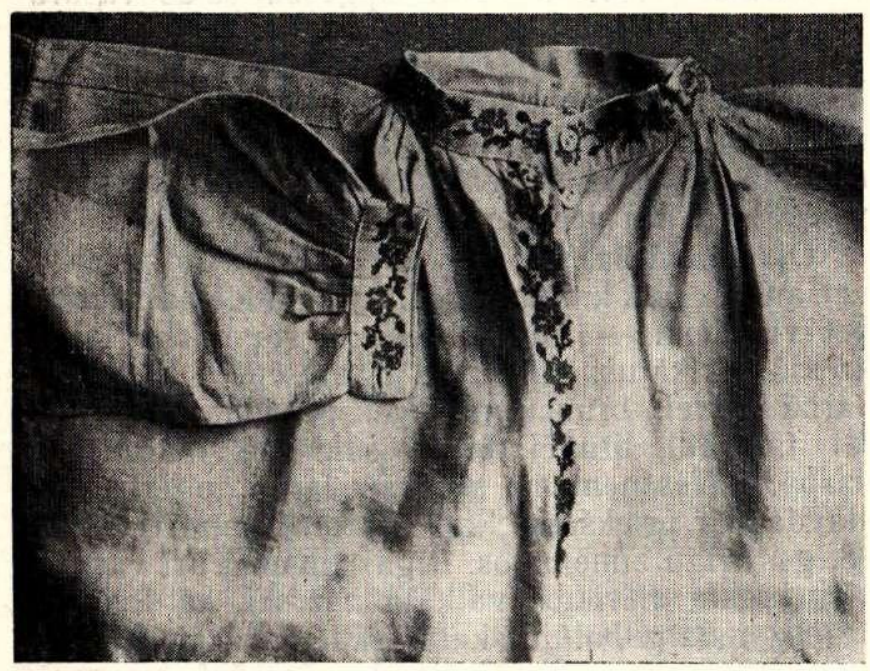

3

21. att. Ziedu raksti kreklu rotājumā: 1-Rucavas; 2 - Ziemellatgales (Sķilbēni); 3 - Krustpils. deva maz gaismas, bet vakaros vajadzēja strādāt pie skala vai petrolejas lampas uguns.

Samērā maz materiālu ir par lauku drēbnieku darba rīkiem 19. gs. sākumā, bet arī esošais materiāls vedina domāt, ka tie nebūs bijuši daudz citādāki kā 19. gs. vidū (grieznes, uzpirkstenis, adatas, gludeklis un koka mërs - olekts). ${ }^{233} 19$. gs. pirmajā pusē mēra n̦emšanai izmantoja vienkāršu auklu vai papīra lenti. Vajadzīgo attālumu auklă atzīmēja ar mezgliem. 19. gs. beigās mēra ṇemšanai sāka lietot lentveida metra mēru.

Pēc mēra noṇemšanas uz auduma ar ziepju ga. baliṇu vai krītu atzīmēja vajadzīgos attālumus; audumu piegrieza bez piegrieztnes. ${ }^{234}$

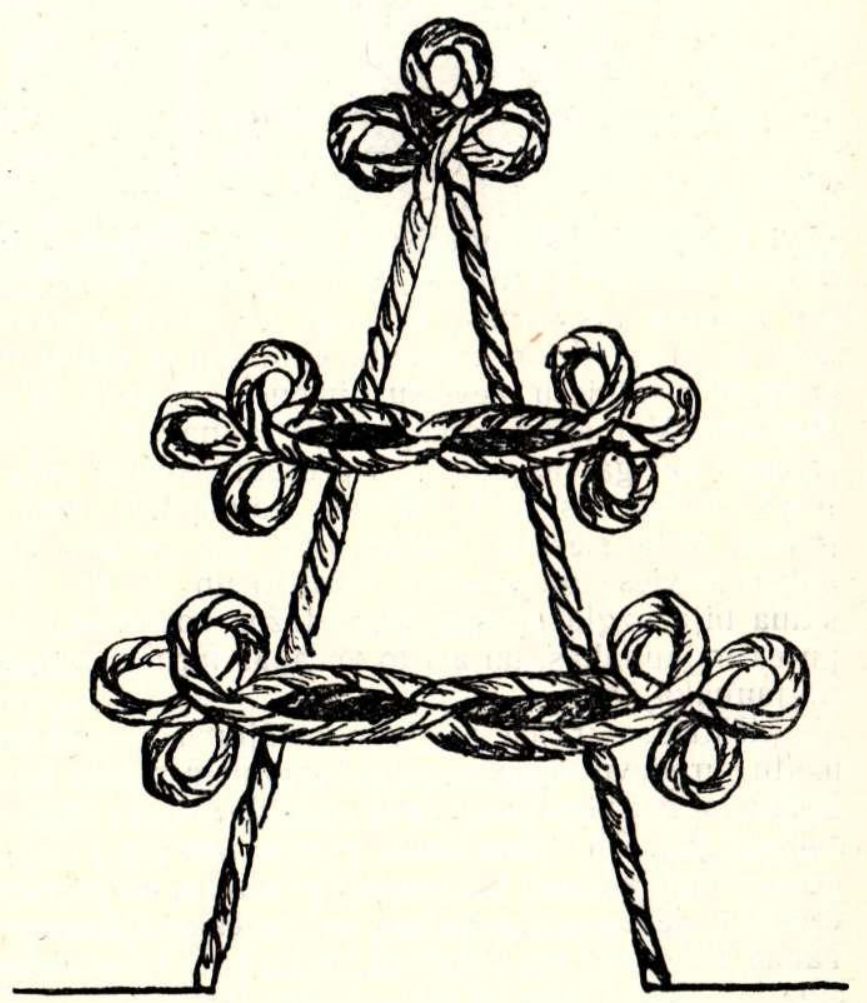

22. att. Auklas rotājuma paraugi.

Sujot apgèrerbu mājas apstākl̨os, visu šuva pēc «acumēra» vai arī piegrieza, uzliekot uz auduma novalkātu apg̀ērba gabalu.

Drēbnieks kā samaksu par savu darbu sañēma uzturu un nelielu atlīdzību, parasti - graudā. 19. gs. 80. gados arī lauku amatnieki pakāpeniski pārgāja uz darba samaksu naudā. ${ }^{235}$ Tā kā bieži vien drēbnieki par darbu prasîjuši visai lielu naudu, tad pat turīgākie saimnieki ne katrreiz varējuši drēbniekiem samaksāt; par to liecina tiesu protokoli. ${ }^{236}$ Naudas trūkuma dēl zemnieki parasti neizmantoja arī pilsētu amatnieku pakalpojumus, bet apgēēbus un apavus iespēju robežās izgatavoja paši. Apkārtklejojoši drēbnieki laukos vêl sastopami 20. gs. pirmajā ceturksnī, kad jau gandrīz visos Latvijas novados valkāja pēc pilsētas modes šūtus apgèerbus. 
Drēbnieki šuva apg̀ērbu ne tikai saimniekiem, bet arī kalpiem, jo drēbes parasti bija pielīgtas pie algas. ${ }^{237}$ Tā, piemēram, Ilūkstes apriṇkịi no 1861. lïdz 1897. g. kalpa alga bija šāda: puisim apmēram 27-30 rubḷi naudā, viena pašausta vilnas svētdienas kārta, 1 pašausts linu vai pakulu audekla uzvalks un uzturs. Bez tam saimnieks maksāja par puisi galvasnaudu; priekšpuisim maksāja 5 lìdz 20 rubḷi vairāk un pielika vēl 3 rubḷus, ja tas atsacījās no linu sēšanas savām vajadzî. bām. Kalponēm maksāja 14-30 rubḷu un deva uzturu, vietām pie algas vēl pielika pāri kurpju. ${ }^{238}$ Tātad saimnieki daḷu algas izmaksāja nevis naudā, bet ar apg̀ērbu, pie kam apgèerba materiālu pagatavoja mājās. Apgèèrbu un apavus kā dạ̣u algas kalpi 19. gs. saṇēma arī citos Latvijas novados. ${ }^{239}$ Tāpat arī ganiem pie algas pielíga apgèērbu - zēniem uzvalku, bet meitenēm - brun čus un apavus. ${ }^{240}$ Protams, ka arī laukstrādnieku apgèrēbus darināja uz visu gadu līgtās meitas.

Lai gan ādu rūpniecība un kurpnieku amats 19. gs. sākumā pilsētās bija visai izplatìts, tomēr Kurzemes, Vidzemes un Latgales zemnieki līdz gadsimta otrajai pusei apavus gatavoja pašu mā. jās lielākoties no liniem, pakulām un lūkiem vai arī no ādām, ko paši bija apstrādājušii. ${ }^{241} 19$. gs. otrajā pusē, spriežot pēc mācekḷ lìgumiem ar meistaru ${ }^{242}$ un sūdzībām par nesamaksātu darbu, ${ }^{243}$ secināms, ka šajā laikā zemnieki izmantoja vietējo kurpnieku darbu.

\section{APG̣ERRBS KĀ VALKĀTĀJA VECUMA, ĢIMENES UN SOCIĀLĀ STĀVOKL̨A ATSPOGUL̨OTĀJS}

Kā jau minēts, apġērbs atspoguḷo ne tikai valkātāju etniskās ìpatnîbas, bet arī ğimenes stāvokḷ un vecuma atškirīibas. Vainagi un sievu galvas auti ar savu stingri nosacīto valkāšanas veidu ir spilgtākie latviešu sieviešu ğimenes stāvokḷ raksturotāji. Vainagus valkāja tikai jaunavas, kamēr cepures vai galvas auti bija precētu sieviešu rota. Kopš mičošanas brīža sievas staigājušas segtu galvu. Auta siešana uzlūkojama par vecāko no abiem sieviešu galvassegu veidiem un 19. gs. sā. kumā bija uzglabājusies tikai dažos novados. Cepures ir jaunākas, un arī to vecākās formas jāškiir no jaunākajām.

Atškirīiosas ir arī apg̀ērba rotājumã - jaunu meitu un sievu apg̀ērbs ar izšuvumiem rotāts bagātāk, kamēr vecāku sieviešu apg̀ērbs rótāts daudz. nabadzīgāk. Tā, piemēram, grezni izšūtās villaines ir tikai jaunavu un jaunu sievu rota, turpretim vecākās sievas sedza baltas vai pelēkas villaines. Tāpat Vidzemes un Latgales baltie koši rakstainie cimdi ir tikai jaunu cilvēku - līgavaiṇu rota.

No pieaugušo apg̀ērba atdalāms bērnu apgèrbs. ${ }^{244}$ Tas darināts tādā pašā piegriezumā kā pieaugušo apḡērbs, vienīgi dažas îpatnības vērojamas atsevišḳu apgēerba gabalu valkāšanas tradīcijās. Tā, piemēram, gandrīz visā Latvijā līdz pat 20. gs. sākumam zemnieku bērni līdz skolas vecumam staigājuši vienā linu kreklā un, tikai sākot skolas gaitas, dabūjuši savas pirmās bikses vai brunčus un apavus. ${ }^{245}$

Apgèērbi pēc valkāšanas nozīmes dalāmi: goda, ikdienas un darba. ${ }^{246}$

God a apg̣ērbs parasti bija greznāks, ar bagātu rotājumu, un tâ darināšanai veltīta liela uz. manība. Goda apgēerbu ātrāk nekā ikdienas apgèerbu sāk darināt no dārgāka un pirkta materiāla. Tieši šī apğērbu grupa visvairāk interesē apg̉ērb: pētniekus, jo tajầ saglabājušās spilgtākas etniskās īpatnības.

Pie šīs grupas zināmā mērā pieder arī ceremoniju tērpi, kas daḷēji komplektējās no goda ap- gèerba, to papildinot ar atseviškāām sastāvdalām, kuras gatavoja tikai kādam noteiktam gadījumam. Tãdas sastāvdaḷas, piemēram, bija līgavu vainagi kāzu ceremonijāa, liggavaiṇu cimdi, dāvanu krekli kāzās u. c. ${ }^{247}$

Ikdienas apgērbus parasti pagatavoja no rupjāka auduma. 19. gs. otrajā pusê, kad goda apgeerrbus sāk darināt no pirkta auduma, ikdienas apgēērbus tāpat turpina šūt tikai no rupjāka pašausta auduma. Bieži vien par ikdienas apgeêrbu izmantoja pavalkātus goda apgèērbus.

$\mathrm{D}$ a r b a apgēerbu parasti veidoja no ikdienas apgēerba komplekta, pielāgojot attiecígajai vajadzíbai. 248

Par pilnu darba têrpa komplektu ir samërā maz ziṇu, bet, spriežot pēc nedaudzajiem J. Broces zīmējumiem un dažiem vispārīgiem norâdījumiem, tomēr iespējams raksturot latviešu zemnieku darba apgèērbus klaušu saimniecības sairuma posmă.

Pirmais sieviešu darba apḡêrba veids vasară ir jau minētais linu krekls (23. att.), ko sajoza ar jostu. Latgalē arī vīrieši vasarā strādājuši vienos kreklos. ${ }^{249}$ Līdzīgas zinas ir arī par igaunu vî. riešu apgeērbu. ${ }^{250}$ Vasarā, darbos iedami, kā vī. rieši, tâ sievietes staigãja kailām kãjām, valkāja vīzes $^{251}$ vai arì vecākas pastalas.

Otrs sieviešu vasaras darba tērpa komplekta variants ir virs krekla uzvilkti linu audekla brunči, bet vīriešiem - linu bikses; karstā darba laikä kreklus valkājuši izlaistus virs biksēm. ${ }^{252}$ Sievietes darbā dažreiz brunču malu aizsprauda aiz jostas, lai tādējādi brunči būtu īsāki un netraucētu darbā. ${ }^{253}$ Neatñemama sieviešu darba apgērba sastāvdala ir priekšauts, kas redzams gandrīz visos 18. gs. beigu zìmējumos. Rìgas tuvumā arī vasarā virs krekla sievietes valkāja bezroci, kā tas redzams siena gubotāju skatā (skat. 3. tab., 1). ${ }^{254} \mathrm{Sa}$ mērā grūti noskaidrot, kādas bijušas galvassegas; spriežot pēc J. Broces zīmējumiem, tās bijušas cepures un vainagi vai matauklas. ${ }^{255}$ Tà kā vainagi bija jaunavu goda rota un rakstîtie avoti ne- 

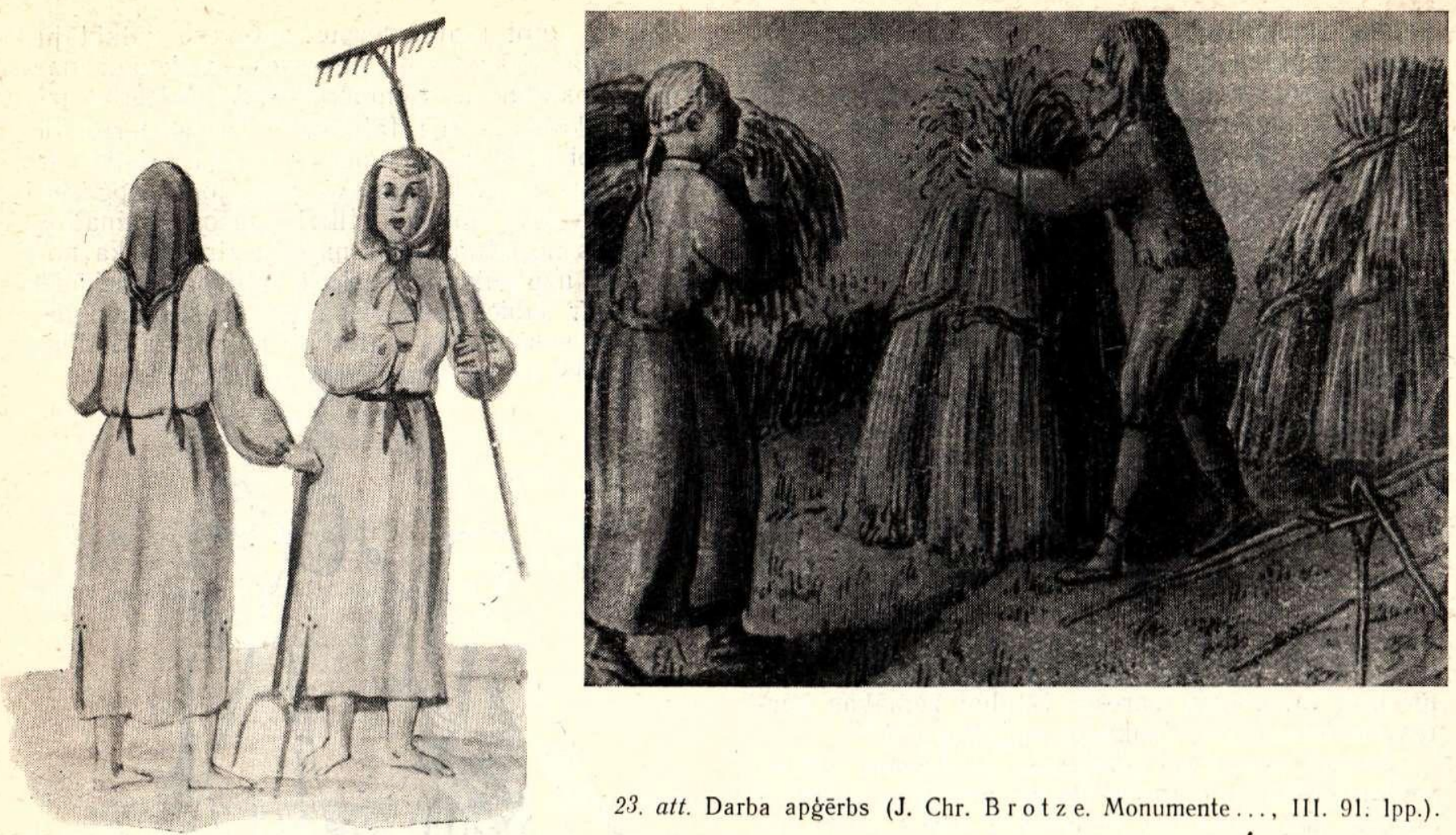

23. att. Darba apgèrbs (J. Chr. B rotz e. Monumente..., III. 91. Ipp.).

sniedz ziṇas, ka jaunavas strādātu vainagos, tad jādomā, ka J. Broces zīmējumi, tāpat kā O. Hūna krājumā ievietotais zīmējums - jēkabpiliete ar grābekli un vainagu galvā, objektīivi neattēlo isteníbu. ${ }^{256}$

Vēsākā laikā un ziemā «...pieaugušie [valkāja] skrandainus kamzoḷus» ${ }^{257}$ vai pussvārkus. ${ }^{258}$ Sie pēdējie apg̉ērba gabali, kā vīriešiem tā arī sievie. tēm, bija vienādi. Visi darba apg̀ērbi parasti bija šūti no rupja pakulu vai sliktas vilnas materiāla un atšḳirībā no godu apgèērbiem bija pilnīgi nerotāti. Izñēmums ir gadījumi, kad darbā tikuši novalkāti veci goda apgēerbi, lai gan ir ziṇas, ka rotātās krekla dalas no noplīsušiem krekla stāviem piešuva jauniem krekliem. ${ }^{259}$ Jādomā, ka šāds apg̀ērba komplekts būs bijis arī trūcīgo kalpu un valinieku goda apg̀ērbs; par to zināmā mērā liecina arī tautasdziesmas:

\section{Nem par labu, vīra māte, \\ Kādu tevim kreklu devu: \\ Isu, šauru, nerakstītu, \\ Kalpodama nopelniju.}

Uzrakstïta 1962. g. etnogrāfu ekspedīcijā Daugavpils rajonā

Kā jau iepriekš norādīts, apg̣ērbs atspogulo valkātāja sociālo piederību. Tã, piemēram, apskatāmā laika posmā muižnieki valkāja sava veida, zemnieki - sava, bet pilsētnieki - atkal sava veida apgèèrbu, kas atkarībā no vietējiem apstākliem dažădi variẻjāàs. ${ }^{260}$ Runājot par apgèerbu kā valkātāja šḳiriskās piederības atspogulotāju, jāiegaumē, ka klaušu saimniecības sairuma posma materiālā un garīgā kultūra, tātad arī apgêēbs, veidojās uz vêlā feodālisma ekonomiskās bāzes, kad valdošā škira pārstāvēja latviešu tautai svešo vācu feodâlu un topošãs buržuāzijas kultūru, kura tāpat bija vāciska.. ${ }^{261}$ Latviešu tautas kultūra joprojām palika tiešo materiālo vērtību ražotāju, galvenokārt dzimtbūšanas laika zemniecības kultūra. Tā kā šai laikā nebija latviešu val. došās šḳiras, tad nebija arī latviešu valdošās šḳiras apgènerba. Cits jautājums ir par latviešu amatniekiem u. tml., kuri dzīvoja gan pilsētās, gan laukos. Viṇu apgèèrbi un to izveide būtu loti interesants pètniecíbas objekts, bet, tā kā šis jautājums neietilpst monogrāfijas ietvaros, tad pakavēsimies tikai îsumā pie tā. Par latviešu amatnieku un citu zemāko «nevācu» kārtas pilsētu iedzìvotāju apgèerbiem bagātus materiālus dod nolikumi «pret greznību», ${ }^{262}$ kurus izdeva Rīgas pilsētas rāte 16 . un 17. gs. Cinna pret izškērdību un greznību vai, labāk sakot, šì ciṇa vācu un nevācu starpā turpinājās arī 18. gs. $^{263}$ Pēc 1753. g. Lielās gildes iesniegtās sūdzỉbas Rịgas rātei ${ }^{264}$ spriežams, ka latvieši, kuriem pilsētā izdevās izrauties no dzimtbūtnieciskās verdzības, parasti centās ieklauties valdošās škiras kultūrā un savā apgèerbā lìdzināties tai. Sửdzībā ir arī noteikums, ka latvieši jāapiespiež nolikt vācu drēbes, kas esot stipri dārgas un neatbilstot vinu zemajam dzimumam. Tiem esot jāvalkā viṇu parastais, kopš seniem laikiem 
lietotais apg̀ērbs. ${ }^{265} \mathrm{Kā}$ rāda J. Broces Rìgas iedzīvotāju apğêrba zīmējumi, pilsētas iedzīvotāju zemāko slānu - latviešu apğērbs ir stipri lïdzīgs zemnieku apgèrerbam ${ }^{266}$ un atškiras no tās pašas kārtas pārstāvju vāciešu apğērba. Teiktā raksturošanai labi noder J. Broces (Monumente..., III. 55. lpp.) pilsētas kalpoṇu - latvietes un vācietes - attēli, kuriem pievienoti šādi komentāri:

1) «Latviešu dzimt|aužu meita, kas pilsētā ir par kalponi. Ka tā nav vāciete, redzams no pastalām un no viñas neapsegtajiem matiem, ap kuriem apsieta lente» (skat. 20. tab., 1); 2) «vācu kalpone, proti, istabene. Tās apgèērbs ir jau tuvāks modei» ${ }^{267}$ (skat. 3. tab., 5). Arī citi latviešu un vācu zemāko slāṇu pilsētnieču apgèēbu zīmējumi rāda šo starpību. 268 Dažos attēlos redzamas atšḳirības vidusškiras un augstākās kārtas pārstāvju apgēerbằ. ${ }^{269}$ Tādēl jo saprotamāks ir kāda laikabiedra greznības likuma novērtējums, proti, ka šo greznỉbas likumu vienīgais «labums» esot tas, ka tas laušot atškirt cienījamu dāmu no tirgotāja sievas, tā savukārt varēšot lielíties amatnieka sievas priekšā, un pēdējā varēšot izzobot zemākās kārtas sievietes vinu vienkāršā apgéēba dēḷ..270

Ja arī zemnieku geereš̌anās ar likumu netika reglamentēta, tad tomēr turīgo zemnieku apğērbs zināmā mērā atšḳiras no trūcīgo lauku laužu apgèērba. 18. gs. otrajā pusē sakarā ar ārējā un iekšējā tirgus paplašināšanos dzimtlaužu vispārējais stāvoklis pasliktinās. Šai laikā viṇu vidū sāk izvirzīties lauku budžu elementi, ${ }^{271}$ kuru materiālais stāvoklis pakāpeniski uzlabojās. Par to lieçina arī apgèērba materiāls. J. Broce, komentējot Vīgantes muižas (Ērğemes draudzē) zemnieka attēlu, raksta: «Pēc vina kārtīgā apgèēba var pazìt, ka vinš nav vis vienkāršs zemnieks, bet gan stārasts. Virs ādas kamzoḷa, kas apšūts ar melnas ādas sloksnēm, viṇam ir linu svārki, bikses ir pla. tas, no slikta tūka vai vadmalas. Pāri vilnas zekeem viṇš [kājas] notinis lïdz pat puslieliem ar baltiem linu autiem. Aiz sarkanbaltās jostas, kas viṇam ir ap vidu, vinš priekšā aizbāzis savus cimdus.» ${ }^{272}$ Vêrtīgs ir J. Broces vērtējums par zvej. nieku apg̣ērbu, kas esot bagātāks par zemnieku apgèērbu. ${ }^{273} 19$. gs. pirmās puses lauku iedzīvotāju nogrupējumus atzīmē arī $\mathrm{K}$. Jirgens: «Zemnieku dzīve bija grūta. Drusku labāk daži izredzētie saimnieki un amata vīri jutās, bet viss vairums saimnieku, līdzīgi bandiniekiem, iebūviešiem, pirtniekiem un nabagiem, dzīvoja nožēlojamu bezizejas, trūkuma, bada un varmācības dzīvi.» ${ }^{274} \mathrm{Par}$ atškirīibām turīgo apg̉ērbā norādījumus sniedz arī citi avoti, piemēram, Latgales turīgākās zemnieces 19. gs. vidū sāk valkāt raibus katūna priekšautus un galvas lakatinus. ${ }^{275}$

Bez tam zināmu radniecību kalpu un saimnieku apğèrbā noteica arī tas, ka vēl līdz 19. gs. beigām gan muižas, ${ }^{276}$ gan saimnieku kalpi apgēerbu sañēma kā savas darba algas dal̨ $u^{277}$ un, ievērojot naturālās saimniecības raksturu, apḡêrba materiālu kā saimniekiem, tā kalpiem auda uz vieniem stāviem.
Tāpat, pētot tautas tērpus, jāievēro valkātāju individuālās tieksmes un intereses, jo vienādi ma. teriālie apstākḷi ne vienmēr noteiks apgēērba iz. veidi, konkrēti - tā rotājumu. ${ }^{278}$ Tautas tērps kā mākslas objekts ne vienmēr ir t i eši saistîts ar sabiedrības sociālekonomisko bāzi, jo tā apg̛ērba formu izveidi noteiks tikai pašos pamatos. K. Markss norādīja: «Par mākslu zināms, ka noteikti tās uzplaukuma periodi neatrodas nekādā saskañā ar sabiedrības vispārīgo attīstību un tā. tad arī ar sabiedrības materiālā pamata attīstību, kurš ir it kä tās organizācijas skelets.» ${ }^{279}$

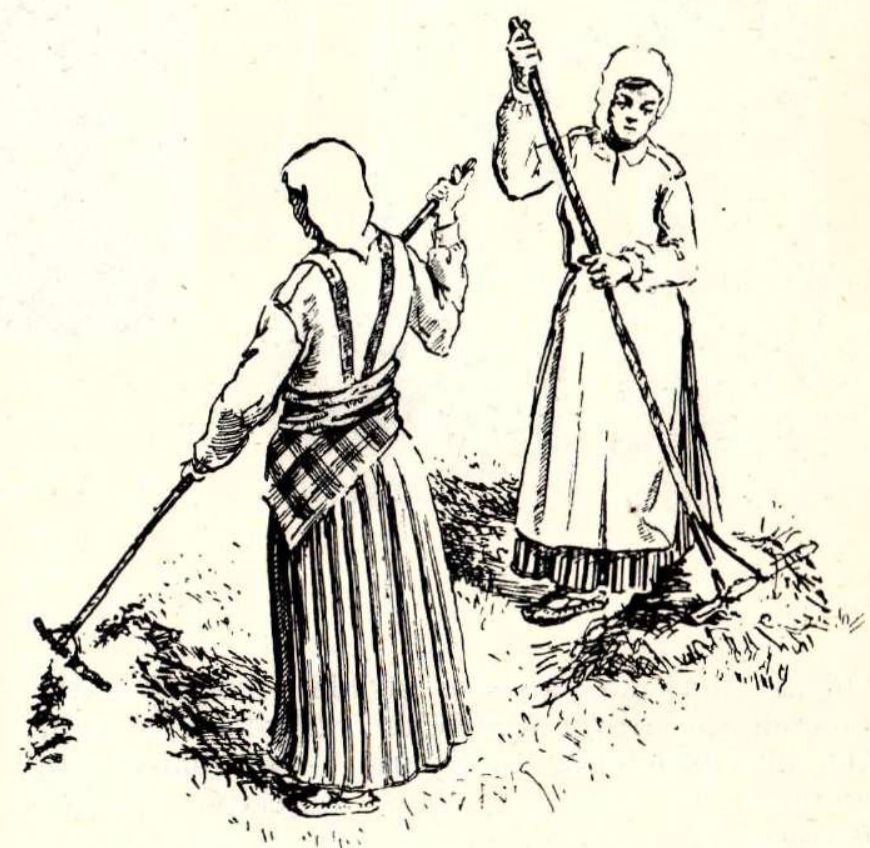

24. att. Mazsalacas muižas zemnieces siena vākšanā (pēc Krievu Ģeogrāfijas biedrības arhīvā esošā A. Pecolda oriğināla zīm. J. Riekstinnš).

Tādēḷ, analizējot latviešu tautas tērpu bagāto rotājumu, jāievēro, ka ne tikai rotājuma darinātāja škiriskā piederība noteiks rotājuma bagātību. Ški riskuma principa zinātniskā lietošana, ideoloğiska rakstura faktu (šai gadījumā tautas mākslas) aplūkošanā prasa šo faktu vispusīgu analīzi. Pretējā gadījumā marksistiskās šḳiriskās analīzes vietā notiks vulgāra socioloğizēšana. ${ }^{280}$

Apskatot apg̀ērba valkāšanas tradīijas, jānoskaidro arī apgèrrba valkātāja skaistuma izpratne, skaistuma jēdziens, kas izpaužas arī apğērbā. Darbalaudīm, kam galvenais dailuma vērtības mērs ir darbā gūtais skaistums, dailais un skais. tais saistīts ar praktiskumu, lietderigumu, ${ }^{281}$ turpretī mantīgās škiiras skaistuma jēdziens saistīts ar pārspīlētu greznību un uzbāzīgu lepošanos, pie kam bagātība un greznums parasti saistās ar ekspluatāciju. Tautasdziesmas pel bajāru meitas, kas ir skaistas, baltas, bet neprot darbu un dižojas ar kalpoṇu pielocito pūru. 
Raksta māte, raksta meita,

Nerakstîtas villainites;

Es rakstìt nemācêju,

Man rakstītas villainites.

LTD, III, 520

Parasti, ligstot ganus vai meitas, tika norunāts, cik meitai jānoauž audekla, cik kreklu u. c. jāizšuj vai arī cik pāru cimdu jānoada ganam. Pat valiniecēm par mitekli pirtī bija jāizpilda zināms daudzums rokdarbu.

Ciku, čiku, ratenīti,

Mana māte saiminiece;

Kā tev bija nečîstēt, -

Meitas darbu padarīja.

Ltdz, I, 4003

Ja saimniekmeitai gadījās jaunaj iziet pie vīra un pūrs vēl nebija pielocīts, tad vairākus mēnešus mājas meitas palīdzēja to pielocīt.

Piektdien uztinu

Liel' ērkulïti;

Sestdienā novērpu

Ar algādžiem.

Ltdz, I, 4002

Turpretim kalpones, lai pielocîtu savu pūru, spiestas strādāt naktīs.

\section{Ai bärene, bārenīte, Kas tev' dailu darināja? \\ - Viegli soli, mazs miedziñš, \\ Tie man' dailu darināja. ${ }^{282}$}

$$
\text { LD, } 4460
$$

Turīgajiem skaistas liekas pat neglītas lietas, ja vien tās ir grūti iegūstamas un dārgas. Tā, piemēram, audēju novadā Piebalgā 19. gs. sastopams lìgavu vainags, kas darināts no mazām zīda lupatiñām un diedziniiem un nebūt nav skaists. Tã kā visas lígavas reto un dārgo zīda audumu dēl šādu vainagu nevarēja iegādāties, tas kḷva par bagāto saimniekmeitu privilëğiju.

Greznas villaines, ko valkāja tiklab gājējas, kâ saimniekmeitas, tomēr zināmā mērā liecināja par valkātājas turības pakāpi. Saimniekmeitām tās bija greznāk izrotātas, bez tam saimniekmeitas varēja segt vairākas villaines uz reizi, lai visas nāktu redzamas.
Lìcam līka tā vietina,
Kur mēs divi stāvējām:
Tautiešam treju svārku,
Man devinas villainītes.
Bija man, bija man, Vēl vajaga, vēl vajaga: Bija man piecas sagšas, Vēl deviṇas vajadzēja.

$$
\text { LTD, III, } 549
$$

LTD, III, 542

Tas pats sakāms par brunčiem, kurus dažkārt bagātās saimnieces vilka mugurā pat sešus uzreiz. Tãdējādi tãs varēja lepoties nabadzīgāko priekšā, kurām labi ja bija vieni goda brunči.

\section{Ko, tautiet, lielījies? \\ Basa kāja zābakā; \\ Es varēju lielīties, \\ Man deviñas villainïtes.}

LTD, III, 546
Lielākajai zemnieku daḷai trūka vajadzīgo lī. dzek|̣, lai dižotos ar vairākām drēbju kārtām, zìda un brokāta lentēm, daudzām saktām un citām pilsētā pirktām greznuma lietām.

$\mathrm{Ne}$ man zelta, ne sudraba,

Balta vien villainīte;

Ielīgoju istabā,

$\mathrm{Ka}$ ar sniegu apsnigusi.

LTD, III, 413

Par to, ka apgèēbu un rotas valkāja atbilstoši valkātājas sociālajam stāvoklim, liecina, piemēram, šãda tautasdziesma.

$$
\begin{aligned}
& \text { Ni es lielu laužu biju, } \\
& \text { Ni es lielu rotu nešu; } \\
& \text { Vidējo laužu biju, } \\
& \text { Vidējo rotu nešu. }
\end{aligned}
$$

$$
\text { LD, II, } 5693
$$

Tāpat bagātām saimniecēm piederējās lieli un kupli raksti, bet kalponēm - sīkie.

Kuplu loku villainīti,
Smagu laižu pūriñā;
Tādu laužu gaidīidama,
Kādi mani bālelini.

LTD, III, 483

Rakst', måsiña, lielu rakstu

Jele vienu vilnānīti,

Ko tu segsi, aizgājusi

Lielajos dieveros.

LTD, III, 511

Sieviešu tautas tērps savas īpatnības saglabā līdz 19. gs. vidum, vīriešu tautas tērps izmainās daudz ātrāk. Iznēmums ir atsevišḳi novadi, par ko būs runa vēlāk.

Tautas tērpu pakāpeniskai nomainai ar pilsētas apğērbu bija vairāki iemesli. Tautas tērpu izzušanu noteica kapitālisma straujā attīstība 19. gs. otrajā pusē un ar to saistītā iekšējā tirgus izveidošanās, naudas ieplūšana laukos un fabrikas ražojumu izplatǐšanās lauku sētās. Līdz ar sieviešu darbaspēka pilnīgāku nodarbināšanu lauksaimniecības ražošanā sievietēm vairs neatlika laika un nebija arī nekādas vajadzības apgèēbus izgatavot pašām. Tāpēc tās aizvien biežāk seviški goda apgēerbu, nodeva pagatavot vietējiem amatniekiem. Arī apgèrèba audumiem aizvien vairāk izmantoja fabrikăs austos audumus; bez tam pašu mājā audzēto aitu vilnu varēja nodot rūpnīcās, pretī saṇemot gatavu audumu.

Pirmos no pirkta materiāla šuva goda apgēerbus, bet darba apgēēbus, kā arī materiālu šim apgērbam dažuviet pat līdz 20. gs. vidum gatavoja mājās. Liela nozīme pilsētu apgèēba izplatībai lauku sētās bija arī dzīvāku sakaru attīstībai ar pilsētu. Tautas tērps visā Latvijas PSR teritorijā neizzuda vienlaikus, bet pakāpeniski atkarībā no atsevišḳu apvidu ekonomiskās attīstības un saka- 
riem ar pilsētām. Tā, piemēram, 1896. g. V. Plute latviešu etnogrāfiskās izstādes kataloga priekšvārdā raksta, ka «Bauskas, Dobeles, Tukuma un Talsu apriṇkos Kurzemē senos apg̉ērbus gandrīz nemaz vairs neredz. Tāpat arī Vidzemē - ap Rīgu, Cēsìm, Valmieru un Valku tie ir liels retums. Tikai še un te kāda vecenite glabā tos pūra visdzilaakā dibenā kā retu un dārgu pieminuu no savas jaunības, vēlēdamās, lai mirstot vinu tanī ietērptu. Vispār senos tautas apgèerbus vēl lieto Inflantijā [t. i., Latgalē], dažos Austruma-Vidzemes apgabalos, kā Âlsvikios un Alūksnē. Arī Augškurzemē Ilūkstes aprinkīi tie atrodami. Ventspils, Kuldigas, Aizputes un Grobiṇas apriṇkos Kurzemē tie vēl labprāt tiek valkāti. Senais sieviešu apgeērbs caur mērā vairāk uzglabājies nekā vīriešu.»284

Tieši tur, kur pilsētu attīstība bija straujāka, tautas tērps izzuda ātrāk, turpretim tālāk no pilsētām tas saglabājās ilgāk. 1836. g. Vidzemē pilsētu iedzīvotāju skaits sastādīja $15,8 \%$, bet 1881. g. - jau $29,5 \%$ no visas gubernas iedzivotāju skaita. Turpretim Kurzemē 1863. g. pilsētu iedzīvotāji sastādīja $12 \%$, bet Latgalē - $11,7 \%$. Laikā no 1863. g. līdz 1897. g. Latvijas pilsētu iedzīvotāju skaits pieauga gandrīz 3 reizes. ${ }^{285}$

Kurzemē visstraujāk attīstījās tās centrālo aprinku pilsētas - Bauska, Dobele, Tukums. Te pēc V. Plutes ziṇām arī visātrāk izzuda tautas tērpi.

\section{APGĒERBA SASTĀVDALAS ${ }^{286}$}

Latviešu tautas tērpā daudzos gadsimtos izveidojušies noteikti apğērba gabali, kuri zināmā secībā vai noteiktā laika posmā iekḷaujas tautas tērpā. Zināma nozīme to izveidē bijusi klimatiskajiem apstākḷiem.

Kā liecina Latvijas PSR Vēstures muzeja materiāli, 19. gs. sākumā latviešu sieviešu apgèērbs sastāvēja no krekla, brunčiem, jakas vai niiebura, jostas, priekšauta, villaines, galvassegas, apaviem, cimdiem, zekēm un rotaslietăm. Dažu šo apǵērba gabalu - villainu, jostu, galvassegu - nēsāšanā vērojamas vairāku gadsimtu vecas tradīcijas, turpretim citi apgèrba gabali - jakas un nieburi, adìtas zeḳes, kurpes un priekšauti - attīstījušies un izveidojušies vēlāk.

Vīriešu apgēērbs sastāvējis no krekla, biksēm, svārkiem, kažoka, jostas, galvassegas, apaviem, zeḳēm, cimdiem un rotaslietām. Zinas par vīriešu krekliem, jostām un galvassegām ir senākas, bet par svārku un kažoku veidiem - jaunākas.

\section{KREKLI}

Krekls ir viens no vecākajiem apğērba gabaliem, ko vilka uz kailas miesas. Sievietes virs krekla valkāja brunčus, jaku vai nieburu, bet vasarā karstā plaujas laikā vēl 19. gs. sākumā strādāja vienā kreklā, sajožot to tikai ar jostu. ${ }^{287}$ S̄āds krekla valkāšanas veids parādīts J. Broces zīmējumā, pie kam zīmējumam pievienotajā tekstā teikts, ka kreklos strādāja tikai mājās, bet, ejot muižas darbos, virs krekla vilka brunčus. ${ }^{288}$ Interesi izraisa arī zìmējumā redzamie krekla apakšmalas škēlumi, kas izrotāti ar sarkanu apmali un 3 pelëkiem aplišiem. ${ }^{289}$ Vēstures muzeja kolekcijā šāda veida krekla varianta nav. Staigāšana vienā kreklā pazīstama arī mūsu kaimiṇu lietuviešu un somugru tautām. 290

18. gs. un 19. gs. pirmajā pusē kreklus šuva no linu audekla. ${ }^{291}$
Pēc arheolog̣iskā materiāla linu krekli Latvijā noteikti konstatējami mūsu ēras 9. vai 10. gs. ${ }^{292}$ Tomēr iespējams, ka latviešiem, tāpat kā pārējām Austrumeiropas tautām, pirms linu krekliem būs bijuši vilnas auduma kreklveida apgēerbi. ${ }^{293}$ Lat. viešu zemnieka apg̀ērbā pazīstami divi galvenie kreklu veidi: t un ikve ida krekls ${ }^{294}$ un krekls ar p i ešū ti em uzpleči em. ${ }^{295}$

Tunikveida kreklus šuj no viena auduma gabala. Latvijã tunikveida krekls pazīstams 3 varian. tos: 1) bez uzplečiem, 2) ar virsū šūtiem uzplečiem un 3) ar iekšā laistiem uzplečiem.

Tunikveida kreklu bez uzplečiem var uzskatît par vecāko krekla veidu Baltijā ${ }^{296}$ (25. att., 1). 19. gs. pirmajā pusē šis krekla veids sastopams visā Latvijā, bet visbiežāk Kurzemē un Zemgalē.297

Igaunijā šis krekla veids izplatīts Igaunijas dienvidu daḷā un Muhu salā. Vissenākais šā krekla tipa variants 19. gs. saglabājies Igaunijā Hallistes novadā, tātad netālu no Latvijas robežas. Krekls ir bez apkakles, ar taisnām, sašaurinātām piedurknēm un îpatnēju vertikâlu kakla izgriezumu. ${ }^{298}$ Hallistes krekli parasti šūti no viena gabala. ${ }^{299}$

Lietuvā tunikveida krekla variants bez uzplečiem nav saglabājies.

Tunikveida krekls ar virsū šūtiem uzplečiem (25. att., 2) ir visizplatītākais krekla tips Baltijā, tāpēc to varētu nosaukt par «Baltijas tipu». Sis ir gandrīz vienīgais vīriešu krekla veids Latvijā 19. gs. sākumā; sieviešu krekli pēc šī varianta ir šūti gandrīz visā Latvijā (izṇemot Augšzemes, Krustpils un Lielvārdes kompleksu). Tomēr krekls visā Latvijā savās detaḷās nav vienāds. Piemēram, Vidzemē krekliem ar virsū šūtajiem uzplečiem vienmēr ir atlocitas apkakles, kas rotātas vienvirziena izvilkuma tehnikā, turpretim Latgalē - neliela, stāva apkakle un sarkans rotājums.

Tunikveida krekls ar virsū šūtiem uzplečiem raksturīgs arī igauṇu tautas apgèrbam, tāpat Lietuvā, atskaitot Klaipēdas un Austrumlietuvas novadus, tas ir valdošais krekla tips. ${ }^{300}$ 
Tunikveida krekls ar iekšā laistiem uzplečiem (25. att., 3) sastopams Krustpils, Piebalgas un Cesvaines novados, turklāt Krustpils novadā šis ir vienīgais krekla tips. Ne igaunu, ne lietuviešu tautas apgèrbā šāda veida kreklus nav izdevies atrast. Minētajiem krekliem ar iekšā laistajiem uzplečiem tuvi ir dienvidkrievu krekli ar slīpajiem uzplečiem («c косыми поликами»), ${ }^{301}$ lai gan pēdējie, šḳiet, ir jaunāki. Tāpēc pareiza liekas S. Tolstova doma, ka krekli ar slīpajiem uzplečiem pēc izcelšanās saistāmi ar tunikveida krekliem. ${ }^{302}$ Kā liekas, šis krekla veids (ar iekšā laistajiem uzplečiem) pārejas formu no tunikveida krekla uz kreklu ar slippiem un pēc tam ar piešūtiem uzplečiem visskaidrāk saglabājis tieši Latvijā. Par to, piemēram, liecina Krustpils krekla
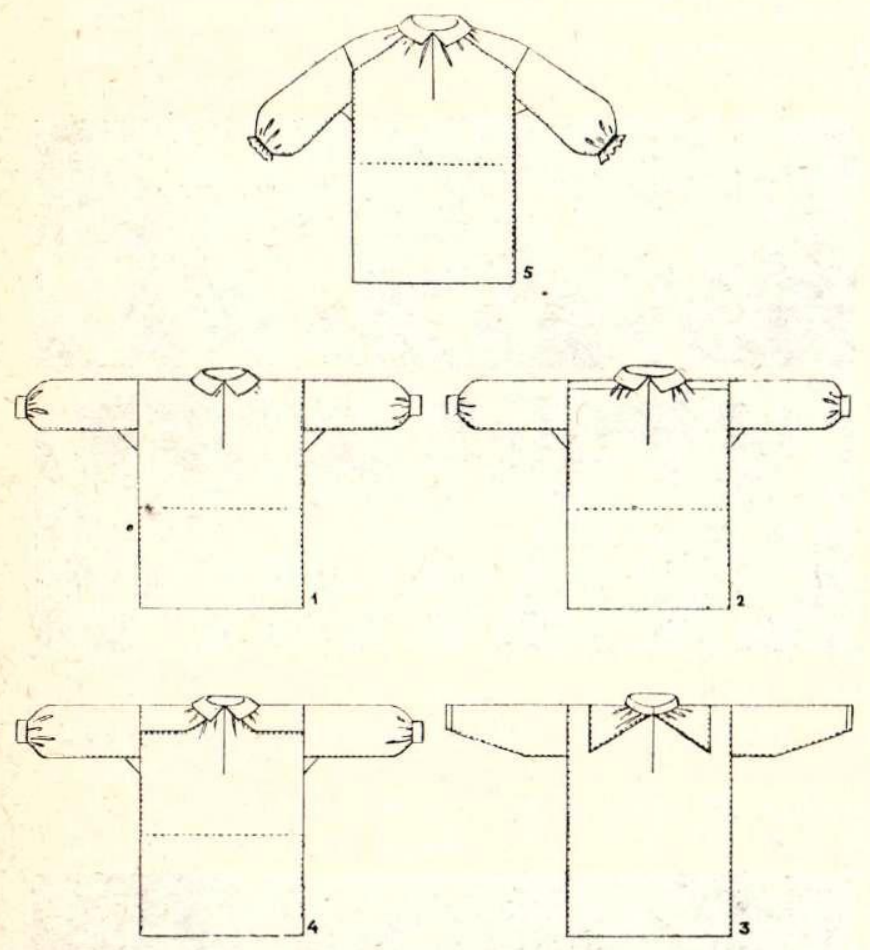

25. att. Kreklu piegriezumi:

1 - tunikveida krekls bez uzplečiem; 2 - tunikveida krekls ar virsū šūtiem uzplečiem; 3 - tunikveida krekls ar iekšã laistiem uzplečiem: 4 - krekls ar piešūtiem uzplečiem audu virzienã; 5 - krekls ar piešutiem uzplečiem velku virzienã.

uzpleču iešūšanas paṇemiens ar uzstieptu diegu palīdzību. Šis pañēmiens ir vienäds ar Augšzemes krekla piešūtā uzpleča piestiprināšanas veidu. Par tuvību ar slīpā uzpleča krekliem liecina arī Krust. pils krekla piedurknu forma ar lieliem kīliem un sašaurinātiem dūrgaliem, kas ir raksturīgi sieviešu krekliem Meščeras novadã un Dienvidkrievijā. ${ }^{303}$ Dienvidkrievu krekli ar slīpajiem uzplečiem valkāti ar nešūtiem brunčiem, kuri nekad neapsedz. kermeña augšdaḷu, ${ }^{304}$ tāpat arī Krustpils un Piebalgas novados jakas vai ṇiebura valkāšana izpla- tãs daudz vēlāk nekā pàrējā Latvijā, - t. i., 19. gs. beigās.

Piebalgas novadā krekliem ar iekšā laistajiem uzplečiem ir loti platas piedurknes $(60-70 \mathrm{~cm})$, kuras beidzas ar šaurām aprocēm, ${ }^{305}$ tāpēc, liekas, ka Piebalgas krekli ir jaunāki par Krustpils krekliem.

Tas, ka krekli ar iekšā laistajiem uzplečiem sastopami tajos novados, kas átdala Vidzemi no Latgales (sēlisko izlokšnnu teritorija), liecina, ka šis krekla veids, tāpat kẩ krekli ar piešūtajiem uzplečiem, Latvijā izveidojies, tās iedzīvotājiem nākot tiešā saskarē ar slāvu tautām. Šo domu vēl apstiprina tas, ka Vēstures muzeja Etnogrāfijas nodalas fondos esošais Krustpils krekls ar iekšã laistajiem uzplečiem un stāvo apkakli ir apakšmalā rotāts ar celu apaudu, ${ }^{306}$ bet šāds rotājums nav raksturīga latviešu kreklu pazīme. Iespējams, ka šis krekls speciāli gatavots valkāšanai bez brunčiem. Zināma nozīme ir bijusi arī šìs teritorijas sēliskajiem elementiem. ${ }^{307}$

Kreklu ar piešūtiem uzplečiem darina, 2 krekla stāva gabaliem piešujot paplatu $(10-15 \mathrm{~cm}) \mathrm{uz}-$ pleci, pēc tam lielo četrstūraino kakla izgriezumu savelkot krokās un piešujot tam apkaklị. Piedurknes piešuj pie krekla stāva un uzpleča. Latvijā krekli ar piešūtiem uzplečiem palaikam ir ar atlocītām apkaklēm un platām piedurknēm, kas noslēdzas ar aprocēm. Vienīgi Vēstures muzeja kolekcijā 2 krekliem - viens no Zemgales, bet otrs no Piebalgas - ir taisnas pusgaras piedurknes. Krekli ar piešūtiem uzplečiem Latvijā raksturīgi Augšzemes un Lielvārdes novadiem, bet Zemgalē, ${ }^{308}$ Dienvidkurzeme ${ }^{309}$ un Piebalga ${ }^{310}$ tie sastopami tur, kur krekla pamattips ir tunikveida krekli bez uzplečiem, Tā kā abiem minētajiem Zemgales un Piebalgas krekliem vairs nav lïdzïgu paraugu, jādomā, ka tie nebija plaši izplatīti un ir daudz jaunāka gājuma. ${ }^{311}$

Latgalē šāds krekla veids sastopams krievu vecticībnieku ğimenēs. ${ }^{312}$ Tas izplatīts Polijā, Ukrainā, Baltkrievijā. ${ }^{313}$ Pēc B. Kuftina domām tie ir visizplatītākie krievu krekli. ${ }^{314}$ Lietuvā krekli ar piešütiem uzplečiem sastopami austrumdalā Baltkrievijas pierobežā un Klaipēdas novadā. ${ }^{315}$

Latvijas teritorijā krekli ar piešūtiem uzplečiem sastopami 2 variantos.

Pirmā varianta krekliem uzplecis krekla stāvam piešūts audu virzienā un sniedzas līdz krekla sānu vīlēm. Piedurkne piešūta tieši uzplecim un krekla stāvam. Uzpleča izmēri samērā lieli -$20 \times 25 \mathrm{~cm}$ (25. att., 4). Izñemot Augšzemes un Lielvārdes novadus, pārējā Latvijā šis krekla veids nav sastopams (atskaitot 2 jau minētos kreklus no Zemgales un Piebalgas). S̄āda ierobežota izplatība vedina domāt, ka šie krekli Latvijā ieviesušies kultūras sakaru rezultātā ar slāvu tautām, kurām tas ir valdošais kreklu tips. Latvijā šis krekla veids ir daudz jaunāks nekā tunikveida krekls. 
Vecu cilvēku atmiṇās, kā arī tautasdziesmās minēti tā saucamie «poḷu lāstaugi»:

Viena pati skaista meita,

Viens pats bija linu krekls

Ar tiem polu lāstaugiem;

Tas ciemā, tas ganos,

Tas svētdienu baznīcā. ${ }^{316}$

«Lāstaugi»,317 liekas, būs ienākuši no krievu uzpleču apzīmējuma (ластовицы). ${ }^{318} \mathrm{Nav}$ izdevies konstatēt termina lāstaugi polisko etimolog̣iju, lai gan krekli ar piešūtiem uzplečiem ir viens no visizplatītākajiem kreklu veidiem Polijā. ${ }^{319}$ Liekas, ka termins «poḷu lāstaugi» Augšzemes novadā nav parādījies nejauši, bet gan kopā ar šo kreklu piegriezumu. Par radniecību ar polu krekliem liecina arī îpatnējā, tikai Augšzemes novadā pazīstamā tehnikā izveidotā izšuvumu savilkuma vieta ${ }^{320}$ (26. att.). Polijā un Lietuvā šādā tehnikā savelk piedurkṇu dūrgalus krekliem ar piešūtiem uzplečiem. ${ }^{321}$ Tomēr jāpiezīmē, ka pēc rotājuma novietojuma Augšzemes krekli tuvāki baltkrievu un ukrainu krekliem. 322

Otrais šì krekla variants atškiras no pirmējā ar to, ka uzpleči tiek piešūti nevis audu, bet velku virzienā (25. att., 5). Latvijā šis krekla variants sastopams tikai Rucavas novadā, ${ }^{323}$ Lietuvā tikai Klaipēdas novadā, pie kam uzplecis šeit jau ir pilnīgi savienojies ar piedurkni, kamēr plecu rotājums palicis agrākajā šuves vietā. ${ }^{324}$ Sāda tipa krekli plaši izplatīti Rietumukrainā un Aizkarpatu apgabalos, ${ }^{325}$ tie pazīstami arī dienvidkrieviem ${ }^{326}$ un Polijā Krakovas vojevodistes dienvidaustrumdậā. ${ }^{327}$

Spriežot pēc krekla auduma un rotājuma tehnikas, secināms, ka Rucavas novadā šî varianta krekli valkāti vienā laikā ar tunikveida krekliem bez uzplečiem. 19. gs. otrajā pusē tunikveida krekliem Rucavā sāk uzšūt uzplečus. ${ }^{328}$

Jautājums, kā tik mazā novadā Baltijas jūras krastā varēja parädīties un tik ilgi (līdz 20. gs.) saglabāties šis îpatnējais krekla veids, vēl pilnībā nav noskaidrots, bet to, ka Rucavas novads kopä ar kaiminu lietuviešu Klaipēdas novadu veido vienotu kultūrvēsturisku apgabalu un tam bijušas tiešas vai arī pirmatnējas saites ar lužiču kultūru, varam apgalvot jau šodien. Arī pārējos Rucavas apgèerba gabalos saskatāmas šìs savdabīgās iezīmes.

Sieviešu kreklus parasti šuva no divām dạām un garākus par vīriešu krekliem, jo bikses šai laikă sievietes nevalkāja.

Vīriešu kreklus šuva îsākus nekā sieviešu, nn viena gabala, bez piešuves..$^{329}$ Sai sakarā apšaubāms šksiet $K$. Strauberga uzskats, ka vīriešu krekli arī šūti ar piešuvi, ${ }^{330}$ jo, pārbaudot arhīvu dokumentus, kas varēja būt par pamatu K. Strauberga apgalvojumam, bija konstatēts, ka vīriešu krekli ar piešuvi minēti tikai vienā gadījumā - no Praulienas pagasta. ${ }^{331}$ Arī 1959. g. ekspedīcijā Madonas rajonā, skaidrojot šo jautājumu, konstatēts, ka vīriešu krekli nekad nav šūti ar piešuvi. ${ }^{332}$ Tāpēc

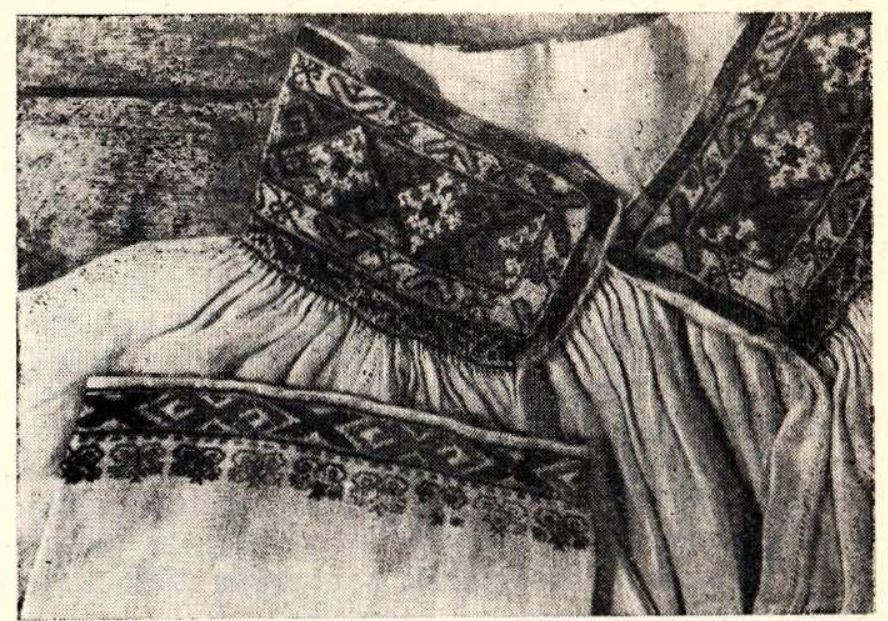

1

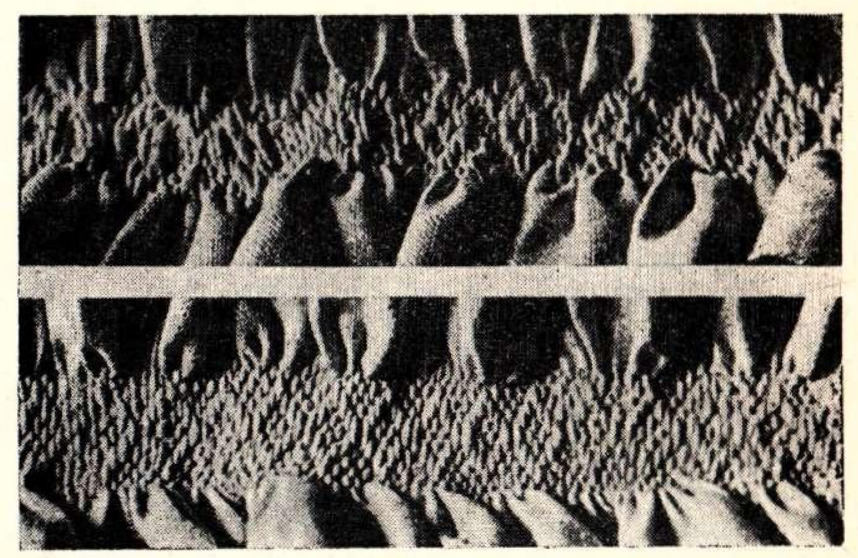

2

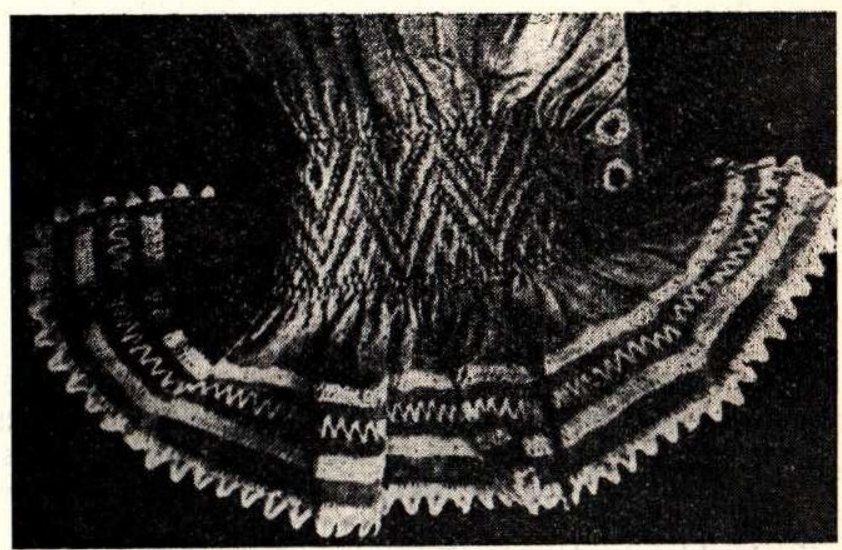

3

26. att. Kreklu kakla izgriezumi un piedurkṇu savilkuma veidi:

1 - Augšzemes krekls ar kakla izgriezuma savilkumā izstrādātu rakstu (RLMV materiāli); 2 - Lietuvas Zanaviku krekla piedurknes (Polijas) krekla piedurknes savilikums (Hafty i zdobienie stroju ludowego. Warszawa, 1955, 66. att.). 
jādomā, ka Praulienas pagasta dokuments, kas pamatojas tikai uz vienas teicējas sniegtajiem datiem, nav precizs.

Kreklus parasti šuva no balināta vai nebalināta linu audekla. Sākot ar 19. gs. 70. gadu otro pusi, Dienvidkurzemē, kur tautiskā apgèēba valkāšana turpinājās visilgāk, valkāti arī kokvilnas auduma krekli. Krekla stāva audumu vienmēr auda vienkārtnī, vienīgi Ziemellatgalē krekla stāvu auda acainä trinītī. Sieviešu kreklu augšējo daḷ sauca par stävu, bet apakšējo - par pierietni, ${ }^{333}$ piešuvi (Vidzemē), pudamenti (Zemgalē), pietriekumu (Kurzemē), pieduri (Augšzemē). Tie bija t. s. divstāvu, divtāžu, pusainie (Kurzemē) krekli. Krekla augšējā dala parasti bija no smalka, balināta linu auduma, bet piešuve - no rupja linu vai pakulu auduma, kas austs trinītì vai nu pa diagonāli, vai arī skujiṇā. Retos gadījumos sieviešu krekli šūti arī no viena smalka linu auduma gabala - tie ir ceremoniju krekli (piemēram, kāzās līgavas krekls, kā arī vīramātei dāvināmais krekls). ${ }^{334}$

Vīriešu krekli parasti sniedzās gandrīz līdz celiem, bet sieviešu krekli - līdz pusstilbiem: tautasdziesmās minēti arī krekli līdz pašai zemei, pēdējie bijuši dāvanu krekli kāzās. ${ }^{335}$

Latviešu zemnieku kreklu piegriezums pavisam vienkāršs ar taisnām vīlēm. ${ }^{336}$

Vecākajiem kreklu veidiem ir nelielas stāvas apkakles; 19. gs. pirmajā pusē tās saglabājušās tikai Latgalē, Piebalgā, Krustpils un dažos Kurzemes novados. J. Broces un O. Hūna zīmējumos apkakles ir redzamas pa lielākai dal̨ai stāvas. ${ }^{337}$ Alsungas novadā goda krekliem virs nelielās baltās krekla apkakles piešuva ar stikla pērlēm un salmiṇiem izšūtu t. s. smeldžoto apkakli (skat. 2. tab., 1-3). Pēc arheologa Fr. Baloža domām smeldžotās apkakles ir kakla riṇkia paliekas 19. gs. apgèrēā. ${ }^{338}$

Spriežot pēc J. Broces un O. Hūna zīmējumiem, sieviešu krekliem bijuši dzili krūšu škēlumi, dažreiz pat līdz jostas vietai $(20-35 \mathrm{~cm})$. Sāds dzilš krūšu šḳēlums bija nepieciešams, lai kreklu nevajadzētu vilkt pāri galvai, bet varētu nolaist pāri gurniem. Daži etnogrāfi to izskaidro ar tïrības sajūtu; ${ }^{339}$ var būt, ka sieviešu krekliem garā «krūšu šḳira» būs bijusi nepieciešama, lai ērtāk būtu zīdīt bērnus, ${ }^{340}$ jo jaunavu un līgavu krekliem krūšu šḳiru netaisīja garāku par $20 \mathrm{~cm}$.

Arī vīriešu kriekliem krūšu škēlumus netaisīja garākus par $25 \mathrm{~cm}$. 19. gs. vidū kreklu priekšu aizdarināšanai sāk šūt speciālu malinu - pogu vietu, kādu vīriešu krekliem šuj vēl šodien. Visā Latvijā, atskaitot atsevišķas vietas Latgalē, vīriešu kreklu škēluma vieta atrodas krekla priekšpuses vidū, tāpat kā tas ir sieviešu krekliem. Latgalē dažkārt sastopami krekli, kuru šḳēlums nebija vis kakla izgriezuma vidū, bet sānos - pēc t. s. krievu kreklu parauga; šādus kreklus arī sauc par krievu modes krekliem vai krievu krekliem. ${ }^{341}$

Kreklus mēdza pagatavot pēc iespējas glītākus, jo kā mājas, tā arī kopējos muižas darbos mei-

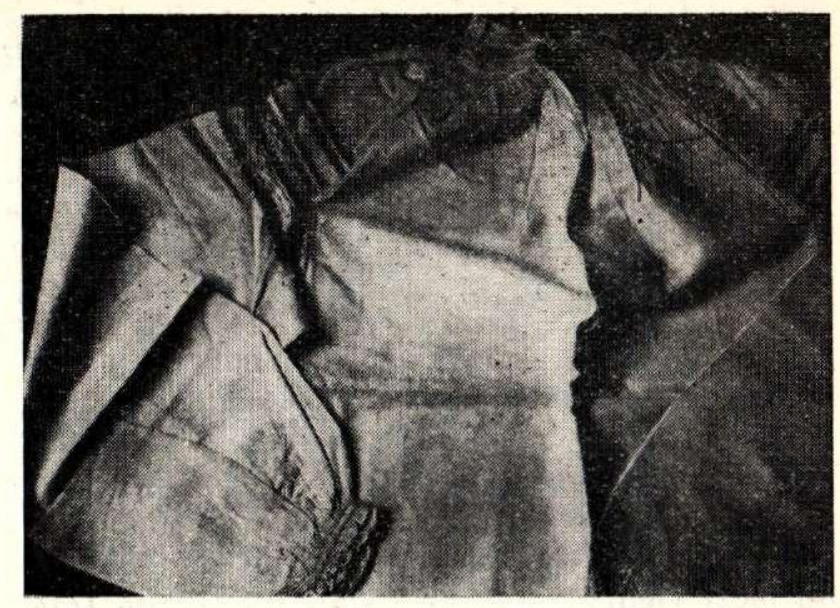

1

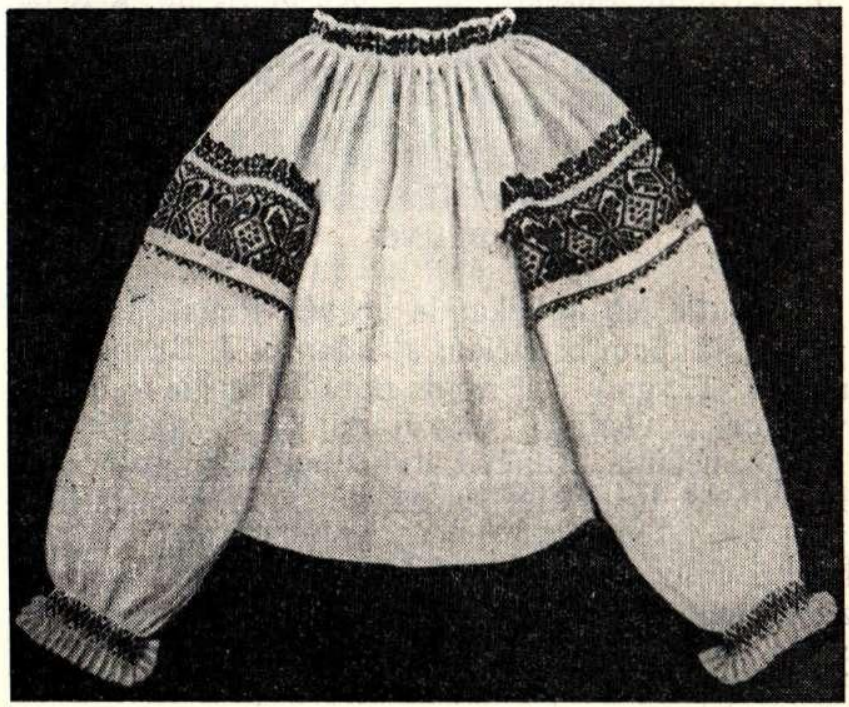

2

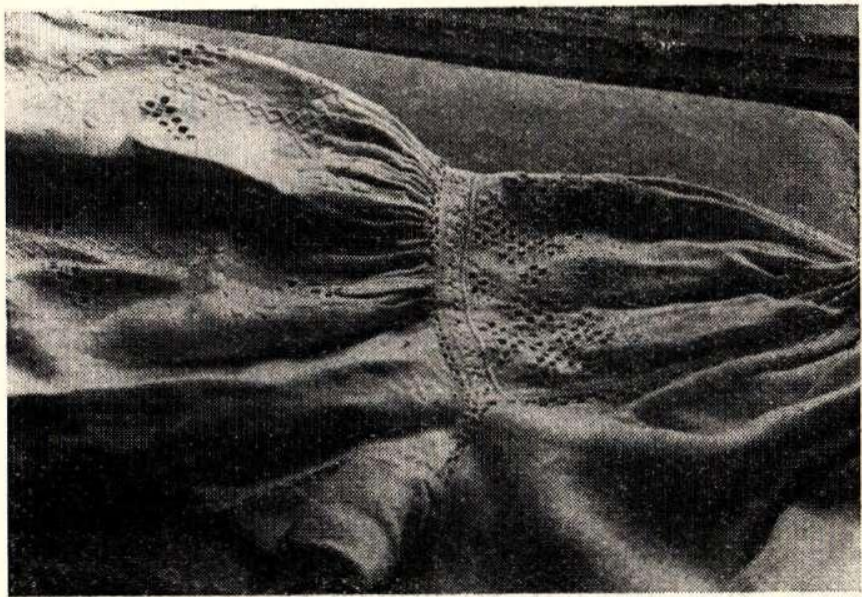

3

27. att. Krekli ar piešūtiem uzplečiem auduma velku virzienā: 1 - Rucavas krekls (Liepājas NM, 167); 2 - Klaipēdas apkārtnes krekls (Lietuvas PSR ZA Vẽstures un etnogrāfijas muzejs, EMO, 1677); 3 - ukraiṇu krekls (Lvovas Etnogrāfijas un mākslas rūpniecības muzejs, EП, 20734). 
tas virs krekla nekādas jakas nevilka; tāpēc krekla rotājums liecināja par meitas čaklumu un labo gaumi. Izrotāt kreklu tā, lai citi to nemtu par paraugu, bija liels gods. Vĩriešu krekli bija mazāk rotāti, lai gan tā skaitījās slikta māsa vai līgava, kuras tuvinieks staigāja ar nerotātu kreklu. Gados vecākiem cilvēkiem grezni izrakstīts parasti bija tikai viens krekls, kuru apvilka, ejot baznīcā, bet ikdienā un arī svētdienā vecāki laudis staigāja ar neizrakstītiem krekliem. Pārnākot no baznīcas, baznīcas kreklu novilka un glabāja nākošajai rei$\mathrm{zei}^{342}$

Visgreznākie bija līgavas un līgavaiṇa krekli; pēc laulībām tos uzvilka tikai svinīgos gadījumos un bieži vien glabāja kā mirstamo kreklu. Dažās vietās vīramāte par mirstamo kreklu glabāja vecākā dēla sievas dāvāto kreklu. ${ }^{343}$ Kāzu kreklus un dāvināmos kreklus šuva bez pierietna. ${ }^{344}$ Krekliem ar izšuvumu visbiežāk rotāja aproces vai valējos dūrgalus, apkakli, piedurkṇu augšgalu, uzplečus un krūšu šḳēlumu. ${ }^{345}$

\section{BRUNCI}

Nešūtie jeb apliekamie brunči. Rakstītas ziṇas par nešūtajiem brunčiem atrodamas J. Branda aprakstā (17. gs.). J. Brands norāda, ka tie ir līdzīgi villainei, vienīgi valkājami ap gurniem. ${ }^{346}$ 18. gs. nešūtie brunči Latvijā konstatējami vairākās vietās, turpretim 19. gs. tie saglabājušies tikai jau pārdzīvotās formās. Loti skaidri nešūtie brunči redzami mākslinieka A. Pecolda krieviṇu zīmējumā (skat. 4. tab., 2). Sēdošajai sievietei kreisajos sānos stipri pavērušies vaḷā rūtotie nešūtie brunči un redzama krekla sānu dą̧a. Neskaidrību rada sievietes apğērba tumši zilā krūšu dal̨a ar brunču krāsas svītraino apmali un saiti uz kreisā pleca. ${ }^{347}$ Otrajai sievietei redzama nešūto brunču rūtainā augšdala. Liekas, ka tā ir plata josta, kas satur smagos apliekamos brunčus.

Līdzīga veida brunči 17. un 18. gs. bija pazīs. tami lietuviešiem ar nosaukumu «margine», ${ }^{348}$ igauniem - ar nosaukumu «pallapool», «sõuke», «kõrt», «sõpp». ${ }^{349} \operatorname{Ar} \overline{1}$ somiem ir līdzīgs apg̀ērba gabals ar nosaukumu «hurstu» vai «ursk». ${ }^{350}$ Latviešu valodā līdz mūsu dienām nav saglabājies speciāls termins, kas apzīmètu šādu nešūtu apgēerba gabalu, bet 19. gs. beigās Vīpes pagastā šãdu ipatnēju apg̀ērbu saukuši par "prošavu». ${ }^{351}$ Prošavu valkāja jaunas meitenes un liggavas. To darināja no diviem tumši zila auduma gabaliem. Viena mala bija piestiprināta krokās pie jostas un sānos sapogājama. Apakšējā mala atlocita un at. šūta, tāpat atlocītas arī brunču sānu malas, t. s. šḳēres, pēdējās tikai bijušas nošūtas ar sīkām, mazām dažādas krāsas zīlītēm. Sāni brunčiem ne. sašūti, uzvelkot pogāti - viena šḳēre vienā, otra - otrā sānā, jo tā brunči, kaut arī sānos nesašūti, neesot vērušies vaḷā. Izrakstītās škēres tos padarījušas skaistus. Brunči bijuši kupli. ${ }^{352}$ Pro- šavas nēsājušas tikai bagătas mātes meitas. ${ }^{353}$ Andreja Jurjāna manuskriptos atrodam aprakstu par snātenēm, kuras «vecos laikos» valkātas lindraku vietā. Vienu gabalu piešuvuši priekšpusē, bet otru - mugurpusē, - kā divus priekšautus. ${ }^{354}$ 19. gs. beigās ar terminu snātans lindraks Latgalē apzimēti apakšbrunči. ${ }^{355}$ Vēl šodien gados vecākās teicējas atceras šo terminu apakšbrunču nozīmē. Pie apliekamajiem .brunčiem pieskaitāmi arī Zemgales brunči, ko veidoja viens $80-90 \mathrm{~cm}$ plats un 2,5-3,5 m garš auduma gabals. S̄ādı auduma gabalu salika krokās un apjoza ar jostu. Šo pašu auduma gabalu bieži vien izmantoja arī par gultas segu. ${ }^{356}$

Ipatnēji ir J. Niedres aprakstītie «apliekamie rakstītie brunči»; tie darināti no rakstā austa linu vai vilnas auduma, kam abi gali vai arī malas izrakstītas krāsainiem ornamentiem. Rakstitos brunčus kopā nešuva, bet tikai augšmalā savilka kopā ar linu diegu. Ejot šādi apliekamie brunči pavērās un nāca redzami apakšējie vilnas goda brunči. ${ }^{357}$ Sāda veida brunči 18 . gs. beigās bija pazīstami Vidzemē, Latgalē un Zemgalē. No Kurzemes ziṇu nav, lai gan par to, ka nešūtie brunči valkāti Dienvidkurzemē, šḳiet, liecina îpatnējais Rucavas villaiṇu valkāšanas veids - apṇemot apkārt gurniemı un sastiprinot ar saktām uz kreisãs rokas locītavas (skat. 4. tab., 3). Bez tam rūtainā Rucavas villaine - mārğene, kas darināta no tumši zila rūtaina auduma, pēc sava raksta un nosaukuma at. bilst J. Branda aprakstītajiem lietuviešu nešūtajiem brunčiem - marginei ${ }^{358}$ (skat. 4. tab., 4). Loti līdzīgas mārğgenes audumam ir tumši zilā pamatā krāsainās rūtīs austās dienvidlielkrievu sieviešu panovas (понева). ${ }^{359}$ Pañova ir nešūtais gurnu apg̀ērbs, kas slāvu cilšu vjatiču un kriviču teritorijā pazīstams jau 12.-13. gs. Par to, ka Rucavas mārğgene kādreiz valkāta kā nešūti brunči, liecina arī īpatnējais zalās lentes ${ }^{360}$ uzšuvums gar märg̀enes apakšejo malu un nelielais škēlums pie šūtās sānu vīles (skat. 4. tab., 1). Mazliet īpatnējāks nešūtā apgèreba veids redzams J. Broces zīmētajā vidzemnieku kāzu skatā (28. att.). ${ }^{361}$ Zīmējuma priekšplānā sēdošās sievietes apğērba, acīm redzot apliekamo brunču, priekšējie stūri noapaloti un ărējās malas apšūtas ar dzeltenām bārkstīm. Pēc J. Broces zīmējuma liekas, ka mugurpusē brunči sniedzas krekla garumā, kamēr priekšpusē tie neaizsedz kreklu. Lìdzịgi apliekamie brunči, tikai daudz īsāki, redzami 16. gs. Livonijas sieviešu apgèrea zīmējumos (29. att.). ${ }^{362}$ Tas vedina domăt, ka šāds apgēerbs līdz i9. gs. bijis plašāk izplatīts. Latvijas PSR Vēstures muzeja Etnogrăfijas nodaḷas fondos nav šāda apgẹerba gabala, jo laikā, kad tika komplektēti muzeja fondi, tam nav tikusi pievērsta uzmanība, uzskatot to par nelatvisku un latviešu tautas tērpam neraksturīgu.

Diemžēl, trūcīgais materiāls nedod iespēju izdalīt atseviškus apliekamo brunču tipus un noteikt to lokalizāciju; tomēr, pamatojoties uz esošā materiāla, secināms, ka apliekamie brunči tika val- 


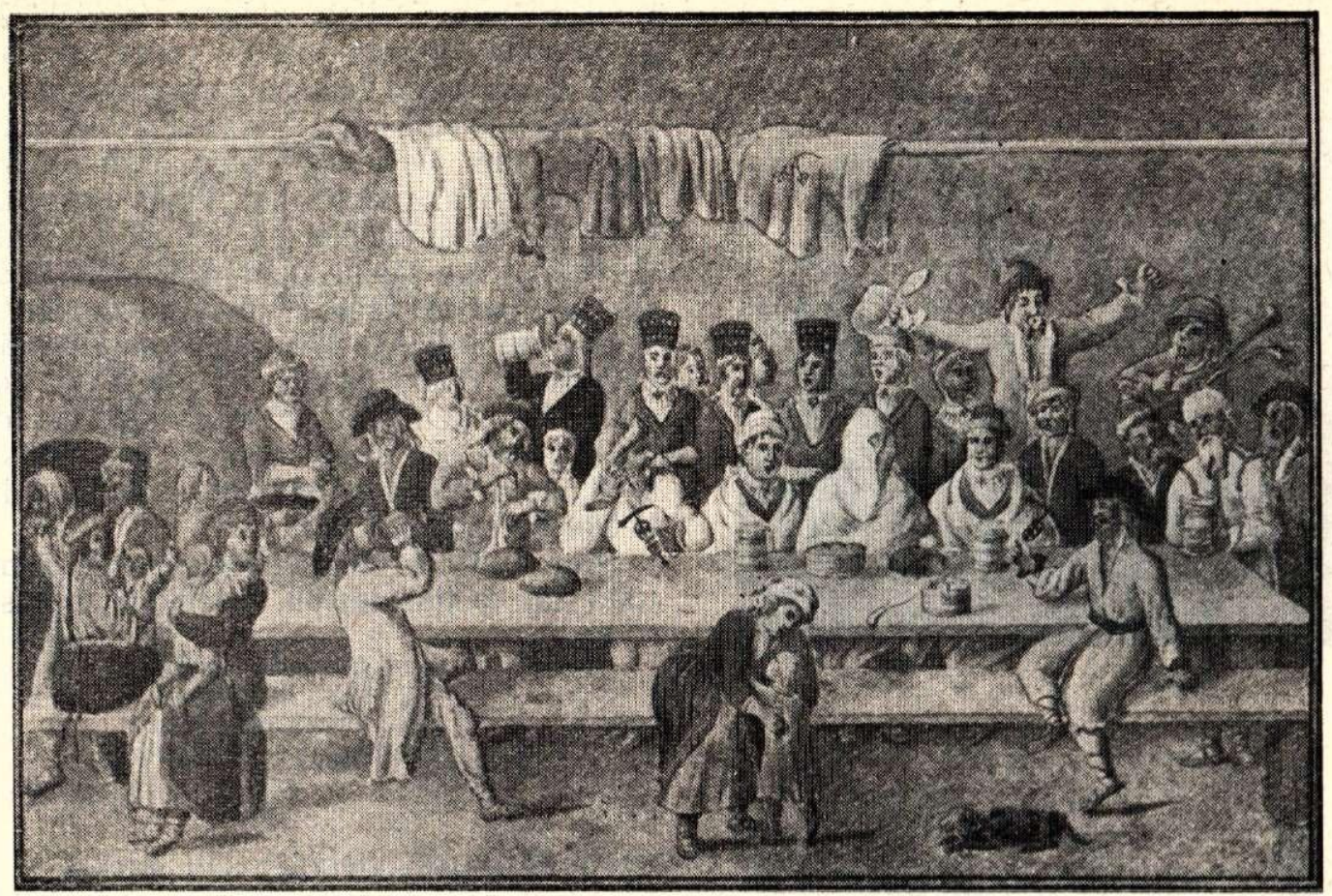

28. att. Vidzemnieku kāzu skats (J. Chr. B rotz e.Monumente..., III. 10. 1pp.). Apakšā detaḷ - kãziniece ar apliekamajiem brunčiem.

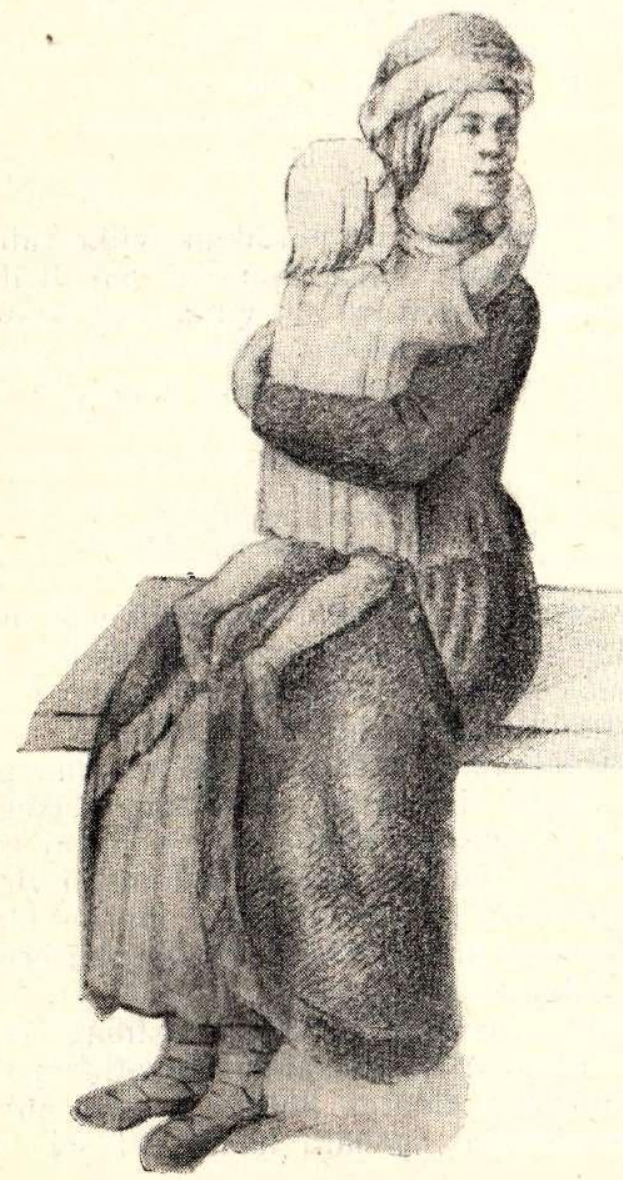

kăti pirms šūtajiem brunčiem, 18. gs. saglabājoties goda apgèēbā.

Šutie brunči ir visizplatītākais brunču veids 18. un 19. gs. Tie pazīstami ar nosaukumu svārki, brunkas,' rinduki, lindruki, lindraki. ${ }^{363}$ Atkarā no auduma veida un ornamenta brunčus sauca par vīzainiem, kūjainiem, galdainiem, grëdainiem, strīpainiem, bantainiem. ${ }^{364}$

Vecākais brunču veids, spriežot pēc arheologiskajiem izrakumiem, ir vienkrāsaini brunči ar krāsainu celu apaudu gar brunču apakšējo malu. 15. gs. brunčus rotāja ar zvaniṇiem, ${ }^{365}$ krellītēm ${ }^{366}$ vai ar izšuvumu gar brunču apakšējo malu (29. att.). Šie brunču veidi līdz 19. gs. saglabājās vienīgi Ziemelllatgalē un Dienvidkurzemē. 18. gs. otrajā pusē un 19. gs. sākumā plašāk izplatîti ir svîtrainie brunči, lai gan parādās arī rūtainie brunči. Par to liecina J. Broces un O. Hūna zīmējumi un Vēstures muzeja bagātās kolekcijas.

Bagātais dažādu nokrāsu svītru un rūšu salikums mainās ne tikai katrā novadā, bet pat atsevišķos pagastos. Brunčus, ko valkāja tikai vienā pagastā, sauca par pagastainiem. ${ }^{367}$

Analizējot atseviškło brunču izplatību 19. gs. pirmajā pusē, secināms, ka rūtainie brunči izplatìti galvenokārt Vidzemē un Latgalē, ar ielasītu rozišu rakstu - Zemgalē, vienkrāsaini brunči ar krāsainu apakšmalu - Dienvidkurzemē un arī Ziemellatgalē.

Brunčus ar vertikālām svītrām ikdienas darbā 19. gs. valkāja visā Latvijā, kamēr kā goda ap- 

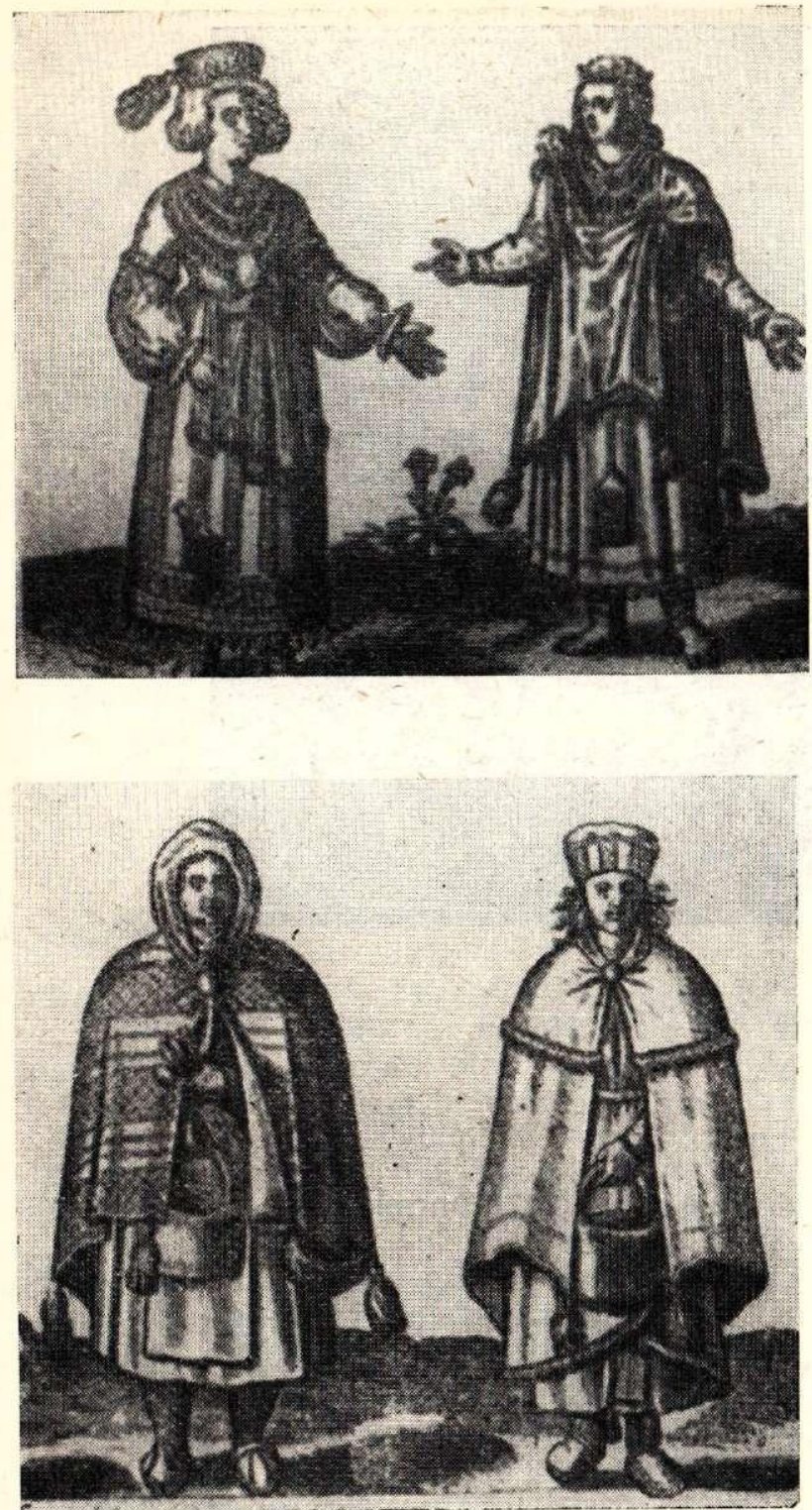

29. att. 16. gs. Livonijas sieviešu apgèerba zīmējumi (Breina albums).

gērbs tie pazīstami dažos Vidzemes novados un Ziemelaustrumkurzemē.

19. gs. otrajā pusē, spriežot pēc mirušo mantu sarakstiem, vēl dominē svītrainie un rütainie brunči, kuri darināti no pusvilnas, kokvilnas un loti retos gadijumos no vilnas auduma. ${ }^{368} \mathrm{Gad}$ simta beigās svītrainus brunčus valkāja tikai kā apakšbrunčus, virs kuriem vilka pelēkus vai melnus virsbrunčus. 20. gs. sākumā svītrainiem apakšbrunčiem šuj slīpā audumā piegrieztu apakšējo malu («volānu»).

Goda brunčus parasti auda linu vai kokvilnas diegu velkos ar vilnas dzijas audiem, bet ikdienas valkāšanai brunči austi arī tikai no linu vai pakulu diegiem. Latgalēe, kur linu audzēšana bija plašāk izplatīta nekā pārējā Latvijāa arī goda brunčus šuva no linu auduma (sevišķi Ziemellatgalē). Goda brunči šūti no viena auduma gabala 3-5 m plati, bet brunču garumu veidoja auduma platums $(70-80 \mathrm{~cm})$. Auduma gabalu savilka krokās un tam piešuva tā paša auduma jostu, kuru aizdarināja ar metāla āḳi. Goda brunčus vienmēr šuva platākus, dažreiz pat 10 olektis platus. ${ }^{369}$

Nabadzīgo laužu meitām brunči bijuši ne tikai šaurāki, bet arī îsāki. ${ }^{370}$ Muzeju fondos bieži vien sastopami lıti šauri brunči, kas darināti no novalkātiem goda brunčiem, pie kam no vieniem goda brunčiem izšūti divi. ${ }^{371}$ Dienvidkurzemes brunči, kas pēc savas formas ir jaunāki, šūti no 5-8 atsevišḳiem gabaliem - paliem; katrs pals ir $50-80 \mathrm{~cm}$ plats. ${ }^{372}$

Par to, ka brunču platums zināmā mērā liecināja par meitas turību, dzied arī tautasdziesmas:

Meit' uz meitu vaicājās,
Cik olekšu lindrakos;
Citai piecas, citai sešas,
Kas bagāta - tai deviṇas. LTD, III, 620

Goda brunči vienmēr šūti garāki - līdz potī tēm, bet valkāšanai brunčus šuva īsākus. ${ }^{373}$

Es mātei viena meita,
Es raženi turējos -
Līdz zemei brūni svārki,
Sarkans rožu vainadziṇš.

LD, 5621

Aud, māmiṇa, man svārciṇus,

Vienu isu, otru garu:

Is' - tautām dublus brist,

Garu - sērst pie bāliṇa.

$$
\text { LD, } 5631
$$

Vēl 19. gs. sākumā bija paradums vilkt vairākus brunčus. Apakšā vilka linu vai pavalkātus pusvilnas brunčus un virs tiem vilnas vai pusvilnas goda brunčus; atsevišķos novados virs goda brunčiem vilka nešūtos apliekamos brunčus. ${ }^{374}$

$$
\begin{aligned}
& \text { Es uzvilku treju brunču, } \\
& \text { Apsagriezu ritenī. } \\
& \text { Divi manis pašas austi, } \\
& \text { Treši - manas māmuliṇas. }{ }^{375}
\end{aligned}
$$

Vairāku brunču valkāšanu uzskatīja par turības pazīmi. ${ }^{376} \mathrm{Ar}$ vairāku brunču valkāšanu, sevišḳi laulību ceremonijā, saistās arī tautas ticējumi par bagātu un pilnīgāku dzīvi. ${ }^{377}$

Lai brunču krokas «stāvētu», tās auduma gabalā tika rūpīgi iediegtas. Pēc tam iediegto audumu lika klētiñā vai istabā uz galda vai grīdas, pārklājot ar tīru, samitrinātu drānu; tai virsū uzlika vai nu tikko izceptus, karstus maizes klaipus vai sakarsētus kieg̣el̨us. ${ }^{378}$ Sādā stāvoklī brun. čus atstāja līdz nākošajai dienai.

Interesanta ir brunču kabatas attīstība. Vecākās kabatas îsteni ir no krāsainām lupatinām vai ādas gabaliṇiem darinātas kulītes, kuras, auklä vai prievîtē piesietas, pakāra kaklā vai sēja ap 


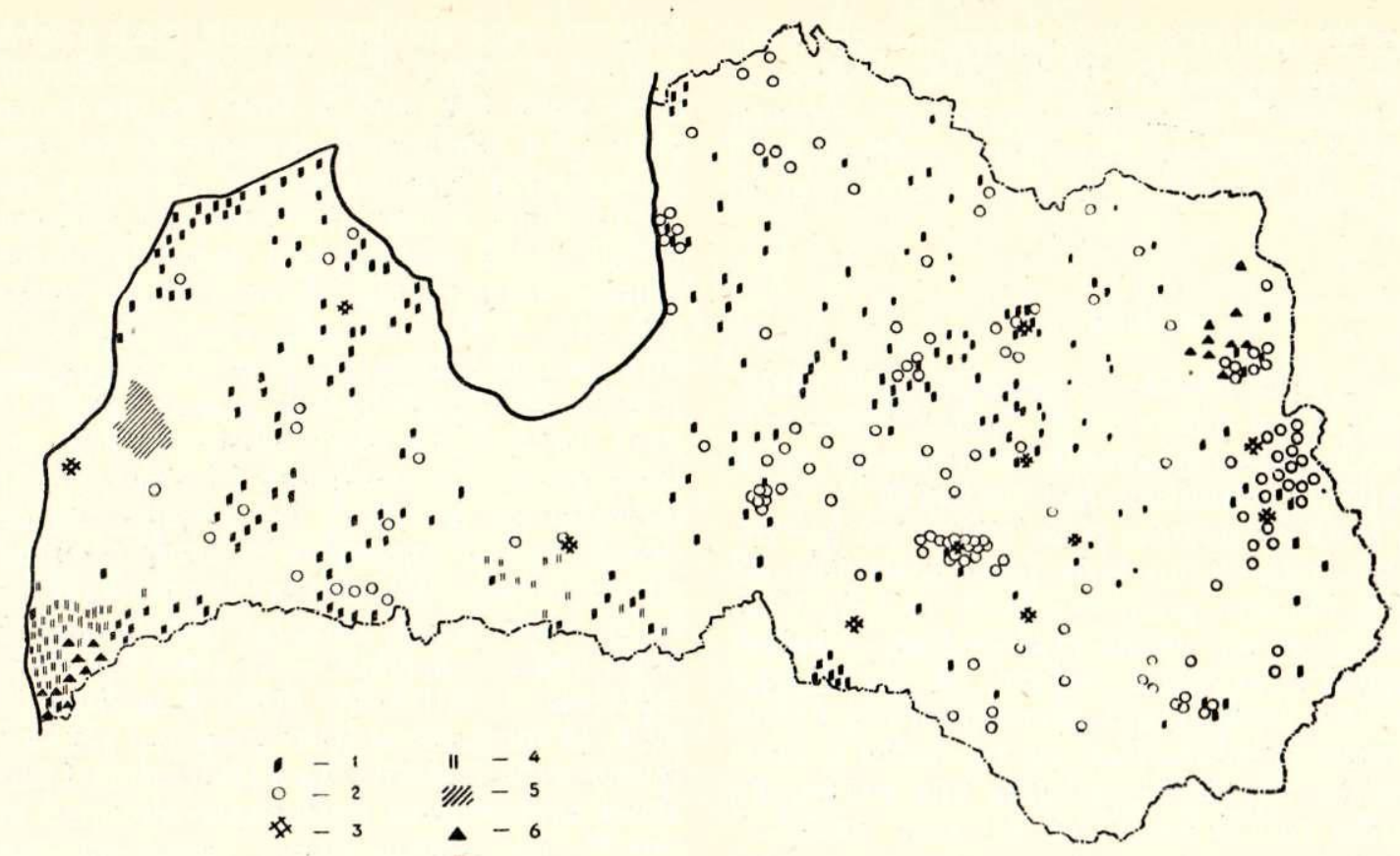

30. att. Dažãdu brunču tipu izplatība:

1 - svītrainie; 2 - rūtainie; 3 - rakstainie; 4 - svītrās austs raksts (Zemgales, Nīcas); 5 - Alsungas; 6 - ar rotātu malu (Ziemellatgales, Bārtas, Rucavas). (Pēc Latvijas PSR Vèstures muzeja materiāliem.)

vidu. Tās valkāja virs krekla zem brunčiem vai zem priekšauta. ${ }^{379}$ Katras meitas pūrā bija divas vai trīs šādas kulìtes. Kad gāja baznīcā, maisināā lika ēdamo - sieru, olas vai zirnus. Braucot mājās no tirgus, kulītēs ielika pirkto tirgus kukuli. Dažkārt kulītes aizstāja ar naudas makiem. Kabatas pie brunču sānu vīles sāka šūt 19. gs., un tad kulītes kaklā kāra tikai gani (skat. 11. tab., $1-3)$.

A. Karnups, iztirzājot 16. gs. Livonijas zemnieču apǵērba zīmējumu, kulīti nosaucis par naža maksti resp. adatu kārbiṇu. Adatu kārbiṇas ir gan raksturīgas igauniem, bet nav sastopamas latviešu tautas têrpā. Škiet, ka zìmējumos redzamās kulītes ir kabatu senākais veids. ${ }^{380}$

Atsevišḳi apskatāmi brunči ar piešūtu ṇieburu: krievu padomju etnogrāfiskā literatūrā tos apzīmē ar terminu «sarafāns». Latviešu apgēerba terminoloğijā termins sarafāns maz pazīstams, ${ }^{381}$ jo sarafānveida apgérēbs parasti saukts tāpat par brunčiem, ${ }^{382}$ lindrakiem, ${ }^{383}$ kleitu ${ }^{384}$ vai kapatu. ${ }^{385}$ 19. gs. pirmajā pusē Latvijā pazīstami divēji šāda veida brunči: 1) ar pārplečiem, 2) ar piešūtu nieburu; tie šüti no pašausta vilnas vai pusvilnas taisniem auduma gabaliem ar savilktām vai iegludinātām krokām.

Brunči ar pārplečiem redzami $F$. Kruzes zīmētajai ventspilniecei (skat. 12. tab., 1). Arī O. Hūna zîmēto kuršu koniniieṇu (skat. 12. tab., 3) ${ }^{386}$ brunču augšdalai piešuta jostiṇa, pie kuras piestiprināti pārpleči. S̄āda tipa brunči raksturīgi Ziemeḷkurzemes tērpu kompleksam. ${ }^{387}$ Retumis tie sastopami arī Vidzemes vidienā un Vidzemes jūrmalā. ${ }^{388}$

Brunči ar piešūtu ñieburu, spriežot pēc Latvijas PSR Vēstures muzeja kolekcijās esošajiem
Ventspils novada tautas tērpiem, ir jaunāki par brunčiem ar pārplečiem (19. gs. sākums) un droši vien ir pirmā tipa tālākās attīstības rezultāts. Alsungas un Ventspils novados brunči ar n̦ieburu 19. gs. ir vienīgais brunču veids.

Vidzemes tērpu kompleksā šĩ veida brunči parādās tikai 19. gs. vidū vietās, kur ilgāk saglabājās lībiešu materiālās kultūras iezīmes, proti, Rietum- un Ziemeḷidzemē (piemēram, Bauñu pagastāa ${ }^{389}$ ) un Lielvărdes novadā. Ziemeḷvidzemē sastopami abi šo brunču veidi, proti, kā brunči ar piešūtu ņieburu, tā arī brunči ar pārplečiem. Svītraini brunči ar paplatu jostu un pārplečiem redzami A. Pecolda akvarelī «Mazsalacas muižas» apkārtne» ${ }^{390}$ (skat. 24. att.).

Parasti nieburs un brunči darināti no viena materiāla; atsevišķos gadījumos brunči pie niiebura nav piešūti. Dažầs vietãs Ziemelvidzemē (Smiltene) brunču augšdala veidota stipri pieguloša ar piedurknēm. Šāda veida brunču vietējais nosaukums ir «kapats».391 Plašāk kapati izplatās 19. gs. otrajā pusēe. ${ }^{392}$

Atškirībā no Kurzemes Vidzemē kā brunču apakšējo dal̨u, tã arī augšējo - ņiebura dą̧u vienmēr šuva no vienāda materiāla. Kurzemē brunču niebura dala šūta no vienkāršāka, rupjāka auduma, jo to nosedza ar jaku.

Minēto brunču veidu izplatība apstiprina B. Kuftina izteikto domu, ka Baltijā sarafānveida brunči ienākuši no rietumiem, t. i., no Skandināvijas un Dānijas, ${ }^{393}$ un, salīdzinot ar nešūtajiem brunčiem, ir daudz jaunāki. Nepamatots liekas uzskats, ka brunči ar n̦ieburu (t. i., sarafānveida brunči) ir vecāks apğērba veids nekā ne- 
šūtie brunči, ${ }^{394}$ turklāt K. Straubergs par sarafānveida brunčiem uzskatījis J. Branda aprakstītos nešūtos brunčus. ${ }^{395}$ Kurzemes brunči ar ñieburu piegriezumā loti līdzịgi Zviedrijas sarafāniem, ${ }^{396}$ un tas runā par labu B. Kuftina uzskatam par to izcelšanos.

\section{BIKSES}

Bikses ir raksturīgākā vīriešu apgeērba dala. tās sauktas arī par paslavām, ${ }^{397}$ ūzām, ${ }^{398}$ jūzām. ${ }^{399}$

Bikšu valkāšanas sākums attiecināms uz mūsu èras pirmajiem gadsimtiem vai vēl agrāk.

Bikses šuva no pakulu, linu, vilnas vai pusvilnas auduma, parasti no tāda paša materiāla kā svārkus. Pie baltiem goda svārkiem valkāja tikai baltas bikses, bet pie pelēkiem svārkiem - baltas linu vai kādas citas krāsas bikses. 19. gs. sākumã reizē ar rūtaino brunču izplatību arī vīriešu bikses šuj no rūtaina auduma, tikai ne tik košās krāsās. Latgalē un Rucavā biežāk valkātas linu vai pakulu bikses. Muižu sulaini valkājuši arī ādas bikses. ${ }^{400}$

Latvijā, tāpat kā pārējā Austrumeiropā, izplatīts viens bikšu tips - ar šaurām bikšu starām.

Valkātas kā garās (līdz potītēm), tā arī îsās (līdz ceḷiem) bikses. Plašāk izplatītas ir garās bikses; îsãs raksturīgas Ziemelkurzemes vīriešu apgèream un droši vien te ieviesušās pēc lïbiešu. igauṇu un zviedru paraugiem. ${ }^{401}$ Iespējams, ka zināma nozīme te bija muižas sulaiṇu apgēēba ietekmei, jo 19. gs. sākumā sulaini parasti valkājuši îsās bikses. ${ }^{402} \mathrm{~F}$. Kruze Kurzemes vīriešu apg̀ērbu zìmējumos rāda tikai îsās bikses (skat. 12. tab.). İsās bikses sniedzās nedaudz pāri ceḷiem, kur tās aizpogāja ar vienu vai divām pogām vai arī apsēja ar krāsainām lentēm. Pie îsām biksēm vilka garas baltas vilnas zeḳes. Dundagā un tālāk uz rietumiem valkāja arī gaiši pelēkas, bet Talsos mēḷas garās zeḳes. ${ }^{403}$ Garăs bikses sniedzas apmēram līdz potītēm.

Bikšu piegriezumā izdalāmi 3 varianti. Pirmā piegriezuma varianta biksēm katra bikšu stara šūta no viena auduma gabala, kuru priekšpusē aizpogāja ar vienu lielu $(2-2,5 \mathrm{~cm} \varnothing)$ misiṇa vai alvas pogu (32. att., 3,4$).{ }^{404}$ Saitîte jostas mugurpusē ḷāva bikšu jostu pagarināt vai saīsināt. Ap jostas vietu bikšu audumu sakārtoja krokās. S̄à piegriezuma veida bikses Latvijā sastopamas visbiežāk. Otrā piegriezuma varianta biksēm ir raksturīga «klape», kas apsedza bikšu vidus šḳēlumu (32. att., 2, 8). «Klapes» aizpogāšanai tās stūros bija pa slipi iegrieztam pogcaurumam, «klapi» aizpogãja ar tādām pašām pogām, ar kādām sapogāja jostu. Šāda veida bikses Latvijā sastopamas tikai atsevišḳos gadījumos. Liekas, šā tipa bikses izplatījušās apvidos, kuru iedzīvotājiem bijuši tieši sakari ar igauñiem. ${ }^{405}$ Trešā piegriezuma varianta bikses atškiras no iepriekšejjām ar to, ka katra bikšu stara šūta no diviem auduma gabaliem; viens - ārējais - ir taisns četrstūris, otrs iekšèjais - kịịlveida; bikšu augšdala kā priekšpusē, tā mugurpusē saiet pamī̌us (32. att., 7). Sis bikšu veids izplatīts Ziemelvidzemē. Lìdzīgs bikšu staru savienojums sastopams čeremisu tautas tërpos; ${ }^{406}$ pēc mūsu rīcībā esošajiem materiāliem igauṇu vīriešu tērpu kompleksā šis bikšu veids nav sastopams.

Sievietes apskatāmajā periodā Latvijā bikses nav valkājušas. Vienīgi J. Broce piemiin bikšu valkāšanu Piebalgā. Liekas, ka autors šai sakarā maldījies, jo visā pārējā Latvijā sievietes bikses sāk valkāt tikai 19. gs. pašās beigās. Varbūt J. Broce par biksēm uzskatījis sietavas, var arī büt, ka 31. att. attiecīgais kāju apğērbs ir garas zeḳes bez pēdām, kuras vietumis valkā vēl šodien. ${ }^{407}$ Tam, ka minētās bikses ir sietavas, par labu runā J. Broces anotācija, kurā nav vis teikts, ka kājās uzvilktas bikses, bet gan, ka «g a r kā jā m karäjas zilas vai melnas platas a pakšbikses», ${ }^{408}$ un tas jau vairāk atbilst sietavu aprakstam. Arī bērnu apğērbā bikses ir samērā jauna parādība. Vēl 19. gs. beigās zemnieku bērni līdz skolas vecumam (Latgalē pat vēl ilgāk) neatka. rīgi no dzimuma staigāja tikai vienā kreklā, bez biksēm.

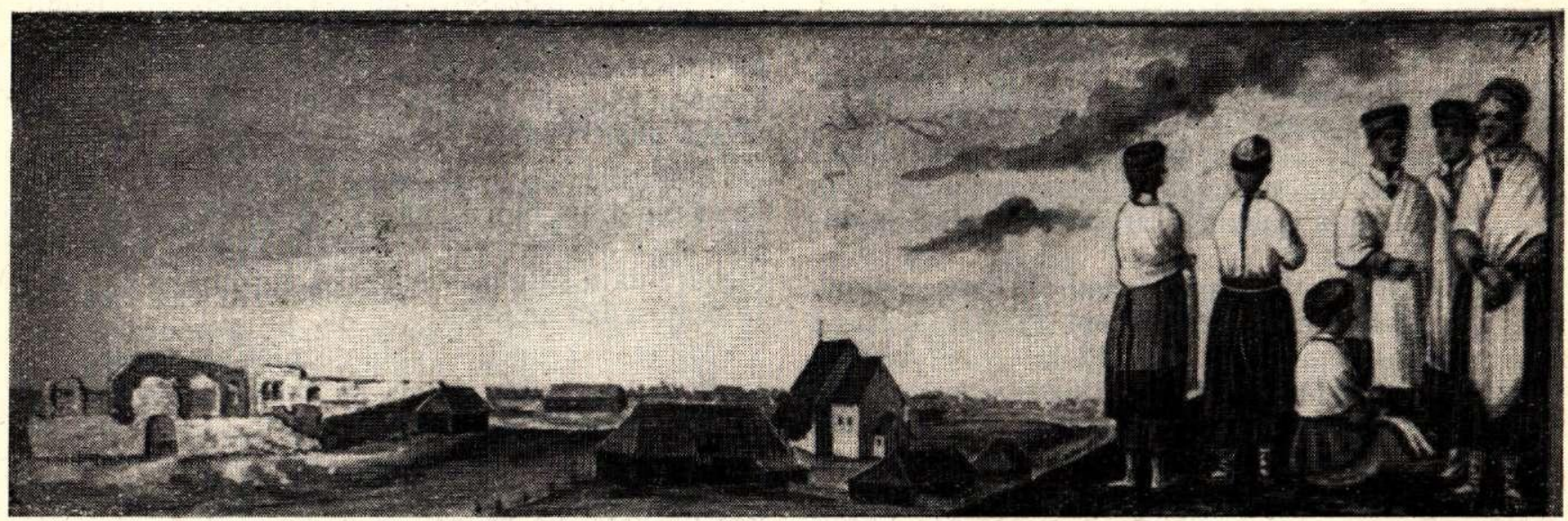

31. att. Piebaldzietes (J. Chr. B rotz e. Monumente..., VII. 66. 1pp.). 
18. gs. latviešu apgēerbā nepieciešama sastāvdaḷa ir jostas. Kā apgèerba saturētājas tās nēsātas visā Latvijā. 19. gs. otrajā pusē dažos Kurzemes novados tās jau izzudušas.

Senā tradīcija - jostas vietā sajozt tērpu ar jostu - plaši pazīstama arī lietuviešu un igauṇu tautas tērpos.

Pèc izgatavojamā materiāla jostas dalāmas trijās grupās: 1) metāla jostas, 2) ādas jostas, 3) no tekstilijām darinātas jostas.

Metāla jostas (33. att.), t. s. sleṇgenes vai ḳēžu jostas, liekas, ir viens no vecākajiem jostu veidiem; arheolog̀iskie izrakumi tās konstatē jau 15. gs., ${ }^{409}$ bet 19. gs. sākumā tās saglabājušās tikai Kuldīgas, Ventspils un arī Alsungas novados. Tās valkāja kā vīrieši, tā arī sievietes. Arheologíiskajos izrakumos sastopamas arī ar metāla apkalumiem vai sprādzēm rotātas ādas jostas. ${ }^{410}$ 19. gs. sākumā ādas jostas ar metāla sprādzēm raksturīgas Kurzemes vīriešu tērpam (33. att., 2-4).

No tekstilijām darinātās jostas var iedalīt austās, pītās, adītās un uz drānas pamata ar stikla zīlìtēm izšūāàs (t. s. zīḷ jostas) (34. att.).

Latviešu, lietuviešu un igauṇu jostas pēc darināšanas tehnikas, materiāla, ornamenta un valkāšanas veida savstarpēji maz atšḳiras ${ }^{411}$ (35. att.). Tikai loti sīki pētot jostu paraugus, var pamanît atšķirības rakstu kompozīcijā un krāsu ziedā. Senākie zīmējumi par jostu valkāšanu, kas saglabājušies, līdz mūsu dienām, ir jau iepriekš minētie 16. gs. zìmējumi.

Pēc aušanas tehnikas a u s tās jostas dalāmas cela inēs un audenēs. Celu tehnika ir viena no vecākajām audumu tehnikām un Latvijas teritorijā plaši pazīstama jau 12. gs. ${ }^{412}$ Celu jostas celaines - savu nosaukumu ieguvušas no darba rīkiem - celu dēlīšiem, ar kuru palīdzību tās tiek austas. Celu tehnikas pamatā griešanas un aušanas savienojums (36. att; 15. tab., 1-7).

Celu audumu tehnika Latvijā visplašāk izplatìta un augstāko attīstības pakāpi sasniegusi Latgalē, kur celos austas dāvināmās jostas sastopamas vēl šodien. ${ }^{413}$ Tomēr krāšñākie celu audumi villaiṇu apaudi izzuduši jau 19. gs. Vidzemē celu audumi sastopami villaiṇu un to bārkšu, kā ari brunču apakšējo malu apaudos, bet kā jostas -.tikai tās austrumdaḷā. Tas pats sakāms par pārējā Latvijā sastopamajiem celu audumiem. Greznākie villaiṇu apaudi ir Bauskas un Ventspils villainēm. Tie ar savu oriğinālo kompozịciju un krāsu salikumu sacenšas ar Krustpils villaiṇu apaudiem. Celos austas jostas Zemgalē un Kurzemē nav sastopamas.

Latvijā pazīstami četri audeṇu tipi: svītrainās, ziedainās, «aulejas» un audenes ar ielasitu rakstu. Audenes auž uz veltṇa vai šḳietiṇa (37. att.). Škiietiṇu lieto šaurāku audeṇu aušanai.

S vītra in ās jostas auž no krāsainām, grodi šḳeterētām vilnas dzijām vertikālās svītrās. Audiem lieto vilnas dzijas tầā pašā krāsā kā malu svìt-

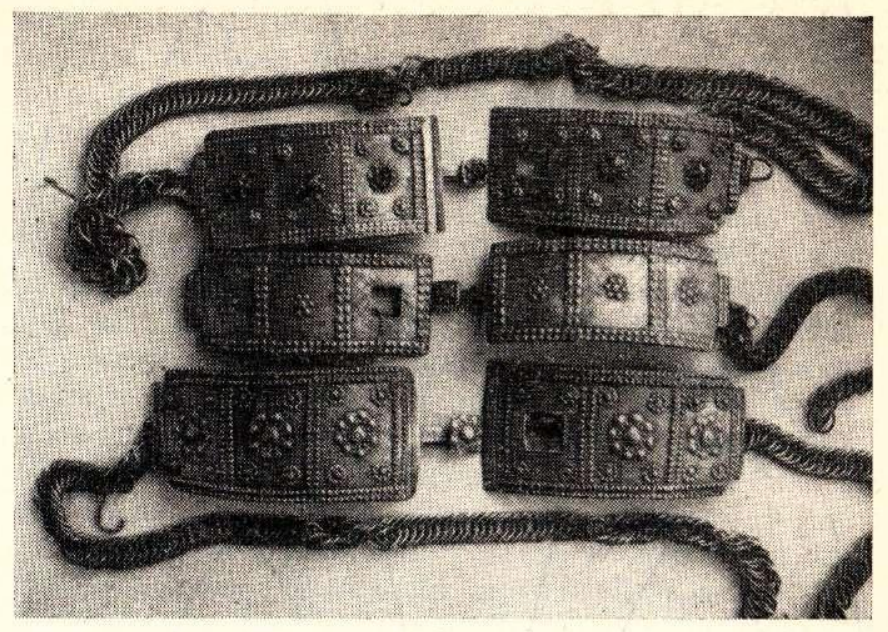

1

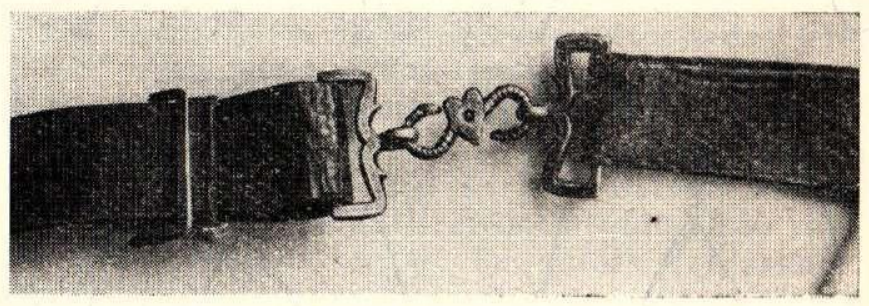

2

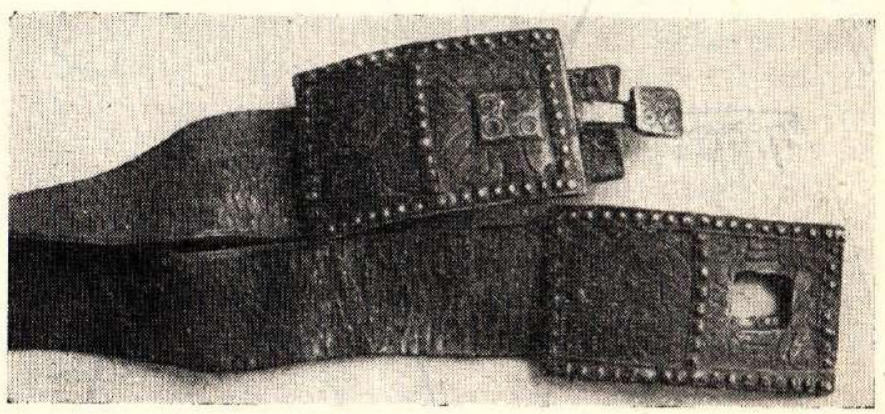

3

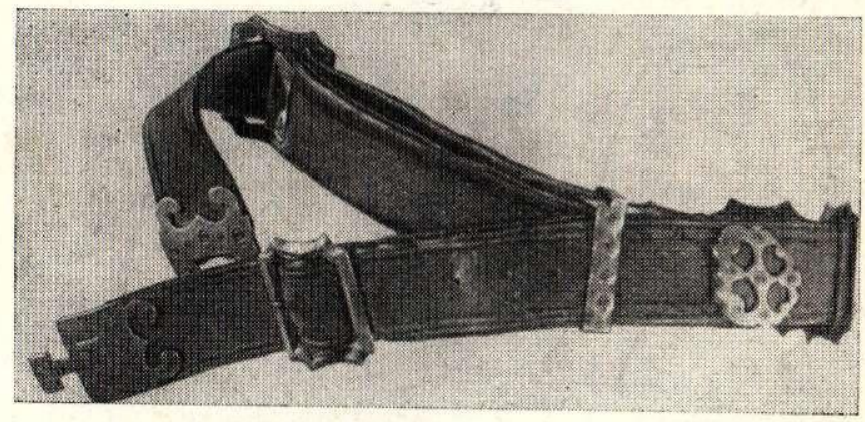

4

33. att. 1-metāla jostas; $2-4-\bar{a} d a s$ jostas ar metāla sprădzēm (Latvijas PSR Vēstures muzeja materiāli). 
ras. Aušana notiek vienīgi ar nīšu palīdzību, neielasot rakstu. Tādā kārtā rodas gareni svìtraina josta. Nereti šādas jostas mēdz aust parastajos lauku aužamos stāvos, šaujot cauri linu diegu. ${ }^{414}$ Svìtrainās jostas raksturīgas Ziemelıidzemes tautas tērpu kompleksam, bet atsevišķos gadījumos sastopamas arī Vidzemes vidiena $\bar{a}^{415}$ (skat. 13. tab., $4-6)$.

$Z$ i e d a i na s jostas sauc arī par trepainām un galdainām jostām. Visraksturīgākās tās ir Austrumvidzemes sieviešu tērpam. Loti platas $(15 \mathrm{~cm})$ un greznas ir ziedainā rakstā austās Piebalgas kažoku jostas. Ziedainās jostas auž, novietojot velkos krāsainās vilnas dzijas, no kurām rakstus neveido; ar velku pabīdīšanu vai izcelšanu iegūst sīkus, spilgtus, ziediem līdzīgus dzīparu krăsu laukumus (skat. 14. tab., 1-5).

A ulejas tipa jostas un prievites sastopamas tikai Latgalē un atšḳiras no rakstainām jostām ar to, ka tās auž tikai no vilnas dzijām un katrai raksta rūtij n̦em vilnas dziju divām kār. tām - kā pamatam, tā rakstam (līdzīgi kā ziedainām jostām). Raksti aulejas tipa jostām veidojas noapal̨oti, abās pusēs vienādi, mainās tikai krāsas.

Jostas ar ielasito rakstu sastopamas visbiežāk. Tās auž uz veltṇa vai šḳietiṇā baltā linu diegu pamatā ar krāsainām vilnas dzijām, ṇemot uz katra raksta diega 2 pamatdiegus. Piebalgas un Gulbenes rakstainajām jostām arì pamata diegu vietā lieto vilnas dzijas, parasti melnā vai tumši zilā krāsā, raksts veidots ar sarkanu vai vēlẳkā laikā - ar violetu dziju. Liela rakstu bagātība šinīs jostās nav vērojama, parasti lietots tikai viens motīvs bez variācijām (skat. 14. tab., 6-11).

Rakstos oriǵ̛inālākās un bagātākās ir Krustpils rakstainās jostas, kur vienā jostā mainảs 20 līdz. 40 ornamentu. ${ }^{416}$ Krustpils jostām raksturīgs ar grezno, izšūto villaiṇu rakstu saskanīgs krāsu kolorīts (skat. 13. tab., 3). Bēru jostām raksts austs ar tumši zilām dzijām. ${ }^{417}$

Cits rakstaino jostu variants sastopams Lielvārdes novadā. Şìs jostas vienmēr austas tikai divās krāsās - baltā linu diegu pamatā ar sarkaniem vilnas dzijas rakstiem. Ipatnējs ir Lielvārdes jostu ornaments, kas atkārtojas vairākos variantos. ${ }^{418}$ Centrālais raksts Lielvārdes jostām sniedzas līdz jostas malām, kamēr Krustpils rakstainajām jostām centrālo rakstu iežogo šauras cita raksta joslinas.

Zemgales rakstainās jostas atšḳiras no Vidzemes jostām ar spilgtākām krāsām. Sarkanie toṇi Zemgales jostās ir tumšāki, tāpat tanīs samērā daudz violetas krāsas. Raksta variācijas nav sevišḳi bagātas, parasti atkārtojas viens vai divi motivi (skat. 13. tab., 2).

Kurzemề austās jostas 19. gs. saglabājušās tikai Alsungas un Talsu novados. Alsungas jostas raksta un krāsu salikuma ziṇā tuvākas Zemgales jostām nekā Vidzemes rakstainajām audenēm (skat. 13. tab., 1).
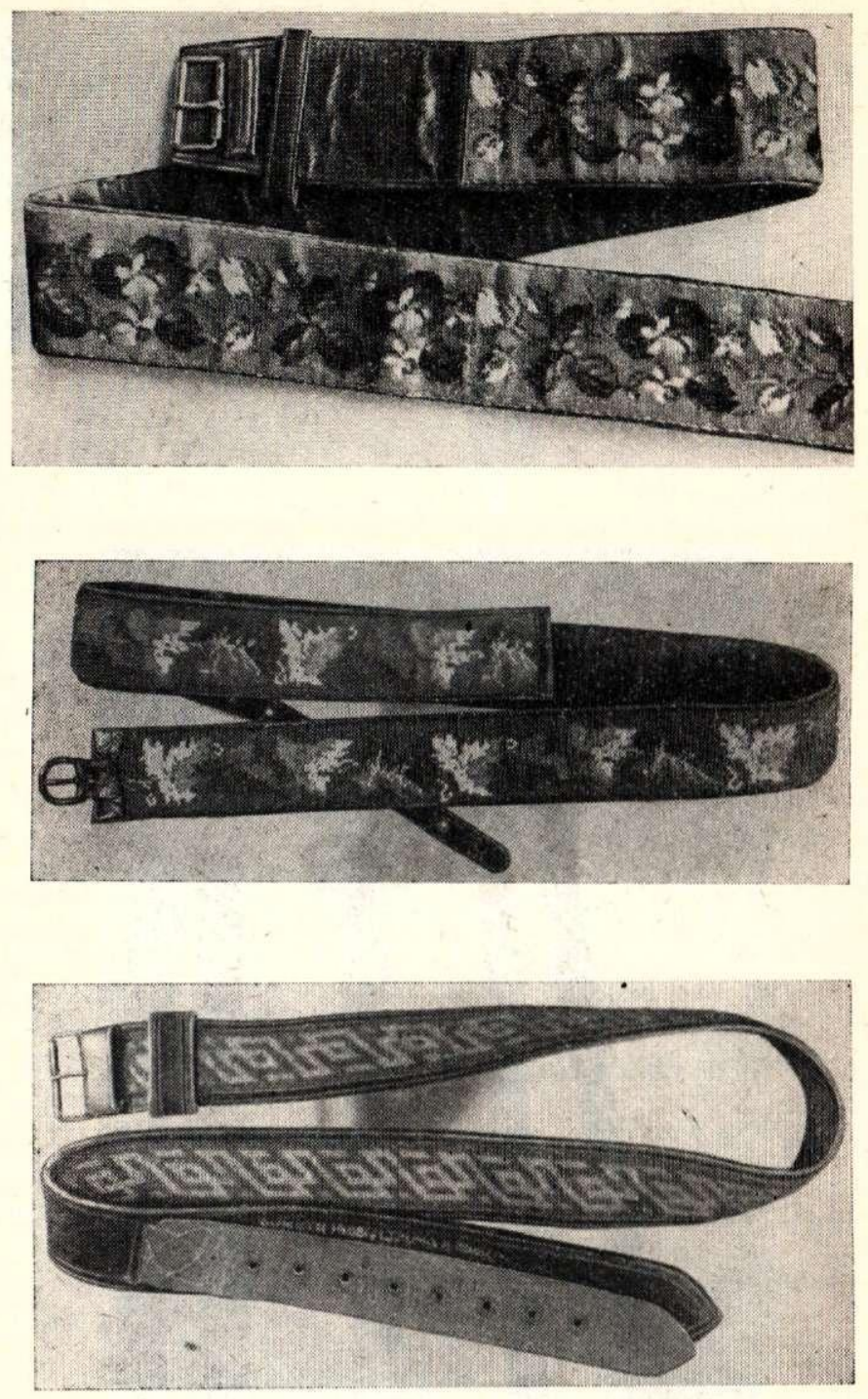

34. att. Zīlu jostas (Latvijas PSR Vēstures muzeja materiāli).

Rakstaino audenu tehnikā austas arī dažādas šaurākas jostiṇas un prievītes, kuras lietoja ne tikai apg̊ērba sasiešanai, bet arī dažädām citām vajadzībām. Prievītes auda veseliem rullịiem un pēc vajadzības nogrieza. Tās parasti auda $1-3 \mathrm{~cm}$ platas, vienīgi «pūra prievītes», ar kurām pārsēja kāzās izdalāmos cimdus un kreklus, auda platākas.

Pìt ā s jostas sastopamas visā Latvijā, lai gan raksturīgākas tās ir Vidzemes vīriešu tērpam. Vienkāršākie pinumu veidi ir sastopami šaurajās prievītēs (pakielēs, üzbantēs), ar kurām sievietes apsēja zek̦es (skat. 15. tab., 8-11).

Vīriešu svārku jostas pina no krāsainām vilnas dzijām $5-10 \mathrm{~cm}$ platas.

Pìto jostu tehnikai pieskaitāmas arī t. s. mežgotās jostas, kuras sastopamas Zemgalē un Latgalē.419

A dîtās jostas ir jaunākas par austajām un pìtajām jostām. Tās sastopamas tikai 19. gs. Dien- 

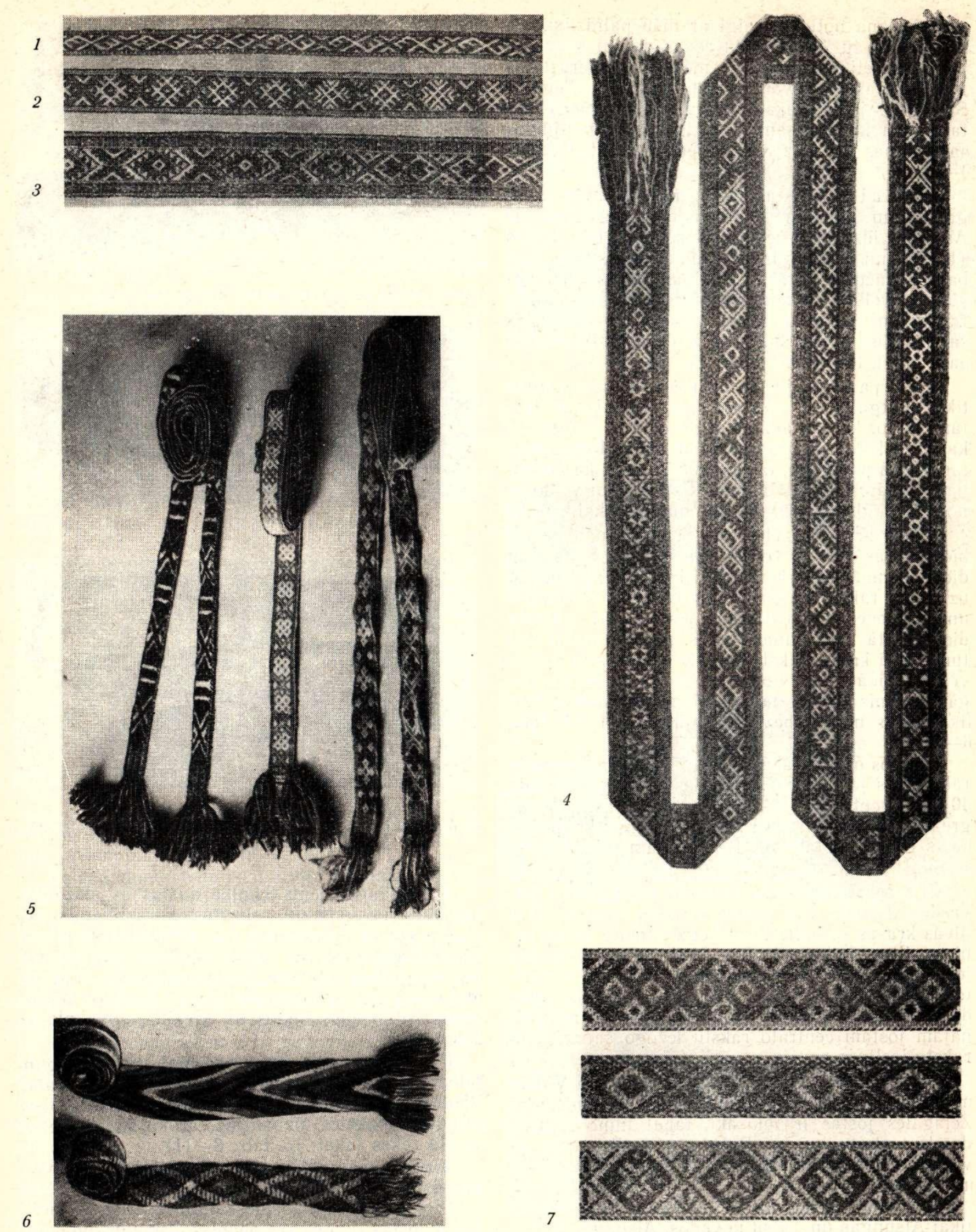

35. att. Latviešu, lietuviešu un igauṇu austās jostas.

Latviešu 1 -Aulejas; 2 - Kapiṇu; 3 - Makašěnu; 4 -Krustpils; 5, 6, - lietuviešu (Lietuvas PSR ZA Vēstures un etnogrāifijas muzeja materiâli); 7 - igauṇu (Эстонская народная одежда. 55. tab.). 


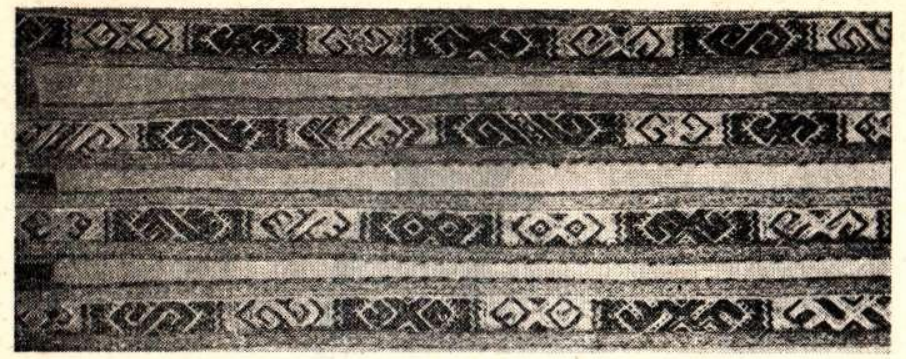

1

36. att. Celu justas:

1 - celu apauds; 2 - dāvanu jostas.
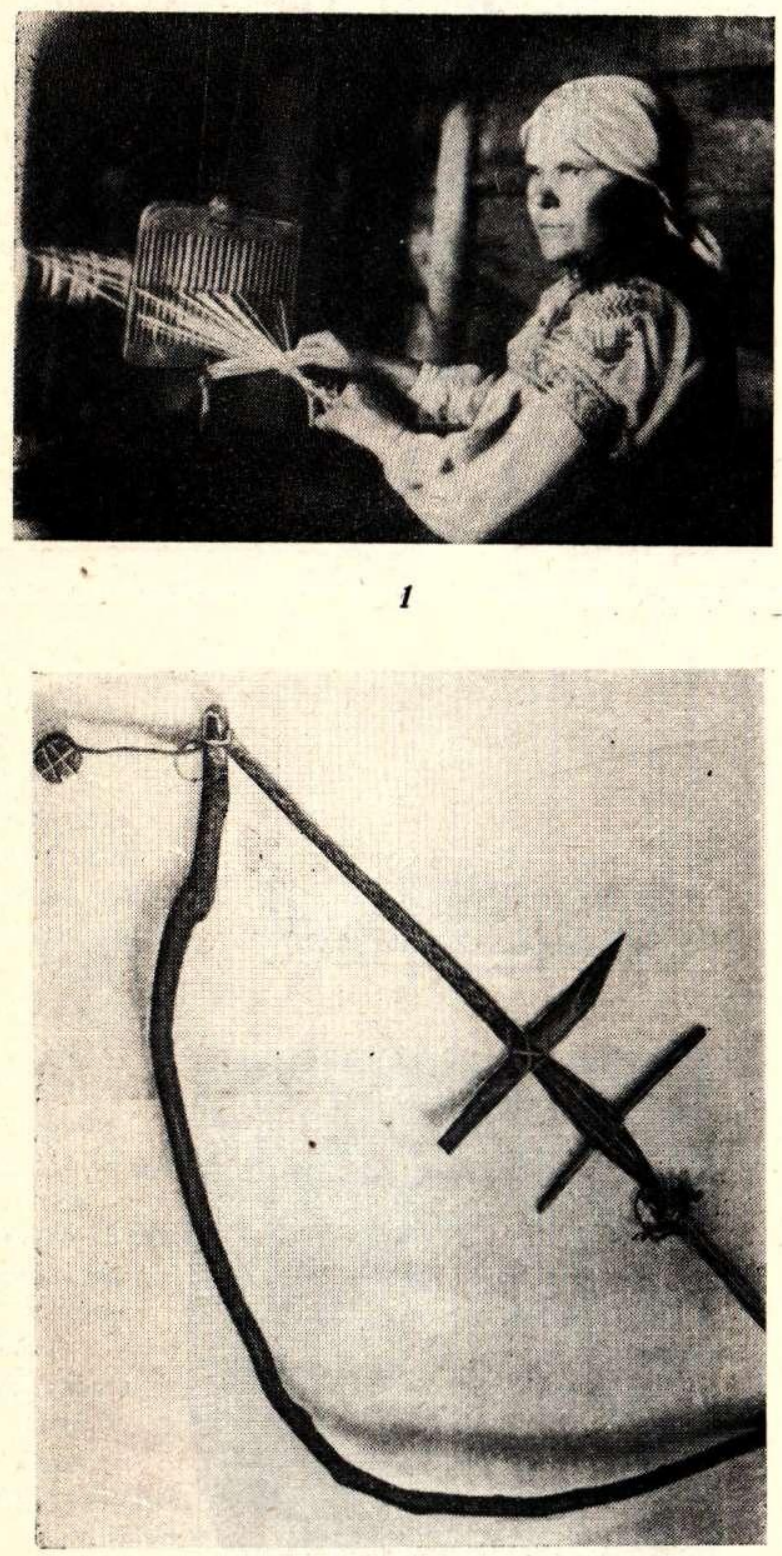

2

37. att. Jostu aušana:

1 - ar škietu; 2 - uz likksts.

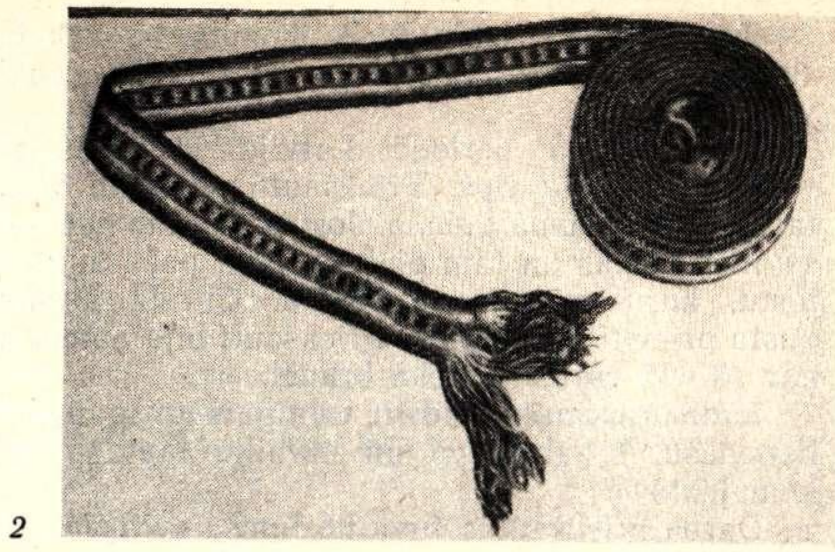

vidrietumkurzemē. ${ }^{420}$ Jostas adītas saulīšu vai ziedu rakstos spilgtās krāsās. Vienkāršākais adīto jostu raksts veidots no krāsainiem posmiṇiem. ${ }^{421}$

Jostām un prievītēm bija savi uzdevumi kā ikdienā, tā arī godos. Ja godos jostas un prievītes bija greznas kā krāsās, tâ rakstos, tad ikdienā lietoja vienkāršākas un ne tik košas. İpatnējas ir t. s. sienamās jostas, kuras sēja virs krekla, stingri notinot vidukli, lai, strādājot smagu darbu, «nepārrautos». Sîs jostas parasti auda vai pina no grodākām dzijām vai diegiem. Viḍzemes vidienā sienamās jostas plaši pazīstamas vēl 20. gs. pirmajā pusēe. ${ }^{422}$

$Z_{1} 1$ l u jostas plašāk izplatās 19. gs. otrajā pusē, un tâs valkāja tikai vīrieši - apjožot kažokus. Zị̣̂u jostu darināšana izmaksāja ḷoti dārgi, tāpēc tās bija turīgo saimnieku lepnums.

No visām minētajām jostām visilgāk saglabājušās austās jostas.

\section{PRIEKSAUTI}

Priekšauts - priekšdrēbe, skotele (arī širce) 18. gs. beigās bija latviešu zemnieču apgèerba nepieciešama sastāvdala. Tomēr kā goda apgèerba sastāvdalai priekšautam latviešu tautas tērpā nebija tādas nozīmes kā igauṇu un lietuviešu apg̉ërba komplektā, kur priekšauts, tāpat kā galvassega, norāda uz sievietes stāvokli gimenē..423

Līdzšinējos publicējumos par latviešu tautas tērpiem priekšautu valkāšanai nav pievērsta vajadzīgā uzmanība, uzskatot priekšautu par latviešu tautas tērpam netipisku sastāvdaḷu, kas plašāk ieviesusies tikai 19. gs. beigās. ${ }^{424}$

Arheolog̀iskie izrakumi nedod tiešu liecību par priekšautu valkāšanu, jo apg̀ērba dạ̣ā, kas varēja atrasties tuvu priekšautam, metāla rotājumu nebija, pie kuriem būtu varējuši saglabāties auduma fragmenti. Turpretim 16.-18. gs. zimējumos priekšauti attēloti nepārprotami (38. att.).

Muzeju kolekcijā priekšautu samērā maz, tomër, spriežot pēc J. Broces un $\mathrm{O}$. Hūna zīmējumiem, ${ }^{425}$ secināms, ka priekšautus valkāja ne tikai darbā, bet arī pie goda apğērba. 
Arī termins priekšauts, t. i., auts, ko liek vai sien priekšā, liekas, liecina par šì apg̀ērba gabala vecumu. 426

Apskatāmajā periodā Latvijā ir pazīstams viens priekšauta tips. Priekšautu šuva no viena taisnstūra auduma gabala. Jostas vietā to nedaudz savilka krokās un tam piešuva tāda paša auduma jostu, kuru mugurpusē sasēja. Citreiz piešuva austu prievīti vai jostiṇu. Priekšauti bija apmēram par $10-15 \mathrm{~cm}$ īsäki nekā brunči.

S̄āds priekšautu veids ir vienīgais arī igauṇu, ${ }^{427}$ lietuviešu, ${ }^{428}$ baltkrievu un ukraiṇu tautas tērp!! komplektā. ${ }^{429}$

Darba priekšautus šuva no tumša svītraina vai rūtaina linu vai pakulu audekla. Ejot talkās vai muižas darbos, kur bija vairāk svešu laužu, apsēja baltu linu priekšautu. Bagātākās meitas savus priekšautus izšuva ar sarkaniem linu diegiem. ${ }^{430}$

Skaistākie priekšautu paraugi ar īpatnējas kompozīcijas sarkanu izšuvumu saglabājušies no Augšzemes. ${ }^{431}$ İpatnējā un senā audumu tehnikā ir darināts linu priekšauts (iegūts 1952. g. ekspedīcijā bij. Neretas rajonā) ar ieaustām neapstrādātām linu škiiedrām (39. att.).

J. Broces zīmējumā Lielvārdes sieviešu priekšauta raksti līdzīgi villainu un sievas cepuru izšuvumu rakstam. Citos J. Broces zìmējumos priekšauti ir gaišās krāsās. ${ }^{432}$

\section{VILLAINES}

Viens no īpatnējākajiem un senākajiem latviešu sieviešu apgère gabaliem ir villaine.

Iespējams, ka villaiṇveida mēteli senatnē valkājuši arī latviešu vīrieši. ${ }^{433}$ S̄āda veida mēteḷs pazīst arī vairākas citas tautas.

Greznās izrakstītās villaines bija kā precēto, tā neprecēto sieviešu greznākais apg̀ērba gabals un zināmā mērā raksturoja villaines valkātājas turības pakāpi.

Arheologiskie materiāli liecina, ka villaines nēsātas jau 7. gs. Tās var uzskatīt par leišu, latviešu un igaunu tipisku plecu apg̀ērbu.

$\mathrm{Ar}$ vārdu villaine, arī vilnaine, villāne u. c.. kuru pamatā vārds villa (vilna), apzīmē dažādus plecu segu paveidus. Augšzemē plaši izplatīts termins sagša (no verba segt) liela rūtaina vilnas lakata apzīmēšanai. Līdzšinējā etnogrāfiskajā literatūrā ar vārdu sagša parasti apzīmē grezni izšùtās vai ar metālu rotātās villaines. ${ }^{434} 18$. gs. vārdnīcās sagšu un villaiṇu nozīmes nav identiskas. No vienas puses, sagša ir greznā villaine «Staatsweepe», bet, no otras, tā ir dubultvillaine ar bārkstīm. ${ }^{435}$ J. Langes vārdnīcā «sakša» ir greznā plecu sega, par kuru «villaines ir sliktākas».436 Pēc J. Endzelīna un K. Mīlenbaha vārdnīcas sagšas nosaukums konstatēts tikai dažos pagastos vilnas vai nātnas sieviešu plecu segas vai arī gultas segas (deķa) nozìmē. ${ }^{437}$ Ceḷotāju ap-

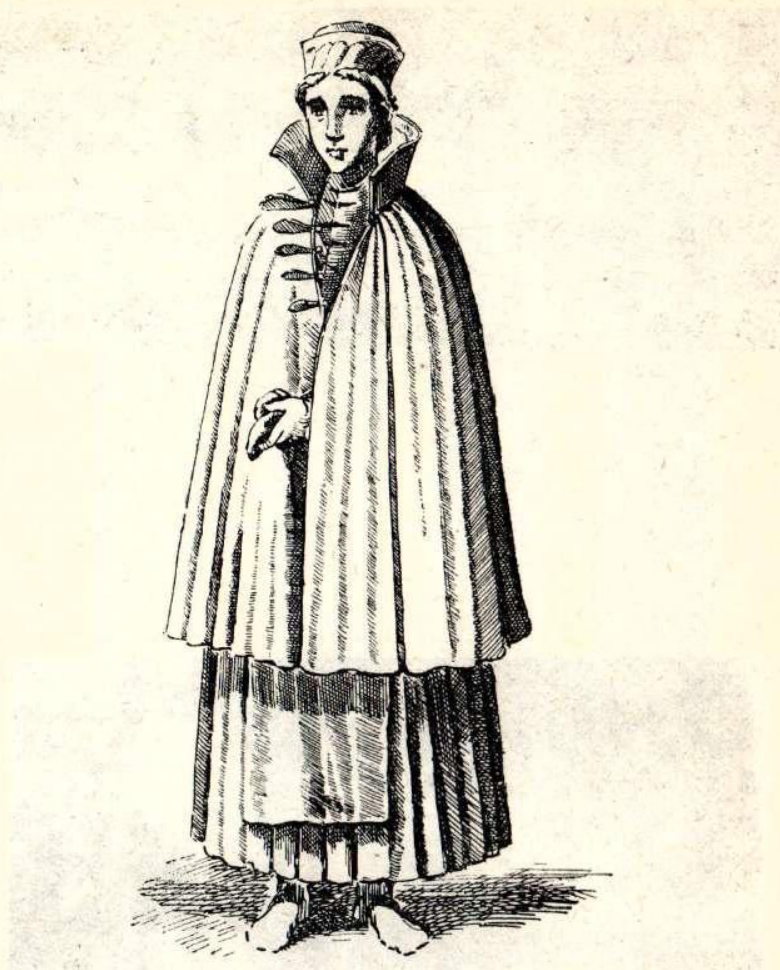

38. att. 16. gs. sieviešu apġērbs (ar priekšautu).
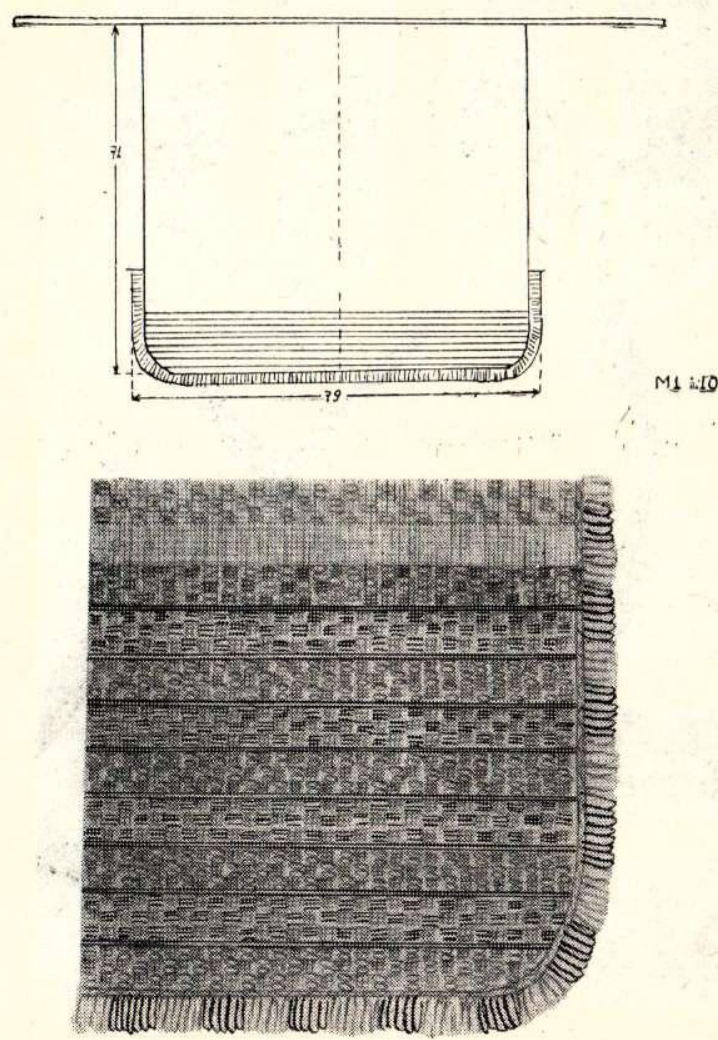

39. att. Augšzemes priekšauts (ZA Vēstures institūta Etnogrāfijas sektora materiāli). 
rakstos termins sagša nav sastopams; ${ }^{438}$ tulkojot šos materiālus vēlākajos gados, terminu sagša ieviesuši tulkotāji. VME nodą̧as arhīva materiālos par sagšām nosauktas dažāda tipa villaines izšūtas, baltas, zilas, pelēkas u. c. Neviens no minētajiem avotiem nedod pamata secinājumam, ka sagša būtu tikai grezni izšùta, rotāta villaine. Par šādu pamatojumu nenoder arī dažos pagastos pazīstamās tautasdziesmas rindas: ... «ja būs māte, sagšu (var.: deḳi) segšu, ja pamāte, villainīti» (LD 25336).

Pārlūkojot Kr. Barona LD substantīvu rādītājus, vërojams, ka tiklab sagšas, kā villaines tautasdziesmās lietotas ar vieniem un tiem pašiem epitetiem. Kā villaines, tā arī sagšas ir gan sudraba, zelta, zīda, gan arī pelēkas, nerakstītas u. tml. Tāpēc vietēja termina (sagša) attiecināšanu uz visā Latvijā sastopamām grezni rotātām villainēm nevar uzskatīt par pareizu.

Skaidrības labā sniedzam kartogrammu par VME arhīvā fiksētiem plecu segu nosaukumiem un veidiem (41. att.), kā arī pārskatu par tautasdziesmās sastopamajiem sagšu un villaiṇu apzīmējumiem.

Tautasdziesmas, kurās minēta «sagša» līdz ar dažādiem epitetiem

\begin{tabular}{|c|c|c|c|c|c|c|}
\hline Epiteti & 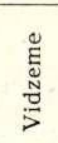 & $\begin{array}{l}\frac{0}{\pi} \\
\text { of } \\
\text { d] }\end{array}$ & 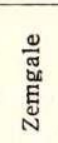 & 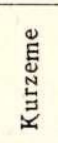 & 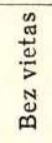 & 용 \\
\hline Bez’apzīmējuma & 76 & 13 & 26 & 66 & 7 & 188 \\
\hline Baltas & 14 & - & 7 & 18 & 2 & 41 \\
\hline Biezas & 2 & - & - & - & - & 2 \\
\hline Dzintara & 2 & - & 1 & 4 & - & 7 \\
\hline Ejamās & 1 & - & - & 3 & 一 & 4 \\
\hline Isās & - & - & - & 1 & 一 & 1 \\
\hline Krāsainās & 7 & - & 1 & 1 & - & 9 \\
\hline Līdz zemei & - & 1 & 1 & - & - & 2 \\
\hline Lielas, kuplas & 2 & - & - & 2 & - & 4 \\
\hline $\begin{array}{l}\text { Nātru, dadžu, } \\
\text { ērkšķu }\end{array}$ & 3 & 1 & - & - & - & 4 \\
\hline Pelēkas & 8 & - & - & 1 & 1 & 10 \\
\hline Platas & 1 & - & - & 3 & - & 4 \\
\hline Pussagšas & 2 & - & - & - & - & 2 \\
\hline Pušķotas & 10 & - & - & 8 & - & 18 \\
\hline $\begin{array}{l}\text { Sagša kā gultas } \\
\text { sega }\end{array}$ & 9 & 2 & 2 & 3 & - & 16 \\
\hline $\begin{array}{l}\text { Sagša kä jumts } \\
\text { Sagša un }\end{array}$ & 1 & - & - & 2 & - & 3 \\
\hline villaines & 14 & - & 6 & - & - & 20 \\
\hline Sēru & - & - & - & 1 & 2 & 3 \\
\hline $\begin{array}{l}\text { Sudrabotas un } \\
\text { zelta }\end{array}$ & 8 & 1 & 1 & 1 & - & 11 \\
\hline Sauras & - & - & - & 1 & 1 & 2 \\
\hline $\begin{array}{l}\text { Dažādas citas, } \\
\text { bez rotājuma }\end{array}$ & 4 & - & 1 & 4 & 2 & 11 \\
\hline
\end{tabular}

Tabula sastādīta pēc Latvijas PSR ZA Valodas un literatūras institūta Folkloras sektora $\mathrm{Kr}$. Barona LD substantîvu rādītājiem.
Tautasdziesmas, kurās minēta «villaine» lìdz ar dažādiem epitetiem

Bez apzìmējumiem

Asaru

Austa

Auzu skaru

Balta

Bārenites, sērdienīšr

Bišu spārnu

Brūtes

Cūku saru, cūkganu, cūciṇu, cūkú zaru, lyuku saru

Dažādi apzīmējumi (trīs devinas, devinas, deviñgreidu, pa desmit, treju loku u. c.)

Dieguloku, ielokaina

Ejamā, promejamā

Ganu

Gara, ĩsa, plata, šaura, smalka, rupja, līdzena, plāna, bieza

Gulamā, sedzamā

Ielokaina, nelocìta, bez ielokiem

Ierakstīta, rakstu

Kupla

Lietus

Maza, viegla

Melna

Mēlu zila

Mìksta

Nemazgāta, nevelēta

Nerakstita, nepunktota

Nobaru

Nobrukusi, noplīsusi, veca, sapelējusi, nobālusi, nosvi-

lusi, pakulu

Pakājišu

Pelēka

Pelnīta, lones

Pirkta

Pubulaina, bumbulaina

Putnu spalvu

Raiba, rūtu, krustrūtaina

Ruda

Samta, zīda

Sarkana

Sīku sprodžu, pogaḷu, skuju, akotāja, sēnalaina, dzenolīsu

Skaista, daila, jauna

Smalku ratu

Sudraba, apzeltīta, zītara, stīgām griezta

Tapināta

Vedamā

Vienu kārtu, trij' gabalu, trīsdzīparu, šḳeterēta

Vilka pinku, suṇu pluču, melna suṇa

Virsas

Vizulu

Zala

Ziedu

Tabula sastādīta pēc Latvijas PSR ZA Valodas un literatüras institūta Folkloras sektora Kr. Barona LD substantīvu rädītājiem.

Kā liecina tabula, arī tautasdziesmas nešḳiro nerotātās villaines no rotātām - sagšām. Tāpēc liekas, ka līdzšinējam villainu dalījumam greznākās sagšās un nerotātās villainēs nav pamata un termins sagša, tāpat kā vildrāna, baltvikāle u. c., lietojams tikai kā vietējais nosaukums.

Pēc krāsas villaines dalās: baltās villainēs, zilās (mēlenes, zilāms), zaḷās (kučas), pelēkās (seg̀enes, sedzenes) un krāsaini vai rakstaini austās (lielie lakati, villāne) u. c. 


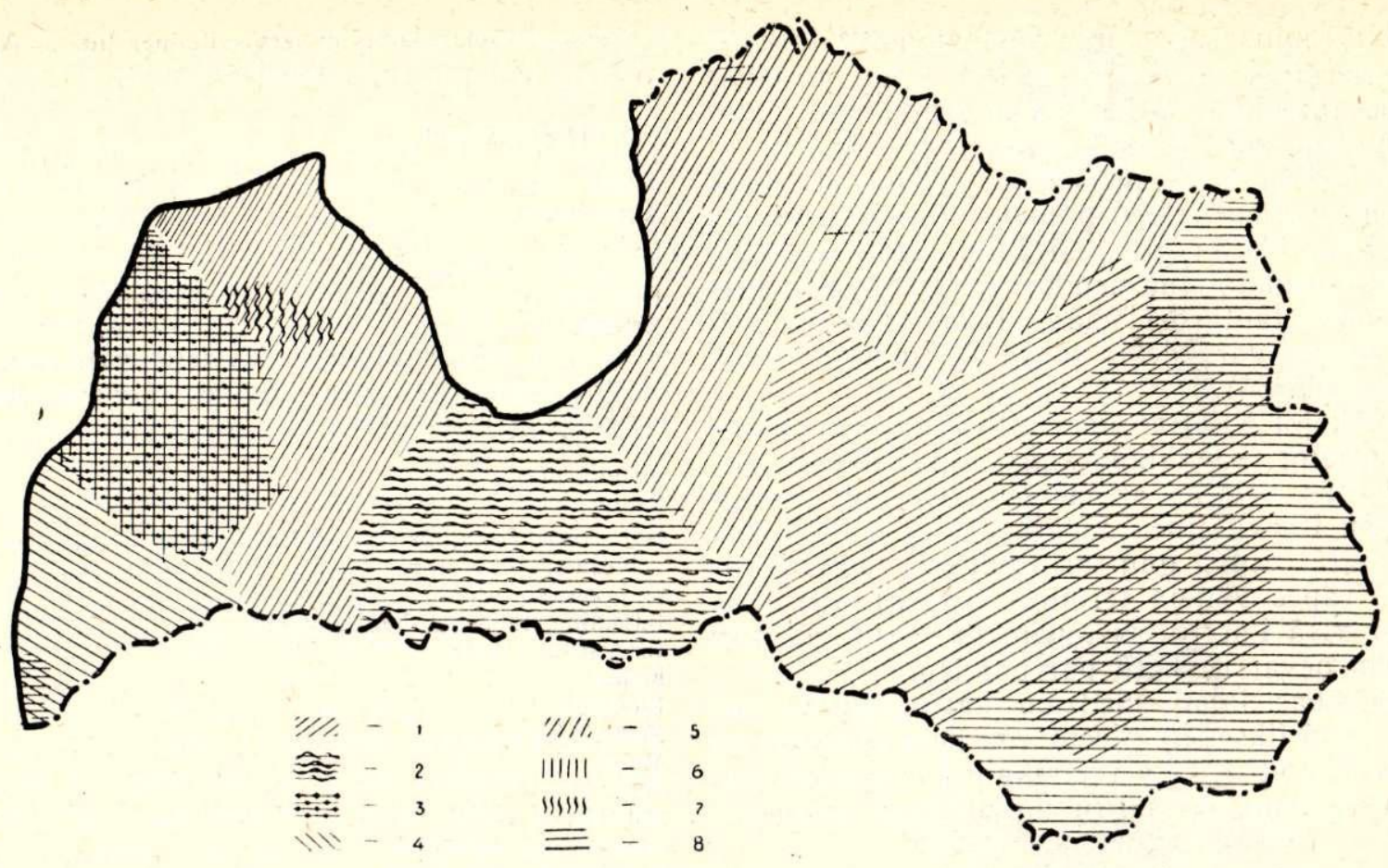

40. att. Villaiṇu veidi 19. gs. pirmajā pusē (pēc Latvijas PSR Vēstures muzeja materiāliem):

1 - Austrumlatvijas; 2 - Zemgales; 3 - Rietumkurzemes; 4 - Dienvidkurzemes; 5 - baltas; 6 - zilas; 7 - Talsu; 8 - snātenes.

No linu auduma darinātās plecu segas sauc par snātenēm, snānēm, snātnēm. Šo vārdu pamatā adjektīvs «nätns».

Villaini darināja no četrstūraina vilnas vai pusvilnas auduma gabala. To sedza pāri abiem pleciem un sasprauda uz krūtīm ar lielu saktu vai arī lika ap vidu un sasprauda uz viena pleca. ${ }^{439}$ Villaines parasti rotāja ar bārkstīm, apaudiem, izšuvumiem vai metāla rotājumiem.

Visgreznākās villaines, kas rotātas izšuvumiem, metāla spirālēm vai daudzkrāsainiem ieaustiem rakstiem, sedza tikai loti svinīgos gadī. jumos, lielos godos vai arī, ja gribēja kādu godināt. Grezni izrakstītas villaines bija turības pazìme, tās valkāja meitas precību gados un jaunas sievas. ${ }^{440}$

Rakst', māsiña, lielu rakstu

Jele vienu vilnānīti:

Ko tu segsi, aizgājusi

Lielajos dieveros.

\section{LTD, III, 511}

Nāc, māsiṇa, tu pie manis,

Es pie tevis nenoiešu,

Es pie tevis nenoiešu,

Man pelēkas villainītes.

LTD, III, 464

Greznā villaine zināmā mērā liecināja par meitas tikumu. Tà bija arī kāzu rota, kā arī dāvana patīkamai vedeklai vai vīramātei. ${ }^{441}$

Grezno villaiṇu bagātais rotājums prasīja gadiem ilgu darbu, tāpēc tās varēja atḷauties tikai bagātās mātes meitas, kurām bija vairāk brīva laika vai iespēja likt citiem izrakstīt villaines. Kà stāsta tautasdziesma, arī sērdiene, nakti negulēdama, darinājusi sev grezno villaini.

Grezno villaiṇu garums svārstās no 120 līdz $250 \mathrm{~cm}$, bet platums - no $80 \mathrm{lid} z 150 \mathrm{~cm}$. Tautas. dziesmā villaines platumu gleznaini salīdzina ar ezeru. Villainu platums bijis atkarīgs arī no meitas auguma.

\section{Platas audu villainītes, \\ Cerē diža izaugusi; \\ Villainītes zemi slauka, \\ Birst man gaužas asariṇas.}

$$
\text { LTD, III, } 367
$$

Vidzemē, Latgalē un Zemgalē vairāk valkātas garās un šaurās villaines $(80 \times 250 \mathrm{~cm})$, bet Kurzemē - īsākas un platākas $(90 \times 140 \mathrm{~cm})$ (42. att.).

Pëc ornamenta un raksta kompozícijas izrakstītās villaines var iedalīt Austrumlatvijas villainēs (42. att., 1), Dienvidkurzemes (42. att., 2), Ziemelkurzemes (42. att., 3) un Zemgales villainès (42. att., 4).

Arī tautasdziesmas dzied par rotäjumu dažādību villainēs:

Māmiṇai trīs meitinas,

Trīs sagšinas pūriñă.

- Parăd' man, māmuliñ

Kuru dosi pirmajai.

- Skaista, balta, lieli raksti,

To es došu pirmajai.

To es došu pirmajai,

Tã ies tāli tautinạăs. 


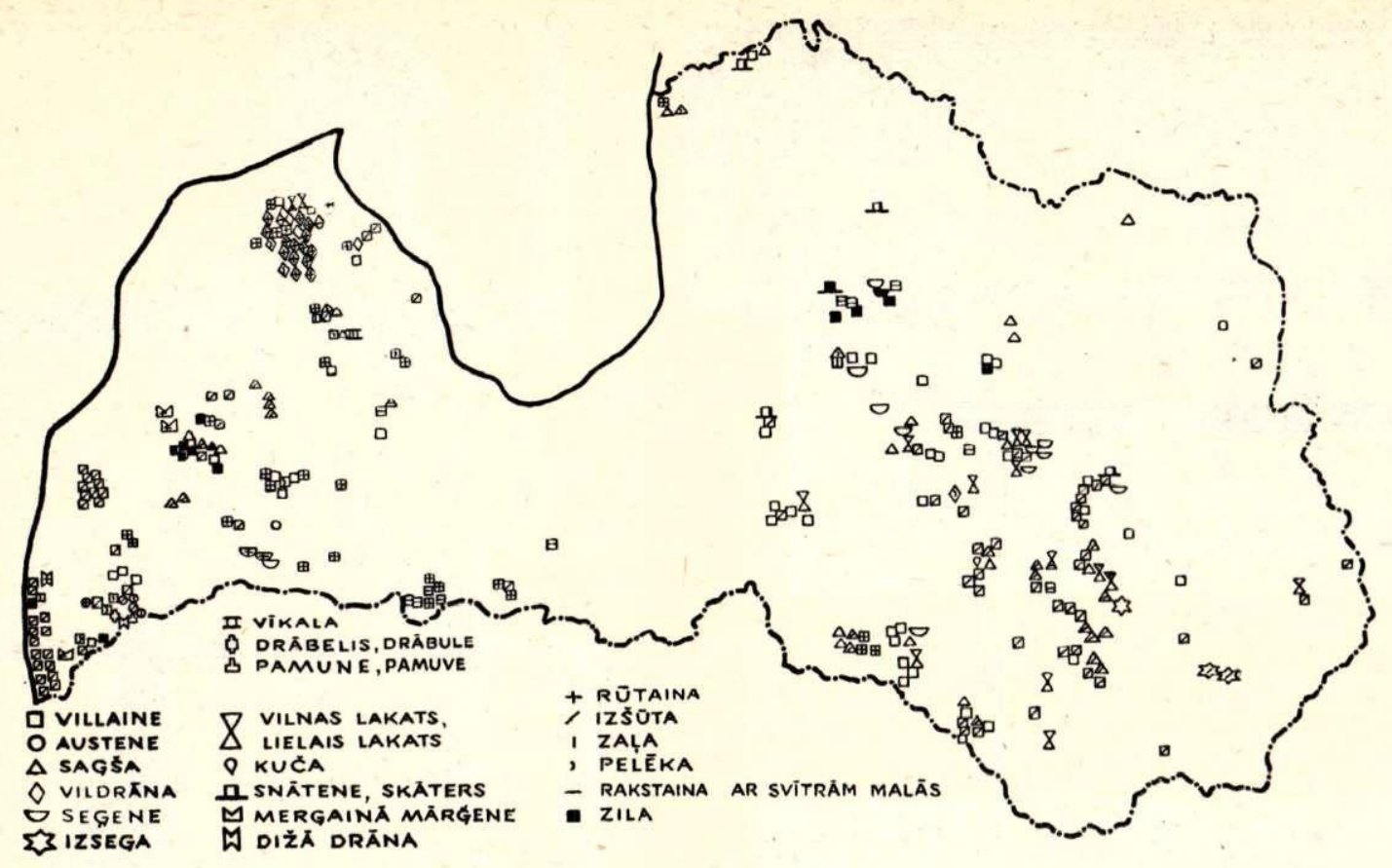

41. att. 19. gs. pirmajā pusē izplatîtākie villaiṇu nosaukumi un veidi (pēc Latvijas PSR Vēstures muzeja materiāliem).

\author{
- Parād' man, māmuliṇ, \\ Kuru dosi vidējai. \\ - Skaista, balta, vizulota, \\ To es došu vidējai, \\ To es došu vidêjai, \\ Tã ies jūras maliṇā. \\ - Parād' man, māmuliṇ, \\ Kuru dosi pastarei. \\ - Skaista, balta, lieli raksti, \\ To es došu pastarei, \\ To es došu pastarei, \\ Tā ies tuvu kaimiños.
}

LTD, III, 525

Pirmajai meitai darināto villaini ar sīkiem rakstiem varētu pieskaitīt pie Austrumlatvijas tipa, otrās meitas villaini - pie Ziemelkurzemes, bet trešās - ar lieliem rakstiem - pie Dienvidkurzemes villaiṇu tipa.

\section{Puško, māte, savas sagšas, Lai stāv manas nepuškotas; Kuras zemes tautas jāja, \\ Tã puškošu vilainìtes.}

LTD, III, 528

Arī šì dziesma rāda, ka katrā novadā villaiṇu raksti bijuši dažādi.

Austrumlatvijas villaiṇu greznākie paraugi ir no Vidzemes un Latgales pierobežas. Austrumlat. vijas villaines darinătas no balta vilnas triniša auduma. Villaines garums vidēji $184 \mathrm{līdz} 225 \mathrm{~cm}$, platums - 80 lidz $95 \mathrm{~cm}$, abos galos villainei plats $(10-15 \mathrm{~cm})$, bet malās - šaurāks (5$10 \mathrm{~cm}$ ) raksts. Dažām villainēm raksts nav vis abās malās, bet tikai vienā, kamēr otra mala vai nu apšūta ar sarkanu dziju, vai arī nav rotäta. Parasti bez raksta bijusi apakšējā mala, turpretim augšējā arvien bijusi izrakstīta. ${ }^{442}$

Dažām Austrumlatvijas villainēm, izṇemot rakstu villaines galos un vienā malā, citu izrotājumu nav, turpretim citām bez raksta abās malās vēl ir šaurs «celu apauds». Villainu galos ir vai nu baltas bārkstis, - no tā paša auduma velkiem, vai arī kuplas, ap $10 \mathrm{~cm}$ garas kräsainas dzīparu bārkstis - ieloki, kas darināti kopā ar villaines auduma galu noslēdzēju prievīti - celaini. Celaines un bārkstis austas no dzeltenām, zalām, sarkanām un zilām vilnas dzijām, pie kam dzeltenã krāsa lielākoties ir bārkšu pamatkrāsa un atkārtojas pềc katra krāsu posma. Krustpils villainu rakstos parasti sastopama zala, dzeltena, sarkana un tumši zila krāsa. Šis krāsu sakopojums loti noteikts un nosvērts, pie kam vienmēr dominē zalā un dzeltenā krāsa. Austrumvidzemes villainēs bez tam vēl sastopama tumši brūnā kräsa un dažkārt arī rupjāki raksti, Latgalē - vairāk zilā, -bet Augšzemes villainēs - sarkanā krāsa ir spilgtāka nekā Krustpils villainēs (skat. 16. tab.).

Austrumlatvijas villaines gan pēc kompozīcijas, gan pēc tehniskā izpildījuma pieskaitāmas pie krāšñākajiem senās tautas mākslas darinājumiem.

Dienvidkurzemes villaines no pirmajām atšḳiras pēc izmëriem, rotājumiem un valkāšanas veida.

S̄â tipa villaines, tāpat kā iepriekšējās, austas no baltâm vilnas dzijām trinīša audumā, tās ir $75-95 \mathrm{~cm}$ platas un $170-200 \mathrm{~cm}$ garas (43. att.).

Izšūtais raksts Dienvidkurzemes tipa villainēm gandrīz vienādā platumā $(8-12 \mathrm{~cm})$ novietojas 

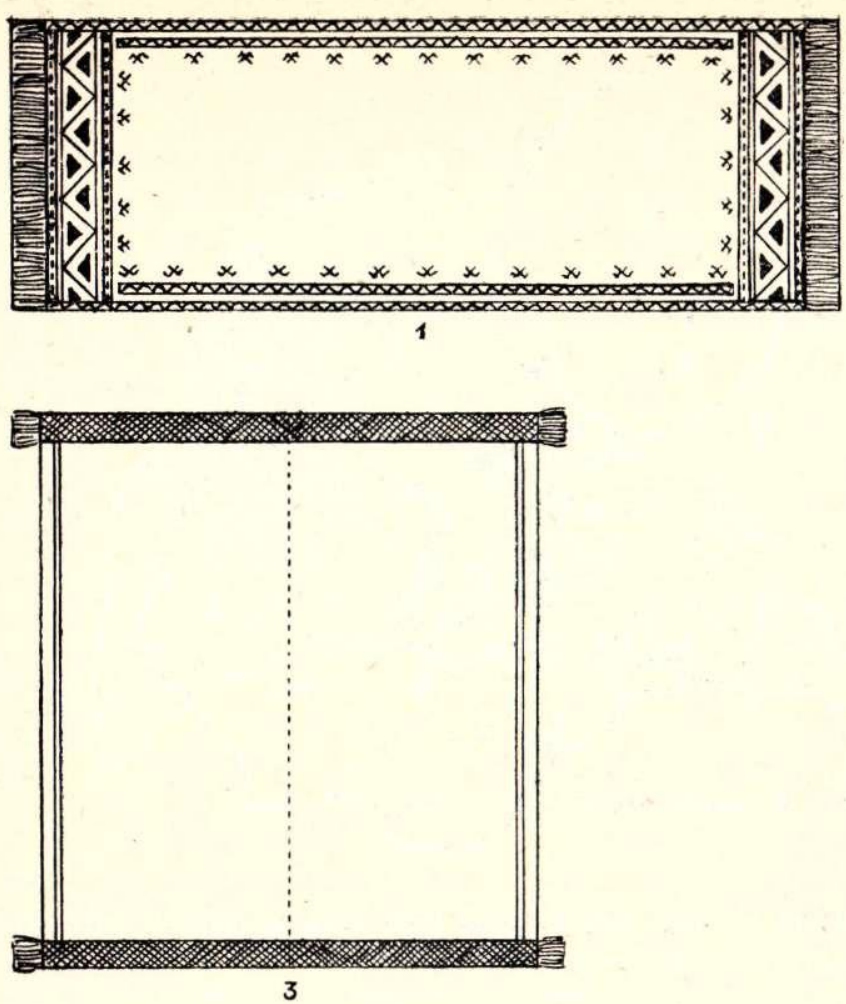

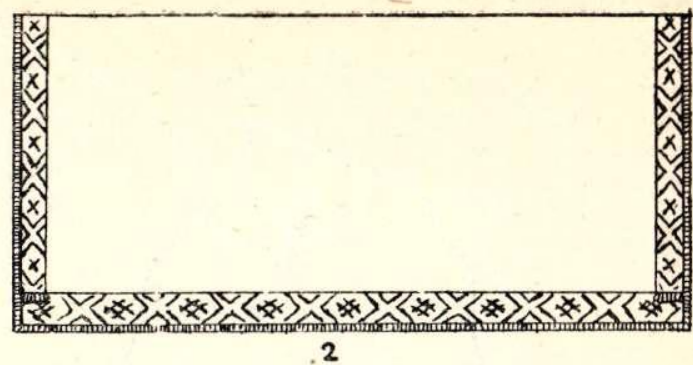

2

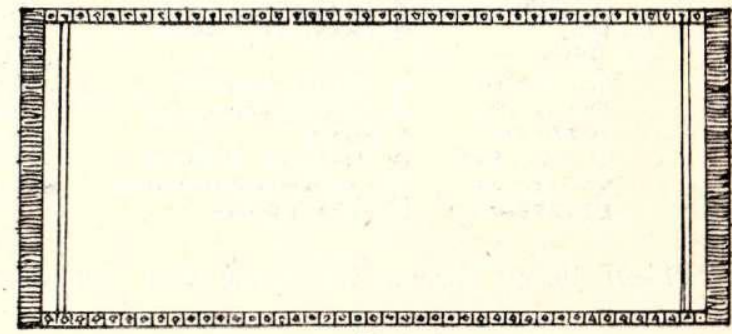

42. att. Villainu tipu shēmas:

1 - Austrumlatvijas; 2 - Dienvidkurzemes; 3 - Zieme|kurzemes; 4 - Zemgales.

gar villaines trijām maläm. Villaines galos vai trijās malās piešūtas $2-3 \mathrm{~cm}$ garas bārkstis. Villaines raksts masivvs, pamatu klājošs, izšūts spilgtās krāsās (sarkanā, zaḷā, dzeltenā, zilā), pie kam dominē spilgti sarkanā krāsa (skat. 17. tab.).

Visā Latvijā, izṇemot Nìcas, Bārtas un Rucavas novadus, greznās villaines sedza pāri abiem pleciem un priekšā sasprauda ar saktu vai arī lāva abiem galiem nesaspraustiem brīvi nokarāties uz leju. ${ }^{443}$

Dienvidkurzemes villaines pa lielākai dalai sasprauda uz viena pleca vai rokas (43. att., 1) ar saktu «čupu». Tautasdziesmās villaines sasiešanai minētas arī zīda lentes un lūki; acīm redzot šis droši vien bijis izplatīts villaines siešanas veids visā Latvijā.

\section{Ar lūcinu es sasēju \\ Savas baltas vilnänìt's. \\ Tā bij mana zīda bante, \\ Par bāliṇu klausījum'.}

\section{F 1400, 6}

Raksturīgais Dienvidkurzemes villainu valkāšanas veids uz viena pleca, liekas, būs izveidojies no apliekamo brunču valkāšanas veida, brunčiem pakāpeniski paceḷoties līdz krūtīm (Rucavā) un uz viena pleca (Nīcā) (salīdz. ar J. Branda aprakstiem).

Tam, ka Rucavas villaiṇu valkāšanas veidam uz viena pleca pamatā ir apliekamo brunču valkāšanas veids, par labu runā arī Berlīnes muzejā

esošais lietuviešu sieviešu apgēerbs: tã gurnu sega «mārğene» ir garāka, sniedzas pāri krūtīm un uz labā pleca sasprausta ar sudraba saktu. H. Mitcels min, ka šâdas formas apgèerbs varējis būt arī balts, - un tad to saucot par «Wapen» - vapu. ${ }^{444}$ Arī latviešu sieviešu villaines gandrīz visi 18.19. gs. autori sauc par «Wapen». Tätad tas pilnībā atbilst mūsu Rucavas villaiñu aprakstam. Vienīgi Rucavas villaines neapjož ar metāla jostu (kā tas redzams attēlā), lai gan metāla jostas Kurzemē vispār ir plaši pazīstamas. ${ }^{445}$

Ziemeḷkurzemes (Alsungas, Kuldīgas, Ventspils) izšūās villaines atšḳiras no Dienvidkurzemes villainēm pēc izmēriem, raksta $(150 \mathrm{~cm} \times$ $\times 75+75 \mathrm{~cm})$ un krāsu zieda (skat. 18. tab.).

Ziemel̨kurzemes villainēm pèc formas līdzīgas ir mēlenes. Tās ir villaines, kas rotātas metāla spirālēm un piekariṇiem - mēlìtēm (skat. 19. tab., 4). Tautasdziesmās villaines ar metāla rotājumu tiek pieminētas loti bieži.

No tālienes tā māsina, Stīgām griezta villainîte: Tās māsiṇas bāleliṇi Rīgā stīgu kalējiṇi.
LD, 20585

Jau tās manas villainìtes

Pušk' ieloku nepanesa;

Vēl dzīrās bālelini

Stūros kalt sudrabiṇu.

LTD, III, 469
Piecu brālu māsa biju, Piecas sedzu villainìtes: Lai spīdēja stūrī̌sos

Piecu bră|u sudrabiṇš. 

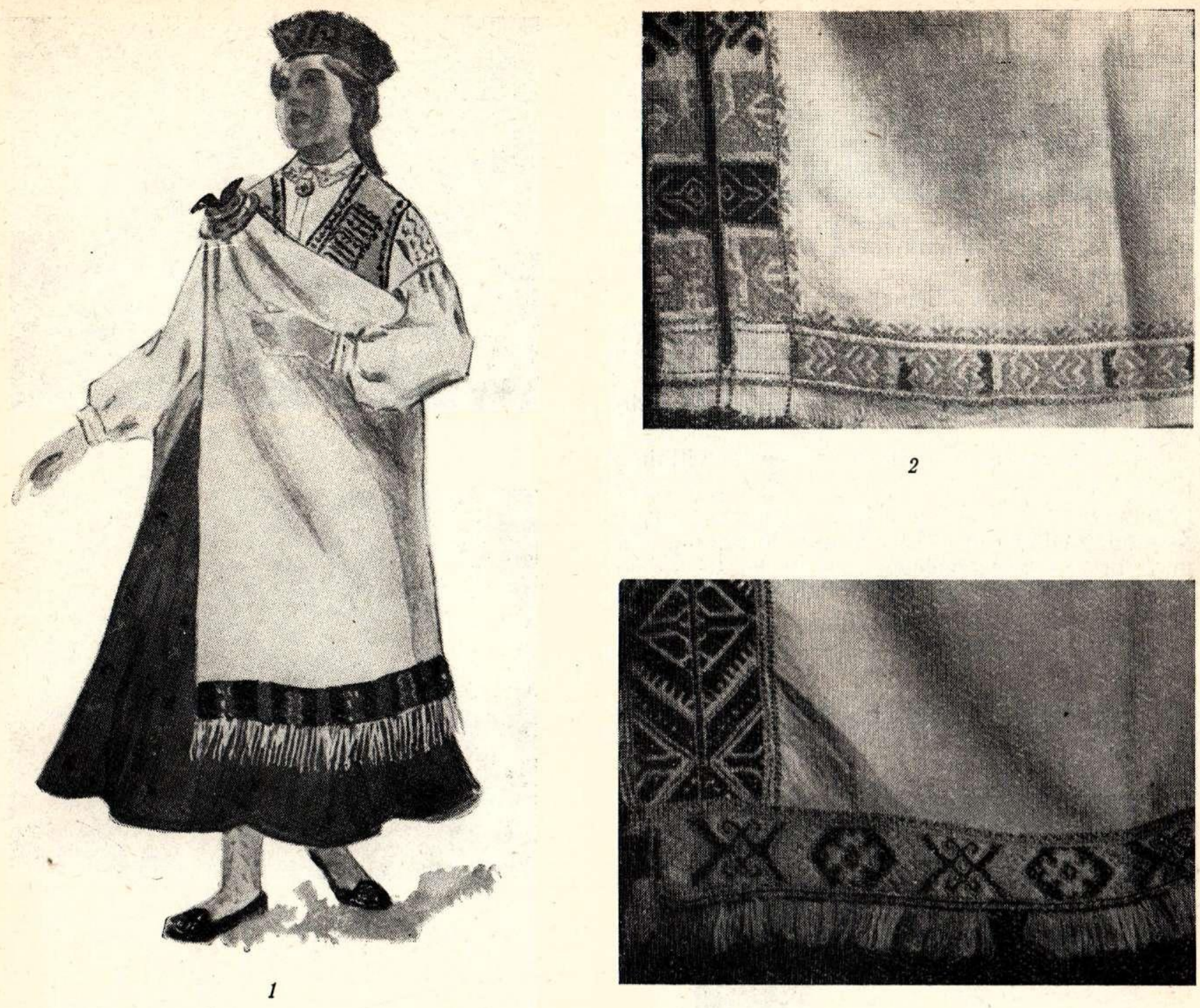

2

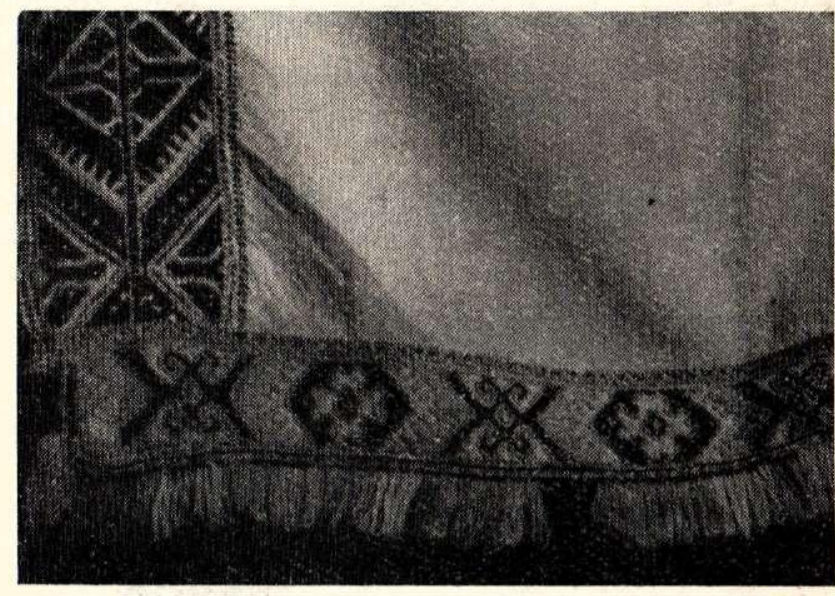

3
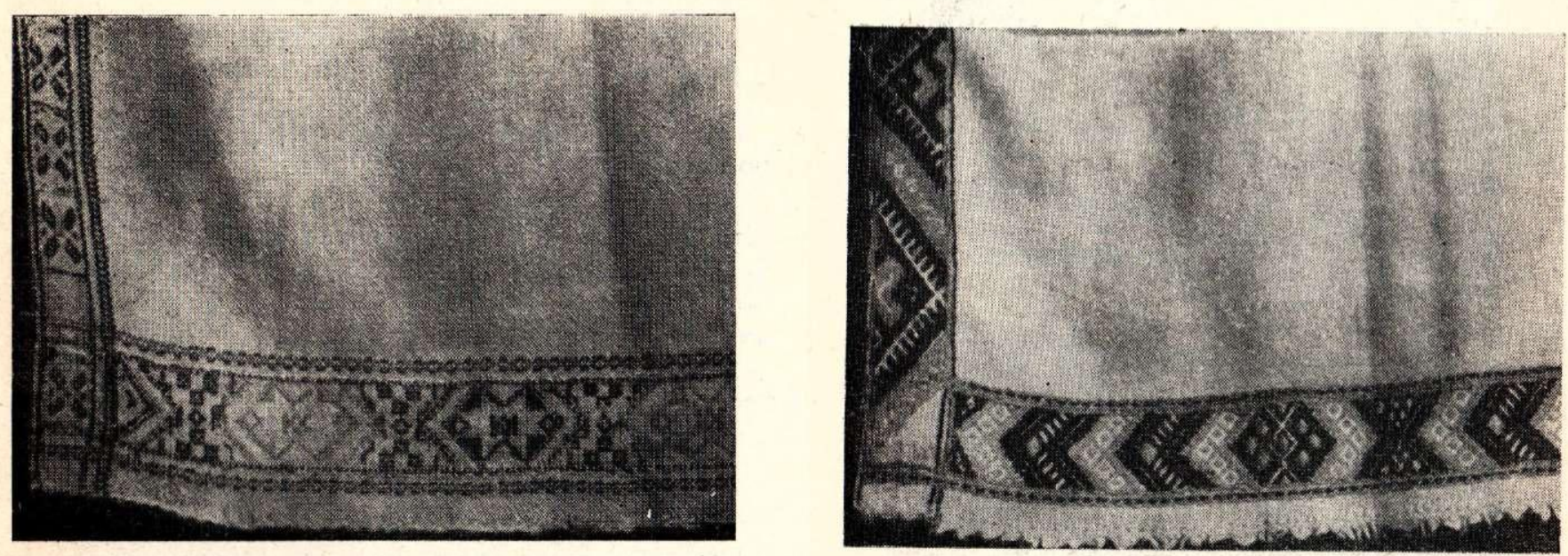

4

5

43. att. Dienvidkurzemes villaines:

1 - Dienvidkurzemes villaines valkāšanas veids; 2,3 - Pērkones; 4 - Medzes; 5 - Rucavas villaines (Liepājas NM materiāli). 
Mēlenes platums $85 \mathrm{~cm}$, garums $130 \mathrm{~cm}$. Auduma veids, tāpat kā iepriekšējām villainēm, trinìtis vai vienkārtnis. Raksts novietots villaines apakšèjā malā un divos apakšējos stūros. Gar villaines apakšèjo malu piešūtas metāla mēlïtes piekariṇi, kas kustoties patīkami žvadzēja. Pie šis grupas pieskaitāma arī Zūru pagasta krāsainiem diegiem šūtā villaine - zilāms, kas pēc kompozìcijas principiem zināmā mērā radniecīga igauṇı villainēm. ${ }^{446}$

Pārējās baltās Ziemeḷkurzemes villaines ir visai līdzīgas Dienvidkurzemes villainēm un atšḳiras no tăm tikai ar grezniem celu apaudiem. Ventspils novada villaines bieži vien ir šūtas no diviem auduma gabaliem, tāpēc sauktas par divkārtenēm.

Zināmā mērā pie Ziemeḷurzemes villainēm pieskaitāma arī Talsu baltā villaine, ar rakstu elementiem stūros, lai gan pēc izmēriem tā tuvāka Zemgales villainēm $(65 \times 156 \mathrm{~cm})$. Rotājuma kompozīcijā tā līdzīga mēlenei. Liekas, ka šis kompozīcijas veids ar atseviškiiem rakstu elementiem stūros ir vecāks par pārējo villaiṇu rotăjumu kompozīcijām, jo sasaucas ar 10.-12. gs. villainēm un mēlenēm.

Tāda pati kompozīcija - ar atsevišķiem elementiem stūros ir arī lielvārdiešu villainēm

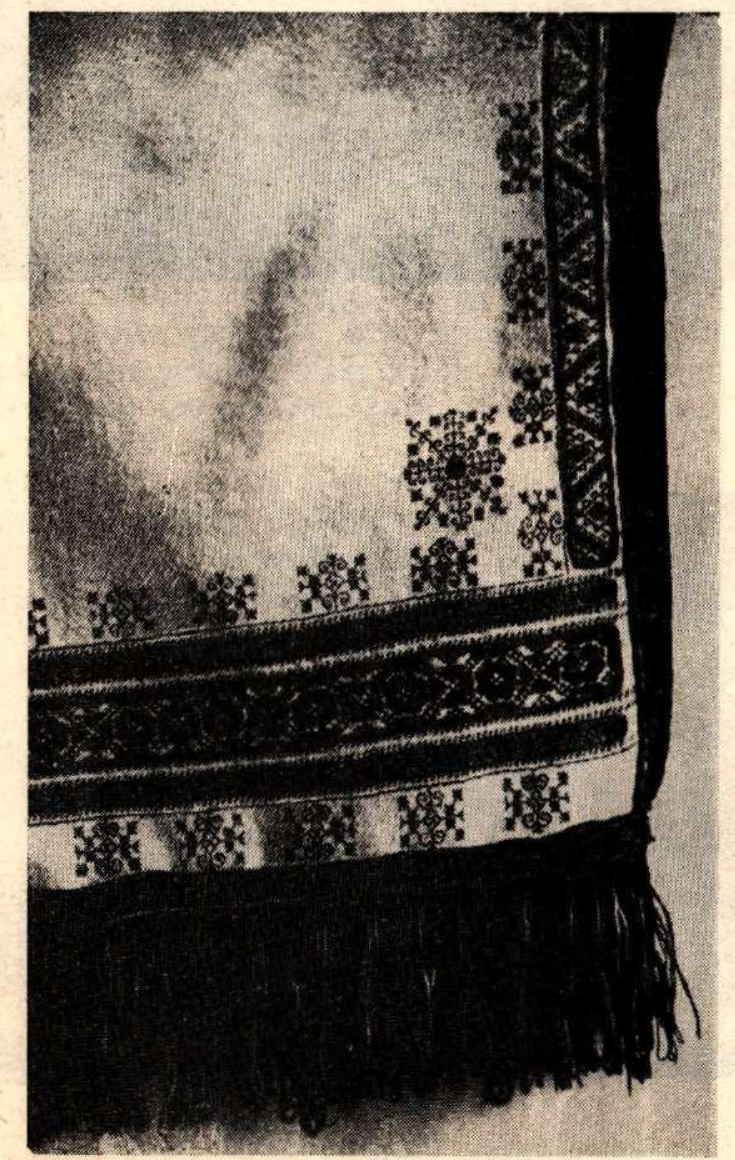

44. att. Krustpils villaine ar ornamentu villaines stūrī (RLMV materiāli).
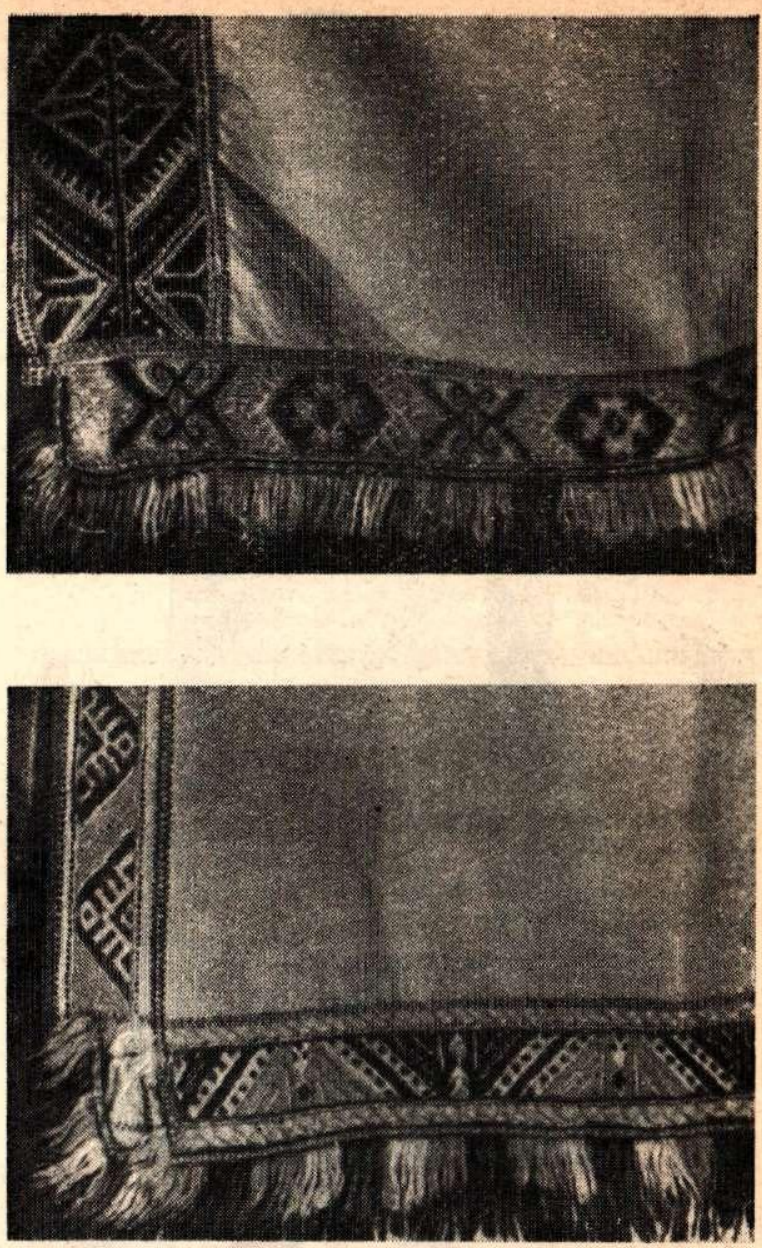

45. att. Kabiles villaines (Liepājas NM materiāli).

J. Broces zīmējumā, vienam Krustpils pagasta villaines variantam (44. att.) un vecākiem Kabiles villainu paraugiem (45. att.).

Zemgales villainēm raksturīgas ieaustas krāsainas svītras un grezns celu apauds gar vienı no villaines malām. Villaines galus rotā celos austas $10 \mathrm{~cm}$ garas bārkstis. Villaines platums $90 \mathrm{~cm}$, garums $-200 \mathrm{~cm}$.

Bez šìm grezni izrakstītām villainēm gandrīz visā Latvijas teritorijā pazīstamas baltās villaines bez rotājuma. Novados, kur izšūtās villaines bija valdošās, neizšūtās villaines, tāpat kā linu auduma snātenes, bija trūcīgo laužu rota. ${ }^{447}$

\footnotetext{
Ne man zelta, tie sudraba,

Baltas vien villainites;

Ielīgoju istabā,

Kā ar sniegu apsnigusi

LTD, III, 413

Ieviṇai balti ziedi,

Man baltāka villainìte;

Kas, ievin (a), tev apsedza?

Man apsedza māmuliṇa.
}

LTD, III, 416 
Baltâs villaines varēja būt divkārtenes un vienkārtenes. Vienkārtenes izmēru ziṇā bija līdzīgas greznajām, izšūtajām villainēm, galos tăm bija bārkstis. Piebalgas, Lielvārdes un atsevišḳos gadījumos arī citos novados baltām vienkârtenēm galos dažkārt ieaustas šauras sarkanas vai zilas svìtrinas.

Divkārtenes $(140 \times 140 \mathrm{~cm})$ sašūtas no 2 auduma gabaliem; gar malām tām bija baltas bārkstis. Divkārtenes valkāja pārlocītas pa vīles vietu. Ziemelvidzemē un Vidzemes vidienā šīs baltās villaines dažkärt sauc par sagšām..$^{48}$

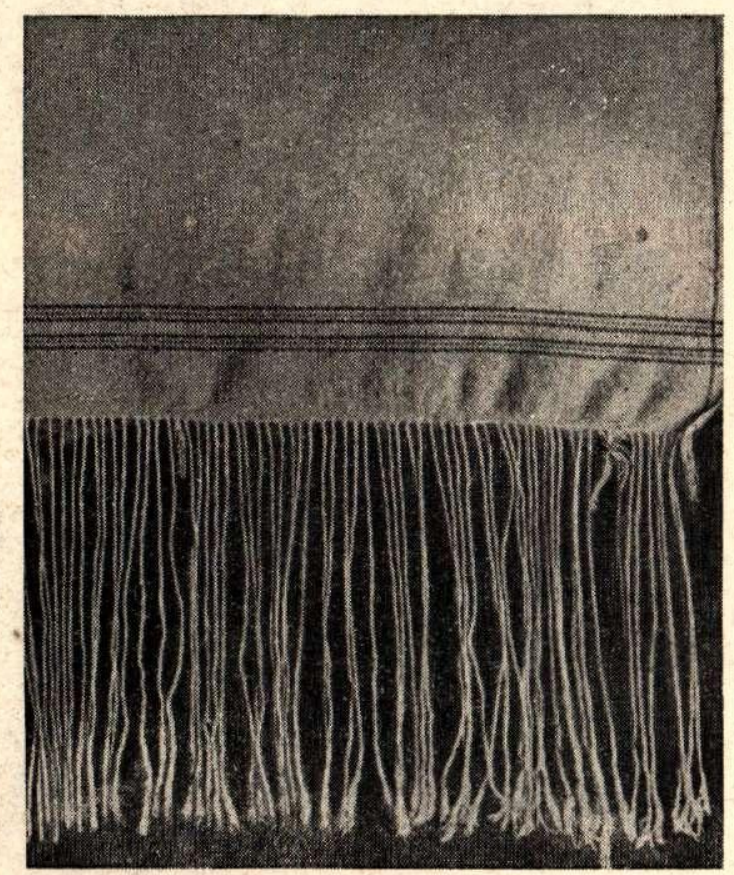

46. att. Piebalgas villaine (RLMV materiāli).

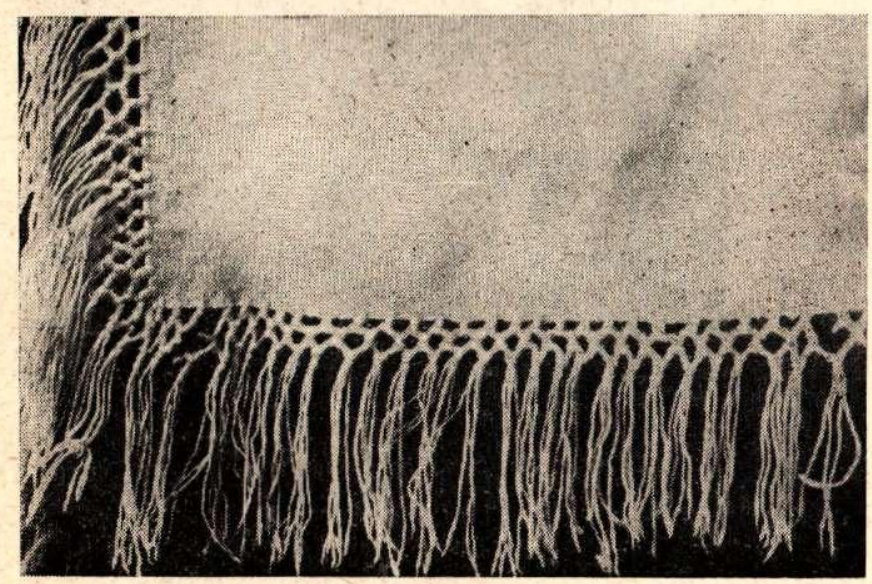

47. att. Baltā villaine ar bārkšu rotājumu malās (RLMV materiāli).

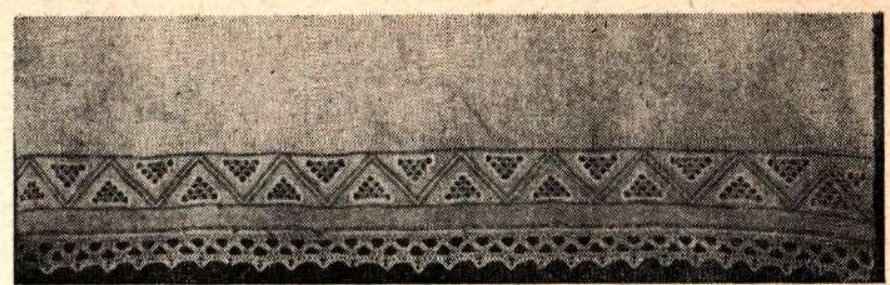

1

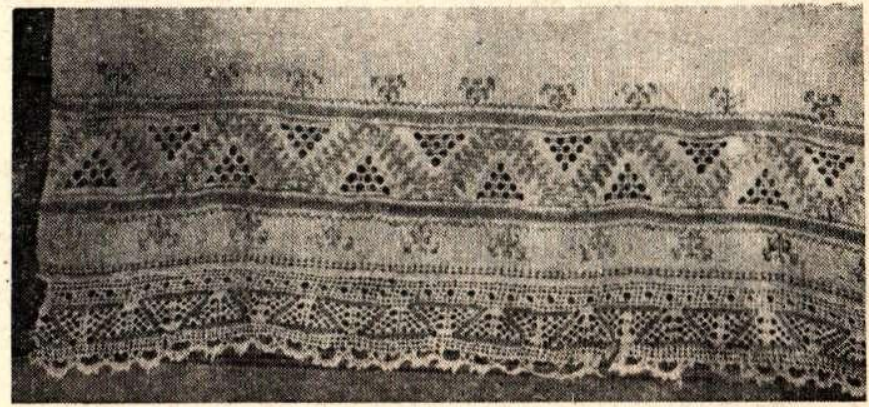

2

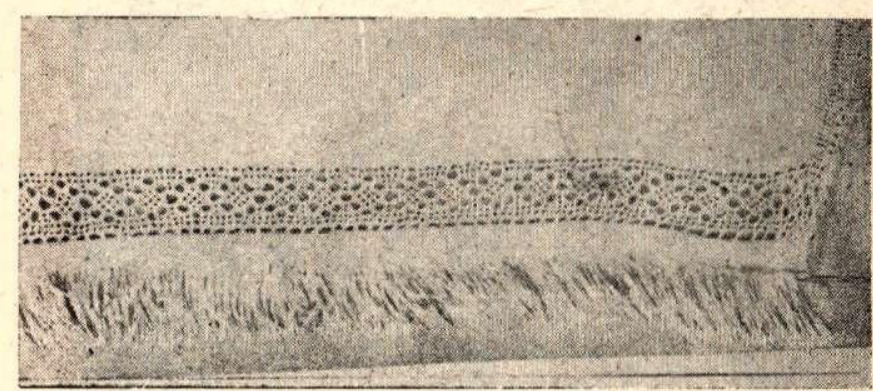

3

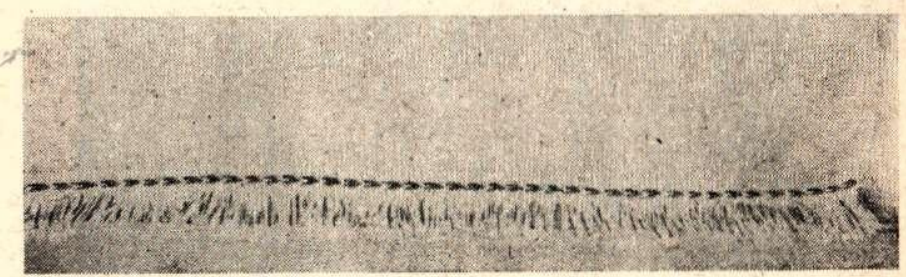

4

48. att. Snātenes (sedzenes):

1 - Preilu; 2 - Vidsmuižas; 3 - Praulienas; 4 - Jasmuižas (RLMV materiāli).

S̄ādā pašā lielumā auda arī pelēkās villaines, kuras sedza lietus laikā vai dodoties ceḷā.

Pelēkā villainīte,

Kur es tevi izgodiju?

Migliṇāi, rasiṇā,

Tur es tevi izgodiju. LTD, III, 455
Käda kura diena bija,

Tādu sedzu villainìti:

Saules dienu baltu sedzu,

Lietus dienu - pelēko.

LTD, III, 456 

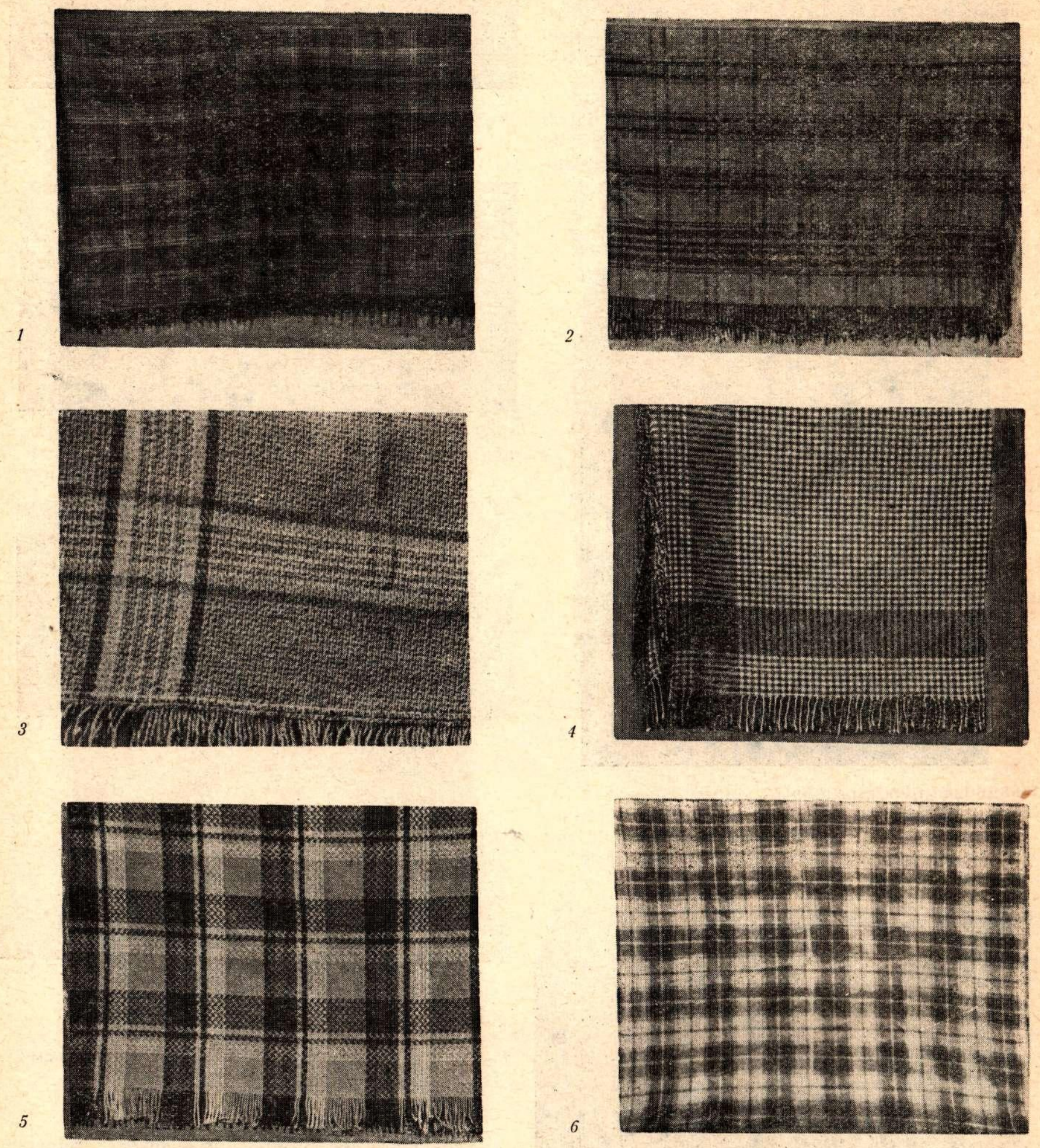

49. att. Rutainăs villaines:

1 -Ventspils; 2 -Vidzemes; 3 - Augšzemes; 4 - Skrundas; 5 -Zemgales; 6 - Alsungas (Baltijas ekspedícijas materiāli). 


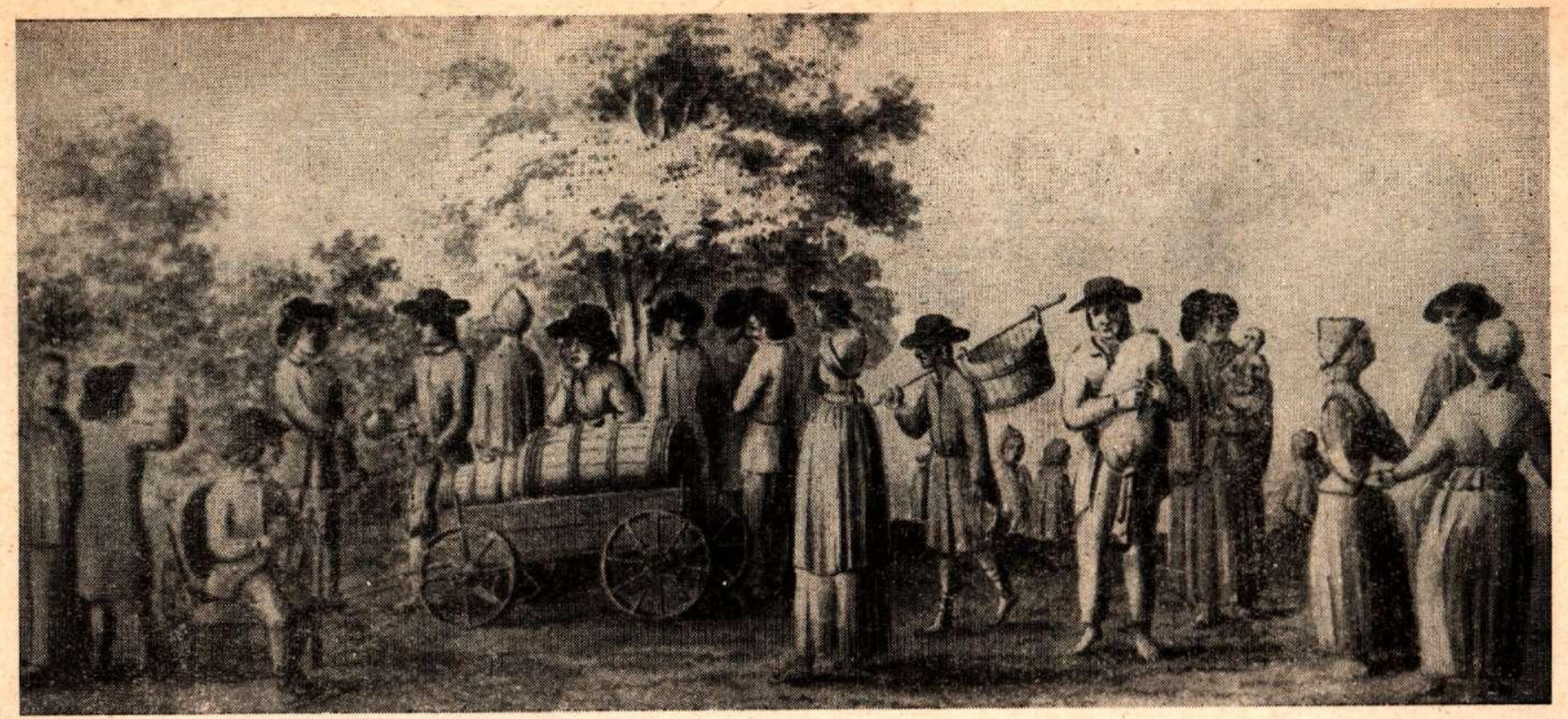

1

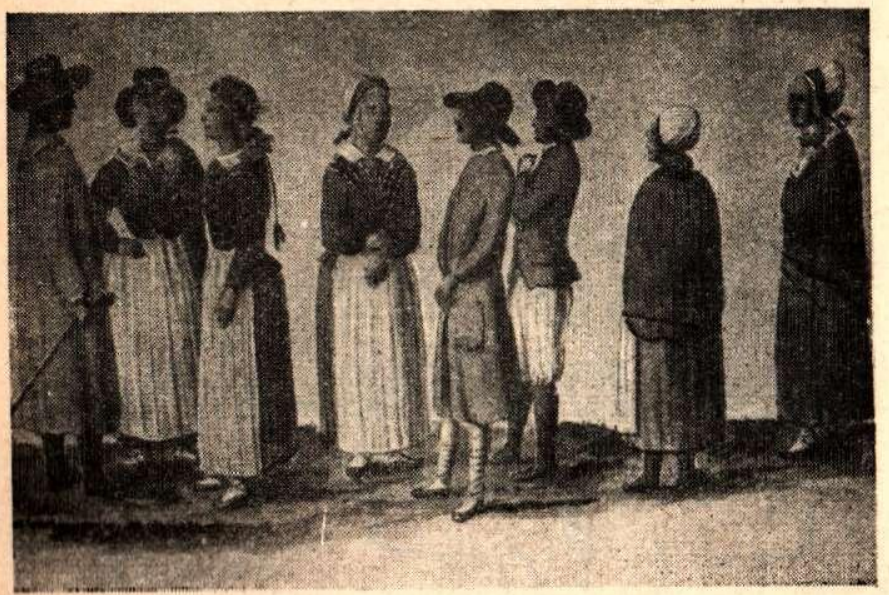

2

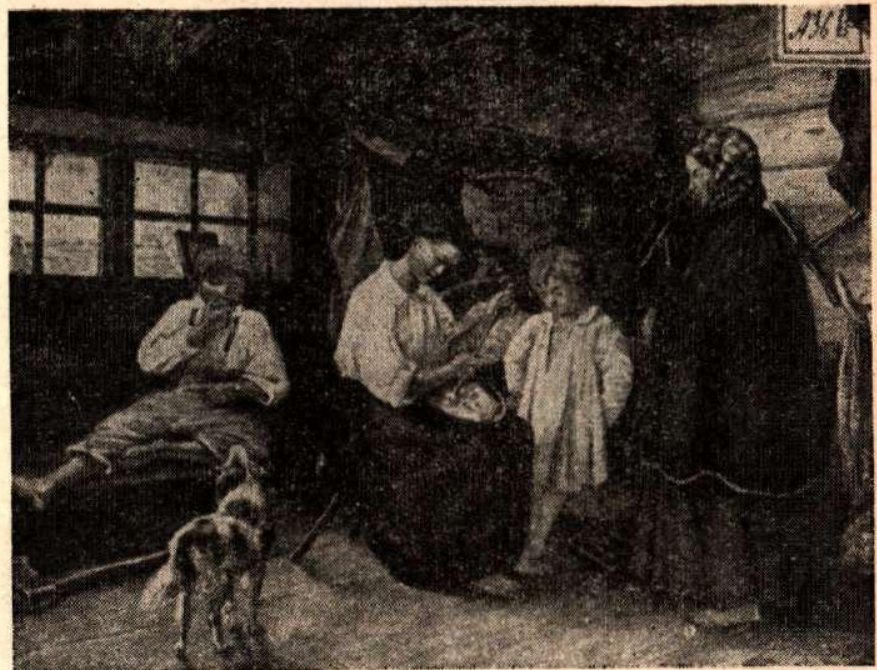

3

50. att. I - Talka Straupes draudzē (J. Chr. B r otz e. Monumente ..., VIII. 4. lpp.); pussvārči redzami sievietei zīmējuma priekšplānā, aiz ratiem stāvošajai sievietei, kā arī sievietei zīmējuma kreisajā malā; 2 - Bīriṇu pag. zemnieki (J. Chr. Brotze. Monumente..., III. 91. lpp.); pussvārči redzami sievietēm zīmējuma labajā pusē; 3 -- lībiešu pussvārči (A. Pecolda akvarelis Krievu Gieogrāfijas biedrïbas arhìvā).

Bez baltām un pelēkām villainēm aukstā laikā sedza arī tumši zalas vai zilas biezas veltas seǵenes. Vidzemē tās sauca par kuču villainēm. Spriežot pēc Latvijas PSR CVVM materiāliem, kuču villaines vairāk izplatītas bijušas 19. gs. otrajā pusē, bet J. Broces zīmējumos tās vairākkārt minētas 18. gs. beigās; tās darināja speciāli audēji un pārdeva tirgos, tāpēc tās varēja valkāt tikai turīgas sievietes. ${ }^{449}$ Kuča bija austa parastā trinīša audumā, tikai krietni rupja un stipri savelta. Viena puse tai bija uzkārsta. Kuča bija parastās seg̀enes lielumā $140 \times 140 \mathrm{~cm}$ (dažreiz arī $120 \times 80 \mathrm{~cm}$ ). To sēja gan stūreniski saliktu, gan arī gareniski pa vidu pārlocītu. Dažkārt kučai visapkārt sietas bārkstis. Aukstā laikā kuča bija nepieciešams apg̛ērba gabals (skat. 20. tab., 1, 3).

19. gs. vidū sāka valkāt raibas - rūtainas, krāsainas vilnas seǵenes, lielos lakatus - austus vienā gabalā $(140 \times 140 \mathrm{~cm})$ ar bārkstīm visās četrās malās. Augšzemē šos lielos lakatus sauc par sagšām ${ }^{450}$ (49. att.). Lielie lakati visdažādākos rūšu un krāsu salikumos iecienīti visā Latvijas teritorijā.

Ziemeḷurzemes rūtainajām villainēm (vildrā- 
nām) līdzīgas villaines konstatētas arheolog̣iskajos izrakumos. No Ziemeḷurzemes rūtainajām villainēm tās atškịiras pēc izmēriem (Daṇilovkas villaine $75 \times 130 \mathrm{~cm}$, bet Ziemel̨kurzemes villaines ir tuvas kvadrātam un valkātas divkārtīgi salocītas). Bez tam Ziemel̨kurzemes villaines gandrīz vienmēr ir bez bārkstīm.

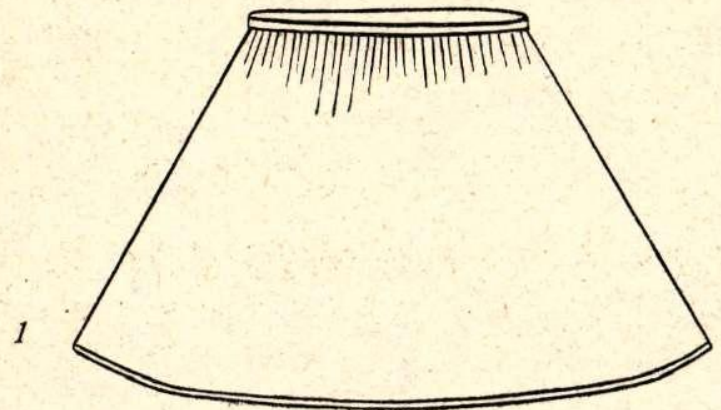

2

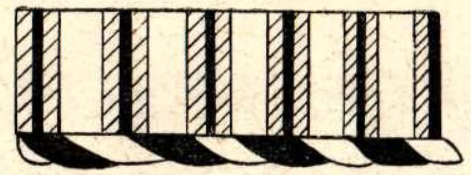

51. att. Pussvārcis:

1 - shēma; 2 - raksts (melnā svītra - dabā tumši brūnā krāsā, svītrojums - tumši dzeltens, baltais laukums - gaiši pelēkā krāsā (1954. g. Baltijas ekspedicijas materiăli).

Atsevišḳi minams Kuldīgas un Liepājas apriṇkos sàstopamais rūtaino villainu veids - austenes, kas pēc izmēriem atbilst lielajiem lakatiem, bet pēc materiālu apstrādāšanas un krāsošanas tehnikas ir vecäkas par tiem (49. att., 4; 20. tab., $2,4,5)$.

Izñemot svinīgos gadijumus (piem., laulības u. tmi.), kad sedza vai nu baltās, vai grezni iz. rakstītās villaines, vasarā nēsātas baltas linu sedzenes, snātenes, pussedzenes, snānes, kas pēc lieluma un formas ir līdzīgas villainēm. Snātenes bagāti rotātas knipelētām mežğinēm un nelielu izšuvumu (48. att.). Snātenes klātas pa vidu pārlocītas, galus uz krūtīm sasienot mezglā vai saspraužot ar saktu, kamēr brīvie gali nokarājušies pār rokàm.

Ipatnējais plecu apsegs ir t. s. pussvārči, kuri redzami jau 17.-18. gs. zīmējumos (50. att.). 19. gs. šādi pussvārči valkāti Kurzemē gar jūras piekrasti, bet Vidzemē - Limbažu un Cēsu apkārtnē, ${ }^{451}$ t. i., rajonos, kur kādreiz dzīvojuši $\bar{l}^{1}$ bieši. Arī A. Pecolda zīmējumos redzami pussvārči Kurzemes lỉbiešiem. No pārējās Latvijas teritorijas ziṇu par šādu pussvārču valkāšanu nav, tāpēc liekas, ka šis ir tipisks lībiešu apg̉ērba gabals. Pussvārčus pie goda tērpa nevalkāja, bet ar tiem sedzās lietus laikā. Pussvārčus auda no vilnas dzijām linu diegu pamatā pelēkus ar dažādām krāsainām svītrām. Pussvārčus šuva tāpat kả brunčus, - auduma gabalu savilka krokās un piešuva tā paša auduma jostiṇu (51. att.; 36. tab., 4).
Pagaidām vēl nav iespējams izskaidrot pussvārču līdzību ar poḷu tautas tērpu «zapasku», kas šūts no svittraina mājās austa vienkārtṇa auduma priekšauta veidā. Šādus priekšautus sedza uz pleciem un priekšā sasēja ar piešūtām lentēm. ${ }^{452}$

\section{SIEVIEŠU JAKAS, N̦IEBURI, METEL̨I UN KAŽOKI}

Sieviešu šūtais plecu apg̀ērbs - jakas, nieburi un mēteḷi - loti dažādās formās izplatīts visā Latvijā.

Pie goda tērpa Vidzemē, Kurzemē un Zemgalē valkāja tumšas vadmalas $\mathrm{j}$ a k a s vai ṇ i e bur us, kuru dažādos veidus sauc par svārciniem, kamzoḷiem (Vidzemē, Ziemeḷkurzemē), buorstēm (Dienvidkurzemē), svītiniiem, lamžiem, spenceriem (Vidzemē) u. c.

Jakas (kamzoḷus) parasti šuva augumam piegulošas, lìdz jostas vietai. Dažos novados (Zemgalē, Ziemelvidzemē) jakām jostas vietā piešūta ar ākiem aizdarināma jostina; citos novados jakas sniedzās vēl $10-15 \mathrm{~cm}$ zem jostas vietas, pie kam jakas pagarinājums paplašināts ar muduriem vai saliktām krokām. ${ }^{453}$

Lamži bijuši sieviešu darba apg̛ērba gabals. ${ }^{454}$ Tie bijuši garāki par jakām (kamzołiem) un ar mazām krokām - muduriem sānos: lamži priekšā aizdarināti ar ākiem tāpat kā jakas.

Spencerus šuva līdz viduklim, tā ka, tos valkājot, nāca redzama josta. ${ }^{455}$

Nieburu piegriezums tāds pats kā jaku piegriezums, vienīgi ñieburi bija bez piedurknēm.

Bez jakām un nieburiem loti aukstā laikā val. kāti mêtel̨i un pusmēteli jeb t. s. mudur a i n i ${ }^{456}$
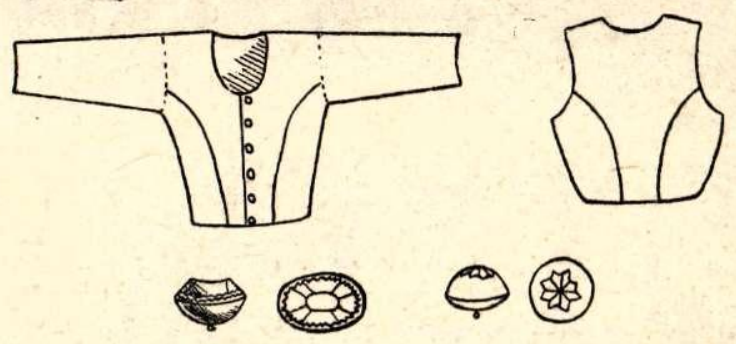

1

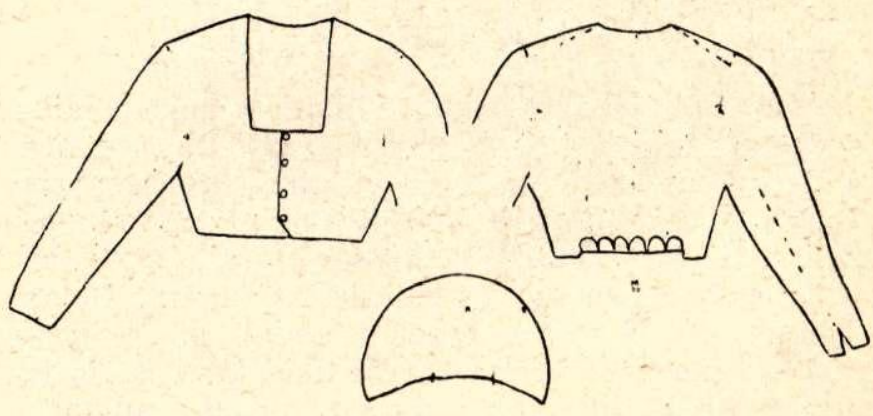

2

52. att. 1 - Zemgales jaka, nieburs, pogas; 2 - Vidzemes jaka; apakšā - jakas austinu piegrieztne. 

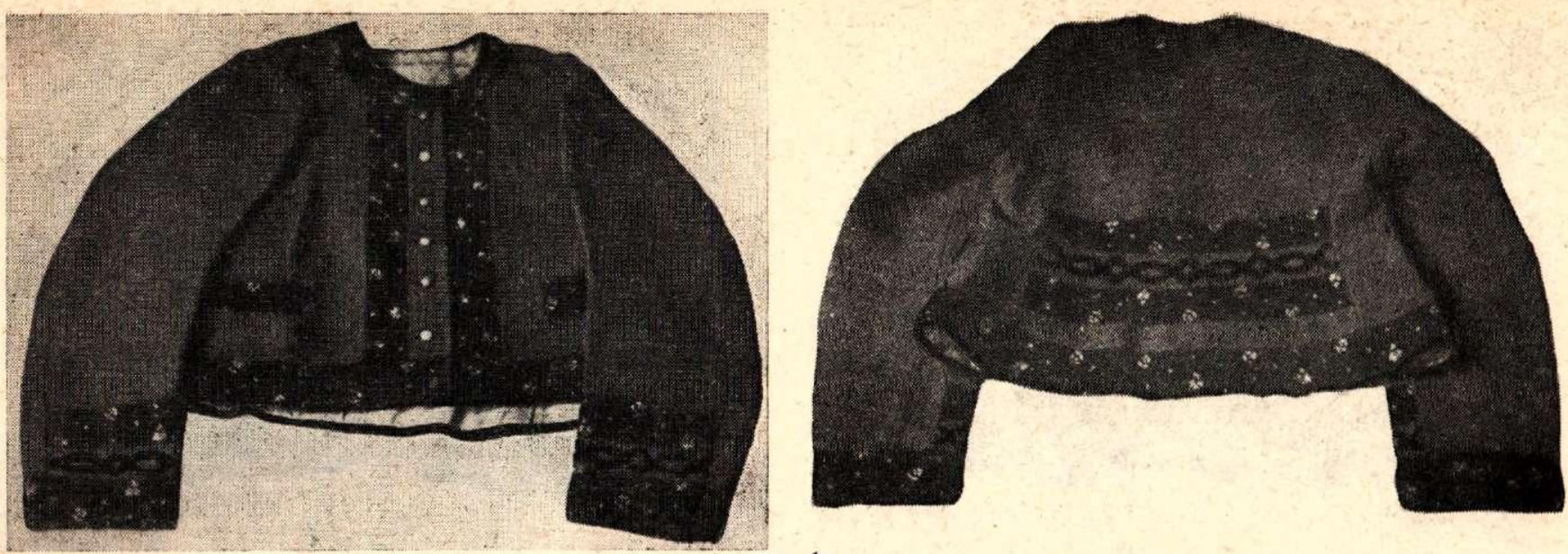

1

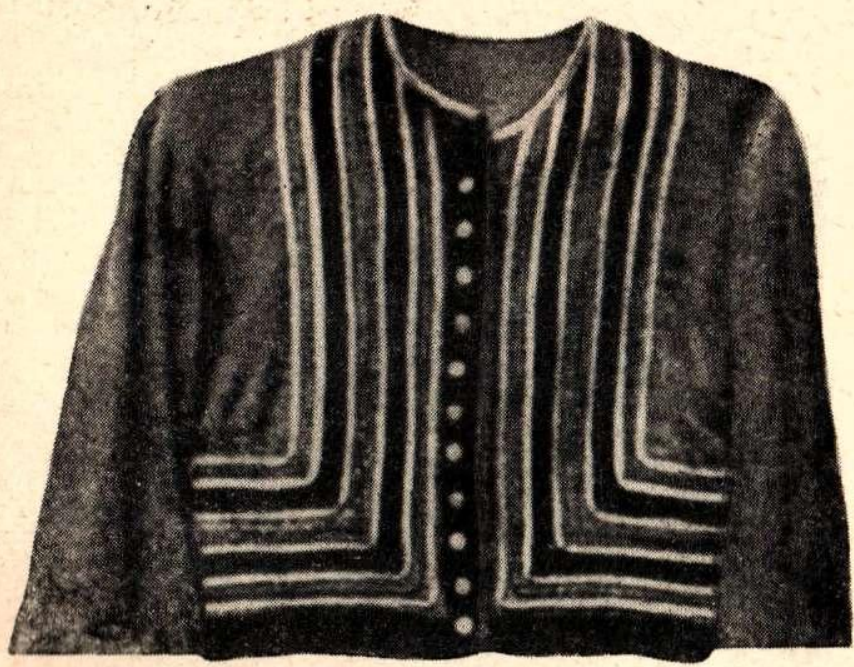

2

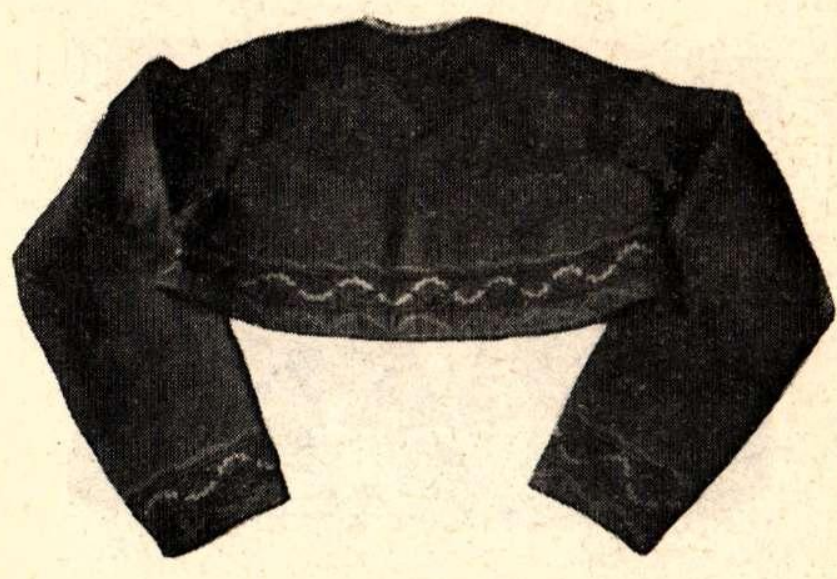

3

53. att. Kurzemes jakas:

1 - Nicas; 2, 3-Alsungas (Liepãjas NM materiãili).

Sieviešu mēteḷi lielākoties bijuši taisna piegriezuma, bez krokām, priekšā tos saturēja misiṇa āki. Mèteḷu piedurknes nebija seviški platas, pie pleciem tās nedaudz sakrokotas, seviški vecāka tipa mēteliem. Vēlāk, kad nēsāti viduklī pieguloši mēteli, kas uz apakšu bija stipri paplatināti, arī piedurknes iešūtas bez krokojuma. Senākie mēteḷ bijuši bez apkaklēm, bet jaunākajiem ir stāvas vai mazas atlocìtas apkakles. Kādā no O. Hūna zî̀mējumiem redzams mētelis ar stāvu, izrotātu apkakli; divos citos zīmējumos mēteḷi ir bez apkaklēm. ${ }^{457}$ Kabatas tāpat kā pārējiem virsdrēbju gabaliem grieztas sānos vertikāli un rotātas ar citas krāsas apmali. Ar apmalēm rotātas arī muduraiṇu priekšpuses un muguras šuves.

Mētelus parasti šuva no pelēkas vai tumši zilas vadmalas vai pusvadmalas. Mēteḷ padrēbēm lietots linu audums vai izvalkāti brunči, pie kam pa- drēbe likta tikai līdz jostas vietai. 19. gs. otrajā pusē mēteḷos sāk iešùt vatelīnu. Mèteḷi valkāti pagari - pāri celiem.

Sieviešu mudurainus - kapatas šuva līdzīgas vīriešu muduraiṇiem ar iešūtiem ḳī|iem sānos un mugurpusē; dažreiz muduraiṇi jostas vietã sakrokoti.

K a ž okus sievietes valkājušas reti. Pēc piegriezuma sieviešu kažoki 19. gs. sākumā bijuši līdzīgi vīriešu kažokiem. ${ }^{458}$ Kažokus parasti šuva nก aitădas ar vilnu uz iekšpusi. Goda kažokiem virspusē likta vadmala. ${ }^{459}$ Latgalē un Augšzemē arī goda kažoki šūti bez virsdrēbes, kā tas redzams O. Hūna zīmējumos. ${ }^{460}$ Tā kā kažokus varēja iegãdāties tikai turīgākie, tad tie tika glabāti un atstāti mantojumā no paaudzes uz paaudzi. ${ }^{461}$ Mēteḷus, muduraiṇus un kažokus parasti šuva speciāli drēbnieki. 

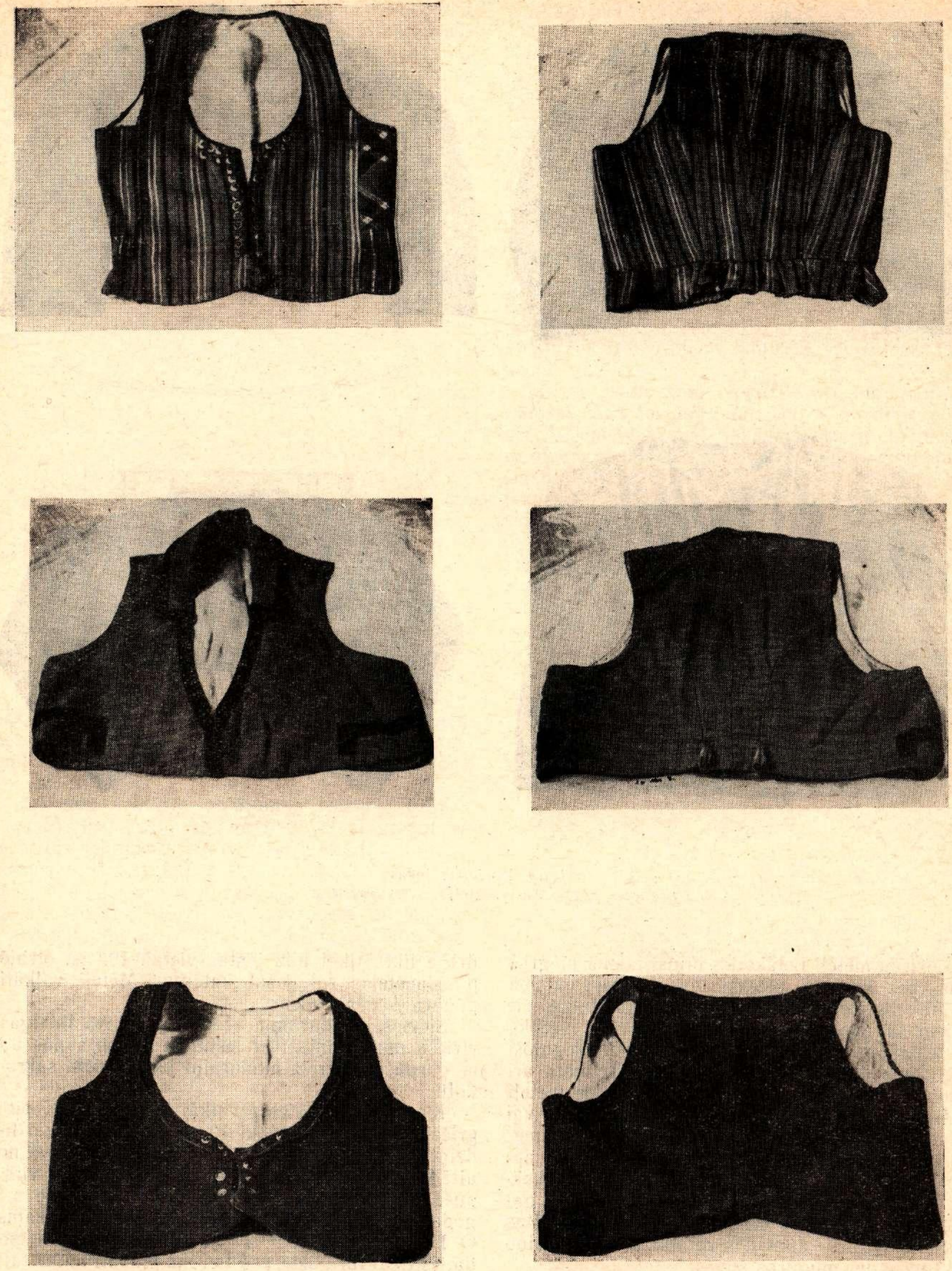

54. att. Dienvidkurzemes ṇieburi (Liepājas NM materiāli). 


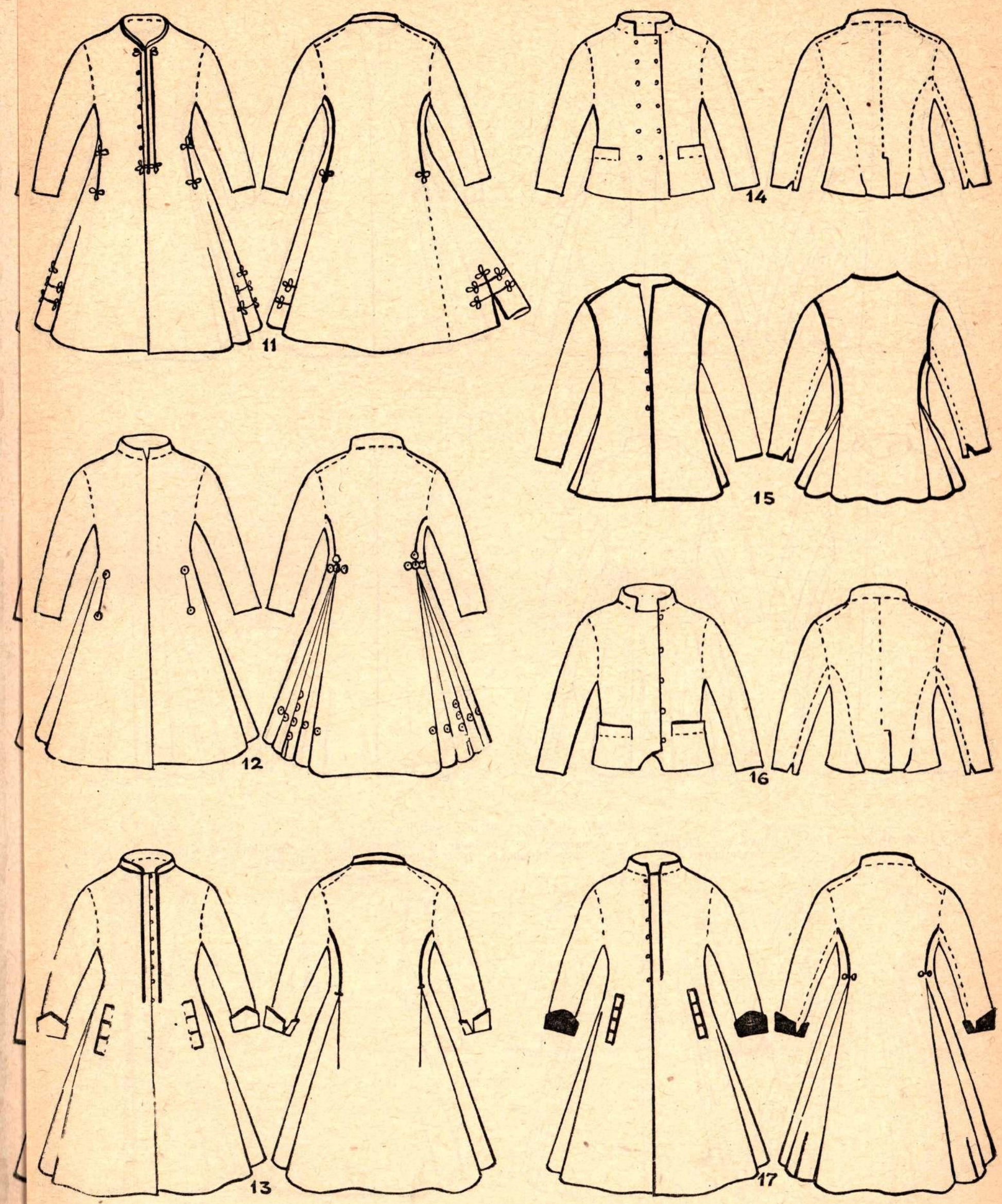
Vīriešu plecu apǵērbam pieskaitāmi svārki, mēteḷi un kažoki. Svārki saukti par vamžiem, ${ }^{462}$ lamžiem (Augšzemē, Vidzemē), k̦elderīšiem, kamzoḷiem, bruslakiem (Kurzemē), svītām, andarakiem (Latgalē), stenderlaužiem (Saikavā - Vidzemē) u. c.

Dažādu novadu vīriešu svārki, kằ arī vispār virsdrēbes, cits no cita neatšḳiras tikdaudz pēe piegriezuma, kā pēc detal̨u izveides, garuma, apdarinājuma un rotājuma. Kā jau iepriekš minēts, vīriešu svārki ir līdzīgi sieviešu garajām jakānı un pusmēteliem, tāpēc tos varēja valkāt kā vīrieši, tā sievietes (sal. vīriešu un sieviešu svārkus J. Broces zimējumos).

Latviešu zemnieku apgeērbā raksturīgi 3 svārku veidi: īsie, pusgarie un garie svārki, ${ }^{463}$ pie kam garos svārkus bieži vien sauca arī par mēteliem.

Svārkus šuva no baltas vai dabiski pelēkas, retāk - zilas vadmalas vai linu audekla. ${ }^{464} \mathrm{~A}$. Hupels un J. Kols atzīmē, ka latviešiem apgēerbā raksturīga ir baltā un gaiši pelēkā krāsa. ${ }^{465}$ Liekas, ka brūnā krāsa, spriežot pēc J. Broces bagātajiem materiāliem, 18. gs. beigās latviešu vīriešu apg̀ērbam nav raksturīga, jo apmēram no 70 zimēju. miem, kur rādīts vīriešu apğērbs, nevienā, izṇemot Dundagas zemnieka attēlu (skat. 21. tab., 1), nav redzámi ne brūni svārki, ne bikses.

$\operatorname{Līd} z$ 19. gs. vidum vīriešu svārkus šuva no mājās austa auduma, bet līdz ar kapitālisma attīstību un fabriku ražojumu izplatī̌sanos pakāpeniski ieviesās pirktie audumi. Sākumā no pirkta materiāla šuva tikai turīgie zemnieki sev goda svārkus, darba drēbēm izmantojot mājās austus audumus. Pirktos audumus, protams, neiegādājās gaišus, bet gan tumši zilus, brūnus un melnus. Ja 18. gs. goda svārki bija balti vai pelēki, tad 19. gs. beigās vislepnākie skaitījās melnie svārki.

Raksturīgs ir J. Broces «Pilsētas tuvumā dzīvojošā turīga zemnieka - zvejnieka» apgēēba apraksts: «...Jau viña apgēerbs liecina, ka viṇš ir labāk pārticis nekẩ lauku zemnieki. Zem zilā mētela viñam ir kažoks un zem tā vēl sarkans kamzolis ...»466 (skat. 30. tab., 2). Līdzīgs paradums valkät reizē vairākus svārkus vai kamzolus sastopams arī Zemgalē un Kurzemē. Nereti šūti drēbes svārki aizstāja arī kažoka virsdrēbi.

Sastopami kā vienrindas, tā divrindas ĩsie svārki, ar stāvu un ar atlocītu apkakli (56.60. att.). İsie svārki, salīdzinot ar garajiem un pusgarajiem, ir jaunāka gājuma, jo tie lielākoties šūti ar padrēbi un darināti pēc muižas sulaiṇu svārku parauga. İsos svārkus parasti valkāja mā. jās, bet, dodoties cẹ̣ā vai ejot godos, tiem pāri vilka pusgaros vai garos svārkus. ${ }^{467}$

Isie svārki vairāk izplatīti Ziemel̨urzemē (arī Rucavā), Zemgalē un Ziemelrietumvidzemē, turpretim Latgalē un Augšzemē tie nav sastopami.

Vecākie isie svārki ir taisna griezuma un snie dzas $10-20 \mathrm{~cm}$ zem jostas vietas. 468 Sāda veida ir Vidzemes un Ziemelkurzemes îsie svārki

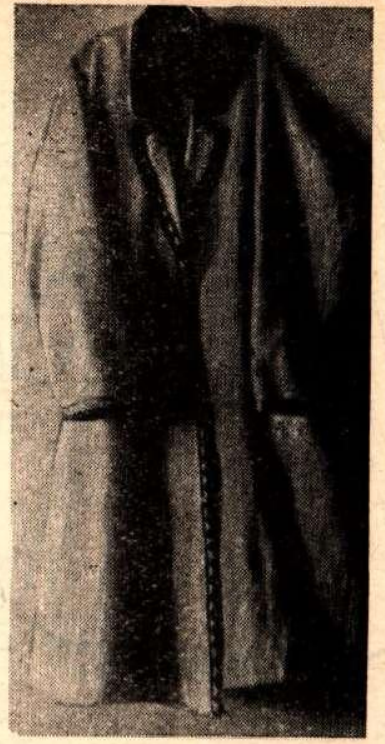

(56. att., 4, 5, 14, 16; 59. att., 4). Turpretī Rendā un Rucavā isie svārki ir pieguloši, ar kroku grupām sānos vai mugurpusē.

Pusgarie svārki sniedzas līdz pusgurniem vai mazliet zemāk, nepārsniedzot celgalus. Spriežcit pēc J. Broces zīmējumiem, ĩsie un pusgarie svārki valkāti Ziemel- un Rietumvidzemē. Iespējams, ka te izpaužas lïbiešu kultūras ietekme, jo arī Kurzemes lïbiešiem raksturīgi ir tikai îsie vai pusgarie svārki.

Ipatnēji ir J. Broces zīmētie raibie svārki (Monumente..., III. 105. lpp., 1. un 3. att.), kuros var būt saskatāma radniecība ar tautasdziesmās minētajiem «raibajiem svārkiem» (skat. 21. tab., 3-4), kas gan nav seviški augstu vērtēti un pieminēti ar izsmieklu. Spriežot pēc zīmējuma, liekas, ka svārki ir linu auduma - vieni rūtaini, otri ar pārtrauktām svītrām. Abi raibie svārki zīmējumos ir no Rietumvidzemes un, kā liekas, būs bijuši līdzīgi ar Roṇu salā un Somijā izplatītajiem rūtainajiem un svītrainajiem svārkiem. ${ }^{469}$ Domājams, ka zīmējumā rādīto rūtaino svārku audums ir tāda paša veida, kāds bija Vidzemē pazīstamais bikšu audums. ${ }^{470}$

Garie svārki (mēteḷi) sniedzās līdz pusstilbiem vai pat lïdz potītēm. Tos šuva no vilnas vai linu auduma un vilka virs kažoka vai vilnas svārkiem, dodoties ceḷā. Garos svārkus sauca arī par uzvalku. ${ }^{471}$ Vilnas garie svārki ir līdzīgi mēteḷiem, un dažkārt tos visai grūti atškirt no pēdējiem. Pēc piegriezuma izškir mudurainos un krunkainos garos svărkus. Pēdējie it îpaši raksturīgi Piebalgai.

Līdz 19. gs. vidum arī garajiem svārkiem līdz pusei lika padrēbi vai arī tos šuva pilnīgi bez tās. Garos svārkus rotāja ar sarkanām aukliṇām, melnām apmalēm, izšuvumiem un krāsainiem atlokiem. Ipatnēji ir baltie Alūksnes vīriešu svārki ar zal̨o pušķu rotājumu (56. att., 12). 

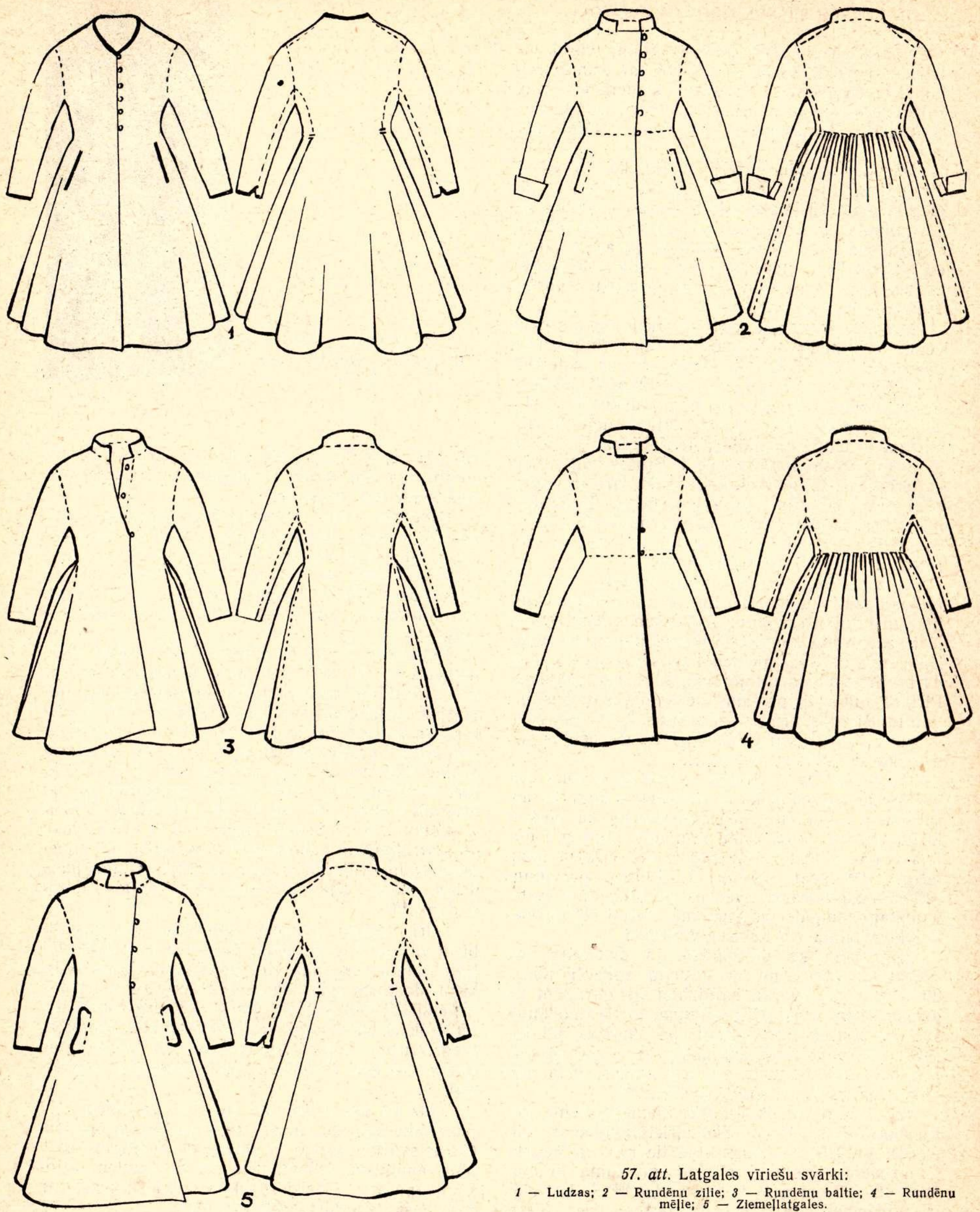
57. att. Latgales vīriešu svärki:
1 - Ludzas; 2 - Rundēnu zilie; 3 - Rundēnu baltie; 4 - Rundēnu
mêlie; 5 - Ziemellatgales.

72 

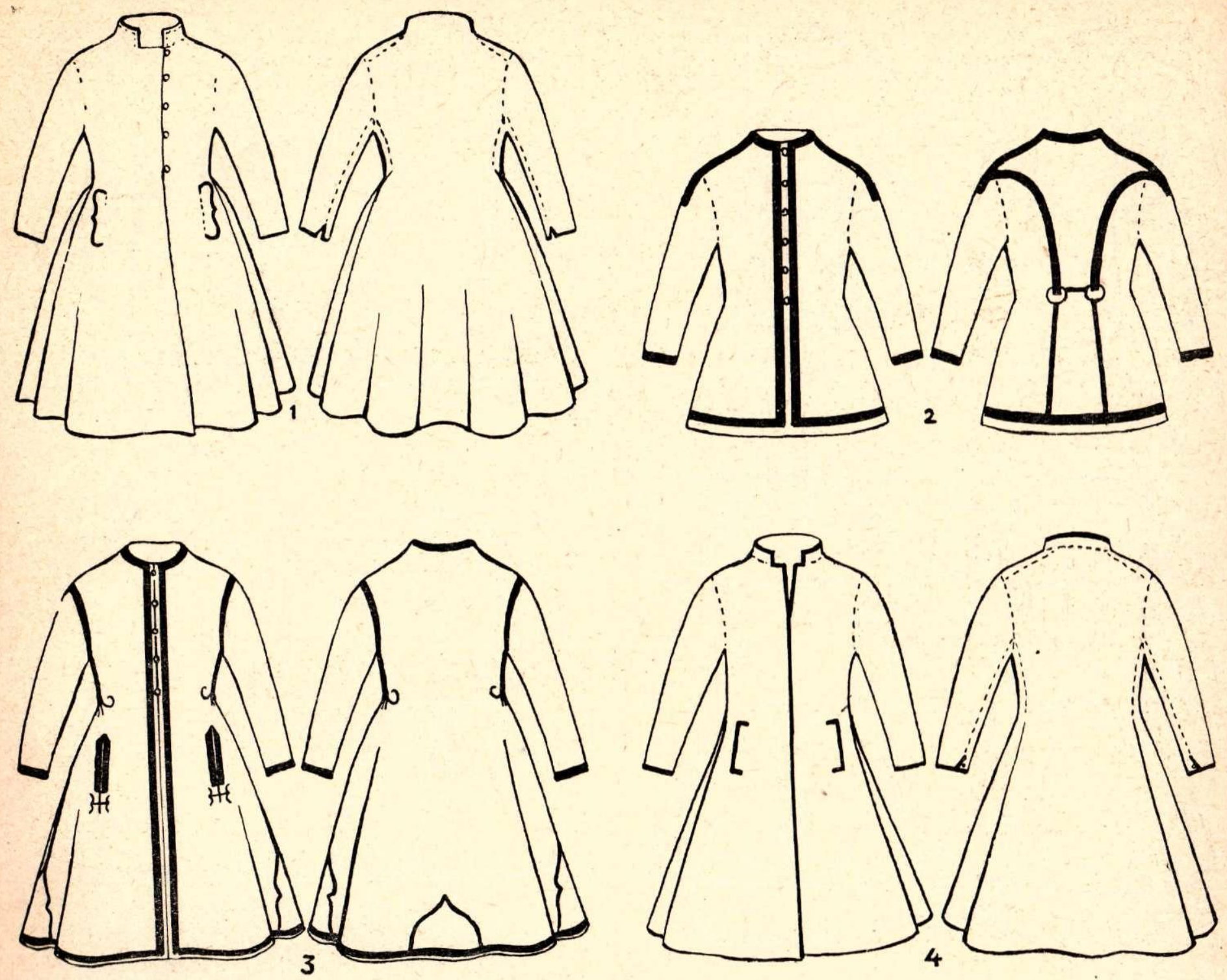

58. att. Augšzemes un Zemgales vīriešu svārki: 1, 2-Augšzemes; 3, 4-Zemgales.

Grezni vīriešu ka žoki redzami $\mathrm{O}$. Hūna un J. Broces zīmējumos. J. Broce, aprakstot Sesavas, Liezeres un Saulesmuižas zemnieku apgèrbu, nav to apzīmējis par kažoku, bet vienkārši par «ziemas goda drēbēm»; tomēr liekas, ka zemniekiem mugurā ir no baltas, miecētas ādas darināti kažoki ar melnas gludas ādas apšuvumiem (skat. 21. tab., 5-7). Par to, ka tie ir kažoki, liecina arī sānu vīḷu melnais apšuvums un trīsstūrveida piešuve sānu gabalam, kāda parasti mēdza būt kažokiem. Pēc rotājuma tie ir līdzīgi $\mathrm{O}$. Hūna zīmētajiem Jēkabpils kažokiem, tikai pēdējie ir îsāki. Vienīgi Liezeres zemnieka zīmējumā nav redzama sānu piešuve un apg̊ērba kritums ir mīkstāks. Tas vedina domāt, ka varbūt arī svārki tikuši tāpat rotāti kā kažoki.
Liekas, ka tieši šie grezni rotātie kažoki ir tautasdziesmās minētie riṇḳētie kažoki.

\section{Man apsmēja ciema puiši, Ka man's puiši neprecēs; Sodien jāja precinieki Riṇ̂̄ēiem kažokiem.}

LD, 14265

Vidzemē par riṇkētiem kažokiem sauc baltos, no nemiecētām ādām šūtos kažokus, kuriem uzšūtas melnas lentes, t. s. rinki. ${ }^{472}$

Bez melnām lentēm kažokus vēl rotā ar krāsainu diegu līkumiem, pie kam raksts novietojies kažoka priekšpusē, abās pusēs no aizdares un ap. roču galos. ${ }^{473}$ 

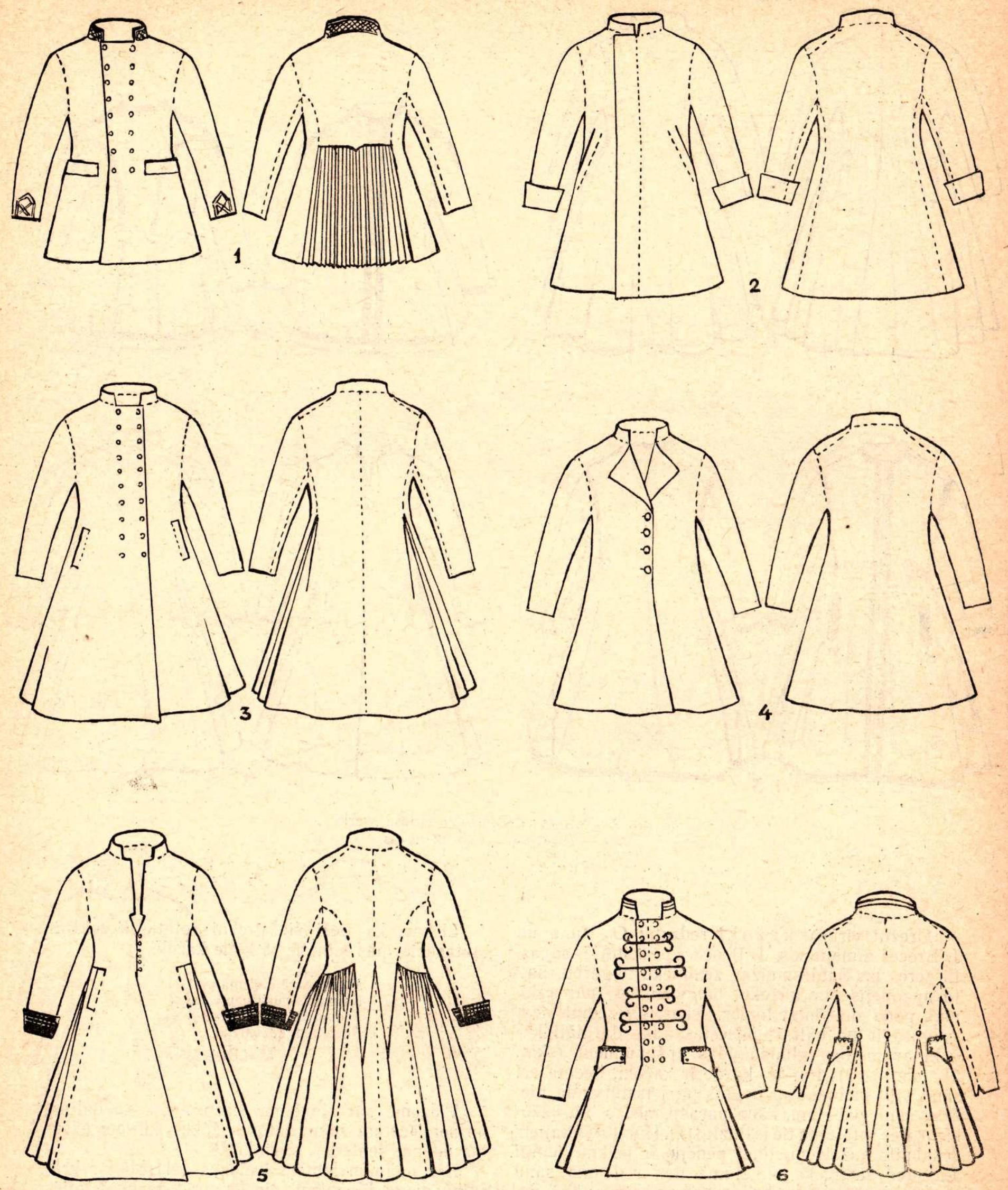

59. att. Kurzemes vīriešu svàrki:

$t$ - Alsungas; 2 - Tukuma; 3, 4 - Talsu; 5, 6 - Ventspils; 7,8 - Kuldigas; 9 - Durbes; 10 - Skrundas; $11,12,13$ - Nĩcas. 

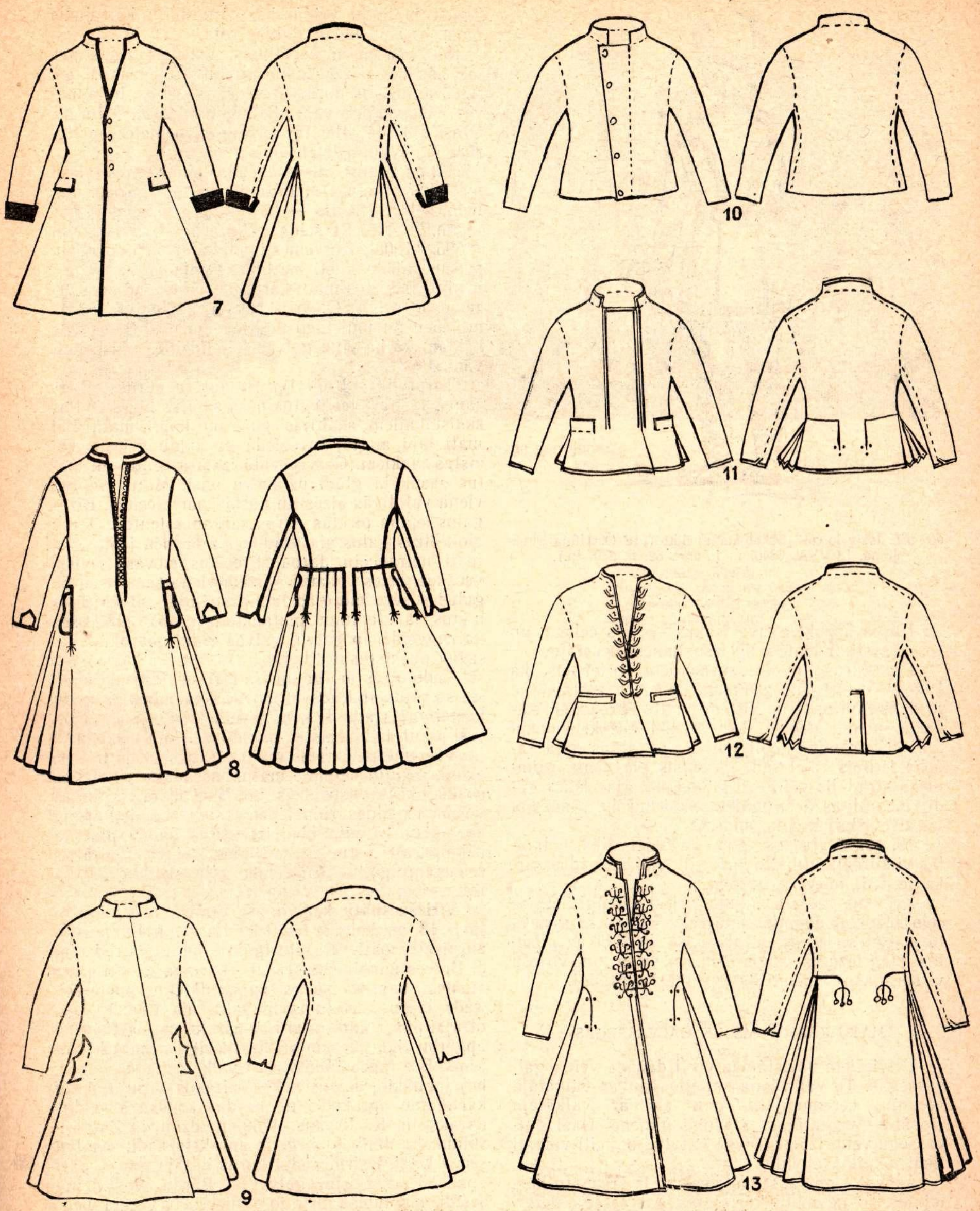


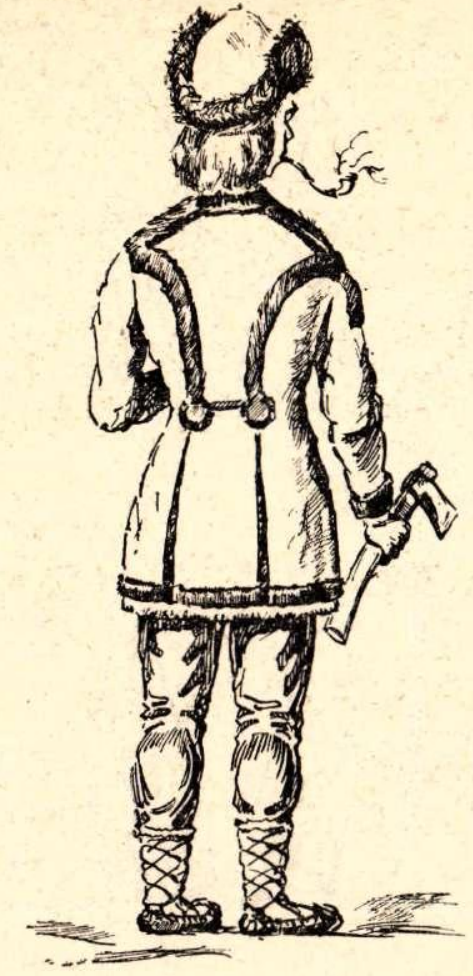

60. att. Isais kažoks Jēkabpils apvidū (pēc O. Hūna zīmējuma, LCVVA, 6840. f., 1. apr., 62. 1., 230. lp.).

Darba kažokus šuva issākus - virs celiem, un tos parasti ar lentēm un izšuvumiem nerotāja.

Pëc mirušo mantu sarakstiem spriežams, ka kažoks ir turīgāko zemnieku apg̀ērba sastāvdal̨a, jo apmēram puse no visiem mantu sarakstiem kažokus nemin nemaz, bet vairāki kažoki vienam ipašniekam minēti loti reti. Kalpu algas daḷā ka. žoks ietilpis tikai tad, ja puisis pie viena saimnieka strādājis vairākus gadus, bet atseviškos gadījumos algas tiesā minēta tikai kažoka sašǔšana un atseviškas kažoka ādas. ${ }^{474}$

19. gs. otrajā pusē goda kažokiem lika vadmalas virsdrēbi, un balto kažociṇu vietā parādās sarkanie, t. i., miecētie kažoki.

Kažokus parasti valkāja vīrieši, vienīgi lielajos ceḷa kažokos, dodoties tālā ceḷā, ietinās kā vīrieši, tā sievietes. 19. gs. otrajā pusē, pārejot uz pilsētas piegriezuma apgèrbiem, sieviešu un vīriešu virsdrānas - mētel̨i - ir pilnīgi atšḳirīgi.

\section{MATU KARTOJUMS UN GALVASSEGAS}

Latviešiem pazīstamas visai dažāda veida galvassegas. To valkāšana saistīta gan ar valkātāja vecumu, ceremonijām, gan arī ar valkātāja (īpaši - valkātājas) stāvokli ğimenē. Daži galvassegu veidi izplatîti visā Latvijā, bet citi valkāti tikai noteiktā apvidū.

Apskatot galvassegas, svarīgs ir arī matu kārtojums, jo no matu kārtojuma galvassega nereti iegūst îpatnēju veidu, bez tam matu kārtojums pats par sevi jau ir galvas rota.

Sieviešu matu kārtojums. Vecākās ziṇas par latviešu sieviešu matu kārtojumu iesniedzas 16. gs. A. Gvaṇini norāda, ka ir vecākas sievas, ir jaunavas, visas staigā valāa atlaistiem matiem. ${ }^{475} 16$. gs. Grasi albumā attēlotās Livonijas sievietes apstiprina A. Gvanini izteicienus. ${ }^{476}$

17. gs. autori sniedz dažādas ziṇas par sieviešu matu kārtojumu. D. Fabricijs runā par gariem matiem, bet J. Strauss - ka matus griež zemāk par aùsīm. ${ }^{477} \quad \mathrm{H}$. Rēršeida (Rörscheidt) zīmētajai (1595.-1605.) Kurzemes jaunavai ir gari, uz abām pusēm vaḷā palaisti mati. ${ }^{478}$ Iespējams, ka 17. gs. ir bijis atšḳirīgs matu kārtojums Vidzemē un Kur. zemē, jo arī A. Oleārijs raksta, ka matus «viñas nesasien un lauj tiem nogrieztiem nokarāties līdz kaklam, tā ka viṇu galvas loti līdzinās puišu galvām.» ${ }^{479}$

Turpretim 18. un 19. gs. autoru aprakstos lasāms, ka sievietes matus nēsā sapītus bizēs. ${ }^{480} \mathrm{Par}$ skaistākajiem skaitījās gari un kupli mati. Lai mati labi augtu, tos zieda ar saldu sviestu vai vistas taukiem. Galvas vidū izškīra celinu un matus sasukāja gludi uz katru pusi. Matus sapina vienā vai divās bizēs un nēsāja pār pleciem. Bizes galos iepina pirktas garas sarkanas lentes. Darba ejot, bizes galus aizsprauda aiz brunču jostas, lai mati netraucētu darbā. Precētas sievas, sevišḳi vecākas, bizes pakausī pārlika vienu zem otras un galus sasēja mezglā. Jaunavas divās pīnēs pītos matus, ar iepītām matauklām galos, aplikušas vainagveidā ap galvu, galvas vidū matauklas sasienot pušḳi (skat. 31. tab., 3).

Radniecīgs ar igauñu setuku sieviešu matu pīšanas veidu ir Rucavas novadā pazīstamais matu kārtojums «ragos», kura izveidošanai, ja mati bijuši plāni, izlīdzējās ar pakulu vai linu vīškiem. ${ }^{48 !}$

Vidzemē pazīstams matu pīšanas veids ir t. $s$. skuja. Skujiṇu pinot, matus nesadala vis trijos posmos kā parasti bizēs, bet tikai divos, no katra posma uz pīnes vidu ieliecot sīku posminu vienu pār otru. Tā pīta bize izskatījās daudz platāka nekā parasti un neiznāca tik bieza. Aptīta vairākas reizes ap galvu, šāda bize bija skaista galvas rota.

Vīriešu matu kārtojums. Vīriešu matu kārtojums 18. gs. beigās, tāpat kā 17. gs., ir līdz ausīm apgriezti mati. Raksturīgākie paraugi redzami J. Broces zïmējumos. Tie ir - pusgari mati (līdz ausim), kas uz pieres apgriezti līdz puspierei. Sāds matu kārtojums ir valdošais līdz 19. gs. otrajai pusei, kad sakarā ar pāreju uz pilsētas tipa apg̀èrbu tika pārnemts arī attiecīgais matu kārtojums. Bez tam vecāki vīrieši valkājuši zoda bārdu, bet jaunākie skuvušies. ${ }^{482}$ Vairākus vīriešu matu kārtojumu aprakstus un bārdas kopšanas veidus aprakstījis K. Jirgens. 1750. g. dzimušo Zaḷalı saimnieku Jāni K. Jirgens apraksta šādi: «Galvu sedza biezi, iesirmi mati, kurus nēsāja garus, pāri apkaklei ar šḳirtni galvvidū. Bārdu vinš dzina sestdienās, tumšā pirtî, jo atmiekšḳētu varēja vieg- 

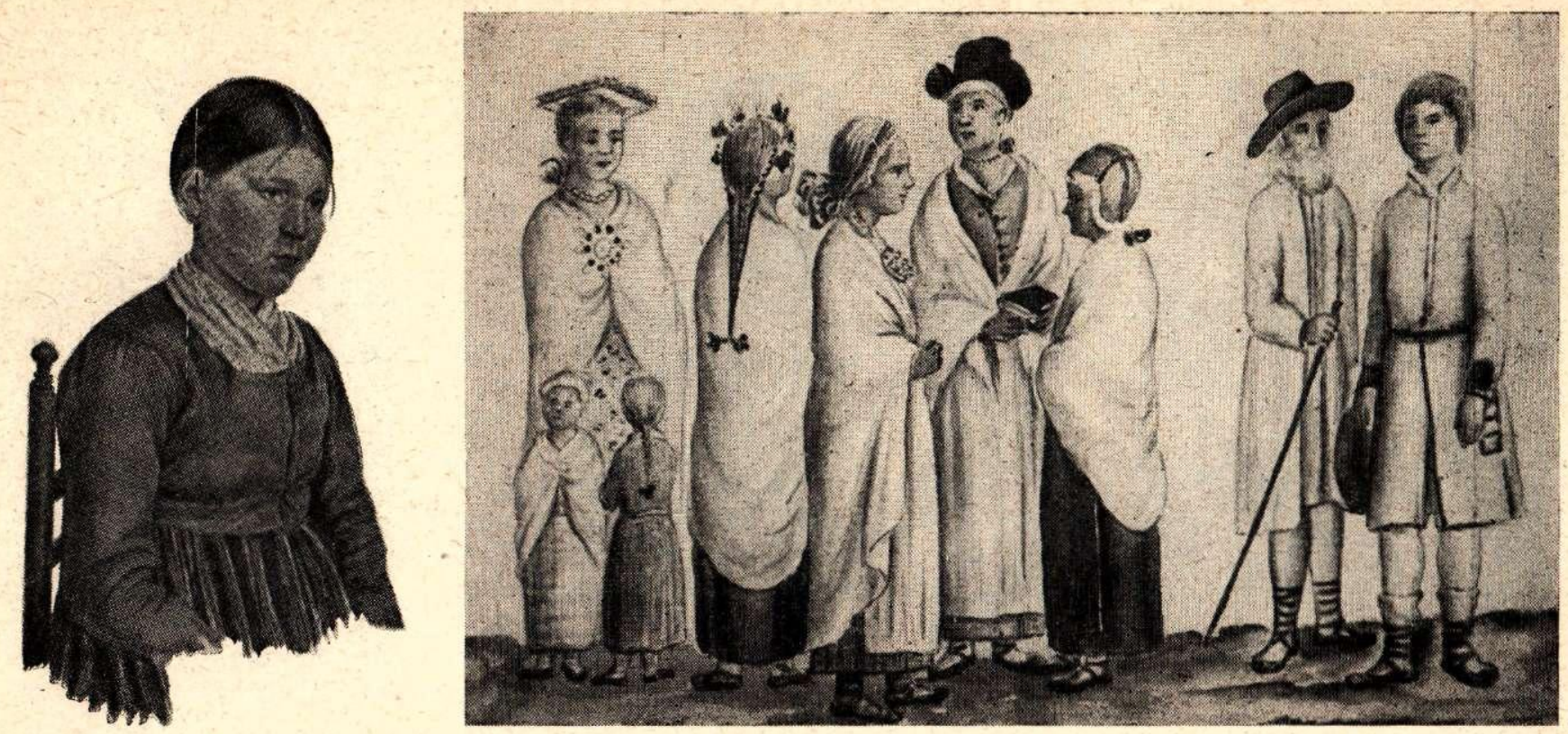

61. att. Jaunavu matu kārtojums:

pa kreisi - H. Brīgenas zimējums «Marija no Lēdurgas»; pa labi - J. Broces zìmējums (Monumente..., III. 87. 1pp.).

lāk nodzìt, bet bakenes audzēja, kas noskatītas no lielkungiem vai kara kungiem. $\gg^{483}$

Sieviešu galvassegas. Jaunavu un sievu galvassegas ir atškirīgas, un to valkāšanu noteica pastāvošās tradīijas.

Kā mājās dzîvojot, tā arī darbā ne jaunavas, ne precētas sievas galvas rotas nevalkāja, tās lika tikai baznīcā un godos. Mājās kā jaunavas, tā sievas ap galvu sēja lakatinus. Lakatiem ir vairāki vietējie nosaukumi - drăna (Kurzemē), skusts (Latgalē), kuska (Rucavā). Lakatinus vai nu nogrieza no tā paša kreklu audekla, vai arī īpaši tam nolūkam auda, lielākoties balti rūtainus $(90 \times 90 \mathrm{~cm})$. Lakatinuus ap galvu sēja dažādi: 1) lakatu locīja stūreniski un sasēja zem zoda (63. att., 1); 2) lakatu salika stūreniski un 2 stūrus sasēja pakausī zem trešā $(63$. att., 4); 3) stūreniski saliktā lakata divus stūrus krusto pakausī virs trešā, apñem apkārt galvai un virs pieres sasien mezglā; šis ir t. s. poliskais lakata siešanas veids. Poliski parasti lakatinu sēja sievas; 4) ejot baznīcā vai godos, stūreniski salikta lakata stūrus pakausī sasēja mezglā, t. i., sasēja bābiṇā.

Jaunavu galvassegas. Godos jaunavas no precētām sievām atškīira galvassegas. Jaunavas lika galvā vainagu, precētas sievas - mices, sievu cepures vai sēja galvas autus.

Visizplatītākā jaunavu galvas rota ir vainags. Vainags ir arī tikumības simbols, tāpēc tas valkājams godam:

Sargu savu vainadziṇu. Kā uguns dzirkstelīti:

Dzirdu ciema meitinām

Bez godina noṇemam.

«Austrums», 1904., 711. sl.
Meitu bez vainaga citi apsmēja:

Trūka man, trūka man, Es nezinu, kas man trūka. Trūka man meitas vārda, Trūka zīlu vainadziṇš.

\section{F, 1400,6}

Vainagu lika taisni galvas vidū līdz matu sākumam. Uz pakauša vai vienu pusi noškiebta vainaga valkātāju uzlūkoja par netikušu:

Kālab mans vainadziñ̌

Škībi stāv galvinā?

Kă tas škīibi nestāvēs,

Pilns ar laužu valodām.

\section{F, 11647,12177}

Jaunavai izejot pie vīra, tā zaudēja tiesības valkāt vainagu un tai bija jāvalkā sievu galvassegas. Jauno sievu mičojot, tai nonēma vainagu un uzlika sievas cepuri. Mičošanā jaunā sieva Alsungas novadā dziedājusi šădas dziesmas:

\section{Aili manu vainadzinu, \\ Vienu roku cilājams; \\ Tautu dēla linu auts, \\ Abu roku tauṇājams.}

Pērc, tautieti, Rĩgā autu

Rakstītām maliṇām;

Es neñemšu nerakstītu

Pretĩ savu vainadzinu.

\section{F, 11647,12177}

Labāk man sirmi mati Zem vizulu vainadzina Nekā man zelta mice $\mathrm{Bez}$ godiṇa galviñâ.

LD, 5506
Vainagi pēc materiāla un rotāšanas veida iedalāmi metāla, zịḷ jeb vizuḷu un astru vainagos. Vainaga funkcijas pildīja arī matauklas. 


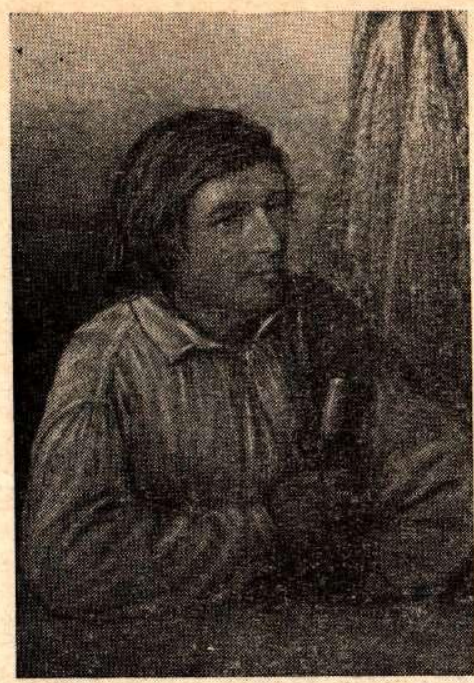

1

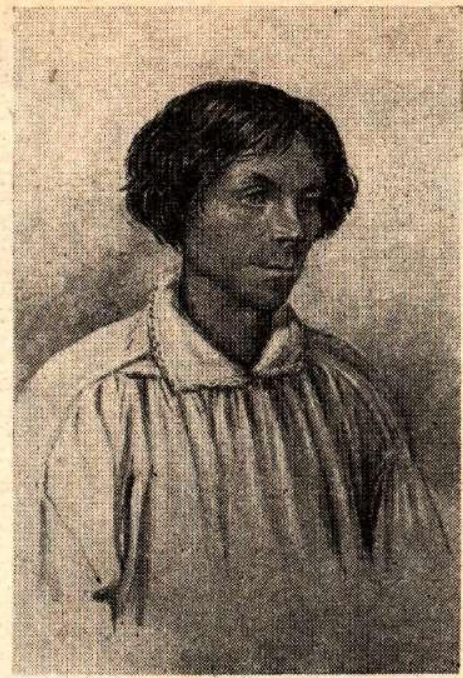

2

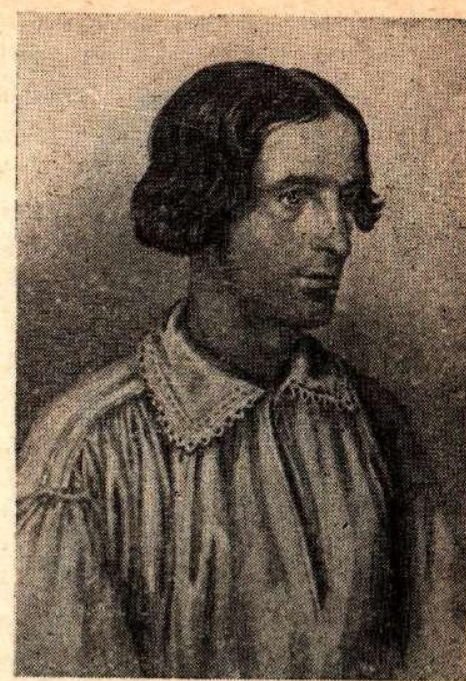

3
Vecākais vainaga materiāls, kas saglabājies līdz mūsu dienām, ir metāls. ${ }^{484} 19$. gs. sākumā metāla vainags saglabājies vairs tikai Alsungas, Kuldīgas un Ventspils apkärtnē (65. att., 1). 18. gs. metāla vainagus darina no plānas $2-3 \mathrm{~cm}$ platas bronzas sloksnes, kuru ar apaḷām metāla «spangām» (misiṇa plāksnītēm) piestiprināja pie sarkana vai zaļa tūka pamata. No spangām arì cēlies vainaga nosaukums - «spangu vainags» (skat. 27. tab., 4-7).

\section{Taisiet kāzas, taisiet kāzas, \\ Nu būs kāzas šovakar: \\ Visa brāla sēta spīd \\ Spožiem spangu vainagiem.}

F 11647,12177

Sudrabina man matini,

Zelta liku vainadziṇu,

Tã bij traka dēla māte,

Kas man savu dēlu liedza.

\section{LD, 5539}

Spangu vainaga izcelšanos nevar atvasināt no 8.-9. gs. bronzas vijiṇu vainaga. Apšaubāms ir V. Giintera norādījums, ka spangu vainags pārṇemts no vācu ienācējiem 13.-14. gs., 485 jo līdz ar to nav skaidrs, kāpēc tieši Kurzemes tērpıi kompleksā vajadzēja pārṇemt metāla vainagu no vāciešiem, ja turpat dzīvojošo lïbiešu 11. gs. kapos atkārtoti ir atrastas sudraba un zelta brokāta pieres saites, kuras bijušas lïbiešu dižciltības zīme. Bez tam jāatceras, ka kuršu apbedišanas veids, mirušos sadedzinot, nelauj pilnībā rekonstruēt seno kuršu apgeērbu. Turpretim bagātīgais latgalu materiāls skaidri rāda, ka 19. gs. Kurzemes metāla vainagos valdošais princips - uz auduma pamata piestiprināt atsevišḳi darinātu rotājošu joslu plaši pazīstams 12. un 13. gs. auduma vainagos. Šajā laikā parādās arī spangu priekšgājējas, t. i.,

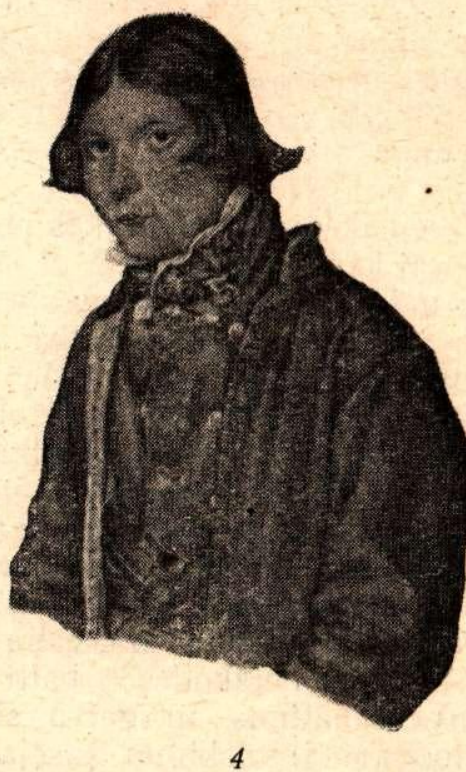

62. att. Vĩriešu matu kärtojums:

1, 2, 3 - A. Pecolda akvareli 'Krievu Geogrãfijas bledrỉbas ạrhivã; 4- H. Brīgenas zimējums «Indriksonu Jānis».

alvas krelles - podziñas, kas tāpat kā spangas vēlākos vainagos novietojas taisnā rindā visapkārt vainagam. ${ }^{486}$

18. gs. visizplatītākais un raksturīgākais jaunavu galvassegas veids latviešu tautas tērpā ir zị|u vainags, Tautasdziesmās raksturoti dažādi zịlu vainagu paveidi - pērḷ, kaulu, vizuḷu, krellu u. c.:

Gludu glaužu sev galviṇu, Pērlu liku vainadziñu; Ne pilìte nestāvēja Manu matu galiṇă.
Es deviṇu brālu māsa, Man devini vainadzini: Trīs bij zị|u, trīs bij kaulu, Trīs dzeltenu vizulī̌s'. 
Zịłu vainagi pēc to darināšanas veida dalāmi mìkstajos un cietajos. Mîkstie vainagi ir raksturīgi Vidzemes, Latgales un Augšzemes, bet cietie - Kurzemes tērpu kompleksam (skat. 24., 26.28. tab.).

Zị̂u vainagi darināti sarkanā tūka pamatā, lielākoties bez padrēbes vai cietāka pamata (65. att., 3, 5, 12, 13). Austrumvidzemē, arī Latgalē un Augšzemes novados vainagu pamatam vietumis izmantots arī pelēks un tumši zils vadmalas audums. Tikai uz melna vai tumši zila pa. mata pērlu vainagi šunti Piebalgă ${ }^{487}$ (65. att., 9) Jădomā, ka zilā pamatā darinātie vainagi ir vecāki par sarkanā pamatā darinātajiem, jo pirmējie parasti gatavoti no mājās austas vadmalas, bet sarkanie visbiežāk no pirkta auduma. Vidzemes vainagu platums $-2-16 \mathrm{~cm}$. Vainagi rotāti garenām cilindrveida vai apalām stikla vai kaula krellītēm un dažos novados arī ar lieliem vizuliem. ${ }^{488}$ Tautasdziesmā bieži tiek minēts vizuḷu vainags:

\section{Saglaudu galviṇu \\ Kā cielaviña, \\ Uzliku vizulu \\ Vainadzinu.}

\section{LD, 5532}

Nīcas, Bārtas un Dienvidkurzemes novados vainagi uzlīmēti uz stingra papes vai bērza tāss pamata, rotāti brokāta lentēm un lielām stikla krellēm (65. att., 26); to augšējā mala platāka par apakšējo (konusveida). Sādi vainagi redzami jau 16. un 18. gs. zīmējumos. 489

Unikāls ar šauru lokālu izplatību ir zirgu astru vainags no Rūjienas (65. att., 16.; 24. tab.,6). Par šāda vainaga valkāšanas veidu iespējams spriest pēc J. Broces lígavas vainaga zīmējuma. ${ }^{490}$ Pèdējais gan, pēc J. Broces apraksta, darināts no četrstūrî saliktām papes sloksnēm, kas aptītas ar krāsainām lentēm. Kà līgavas vainagu to, saprotams, varēja darināt arī no cita materiāla. (Līdzīgi gadījumi ir zināmi no Piebalgas, Latgales un Augšzemes.)
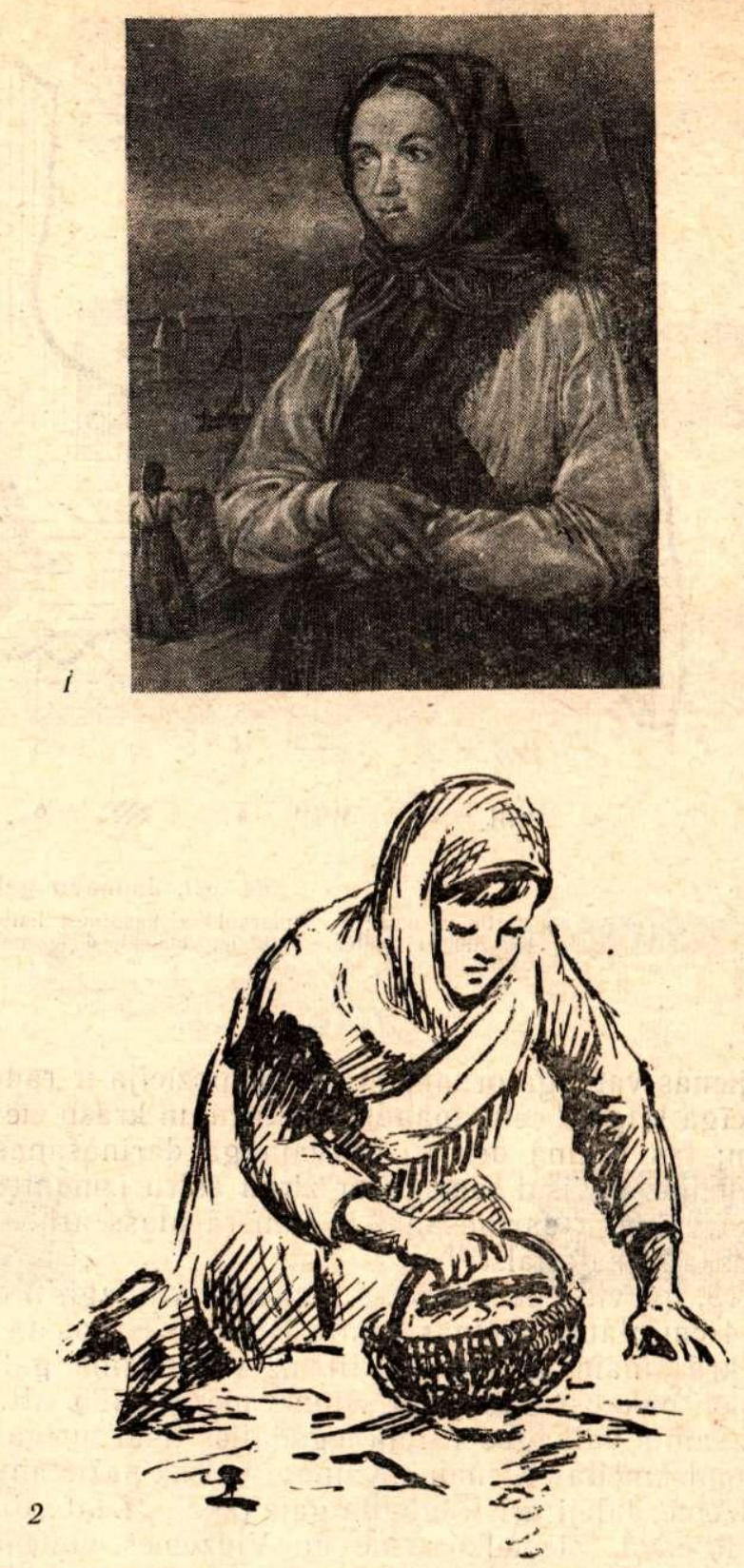
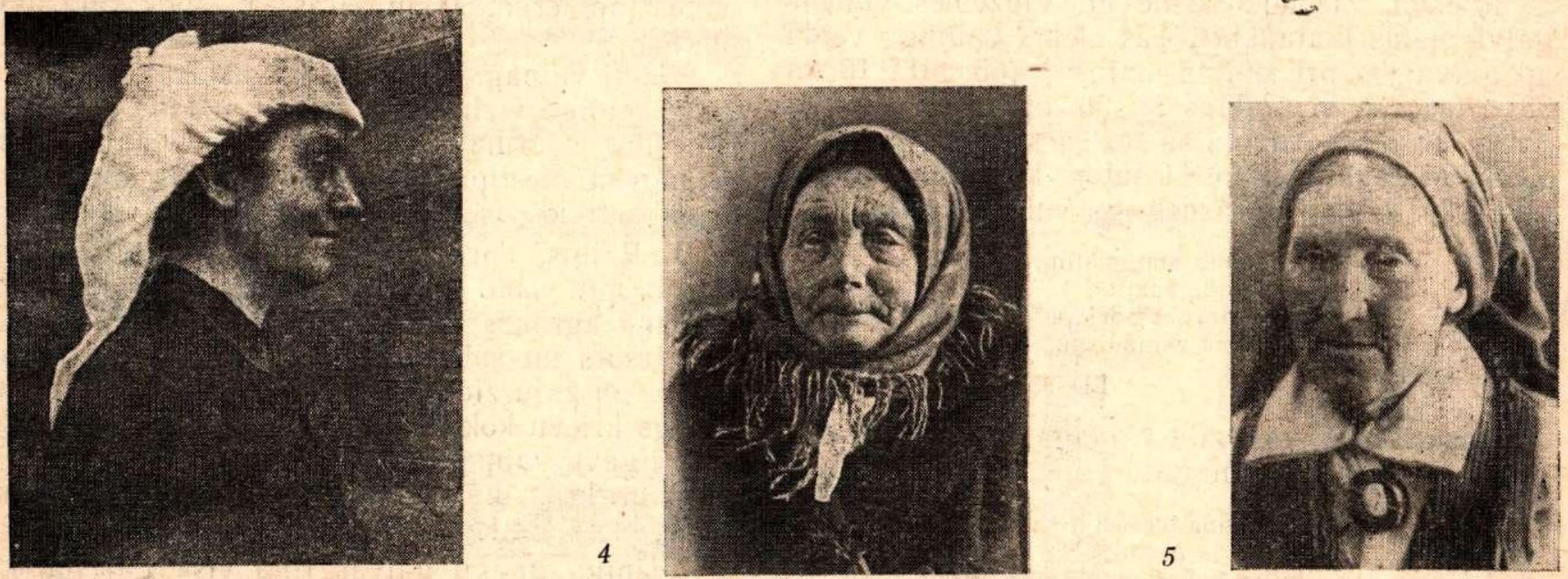

63. att. Lakatu siešanas veidi:

1 - A. Pecolda akvarelis; 2 - pềc māksl. A. Alkšṇa skices; 3, 4, 5 - lakatu siešana Kurzemẽ (Liepājas NM materiāli). 


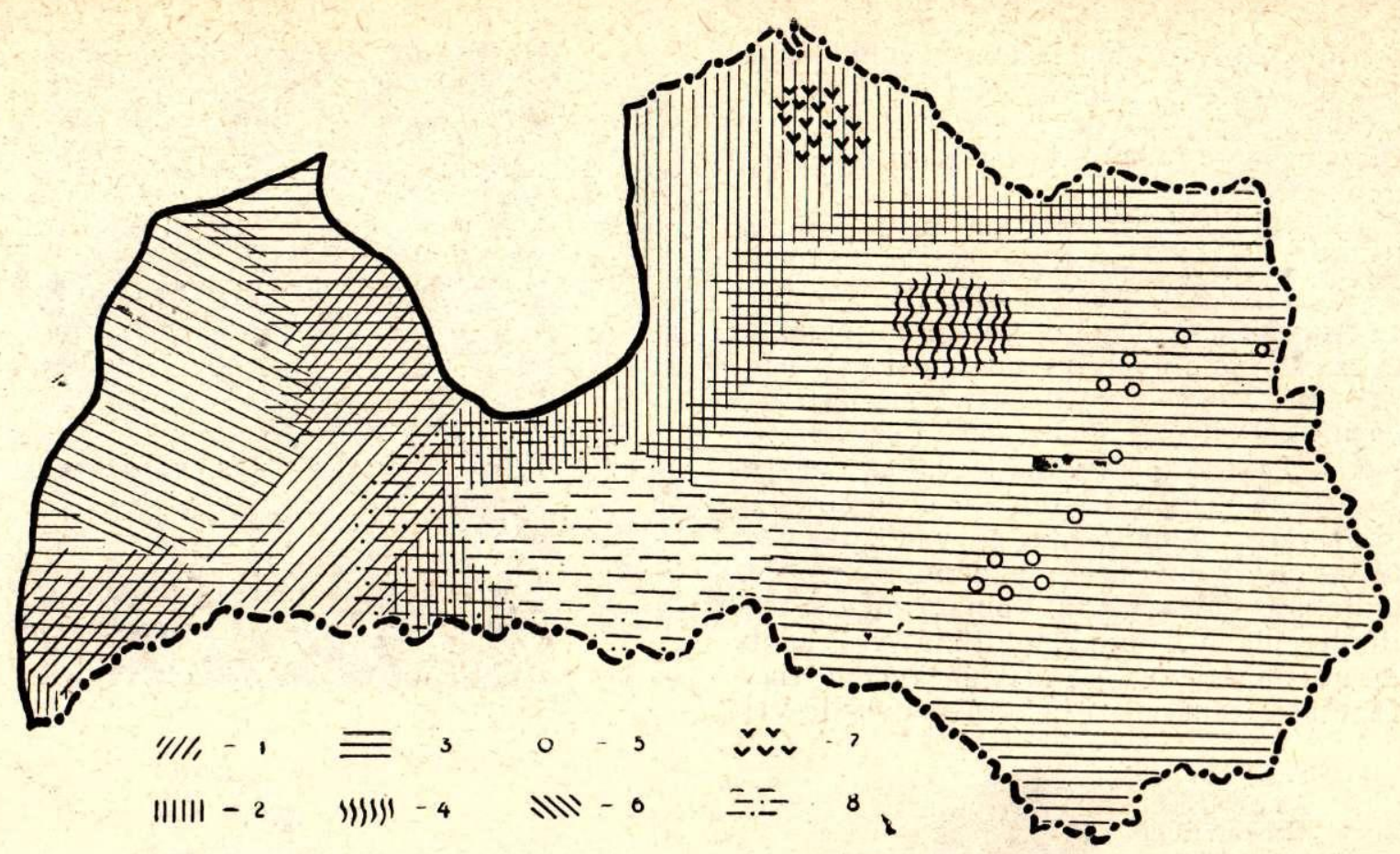

64. att. Jaunavu galvassegu veidu izplatíba:

1 - sarkanie cietie vainagi; 2 - matauklas, kaspines, lentes; 3 - sarkanie mikstie vainagi; 4 - melnie mîkstie vainagi; 5 - zilie vai pelēkie mìkstie vainagi; 6 - metāia vainagi; 7 - zirgu astru vainags; 8 - zỉda lakati. .

Rūjienas vainaga ornamentālā kompozīcija ir radniecīga latgalu celu apaudu rakstiem un krāsu zie. dam; tas vedina domāt, ka vainaga darināšanas tradicijas ir visai senas. Par zirga astru izmanto. šanu vainagu darināšanai ir samērā plašs arheoloğiskais materiāls. ${ }^{491}$

19. gs. vidū parādās t. s. sienamie vainagi, t. i. 2-4 cm platas, melnas samta lentes, kas nošūtas ar krāsainām apạ̦ām krellītēm. Vainadziṇa gali sasieti pakausĩ zem matu sējuma mezglā (65. att., 6). Samta vainagus varēja iegādāties tikai turīgās saimniekmeitas. Sienamie vainagi vairāk pazīstami Vidzemē, dậeji arī Rietumlatgalē (skat. 24. tab., 5).

Rucavā, Ziemelkurzemē un Vidzemes vidienē galvā sietas matauklas. Tās sietas vainaga veidā ap galvu vai arī iepītas matos ${ }^{492}$ (65. att., 15 un 22). Vecākās matauklas austas apmēram $3-4 \mathrm{~m}$ garas un $5-8 \mathrm{~cm}$ platas no sarkaniem linu diegiem. Matauklu galos izšūtas krāsainas puḳes (skat. 25. tab.). Tautasdziesma min arī zalu matauklu.

\begin{abstract}
Melna samta man matini,
Zala zìda matauklïte;

Vajag gudra tēva dēla,

Kas nonēma vainadziṇu.
\end{abstract}

\section{LD, 5524}

Vasarā bieži vien zịlı vainaga vietā galvā lika ziedu vai zal̨umu vainagus.

Man māmiṇa piesacīja

Bez vainaga nestaigăt;

- Ja tev nava citu pušķu,

Apliec bērza žagariṇu.

E 3, 485 Alūksne
Sevišḳi grezni tika darinäti līgavas vainagi (65. att., 23 un 25). Tos rotāja ar dažādiem vizuliem un sīkām zìda lupatinām. Tā kā šādu vainagu vis nevarēja pagādāt katra meita, tad trūcīgās meitas līgavas vainagu dažkārt aiznēmās. ${ }^{493}$

Vidzemē līgavu vainagi bijuši l̦oti plati. Tos gatavojot, bieza papīra pamatu apšuva ar drānu un drănai uzšuva zīda lupatinas, pušḳišus, zîlītes un vizulus. Vizuḷ - plānas, apaḷas, dzeltenas metāla plāksnìtes ar caurumu vidū - tika vesti no Rīgas. Tikko pakustināja galvu, vizu|i laistījās, kustējās un skanēja.

Vainaga mugurpusē bija piešūtas vairākas zīda lentes (apmēram $60 \mathrm{~cm}$ garas), kas nokarājās pāri pleciem. 494

Vizuḷi vainagiem iegūti arī, akmeñiem noskru. binot spīdīgo vizlu un ar adatu vizlas plāksnītēm izurbinot cauruminus.495 Kurzemē vizuḷi līgavu vainagiem piestiprināti garā‘ stieplēs un, valkātājai kustoties, viegli liggojās (skat. 28. tab., 3).

J. Rainis, aprakstot kāzu paražas Višķu pagastā, min šădu lígavas vainagu: «Lielais rūtu vainags agrākos laikos bijis sarkans, stikla pērlēm izšūts un spigguliem izrotāts... ar sarkanām rozēm un zalu zīdu .... kā tautas dziesmās teikts, lìdzīgs krievu kokošnikam.... ${ }^{496} 19$. gs. vidū Latgalē līgavu vainagus darināja no mākslīgiem ziediem un krāsainām zīda lupatinām, kas piestiprinātas metāla stieplei. ${ }^{497}$

Vienīgā līgavu galvas rota visā Latvijā, kas pēc savas formas vairāk atgādina sievu nekā jaunavu galvassegu, ir linkainis, kas pazīstams 


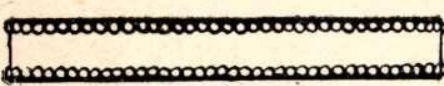

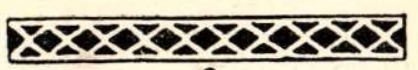

2

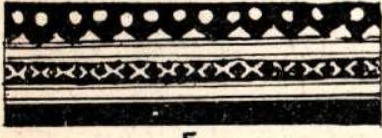

5

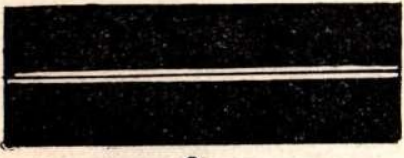

9

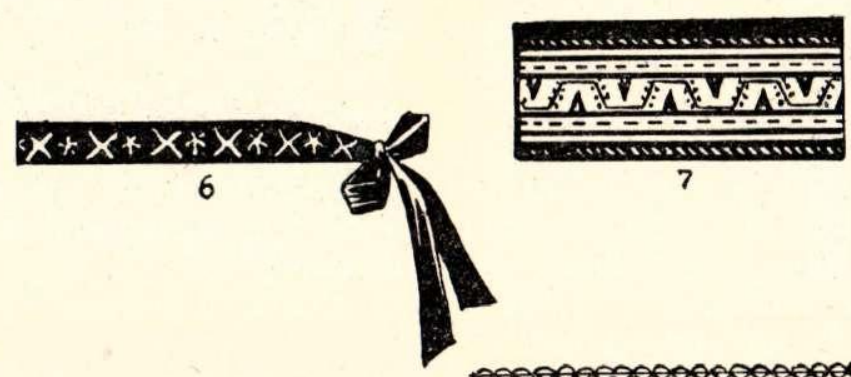

0

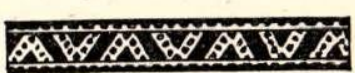
10

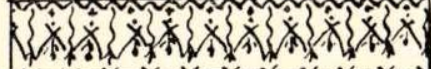

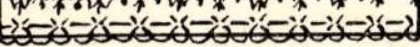
11
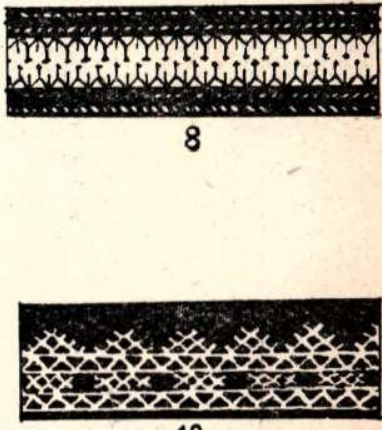

12

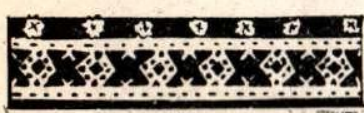

13

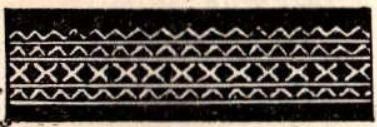

17

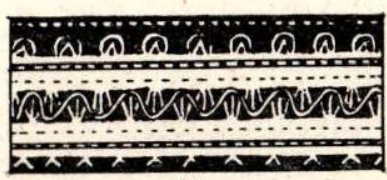

14

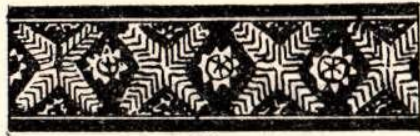

18
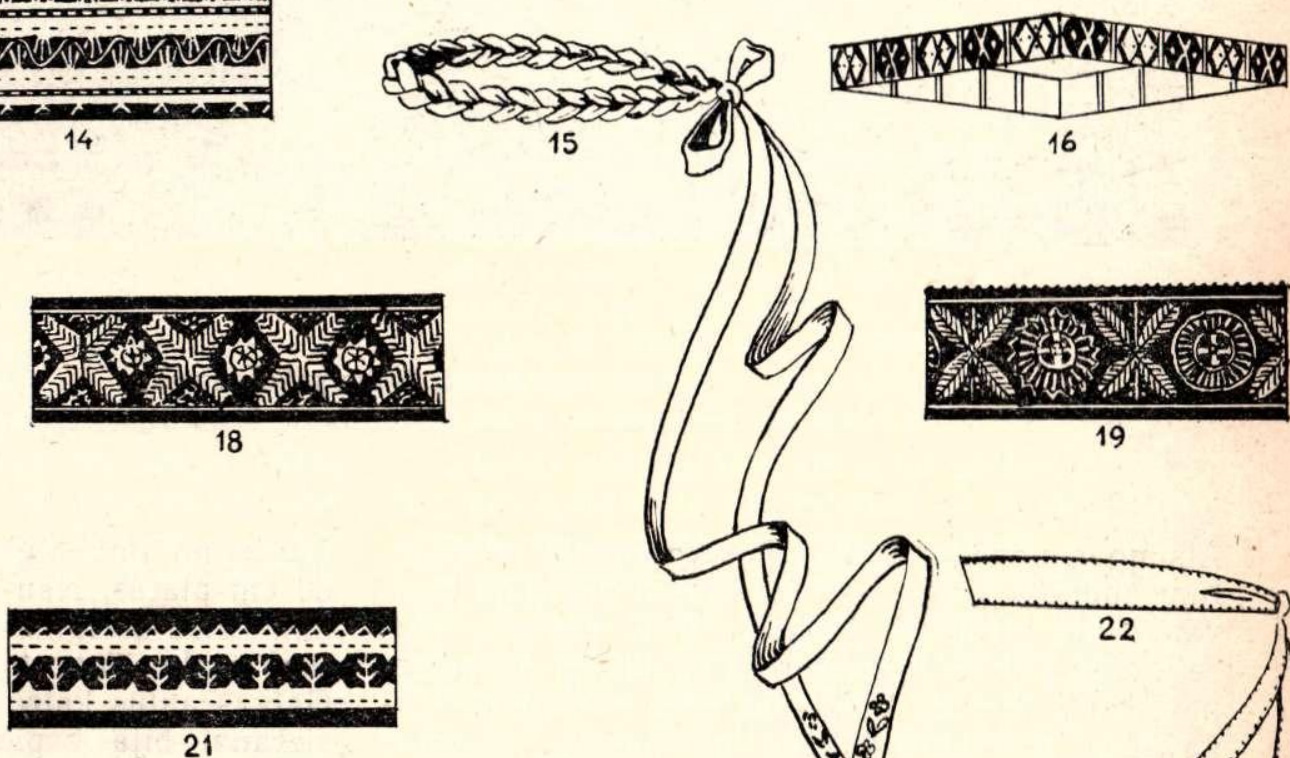
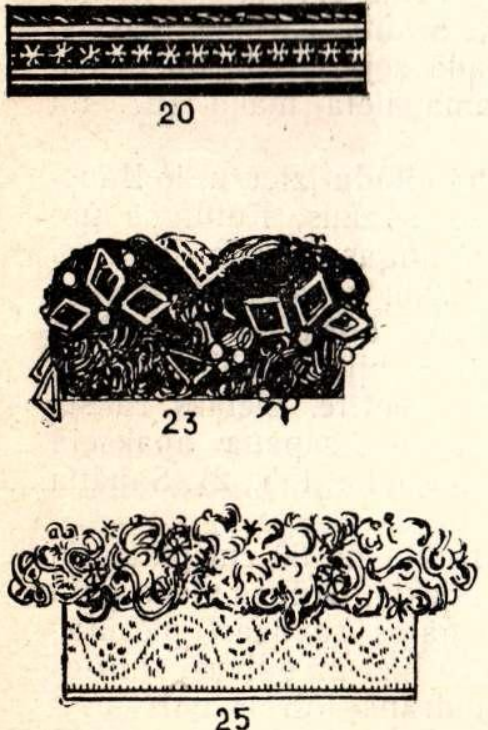

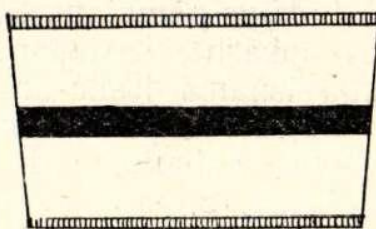

24
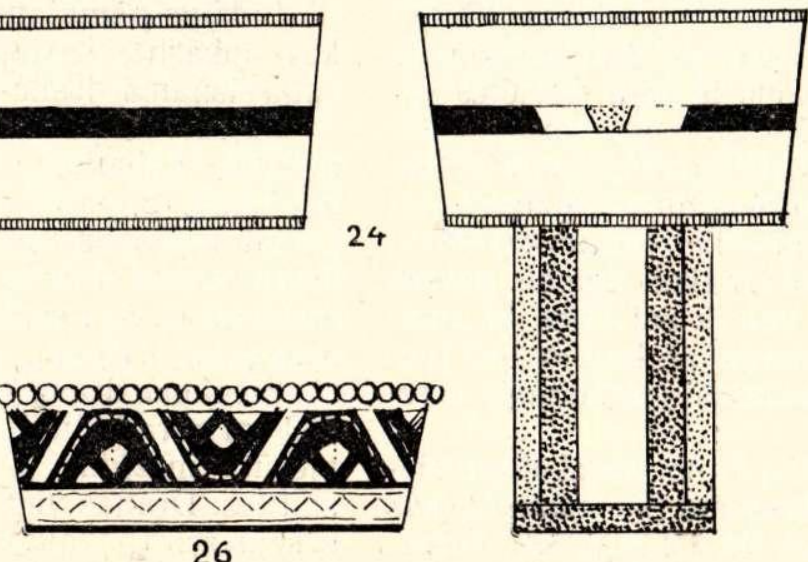

65. att. Vainagu shēmas:

1 - Kuldigas, Alsungas, Ventspils spangu vainags; 2 - Krustpils; 3 - Dienvidlatgales: 4 - Cesvaines; 5 - Jumurdas: 6 - Praulienas; 7 -

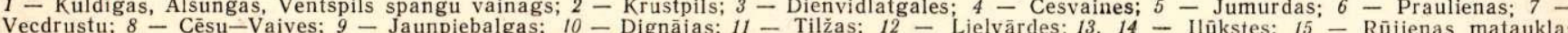
16 - Rüjienas zirgu astru vainags; 17 .. Augśzemes; 18 - Talsu; 19 - Skrundas-Aizputes; 20 - Alükstes; 15 - Rūjienas mataukla;

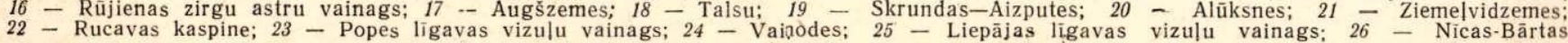
vainags. 


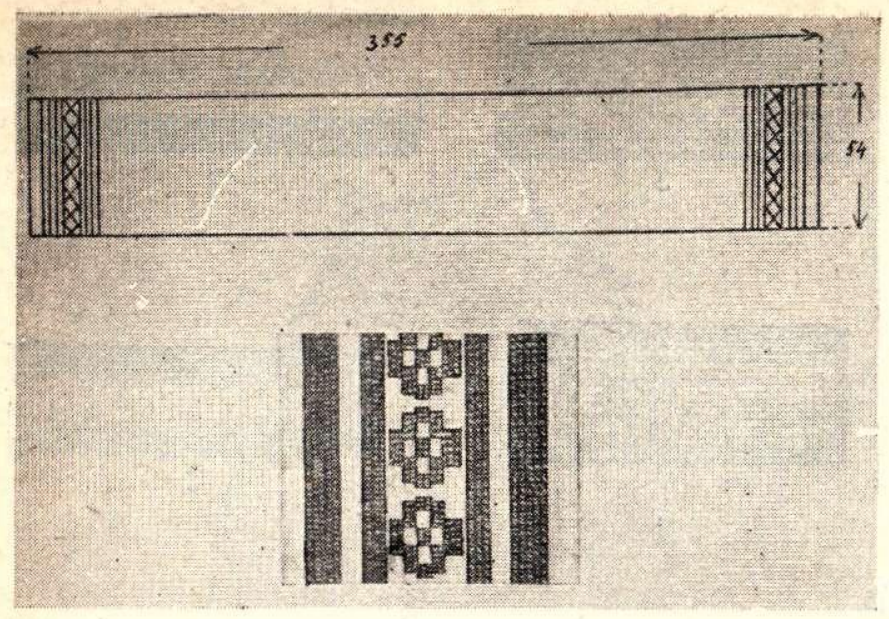

1

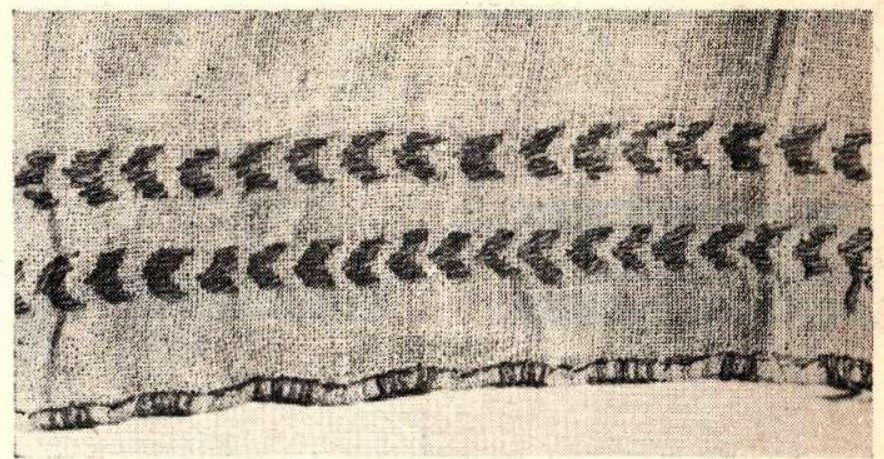

2

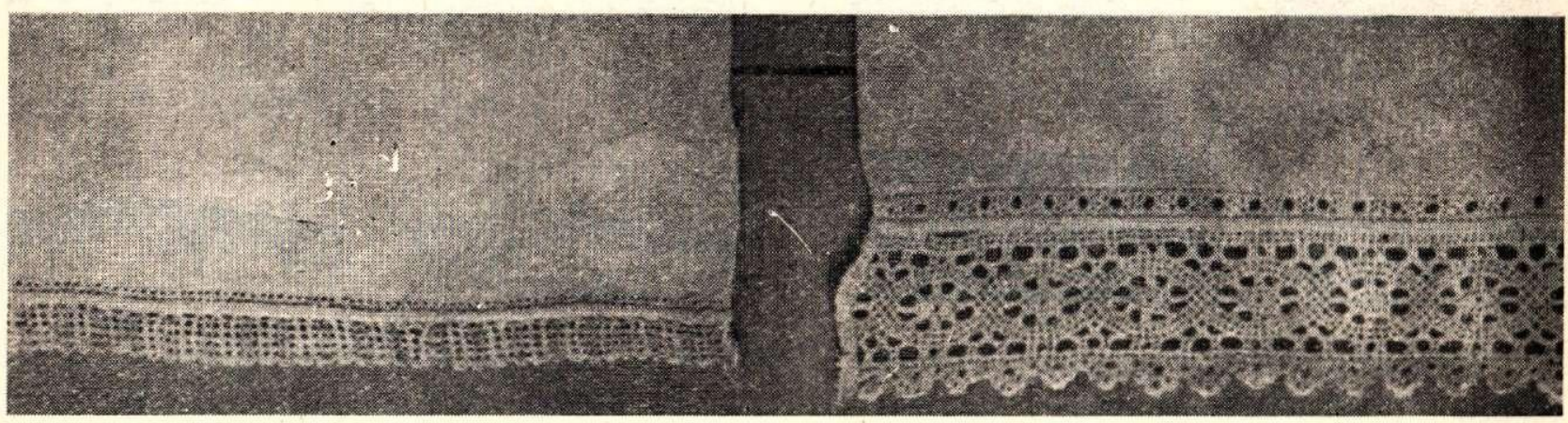

3

66. att. Sievu galvassegas:

1 - Augšzemes galvas auta shēma; 2 - Augšzemes galvas auta noslēgums un rotājuma raksts; 3,4-Jasmuižas galvas auta mala.

Alsungas novadā. Linkainis pagatavots no balta linu audekla, un parasti to liggavai dāvināja līga vainis vai vīramāte. Latvijas PSR Vēstures muzejā ziṇu par šo lïgavas rotu no citiem novadiem nav, bet J. Broces Vidzemes käzu zīmējumāā ${ }^{498}$ līgavai ir linkainim līdzīga galvassega. Termins «liniks» vēl saglabājies vecāko zinuu sniedzēju atmiṇās arī Gulbenes rajonā, kur bijušas lỉbiešu un igauṇu iedzīvotāju «saliṇas». Galvassega ar nosaukumu «linik» pazīstama igauṇu sievietes apgèrbā jau 11.-13. gs. ${ }^{499}$ Kopējais galvas auta nosaukums vedina domāt, ka šĩ galvassega saistāma ar lībiešiem, lai gan pēc formas liniks lìdzīgs senai baltkrievu galvas segai nametkai (наметка). ${ }^{500}$

Tā kā Alsungas linkainis ir tikai līgavas galvas rota, tad jādomā, ka tas vairāk saistāms ar somugru tautu paražām, saskaņā ar kurām arī jaunavas var valkāt galvas autus (piemēram, čeremisi) .501

Sievu galvassegas. Viena no vecākajām sieviešu galvassegām ir galvas auts - nāmats, kas 19. gs. sākumā saglabājies tikai Latgalēe, ${ }^{502}$ Augšzemē un Rucavā (66. att., 1, 2). Galvas autus da- rināja no linu audekla $2,5-3 \mathrm{~m}$ garus un $40-$ $50 \mathrm{~cm}$ platus. Nāmata galos bijušas bārkstis vai knipelētas mežg̀ines. Augšzemē greznajiem nāmatiem galos ieausts vai uzšūts sarkans raksts. Galvas autus katrā novadā sēja citādi, un to uzsiešanai bija nepieciešama liela māka (67. un 68. att.).

Lìdzīgs nāmatam, tikai citādu izmēru, ir Baus. kas apkārtnē sastopamais sapāns, Kuldigas novada sienamā drāna un Alsungas novada «lupata».

Sapāns ${ }^{503}$ darināts no trim kopā sašūtiem linu audekla gabaliem, pie kam apakšējā dala bija rakstaina. Sapāna augšpusē bija piešūta neliela, krāsainiem diegiem izšūta lentîte. Lielāks raksts tādās pašās krāsās novietots sapāna apakšējā malā (skat. A. Pecolda akvareli 4. tab., 2). Sapāna izmēri $140 \times 70 \mathrm{~cm}$.

Sienamā drāna ${ }^{504}$ darināta no $60 \mathrm{~cm}$ plata un $150 \mathrm{~cm}$ gara balta linu audekla. Drānas vienā galā piešūta mežğine, kuras galos savukārt piešūtas saitītes. Drānas vienu galu lika uz galvas, saitītes sasēja zem pakauša, bet drānas otrais gals brīvi nokarājās uz muguras (68. att., 1). 
Alsungas novada lupata ${ }^{505}$ darināta no loti smalka balta $87 \times 80 \mathrm{~cm}$ liela linu audekla gabala. Gar lupatas abām malām un lejas galu piešūta $9 \mathrm{~cm}$ plata tamborēta mežğine. Gar augšējo malu, kas likta virs pieres, piešūta šaurāka mežğine. Ap galvu lupatu sēja tāpat kā Kuldīgas sienamo drānu.

Ka 18. gs. galvas auti bijuši izplatīti plašākā Kurzemes teritorijā, liecina arī viens no $\mathrm{O}$. Hüna zīmējumiem. .06 $^{50}$

19. gs. visizplatītākās sieviešu galvassegas ir dažādas cepures. Bagātākajām saimniecēm bijušas pat vairākas. Tikai pavisam trūcīgām sievām cepuru nebija. Turpretī bagātas saimnieces, braucot kāzās vai citās godībās, ñēma līdz 3 vai 4 cepures, lai katru dienu varētu dižoties ar citādu cepuri. ${ }^{507}$

Cepures pēc formas dalāmas apalajās izšūta. tajās, torṇa cepurēs - micēs un aubēs. Atsevišḳi minamas ziemas cepures.

Apal̨as izšūtas cepures redzamas jau 16. gs. zīmējumos ${ }^{508}$ (29. att.). 19. gs. sākumā šīs cepures sastopamas Austrumvidzemes un Bārtas novadā (15. att.; 69. att., 12, 16). Tās darinātas no balta, smalka linu auduma. Cepurei ir ap 12$14 \mathrm{~cm}$ plata apmale; tās rotājums novietots škērssvītrās. Raksta kompozīciju svītrās veido dažădas rūtinas un zobiṇi. Svītru raksti ir dažādi - pēe katras ar melniem diegiem šūtās svītras ir krāsaina raksta josla. Raksts šūts loti smalkiem diegiem vienā variantā; melnie raksti dažkārt bijuši arī ieausti, un tad tos iežogo brokāta lentes. Pie cepures apmales apakšējās malas piešūts dibens. Cepuri uzliekot galvā, dibens izliecās uz augšu pēc galvas formas tā, ka cepures apmales augšèjā mala, brīvi uz augšu stāvēdama, to gandrīz aizsedza. Cepures dibens darināts no šaura $(52 \times$ $\times 24 \mathrm{~cm}$ ) drānas gabala, kas pie cepures apmales piešūts gludi, bet galvas vidū savilkts kopā biezās krokās, pie kam savilkuma vieta izgreznota ar sarkanu vai zą̧u izšuvumu (skat. 29. tab., 4).

19. gs. sākumā Vidzemē izplatītas no kokvilnas diegiem adītas cepures ar smailu galu. Sī veida cepures sauktas par micēm, to galā diedzinu pušḳis. Tās parasti bija baltas ar sarkanām svìtrām vai arī ar krāsainu diegu sprodziṇām. ${ }^{509}$

Torṇa cepures (arī tās sauca par micēm) visvairāk pazīstamas Vidzemē un Augšzemē (69. att., $3,11,15)$. Tās darinātas no balta plāna linu vai kokvilnas auduma kulïtes veidā ar asu stūri. Cepures priekšējai malai bija piešūta mežg̀ine, bet pakauša dal̨ā paliela $-1 \mathrm{~cm}$ plata vīle, kur ievilka šauru saitīti. Saitīti savelkot, mices pakauša dala sakrokojās. Micēm darināja speciālas - knipelētas linu diegu mežğines, ${ }^{510}$ dažreiz mežğines izšūtas tillā. Nereti ap torṇa cepurēm sēja lentveidā salocìtu zīda lakatu ${ }^{511}$ (69. att., 11).

Tikai Piebalgas novadā sastopamas t. s. zalmalïtes, kas darinātas no gaiši zaḷas, tumši zilas vai melnas vilnas drānas ar cietām, uz augšu vērstām malām un plakanu dibenu (69. att., 9).

Krustpils novadā micei, kuru lika galvā jauna. jai sievai, to mičojot, gar pieres malu bija no sārtām zīda lentēm izveidotas «rozītes». Mici parasti dāvināja vedējmāte - vedējīša, kas bija vīra tuva radiniece un mičošanas ceremonijā ienēma galveno vietu. ${ }^{512} \mathrm{Ar}$ šìm micēm parasti gāja baznīcā un godos, bet tikai bagātākās saimnieces, jo nabagāaās sēja apal̨iski lakatu.

19. gs. vidū muižu ietekmē ieviesās cepures no loti plāna auduma ar smalkām knipelētām mežg̀inēm uz pieres. Atškirīibā no iepriekšējām torṇa cepurēm šis cepures šuva no diviem gabaliem, priekšpusē tas bija taisns, bet mugurpusē savilkts krokās, tā ka pakausī cepure stāvēja kupli apaḷa. Sīs cepures valkāja tikai cietinātas $\left(69\right.$. att., 2). ${ }^{513}$

Pie šĩs cepures tipa jāpieskaita arī Lielvārdes sievu cepures: arī tās šūtas no smalka balta linu auduma kulites veidā. Smailo cepures galu nolocīja uz pieres. Tādējādi izveidojās divi nelieli asi stūri. J. Broce, aprakstot Lielvārdes cepuri, to sauc par divstūrainu (zweyzackigten). Cepures priekšejā mala bagātīgi rotāta ar krāsainu vilnas dziju rakstu (69. att., 8; 29. tab., 1-3).

Trešajam cepuru tipam pieskaitāmas Kurzemē pazīstamās aubes, kuras darināja no loti smalka balta vai puķota kokvilnas vai zīda auduma ar mežğinēm un lentītēm (69. att., 6, 14, 17). Cepure šūta no diviem gabaliem, tās dibens sakrokots. Sii tipa cepures pazīstamas arī igaunu, somu un zviedru tautas tērpa komplektā. ${ }^{14}{ }^{14}$ Šis cepuru tips ir jaunāks par iepriekšējiem. 19. gs. otrajā pusē arī Vidzemēe sāk izplatīties līdzīgas, tikai mazāku izmēru cepures. (Par tām skat. arī nākošajā nodalāa.)

Ziemas cepures bija šũtas no sarkanas vadma. las, bet turīgākām saimniecēm - no samta. Pie ziemas cepurēm pieder Vidzemes vatētās cepures, t. s. santenes ${ }^{515}$ vai benītes. ${ }^{516}$ Šo galvassegu parasti valkāja gados vecākas sievas. Ziemas cepurēm bija silta padrēbe. Dažkārt cepurēs iešüta arī balta jērādiña. Sādas cepures valkātas arī vasarā, tikai tad tām bija linu auduma padrēbe. S̄ādas cepures bija apaļas, šūtas no četriem gabaliem, kas ausu vietã pagarinäti (70. att.). Cepures bija apšūtas ar apmēram $3,5 \mathrm{~cm}$ platu samta sloksnīti vai pelēku jērādiṇu. ${ }^{517} \bar{S}_{1}$ veida vasaras cepures bija apšūtas ar baltām krokotām mežğinēm, kas nầca redzamas $1 \mathrm{~cm}$ platumä.

Pēc J. Broces zīmējumiem spriežot, liekas, Vidzemē ir bijušas vēl citāda veida cepures - ar apal̨u dibenu (skat. J. Broces vidzemnieku kāzu ainu 28. att.).

İpatnēja veida ziemas cepure redzama J. Broces Gaujienas zemnieku apgèrbu zīmējumos. «Latvju Rakstos» šāda veida cepures sauktas par krievu cepurēm. ${ }^{518}$ Cepure, liekas, darināta no lāčādas, tai loti augstas malas. Tā kā šāda veida cepures sastopamas tikai Piebalgā un Latgalē, jā. domā, ka tās šeit atnesuši krievu tautības iedzīvo- 

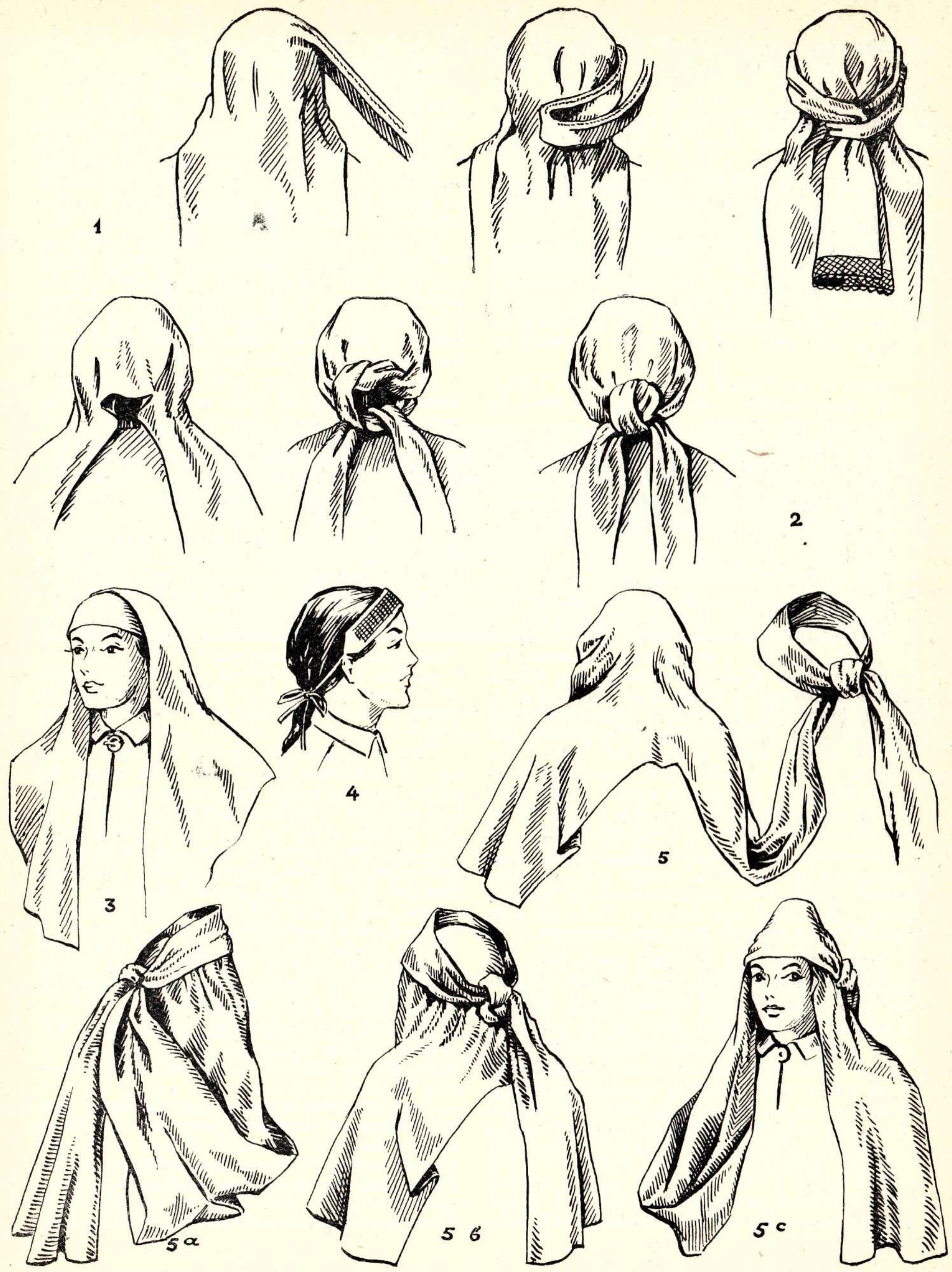

67. att. Galvas auta siešanas veidi: 


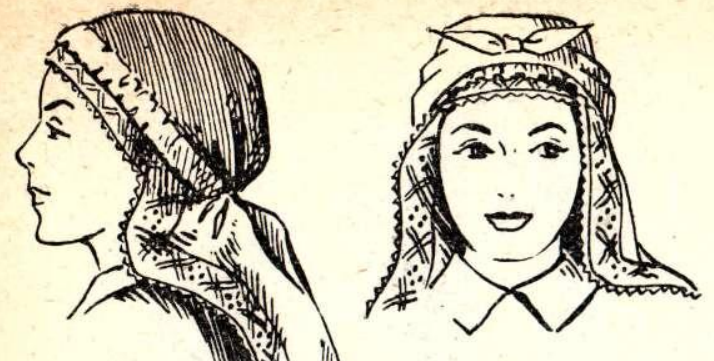

B

11

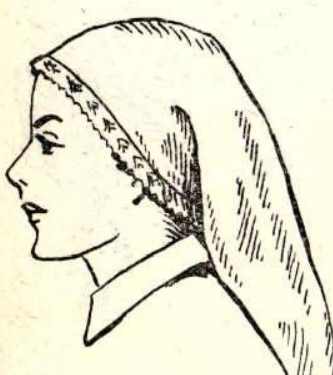

A
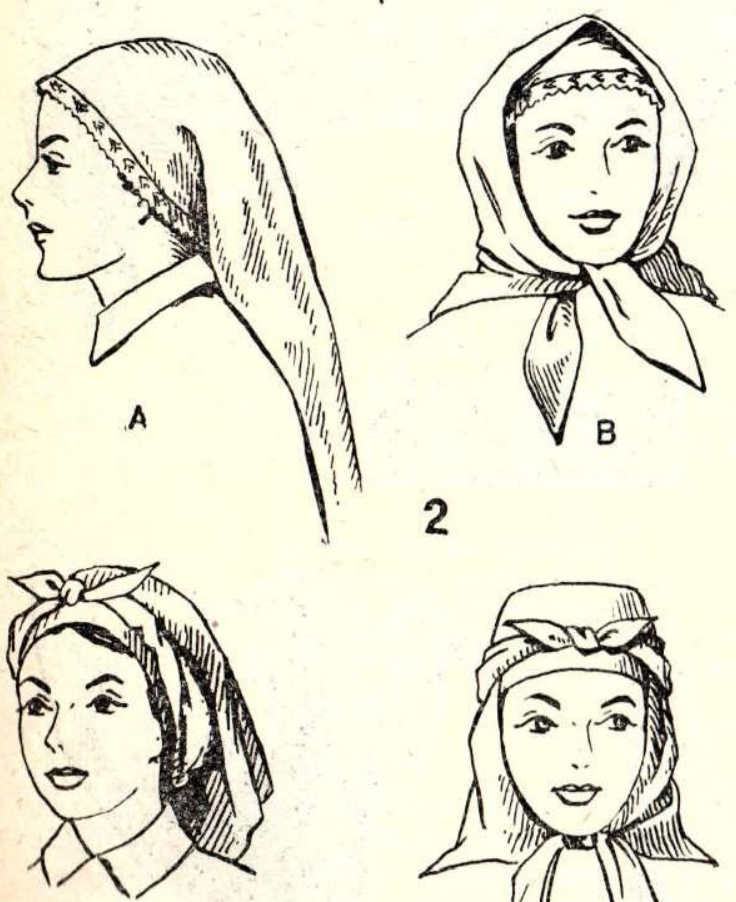

3

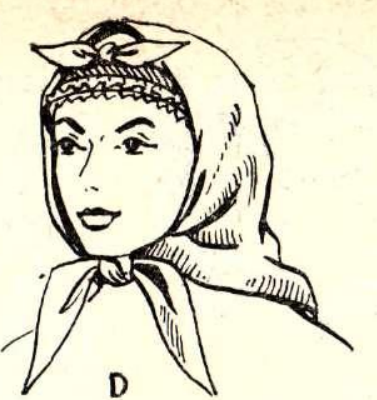

1

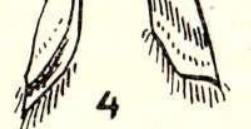

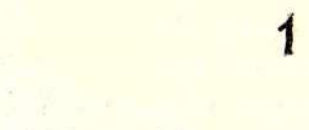

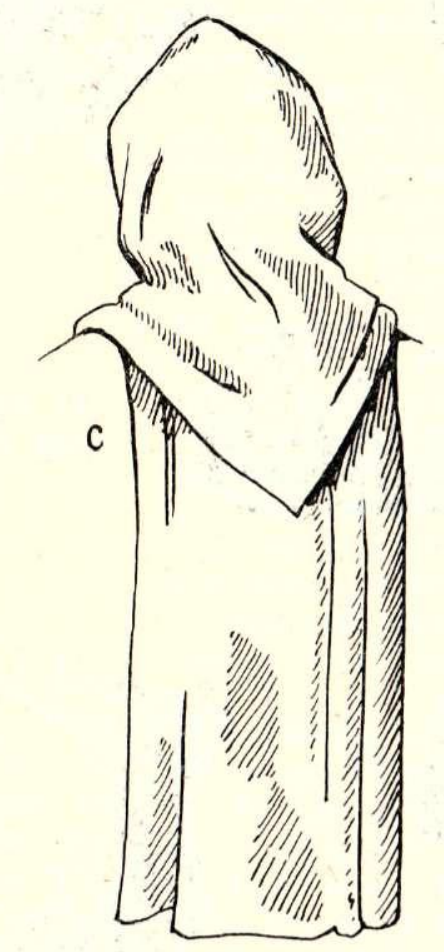
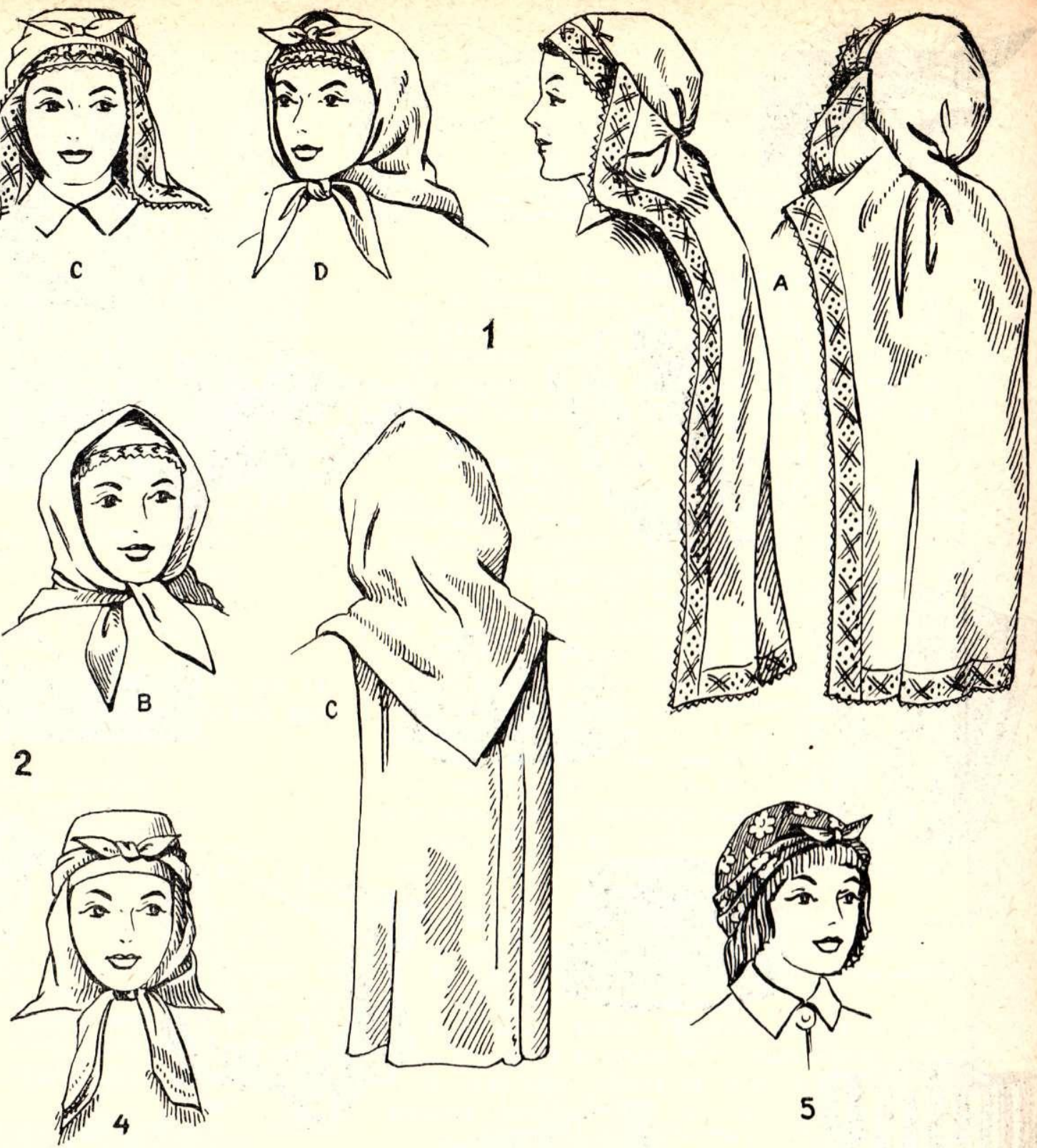

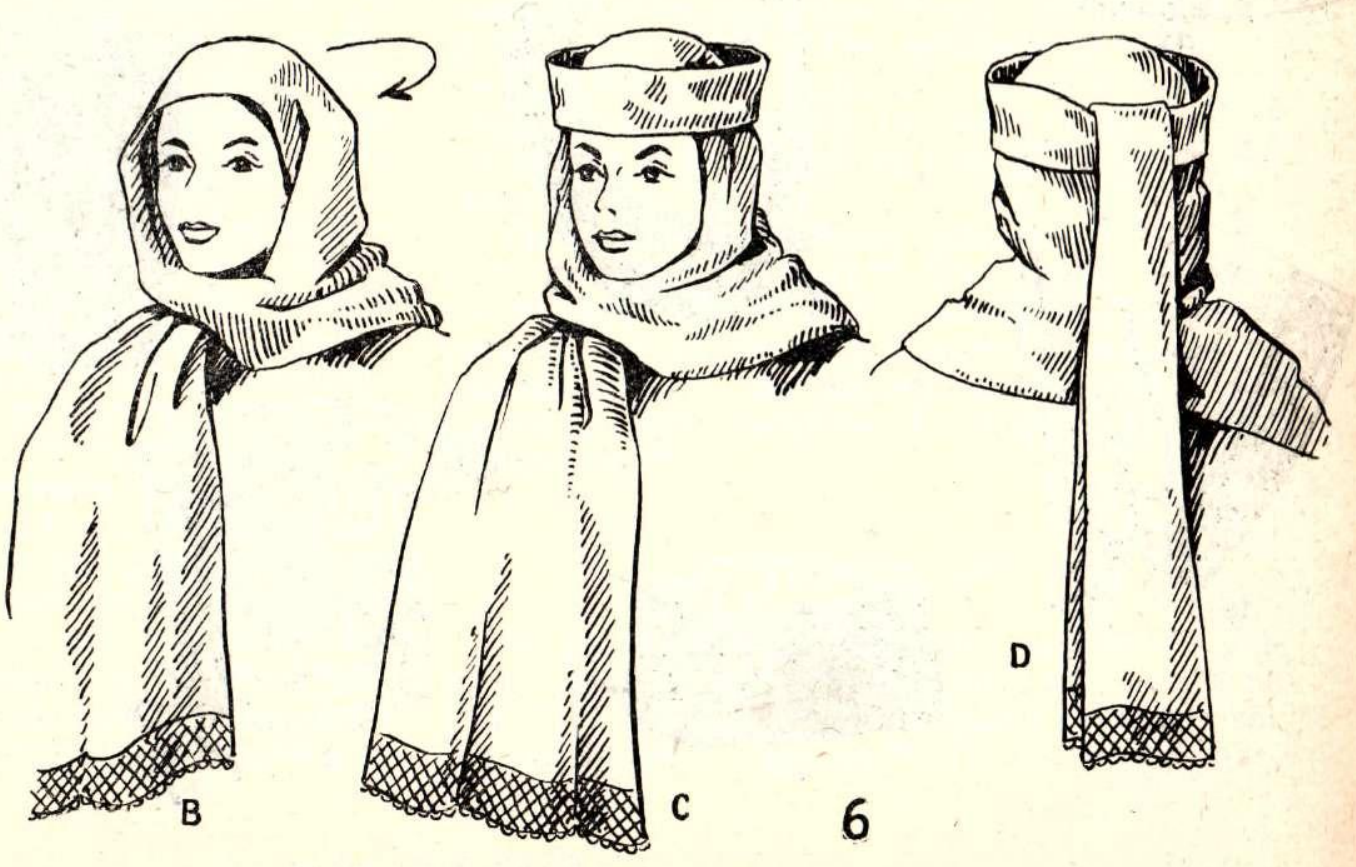



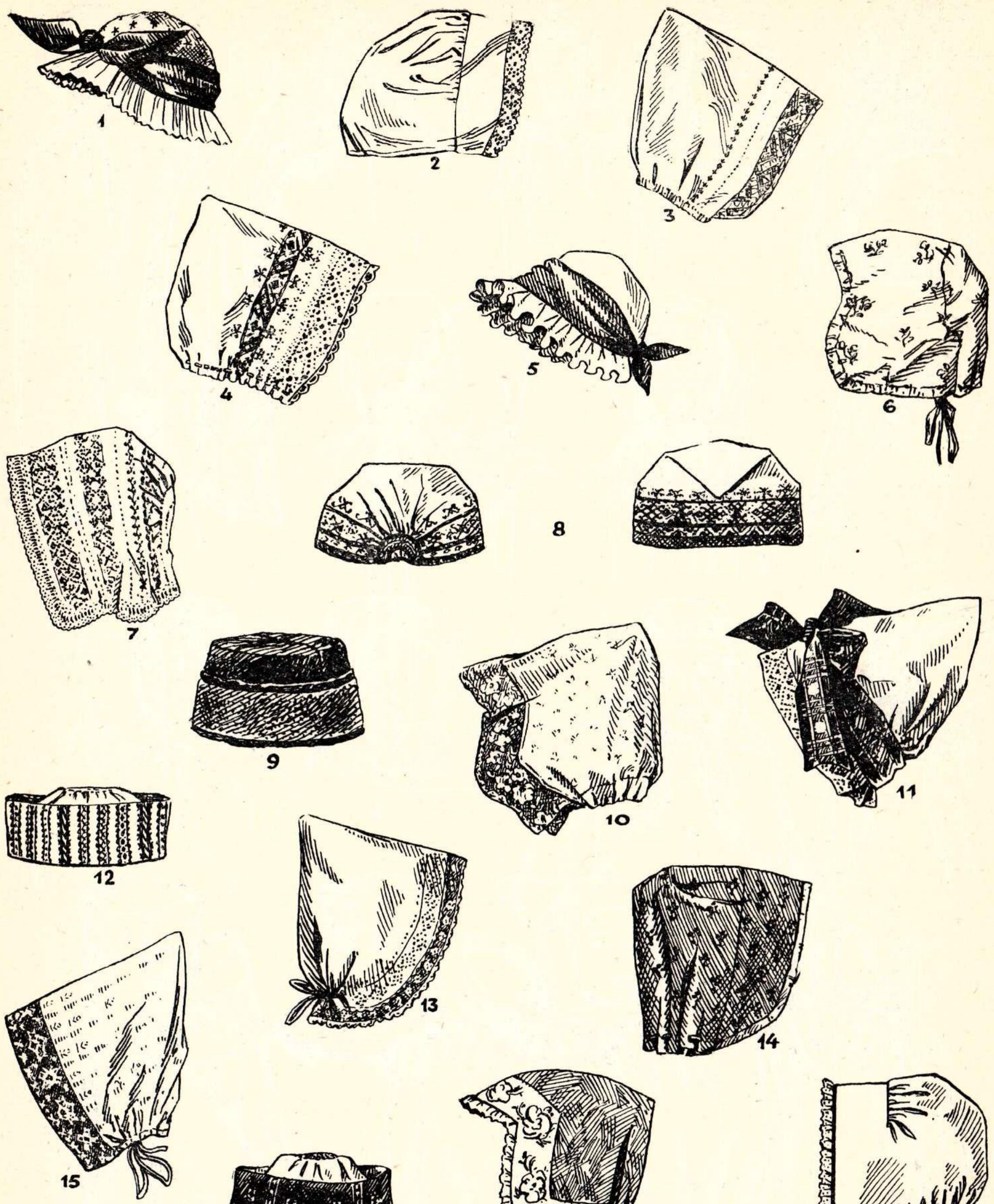


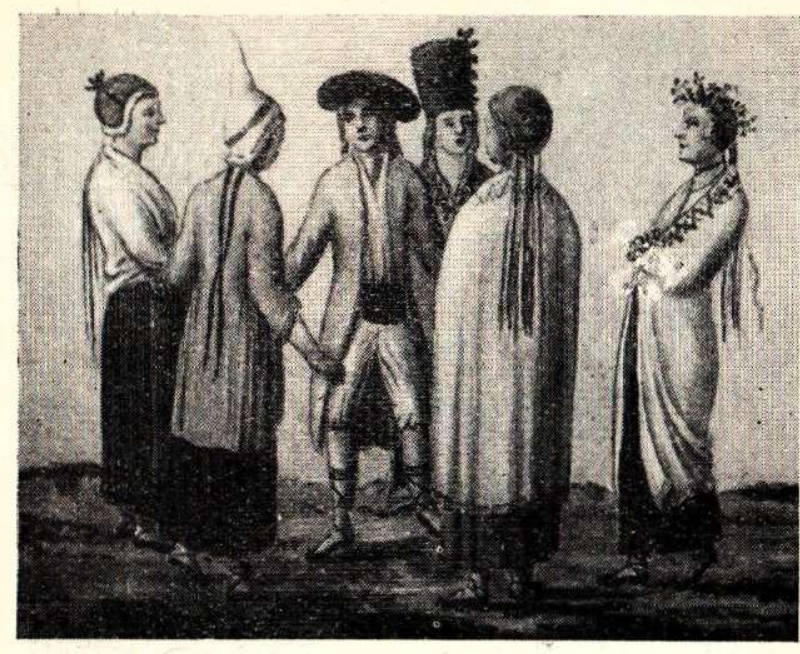

70. att. Sieviešu galvassegas Gaujienā (J. Chr. B rotz e. Monumente..., VI. 5. 1pp.).

tāji, kuri 18. gs. dzīvojuši šajos rajonos. Arī tautasdziesmās bieži vien ir pieminētas krievu cepures..$^{519}$

Es būt' laba krieva sieva,

Būt māmina man' devusi:

Piedien man krievu svärki,

Piedien krievu cepurite.

LTD, X, 1080, 1081

Vīriešu galvassegas. Vīriešu galvassegas nešḳiroja ne pēc valkātāja vecuma, ne ğimenes stāvokḷa. Izškir četrus vīriešu cepuru veidus: ảdas cepures vai cepures ar ādas rotājumu, veltās platmales (ratenes), no salmiem pītâs un adìtās cepures.

$\overline{\mathrm{A}} \mathrm{d}$ a s cepures 18 . gs. sastopamas 4 variantos: pirmkārt, tās bija ausainas ar nolaižamām un uzsienamām «ausīm» (71. att., 1)..$^{520}$ Tās mēdza dēvèt arī par igauñu cepurēm, lai gan nosaukums nav pamatots, jo šĩs formas cepures izplatītas visã Ziemeleiropā.. ${ }^{51}$ Ausainās cepures lielākoties bija darba cepures.

Sì veida cepuru vienam variantam ir neatlokāma zvērādas apmale un samta vai vilnas auduma apal̨š dibens (71. att., 3, 4, 5); spriežot pēc J. Broces zìmējumiem, tās bijušas izplatītākas nekā ādas cepures. Šìs cepures vairāk valkāja godos, svētkos, mazāk - ikdienā un darbā, turklāt tās valkājuši kā vīrieši, tā arī sievietes. ${ }^{522}$

Dažuviet vīriešu ādas cepures darinātas līdzī. gas sieviešu benïtēm un santenēm. Tās cieši piekḷaujas pierei, ausīm un kaklam, tām šaura zvērādas apmale (71. att., 6). Sīs cepures varēja būt šūtas tikai no ādām vai arī no drānas ar ādas rotājumu. ${ }^{523}$ S̄i veida cepures ir vecākās, tām atbilst arheoloǵiskajos izrakumos atrastie cepures fragmenti ar metāla plātṇu rotājumu. ${ }^{524}$ Lie- kas, ka šādā piegriezumā būs bijušas darinātas tautasdziesmās minētās plikcepures:

Kad es biju bandenieks,
Man bij piecas cepurinas:
Div' caunenes, div' seseles,
Balta jēra plikcepure.

LD, 5645

Ar četrstūrainu dibenu darinātās kažokādas cepures «polu gaumē» plašāk valkătas Latgalē, Zemgalē un Kurzemē, kur vēl līdz 18. gs. beigām bija jūtama poḷ ietekme. ${ }^{525} \mathrm{~J}$. Broce rāda vairākus poḷu tirgotājus, kas nākuši uz Latviju tirgoties. ${ }^{526}$ Jādomā, ka poḷu tirgotāji atnesuši arī šīs cepures paraugu.

Otrā veida cepures - veltās platmales jeb ra tenes 18. gs. plaši izplatītas visā Latvijā. Vecākās cepures, t. s. gardibenes, ir ar stipri augstiem dibeniem, kas jaunāka gājuma cepurēm pakāpeniski kḷūst zemāki $(72$. att., $1,6,7)$ un platāki. Šādas platmales valkātas ne tikai godos, bet arī darbā - seru celot, lai akoti nekristu acīs, ${ }^{527}$ utt. Platmal̨u malas varēja būt dažādi uzlocītas. İpatnējas ir trīsstūrveida cepures ar uzlocītām malām, kuras sauc par «trīsstūrenēm» (72. att., 3). Sādas formas cepures 18. gs. sākumā valkāja karavīri un arī civilpersonas. ${ }^{528}$ Arî igaunu zemnieki valkājuši trīsstūrenes, kā to redzam pēc Rīgā aizturēta igauṇu jaunekḷ apgèērba apraksta. ${ }^{529}$

Tautasdziesmâs trīsstūrenes min ar izsmieklu; sevišǩi bieži tās minētas apdziedāšanās dziesmās. ${ }^{530}$

J. Broces latviešu zemnieku zīmējumos trīsstūrenes redzamas tikai Liezeres zemniekiem. ${ }^{531}$

Rietumvidzemē un Rīgas apkārtnē rateṇu malas ir šauräkas ${ }^{532}$ (72. att., 5) .

Kurzemes vīriešu cepurēm dibeni ir zemāki nekā Vidzemes ratenēm, ${ }^{533}$ bez tam Kurzemes platmales bagātīgi rotātas ar zīda lentēm un stikla krellǐšu virknëm ${ }^{534}$ (72. att., 6).

Lìdzīgas platmalēm formas ziṇā ir arī s a $1 \mathrm{~m} \cdot \lambda$ cepures. Salmu platmales 19. gs. sākumä plaši izplatītas visā Latvijā. Tās valkājuši kā vīrieši, tā sievietes. ${ }^{535}$ Salmu cepures ar saules aizsegu priekšā parādās tikai 19. gs. pašās beigās, un tās darinātas pēc tajā laikā izplatīto nagu cepuru pa. rauga..$^{536}$

Vidzemē 19. gs. sākumā valkātas arī a dìt a s c e pures ar puški galä. ${ }^{537}$ Sìs cepures ir vienādas ar Igaunijas salâs pazīstamajām adītajām cepurēm ${ }^{538}$ un, kā liekas, pie mums pārnākušas no Skandināvijas. ${ }^{539}$ Šo cepuru valkāšanai ir loti ierobežots, lokāls raksturs: tās valkājuši kā vīrieši, tā sievietes. ${ }^{540}$

\section{APAVI, ZEKES, CIMDI}

18. gs., tāpat kā iepriekšējos gadsimtos, galvenie zemnieku apavi bija pastalas un vizes, ${ }^{541}$ un tikai 18. gs. pašās beigās turīgākie saimnieki sāk iegādāties ādas zābakus. ${ }^{52}$ 19. gs. otrajā pusē 

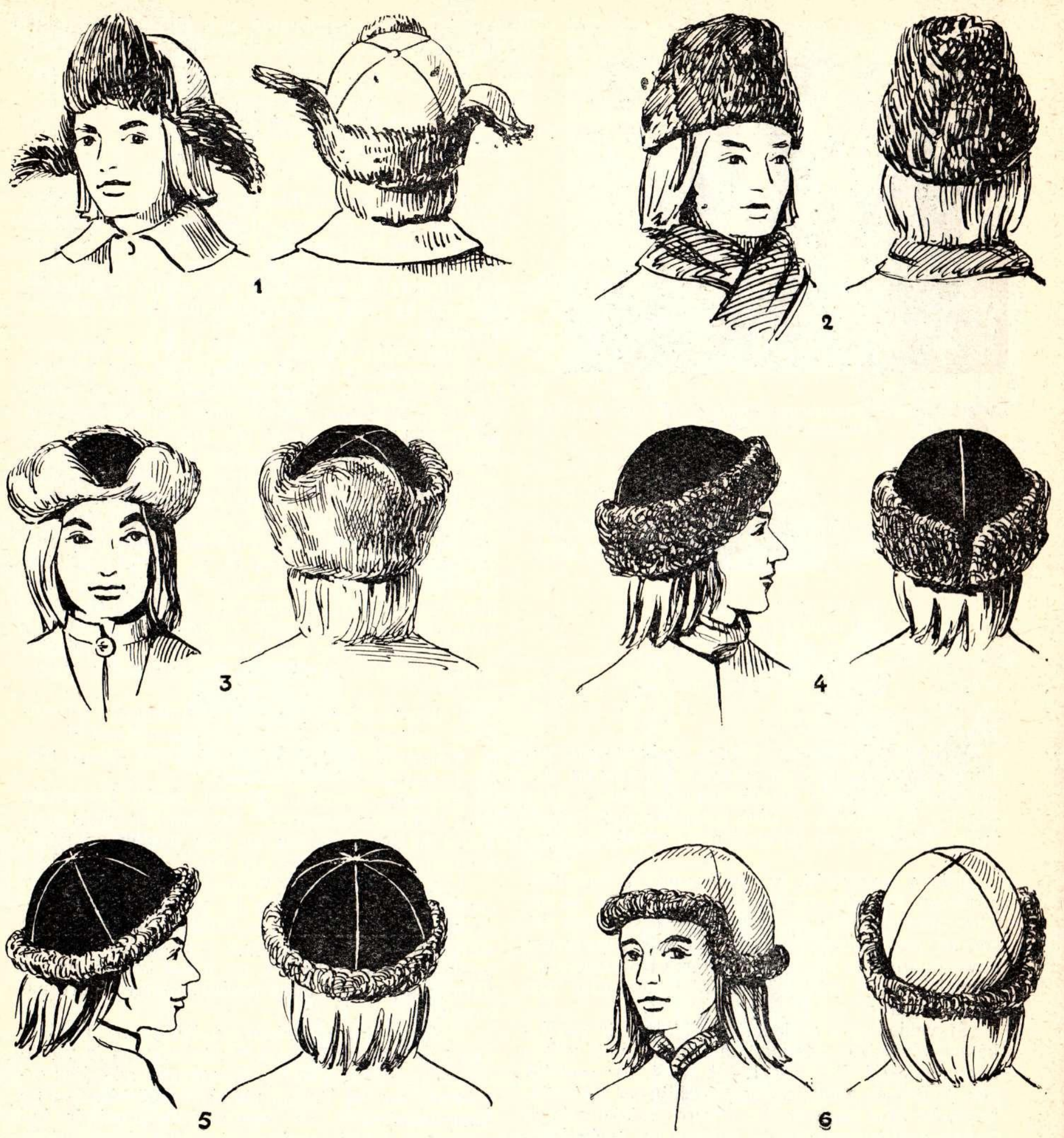

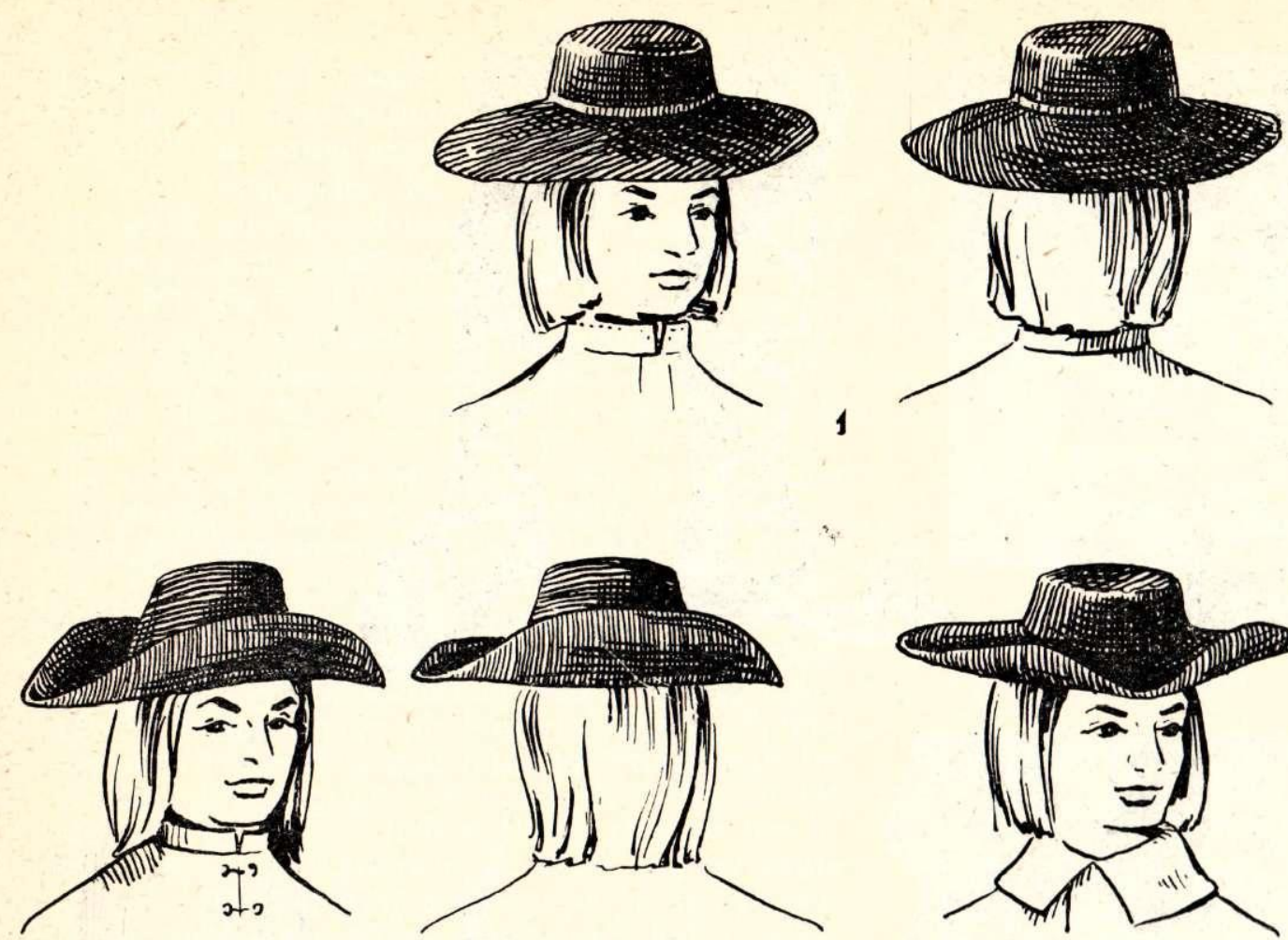

2
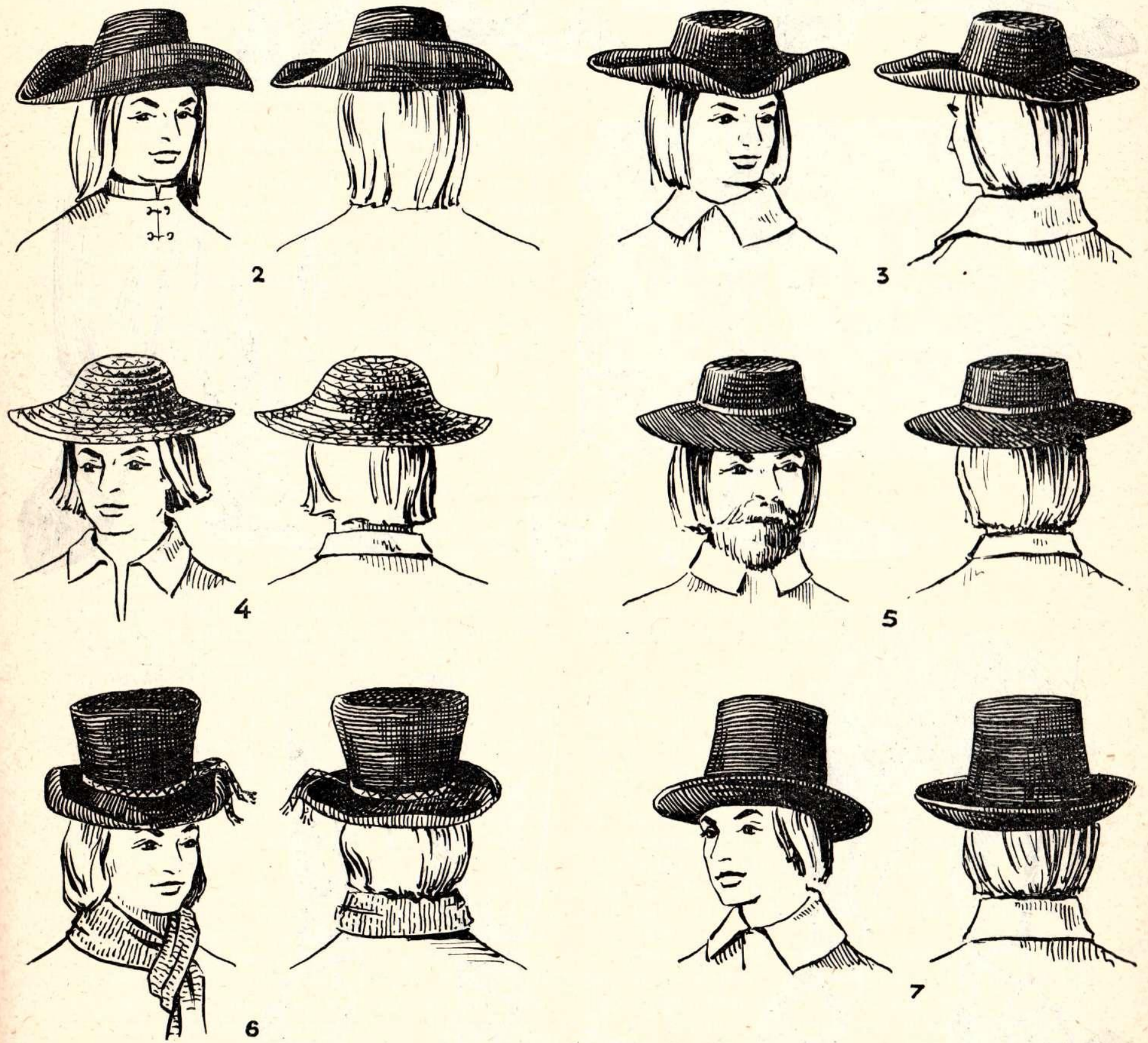

72. att. Vīriešu cepures:

1 -Vidzemes (arĩ Zemgales); 2 - Liezeres; 3 - Zemgales; 4 - sạlmu cepures (visāa Latvijāa); 5 - Riggas; 6 - Alsungas; 7 - Piebalgas 

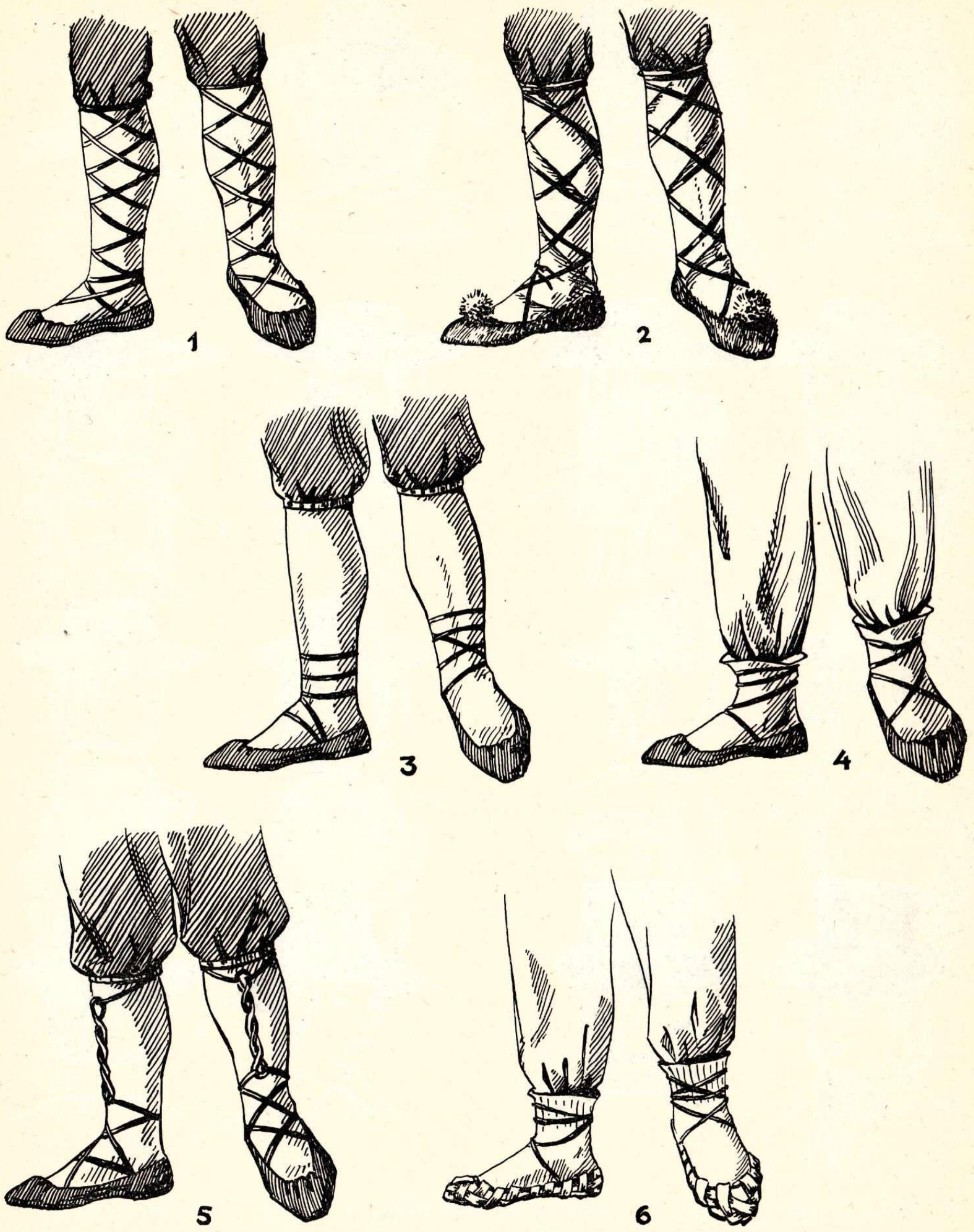

73. att. Kāju aušanas veidi:

1 - Drustu; 2 - nemiecētas ādas pastalas ar pušḳiem; 3 - Erğemes; 4 - Sausnējas; 5 - Tirzas; 6 - vī̌̌u siešana. 
âdas zābaki vai kurpes sāk plašâk ieviesties un tos valkā ne tikai saimnieki, bet arī gājēji, apavus saṇemot no saimniekiem kā daḷu atalgojuma. ${ }^{543}$

Tiesu protokolos 19. gs. otrajā pusē zābaki visbiežāk minēti sūdzībās, kalpiem žēlojoties par neizmaksātām algām; daudz retāk tie minēti mi. rušo personu mantu sarakstos.

Viens no vecākajiem apavu veidiem ir no lūkiem pītas vīzes. Tâs galvenokārt izmantotas kā darba apavi. Trūcīgiem zemniekiem vīzes bija arī godu apavi. ${ }^{544}$ Vìzes pina no liepu un kārklu lūkiem. Paegḷu lūkus vīzēm neplēsa, jo tie nebija tik izturīgi. Lūkus vīzēm parasti plēsa pavasarī «tad, kad kokiem miza vaḷā», t. i., aprîlī un maijā. 19. gs. vidū muižas mežsargs norādīja vietas mežà, kur varēja plēst lūkus. ${ }^{545}$ Tā kā lūku plēšana kokiem bija l’oti kaitīga, tad vietās, kur nebija daudz mežu, materiāla vīžu pišanai nepietika. $^{546}$ Lūkus varēja pirkt arī tirgū, tos pārdeva satītus riteños. ${ }^{547}$ Sagatavojot materiālu vīžu pī. šanai, lūkus sagrieza ar nazi $1 \overline{\mathrm{d}} \mathrm{dz} 2 \mathrm{~cm}$ platās sloksnēs un satina ritenos. Pirms pī̌sanas tos izmērcēja, lai pinot tie nelūztu. Vìzes pina ar kaula adatas palīdzību. Kājās vīzes sasēja ar linu vai kaṇepāju auklām. Vĩzes nopīt prata katrs valkātājs, jo vižu valkāšanas ilgums bija tikai divas, trīs dienas.

Latvijā pazīstamas vīzes ar taisnu pazoles pinumu un slīpā virzienā pītās vīzes, kam cilpas atstātas sānos (74. att., 1). Pirmā veida vǐžu virspuse veidoja lūku cilpas, kurās ievēra auklu vai lūku pavedienu un cilpas savilka, lai vīze piegu. lētu kājai. S̄āda pinuma vīzes izplatītākas bija Augšzemē un Latgalē, bet retāk tās sastopamas Kurzemē un Vidzemē. Tãs līdzīgas lietuviešu un baltkrievu vīzēm. ${ }^{548}$ Slīpā virzienā pītās vīzes vairāk izplatītas Kurzemē un Ziemeḷidzemē, un tās līdzịgas Igaunijā pazīstamajām vīzēm. ${ }^{549}$

Visizplatītākie apavi apskatāmajā laika posmā ir pastalas. Līdz 19. gs. vidum pastalu ādas lielā. koties miecēja mājās, retāk nodeva ādu apstrādātājiem - g̀ēermaņiem; vēlāk ādas nodotas miecēšanai tuvākajās pilsētās. Mājas apstākḷos ādas miecēja šādā veidā: miecējamā baḷā lika vienu kārtu alkšnu mizas, bet otru - pelnus; virs pelnu kārtas lika nodīrātu ādu, pēc tam. atkal sekoja mizu kārta utt. Tā āda raudzēta divas nedēḷs, pēc tam tā bija derīga pastalām. No šādi apstrādātas ādas parasti gan taisija tikai darba pastalas, bet svētdienas pastalām ādu pirka no apkārtcel̨ojošiem tirgotājiem..$^{550}$

Pastalām no ādas izgrieza vajadzīgā lieluma garenu četrstūrainu gabalu. Pastalas purna galā (dažkārt arī papēža galā) ar kaltu iecirta vai iegrieza robus, lai pastalu varētu savilkt, bet ādas gabalam visapkärt izdūra caurumiṇus. Purna galu savilka ar auklu krokās un apgrieza uz labo pusi. Caurumos visapkārt pastalai ievēra linu vai kañepāju auklas, papēža galā katrā pusē izvilka cilpu, ko, kājā aujot, lika krusteniski. Vidzemêt 19. gs. 30. gados bijis paradums sievietēm baz-
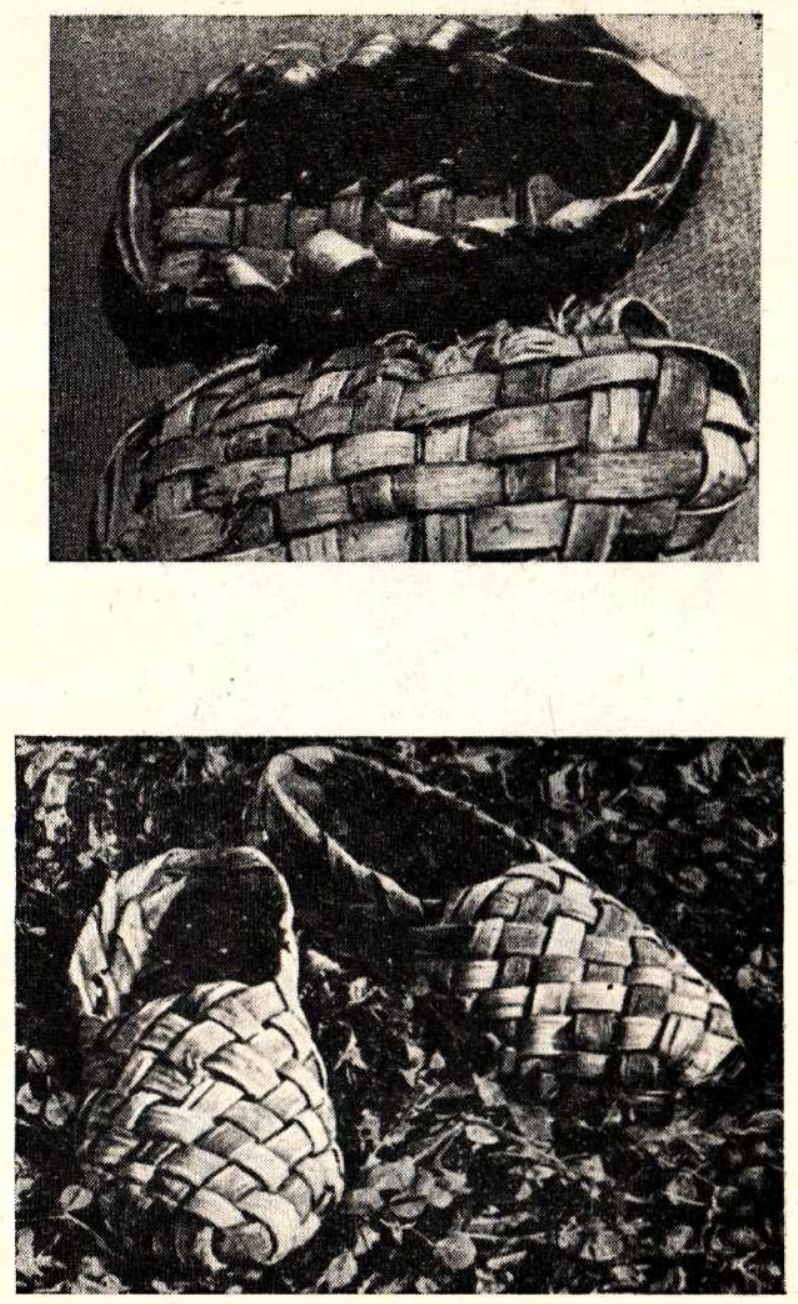

74. att. Vižu veidi:

1 - izplatìtas visā Latvijā; 2 - izplatītas Latgalē.

nīcā ejamo pastalu purnus izgreznot, apšujot tos ar krāsainiem dzīpariem. ${ }^{551}$

Kā vīzēm, tā pastalām auklas vispirms krustoja ap papēdi, tad gar potītēm pēdas virspusē un turpināja krustot tā, lai priekšpusē līdz celim iznāktu divi krusti (73. att., 2). Bijis pazīstams arī cits siešanas veids, kad otrā krustojuma vietā auklas vienreiz sasēja un pēc tam savija vienu ar otru; zem ceḷa savīâs auklas atkal sasēja (73. att., 5). Dažkārt sēja arī trepītē. ${ }^{552}$ Spriežot pēc J. Broces zìmējumiem, gandrīz katrā pagastā bijis savs, raksturīgs pastalu auklu siešanas veids, kas bijis atkarīgs no tā, kādas zeḳes - garās vai īsās bija kâjā un vai kājas bija aptītas ar autiem vai sietavām.

Zemnieku lielā nabadzība un daḷēji arī naturālais saimniecības veids veicināja vǐžu un pastalu ilgo saglabāšanos, ${ }^{553}$ atsevišḳās vietās pat $\operatorname{li} d z$ 20. gs. sākumam. Sevišḳi tas sakāms par gājēju l̦audìm un bērniem, kas pirmās kurpes vai zābakus sanēema, tikai sākot iet skolā vai arī iesvētī̌sanas dienā. ${ }^{554}$ 
19. gs. vidū turīgākajâm saimnieku meitầm vietējie kurpnieki šuva ādas kurpes ar zemiem papēžiem un platiem purniem (75. att.). Viens pāris kurpju pietika visam mūžam, jo tās lıti taupīja un kājās vilka, tikai ejot godos. Ejot uz baznīcu, sievietes vasaru kurpes un zeḳes nesa rokā un tikai pie baznīcas apāva kājas; kājas noāva, arī ejot uz māju. Gandrīz visā Latvijā sieviešu kurpes ir puslīdz vienādas, iznēemums ir tikai Zemgales kur-

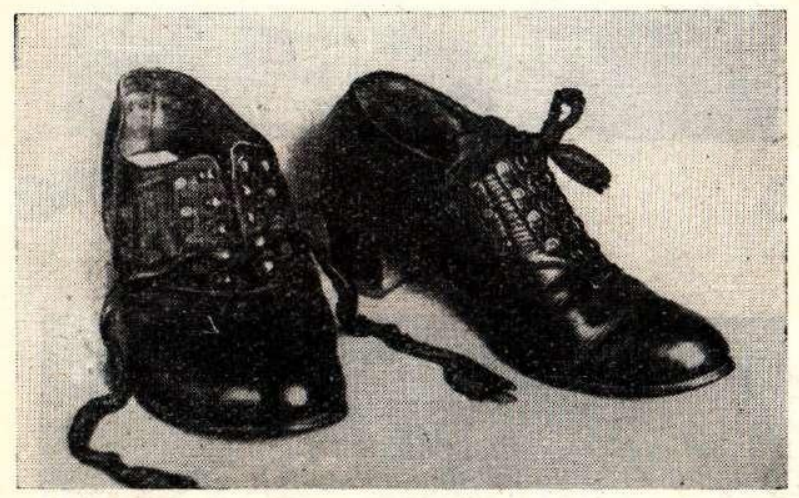

75. att. Sieviešu kurpes 19. gs. otrajā pusē.

pes ar sudraba sprādzēm un Lejaskurzemes kurpes ar metāla apkalumiem. Vīriešiem, kā tas redzåms J. Broces zīmējumos, ${ }^{555}$ arī bijušas kurpes ar sudraba sprādzēm jau 18. gs. beigās.

Îpatnēji apavi, kurus valkāja gan ziemā, gan arī vasarā, ir t. s. čabas, kas sevišḳi plaši pazistamas Vidzemē. ${ }^{556}$ Cabas šuva no nekrāsotas zirga ādas, stipri garas - pāri cę̣iem. Tā kā čabu stulmi nebija cieti, tie nobruka lìdz celgaliem un stilbos sakrokojās. Čabas parasti šuva lielākas, lai ziemā aukstā laikā varētu tajās ielikt salmus.

Veltas tūbas un gumijas apavi apskatāmajā periodā lauku sētās vēl nav sastopami, tie parādās 19. gs. beigās. ${ }^{557}$

Spriežot pēc J. Broces un O. Hūna zìmējumiem, 18. gs. beigās un pat 19. gs. sākumā, liekas, ka zeḳes zemnieku apgēerba komplektā visā Latvijā ${ }^{558}$ aizstāja sietavas.

Sietavas darināja no apmēram $10-15 \mathrm{~cm}$ platas un 1-1,5 m garas lentes, parasti no kāda vecāka novalkāta drēbes gabala. Sietavas sāka tît no pēdas, pašu pēdu atstãjot nenotìtu, un notina kāju stilbus līdz cę̣iem. Zem ceḷa sietavas nosēja ar prievīti vai arī ar sietavas galā piešūtu saitíti, ko aptina ap kāju, galus aizbāžot aiz tinuma. Sietavas nēsāja, gan baznīcā ejot, gan arī darbā. Sietavas sēja arī tad, kad gāja kailām kājām, tāpēc škiet, ka J. Broce, redzot Piebalgas sievas pie baznìcas ar sietavām kājās, uzskatijis sietavas par garām biksēm. 559

Izplatīts latviešu zemnieku kāju apaušanas veids bija arī kāju aptī̌̌ana ar autiem. Vasarā kājas aptina ar baltiem linu autiem, bet ziemā - ar tumšiem (pelēkiem) vilnas autiem. Autus darinãja no $40-60 \mathrm{~cm}$ platiem un 1,5-2 $\mathrm{m}$ gariem auduma gabaliem, pie kam aptina kā pēdas, tā arī stilbus.

Sievietēm īpašus autus neauda, bet tos pagatavoja no izvalkātiem brunčiem vai krekliem. Tā kā parasti kāju lielus notina ar sietavām, tad autus sāka tīt no potītēm, kur sietavas beidzās, nedaudz skarot arī sietavas, un notina visu kājas pēdu. Dienvidkurzemē sievietes tina autus un sietavas vairākās kārtās un pāri vilka adītas zeḳes, lai kājas izskatītos resnākas. No vienas puses, šu parādību var izskaidrot ar zināmu tā laika paražu, jo arī dienvidlielkrievi mēdza aptīt kājas ar 3-4 pāriem autu. ${ }^{560}$ No otras puses, Dienvidkurzemes brunči ar rupju linu auklu vai apšuvumu gar brunču apakšejo malu, kā arī paraža valkāt brunčus îsākus - līdz pusstilbiem - radijja nepieciešamību kāju stilbus notīt vairākkārt, jo pretējā gadījumā brunču mala varēja noberzēt kāju stilbus. Liekas, ka pēdējais apstāklis būs svarīgāakais iemesls tam, kāpēc Dienvidkurzemē kājas aptītas ar vairākiem autiem. Ukraiṇi un igauṇi ti. nuši kājas ar sietavām līdz potītēm. ${ }^{561}$ Kăju aptīšana ar autiem un sietavām saistīta arì ar vīžu un pastalu valkāšanu: tās bija pietiekami lielas un ērtas, tāpēc autu tinumi nenospieda kājas. Arī valkājot garos zābakus, vajadzēja kājas aptīt ar autiem. Autus valkāja ne tikai ikdienā; ar autos tītām un vīzēs apautām kājām gāja arī baznīcā trūcīgākie zemnieki vēl 18. gs. Turīgākie kājās sāka vilkt zeḳes.

J. Broce, aprakstot Dzērbenes zemnieku, atzīmē, ka tas sevišḳi izceḷas ar savām zilajām zekēm, ko uzvilcis pāri ceḷgaliem. ${ }^{562}$ 19. gs. zekes jau valkā ne tikai pie goda tērpa, bet arī darbā, tikai pēdējās bija no rupjākas dzijas un bez rakstiem. Ziemā parasti valkāja pelēkas vilnas zekes, bet vasarā - linu vai pakulu diegu zeḳes. Šai laikā zeḳes valkā arī kalpones. Saskaṇā ar lịgumu saimniekam bijusi jādod vilna un brīvs laiks vakaros, un meitas pašas noadījušas sev zeḳes. ${ }^{563}$

Vecākās zeḳes adītas kulītes veidā - bez papēža ${ }^{564}$ Bijuši pazīstami divi zeḳu veidi: garās -līdz celiem un ĩsās - līdz potìtēm vai nedaudz virs tām. Katră novadā bija savi iemīloti zeḳu raksti un krāsu toṇi, kas pieskaṇoti pārējām tērpa sastāvdaḷām (skat. 22. tab.).

Vasarā pie goda tērpa sievietes valkāja caurumotā adījumā adītas linu diegu zeḳes. Visgreznākie caurumoto zeķu raksti ir sastopami Nìcä, Bārtā un Rucavā. Ventspils novadā caurumotās zeḳes adītas ar krāsainām svītrām.

Vilnas zeḳes adīja vai nu gluži baltas, vai arī raibas labiskā vai rievainā (sviḳelainā) adījumā. Vidzemē parasti garās goda zeḳes adīja baltā krāsā ar nelielu rakstu josliṇu zeḳes sākumā. Kurzemē un Zemgalē vairāk pazīstamas raibās zeḳes. Viskošākie zeḳu adījumi sastopami Alsungas novadā. Alsungas novada zeḳes kā pēc rakstiem, tā krāsām līdzīgas igauṇu zeḳēm. ${ }^{565}$ Sai 

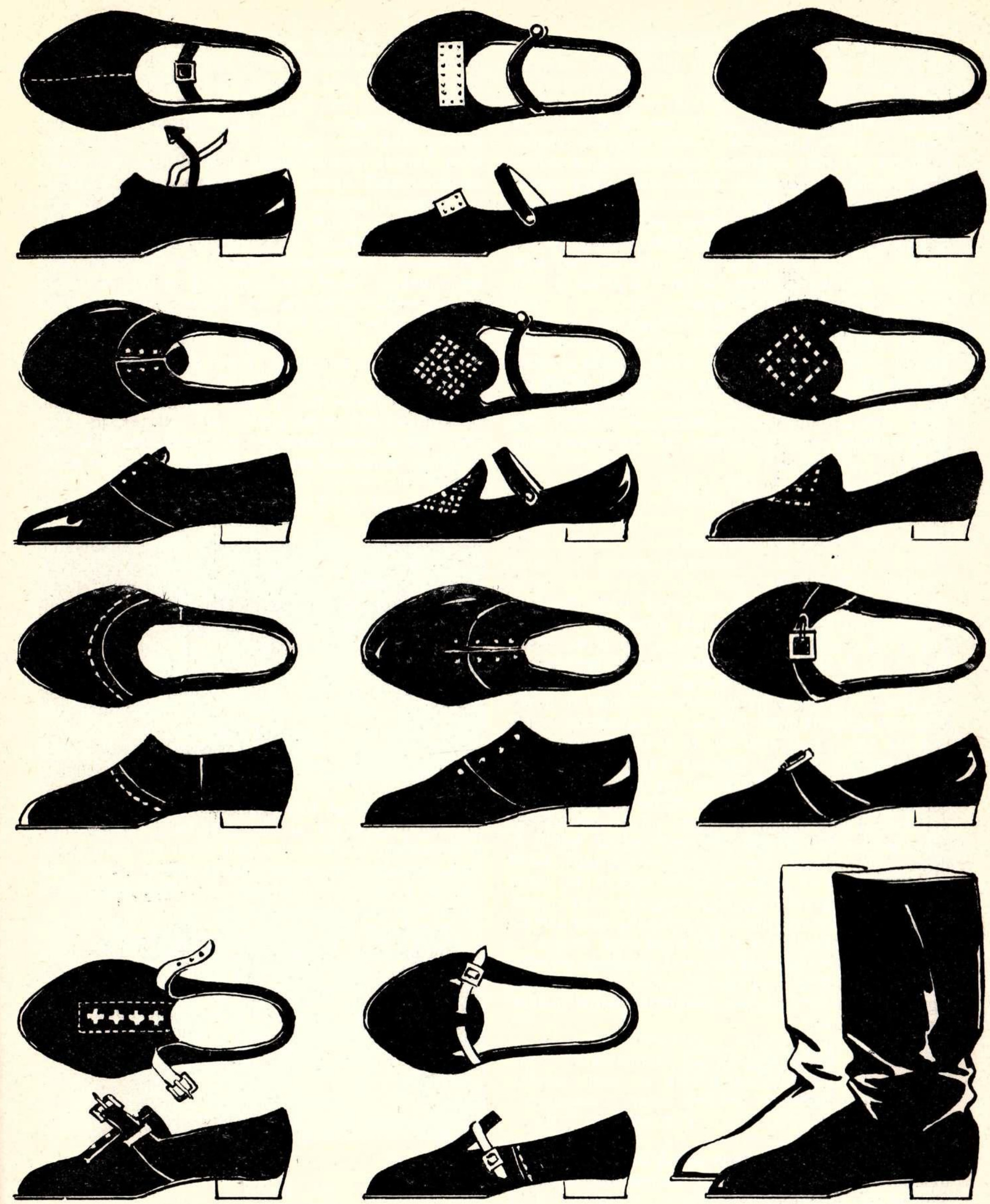

76. att. Apavi (no kreisās uz labo): 1 - Latgales, Vidzemes, Augšzemes sieviešu kurpes; 2 - Zemgales sieviešu kurpes; 3 - Ziemelvidzemes sieviešu kurpes: 4 - Latgales kurpes; 8 - Alsungas viriešu un steviešu kurpes; 9 - Austrumkurzemes sieviešu un vīriešu kurpes: 10 - Dienvidkurzemes viriešu kurpes; 11 - Zemgales viriešu kurpes; 12 - Latgales un Vidzemes vĩriešu zăbakị. 
līdzībai nav tikai gadījuma raksturs, bet, kā jau minēts, tā vedama sakarä ar lỉbiskajām iezīmēm Rietumkurzemes apğērbā.

Zemgalē izplatîtas ir melnas zekeses ar baltiem «rozišu» rakstiem. Ipatnējs svītru un rakstu salikums ir Ziemel̨urzemes lïbiešu sieviešu zekēm. Latgales garajām zeḳēm raksts novietojies potītes vietā un pēdas virspusē. S̄āda veida zeḳu raksta novietojums pārējā Latvijas teritorijā nav sastopams. Isās zeķes, t. s. kapzeḳes, parasti adíja vienkrāsainas ar rakstainu valni. Tās valkāja galvenokārt vīrieši. Lai garās zeḳes neslīdētu uz leju, tās zem ceḷa apsēja ar austām vai pītām prievītēm - lielsaiškiem, ūzbantēm.

Cimdu rotājumi bija daudz bagātāki un greznāki nekä zeḳu raksti (skat. 23. tab.). Izšḳirami darba, goda un dāvināmie cimdi. Darba cimdus parasti adỉja sīkiem rakstiem pelēkā vai brūnā pamatā ar baltiem vai kādas citas krāsas rakstiem. Goda cimdus adīja ar platiem rakstainiem va!ñiem un bārkstīm, Dāvināmos cimdus katrai vajadzībai adīja citādus. ${ }^{566}$

\section{Es adiju raibus cimdus, \\ Bërzināā lūkojoti; \\ Cik lapinu bềrzināa \\ Tik raibumu cimdiṇā.}

LTD, 7239

Kurzemes cimdiem raksturīgi lieli, spilgtās. krāsās adīti raksti. Vidzemes cimdiem raksti ir sīkāki, to krāsas nav tik spilgtas, un tanīs sastopama ļoti dažāda adījuma tehnika. İpatnēji cimdi ar virsū šūtu rakstu sastopami Zemgalē, Bauskas apkärtnē. Arī Igaunijā pazīstami cimdi ar uzšūtiem rakstiem. Tāpēc, liekas, ka šo cimdu veidu latvieši būs pārṇēmuši no t. s. krieviṇiem, kuri dzīvojuši šai rajonā. Cimdus adījuši ne tikvien kāzām, kur līdz ar zeḳēm tie bijuši galvenā velte, bet tos dāvināja arī citos gadijjumos. Tã iesvētāmai meitai bija jädod pa cimdu pārim mācītājam, ērğelniekam un zvaniḳim, ${ }^{567}$ arī lìgavai, ejot «rādìties», vajadzējis dot mācītājam cimdu pāri, ${ }^{568}$ täpat precībās - saderinoties - meitai bija jāapveltī līgavainis un precinieki ar cimdiem un zek̄em.

Ja meita bildinājumu pien̦ēma, tā sūtīja līgavainim kā dāvanu cimdus, līgavaina tēvam kreklu, mātei - garās zeḳes, preciniekiem arī cimdus, tikai pēdējie bija vienkāršāāā adījumā nekā līgavaiña cimdi. ${ }^{569}$ Lìgavaiña cimdus adijja ar dzelteniem dzīpariem:

\section{Es cimdinus neadǐšu \\ Bez dzeltena dzīpariṇa: \\ Zinu savu arājinu \\ Dzelteniem matiniem.}

$$
\text { LTD, } 7259
$$

Pūra vedējam uz pūra uzlikti cimdi, zeḳes vai dvielis. Pie püra vedēja zirgiem un lokiem dažuviet sējuši prievītes. Arī lìgavas vedējam deva cimdus un dvieli.

Tãpat kā vīra tēvs un māte, arī vīra brāḷi kāzās no līgavas saṇēmuši cimdus, kreklu, zeḳes vai dvielus. Citiem radiem dāvinăti cimdi, zekes, jostas. Cimdus un zeḳes pie jostas piesējuši tā, ka, jostu krustiski pār muguru uz priekšpusi apñemot un priekšpusē sasienot pušksī, viena no veltè̉m cimdi vai zeḳes - karājušies muguras pusē, bet otra priekšpusē. Parasti cimdiem un zekēm pie kāta atstāts garāks uzmetuma diega gal̉s, kuru sameta pīnìtē un ar to sasēja abus cimdus kopā.

Kāzās vīramāte ar citām kāziniecēm dziedādama vedusi jauno saimnieci pa visu saimniecíbu. kur jaunā sieva ik uz soḷa ziedojusi cimdus un prievītes - ieejot istabā, cimdi atstāti uz sliekšna un pavarda, tāpat cimdi atstāti uz katras saimniecības ēkas sliekšña. Uz laidara, aitu un cūku kūts sliekšṇa ziedotie cimdi pienākušies ganam, bet pārējās veltes pēc tam uzlasījusi vĩramāte. Kāzu nedēlas sestdienā jaună sieva un vĩramāte iet pirtī, kur vedeklai atkal jāziedo daudz cimdu un jostu. Cimdus liek uz pirts sliekšna, uz lāvảm, uz krāsns, ar jostām apsien pirts slotas, jo tādē. jādi tiekot nodrošinātas laimīgas dzemdỉbas. ${ }^{570}$ Līgavai cimdu pāris bija jāatstāj arī pirts kūrējam. ${ }^{571}$

Sena paraža, kas vēl ilgi saglabājās un plaši pazīstama visā Latvijā, atskaitot Latgali, ir cimdu dāvināšana kalējam par jauna zirga apkalšanu.

Nepieciešama velte cimdi bija arī bēru gadījumā. Piemēram, bēru dienā, kad mirušo iznesa, lai vestu uz kapiem, tuvinieki uz šḳirsta lika cimdus, kas pienācās zārka nesējiem.

Cimdus valkāja ne tikai ziemā, bet arī vasarâ svinīgos gadījumos, pie kam cimdus aizbāza aiz jostas tā, lai tie būtu labi redzami. ${ }^{572}$ Jaunais pāris apvilka baltā pamatā ar krāsainām vilnas dzijām adītus pirkstainus cimdus, kuru galos bija platas bärkstis. Raksta krāsas bija pieskañotas villaiṇu raksta krāsām. Dažuviet jaunais pāris cimdus atstāja rokās, arī ēdot pirmo maltīti. Pirkstainiem cimdiem bija izrakstits valnis un plauksta, bet paši pirksti atstāti gluži balti. 19. gs. vidû, pakāpeniski izzūdot senajäm kāzu un bēru paražām, mazinās balti rakstaino cimdu skaits, un 19. gs. beigās tie ir retums, kas saglabājies vairs tikai retā pūra lādē.

Tātad līgavai bija nepieciešams loti daudz cimdu un zeḳu, ko nevarēja noadìt viena vai divu gadu laikā, tāpēc meitas sāka adīt sev pūra cimdus, jau ganos iedamas, lai līdz kāzām būtu noadīti vismaz 20 vai 30 pāri. Ja nebija noadīts vajadzīgais cimdu skaits, meitu izsmēja.

Lai veicas, kas veicas,

Adī̌ana man veicas:

Par trīs gadi cimdu pāri

Kā margot nomargoju.

LTD, 7284

Pie vīra, pie vīra

Kā visas meitas!

Puscimda pūrā,

Pusotras zekses.

LTD, 7789 
Kalpones pûrā, protams, nebija tik daudz cimdu pāru, un nebija arī vajadzības pềc tiem, jo tai nebija daudzo saimniecības ēku un dārzu, kur būtu jāmet veltes. Pārējos gadījumos kalponei tāpat bija jādod cimdu pāri u. c. veltes. ${ }^{573}$

19. gs. otrajā pusē mirušo mantu sarakstos cimdi un zekes minēti samērā reti un tad arī tikai nelielā skaitā - pa 2-10 pāriem. Trūkst arī sī. kāku aprakstu, vài šie cimdi bijuši vienkrāsaini vai arī rakstaini. Latvijas PSR Vēstures muzejā esošās cimdu kolekcijas ļauj secināt, ka cimdu bagātā ornamentācija šai laikā attīstās tālāk. Lauku sētās ieviešoties kīmiskajām krāsām, krāsu zieds cimdos kḷūst spilgtāks, bet vecais ornaments turpina dzīvot un tālāk attīstīties vēl šodien.

\section{ROTASLIETAS}

Sieviešu apğērbā liela nozīme bijusi rotaslietām. Dažām rotaslietām vienlaikus bija arī praktiska nozīme - ar tām varēja saspraust apgèērbu, tās lietotas jostu savienošanai (piemēram, saktas un vīriešu jostu sprādzes), turpretī citām, piemē-

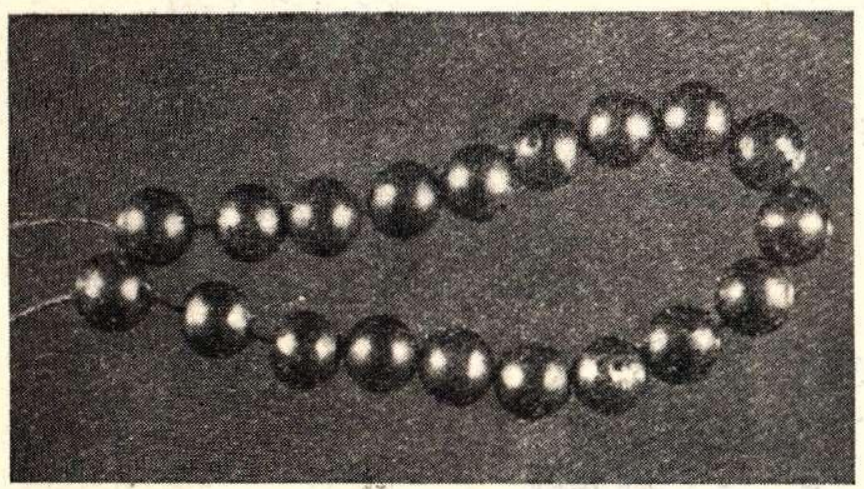

1

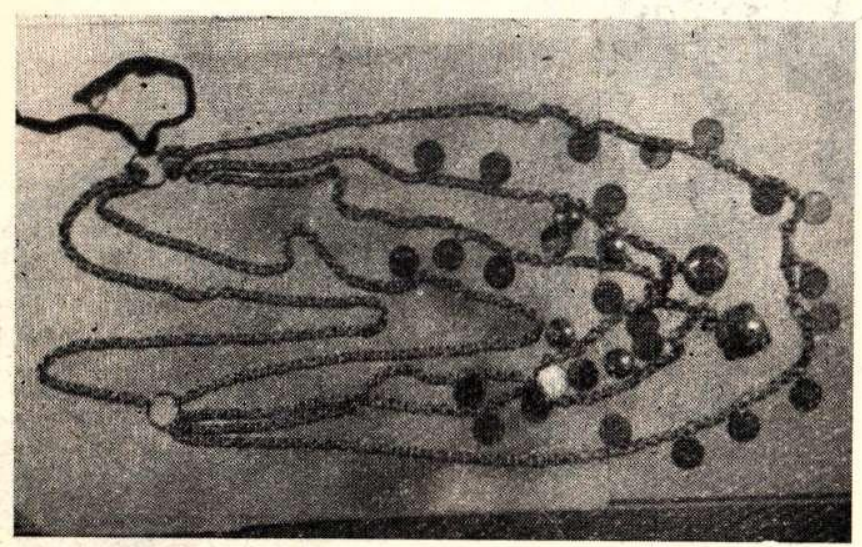

2

77. att. Kakla rotas: 1 - Zemgales krelles; ${ }^{2}$ - Monētu kakla rota (no Pečoras; šãdas
monētu kakla rotas min ${ }^{2}$. Broce lielvārdiešu têrpa aprakstā) (Latvijas PSR Vēstures muzeja materiāli). ram, krellēm, gredzeniem, ir tikai rotājošs raksturs.

Bagātu materiālu par rotaslietām dod arheoloğiskie izrakumi un dažādi zīmējumi un apraksti, bet par 18. un 19. gs. rotām - mūsu rīcībā esošais etnogrāfiskais materiāls.

Viens no latviešu amatiem, kas pirms vācu iebrukšanas 13. gs. bija sasniedzis augstu attīstibas limeni, bija rotkal̨u amats. Arheologiskajos izrakumos atrastās sudraba un bronzas rotaslietas ir tehniski labi izstrādātas. Pēc vācu iebrukuma rotaslietu daudzums kapu laukos strauji samazinās; latviešiem nonākot verdzības jūgā, sašaurinās arī latviešu rotkaḷu darbības apjoms. Tomēr rotkaḷi savu darbību turpina, izveidojot ipatnēju rotu stilu, kas saglabājies vēl līdz mūsu dienām. Rotkaḷu darbs šai nozarē izbeidzas tikai 17. gs. Laikā no 13. līdz 17. gs. latviešu lietotās saktas ir latviešu rotkal̨u ražojums. Rīgā vēl 16 . gs. pastāv latviešu saktu kalēju amats, kam ir tiesības gatavot un tirgoties ar pašu gatavotām saktām un spraudēm. ${ }^{574}$

Pazistamais saktas tips, käds uzglabājies līdz. mūsu dienām, izveidojies 17. gs. pašā Latvijā uz iepriekšējo gadsimtu rotu pamata. Vācu zeltkaḷi tikai pārnēema latviešu saktu kalēju izstrādātos tipus. 17. gs., kad sudraba un zelta lietu izstrādā. jumu ražošana pilnīgi koncentrējās Rīgā zeltkaḷu amata rokās, vācu zeltkaḷi joprojām gatavoja dokumentos apzimētās «Bauer-Bretz», «WepenBretz», t. i., zemnieku saktas, villainu saktas pēc latviešu saktu kalēju paraugiem. Rỉgas vācu zeltkaḷi, pārṇemot šo nozari, pārkāpa pat zeltkalı šrāgu pamatnoteikumus un zelta un sudraba rotaslietās iekala viltotus akmeṇus, latviešu sudraba saktās liekot krāsainus stiklus.

Sudraba un zelta saktu formas, vismaz Rīgā, amatam pārejot vācu zeltkalu rokās, sastingst noteiktās, jau latviešu saktu kalēju izstrādātās pamatformās. ${ }^{575}$

Vācu zeltkaliem laikā no 17. līdz 19. gs. latviešu îpatnējās rotaslietas ir tikai tirgus prece, tāpēc tie centās iztapt latviešu gaumei un prasībām. Līdz ar to šajās rotaslietās vācieši sargājās ieviest kādas lielākas pārmainas, bet strādāja pēc vecajiem latviešu rotkalu paraugiem. Tātad nav nekāda pamata par latviešu rotaslietu veidotājiem uzskatìt vāciešus, lai gan vairākos gadijjumos saktu otrā pusē ir vācu meistaru zīmes un paraksti.

17. un 18. gs. autori sniedz ziñas arī par latviešu rotaslietăm. Tâ, piemēram, J. Brands bez saktām min vēl gredzenus, ${ }^{576}$ bet A. Hupels apraksta divus saktu tipus - ar burbuliem un krāsainiem akmeṇiem. ${ }^{577}$ Bagātus materiālus par rotaslietām sniedz arī Kurzemes baznīcu hronikas; tās liecina, ka dažādas saktas un gredzeni piederējušas vairākām ğimenēm. Hronikăs ir minētas arị rotaslietu cenas, piemēram, «lielās saktas maksā 8 albertdālderus, bet mazās -2 dālderus». ${ }^{578}$

Par krieviṇu rotaslietām interesantas ziñas sniedz J. Šegrēns, pasvītrojot, ka 1846. g. (t. i., 

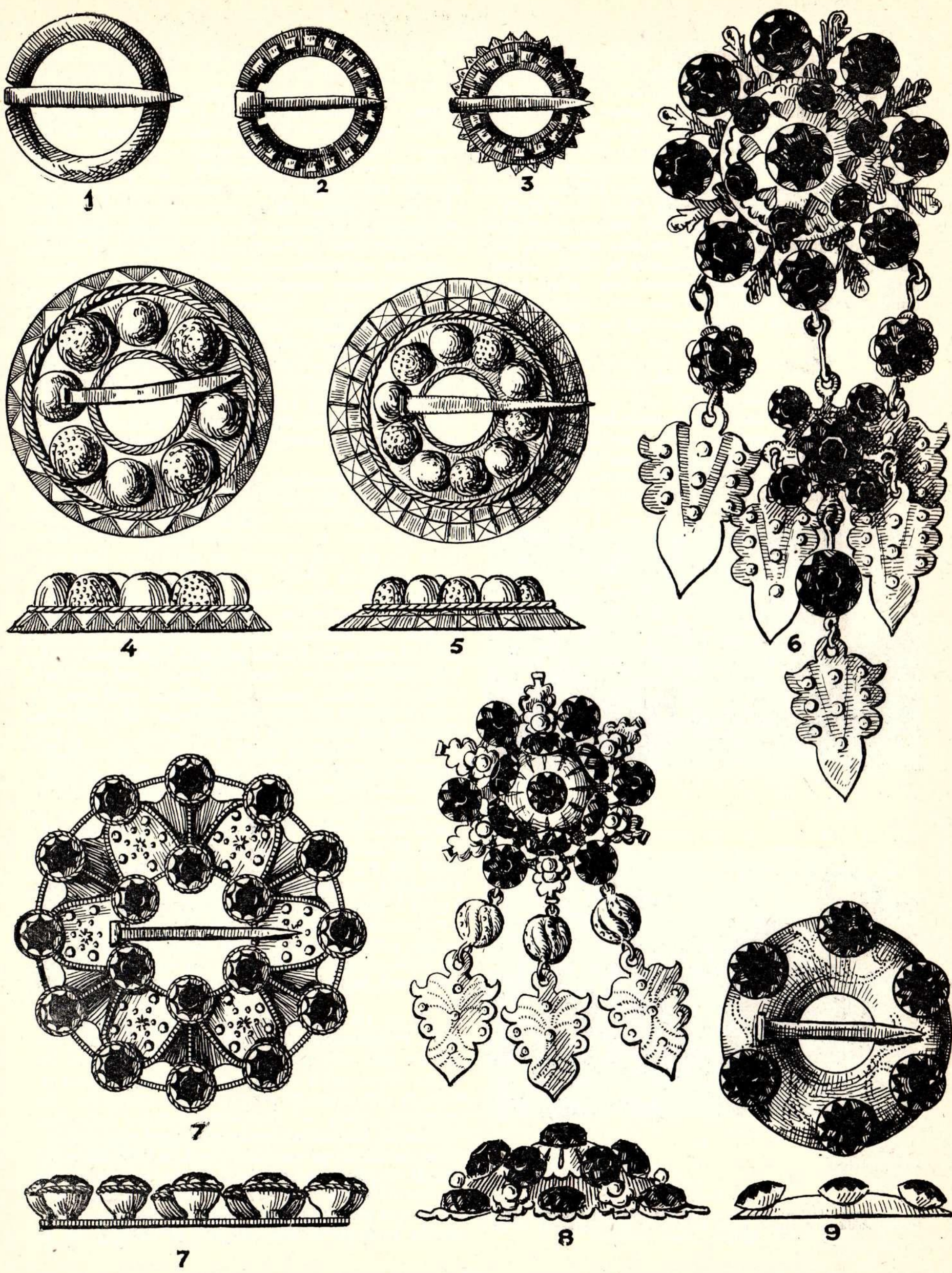

78. att. Vidzemes saktas:

1-3 - Krustpils kreklu saktas; 4-5 - Krustpils villainu saktas (1:2); 6-7 - Austrumvidzemes; 8 - Krustpils; 9 - Lielvārdes. 

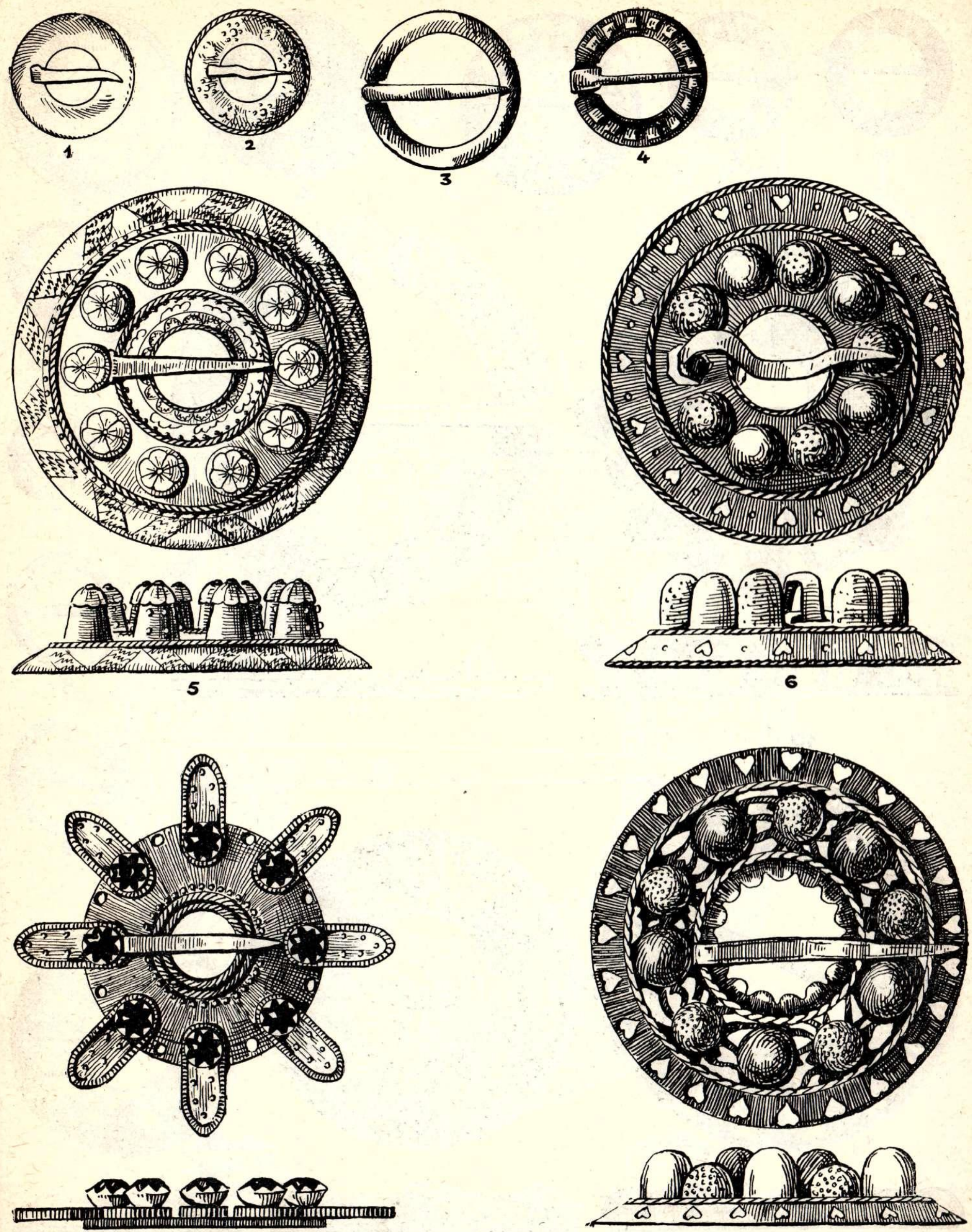

79. att. Zemgales un Augšzemes saktas:

1, 2 - Zemgales kreklu saktas; 3, 4- Augšzemes kreklu saktas; 5, 6-Zemgales villainu saktas; 7 - Jēkabpils saktas rekonstrukcija pẽc O. Hūna zĩmējuma; 8 - Augšzemes villaiṇu sakta. 


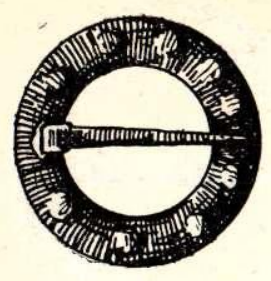

1

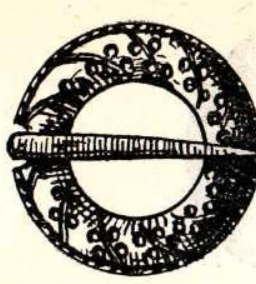

2

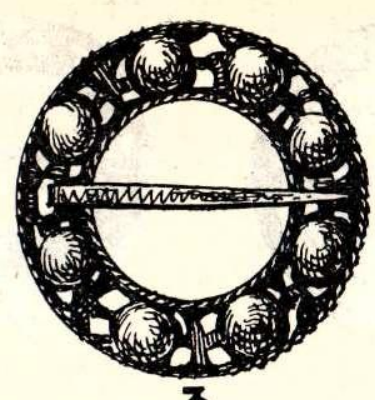

3
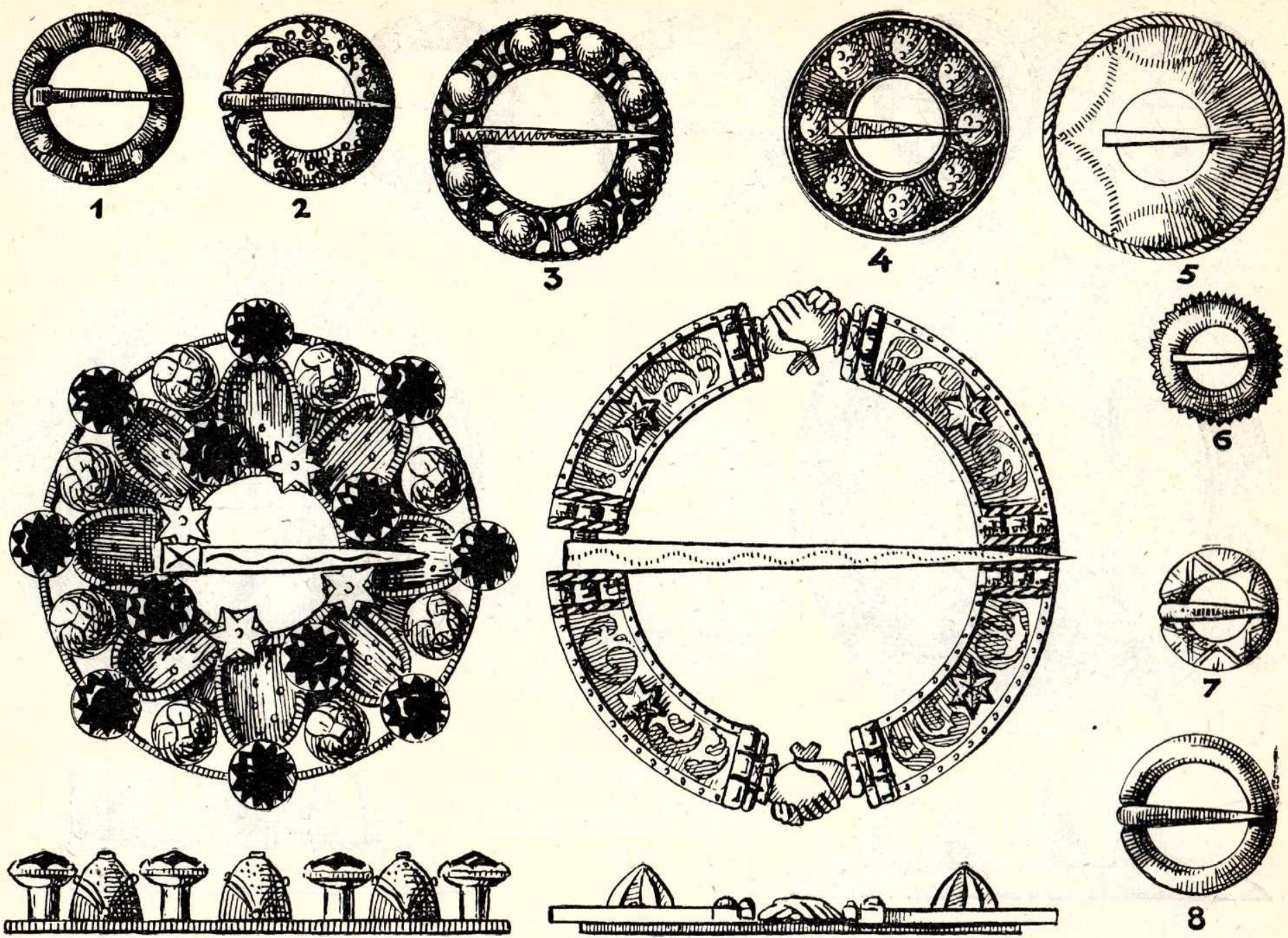

10
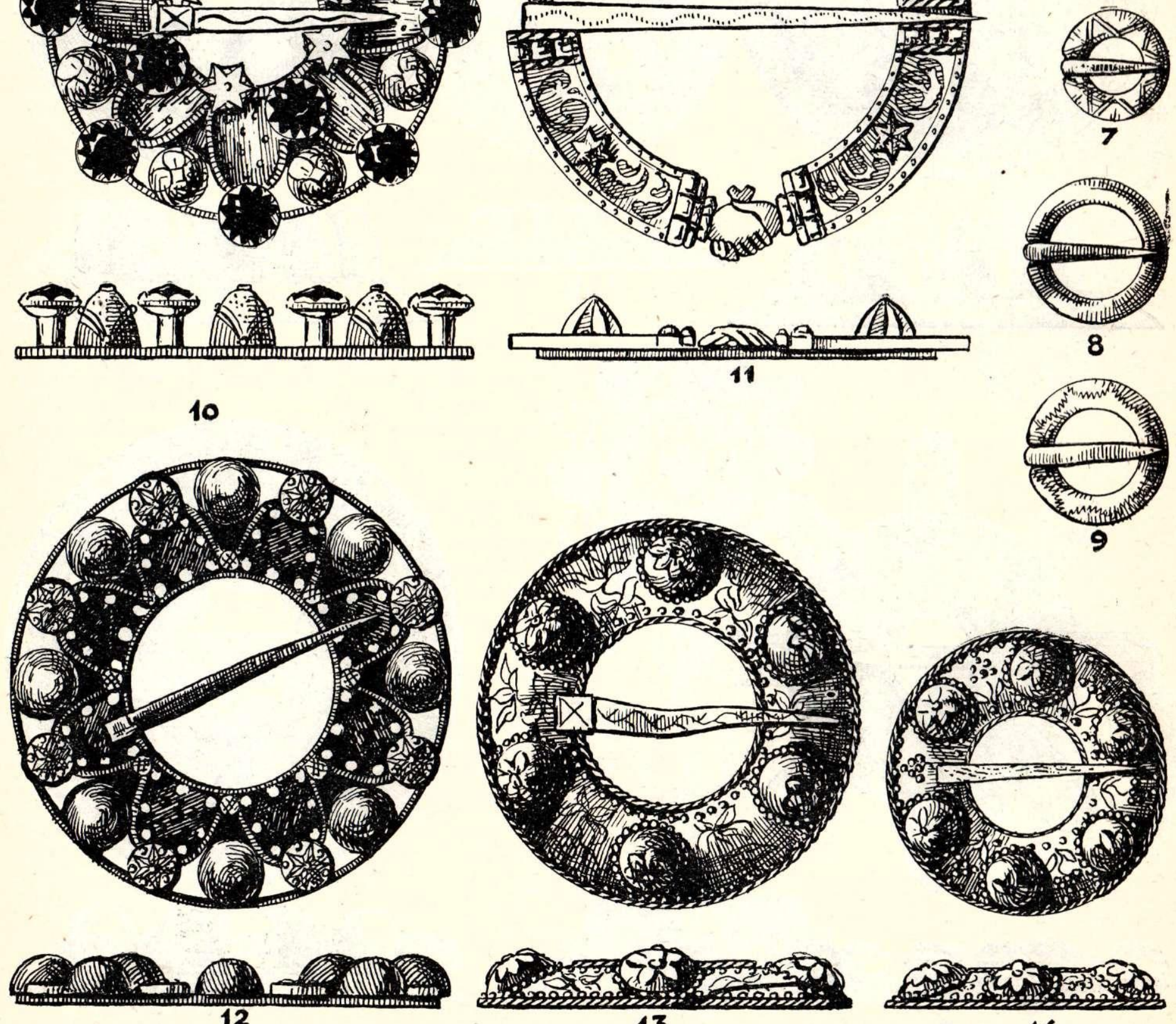

(10) 13
14. 14

80. att. Kurzemes saktas:

$1-3$ - Vainodes krekla saktas; 4-6 - Liepājas krekla saktas; $7-9$ - Ziemelkurzemes krekla saktas; 10 - Alsungas; 11 - Sakas; 12 Aizputes; 13,14 - Liepājas apkārtnes. 

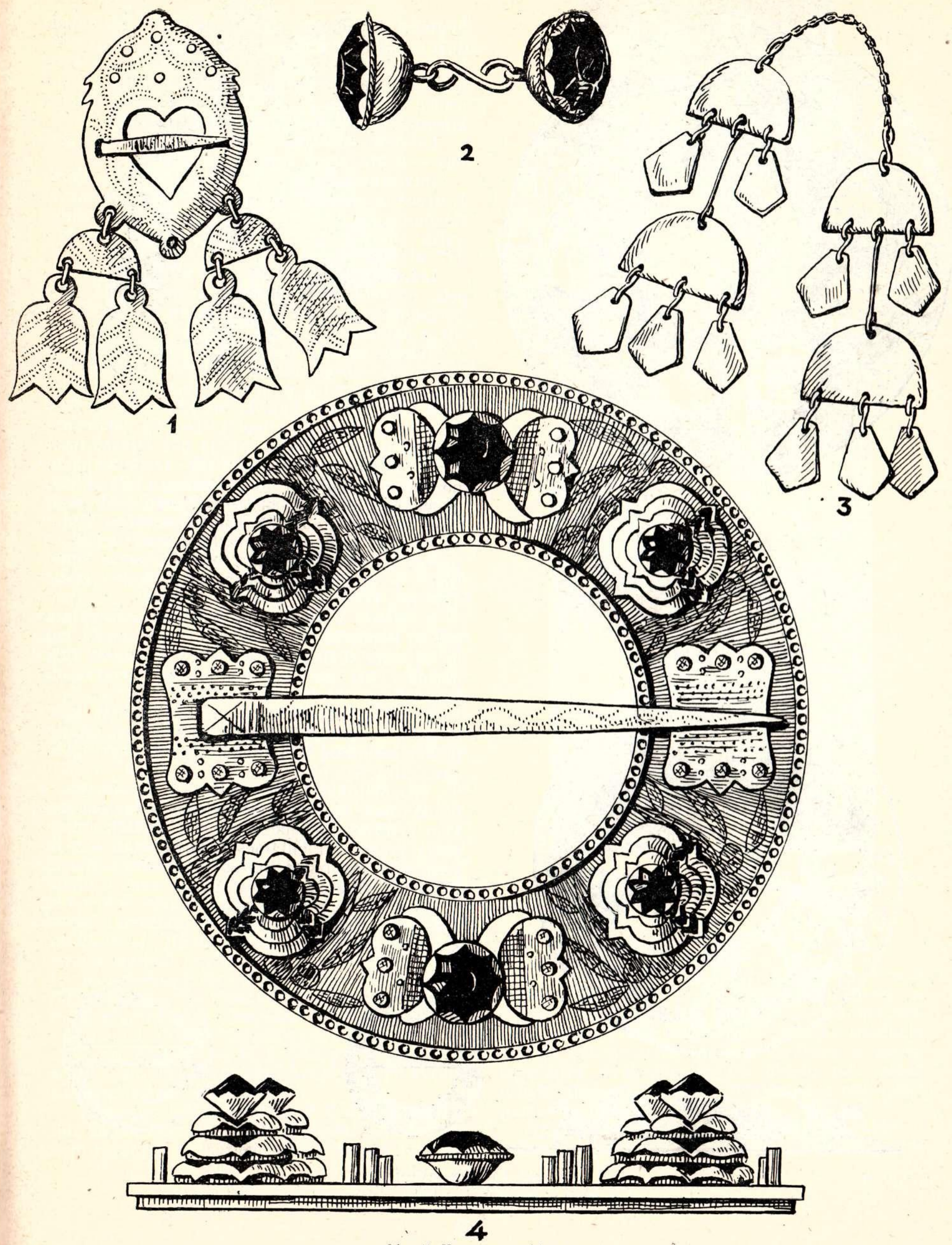

81. att. Kurzemes saktas:

1 - Austrumkurzemes; 2 - Skrundas; 3 - Rucavas; 4 - Aizputes. 


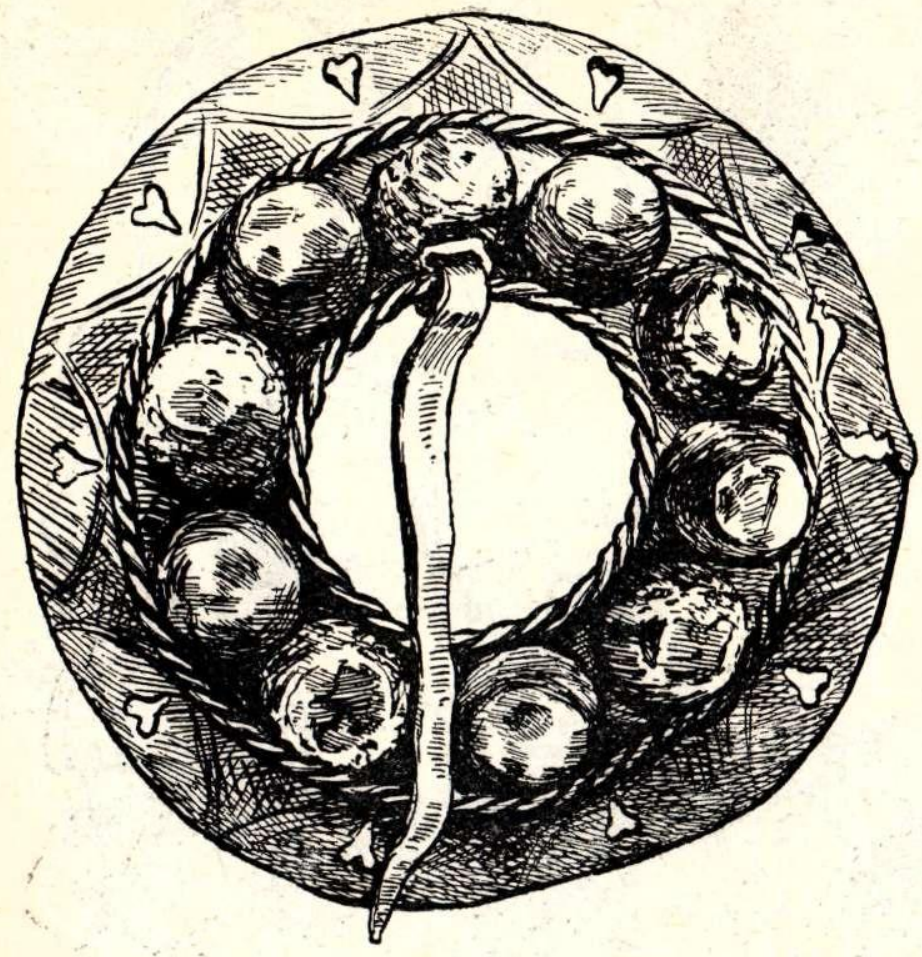

82. att. Krustpils burbulsakta (RLMV materiāli).
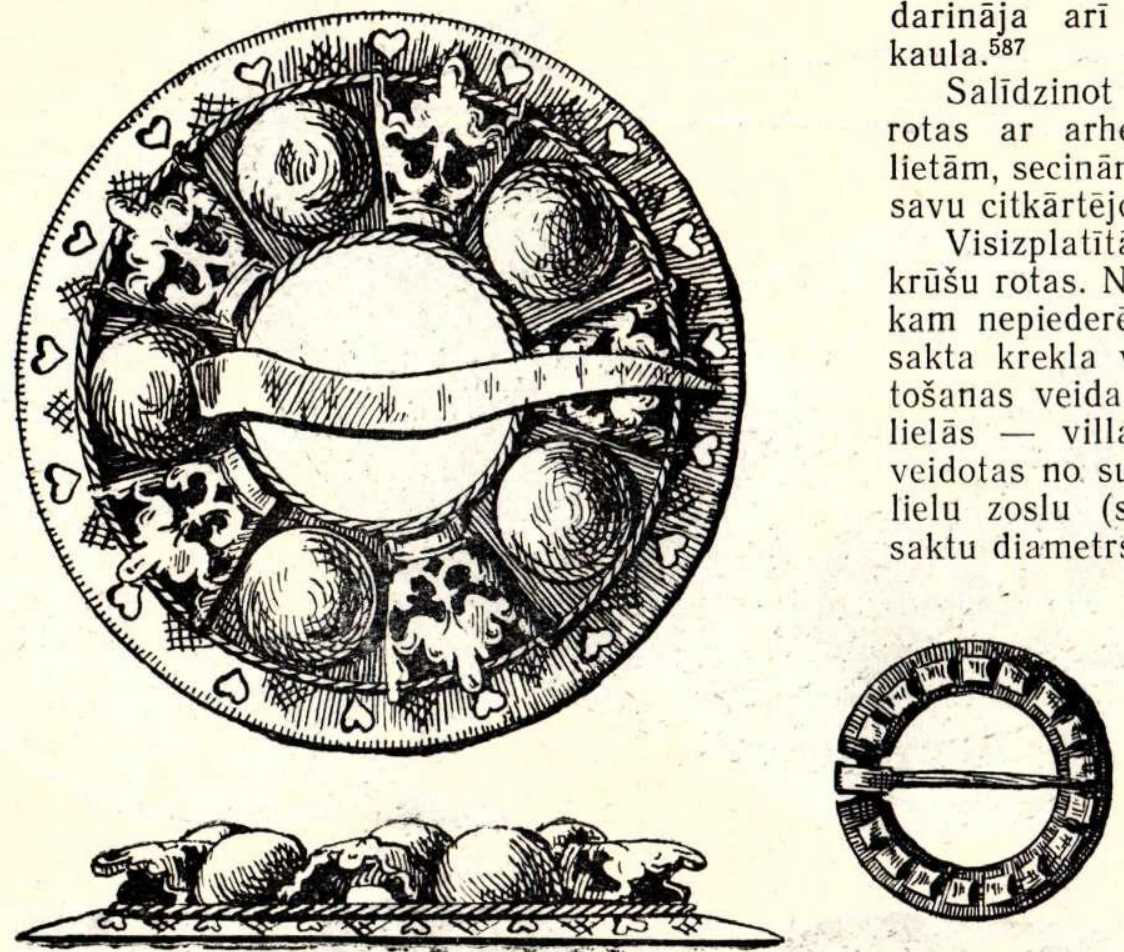

83. att. Latgales saktas:

1 - «sakta ar kroṇiem»; 2 - kreklu saktas.
Šegrēna ekspedīcijas laikā) sieviešu rotas sastāda tikai vienu ceturto dą̧u no tām rotām, kādas bijušas agrāk. Sevišḳs greznums bija lielās saktas, kas darinātas no sudraba un zelta. 1812. g., kad franču iebrucēji pieprasīja maksāt kontribūciju, krieviṇu sievietes savas dārglietas zaudēja. ${ }^{579}$

Latviešu rotaslietas dalāmas trīs lielās grupās - kakla, krūšu un roku rotaslietas.

Interesantu kakla rotu aprakstu sniedz J. Broce tekstā pie Lielvārdes sievas un jaunavas zīmējuma, norādot, ka zem villaines lielvārdietes valkā sudraba krelles ar monētu piekariṇiem ${ }^{50}$ (77. att., 2).

Lìdzìgas igaunu kakla rotas aprakstījis $\mathrm{A}$. Hupels, norādot, ka nabadzīgie laudis šādas rotas darinājuši no sīkām monētām un pašdarinātiem alvas dālderiem. ${ }^{581}$

Teicēju nostāsti lauj secināt, ka šāda veida rotājumi vēl 19. gs. otrajā pusē bija saglabājušies atsevišķās bagātās gimenēs, ${ }^{582}$ bet muzeja kolek. cijās tādu objektu nav un arī arheologiskie izrakumi nedod šādas liecības. Liekas, ka kakla rotas ar monētu piekariṇiem Latvijā būs bijušas izplatītas tur, kur vietējā etniskā sastāvā lielāka nozīme nekā baltiem bijusi somugru cilmes komponentiem, jo visplašāk šis rotājumu veids izplatījies somugru tautās, ${ }^{583}$ kamēr no slāvu tautām tas 19. gs. sastopams tikai Rietumukrainā dzīvojošiem ukrainiem. ${ }^{584}$ Kakla rotai pēc savas formas tuvas ir Zemgalē pazīstamās sudraba krelles (77. att., 1) ${ }^{585}$

Latgales, Vidzemes un Augšzemes kompleksu svētku tērpus bagātās sievietes rotāja ar zila, zaḷa un sarkana stikla krellem. ${ }^{586} \mathrm{Bez}$ tam kakla rotas darināja arī no dzintara, māla, bronzas un kaula.587

Salīdzinot 18. un 19. gs. sastopamās kakla rotas ar arheologiskajos izrakumos atrastajām lietām, secināms, ka 18. gs. kakla rotas zaudējušas savu citkārtējo nozīmi.

Visizplatîtākais rotu veids 18 . un 19 . gs. ir krūšu rotas. Navi gandrīz nevienas tādas ġimenes, kam nepiederētu kāda maza vai lielāka sudraba sakta krekla vai villaines saspraušanai. Pēc lietošanas veida izšḳir mazās - krekla saktas un lielās - villainu saktas. Mazās saktas parasti veidotas no sudraba ripinas ar cauru vidu un nelielu zoslu (saktas adata) iespraušanai. Krekla saktu diametrs $-2-3 \mathrm{~cm}$ (78. att., $1-3 ; 79$. att.,

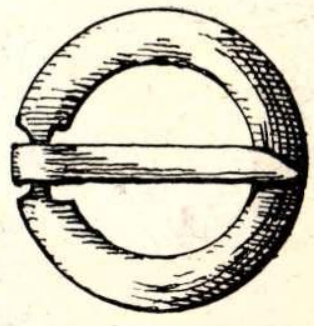

2 


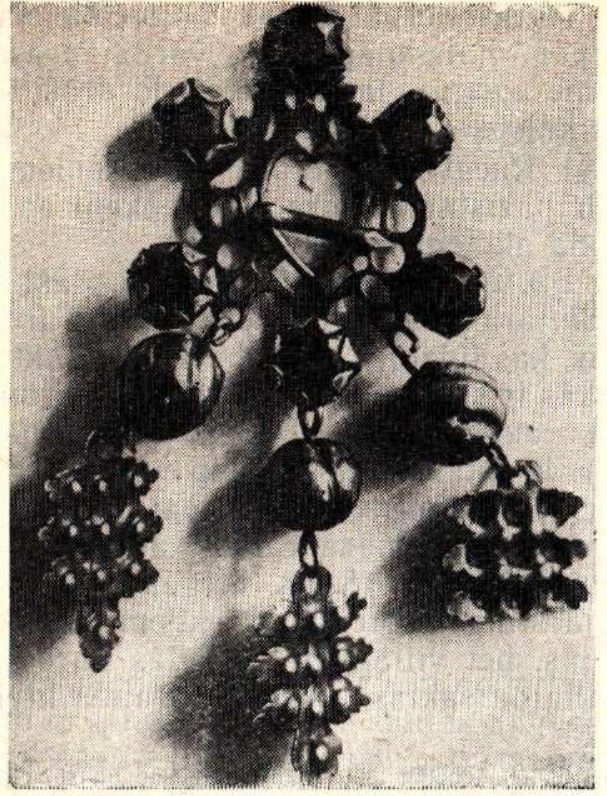

84. att. Krustpils sakta ar piekariṇiem (RLMV materiāli).

1-4; 80. att., 1-9). 19. gs. sākumā bija sastopami vairāki lielo saktu tipi: Vidzemes, Augšzemes, Zemgales, Ziemel̨kurzemes un Dienvidkurzemes.

Vidzemes saktu tips izplatīts visā Vidzemē un Latgalē. Tās ir t. s. burbuḷsaktas (78. att., 4, 5). Sakta noklāta ar 8-10 puslodveida izciḷniem burbuliem, pie kam gludu izcilni nomaina rotāts. Vidzemē, Zemgalē un Latgalē parasti uz saktas ārējās taisnās plāksnes caurumotā tehnikā veidotas sirdis (82. att., 1), bet Krustpils saktām plāksne paliek gluda. Zviedru amatnieku ietekmë radušās saktas, kur gludo burbuḷ vietā ir vald. nieku kroṇiem līdzīgs veidojums (83. att.), iecienītākas ir Latgalē un Austrumvidzemē. Vēlākā laikä gludie un ciḷnainie burbuḷi aizstāti ar krāsainiem stikla akmeñiem un kaldinātiem lapu un ziedu motīviem (78. att., 7).

Retāks ir otrs Vidzemes saktu tips. Ša tipa saktām apalajai, ar akmeniem un kaldinātām lapiñām rotātajai vidusdalai ir 3-4 piekariṇi, kuri veidoti no tukšām sudraba bumbinām. Greznākajiem variantiem piekariṇi nobeidzas ar lapinām un mēlītēm, kas noklātas ar 3-4 vienkāršiem rakstiem (78. att., 6,$8 ; 84$. att.). ${ }^{588}$ Unikāls burbulsaktas paveids redzams $O$. Hūna zīmējumos (79. att., 7) ${ }^{589}$ Saktas pamats ir ieapalšs, stipri izvirzītie burbuḷi novietoti nevis kā parasti - saktas virspusē, bet uz saktas ārējām malām, tādējādi veidojot it kā starainu saulīti. Sīs saktas arī rotātas krāsainiem akmeñiem. Līdzīgu saktu redzam arī J. Broces Lielvārdes jaunavas un sievas zīmējumā. ${ }^{590}$ Latvijas PSR Vēstures muzejā šāda veida saktu nav, bet ir tikai Krustpils tipa burbulu saktām līdzīgas saktas. ${ }^{591}$

Kurzemes saktas izmēros ir daudz lielākas līdz $25 \mathrm{~cm}$ diametrā ar burbulveida, stipri izcilṇotiem rakstiem, uz kuriem novietotas sešlapu roze-
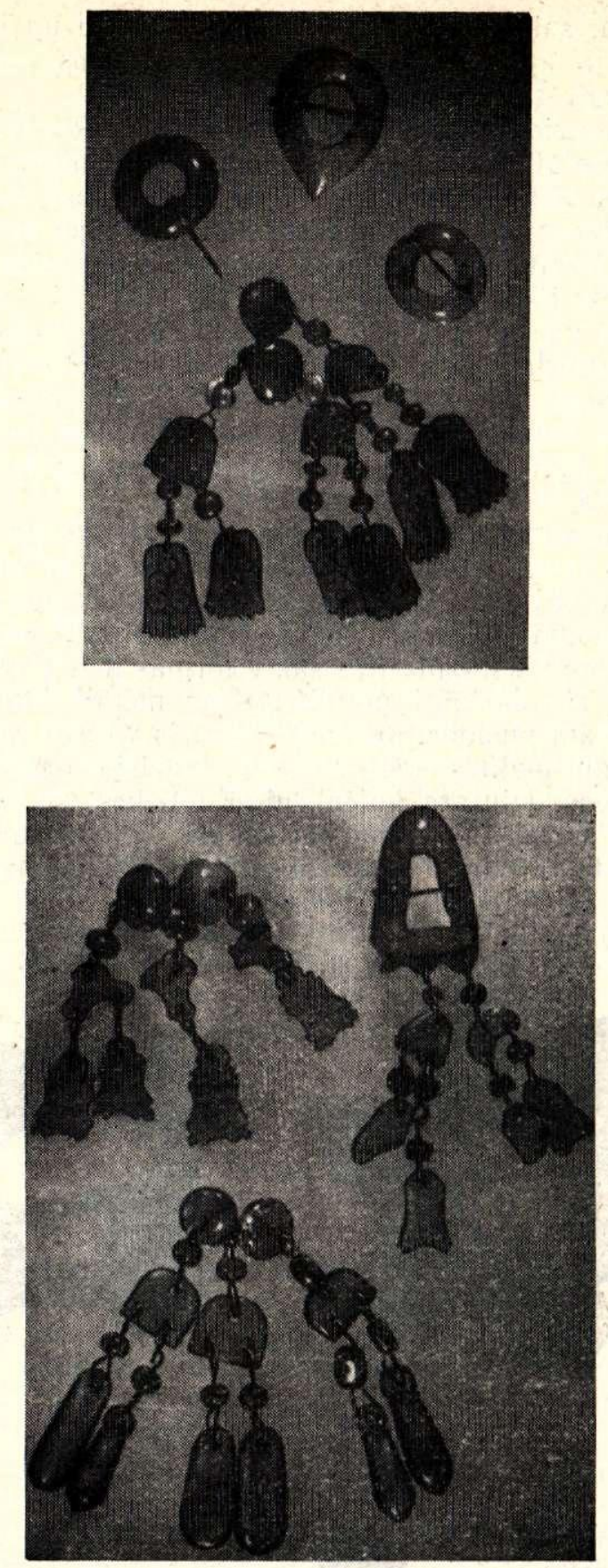

85. att. Dzintara saktas (Latvijas PSR Vēstures muzeja materiâli).

tes un citi izgrieztie stādu ornamenti (80. att., 11, 13; 81. att., 4). Kurzemes saktu pārblīvētie virsmu rotājumi ar ciḷniem un krāsainiem akmeñiem, no vienas puses, atspoguḷo tolaik Rietumeiropā valdošā mākslạs virziena iezīmes latviešu lietiškajā mākslā, bet, no otras, loti labi sasaucas ar arheolog̣iskajos izrakumos iégūto lībiešu rotu stādu ornamentiem un košajām emaljām, kas reti sastopamas baltu tautu rotās.

No Ziemel̨kurzemes saktām raksturīgākās ir Alsungas novada saktas. To diametrs nepārsniedz 
$20 \mathrm{~cm}$; saktas rotātas ar krāsainu stiklu un bieži vien ir apzeltītas (80. att., 10). Šādas saktas Alsungā saglabājušās vēl šodien.

Dienvidkurzemē - Nīcā, Bārtā un Rucavā bija izplatîtas saktas ar nelieliem burbuliem. Šìs saktas villainēs nesprauda pa vienai, bet veselu «kaudzi» vai «čupu». Saktas saturēja kopā ar sarkanu lentīti. Sāds villainu saspraušanas veids pazīstams tikai minētajos novados.

Kā vīriešu, tā sieviešu kreklu saktas visā Latvijā gandrīz bija vienādas, iznemot Lielvārdes, Alsungas un Zemgales novadus, kur sieviešu krekla saspraušanai 19. gs. pirmajā pusē iecienītākas bija saktas ar krāsainiem akmeṇiem, bet Rucavā - dzintara saktas.

Kurzemes dienviddaḷā un Zemgalē 19. gs. parādās jauna saktas forma - sirdsveida ar piekariṇiem (81. att., 1), lai gan līdztekus vēl joprojām sastopamas parastās apaḷās ripu saktas. Dienvid. kurzemē plaši izplatītas saktu formas ir t. s. kniepķeni. Tie darināti no divām, ar metāla stieplīti saistītām puslodītēm; puslodītēm ir vairāki piekariṇi un mēlìtes (81. att., 3). Sevišḳi bagāti ir Rucavas dzintara kniepkeni. Kā liekas, šo rotaslietu formu latvieši pārṇēmuši no zviedriem; par to liecina pats nosaukums «kniepkiens».

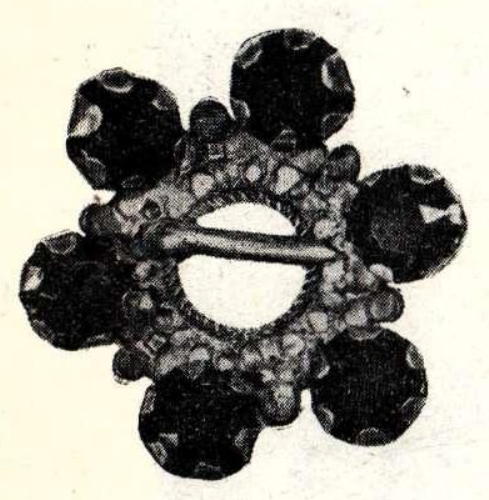

1

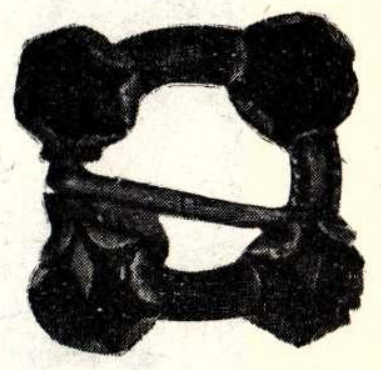

2

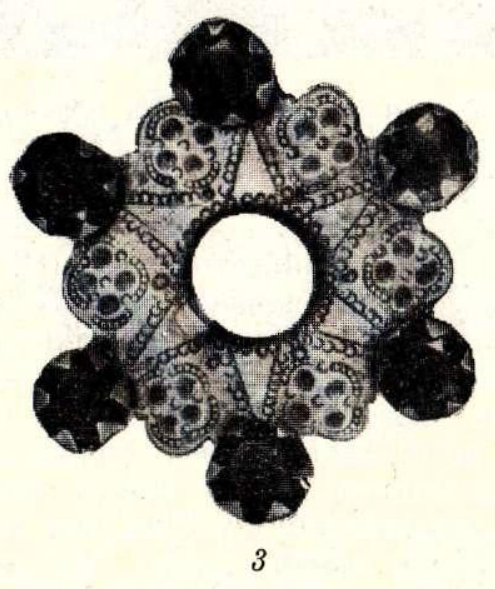

86. att. Igaunu saktas:

1 - Ziemeligaunijas; $2-$ salu: $3-$ Rietumigaunijas.
Zviedru tautas tērpā šādas pogveida saktas ${ }^{592}$ sauktas par «hals-knapp», no vārda otras dalas, kas apzīmē «pogu», latviešu valodā droši vien izveidojies kniepkena nosaukums. ${ }^{593}$

Lìdzīgi Rucavas dzintara kniepkeniem Talsu novadā ir pazīstami sudraba kniepkeni ar krāsainiem stikla akmeniem (81. att., 2).

Nìcā, Bārtā un it seviški Rucavā plaši izplatī. tas ir dzintara saktinas. Vienkāršākās ir gludas un apalas, kas līdzīgas sudraba krekla saktām, bet iecienītākās ir sirdsveida vai ovālas ar kemmveida zobiniem augš-, bet dažreiz arī apakšpusē (85. att.). Dzintara izstrādājumi varēja būt gludi, bet ir arī sastopami iededzināti vai izzāgèti raksti, ko veido lielāki un mazāki apliši un svìtriṇas.

Saktu valkāšana 18. gs. beigās un 19. gs. sākumā bija stingri noteikta: krekliem sprauda mazās, apaḷās, bet villainēm - lielās burbulsaktas. Lielās villaiṇu saktas nekad nesprauda kreklā vai ñieburā.

Dažkārt ğimenes glabāja saktas, kurām piedēvēja mistisku spēku, t. s. apmirtās saktas. Ar tām bija sasprausts mirēja apg̀ērbs miršanas brīdī; šīs saktas lietotas dažādu vainu riebšanai, ar šādām saktām ārstējuši lopus, ja tos sakodusi čūska vai ja tiem piemetusies nezināma vaina. ${ }^{594}$

No roku rotām apskatāmajā periodā saglabājušies tikai laulājamie gredzeni, bet greznăs aproces un dažāda veida gredzenus, kas lielos daudzumos sastopami arheologiskajos izrakumos, neviens no 18. un 19. gs. autoriem nepiemin. Vienigi F. Kruze runā par senajiem vītajiem gredzeniem, kurus valkājuši kā talismanu, lai izsargātos no dažādām nelaimēm. ${ }^{595}$ Daudzu gredzenu nēsāšana apdziedāta tautasdziesmās, piemēram,

No tālienes jau pazinu,

Kur nāk mana līgaviṇa;

Pilnas krūtis sidrabina,

Pilni pirksti gredzentinuu.

LTD, 2432

Klaušu saimniecības sairuma posmā, kad valdošā bija naturālā saimniecība, zemnieku saimnie. cībās nebija brīvu līdzekḷu rotaslietu iegādei. Tāpēc arī rotaslietas bija tikai turīgo zemnieku gìmenu îpašumā un tika mantotas no paaudzes uz paaudzi. Ar to arī izskaidrojams, ka 19. gs. sākumā tērpu kompleksā iekḷaujas rotas no iepriekšējiem gadsimtiem neizmainītās formās. Trūcīgām zemniecēm, kalponēm dažkārt nebija pat mazı) apą̧o saktinu krekla saspraušanai, nerunājot nemaz par lielām villainuu saktām. Par to, ka rotaslietas valkātas atbilstoši materiālajam stāvoklim, liecina arī tautasdziesmas, piemēram,

Es nebiju lepnu laužu,

Es tik lepni nenesos,

Es nespraudu div' saktiṇu

Sava krekla vīlìtē.

LTD, 2553 


\section{LATVIEŠU TAUTAS TËRPA KOMPLEKSU LOKĀLIE VARIANTI}

Feodālisma posmā latviešu apg̉ērbs ir apspiestās un ekspluatêtās darba tautas apgēerbs, kurã at. spogulojas tā laika latviešu kultūras veidotāju sasniegumi. 18. gs. beigās un 19. gs. pirmajā pusē Latvijas teritorijā feodālās attiecības sairst, un to vietā dzimst kapitālistiskās attiecības, kad naturālo saimniecību grauj un ārda preču ražošanas attīstība un naudas apgrozības pastiprināšanās. Sakarā ar izmainām ražošanas spēkos un attiecĩbās norit pārmaiṇas arī apgēēbā. Līdz ar kapitālisma attīstību un iekšējā tirgus izveidošanos sākas agrāk atškirīigo novadu ${ }^{596}$ nivelēšanās process. 19. gs. otrajā pusē, lauku sētās strauji izplatoties fabriku ražojumiem, tradicionālais tautas tērps pakāpeniski zaudē savu nozīmi un pilnīgi pārveidojas, tā valkātājiem pārejot uz pilsētas apg̀ērba formām. Tērpu pārveidošanās nenotika visā Latvijā vienlaikus, bet šo procesu noteica sociālekonomiskie apstākḷi un valkātāja turības pakāpe.

Runājot par latviešu tautas tērpiem, jāatceras, ka 19. gs. pirmajā pusē «Kapitālisms vēl lēni attīstījās lauksaimniecībā. Lauksaimniecībai vēl bija dzimtniecisks naturāls raksturs. Rūpniecības uz. ñēmēji un amatnieki vēl nebija pilnīgi atdalījušies no lauksaimniecības. Vietējie rūpniecības uzñēmumi vēl bija noslēgušies šaurā rajonā, sakari starp rajoniem bija văji.»597 Tāpēc 19. gs. pirmajā pusē, atsevišḳās vietās pat vēl līdz 70. gadiem, konstatējami lokāli apgèerba varianti. Tautas tērps veidojas vienlaikus ar nācijas konsolidācijas procesu, tāpēc tas atspogulo kultūras specifiku un māksliniecisko gaumi, kas darbą̧aužu vidū saglabājās arī vēlākos posmos. Tomēr, kā jau norādìts, daudzo novadu atškirirībām ir zināms sakars jau ar cilšu apvienību materiālās kultūras specifiku, kuru vēl vairāk padzị̣ināja feodālā sadrumstalotība, kas turpinājās pēc vācu iekarotāju iebrukuma. Väjie ekonomiskie un kultūras sakari, plašākas tirdzniecības gausā. attīstības gaita bija par cēloni tam, ka latviešu tautības izveidošanās ieilga uz vairākiem gadsimtiem; $l \bar{l} d z$ ar to arī saprotams, kāpēc tautas tērpa izveide notika tik lēnām un kāpēc tai bija lokāls raksturs. "Latviešu tautība galīgi izveidojās tikai tad, kad visa Latvijas teritorija apvienojās Krievijas sastāvā,»598 t. i., 18. gs. beigās. Täpēc tērpiem, kas valkāti no 18. gs. beigām līdz latviešu buržuāziskās nācijas izveidošanās beigu posmam - 19. gs. 70. gadiem. ir nozīmīga vieta latviešu apgèerba vêsturē. Pēc tam raksturīgãs formas sāk mainīties atbilstoši jaunajam ražošanas spēku attīstības līmenim. Mūsu rīcībā esošie muzeju fondi un arhīvu dokumenti galvenokārt arī attiecas uz šo laika posmu. Protams, par visiem lokāliem variantiem nav vienādi daudz materiālu, kas lautu vilkt stingṛu teritoriālu robežu, tāpēc par kritēriju atsevišḳa lokāla varianta izdalīšanai nemtas radniecīgākas kopējas īpatnības, kas kādā noteiktā vietā zināmā laika posmā parādās tērpā.

Izdalot atsevišḳus lokālos variantus, jāiegaumē, ka tērpu valkāšanas novada robežas nav iespējams vilkt precīzas līnijas veidā, bet tās parasti savstarpēji saplūst un mijas. Tāpat arī kāda novada iedzīvotāju tērps nebūt nav «uniforma». kuru visi novada iedzīvotāji šuj pēc viena stingra standarta; piemēram, dažuviet Vidzemē pat katrā pagastā ir bijuši citādi brunči. Protams, ka, izdalot atsevišķus tērpu lokālos variantus, šīs mainīgās îpatnības nav nuemtas vērā, bet variants izdalìts pēc veselas īpatnību grupas.

Kā jau iepriekš norādīts, visā Latvijas teritorijā valkātos apg̀ērbus var iedalīt 5 lielos apgèēbu kompleksos. So kompleksu ietvaros sociālekonomisko, etnisko un vēsturisko apstākḷu rezultātā izveidojušies lokāli varianti jeb novadi.

Tă, piemēram, Vidzemes tautas tērpa kompleksā iespējams konstatēt 6 lokālos variantus, kuru izveide ir bijusi visai dažāda. Pirmā varianta - Rietumvidzemes - tērpi valkāti gandrīz visă Rīgas apriṇkị̄ing (iznemot Lielvārdes novadu), kā arî Cēsu un Valmieras apriṇkia rietumu daḷā (6. att., 1). ${ }^{600}$

Rietumvidzemes tērpa izplatības ziemelu robeža saplūst ar Ziemel̨vidzemes tērpa valkāšanas robežu; tā îpatnības sniedzas pat līdz Igaunijas robežai Rīgas jūras līča krastā. Tieši par Rietumvidzemi bagātus materiālus sniedz J. Broce, ${ }^{601}$ H. Brigena, ${ }^{602}$ T. Gelhārs, ${ }^{603}$ A. Pecolds, ${ }^{604}$ J. Krēsliṇš ${ }^{005}$ (skat. 31. un 32. tab., 2). Mazāk materiālu ir Latvijas PSR Vēstures muzeja kolekcijās un arhī- 
vos, jo neviena no bij. Pieminekḷ valdes ekspedicijām nav rīkota uz šìm vietām. Rietumvidzemes tautas tērpa izveidē nozīmīgi ir divi galvenie faktori - lībiešu tautības iedzīvotāju un Rīgas pilsētas ietekme.

Nav nejaušìba, ka Rietumvidzemes novada robežas sakrīt ar 13. gs. saglabājušos lībiešu teritorijas robežu. ${ }^{606}$ J. Segrēns, kas 1846 . g. Krievijas Geogrāfijas biedrības uzdevumā speciāli nodarbojās ar lỉbiešu pētīšanu, Vidzemē saskaitīja 22 lībiešus $^{607}$ un atzīmēja vinu atškirības apg̣êrbā, kas tos atdala no pārējiem vidzemniekiem. ${ }^{608} 18$. gs. beigās pēc $A$. Hupela ziṇām lībiešu skaits jau tik stipri samazinājies, ka tos nevarot uzskatīt par ippašu tautu. ${ }^{609}$ Liekas, ka visvairāk Vidzemes lībiešu būs izmiruši lielajā mērī.

Neskatoties uz lībiešu fizisko iznīkšanu 18. gs. un asimilāciju, lībiešu kultūras ietekme Rietumvidzemē apskatāmā laika posmā joprojām stipri jūtama.

18. gs. beigās un 19. gs. sākumā Latvijas rūpniecība vēl atradās veidošanās stadijā. Darbojās tikai neliels skaits manufaktūru, sabiedriskā darba dalīšana bija vāji attīstīta. Pats lielākais ekonomiskais un kultūras centrs Latvijā bija Rīga, kuras ietekme sevišḳi jūtama tai tuvākajos novados.

Saprotams, ka arī svešu zemju modes 18. gs. izplatījās vispirms Rīgas pilsētā. ${ }^{610} \mathrm{~J}$. Broce rāda Rịgas tuvumā dzīvojošās turīgās zemnieces, kas pēc pilsētnieku parauga g̀ērbušās dārgos kažokos un kurpēs ar metāla sprādzēm, ${ }^{611}$ tāpat arī zemnieku-zvejnieku, kas tērpies tumši zilos svārkos ar pògām, ${ }^{612}$ utt.

Raksturīgākā pazīme, kas Rietumvidzemes tērpus škir no pārējās Vidzemes tērpiem, ir sedzamie brunči - pussvārči (50., 51. att.). Jādomā, ka šāda veida plecu segas valkāšana nav tikai saistāma ar pilsētas modi, jo tā pazīstama arī Kurzemē dzīvojošo lībiešu teritorijāa ${ }^{613}$

Krekli Rietumvidzemes novadā nēsāti gludi, ar atlocītu apkakli, nerotāti. Rìgas tuvumā apkakles sniegušās gandrīz lìdz plecu galiem. ${ }^{614}$ Iecienita bija t. s. uzkreklinu valkāšana.

Brunči Rietumvidzemē valkāti dažādi 18. gs. svītraini vai vienkrāsaini - sūnu zali vai brūni sarkani, bet 19. gs. - rūtaini un rakstaini. Brunčus darināja tādā pašā veidā kā citos novados - auduma gabalu paredzamajā jostas vietā savilka krokās un tam piešuva tā paša auduma jostinu.

Austās jostas Rietumvidzemē nevalkāja, bet jostas vietā mēdza siet baltu vai sīkās rūtīs vai svītrās austu priekšautu (skat. 31. tab.).

Raksturīga Rietumvidzemes sieviešu tērpa sastāvdala ir jaka. Bez jakas staigāja tikai sievietes Austrumvidzemei tuvējos novados. Jakas šuva no vienkrāsainas vai svītrainas drānas, kas bieži vien bija pirkta Rīgā. Svītras parasti sakārtotas vertikāli. Priekšā jakas bija aizākēejamas. Lielos jaku kakla izgriezumus aizsedza ar lakatiṇu, tā ka krekla apkakle nemaz nebija redzama. ${ }^{615}$

Rietumvidzemē baltās villaines nevalkāja, bet plecus sedza ar vienkrāsainiem drānas gabaliem vai puḳainiem zīda lakatiem, kurus uz krūtīm ar saktu nesasprauda. Rīgas tuvumā izplatītas bija zalās «kuču» villaines. Ipatnējs paradums ir arī balta vai krāsaina zīda lakatiṇa segšana uz pleciem, pāri jakai zem krāsainā lielā lakata ${ }^{616}$

Jaunavas galvā sēja zīda lakatus, vienīgi no. vada austrumdaḷā sēja sienamos vainagus, tādus pašus kā Austrumvidzemē. Sievas lika galvā torṇa cepuri, kuru pārsēja ar krāsainu zīda lenti vai lentveidā salocîtu zìda lakatu.

Vĩrieši Rietumvidzemē vilka gaiši pelēka vai tumši zila auduma îsus svārkus un bikses līdz ceḷiem. Garos svārkus 18. gs. vairs nevalkāja. ${ }^{617}$

$Z$ i e m eḷi i $z$ e mes tērps valkāts. Valkas apriṇkīi rietumos pa līniju Rūjiena-Valmiera tērpa valkāšanas robeža saplūst ar Rietumvidzemes novadu, ziemelos saskaras ar Igauniju, dienvidos ar Piebalgas un Austrumvidzemes novadiem, bet austrumos no Ziemellatgales novada to šḳir Pededzes upe (6. att., 2). . $^{18}$

Ziemelvidzemes tērpa īpatnību izveidē nozīmiga vieta ir igauṇiem, kuri ne tikai vienmēr ir dzīvojuši ziemeḷidzemniekiem kaimiṇos, bet bieži vien tikuši pārvietoti no Igaunijas uz Latviju. Igaunu tautības iedzīvotāji ieceloja un vietumis apmetās Ziemeḷidzemē pēc Ziemeḷu kara. 18. gs. beigās un 19. gs. sākumā bēgḷ sarakstos bieži vien minēti ne tikai igauñi no Vidzemes, ${ }^{619}$ bet arī latvieši, kas prot igauṇu valodu. ${ }^{620}$ Bez tam muižnieki, kuriem muižas piederēja kā latviešu, tā igauṇu apdzīvotajā teritorijā, bieži vien saimniecisku apsvērumu dēl igaunus kā darbaspēku pārvietoja uz Latviju, bet latviešus - uz Igauniju. ${ }^{621}$ A. Bīlenšteins min vairākas igauṇu kolonijas Ziemelvidzemē: Ilzenes un Kalnu muižā, Zeltinu apkārtnē un Gaujienā. ${ }^{622}$ Lai gan igauṇu ieceḷotāji ilgajos kopdzīves gados ar latviešiem asimilējušies, tomēr zināmas iezīmes tie atstājuši arī latviešu tautas tērpā.

Par Ziemeḷidzemes tērpu īpatnībām iespējams spriest galvenokārt pēc J. Broces zīmējumiem (70. att.). Muzeju kolekcijās nav pilnīgs Ziemeḷvidzemes tērpa komplekts, bet ir tikai atseviški apgèrba gabali, katrs no sava pagasta un bieži vien no sava laika posma. Ziemel̨idzemes tērpa rekonstrukcijā nozīmiga vieta ir Etnogrāfijas sektora ekspedīciju materiāliem (bij. Alūksnes, Limbažu un Valmieras raj.). Pārbaudot mūsu rīcībā esošos materiālus un salīdzinot tos ar ekspedīcijās iegūtajām ziṇām, rekonstruēts Ziemelvidzemes tērpa komplekts (skat. 32. tab., 1, 6).

Ziemelvidzemes tērpus pie Vidzemes tērpa kompleksa vispirms lauj pieskaitīt tunikveida krekli ar virsū šūto uzpleci, otrkārt, vienvirziena izvilkuma tehnikā izstrādātais baltais izšuvums un, beidzot, sieviešu ziemas un «torna» cepures.

No pārējiem Vidzemes tērpa lokālajiem variantiem Ziemelvidzemes tērps atškiriras ar jaunavu galvassegām - matauklām un zirgu astru vainagiem, baltajām villainēm, svītraino brunču krāsı tonējumu un svītrotajām jostām. ${ }^{623}$ 
Ziemeḷidzemes novada tērps apskatāmajā periodā nemitīgi pārveidojies. Salīdzinot J. Broces Rūjienas un Gaujienas apgèrebu zīmējumus ar muzeja kolekcijās esošajiem priekšmetiem un arhīvu aprakstiem, redzams, ka 18. gs. beigās valkāti vienkrāsaini brunči. Rūjienas tērpu linu auduma snātenu forma tuvojas kvadrātam. J. Broces zìmējums ir vienīgais avots, kas rāda rotātas villaines arī Ziemelvidzemes novadā. Kā liekas, tās šeit, tāpat kā zịlu vainagi Ziemelvidzemes novada austrumu dalā, pārnäkušas no Austrumvidzemes novadu tuvības rezultātā.

Iespējams, ka izšūtās Gaujienas villaines vedamas sakarā ar Dienvidigaunijas izšūtajām villainēm, ${ }^{624}$ lai gan pēdējās no Gaujienas villainēm atšḳiras kā pēc izmēriem, tā arī pēc kompozīcijas îpatnībām. Dienvidigaunijas villaines varēja ieviesties jau no iepriekš minētajiem igauñiem. ${ }^{62}$

Ievērību pelna līgavas villaines sakta J. Broces rūjieniešu zīmējumā. Tai, tāpat kā $O$. Hūna zìmētās jēkabpilietes saktai, burbuḷi izvirzīti nevis uz augšu, bet uz sāniem (sal. 61. att.; rekonstrukcija 79. att., 7).

Spriežot pēc Latvijas PSR Vēstures muzeja materiāliem, 19. gs. pirmajā pusē izmainās Ziemelvidzemes novada brunču materiāls. Dominējošo vietu ienem vertikāli svītrainie brunči; 19. gs. otrajā pusē novada dienvidaustrumdalāa pārsvaru gūst rūtainie brunči, 626 lai gan vēl, piemēram, 1881. g., vilkti arī svītraini brunči. ${ }^{627}$

Sai pašā laikā Ziemelvidzemes austrumdalā valkāti arī zīḷu vainagi. ${ }^{628}$ Vēstures muzeja kolekcijās un arhīvu dokumentos nav aprakstu par kāzu priekšautu valkāšanu šai novadā, bet, spriežot pēc J. Broces loti sīkā un precīzā apraksta un skaidrā zìmējuma, jādomā, ka 18. gs. beigās Ziemeḷidzemē tādi valkāti. ${ }^{629}$

Bagātus materiālus par Ziemeḷidzemes vīriešu tērpiem sniedz J. Broces vīriešu apgēēbu zīmējumi līdz ar nelielām anotācijām no Naukšēnu, Ẽrğemes, Palsmanes, Gulbenes un Alūksnes (skat. 33. tab.). ${ }^{630}$

Vīriešu krekli piegriezti tunikveidā; tiem virsū šūti uzpleči. Rotājums - vienvirziena izvilkums vai caurā vīle. Bikses parasti lìdz potītēm, lielākoties baltā, pelēkā vai mēlu zilā krāsā. Ërğemes pagastā bikses tumši zilā krāsā un ìsas - tikai līdz celiem. Liekas, ka šāda veida bikses radušās kaimiṇu igaunu ietekmēè, kas lielā skaitā dzīvoja arī Êrg̀emes apkārtnē.

Raksturīgi ir Ziemeḷvidzemes vīriešu svārki, kas atškirīiā no pārējās Vidzemes svārkiem bagātīgi rotăti ar krāsainu auklu un apmalēm. Unikāli ir baltie Alūksnes svārki ar krāsaino puškīišu rotājumu, kādi nav sastopami ne pārējā Latvijas teritorijā, ne arī kaiminos Igaunijā. Pèc sava piegriezuma tie pieskaitāmi garajiem mudurainajiem svārkiem. ${ }^{631}$

Svārkus un kažokus apjoza ar $5-10 \mathrm{~cm}$ platu vertikāli svītrotu jostu. Svītrotā josta ir Ziemeḷ- vidzemes vīriešu tērpa īpatnēja un neatṇemama sastāvdala. ${ }^{632}$

Salīdzinot Ziemelvidzemes un Igaunijas dien. viddaḷas tērpus, vērojama nenoliedzama līdzība, ${ }^{63}$ turklāt ne tikai atsevišḳās tērpa detaḷās, bet visā komplektā, pat svītraino brunču, vīriešu svārku, sieviešu jaku, sievu cepuru u. c. krāsu ziedā. Dienvidigaunijā, tāpat kā Latvijāa, ir raksturīgs ǵeometriskais raksts. ${ }^{634}$ Arī igaunu etnogrāfi norādījuši uz Dienvidigaunijas, it îpaši tās rietumdalas, tautas tērpu lielo radniecību ar latviešu tautas tērpiem. ${ }^{635}$ S̄ī radniecība izskaidroiama ne tikai ar nolītiski ekonomiskajiem un kultūras sakariem. bet, kā liekas. nozīmīga vieta te ierādāma jau sen asimilēiušos lībiešu materiālās kultūras paliekām. kuras līdzšinēije apg̛ērbu pētnieki atstāiuši bez ievērības. Ziemelaustrumvidzemes novada tērpı atseviškios elementos (ornamentā, arī vīriešu kreklu valkāšanas veidā virs biksēm) vērojama radniecība ar Ziemelllatgales un igauṇu (setuku) tautas tērpiem.

$\mathrm{P}$ ie ba lg a s tērpi ir biiuši stipri vienveidīgi un krasi atškīrušies no citu pagastu tērpiem ${ }^{636}$ (6. att.. 3). Tie loti vienkārši. bez iebkāda greznuma. Piebalgas novada tērni valkāti Vecpiebalgas, Jaunpiebalgas, Velḳu, Druvienas, Gatartas, Lizuma un Rankas pagastos.637 Tërps ar savu melno brunču un vainagu krāsu atdalās no pārēiiem Vidzemes tērpu variantiem. Daži autori Piebalọas ĩpatnības cenšas izskaidrot ar krievu audēiu ietekmi. Pēc Ziemelu kara grāfs Seremetjevs tos it kā nometināiis šeit no savām Jaroslavlas guberṇas muižām. ${ }^{638}$ Izsekojot Jaroslavlas guberñas apg̛ērba īpatnībām, līdzība ar Piebalgu grūti konstatējama. Vienīgi sieviešu cepures «zalmalītes» ir radniecīgas ar Jaroslavlas gubernas sievu cepurēm. Tā kā šīs cepures pazīstamas tikai Piebalgā, tad iespējams, ka tas šai hipotēzei runā par labu.

Liekas, ka pareizāka ir A. Dzērviša hipotēze, ka Piebalgas novada tērpa îpatnības 19. gs. sākumā saistāmas ar hernhūtiešu ietekmi. Hernhūtieši, noliegdami dzīves prieku un lieku greznību, varēja ietekmēt arī ang̉ērba veidošanos. ${ }^{639}$ Spriežot pēc ekspedīciiā vāktajiem materiāliem, kā arī pēc Latvijas PSR Vēstures muzeja arhīva dokumentiem, vairākos Dagastos, kur bijušas brālı draudzes, apg̣ērbā dominē melnā krāsa, kas pārējā Vidzemē nav raksturīga. Ziṇas par brālu draudžu ietekmi apg̛ērbā iegūtas arī no Valkas. ${ }^{640}$

Saprotams, ka hernhūtieši nebūt neienesa kādu «jaunu modi» savas puses iedzīvotāju apgēēbā. $\mathrm{Ne}$ jau par to ir runa. Bet, ka religijas dogmas var ietekmēt tās piekritēju apǵērbu, liecina kaut vai Latgales īsā galvas auta îpatnējais valkāšanas veids nesasienot (tas atspogulo vecticībnieku baznīcas tērpa valkāšanas veidu, jo saskañā ar vecticībnieku mācību baznīcā ejamā tērpā nedrīkstēja būt mezgli). Bez tam dažādo sektu aklie piekritēji allaž mēdz tērpties tumšās drānās, tā liekulīgi noliedzot pasaules priekus.

Var būt, ka Piebalgas īpatnējā tērpa izveidošanā sava nozīme bijusi kādreizējam šì novada 
etniskajam sastāvam (par to gan vēl trūkst noteiktu ziṇu). Bet tad liekas savādi, kāpēc Piebalgai tuvējos apvidos, kur iedzīvotāju etniskajā sastāvā ir daudz, piemēram, lībisko vai arī igaunu elementu (Ilzenē, Zeltiṇos, Mārcienā, arī Lielvārdē), apğèrbā nav manāma attiecīga ietekme. Te savs vārds sakāms antropologiem, lingvistiem u. tml. zinātṇu nozaru pārstāvjiem.

J. Broce, aprakstot Piebalgas draudzes sieviešu apğērbus, min kreklus ar platām apkaklēm, kuras pie kakla satur sudraba saktina. Sie krekli atškiras no Vēstures muzejā esošajiem Piebalgas krekliem, jo neviens no tiem nav ar lielu apkakli. Tas zināmā mērā mudina domāt, ka krekli ar stāvajām apkaklēm varētu liecināt par slāviskiem elementiem. Uz to varbūt norāda arī loti kuplās krekla piedurknes, kam pārējos novados nav lī. dzīgu. Bet iespējams, ka 19. gs. Piebalgas kreklu loti smalkās un kuplās piedurknes ${ }^{641}$ ir novadā attīstītās aušanas rezultāts.

Jaunāka gājuma (19. gs.) Piebalgas brunči ir melnā pamatā ar vertikālām krāsainām svītrām, turpretim senāk Piebalgā bijuši pazīstami arī rūtaini vai vienkrāsaini - melni un pelēki brunči. ${ }^{642}$ N̦ieburus un jakas 19. gs. Piebalgā nevalkāia, bet ap vidu sēja Vidzemes vidienes jostām līdzīgas austas jostas. J. Broces zìmēiumos, kas attiecināmi uz 18. gs., sievietēm redzamas pelēkas un pusgaras, vīriešu svārkiem līdzīgas jakas. Izšūtas villaines Piebalgas novadā nevalkāja un pat pie goda tērpa sedza baltu, no loti smalkas dzijas austu villaini ar šauru, sarkanu svītriṇu ieaudumu galos.

Atšḳirīgs no pārējo novadu vainagiem ir Piebalgas jaunavu vainags, kas šūts no melna, zila vai retumis arī no sarkana auduma plaukstas platumā ar nedaudzām krāsainām pērlīšu svītrām vainaga vidus dala . $^{643}$

Sievu cepures bija mazas, apaḷas, šūtas no melnas vai tumši zilas vadmalas. Cepures apakšdala apšūta ar dzeltenu vai zal̨u audumu bez jebkāda rotājuma. Cepures forma atgādina vainagu ar segtu augšdaḷ. Bez šĩm cepurēm Piebalgā pazīstamas vēl apalas ādas cepures un visām Vidzemes cepurēm līdzīgās «ausaines». ${ }^{644}$

Piebalgas vīriešu tērps zināmā mērā izdalās no Vidzemes tērpu kompleksa ar saviem tumši brūnajiem vai pelēkajiem garajiem svārkiem. 19. gs. Piebalgā valkāti arī tumši zili svārki. Svārkus šuva jostas vietā iekrokotus. Tie ir t. s. krunkainie svārki jeb krumpaiṇi. ${ }^{645}$ Atšḳirīgas no pārējām Vidzemes vīriešu galvassegām ir Piebalgas augstās ratenes ar platām malām. ${ }^{646}$

Vîriešu jostas Piebalgas novadā tādas pašas kā Ziemelvidzemē.

Piebalgas novadā ātrāk nekā citur sāka valkāt garos stulmu zābakus, liekas tāpēc, ka šeit dzīvoja vairāk amatnieku, kas bija turīgāki par zemniekiem. Bez tam, tā kā piebaldzēni paši veda uz pilsētu pārdot noaustos linu audeklus, tad bija nepieciešami par pastalām izturīgāki apavi.

Liekas, ka J. Broces vidzemnieku kāzu zīmē- jumā (skat. 28. att.) redzamie apgeērbi attiecināmi uz Piebalgas un Austrumvidzemes (skat. tālāk) novadu robežu. Augstie melnie un tumši zilie jaunavu vainagi ir lỉdzīgi Piebalgas vainagiem, bet sievu apaḷâs, ar ādām apšūtās cepures un nešūtie (apliekamie) brunči tuvāki Austrumvidzemes tērpa attiecīgajām sastāvdaḷām. Iespējams, ka 18. gs. arī Piebalgā valkāti apliekamie brunči. Priekšplānā sēdošā vỉrieša lēzenā cepure ar stipri platām malām zināmā mērā atgādina Liezeres zemnieku galvassegas. ${ }^{647}$ Attēlā redzamie vīriešu svārki ir dažādās krāsās; kāzinieki tumši pelēkajos vai brūnajos svārkos varētu būt piebaldzēni. Gaiši pelēkie un baltie svārki, tāpat kā vīriešu kāju āvums un pastalu auklu siešanas veids, ir tādi paši kā Austrumvidzemē. ${ }^{648}$

Tātad Piebalgas novada īpatnību veidošanā, no vienas puses, nozīmīga vieta bijusi brâlu draudzēm (melni svìtrotie brunči un melnie vainagi), no otras puses, iedzīvotāju nodarbošanās veidam un ar to saistītajiem tirdzniecības sakariem (iespējams, ka tieši sievu cepures «zal̨malītes» un krekla piegriezums ar piešūtiem uzplečiem ir noskatīts, tirgojoties ar krieviem).

Lielvārdes tērpi valkāti Rĩgas apriṇka dienvidaustrumu stūrī - Lielvārdes, Rembates, Lēdmanes un dalēji arī Kokneses pagastä ${ }^{649}$ (6. att., 4 ; 32. tab., 3-5).

Lielvārdes novadā 19. gs. vidū tērpam piemīt vienveidigs izskats. Brunčus, villaines un vainagus te darināja pēc viena parauga. Lielākā dažādība ir vienīgi sievu cepurēs un jostu rakstos. Salīdzinot J. Broces zīmētos lielvārdiešu tērpus ar Vẽstures muzejā esošo 19. gs. otrās puses Lielvārdes novada tērpu, redzamas izmaiṇas, kādas notikušas sieviešu apḡērbā gadsimtu mijā. Savu pirmatnējo veidu saglabājusi tikai sievu cepure, beí viss pārējais têrps izmainījies. Zìmējumiem J. Broce devis arī paskaidrojošo tekstu: «Zemnieka meita no Lielvārdes svētku tērpā. Uz neapsegtajiem matiem, kas nokarājas sapīti pīnē, ir sarkana tūka lenta (vainadziṇš), kas nosegts ar raibām smeldzēm. Ap kaklu ir k̦ēde, pie kuras piekārti zviedru piecnieks [monēta] un pie tā virs baltā krekla liela un maza sudraba priece. Linu kakla lakatam ir caurumota apmale, un pāri tam apnemta balta vilnas sedzene, kas izrakstita ar raibām dzijām un tādām pašăm bārkstīm. Brunči un priekšauts ir balti, pēdējais - izrakstīts.» Nākošajai figūrai šāds apraksts: «Kāda sieva no Lielvārdes savā [sievas] cepurē ar diviem izliekumiem.» ${ }^{650}$

J. Broces zīmējumā sieviešu krekliem ir stāvas apkakles, kas izšūtas krāsainām dzijām. Pēc Vēstures muzeja materiāliem šādas apkakles konstatējamas Krustpils, Dignājas un Cesvaines pagastu krekliem. O. Hūna zīmējumā šãda apkakle ir jēkabpilietei. Tāpēc jādomā, ka sieviešu krekli ar krāsainā izšuvumā darinātām apkaklēm 18. gs. bijuši plašāk izplatīiti kā Vidzemē, tā Augšzemē un uzskatāmi par sēlu apdzīvotās teritorijas īpat- 
nību. 19. gs. krāsaino izšuvumu nomaina baltais vienvirziena izvilkums. ${ }^{651}$

Par tuvību ar Augšzemes novadu liecina arī Lielvārdes krekla piegriezums ar piešūtiem uzplečiem, kādi pārējā Vidzemē nav sastopami ${ }^{652}$ un kurus te, tāpat kā Augšzemē, sauc par «lāstaugiem».

Unikāls ir Lielvārdes greznais krekls, kam kuplās piedurknes visā garumā izšùtas ar baltām zvaigznitēm un saulītēm. Kreklam uzpleča galā izstrādāts grieztais raksts, kas vēl sastopams tikai Rucavas kreklos. ${ }^{653}$

Brunčus parasti auda koši sarkanā pamatā ar melnām un baltām rūtīm, tos šuva kopā ar niieburam līdzīgu augšdaḷu, atstājot redzamu kä krekla priekšpusi, tā piedurkṇu augšdaḷ. Rūtainie brunči ir jaunāki par J. Broces baltajiem brunčiem. 70. gadu beigās Lielvārdē rūtaino brunču vietā ieviešas pelēki. ${ }^{654}$

Lielvārdes goda jostas ar sīko un bagāto rakstu atšḳiras no visām pārējām Latvijas jostām. Kompozicionāli lielo vidusrakstu iežogo tikai šaura svìtriña. Jostu raksts visai sarežğits; parasti tās auduš̀as ipašas jostu audējas. ${ }^{655}$

Vēstures muzeja materiālos no Lielvārdes, tā. pat arī no Ziemelvidzemes un Rietumvidcemes, ir tikai baltas villaines ar šaurām svītrinām galos un nelielām velku bārkstīm. Turpretī J. Broces zimējumā ļoti skaidri redzamas izšūtas villaines, bez tam sievai virs izšūtās villaines, liekas, ir balta snätene. Interesi izraisa villaiṇu rotājuma kompozīcija ar apvienoto stūri un atsevišḳu rakstu elementu vienā stūrī. Šāds kompozīcijas princips ir , raksturīgs Ziemelaustrumkurzemes izšūtajām villainēm; turpretim greznās krāsainās bārkstis un izskanu raksti radniecĩgi Austrumvidzemes villainu tipam. Lielvārdē, tāpat kā Augšzemē, biezās pelēkās un raibās villaines apzīmē par sagšām, ${ }^{656}$ un tas vēlreiz liecina par Lielvārdes un Augšzemes novada tuvību.

Pēc Vēstures muzeja materiāliem villaines $u z$ krūtīm sasprauda ar nelielām sudraba saktām, kas rotātas ar sarkaniem stikla akmentiniem. Arī krekla saspraušanai lietota mazāka saktiṇa ar sarkaniem vai zaliem stikla akmentiniem.

Lielvārdē ir visplatākie «mīkstie» vainagi (12 cm plati). Tos šuva no sarkana vilnas auduma (tūka) bez stingra pamata. ${ }^{657} \mathrm{~J}$. Broces zìmējumā vainags nav seviški augsts un liekas līdzīgs Krustpils un Austrumvidzemes vainagiem.

Visgreznākais Lielvārdes novada apgēēba gabals ir sievu cepure, kas pēc formas maz atšḳiras no torṇa cepures. Tās smailais gals nolocìts, apakšējā mala mugurpusē savilkta krokās, un taisnajā priekšmalā novietots krāsainām dzijām izšn̄its raksts, kas joslu dalījumā un sīko rakstu ziṇā atgādina Krustpils villaiṇu galu rakstu; krāsas gan ir spilgtākas, turklāt dominē zilā krāsa. Sievu cepuru rakstiem ir vairāki varianti, bet pamatprincips ir viens un tas pats.

Interesants ir J. Broces norādījums par monētu izmantošanu rotaslietām. Iespējams, ka šeit saska- tāma zināma radniecība ar igauniem, kuriem mo. nētu nēsāšana bija loti raksturīga. ${ }^{658}$

Lielvārdes novada vīriešu tërpi, izṇemot ippatnējos ìsos svītrainos svārkus, maz atškiras no Rietumvidzemes vīriešu tērpiem. ${ }^{659}$

Kā liecina E. Dunsdorfa dati, $66060-80 \%$ no mēra upuriem ir no Lielvārdes novada. Nemot vērā kartes sastādītāja norādījumus, ka galvenā iedzīvotāju pārvietošanās notikusi austrumu rietumu virzienā, iespējams, ka kreklus ar augstām apkaklēm un izšūtajām villainēm Lielvārdes novadā atnesuši pārceḷotāji no Augšzemes. Tam par labu runā arī ar Augšzemes krekla piegriezumu vienādais Lielvārdes krekla piegriezums. Nenoliedzama nozīme Lielvārdes tērpa izveidē ir arī sēliskajiem elementiem, jo pēc valodniecības datiem augšzemnieku izloksne Vidzemē sniedzās līdz Lielvārdei. ${ }^{661}$ Tātad lībiskie elementi 18. gs. Lielvārdes tērpä ir stipri samazinājušies (palikušas sievu cepuru un jostu kompozīcijas īpatnības).

Krustpils têrpi valkāti Krustpils, Ungurmuižas pagastā un Līvānu pagasta dalăä62 (6. att., 5). Kā jau norādīts iepriekš, ${ }^{6}{ }^{63}$ buržuāziskās Latvijas laikā Krustpils tika uzskatīta par Austrumlatvijas centru (skat. 33. tab., 1).

Krustpils tērpi no pārējās Vidzemes tērpiem atškiras ar îpatnēju krekla piegriezumu - tie ir tunikveida ar iekšā laistu uzpleci. ${ }^{664}$ Krekla rotājumā izšḳirami divi veidi. Pirmā veida rotājums ir neliels balti sarkans lïkloču raksts apkakles galos un valējos dūrgalos. ${ }^{665}$ Pēc otrā veida rotāta krekla apkakle bija stāva, izšūta ar krāsainām vilnas dzijām villaines rotājumam līdzīgos toṇos. ${ }^{666}$ S̄aurāks krāsains raksts rotāja arī greznās aproces vai val̨ējos dūrgalus. ${ }^{667}$

Goda tērpa brunčus vienmēr auda rūtainus. No krāsām parasti dominēja mālaini sarkanā krāsa, kas smalkā toṇu salikumā ar zilo, dzelteno un melno radīja acīm tīkamu mierīgu iespaidu. ${ }^{668}$

Krustpils novadā pazīstami arî svìtraini un vienkrāsaini darba brunči no vilnas vai linu auduma ${ }^{669}$

Nieburus un jakas pie goda tērpa Krustpils novadà nevalkāja, bet ikdienā nēsātas arī îsās un garās jakas. Šeit pazīstami bagātākie austo jostu raksti, ${ }^{670}$ kas vienä jostä vairāk par $2-8$ reizēm neatkārtojas.

Vīriešu apgēērbs Krustpils novadā bija visai vienkāršs, bez grezniem rotājumiem.

Atšḳirībā no sieviešu krekliem vīriešu krekli bija tunikveida ar virsū šūtu uzpleci un nelielu rotājumu vienvirziena izvilkumā apkakles galos. 19. gs. vidū krievu un poḷu plostnieku ietekmē izplatījušies krekli ar sarkanu izšuvumu. ${ }^{671}$

Krustpils novadā vīrieši vairāk valkāja garos svārkus, kurus apjoza ar košām pītām jostām.

Goda apg̣ērba svārkus šuva no baltas vai pelēkas vadmalas ar stāvu apkakli un muduru grupām sānos.

A ustrumvidzemes tērps valkāts gandrīz visā Madonas apriṇkī, atskaitot dažus pagastus ziemel̨os no Jaungulbenes un Galgauskas pagasta 
un Cēsu aprinkka austrumdaḷu (6. att., 6) ${ }^{672}$ Senās tērpu darināšanas tradīcijas vislabāk saglabājušās ap Madonu, kamēr rietumos vērojama stiprāka Lielvārdes, Rietumvidzemes un Ziemeḷvidzemes tērpu ietekme (skat. 33. tab., 2, 3).

Austrumvidzemes krekli bija balti, rotāti ar samērā niecīgu izvilkuma rakstu vai arī pilnīgi bez rotājuma. Tuvāk Krustpils novadam pazīstami arï krekli ar stāvām apkaklēm, kas izšūtas ar krāsainām dzijām un ielaisto uzpleci. ${ }^{673}$ Kreklu pie apkakles sasprauda ar vienu vai vairākām mazām sudraba saktiṇām.

Brunčus lielākoties auda svītrainus, rūtainie brunči ir jaunāki, sastopami retāk, turklāt biežāk novada austrumu daḷā. Madonas apkārtnē seviškii cienīja rakstainos brunčus. ${ }^{674}$

Austrumvidzemē sievietes, tiklab sievas, kā meitas, loti bieži valkāja jakas, turpretim n̦ieburi tur mazāk pazīstami. Parasti jakas vilka, kad nesedza villaines. Lielos godos jakas nevalkāja. Jakas darināja no vienkrāsaina vai svîtraina auduma, visizplatītākās bija gaiši pelēkās un tumši zilās jakas ar muduriem, t. i., kroku kūlīšiem un austiṇām, dažreiz arī ar sarkanām apmalēm un nelieliem izšuvumiem (Cesvaines jaka).

Austrumvidzemes jostas ir līdzīgas Krustpils jostām, tās rotātas ar mainu rakstiem, tikai raksti tām nav tik bagāti kā pēdējām; bez tam malu svìtras ir platākas par vidusdal̨u. Bez rakstainām jostām novada rietumdaḷā iecienītākas ir svītrainās un t. s. ziedainās jostas. ${ }^{675}$

Aụstrumvidzemē pie goda tērpa sedza grezno - izšūto villaini (skat. 16. tab., 1, 2).

Novada rietumu daḷā greznās villaines nevalkāja, bet arī pie goda tērpa sedza baltās villaines vai snātenes. Snātenes ar saktām nesasprauda; greznās villaines un dažreiz arī villaines sasprauda ar burbuḷu vai pakaru saktu. Bez šìm goda villainēm valkātas arī vēl gaišas, pelēkas un zilganas villaines, kā arī visā Vidzemē sastopa. mâs kuču villainìtes, kas darinātas no zalas veltas vadmalas.

Jaunavu galvassega bija sarkani auduma vainagi ar krāsainu stikla krellǐšu rotājumu, tie bija platāki par Krustpils novada vainagiem. Atsevišḳos gadījumos vainagi šūti arī uz tumši zila un pelēka tūka pamata.

Viens no senākajiem Austrumvidzemes novada apgēerba gabaliem ir izšūtās sievu cepures, kuras, kā jau minēts, redzamas arī 16. gs. zīmējumos. Cepures darinātas no balta, smalka linu audekla.

Austrumvidzemes vīriešu tērpus J. Broce uzzīmējis Drustu, Dzērbenes un Liezeres draudzēs. ${ }^{676}$ Krekli te darināti tunikveida ar virsū šūtu uzpleci un nelielu atlokāmu apkaklīti. Piedurknes nobeidzas ar aprocēm. Visiemīḷtākie bijuši balti krekli vai nu gluži bez raksta, vai arī ar loti niecīgu rotājumu. Krekli ar sarkaniem izšuvumiem bija sastopami samērā reti, un tie darināti 19. gs. otrajā pusē. Sādus kreklus līgava darināja līgavainim kāzu dāvanai. Kā kāzu jeb līgavaiṇa («brūtgana») krekli tie līdz šai dienai saglabājušies vecu ḷaužu atmiṇā.

Raksturīgākie Austrumvidzemes novada vīriešu svārki ir garie vai pusgarie. Svārki šūti no balta, gaiši pelēka vai zili pelēka vilnas auduma. Ipatnēji ir jau pieminētie Drustu zemnieku linu svārki - «uzvalks», ko velk virs kažoka. ${ }^{677}$ Šai novadā, tāpat kā Piebalgā, ir pazīstami arī «krunkotie» svārki, kas pārējā Vidzemē nav raksturīgi.

J. Broces ievērību saistījušas Sausnējas zemnieku jostas, kas bijušas blāvi sarkanā krāsāa ${ }^{678}$ Liekas, ka tās ir rakstainās jostas baltā linu pa. matā ar sarkaniem rakstiem, kas koptonī radá blāvi sārtu krāsu. Arī citos zīmējumos, kas attēlo Vidzemes vidienes iedzīvotājus, J. Broce rāda gaiši sārtas jostas, kas kreisajos sānos sasietas puškī.

İpatnējs ir šĩ novada kāju āvums - kājas līdz ceḷiem krusteniski nosietas ar pastalu auklām. Otrs kāju āvuma veids - zilas garas zekes, kas uzvilktas pāri celiem, ${ }^{679}$ redzams J. Broces Dzērbenes zemnieka zīmējumā. Šis ir vienīgais zīmējums, kur redzams zemnieks tumši zilām zeḳēm kājās. ${ }^{680}$

Nobeidzot Vidzemes tautas tērpu kompleksa lokālo variantu apskatu, secināms, ka lībiskie elementi tajâ novērojami daudz mazāk nekā Kurzemes tērpu kompleksā. Daḷeji tas izskaīdrojams ar etniskā sastāva izmainām. Austrumvidzemes un Krustpils novadu tērpos vērojama nenoliedzama tuvība ar Latgales un dal̨ēji arī ar Augšzemes tērpiem, kamēr Lielvārdes novadā, saskaroties lïbiskajiem un sēliskajiem elementiem, izveidojās îpat: nējs tērpa variants.

Pie Vidzemes tērpu kompleksa nevar pieskaitīt bij. Alūksnes rajona austrumu dą̣ā valkāto tērpu, kas ir tuvāks Latgales tērpu kompleksam. ${ }^{681}$

Latgales tērpa kompleksā vairāk nekā citos tērpu kompleksos manāma baltu un slāvu tautu kultūras mijiedarbība, pie kam šie sakari ne tikai sakṇojas tālā pagātnē, bet saistīti ar iedzìvotāju maiṇām Latgalē 18. gs. Lielajā mērī izmirušo latviešu zemnieku vietā uz dzîvi Latgalē apmetās ienācēji no Krievijas, Baltkrievijas ${ }^{682}$ un Vidzemes. Ienācēji no Vidzemes lielākoties bija bēgli, kas pēc toreizējiem Latgales likumiem nebija jāizdod.

17. gs. beigās Latgalē sākās krievu vecticībnieku ieplūšana (pēc 1935. g. tautas skaitišanas datiem vecticībnieku Latgalē bija $20 \%$ no visa Latgales iedzīvotāju skaita); visvairāk vecticībnieku dzīvo Daugavpils, Rēzeknes, dalệji arī Ludzas rajonā. ${ }^{683}$ Neskatoties uz noslēgto dzives veidu, zināmas iezīmes latgaliešu materiālajā kultūrā atstājuši arī vecticībnieki.

Kultūras sakarus ar baltkrieviem sekmējuši ne tikai baltkrievu iedzīvotāji ${ }^{684}$ Latgalē, bet arī tirdzniecības ceḷi un tirgi, kuros liela nozīme bija baltkrievu tirgotājiem. 18. gs. beigās Ludzas gada tirgos, kas notika 4 reizes gadā, sabrauca tirgotāji no Rēzeknes, Sebežas, Veḷikije Lukiem, Pleskavas, Neveles, Polockas, Vitebskas, Novgorodas gan ar vadmalu, zīda audumiem, gan arī ar citām 
precềm. Zemnieki uz gada tirgiem atveda lauksaimniecíbas ražojumus. ${ }^{685}$

18. gs. beigãs, pastiprinoties produktu ražošanai tirgum, uzplauka amatniecība un tirdzniecība. Paplašinoties muižu laukiem, lielāku nozīmi ieguva zemnieku klaušu darbs. Lai gan zemnieku mantas stāvoklis bija loti dažāds, ${ }^{686}$ tomēr visumā zemnieku sētas Latgalē nebija pārāk lielas, tāpēc zemi apstrādāja paši g̀imenes locekḷi (arī precētu dēlu gimenes loceklii). 19. gs. vidū saskaṇā ar Latgales mantošanas tiesībām, pēc kurām zemi vienlīdzīgās dậās sañēma visi dēli, ${ }^{687}$ saimniecības kḷva tik mazas, ka pieaugušiem g̀imenes locekḷiem mājās darba nepietika un tie devās peḷnàs. Peḷnās iegūto naudu parasti izmantoja apgēerba u. tml. iegādei. Tâpēc arī, lai gan Latgalē bija plaši attīstīta aušana, tur tomēr samērā ātri sāka parādīties pirkti apḡērbi ne tikai turīgāko zemnieku, ${ }^{688}$ bet arī trūcìgo zemnieku ğimenēs. ${ }^{689}$

Peḷnās iešanu izmantoja arī muižnieki, kas sāka atdot savus zemniekus darbā dažādiem uzñēmējiem, cel̨u meistariem u. c. gan savā, gan attālākās guberṇās ${ }^{690}$ 1835. g. grāfs Borhs uz citām guberñām nosūtīja darbos $300-700$ zemnieku. ${ }^{691}$

V. I. Lennins peḷnās iešanu novērtēja kā progresīvu parădỉbu, kas «izrauj iedzīvotājus no pamestām, atpalikušām, vēstures aizmirstām nomalēmı un ievelk viṇus modernās sabiedriskās dzīves virpulī». ${ }^{692}$ Pelṇ̂as gājēji, atgriežoties mājās, pārveda no citurienes redzètās lietas, apg̀ērba gabalus u. tml. un mēgināja tos atdarināt. Ar to laikam arī izskaidrojama parādība, ka blakus senajai latviskajai apgéerba terminolog̣ijai sastopami arī loti daudzi aizgūti nosaukumi, turklāt tieši tiem apg̀ērba gabaliem, kurus pirka kā pirmos (kopka, armjaks, svìta, burnuss u. c.).

Līdz ar to kḷūst saprotama lielā dažādība gan apg̀ērba terminolog̣ijāa, gan formās, kas turklāt variē pat viena pagasta robežās. Tomēr, nemot vērā tikai raksturīgākās un izsekojamās senākās apğērba valkāšanas tradīcijas, kas Latgalē saglabājušās līdz 19. gs. 70.-80. gadiem, visu Latgales kompleksu var iedalìt 2 lielos lokālos variantos: Dienvidlatgales un Ziemelllatgales.

Latgales tērpa krekli atšḳiras no pārējās Latvijas tunikveida krekliem ar virsū šùtiem uzplečiem, jo ir rotāti ar sarkanu izšuvumu. Brunči rūtaini, Ziemẹllatgalē - balti. Greznajās izšūtajās villainēs atšḳirīibā no Austrumvidzemes villainēm vairāk dominē zilā un zalā krāsu gamma; vasarā segti linu «puspalagi». Jaunavām sarkani zịlu vainagi, sievām - galvas auti.

Dienvidlatgales tērps valkāts Daugavpils, Rēzeknes un Ludzas apriṇkī (6. att., 7).693 Dienvidlatgales novada austrumdậa arī pie goda tērpa valkāja nerotātus kreklus ar val̨ējiem dūrgaliem un atlocītu apkakli. ${ }^{694}$ Pārējā novada dậa (pēc Vēstures muzeja materiāliem) sastopami krekli ar nelielu sarkanu rakstu apkakles galos. uzplečos un aprocēs. ${ }^{695}$ Arī Latgalē krekli šủti no diviem dažādiem audumiem, augšdaḷai parasti ñēma smalkāko audumu, bet apakšdalai no jostas vietas lîdz celgaliem vai pusstilbiem - rupja linu vai pakulu auduma «pīrūti». 696

Dienvidlatgales tērps valkāts loti plašā teritorijā, tāpēc arî brunči - lindraki ir ārkārtīgi dažādi un krāsās bagāti ${ }^{697}$ Parasti dominē spilgti sarkanā un zaḷā vai zilā un sarkanā krāsa. Vecākiem brunčiem krāsas saliktas rūtīs - kristos, bet 19. gs. otrajā pusē svītrās - streipās, ailiṇās. ${ }^{698}$ Brunčus vienmēr šuva stipri krokotus. Jakas val. kāja tikai aukstā laikā darbā, bet niieburus nevalkāja (skat. 34. tab., 1, 2).

Jostas Latgales novadā bija vai nu rakstainas, vai svītrainas, lielākoties celu tehnikā. ${ }^{699}$

Greznās izšūtās villaines Latgalē valkātas tikai tās rietumdalā̄; ${ }^{700}$ tās pieder pie Austrumvidzemes tipa villainēm, vienīgi krāsu salikumā vairāk nekā parasti šî tipa villainēs dominē zilā un zaḷā bet mazāk - sarkanā krāsa. ${ }^{701}$ Ornamentā bieži sastopami stilizēti ziedi; tas liecina par radniecību ar kaiminu - krievu ornamentu. Izšūtās villaines bija liels greznums, tāpēc tās piederēja tikai pašām turīgăkām vai loti čaklām meitām. ${ }^{702}$

Daudz biežāk nekā citos novados Latgalē grezno villaini aizstāj snātene - izsags, kura pagatavota no smalka rakstaina linu auduma.

Krāsainās villaines - sagšu, liẹ̣o skaru, lielo skustu sedza aukstā laikā pări snātenei vai izšūtajai villainei. Tās bija vienkrāsainas vai rūtainas, dažādos krāsu salikumos.

Jaunavas vainagus darināja no sarkana tūka vai vadmalas, tos izrotāja krāsainām stikla zịlitēm. Latgales vainagi ir platāki un pašas zīlìtess rupjākas nekā Austrumvidzemes vainagiem. Parastos zīlīšu vainagus bieži vien kuplināja ar mugurpusē piešūtām krāsainām zî̀a lentēm. ${ }^{703}$ 19. gs. vidū valkāti arī no ziediem vīti vainagi. ${ }^{704}$

Sievu galvassegas vecākais veids ir auts. Tas parasti austs no baltiem linu diegiem un rotāts ar tamborētām mežğinēm vai sarkanu izšuvumu. ${ }^{705}$ Pie sievu galvas rotas piederēja arī pārpieris; tas bija izšūts vai austs no krāsainas vilnas dzijas, un to sēja zem lakata (skat. 34. tab., 2).

Vīriešu tērpi Latgalē ir stipri vienveidīgi. Krekli bija tunikveida ar virsū šūtu uzpleci, parasti ar nelielu, stāvu apkakli. Atškirīībā no sieviešu krekliem vīriešu krekli dažkārt rotāti arī ar nelielu baltu izšuvumu. Latgalē valkāti arī t. s. krievu krekli ar krūšu šḳēlumu kreisajos sānos un krāsainu izšuvumu. 706 Jädomā, ka šie krekli pēc krievu parauga valkāti virs biksēm un ๖ijuši pazïstami visā Latgalē; arī parastie krekli ar atlocîtu apkakli un škēlumu priekšā te dažkārt valkäti virs biksēm..$^{707}$

Svārki - garie un pusgarie un biežāk nekā citos novados tumši pelēkā krāsāa ${ }^{708}$ Latgalē pazīstami ne tikai taisnie svārki, bet arī krokainie. Vīrieši un sievietes valkāja vienāda piegriezuma svārkus. ${ }^{709}$

Jostas sēja kā svītrainās celaines, tā arī pītās.

Îpatnējas Latgalē ir pastalu auklas - siksnas, kas darinātas no $1-2 \mathrm{~cm}$ platām ādas sloksnītēm..$^{710}$ 

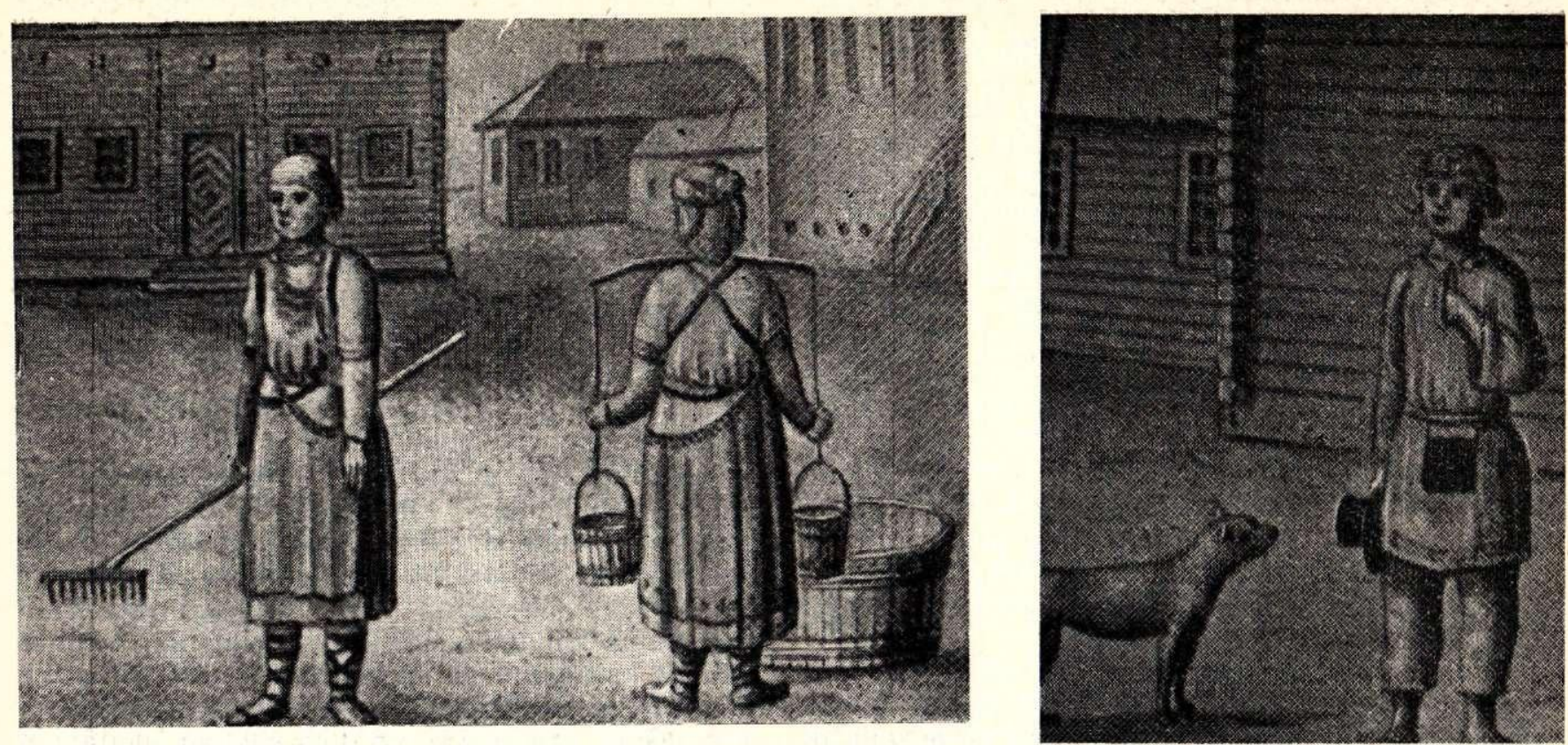

1

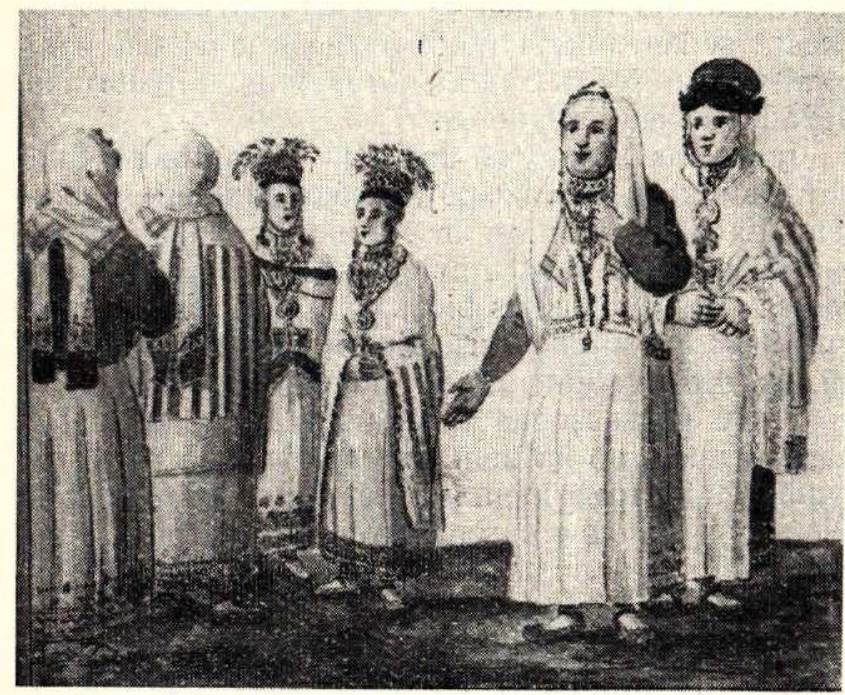

87. att. Vilakas $(1-2)$ un Daugavpils (3) apkārtnes zemnieku apgēerrbi pēc J. Broces (Monumente ..., VIII. 76. lpp. un VII. 128. lpp.) un G. Manteifela (Polnisch-Livland. 34., 35. lpp.).

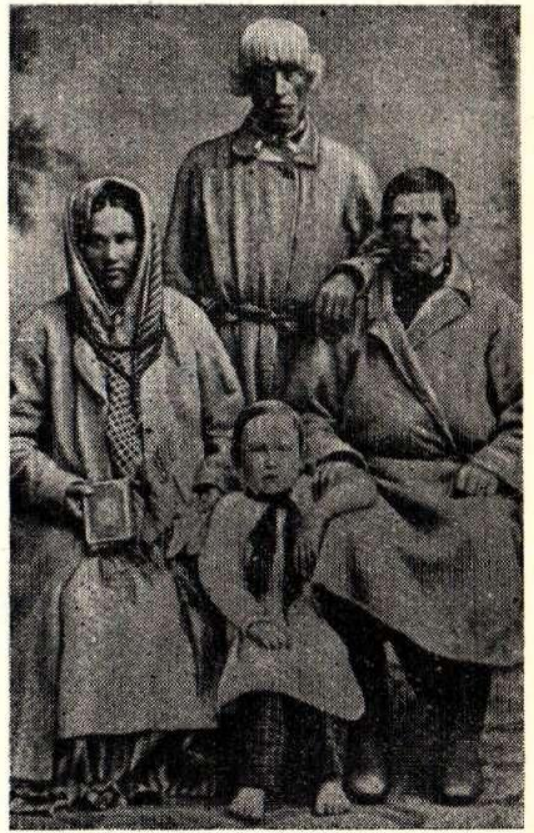

Vīrieši nēsāja zemas platmales ar platām malām. ${ }^{711}$

$\mathrm{Z}$ i e meḷ l a t g a les sieviešu apgèrbs (6. att., 8) vienīgais visā Latvijā ir nemainīgi saglabājis savu balto krāsu līdz pat 19. gs. Tāpēc liekas, ka tautasdziesmās minētajai baltajai tautu meitai vai māmuḷai atbilst tieši ši novada apğērbā tērpusies sieviete. Muzeja fondos ir samērā maz materiālu par šo novadu, bet arī pēc J. Broces 3 zīmējumiem iespējams gūt labu priekšstatu. ${ }^{712}$

Ziemellatgales tērps valkāts Ludzas aprinka ziemeḷu dạ̣ā ${ }^{713}$
Ziemeḷlatgales sieviešu tērps vairāk nekā citu novadu têrps radniecīgs kaimiṇu - igauṇu (setuku) un baltkrievu tautas tērpam. ${ }^{714}$

Ipatnējs ir Ziemeḷlatgales krekls ar virsū šūtiem uzplečiem, kas rotāti ar sarkanu rakstu. ${ }^{715}$ Viens no visizplatītākajiem Ziemeḷlatgales krekla uzpleču rotājumiem raksta un tehnikas ziṇā ir pilnīgi vienāds ar Baltkrievijas vīriešu kreklu rakstu. Liekas, ka šeit pārnemts raksts, kas savā izveidē atbilst kolektīva gaumei un ieguvis vietēju raksturu.

Vecākās brunču darināšanas paražas vēroja- 
mas Ziemellatgales baltajos brunčos, lai gan vietumis Ziemelllatgales novada sievietes apgèrēā sastopami arī vertikāli svītraini un rūtaini brunči (skat. 34. tab., 3).

Baltos brunčus auda no vilnas dzijām vai linu diegiem. ${ }^{716}$ Brunču apakšmalu rotāja ieaustas sarkanas svìtras, krāsains celu apauds un knipelētas mežğines vai arī viens vai otrs no šiem rotājuma veidiem. J. Broces zīmējumos brunču apakšñalas vēl rotätas ar izšuvumiem (87. att.). ${ }^{717}$ Izšūta brunču apakšmala bijusi ne tikai goda brunčiem, kā tas redzams minētajā attēlā, bet arī darba brunčiem, kas redzami Viḷakas muižas pagalma skatā. ${ }^{718}$ Iespējams, ka attēlā redzamais apğērba rotājums nav vis brunču, bet krekla apakšmalas rotājums (kā baltkrievu krekliem) ${ }^{719}$

Ziemelllatgales jaka darināta no balta vilnas auduma, tā rotāta ar stāvu melna tūka vai samta apkakli, celu apaudu un sarkanäm auklām.

Ziemeḷlatgales novada villaines (Austrumlatvijas tipa) rotājuma joslas ir šaurākas, tai nav arī grezno krāsaino bārkšḳu, bet ir tikai baltās velku bārkstis. ${ }^{720}$

J. Broces zīmējumā redzamā villaine izskatās it kā sašūta no 3 gabaliem, pie kam vidējais ir rotāts ar sarkanām rakstainām svītrām. Muzeja fondos nav saglabājusies neviena šāda veida villaine, bet Latgales snātenes arī auž no 3 gabaliem, pie kam vidējais ir rakstainā audumā.

Ipatnējs ir arī Ziemel̨latgales vainags, kas ar krāsaina stikla krellītēm izšūts sarkanā, no linu diegiem tamborētā vai tāpat kā citos novados sarkanā tūka pamatā. ${ }^{721}$ Liekas, ka tamborētie vainagi būs bijuši trūcīgo meitu rota, jo linu diegi bija daudz lētāki nekā tūka audums.

Sievu galvassega - balta linu auduma galvas auts siets tāpat kā Dienvidlatgales auts.

Villainu saspraušanai agrāk lietotās burbulsaktas 19. gs. pie Ziemel̨latgales tērpa vairs nav saglabājušās; arī kreklu saspraušanai saktas lietotas daudz retāk nekā citos novados, jo parasti kreklu pie kakla sasēja ar krāsainām vai baltām lentītēm.

Augšzemes tērpa komplekss aptver Ilūkstes un Jēkabpils apriṇkus līdz Daugavai, ${ }^{722}$ saplūstot ar Zemgales novada austrumu dalu (6. att., 9).

Labāko materiālu par Augšzemes novada tērpiem sniedz $\mathrm{O}$. Hūna zīmējumi ${ }^{723}$ un $\mathrm{S}$. Navicka apraksts. ${ }^{724}$

Augšzemes sieviešu krekliem uzpleči piešūti audu virzienā. Izškirami trīs Augšzemes krekla veidi: 1) krekli ar kuplām piedurknēm, kas rotātas ar sarkanām ieaustām vai iešūtām rakstu svītrām (skat. 34. tab., 4), kādas bieži sastopamas baltkrievu un ukrainu tautas tērpā; ${ }^{725}$ 2) krekli ar atlocítu apkakli un 4 sarkaniem raksta elementiem katrā tās stūrī; arī platais krekla uzplecis rotāts ar sarkanbaltu izvilkumu; ${ }^{726}$ 3) krekli ar stāvu krāsainu apkakli un krāsainu vaḷējo dūrgalu rotājumu. Šì veida krekli izplatīti Krustpils novada tuvumā. ${ }^{727}$

Brunči - lindraki Augšzemes tērpu kompleksā ḷoti dažādi, gan svîtraini, ${ }^{728}$ gan rūtaini, gan arī vienkrāsaini dažādā krāsu salikumā, kurā līdz ar kịmisko krāsu parādī̌sanos 19. gs. otrajā pusē ienāk spilgti sārtā (rozā) un violetā krāsa. Tikai Augšzemei raksturīgi ir sarkanie brunči ar lāsojumiem. Lāsojumu panāca, ja, dziju krāsojot, to dažās vietās stingri nosēja, tā ka šîs nosietās vietas palika nenokrāsotas. No šădi krāsotas dzijas austajos audumos izveidojās lāsīšu un svîtriṇu raksti. ${ }^{729}$ Ipatnēji ir .Augšzemes novada priekšauti ar sarkaniem ieaustiem vai izšūtiem rakstiem. ${ }^{730}$

Virs krekla dažkārt vilka jaku ar augstu, stāvu apkakli, lielu krūšu izgriezumu un kroku grupu mugurpusē, bet $\mathrm{O}$. Hūna materiālos sievietēm redzamas arī vīriešu svārkiem līdzīgas garās jakas gaiši pelēkā un tumši zilā krāsā. ${ }^{731}$ Tādas pašas krāsas bijuši arī tur valkātie niieburi. ${ }^{732}$

Greznākā tērpa sastāvdaḷ Augšzemes tērpa kompleksā ir villaine, kas pieder pie Austrumlatvijas villainu tipa. ${ }^{733}$ Villaines krāsas tomēr daud\% spilgtākas nekā parasti šā tipa villainēm; bez tam daudziem villainu variantiem austras koki ir kḷvuši smagāki par vieglo joslu rakstu. Villaini sasprauda ar burbuḷaktu, tāpat kā Vidzemes vai Latgales novados. Trūcīgākās zemnieces valkājušas arī baltas, nerotātas villaines. ${ }^{734}$

Bez greznajām izšūtajām villainēm pazīstamas arī rūtainās villaines un snātenes, kuras godos ne. valkāja (skat. 34. tab., 5) .

Augšzemes novadā sastopami gan šaurāki, gan platāki sarkana tūka vainagi, kas rotāti zīḷ rakstiem. ${ }^{735}$ Ipatnējs ir Ilükstes vainags, kuram virs pērlišsu raksta uzšūta zila zīda lente, pie kuras piešūtas sārta auduma rozītes (skat. 26. tab., 5).

Sievu galvassega bija no balta smalka linu auduma darināts auts ar sarkanu rakstu un bārkstīm galos. ${ }^{736}$ Krustpils novada tuvumā 19. gs. sākumä sievas valkājušas arī torña cepures, bet ziemā - cepures ar aitādas apšuvumu. ${ }^{737}$

Augšzemes vīriešu apğērbi līdzīgi Vidzemes un Latgales vīriešu apǵērbiem, tādēḷ tie atsevišḳi netiks apskatīti. Mētel̨us un kažokus vīrieši un sievietes valkāja vienādus ${ }^{738}$ (skat. 34 . tab., 6).

Zemgales kompleksa tērpi valkāti Jelgavas un Bauskas aprinkịi, kā arī Kuldígas un Tukuma aprinka austrumu dalāā, kas piekḷaujas Jelgavas apriṇkim (6. att., 10). ${ }^{739}$

Krekli Zemgalē valkāti tunikveida ar vai bez uzplečiem; parasti krekli rotāti ar šaurākiem vai platākiem rakstiem, kas izstrādāti balto darbu tehnikā. ${ }^{740}$ Jaunākajiem darba krekliem Zemgales novadā, tāpat kā Piebalgā, ir piešūts uzplecis un nav apkakles. ${ }^{741}$ Darba kreklus pie kakla aizsēja ar lentītēm vai aizdarināja ar diegu pogām. Goda kreklus sasprauda ar mazām apaḷām vai sirdsveida saktin̄ām ar vai bez piekariniem.

Kā jau minēts, Zemgales brunči atškiras no pārējo novadu brunčiem ar ziedainām vai galdainām svītrām. Brunču raksts bija tik grezns, ka atkrita nepieciešamība nēsāt izšūtās greznās villaines. ${ }^{742}$ Sie îpatnējie brunču audumi veidojušies Kurzemes hercoga Jēkaba aušanas darbnīcu ražo- 
jumu ietekmē. Darbnīcās dzimtcilvēki auda dažādus puḳotus audumus pēc rakstu grāmatām, no šĩm grāmatām sāka aust arī mājamatnieki. ${ }^{743}$

Novada rietumdąā pie goda tērpa valkāja arī parastos svītrainos brunčus (tāpat kā Austrumkurzemē), kurus šuva l̨oti kuplus.

Ipatnēji ir brunči ar lielām, retām rūtīm un rūšu vidū ieaustām puḳēm. Šādi auduma raksti, tikai priekšautiem, sastopami arī Lietuvā, vienīgi citā krāsu salikumā.

Jaunākā laikā pie goda tērpa sievas valkāja jakas, bet jaunavas - ṇieburus, kuri, tāpat kā jakas, sniedzās līdz jostas vietai un priekšpusē bija aizdarināmi ar sudraba vai dzintara pogām. Parasti jakas un nieburus šuva no vilnas auduma, bet ir ziñas arī par zīda ñieburiem. ${ }^{74} \mathrm{~J}$. Kola zimējumā redzams ar lentēm krustiski aizdarināts nุieburs. ${ }^{745}$

Zemgales novada jostas līdzīgas Krustpils novada jostām, tikai to krāsas ir spilgtākas un zilās krāsas vietā dominē spilgti violeta krāsa. ${ }^{746}$ Ari raksta varianti nemainās tik bieži kā Krustpils jostām. 19. gs. jostu siešana vairs nav iecienīta, atskaitot gadijumus, kad nevilka jaku vai n̦ieburu.

Rakstainäs villaines Zemgales novadā nav sastopamas, bet pie goda tërpa sedza baltas villaines, kas austas balinātu linu diegu velkos un baltu vilnas dziju audos. Villaines galos ieaustas krāsainas svîtras. Atškirīībā no Vidzemes baltajām villainēm Zemgales villainei gar abām malām piešūts celu apauds un galos krāsainas, celos austas bārkstis ${ }^{747}$ (skat. 35. tab., 2, 3).

Pilsētu modes ietekmē pie goda tērpa bieži vien sedza krāsainus zīda lakatus ar garām bārkstīm.

Visos pārējos Latvijas novados raksturīgā jaunavu galvas rota - vainags jau 19. gs. vidū Zemgales tērpu kompleksā nav valkāts; drānas vainaga vietā valkāja ziedu vainagu vai raibu zīda lakatu; spriežot pēc J. Kola zimējumiem, Zemgalē valkātas matu lentes; tās valkātas tâpat kā Rucavas kaspine un lietuviešu jaunavu matu lentes. ${ }^{748}$

Sievu galvas rota bija linu drānas vai šķidrauta cepure, pārsieta ar lentveidā salocītu lakatiṇu. 18. gs. valkāti arī krieviṇu sapānam līdzịgi galvas auti. ${ }^{749}$

Zemgales novada austrumdậa valkātas baltas vilnas zekes, ar krāsainu valni, bet rietumdalāa baltas vilnas zeķes bez valṇa vai arī caurumotā rakstā adītas diegu zeķes.

Kurpes valkāja melnas vai tumši brūnas ar siksninuu päri vidus daḷai. Dažkārt loti turīgas saimnieces kurpes rotāja ar sudraba sprādzem. Pēdējās ir jāuzskata par 18. gs. Rietumeiropā valdošās kurpju modes tālu atblāzmu. ${ }^{750}$ Arī vīrieši, it îpaši turígie, 19. gs. pirmajā pusē nēsāja līdzīgas kurpes ar sudraba sprādzēm.

Zemgales vỉriešu apg̀ērbu pašu pirmo nomainīja pilsētas apgèress, tāpēc arī muzeja fondos grūti atrast labus Zemgales novada vīriešu apg̀ērbu paraugus. Vieniggais materiāls šai ziṇā ir J..Broces zìmējumi. J. Broce zìmējis zēnu no Bal- dones, zemniekus no Saules muižas un Mežmuižas apkārtnes. ${ }^{751}$ Zemnieku no Saules muižas J. Broce ir nosaucis par krieviṇu, ${ }^{752}$ bet tā apgèrbs ir tāds pats kā jau agrāk minētajiem Liezeres un Sesavas zemniekiem un stipri atškiras no A. Pecolda 1846. g. zīmēto krieviṇu apgèrba. Tàpēc jādomā, ka jau 18. gs. lielākā dala krieviṇu bija zaudējuši savu îpatnējo apg̀ērbu un gērbằs tāpat kā latvieši (skat. 21. tab., 5-7).

Zemgales novada vīriešu krekli bija divējādi austrumdậa valkāti Augšzemes vīriešu krekliem līdzīgi krekli, bet rietumdalāa - nerotāti krekli, izṇemot koši sarkanas drēbes uzšuvumu pie apkakles uzpleča galāa ${ }^{753}$

Zemgales ziemel̨u daḷā vīriešu svärki parasti šūti no baltas un gaiši pelēkas, bet dienvidu dalāa lỉdz 19. gs. 40. gadiem - no zilas drānas ${ }^{754}$ (skat. 35. tab., 4-6).

Zemgales novadā ātrāk nekä citur, proti, jau 19. gs. sakumā, sāk izplatīties zīlēm izšutas jostas.

Kurzemes kompleksā tautas tërpa valkāšanas tradīcijas dažos novados saglabājäs pat līdz 20. gs. vidum. No otras puses, tieši Kurzemes kom. pleksā saglabājušies visvecākie rotātie apgēerba gabali - zilās mēlenes ar metāla rotājumu un metāla vainadziṇi. 17. gs. vidū merkantilisma politikas rezultātā strauji uzplaukst Kurzemes hercogistes manufaktūras un tirdzniecība. Kurzemes hercoga tirdzniecības kug̀i veda uz ārzemēm hercogistes ražojumus, lai pēc tam atgrieztos Kurzemē ar ārzemju precēm. Hercoga manufaktūrās darinātos audumus pārdeva Vidzemē, Lietuvā, Polijā un Krievijā.

Manufaktürās bija nodarbināti hercoga apkärtējo muižu zemnieki, kas te pildīja savas klaušas. Bez tam hercoga manufaktūrās strādāja arī algoti strādnieki un ārzemju meistari. Dabiski, ka no hercoga manufaktūrām jaunā tehnika un ornaments ieviesās arī mājamatniecībā. Merkantilisma politika sekmēja naturālās saimniecības sairšanu, bet tas savukărt ietekmēja arī apgèrba attīstību. Tāpēc arī Kurzemē vairāk nekā pārējā Latvijā tautas tērpa sīkdaļas veidotas no pirktiem ievestiem materiāliem (zīda, brokāta un samta lentes, pogas, zỉda lakatiṇi u. c.). 17. gs. otrajā pusể hercogistes rūpniecība nespêja vairs tālāk attīstīties. Klaušu manufaktūra nevarēja sacensties ar kapitālistisko Rietumeiropas manufaktūru. Negatīvi rūpniecību ietekmēja jauns poḷu un zviedru karš 17. gs. 50. gados. Sakarā ar visiem šiem apstākliem rüpniecíba un tirdzniecība Kurzemes hercogistē pèc îslaicigga uzplaukuma strauji panīka, un 18. gs. Kurzemes rūpniecība attīstijjās daudz gausāk nekā Vidzemē. Vēl 19. gs. vidū Kurzemē nebija lieluzñēmumu, bet pastāvēja sīkas kapitālistiskas darbnìcas ar zemu mehanizācijas lïmeni. ${ }^{75}$ Ari pilsētu amatniecība bija vāji attīstìta. Tādēl arī Kurzemes tērpu bagātās rotas, kas savu izveidi iegüst 17. gs., paliek sastingušas $l i ̄ d z 20$. gs. Nozīmīga vieta tautas tērpu izveidē ir arī Kurzemes iedzīvotāju etniskajam sastāvam. Visi šie apstākli veicināja Kurzemes tērpa kompleksa un tā lokālo 
variantu īpatnību izveidi. ${ }^{756}$ Kurzemes tērpa kompleksa izplatības robežas visumā sakrīt ar Kurzemes administratīvajām robežām buržuāziskajā Latvijā.

Têrpa kompleksa atšḳirīgas îpatnības ir kreklu rotājums, īpatnējās villaines, metāla jostas, metāla vai zịlu vainagi ar cietu pamatni un spēcīgais krāsu zieds. Kurzemes tērpu komplekss dalās 6 lokālos variantos: Ziemeḷurzemes, Ventspils, Alsungas, Kuldīgas, Austrumkurzemes un Dienvidkurzemes.

Zi emelkurzemes tērpi valkāti Talsu apriṇkī un Ventspils apriṇķa ziemeḷu dą̧ā (6. att., 11) ${ }^{757}$ Lìdzšinējos pētijumos par tautas tērpiem Ziemeḷkurzemē atsevišḳi tiek izdalīts lïbiskais apgabals ${ }^{758}$ un latviskais apgabals. ${ }^{759}$ Tā kā šajā teritorijā lībieši un latviešu vienmēr dzīvojuši jaukti un asimilācijas process bija ļoti lēns, runāt par kardinālām atškiirībām 19. gs. sākuma lỉbiešu un Ziemeḷurzemes latviešu apgèreā nevar. 18. gs. sākumā mērī apmēram $50 \%$ Kurzemes hercogistes iedzīvotāju, tai skaitā arī lībieši, izmira, ${ }^{760}$ un viṇu vietu pamazām ieṇēma latvieši. Arī salīdzinot A. Pecolda un A. Heikela lībiešu tērpu zīmējumus $^{761}$ ar Tukuma un Talsu tērpiem, skaidri redzams, ka minētais dalījums ir lieks, jo stipri daudz lībisko elementu ${ }^{762}$ ir visas Ziemel kurzemes tērpos. Ziemeḷurzemes tērpā visilgāk saglabājies lïbiešiem raksturīgais kolorīts - tumši sarkanā, zilā un zaḷā krāsa (skat. 36. tab., 2-4).

Sieviešu krekli ir loti vienkārši, tunikveida ar virșū šūtu uzpleci, ${ }^{763}$ bieži vien bez rotājuma. Kā gados vecākas teicējas zina stāstīt, ar baltiem un kupliem rakstiem izrakstītie sieviešu krekli jūrmalienē esot radušies, atdarinot vīriešu kreklu rotājumus. ${ }^{764}$

Ziemeḷkurzemē konstatējama zināma rakstu nabadzība, kāda citos novados nav sastopama. Tã, piemēram, Talsu kreklam tas pats villaines stüru žuburotais elements tiek šūts arī krekla apkakles stūros. ${ }^{765}$

Brunči - svītraini, to krāsas samērā spilgtas, dominējošās - sarkanā un zą̣āa ${ }^{766}$ Izṇēmums ir Laidzes brunči, kuru mierīgo smilšu krāsas pamatu škērso baltas rütis, kurās ieausts sarkans ziediṇs. Šie brunči radniecīgi Zemgales brunčiem un zināmā mērā norāda, cik tālu sniedzas Zemgales kompleksa ietekme. Brunči šūti vai nu savilkti krokās, vai arī sakārtoti noteiktās kroku grupās kā Kuldīgas novadā. Senākajiem brunčiem svītras kārtotas horizontālā virzienā.

19. gs. pie goda tērpa valkāja jaku vai n̦ieburu ar muduru grupām mugurpusē. Kandavas apvidı̄ı jakas vai ṇieburus aizdarināja ar sudraba pogām. N̦ieburu un jaku krāsa ļoti dažāda.

Ziemeḷurzemē pie goda tērpa bez baltas villaines, kas rotāta ar primitīvu aplišu rakstu gar villaines malām un lielākām žuburainām saulītēm visos četros stūros, ${ }^{767}$ sedza rūtainas villaines -lielos lakatus. ${ }^{768}$

İpatnējs apg̉ērba gabals, kādu 19. gs. otrajā pusē citos novados nevalkāja, ir t. s. pussvārcis resp. sedzamie brunči (51. att.). Pussvārči neko neatšķiras no parastajiem brunčiem, bet tos valkāja tikai aukstākās vai lietainās dienās un ziemā, uzsegtus uz pleciem. Saliktus divām kārtām, pussvārčus ñēma apkārt pleciem un priekšpusē, pakaklē saāḳēja. Lietum līstot, vienu pussvārču pusi pārsedza pāri galvai (skat. 36. tab., 4) .

Galvā jaunavas lika rupjiem stikla salminiem izrakstītu platu drēbes vainagu, kurš veidots uz stingra tāss vai kartona pamata. Sēja arī zīda lakatu (kā Zemgales novadā) ${ }^{769}$

Sievu galvassega bija t. s. aube ar krokotu mežg̀ini vai spilgtu zīda lenti gar malām. Cepurei pāri sēja lentveidā salocītu zīda lakatu. Bez tam dažuviet galvā sēja baltu dvielveida rakstītu linı autu un virs tā lika sievu cepuri. ${ }^{770}$ Autu sienot, tả viens gals aizsedza zodu. Liekas, ka šāds zoda aizklāšanas veids bijis raksturīgs lïbiešiem, kas arī mēdza zodu apsiet ar speciālu lakatiṇu mundoku. ${ }^{771}$

Jostas Ziemelkurzemē nemēdza siet. Ar austām vai pītām prievītēm apsēja zeḳes.

Villaines Ziemeḷkurzemē parasti ar saktām nesasprauda, kreklus sasprauda ar sudraba, dzintara vai perlamutra saktiṇām.

Sakarā ar Ziemeḷurzemes tērpu vietā minēt O. Hūna zīmējumus no Tukuma apvidus ${ }^{772}$ un Plieṇu ciema, kas teritoriāli ietilpa Ziemelkurzemes un Zemgales tērpu valkāšanas robežās.

Pirmajā zīmējumā redzama jaunava no Tukuma apvidus; zem zīmējuma uzraksts krievu valodā: «latviete. a. R.». Jaunavai ap galvu ir divas sarkanu pērḷu rindas. Krekla stāvā apkakle un aproces izrotātas ar sarkaniem izšuvumiem. Virs krekla melns nieburs. Brunči balti, kupli, ar sarkanu raksta joslu. Visinteresantākā zìmējuma dạa ir baltā, garā villaine ar îsām baltām bārkstīm visapkārt un noapaḷinātiem stūriem. Bārkstīm līdzi stiepjas šaura sarkana josla.

Otrajā zīmējumā redzams Plieṇu ciema sievas tērps. Zem attēla paraksts «Curländische Bäuerin in der Gegend von Ploenen». Sievai balts galvas auts, villaine ir tumši zila vai mẹla, tai visapkārt pelēka mala; pēc zīmējuma nav izprotams, vai pelēkā mala ir izšuvums vai cits kāds rotājums. Brunči melni ar sarkanu malu. Kājās valkātājai, liekas, ir divi pāri baltu zeḳu, viens pāris garo, otrs - ìso, īsajām - dzeltens valnītis ar sarkanı līkloču rakstu.

Lai arī šie zīmējumi nav visai veikli, tomēr tajos redzamās apḡērba sastāvdalas pilnīgi atbilst muzejā esošajiem materiāliem. Tukuma apkārtnes jaunavas tērps vairāk atbilst Kuldīgas novada tērpam, bet Plieṇu ciema sievas tērps Alsungas novada tērpam. ${ }^{773}$ Tas, ka Tukuma apvidū ir valkāts Kuldīgas tērps, nav neparasta parādība, jo atsevišḳi apgèērba gabali, kas līdzīgi attiecīgiem Kuldīgas apvidus tērpa apgèēba gabaliem, Ziemeḷurzemes novadā sastopami arì vēlākā laikā. 
Vĩriešu tērpi Ziemeḷurzemē ir samērā vienveidīgi - Ziemeḷkurzemes vīrieša tērpa zīmējums redzams $\mathrm{O}$. Hūna materiālos. ${ }^{774}$

Krekli bija tunikveida ar virsū šūtu uzpleci un atlocītu apkakli. Tie nebija bagāti izšūti, vienīgi gar apkakles malu bija pašaurs cauro vị̣u rotājums, kā tas redzams arī $A$. Pecolda lībiešu vīriešu zīmējumā no Mazirbes. Izñēmums ir Talsu vīriešu krekls, kas rotāts ar tādu pašu saulišu motīvu kā sieviešu krekls. Kreklus pie kakla nesasprauda ar saktinu, bet sasēja ar krāsainām diegu lentītēm, kuru galā bija puški i. Līdzīgs krekla sasiešanas veids redzams vēl A. Pecolda krieviṇu zìmējumā (skat. 4. tab., 2).

Ziemeḷkurzemes vīriešu tērpiem raksturīgas īsas bikses, kas sniedzas nedaudz pāri celiem. Bikses zem celiem aizpogāja ar vienu vai 2 pogām un apsēja ar greznām saitēm. ${ }^{775} \mathrm{O}$. Hūna zìmējumā platmalei ir grezna, vairākkārt apvīta krāsaina lente ar pušḳiem galā.

Svārkus valkāja ìsus vai pusgarus. Vairākus svārkus vilka tikai aukstā laikā. Ziemeḷurzemes svārki, tāpat kā svārki Ziemeḷvidzemē, rotāti ar bagātu aukliṇu un apmal̨u rotājumu.

Ventspils tērps valkāts Ventspils aprinka lielākajā daḷā776 (6. att., 12). Liekas, ka lỉbieš̉u ietekmē tērpā dominē drūmākas krāsas un citādi rotāšanas principi nekā Kuldīgas un Alsungas tērpos (skat. 35. tab., 5, 6).

Pēc brunču piegriezuma, metāla vainagiem un jostām, kā arī tumši zilajām villainēm Ventspils tèrpā vērojama radniecība ar Alsungas un Kuldìgas tērpiem. Lai gan apgiērbu krāsas un valkāšanas tradīcijas ir dažādas, liekas, ka pirms lokālo variantu izveidošanās šajos novados ir valkāti vienādi tērpi.

Ventspils krekls tunikveida ar virsū šūtiem uzplečiem. Pēc rotājuma tas ir daudz vienkārš̌āks nekā Kuldīgas novada krekls. Tas rotāts ar vienvirziena izvilkumu balto darbu tehnikā apkaklē, uzplečos un aprocēs. ${ }^{777}$ Izšuvuma tehnika tikpat vienkārša kā Ziemeḷkurzemes tērpā. Kreklu priekšpusē sasprauda ar mazu sudraba saktiṇu; saktiṇa bija gluda vai arī rotāta ar krāsainiem stikla akmentiniem.

Brunči austi no brūngansarkanām dzijām ar gaišākām šaurām svītrām. ${ }^{778}$ Tie šūti, savilkti vairākas reizes sīkās krokās virs jostas vietas; tiem piešüta svītraina vai puḳota ṇieburveida augšdal̨a. Priekšpusē divu plaukstu platumā brunči nav krokoti, bet atstāti gludi. ${ }^{79}$ S̄āds brunču piegriezums, kā jau iepriekšējā nodaḷā bija minēts, raksturīgs zviedru tērpiem. ${ }^{780}$ Pāri brunčiem un kreklam vilka jaku, kas šūta no tumši zila vai zaḷa vilnas auduma. Jakas krāsa labi saskan ar brunču krāsu. Jaku priekšpusē aizdarināja ar misiṇa āḳiem, kam virsū uzlodètas gludas un apalas «cepurītes».

Austas jostas Ventspilī, tāpat kā Kuldīgas novadā, nav pazīstamas; parasti ap vidu likta metāla sleñgene. ${ }^{781}$

Ventspils novada villaines - vildrānas gandrīz visas ir divkārtnes. ${ }^{782}$ Raksts novietojas vil- laines galos, dažreiz arĩ vienă malā; tas veidots no ieaustām svītrām, kuru starpā šūti līkloči un t. s. kocinini. Villaines galus rotā krietni plats brūnimelns vai brūnizalš apauds ar lielu pušķi noslēgumā. Sarežğîtā apaudu tehnika liek domāt, ka tos audušas amatnieces. Villaini sasprauda ar vienu vai divām saktām, ko sprauda vienu virs otras.

Bez baltās villaines - baltvīkāles, dubultvīkāles vēl bija pazīstamas mēlenes ar bronzas rotājumu ${ }^{783}$ vai arī ar krūmiem stūros, kas bija izšūti ar krāsainiem diegiem. S̄is mēlenes sauca par zilāmu, un tās liecina par lībiešu vai slāvu ietekmi.

Ventspils sievas parasti sedzās ar melnbalți rūtainām villainēm, kuru brūnā apakšmala ${ }^{784}$ atgādina balto villaiṇu celu apaudu.

Jaunavu galvas rota - spangu vainags, ${ }^{785}$ bet sievu - divi vai trīs zīda lakati un galvas auts. ${ }^{786}$

Spriežot pēc $F$. Kruzes zīmējumiem, vīriešu tērps radniecīgs Ziemeḷkurzemes tērpiem. Pēc P. Keizerlinga un E. Deršava apraksta Ventspils vīriešu tērps vienāds ar $\mathrm{O}$. Hūna zīmēto Plieṇu ciema vīriešu tērpu (augsta cepure, krekls sasiets ar baltām aukliṇām un balti svārki bez rotājuma). ${ }^{787}$ Pēc Latvijas PSR Vēstures muzeja fondos esošajiem materiāliem redzams, ka Ventspils vīriešu svārkiem, tāpat kā Kuldīgas svārkiem, bijuši misiṇa āḳi. ${ }^{788}$

A ls ung a s novada tērpā senās tērpu valkāšanas tradīcijas saglabājušās visilgāk. ${ }^{789}$

Alsungas novads aptver Aizputes aprinka ziemel̨u dal̨u ${ }^{790}$ (6. att., 13). Liekas, ka Alsungas tērpu poliskās îpatnības, kas to atškiir no Kuldīgas un Ventspils tērpiem, nav pārāk senas un to izcelsme saistāma ar Alsungas vēsturi. Alsunga jau 1230. g. dokumentos minēta kā kuršu ciems; 17. gs. sākumā blakus pilij bijis prāvs miests, kas piederējis grāfam Šverinam. Miests, atrazdamies lıti izdevīgā vietā, strauji uzplauka. Kad grāfs Šverins, savas katoḷticīgās sievas polietes pamudināts, pārgāja katoḷticībā, tas piespieda arī miesta iedzīvotājus pieñemt šo ticību, nepaklausīgos no miesta padzenot. Rezultātā gandrīz visi tirgotāji un amatnieki miestu atstāja. Grāfs miestā novietoja klaušu zemniekus un amatniekus. ${ }^{791}$ Kad pēc Šverina nāves (1636. g.) viṇa atraitne abas Alsungas novada baznicas nodeva katolu draudzēm, visa novada zemniekiem bija jāpāriet katoḷticībā.792 Droši vien, vismaz daḷa uz Alsungu pārvietoto klaušu zemnieku būs bijuši poḷi no Sverina sievas dzimtlaudīm, kuri, šeit părceldamies uz dzīvi, ieveda jaunas modes jakas, sarkanos brunčus, krāsainiem diegiem izšutas kreklu aproces un smeldžotās apkakles, tāpat arī košās krāsas. Rezultātä Alsungas tērpa atsevišķi apğērba gabali liekas pat pilnigi vienādi ar poḷu apgèēba gabaliem. ${ }^{793}$

Senākie Alsungas krekli ir ar garām aprocēm, kuras izšūtas ar balinātiem un nebalinātiem linu diegiem, kamēr jaunākajiem krekliem aproces ir izšūtas ar violetām, dzeltenām, zaḷām un sarkanām dzijām..$^{794}$ Arī Alsungas krekla smeldžotā ap- 

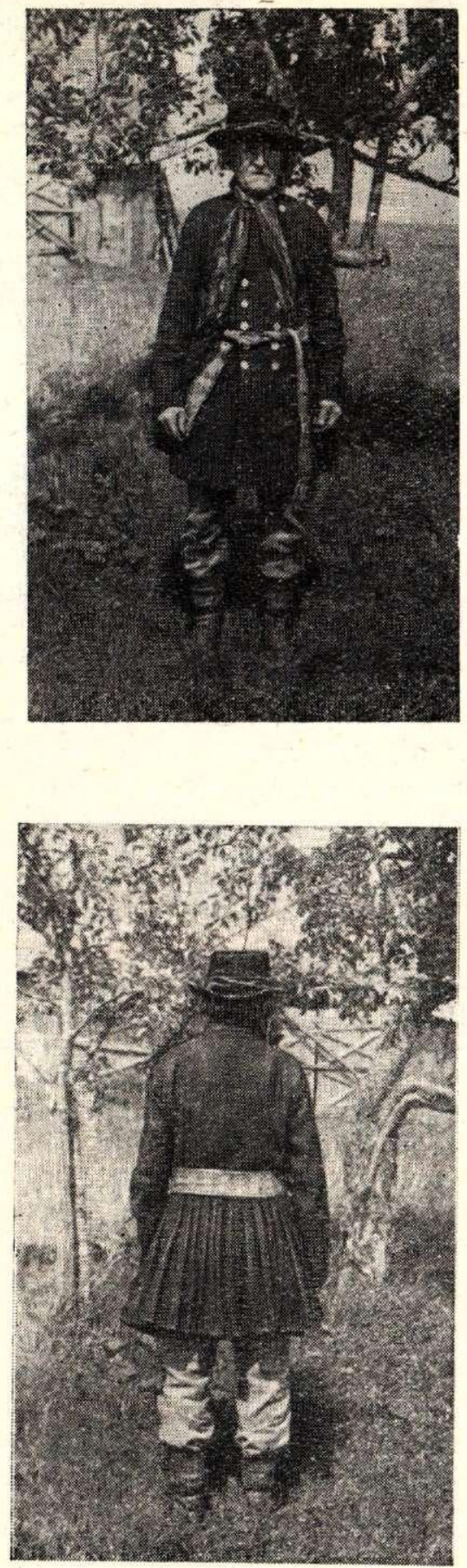

88. att. Alsungas vïriešu tërps.

kakle stipri atšḳiras no pārējo novadu kreklu apkaklēm, - tā ir stāva un rotāta ar stikla zilītēm.

Brunčus darināja no koši sarkanas, sỉki lāsumainas drānas, jo audumam ṇemtās dzijas krāsojot nosēja; lāsainumu panāca arī, sašḳetinot vienu gaišāku un vienu tumšāku dzijas pavedienu. Vecāko brunču krāsa bija violeta vai violeti sarkana. Brunči šūti līdzīgi Ventspils brunčiem - ar paaugstinätu jostas vietu (skat. 37. tab).
Brunču niebura dạai pāri vilka melnu īsu jaku, kas bija izšūta ar sarkanām, zạ̣ām un dzeltenām vilnas dzijām. 19. gs. otrajā pusē jaka šūta no sarkanajiem brunčiem radniecigga materiāla. ${ }^{795}$ S̄îs jakas ir pilnīgi vienādas ar jakām poḷu tautas tērpa kompleksā. ${ }^{796}$

Alsungas novads ir vienigais Kurzemes novads, kur saglabājušās baltā pamatā ar krāsainām dzijām austas jostas. Dominējošā ir tumši sarkanbrūna un violeta krāsa. ${ }^{797} \mathrm{Bez}$ tam Alsungas novadā, tāpat kā Kuldīgas un Ventspils novados, valkātas metāla sleṇgenes.

İpatnēja ir Alsungas novada goda villaine, kas austa lielās rūtīs no sarkanām, dzeltenām, melnām un - mazākā mērā - no zaḷām vilnas dzijäm..$^{798}$

Vecākas par rūtainajām villainēm ir baltās izšūtās villaines ar zilizal̨u rakstu villaines galos un krāsainām bārkstīm. Bez rūtainās un baltās villaines Alsungas novadā vēl pazīstamas zilās mēlenes ar spirălu rotājumu, kā arī pavisam baltas vai melni baltas rūtainas villaines. Pēdējās radniecīgas Ventspils novada villainēm.

Jaunavu galvassega, tāpat kā Ventspils un Kuldīgas novados, bija spangu vainags.

Sievas galvā vispirms sēja galvas autu, tam pāri lika cepuri ar krokotu mežğiṇu. priekšmalu, tad sedza zalı zīda lakatu, kura galus sasēja virs pieres mazā mezglā, tam pāri lika vēl vienu lakatu, kuru sasēja zem zoda.

İpatnējas ir arī Alsungas sieviešu zeḳes ar košiem sarkandzelteniem rakstiem. Līdzīgas rakstainas zeḳes pazīstamas arī igauṇiem. ${ }^{799}$

Alsungas novadā kreklu sasprauda ar mazu sudraba vai apzeltītu saktinu. Arī villaiṇu sakta parasti bija apzeltīta, ar lieliem izcilnniem un sarkaniem akmeṇiem.

Alsungas novada vīriešu krekli visumā līdzīgi Kuldīgas novada krekliem; tiem bagätīgi vienvirziena izvilkumā rotāta apkakle. Apkakli valkāja neatlocitu, to sasprauda ar saktinum; virs krekla vīrieši vēl sēja kakla lakatinu. Bikses lielākoties šùtas baltas ar krietni platiem stilbiem. Bieži vien bikses bagāti krokotas.

Senākie Alsungas novada svārki bijuši balti garie svārki, bet 19. gs. vidū vīrieši staigāja pusgaros melni pelēkos svārkos, t. s. bruslakos; mugurpusē tiem bija bagātas kroku grupas, bet priekšpusē tos aizpogāja ar perlamutra pogām. Pogas šūtas divās rindās. Bruslakus apjoza ar ādas jostu, kas greznota daudzām misiṇa sprādzēm.

İpatnējas ir Alsungas vīriešu galvassegas melnas ratenes ar nedaudz uz augšu uzliektăm malām un paplatu, ne visai augstu dibenu.

Kuldīg a s têrps valkāts Kuldīgas apriṇk ra rietumu daịa (6. att., 14) ${ }^{800}$ Acīm redzot to valkāja arī Turlavas pagastā dzīvojošie kuršu ķoniṇi, ${ }^{801}$ jo mūsu rīcībā esošie materiāli par ḳoniṇu apğērbu nekādas būtiskas atšḳirības no Kuldīgas tērpiem neparāda. Vienīgi k̦oniṇi ātrāk sākuši valkāt pirktās drānas un zîda lakatus, turpretim pie- 
griezuma ziṇà starpības nav. ${ }^{802}$ Salīdzinot O. Hūna sniegto ḳoniṇieṇu zīmējumu (skat. 12. tab., 3) ar Kurzemes provinces aprakstā ievietoto Kuldīgas sieviešu tērpa iztirzājumu ${ }^{803}$ un A. Dzērvī̌sa kādu senu Kuldīgas brunču aprakstu, ${ }^{804}$ redzams, ka izdalīt ḳoniṇus atsevišḳi nav nekāda pamata.

Goda krekli Kuldīgā bija grezni rotāti; tos sauca par dižajiem krekliem. ${ }^{805}$ Ipatnēja ir Kuldīgas krekla stāvā apkakle; tā izšūta ar tumši zilām vilnas dzijām. Dažkārt šūtas arī smeldžotās apkakles. Krekla plecu dạ̣ā un piedurkṇu augšdaḷā izšūts balts raksts, aproces izšutas ar tumši ziliem vai baltiem diegiem. Kreklu sasprauda ar vienu vai vairākām sudraba saktinām; nevelkot niieburu, zemāk par mazo saktiṇu sprauda arī lielo saktu ar zaḷiem vai sarkaniem akmeniem. ${ }^{806}$

Kuldīgas brunči - rinduki, lindraki bija dažādi - svîtraini, rūtaini vai vienkrāsaini. 19. gs. sākumä valkāti arī melni linu brunči ar paaugstinātu jostas vietu un nieburveida augšdaḷu, tāpat kā Alsungā un Ventspilī. 807

19. gs. vidū visiecienītākie bija pelēkā pamatā ar krāsainām šḳēerssvītrām austie brunči, t. s. guldītie brunči; tos šujot, krokas salika četrās grupās. ${ }^{808}$ Vertikāli svītrainos un rūtainos brunčus šuva sīki krokotus un bez niieburveida augšdaḷas.

Kuldīgas ņieburi - borstiḳi darināti no balta vilnas auduma ar pagarinātiem priekšpuses stūrišiem, kur novietojās zili dzeltens izšuvums. Ziemā valkātas jakas (kamzoḷi); tās bijušas šùtas tāpat kā ñieburi, tikai ar garām piedurknēm.

Parasti, kad novilka n̦ieburu, brunčus apjoza ar sleṇgeni, kas bija darināta no 4-6 metāla plāksnềm un važiṇu mugurpusē. Austās jostas Kuldīgas novadā nepazīst.

Kuldīgas novada goda tērpa lielākais greznums bija villaines; tās parasti sedza divas. Apakšà sedza zilo mēleni ar bronzas spirāḷ rakstu un piekariniem apakšējā malā, bet pāri tai balto villaini ar ieaustiem rakstiem tâ, lai būtu redzama mēlenes izrotātā mala. 809

Baltās villaines - baltvīkāles austas no baltas vilnas dzijas. Villaines varēja būt vienkārtenes vai divkārtenes (t. i., kopā sašūtas divas vienkārtenes). Villaines rotātas ar zili zaḷām celos austām bārkstìm un ieaustu greznu rakstu brūnā, sarkanā, tumši zilā, zaḷā un dzeltenā krāsā. Celu apaudu noslēdz lieli puški katrā malā. ${ }^{810}$

Bez šìs greznăs baltās villaines pazīstamas arī gluži baltas villaines, kam dažkārt ieausts svītriṇu raksts. ${ }^{811}$

Jaunavu galvas rota vēl līdz 19. gs. 60.70. gadiem bija spangu vainags. Tas bija darināts no šauras bronzas stipiṇas, kas piestiprināta sarkanas vai zaḷas drānas pamatam ar mazām apalām metāla ripiṇām - spangām. ${ }^{812}$ Garāku ceḷu ejot, vainagam pāri sēja zìda lakatu, bet istabā un pat dejojot lakatu nesēja, tāpēc valkātājai vajadzēja būt ḷoti uzmanīgai, lai vainags nenoslīdètu uz pakauša vai uz vienu pusi, jo to uzskatīja par lielu negodu. Novada austrumdą̣ā valkāti arī uz cieta papes vai tâss pamata šūtie sarkanas vilnas auduma vainagi, kas bija rotāti ar stikla zîlītēm un smeldzēm. Vainaga mugurpusē piestiprinātas krāsainas zịda lentes. ${ }^{813}$ Laulībām bija speciāli dižie kroṇi, kuru augšmala rotāta ar daudziem zariṇiem - spurām, šḳindelišiem u. c. vizuliem. ${ }^{814}$

Sievas godos galvā sēja divus zīda lakatus un linu auduma sienamo drānu, t. i., galvas autu. 19. gs. sākumā valkātas arī mazas katūna mices. ${ }^{815}$

19. gs. sākumā kājas no ceḷiem līdz potītēm notina ar ziliem vilnas autiem, virs tiem kā sievietes, tā vīrieši vilka îsas raibi adītas zeḳes. Kājās vilka pastalas, bet vasarä staigāja tikai ar zilajiem autiem - bez zek̄ēm un pastalām. . $^{816}$

Vēl 20. gs. sākumā Kuldīgas novadā kāju stilbus līdz ceḷiem notina ar autiem un tiem pāri vilka baltas zeḳes ar platu krāsainu valni. Vēlākā laikā autus vairs nevalkāja, bet vilka tikai garas baltas vilnas vai diegu zekes.

Senākais Kuldīgas novada vīriešu goda tērps bijis balts un samērā vienkāršs. Krekli bagātīgi rotāti ar izšuvumu balto darbu tehnikā, ${ }^{817}$ pie kam raksti novietojušies katrā pusē krekla krūšu šḳēlumam. Apkakle bija atlokāma un nedaudz rotăta. 19. gs. sākumā vīriešu krekliem, tâpat kā sieviešu krekliem, bijusi tumši ziliem diegiem izšūta stāvā apkakle. ${ }^{818}$

18. gs. vīrieši valkāja garus un pusgarus svārkus, bet 19. gs. - baltus garus svārkus ar krokām mugurpusē un zaḷām vai zilām apmalēm. Kā pusgaros kamzolus, tā garos svārkus aizdarināja ar metāla ākiem tikai dạ̣eji, lai būtu redzama izrakstītā krekla priekšpuse. Līdz mūsu dienām nav saglabājies neviens no seno kažoku paraugiem, bet, spriežot pēc aprakstiem, tie būs bijuši tādi paši kā Zemgales un Vidzemes kažoki - no baltas aitādas ar melnas ādas rotājumu. ${ }^{819}$

Pusgaros svārkus valkāja nesajoztus, bet garos svārkus - mēteli sajoza ar metāla sleṇgìi. ${ }^{820}$ 19. gs. otrajā pusē biežāk valkāja platas ādas jos. tas ar metāla sprādzēm.

Galvā vīrieši lika Alsungas novadā valkātajām ratenēm līdzīgas platmales, vienīgi ar zemāku un apaḷu dibenu.

Svētku bikses (ūzas), tāpat kā viss apgèerbs, darinātas no vilnas auduma, bet vasarā pie vilnas svārkiem valkātas arī linu bikses. Bikses bija aizdarināmas ar klapēm. Bikšu staras bija šauras, un tām virsū vilka ìsās zeḳes ar loti grezniem, košās krāsās adītiem vaḷiem. ${ }^{821}$

Austrumkurzemes tērps valkāts Kuldīgas, Aizputes un Liepājas apriṇka austrumu dalā un Tukuma aprinka rietumu dậa (6. att., 15).$^{822}$ Visradniecīgākie Austrumkurzemes tērpi ir Ziemelkurzemes tērpiem, vienīgi pirmējo krāsu noskaṇa ir spilgtāka, pie kam biežāk sastopams sarkanās un zaḷās krāsas salikums, kas norāda uz zināmu lietuvisku noslieci. Nozīmīga vieta šì varianta izveidē ir iedzīvotāju etniskajam sastāvam, jo Austrumkurzemes tērps valkāts teritorijā, kur sa- 


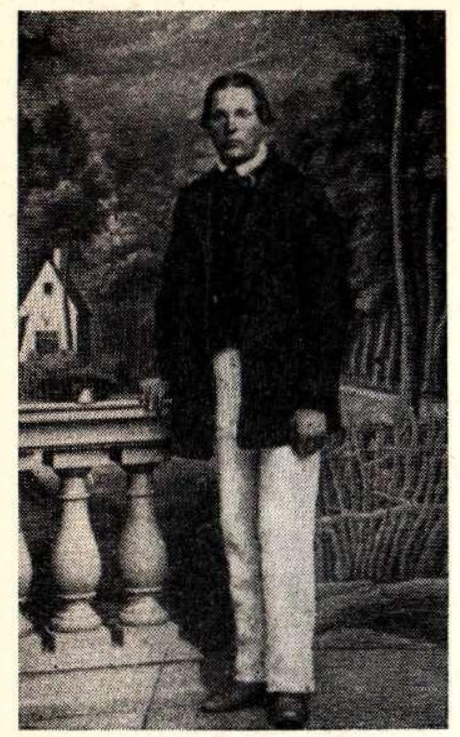

1

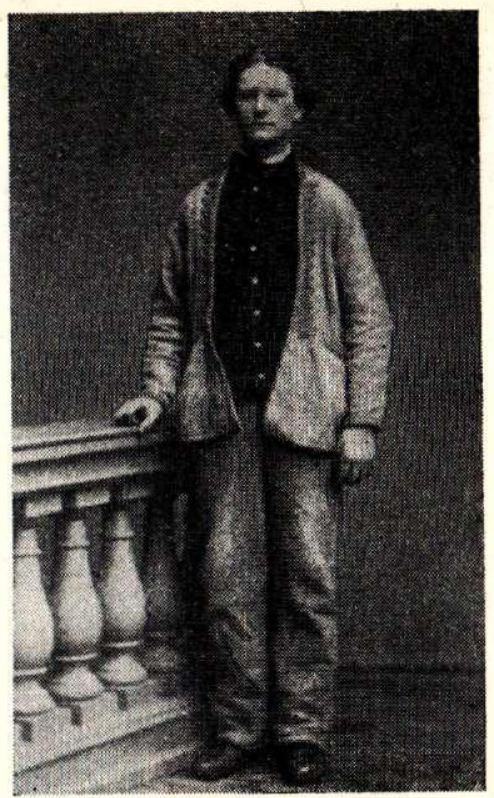

2 stopas kuršu un zemgaḷu apdzīvoto teritoriju robežas. Muzeju materiālos samērā maz ir ziṇu par šā varianta tērpiem; arī 1960. g. Baltijas ekspedī. cijā vairs neizdevās iegūt būtiski jaunus materiā. lus (skat. 36. tab., 1).

Austrumkurzemes krekli tunikveida ar virsū šūtiem uzplečiem. Krekli izšūti ar baltiem, nelieliem vienvirziena izvilkuma rakstiem, kas radniecīgi ar Ziemel̨kurzemes un Vidzemes kreklu rakstiem. 19. gs. otrajā pusē sieviešu kreklu apkakles malai un aprocēm piešūtas tamborētas mežgines.

Brunči - rinduki bija svītraini, godiem spilgtās, bet ikdienai - pelēkās krāsās. Rūtainie brunči ieviesušies vēlāk par svītrainajiem.

Pie goda tērpa valkāta jaka vai nุieburs (brunčeḷi, borste) ar lielu krūšu izgriezumu un sīki krokotu gurnu dal̨u. ${ }^{823}$ Šāds sîks krokojums nekur citur Latvijā nav sastopams, bet ir līdzīgs vienīgi Dienvidkurzemes brunču sīkajam krokojumam. No kaiminiem zemgaliem ieviesies paṇemiens jaku aizpogāt ar dzintara vai sudraba pogām.

Jostas pie goda tērpa nevalkāja, bet darba tērpa sajošanai auda šauras prievītes.

Austrumkurzemē, izñemot Kabiles apkārtni, nav saglabājušās grezni izšūtās villaines. Pie goda apğērba sedza rūtainus lielos lakatus - austenes košās krāsās vai baltas villaines - villānes, se. dzamās drānas. Neparastas ir Kabiles izšūtās villaines, kas pēc kompozīcijas veida - ar saulišu motiviem villaines divos apakšējos stūros - atgādina Talsu villaines, vienīgi izšūšanas tehnika ir pavisam cita. Spriežot pēc krāsu toṇiem, kas iegūti, krāsojot ar augu krāsām, un izšūšanas veida, liekas, ka tās ir stipri senas. ${ }^{824}$

Jaunavu galvas rota pie goda tērpa līdz 19. gs. vidum bijusi plats, uz papes vai tāss pamata šûts sarkana auduma vainags, ${ }^{825}$ rotāts ar smeldzēm

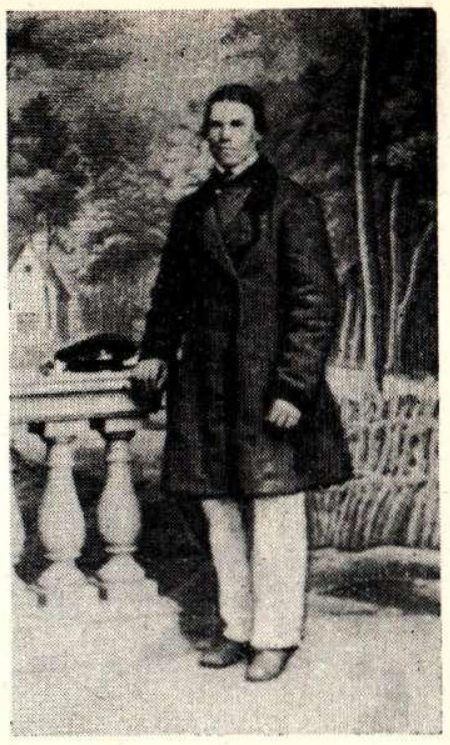

3

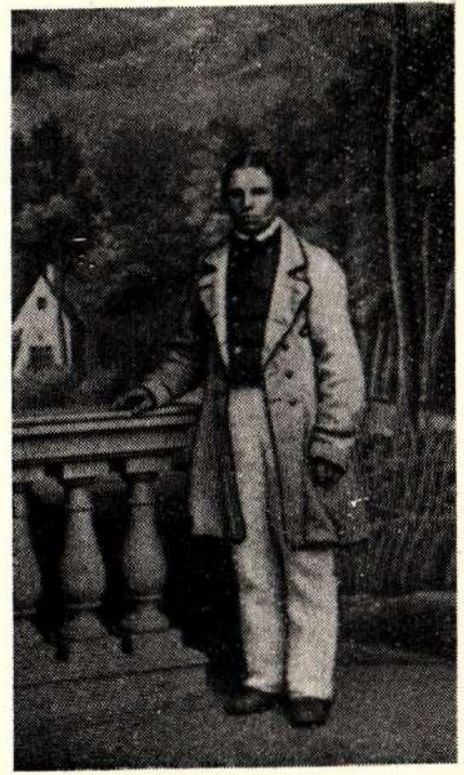

4

un zīlītēm. Liekas, ka tāda lokāla zịḷu vainagu izplatība Kurzemē saistāma ar stikla ceplu darbību 17. gs., kur ražoja arī stikla krelles. Sievas galvā lika aubes vai zỉda lakatus. ${ }^{826}$ Bieži uz aubēm (tāpat kā Rietumvidzemē) siets lentveidā salocîts zīda lakats. ${ }^{827}$

Austrumkurzemē kreklus sasprauda ar sudraba kniepḳeniem (kṇopēm, kniepḳēm) vai arī ar mazām apalām sudraba saktiṇām. Bez grezniem sudraba kniepḳeniem bijuši arī vienkārši alvas kniepkeni. ${ }^{828}$

Austrumkurzemē vīrieši valkāja kreklus ar lielām atlokāmām apkaklēm, kuplām piedurknēm; tās noslēdza «apdūri» - aproces, kuras dažreiz bija izrakstītas. Bikses îsas, ar klapi priekšā un 


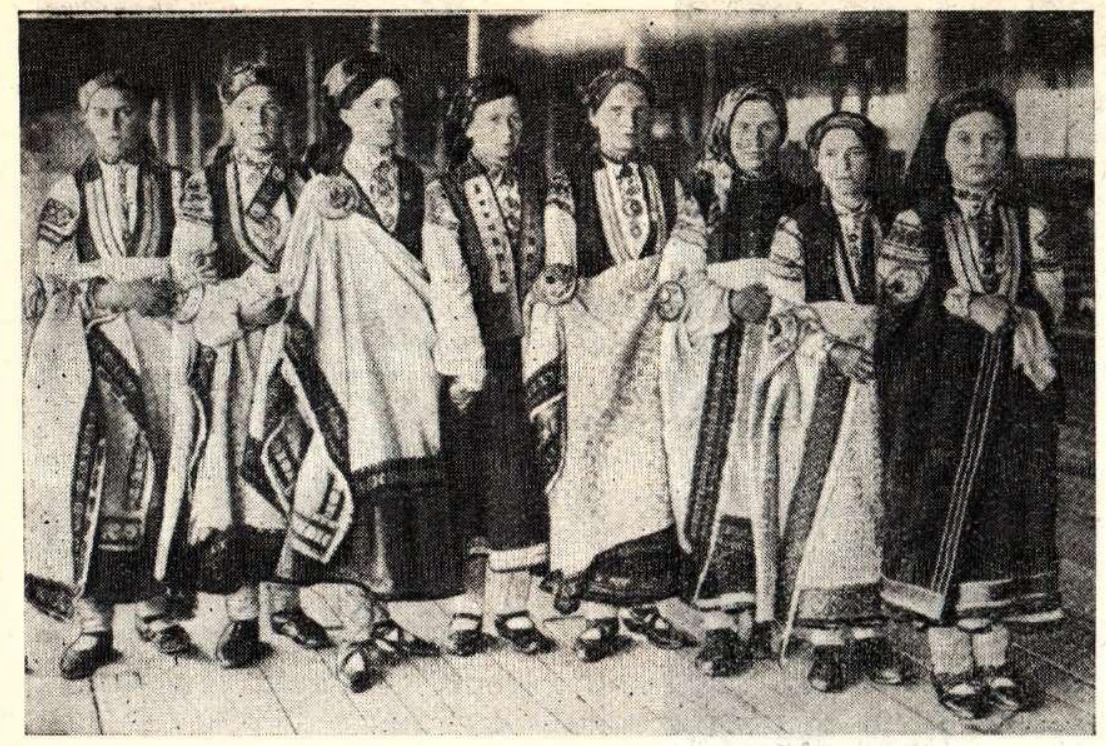

90. att. Rucavietes (uzñēmums izdarīts Rīgä, 1910. g. dziesmu svētku laikā).

plaukstas platumā zem ceḷa sapogātas ar 2 vai 3 pogām. Tās sajoza ar ādas vai pītu jostu un šuva no pelēkas vai zilas drānas, bet gadijās, ka šuva arī no rindukú drānas. ${ }^{829}$ Laulībām šuva garas bikses. ${ }^{830}$ Svārki bija šauri, līdz augšai aizpogāti, ar kroku grupām sānos. Svārku garums apmēram $10 \mathrm{~cm}$ virs celá. Siltākā laikā valkāti kam. zoḷi ar škēlumu mugurpusēe. ${ }^{831}$ Kažoki šūti no baltas aitādas ar melnas ādas rotājumu. Dažreiz kažoku rotāja uz spalvaino pusi likta āda.

Par zināmu savdabību jāuzlūko adītās vīriešu cepures, kas Austrumkurzemē valkātas līdz ar parastajām ziemas cépurēm un vasaras platmalēm.

Kājas parasti aptina ar autiem vai arī vilka garās zeḳes. No apaviem izplatītākie bija pastalas vai - jaunākā laikā — zābaki.

Ap kaklu vīrieši lika kakla drāniṇu (raibu, kokvilnas, pirktu), saspraužot to ar saktinu.

Dienvidkurzemes tērps valkāts Liepājas apriṇḳa rietumu daḷa $\left(6\right.$. att., 16) ${ }^{832}$ Nīcas, Bārtas, Rucavas un Liepājas apkārtnes tērpu apvienošana vienā tērpu variantā var likties gluži nepamatota kaut vai lielās tērpu krāsu dažādības dēḷ. Tomēr pēc mūsu rīcībā esošajiem materiāliem iespējams konstatēt, ka krāsu dažādība dažkārt ir visai jauna gājuma un radusies 19. gs.; izdalot šo tērpu variantu, balstījāmies uz senākām tradīcijām, kas liecina par šo apvidu kopību; tāpēc varianta nosacīšanai vispirmām kārtām izmantojām ornamenta principus, izvietojumu, izplatību un, visbeidzot, raksturīgos vīriešu tērpus. ${ }^{833}$

Lai gan pagasti atradās cits citam kaiminos, katrā pagastā valkātajiem tērpiem ir savas īpatnības. Senās geerešanās tradīcijas te bija saglabājušās vēl 20. gs. Tomēr tērpiem ir arī kopējas iezīmes, kas lauj tos visus apvienot vienā tērpu valkāšanas novadā (skat. 38. tab.).

Liepâjas apkärtnes zemnieku apgēerbs jau
19. gs. sākumā ir atšḳīies no Kuldīgas un Ventspils apgèrbiem un vairāk līdzinājies kaiminu lietuviešu - žemaišu apgèrbiem. ${ }^{834}$ S̄āda līdzỉba liecina ne tikai par labām kaiminu attiecībām, bet arī par to, ka daudzie lietuvieši, pārceloties uz dzīvi Dienvidkurzemē, atstāja iezīmes vietējos tërpos.

Dienvidkurzemes kreklu muzeju kolekcijās ir visvairāk - vairāki simti, turklāt neviens no tiem pilnībā nekopē otru. Tomēr krekliem visiem raksturīgi lieli, smagi raksti un augu ornaments. Novada ziemelaustrumu daḷs kreklu raksti tuvāki Austrumkurzemes kreklu rakstiem, tos rotā neliels izvilkums.

İpaši minami Rucavas krekli, kuru daži varianti nav sastopami ne tikai citos Dienvidkurzemes pagastos, bet pat visā Latvijā. Senākie krekli Rucavā bijuši ar piešūtiem uzplečiem - «perepečotie» krekli. ${ }^{835}$ Uzpleči bijuši grezni rotāti ar ieausto - lesto (ar plato «ę») vai griezto rakstu. Uzpleči piešūti krekla stāvam vai nu audu, vai velku virzienā. Krekli ar velku virzienā piešūtiem uzplečiem nekur citur Latvijā vairs nav konstatēti. Loti reti sastopama (vēl tikai Lielvārdes apkārtnê) ir Rucavas kreklu grieztā raksta tehnika. Pēc piegriezuma, rotājuma tehnikas un kompozīcijas Rucavas krekli loti tuvi Rietumukrainas - Aizkarpatu sieviešu kreklu rotājumam. Sī rotājuma detaḷu Ĺvovas muzejā ir vairāki simti. ${ }^{836}$ Liekas, ka nepareizs ir literatūrā sastopamais uzskats, ka Rucavas griezto rakstu tehnika tieši saistāma ar Ziemeḷietumeiropā pazīstamo hardangeru, ${ }^{837}$ jo pēc Rucavas kreklu grieztā raksta kompozīcijas šis rotājuma veids tuvāks ukraiṇu kreklos sastopamajam. ${ }^{838}$

Rucavas tunikveida krekli bez uzpleča vai ar virsū šūto uzpleci, it îpaši krekli, kuru uzplečus rotā ieausti raksti, līdzīgi pārējiem Kurzemes krekliem. Vienīgi Rucavas krekliem raksturīgs ir krūma rakstu ornaments un pito krustdūrienu tehnika. 


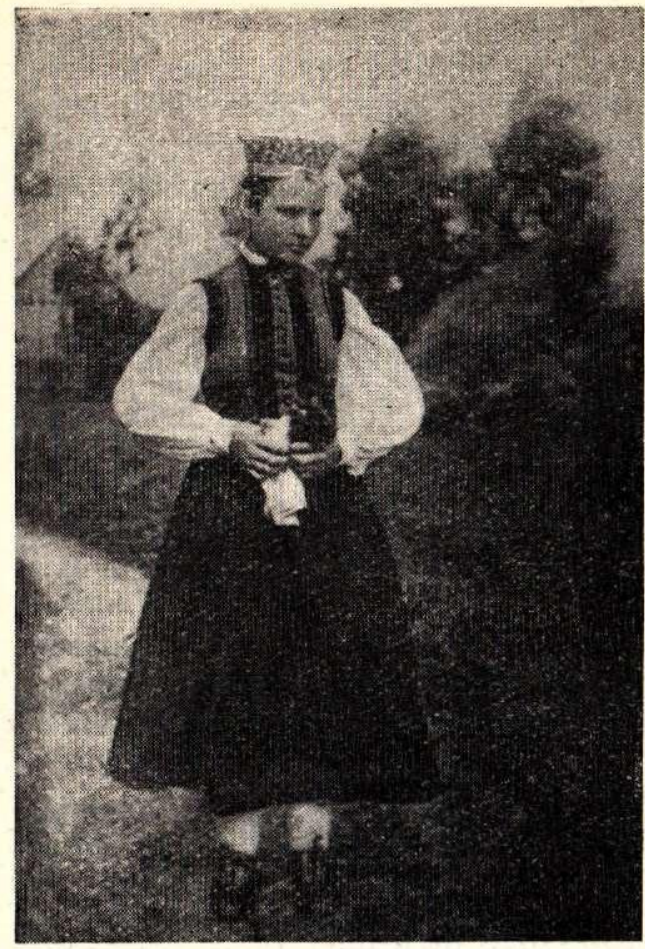

91. att. «Latviešu jaunava no Nīcas 1896. g.» Daškova Etnogrāfijas muzejam dāvinātā V. Sizova fotouzṇēmuma kopija.

19. gs. pirmajā pusē dienvidos no Liepājas val kāti vienkrāsaini, melni vai tumši zili brunči. Nīcā melnajiem brunčiem gar apakšējo malu gājusi plaukstu plata sarkana svìtra, kas izrakstita za’̣ām, dzeltenām vai arī citādas krāsas dzijām. Zilajiem brunčiem bija gareniski ieaustas krāsainas svītras - zal̨as, dzeltenas, bet visbiežāk sarkanas; tos sauca par svēdrainiem jeb strīpainiem brunčiem (skat. 38. tab., 4). Šo brunču apakšmalu noslēdza šaurs sarkans apmetinājums. ${ }^{839}$ Svītrainie brunči valkāti arī ziemeḷos no Liepājas. ${ }^{840}$ Koši sarkanie brunči Nīcā izplatījās tikai 19. gs. 60. gados. ${ }^{841}$

Šeit valkātās baltās, izšūtās villaines visas pieder pie Dienvidkurzemes villainu tipa ar smagiem, pamatu klājošiem rakstiem un tikai te raksturīgu valkāšanas veidu uz viena pleca vai rokas. Rucavā valkāja arī rūtainās mārğenes un linu auduma drābules, skāterus. ${ }^{842}$ Rucavas īpatnējā villaiṇu valkāšanas veida pamatā, kā jau iepriekš (48. lpp.) norādīts, ir nešūto brunču kādreizējais valkāšanas veids; zināmā mērā to varbūt noteica arī greznie kreklu plecu raksti, kurus valkātājas negribēja apsegt, lai lielais darbs, kas bija paveikts, rotājot kreklu, netiktu apslēpts. ${ }^{843}$ Arī Kuldīgā un Alsungā ir ne mazāk grezni kreklu piedurkṇu raksti, bet te tos tomēr apsedz ar villaini.

Dienvidkurzemē pie goda tērpa vienmēr valkāti ṇieburi un jakas, galvenokārt brūnā krāsāa ${ }^{844}$

Jaunavu galvas rota Nīcas un Bärtas pagastos bija plats zịlu vainags, tā nēsāšanai bija nepieciešamas zināmas iemañas, jo tas viegli krita zemē. Rucavā jaunavas lika galvā kaspines. Pēdējās būs pārnākušas no lietuviešu tautas tërpiem, kur kaspines ir jaunavu valdošā galvas rota. ${ }^{845}$ Novada pārējā daḷā vainagi pēc formas ir radniecīgi Nīcas un Bārtas paplatinätajiem vainagiem. Pērkones vainaga pamatu veido plata sudraba brokäta lente, tai pări augšpusē piestiprinātas sudraba stīdziñas ar krāsainiem vizulīšiem. ${ }^{846}$ Vaiṇodes vainags ir apmēram $15 \mathrm{~cm}$ plats, uz augšu paplatināts, tā. pat kā Nīcas un Bärtas vainagi. Vainags apšūts ar brokāta lentēm, pa vidu tam iet brūna samta lente.

Sievu cepures valkātas visā Dienvidkurzemē, bet Rucavä vēl 19. gs. bija saglabājies nāmats.

Dienvidkurzemes vīriešu tērpam raksturīgs bagāts rotājums. Krekli tunikveida, ar vai bez uzplečiem, ar grezni rotātām apkaklēm, aprocēm un krūšu škēlumu. Raksturīgi ir krāsaini izšuvumi. Bikses 19. gs. sākumā valkātas îsās, ${ }^{847}$ bet vēlāk garās.

18. gs. Dienvidkurzemē valkāti garie svārki, bet 19. gs. pārśvaru gūst ar greznu izšuvumu rotāti īsie svārki pelēki brünā krāsā. ${ }^{848}$ Ipatnējs ir Rucavas svārku audums - balināts vai nebalināts linu drellis. Ar bagātu tumši zilo izšuvumu šā novada vīriešu svārki atšķiras no pārējo novadu vīriešu svārkiem.

Dienvidkurzemē vīrieši valkāja baltas zekes ar koši sarkanos toṇos adītiem vaḷniem, kā arī garās pelēkās zekes. ${ }^{849}$

Pie goda tērpa valkāti arī baltie grezni adītie cimdi, kuriem adījumu tehnikas ziṇā lìdzīgu nav visā Latvijā. 


\section{KULTŪRVĒSTURISKO SAKARU ATSPOGUL̨OJUMS LATVIEŠU TAUTAS TERPA}

Apgeērbs kā materiālās kultūras sastāvdaḷa atspogulo ne vien ğeogrāfiskos, klimatiskos un sociālekonomiskos apstākḷus, kādos dzīvo tauta, bet liecina arī par dažādu tautu kultūras sakariem. Tāpēc, aplūkojot kultūras attīstību uz vietas, nedrīkstam ignorēt arī kultūras vērtību aizguvumus. Kultūras vērtību aizgūšana, protams, nav jāsaprot kā migrācijas rezultāts. Sie aizguvumi meklējami katras tautas vēsturē un saistāmi ar tiem cēloniem, kas tos noteikuši. Apḡērbā, bet jo sevišḳi apğērba rotājumā, saglabājas loti senu tradīciju atblāzma, kuru pamatā ir apgèrēba darināšanas un vajadzību specifika. Ja apgèērbs kā k̦ermeña aizsegs pret nelabvēlīgiem klimatiskiem apstāḳ̣iem ir saistîts ar sociālekonomisko bāzi, tad turpretim apgèerba ro. tājums ne katrreiz būs tieši saistīts ar to.

Salīdzinot latviešu tautas tērpu ar kaiminu lietuviešu, igauṇu un slāvu tērpiem, vērojama lielā līdzība gan senākās apgèerba formās un daḷās, gan arī jaunākās tautas tērpa sastāvdaḷās. Līdzība latviešu un lietuviešu tautas apg̀ērbā vislabāk novērojama Latvijas un Lietuvas pierobežas rajonos, kur abu tautu kontakts, dabiski, bija ciešāks.

Latviešiem un lietuviešiem kopējs gan apg̉ērba materiāls, piegriezums un apgèrēba dậas, gan arì krāsu salikums un ornamenta izvietojums. Tiklab latviešu, kā lietuviešu krekls ir tunikveida, ar virsū šūtiem uzplečiem. Minētais krekla piegriezums izplatīts visā Lietuvā, izṇemot Klaipēdas novadu, kur sastopams krekls ar piešūtiem uzplečiem. Latvijā turpretim bez tunikveida krekliem ar virsī šūtiem uzplečiem ir arī krekli bez uzplečiem.

Latviešu tunikveida krekls ar virsū šūtiem uz. plečiem pēc rotājuma veida un novietojuma tomēr atškiras no lietuviešu krekla. Lietuviešu sievietes ar spilgti sarkaniem izšuvumiem rotā krekla apkakli, aproces un uzplečus. Latvietes turpretim rotā piedurkṇu augšējo daḷu balto darbu tehnikā; vienīgi Latgalē, Rucavā un Augšzemē sastopams arī spilgti sarkans izšuvums. Klaipēdas rajonā izplatîtais krekla tips, kas atškiras no latviešu krekliem pēc sava piegriezuma, ir tuvs latviešu tunikveida krekliem bez uzplečiem pēc rotājuma novietojuma veida. Rucavas kreklam ir pat vienāds ornaments ar Klaipēdas kreklu.
Arī brunču audums gan pēc krāsām, gan auduma tehnikas latviešiem un lietuviešiem ir līdzīgs. Abu tautu tērpā plaši izplatīti vertikāli un horizontāli svītrainie, kā arī rūtaini brunči. Vienāds ir arī brunču piegriezums.

Zemgalē vēl 19. gs. sākumā bija izplatīti brunči ar ielasīto rakstu. Şādi audumi raksturīgi arī Lietuvas Žemaitijas daḷai, bet tur no šì auduma gatavoti kā brunči, tâ arī priekšauti. Zemgalē un Žemaitijā daudz ilgāk saglabājās nešūtie brunči, kamēr pārējā Latvijā tie izzuda jau 18. gs.

Kopīgas iezīmes vērojamas arī jostās. Latviešiem un lietuviešiem raksturīgas ir austās un pītās jostas. Vien̄igi Latvijā pītās jostas parasti valkā vīrieši, bet austās - sievietes, turpretim Lietuvā šādas atškirīîbas nav novērojamas. Latviešu jostām raksturīgā trīsdal̨u kompozīcija, kur ornaments neatkārtojas, nav raksturīga iezīme lietuviešu jostām, jo pēdējās parasti atkārtojas viens un tas pats raksts vai arī mainās divi raksta varianti.

Lietuviešu sieviešu apgēerba neatṇemama sa. stāvdala ir priekšauts, kamēr latviešu sievietes (izṇemot Augšzemi) apğērbā tas nav obligāta sastāvdaḷ. Spriežot pēc avotiem, arī Vidzemē 18. gs. ir valkāti priekšauti. Tas vedina domāt, ka priekšauts agrāk Latvijas teritorijā valkāts daudz plašāk nekā 19. gs., bet izzudis ātrāk nekā Igaunijā un Lietuvă.

Nieburs, liekas, ir samērā jauna sieviešu apgèrba dą̣a, kuru valkāja kā Lietuvā, tā Latvijā. Atškirīiba bijusi tikai tā, ka latvietes valkāja vienkrāsainu (zilu, melnu, sarkanbrūnu) ņieburu ar raibiem brunčiem (izṇemot Rucavas novadu), turpretim lietuvietes nnieburıs darināja no krāsaina rotāta auduma, tā ka brunči un ņieburs ir dažādi ornamentēti.

Lietuviešu un latviešu sieviešu virsjakas atšḳiras pēc piegriezuma. Latvietes valkāja īsas jakas, kas stipri lïdzīgas nieburiem, bet lietuviešu jakas bija garas un sniedzās gandrīz līdz cę̣iem. Krāsas ziṇā tās līdzīgas vīriešu svārkiem.

Tāda sena neatnemama latviešu sievietes ap. gèēba sastāydaḷa kà villaine, kas apğērbā sagla- 
bājusies līdz pat 20. gs., nav raksturīga lietuvietes apgēerba daḷa; Lietuvā villaine sastopama vienīgi Augštaitijā un Žemaitijā.

Lietuviešu nešūto brunču nosaukums «margina» Latvijā sastopams tikai Rucavas apkārtnē; turklāt te ar mārg̀eni apzīmē nevis brunčus, bet gan īpašu villaini. Tomēr jāpiebilst, ka arī dažos Lietuvas rajonos ar «marginu» apzīmē villaini, kuru apliek ap gurniem, bet brīvos galus pārliek pāri kreisajai rokai un piesprauž pie piedurknes ar saktām. Liekas, ka tāds villaines valkāšanas veids saistāms ar nešūto brunču nēsāšanu šajā rajonā.

Tâpat kā Latvijā, arī Lietuvā sievietes galvas rotu noteica nēsātājas vecums un g̀imenes stāvoklis. Latviešu jaunavas galvas rota ir auduma vainags, kas izšūts raibām zīlītēm; tikai dažos Latvijas novados (Rucavā un Ziemelvidzemē) sastopamas zīda un vilnas lentes, bet Ziemelrietumkurzemē - metāla vainagi.

Lietuviešu jaunavas nēsāja raibas pašaustas vai zīda lentes, sasienot tās visdažādākā veidā. Jāatzīmē, ka Rucavas jaunavas galvas rotas nosaukums kaspine ir analogs lietuviešu vārdam «kaspina», kas apzīmē jebkuru lenti.

Vecākajai latviešu sievas galvassegai - nāmatam - ir daudz kopēja ar lietuviešu galvassegu «noumetas». Šāda veida galvassega raksturīga arī austrumslāviem.

Latvijā nāmats 19. gs. sākumā sastopams Latgalē, Augšzemē un Rucavā. Bez nāmata kā latviešu, tā lietuviešu sievietes valkāja aubes, cepures, kā arī lakatus, ko Latgalēe, Rucavā un Augšzemē sauca par skustiem, bet Lietuvā - par skepetiem.

Cimdus un zekes kā latvietes, tā lietuvietẹs adīja no vilnas dzijas (ziemai), bet no linu diegiem mežğiṇadījumā - vasarai. Lietuviešu cimdos pārsvară ir spilgtie toṇi un dominē augu ornaments; tas pats novērojams Latgalē, Augšzemē un Rucavas apkārtnē.

Senākos materiālus par latviešu un lietuviešu apgēerbu radniecību dod arheolog̀iskais, lingvistiskais un antropolog̀iskais materiāls, kas saista augštaišus ar augšzemniekiem, zemgaliešus ar žemaišiem un kurzemniekus ar Klaipēdas novada iedzīvotājiem. ${ }^{850}$ Daudzie kopējie apgēerba gabalu nosaukumi, kuru pirmsākumi meklējami kopējā valodā, liecina par to senumu. Sniedzam šădus kopēju apg̀ērba gabalu nosaukumu piemērus:

lietuviešu val.

\section{drabužiai} prijuostè pirštinès juostos rinktinès juostos pintinès juostos apavas vyžos nuometas marginè latviešu val.

drēbes ${ }^{851}$

priekšauts pirkstaini

jostas

rakstainās jostas

pītās jostas

apavs

vĩzes

nāmats

mārğene
Zemgales un lietuviešu kultūras sakari visciešāk saistīti ar tirdzniecības ceḷiem, kas gāja cauri Zemgalei uz Rīgu, ${ }^{852}$ kā arī ar amatnieku speciā. listu darbību, jo citādi nav izskaidrojama Zemgales rakstaino brunču un lietuviešu priekšautu audumu līdzība, kas jo sevišķi spilgti izpaužas to senākajos veidos. Noteikt šo radniecības vecumli droši nav iespējams, bet liekas, ka tās sākumi meklējami 17. gs., kad Kurzemes hercogistē strauji uzplauka manufaktūras un no tām arī vietējie amatnieki iemācījās sarežg̀îtāku tehniku. 19. gs. no lietuviešu tērpa Zemgalē sāk izplatîties caurumotā (broderejas) tehnikā izšūtie krekli, kas Lietuvas muzejos (Viḷnā, Kauṇā) savākti vairākos variantos.

Varbūt ka no Francijas karąa Luija XVIII galminiekiem, kas Jelgavā cara varasvīru paspārnē meklēja glābiṇu no franču tautas dusmām, Zemgales amatnieki noskatijjušies sudraba kurpju sprādzes un pagatavoja tās vietējiem pasūtītājiem. ${ }^{853}$

Lietuviešu un slāvu ietekme vērojama Augšzemes un Dienvidkurzemes apḡērbā. Senākie sakari, kas vērojami vēl 19. gs. apgēerbos, atspogulojas it ipaši Rucavas un Klaipēdas apvidus tērpos un skaidrojami ar kursiskajiem elementiem Klaipēdas apgabalā (Kuršu kāpās) un Rucavā, Asimilējušies kurši atstāja savas iezīmes gan Rucavas, gan Klaipēdas apgabala iedzìvotāju apgèērbā. Ar to arī izskaidrojama radniecība abu novadu apg̀ērbos.

N̦emot vērā valodniecības un arheologiskos datus, kā arī antropolog̣isko materiālu, samanāma Liepājas apkārtnes seno iedzīvotāju tuvība ar Pomerānijas un Meklenburgas 9.-12. gs. apdzīvotājiem. ${ }^{854}$ Zināmā mērā iespējams izskaidrot arī Rucavas tērpu radniecību ar Rietumukrainas tautas tērpiem. Seno lužiču aizṇemtā teritorija Oderas un Vislas baseina ziemeḷos sniedzās lỉdz Baltijas jūrai, bet dienvidos - līdz Karpatu kalnu piekājei. ${ }^{855}$ Radniecība Rucavas un Rietumukrainas tērpos, škiet, ir tāla atblāzma no senās lužiču kultūras; lužičiem bija cieši sakari ar baltu ciltìm, tai skaitā arī ar kuršiem.

Antropologíijas pētijumi sniedz vēl tālākas zi. ṇas. Tie Liepājas un Ventspils apkārtnes antropoloğiskās îpatnības uzskata par pamatojumu hipotēzei par vendu slāvisko izcelšanos. ${ }^{856}$ Rodas jautājums, kāpēc īpatnības, kas atspogulojas antropolog̣iskajā materiālā un uzrāda Ventspils un Rucavas novadu līdzību, nav manāmas 18. gs. apg̣ērbā? Liekas, ka izšḳirīga nozīme te bijusi novadu atrašanās vietām - ja Ventspils apkārtne nepārtraukti ir cieši saistīta ar lībiešiem, tad Rucava tikpat cieši ir saistīta ar lietuviešiem, bez tam vēl zināms, ka 13.-14. gs. Kurzemes dienvidos ieplüda zemgaḷi, ${ }^{857}$ lìdz ar to atdalot Ventspili no Rucavas. Arī Latviešu Indriḳis min vendu pārcelšanos uz Vidzemi. ${ }^{858}$ To visu ievērojot, liekas saprotama arī vēlākā atšķirība apgèèrbā. 17. gs. Ventspils bija nozimīga osta, un šai laikä tur apmetās daudz kuldīdznieku, kas te atrada no. 
darbošanos. Acīm redzot ar to izskaidrojami vienādie elementi Ventspils un Kuldīgas tērpos, lai gan daži apğērba gabali, kā, piemēram, Ventspils brunču audums, ir līdzīgi Rietumukrainas tērpam raksturīgajiem plisēto priekšautu ${ }^{859}$ un zapaskı (nešūto brunču) audumiem. Arī viens no Ventspils villaines, t. s. zilāma variantiem ar krūma un sarkanu apmalojumu pat ir pilnīgi vienādi ar Rucavas brunčiem. Rucavas kreklam izmantotā izšuvumu tehnika - grieztais raksts - loti plaši sastopama rietumukrainu kreklos. Stilizētais dzīvnieku ornaments kreklu izšuvumā, kas, izṇemoi Rucavu, nav sastopams nevienā citā Latvijas no. vadā, arī ir zināma slāviska iezīme.

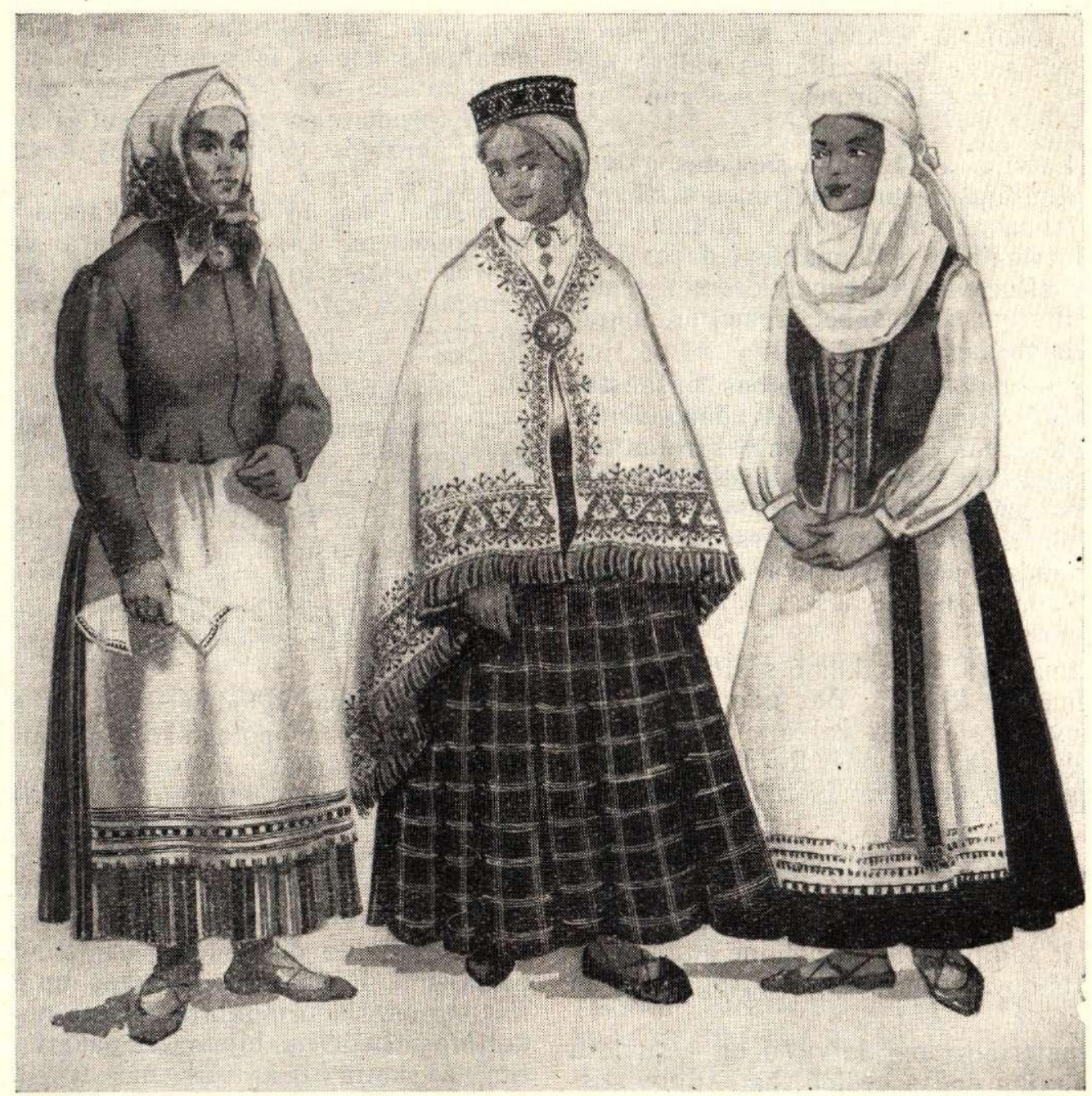

92. att. Igauṇu (pa kreisi), latviešu (vidū) un lietuviešu (pa labi) sieviešu tērps 19. gs. vidū.

rakstu stūros atškiras no pārējām villainēm. Tās rotājuma veids radniecīgs Rietumukrainas un Austrumpolijas tērpu rotājumiem.

Diemžēl, vēl nav iespējams droši apgalvot, kad izveidojusies Rucavas, Klaipēdas apgabala un Rietumukrainas tērpu radniecība, kas saskatāma vēl 19. gs. sākuma apg̀ērbos. Vienādais kreklu piegriezums, rotājuma tehnika, nešūto brunču mārg̀enes un Rietumukrainas «zapaskas» krāsu kolorīts un valkāšanas veids liek domāt par zi. nāmu etnisku specifiku. Gorodenkas rajona tumši zilie brunči - spidnica ar zelta brokāta lenti
Ippatnējais villaines valkāšanas veids Rucavas apkaimē norāda, ka te agrāk valkāti nešūtie brunči, kas ir raksturīga sieviešu apg̀ērba sastāvdaḷa visām slāvu tautām. Galvassega - nāmats pēc sava veida (un arī nosaukuma) radniecīga ukraiṇu namitkai un citām slāvu dvieḷveidīgām galvassegām.

Gorodenkas krekliem ir piešūts uzplecis, sarkana ielasītā raksta rotājums un loti savdabīgs piedurkṇu piegriezums trīsstūraina gabala veidā.860 Kreklam nav apkakles, bet pie kakla izgriezuma krokās savilktais krekla stāvs un uzplecis rotāts 
ar nelielu sarkanu rakstu. Kā piedurkṇu ipatnējā forma ar vaḷejiem dūrgaliem, tā arī krekla izgriezuma apdarinājums liecina par šā krekla tipa senumu. Rietumukrainā izplatīti vēl arī sīki krokotie - «plisētie» brunči, kuriem, tāpat kā dažiem senākajiem Rucavas un Ventspils brunčiem, priekšējā daḷa atstāta gluda, bez krokojuma. Rietumvolīnijā šādi brunči šūti no pelēka vilnas auduma ar sarkanu vai zal̨u apmalojumu.

Zināmu radniecību ar Nîcu un Bārtu vēl parāda L,vovas apgabala Sokalas rajona tērpa variants, - tā krekli rotāti ar melnu rakstu krustdūrienu tehnikā, jakas baltas, veltas, ar tumši zila samta un auklu rotājumu täpat kā Nīcas n̦ieburam.

Kultūras sakari ar lietuviešiem un slāvu tautām - poliem, baltkrieviem un krieviem vislabāk atspoguḷojas Augšzemes tērpos. Augšzemē - Sēlpilī, Jēkabpilī, Ilūkstē, Subatā u. c. Kurzemes hercogistes laikā nepārtraukti ieplūda poḷu, baltkrievu un krievu iedzīvotāji, apmetoties te uz pastāvīgu dzīvi. Tã hercogistes austrumu un dienvidu kaimiṇu iedzīvotāju piesaistǐšanai Jēkabpilī 17. gs. beigās bija stingri noteikts, ka neviens vācietis nedrīkst apmesties vai iegūt pilsoṇu tiesības šai jaunajā pilsētā, to drīkstēja darīt tikai krievi, poḷi vai lietuvieši. Arī amatpersonas bija polu un krievu tautības. ${ }^{861}$ 1636. g. katolticīibā pārgājušais grāfs Zỉbergs arī veicināja katoḷticīgo poḷu, baltkrievu un latgaliešu ieplūšanu Augšzemē. ${ }^{862}$

Poḷu tērpu ietekme vislabāk novērojama Augšzemes novadā, sevišḳi tā centrālajā un rietumu dą̣ā, ko šḳērsoja satiksmes cel̨i uz Rīgu. J. Broces materiālos ne vienreiz vien minēti poḷi, kas tirgojas vai arī strādā Rīgā. Par poḷu ietekmi liecina jau teiciens - apsiet galvu poliski, poḷu lāstaugi, tāpat arī îpatnējais rotājuma veids - izšujot uz savilktām krokām u. c.

Baltkrievu ietekme vairāk jūtama Augšzemes austrumu dạ̣ā. Tā izpaužas krekla piegriezumā (ar piešūtiem uzplečiem) un ieaustā raksta rotājumā (Gārsenes krekls).

It îpaši latviešu materiālo un garīgo kultūru ietekmējuši krievi. Arī laikā, kad Latvijas teritorija bija poḷu un zviedru atkarībā, krievu tautas kultūras ietekme joprojām turpinājās. Kultūras sakari ar krievu tautu bija iespējami pa dažādiem ceḷiem. Vispirms jāatzīmē tirdznieciskie sakari. Krievu tirgotāji ar savām precēm tirgojās kā Latgalē, tā arī Vidzemēe. ${ }^{863}$ Krievu ietekme sevišḳi pieauga 18. gs., kad Vidzeme ar Rìgu, bet beidzot arï Latgale un Kurzemes hercogiste nonāca krievu impērijas sastāvā. J. Broces materiāli liecina, ka 18. gs. Rịgā var satikt daudzus krievu tirgotājus, ierēdnus, amatniekus un strādniekus. No Rìgas krievu ietekme izplatījās arī lauku apkārtnē.

Krievu tautas ietekmē veidojās arī Latgales tērpu komplekss (sarkanais rotājums krekliem ar virsū šūtiem uzplečiem, ielasītais raksts kreklu rotājumā u. tml.).

Arī 17. gs. uz Latgali pārcēlušies vecticībnieki, neraugoties uz noslēgto dzīves veidu, atstāja savu ietekmi latviešu tērpā. Šai sakarā minams, ka vecticībnieču ietekmē Latgales sievietes sāka ap galvu siet îsos autus.

Ziemeḷlatgales tērpos manāma liela radniecība ar igauņu - setuku un baltkrievu apgèrbu (baltie brunči ar nelielo rotājumu apakšmalā, sarkanais ielasītais raksts kreklu rotājumā un galvas auti) . Rodas jautājums, kādēl sakari ar baltkrieviem atspoguḷojas tieši Ziemellatgales tērpos un nevis Dienvidlatgalē, kas robežo ar Baltkrieviju? Ziemeḷlatgales tērps kopš 18. gs. saglabājies līdz mūsu dienām nemainìts, turpretim Dienvidlatgalē sakarā ar iedzīvotāju plašo pelṇās iešanu senais apğērbs, kas droši vien bijis līdzīgs baltkrievu tērpiem, nomainīts daudz agrāk. Dienvidlatgalē spēcīgāk saglabājušies sēliskie elementi, kas līdz ar to šã apvidus tērpu vairāk saista ar Augšzemes nekā ar Ziemellatgales tērpiem. Liekas, ka tāpēc arī no starpjoslas, kas saista Baltiju ar Krieviju, ${ }^{864}$ apğērbu ziṇā izdalās Dienvidlatgales tērps un klūst saprotama baltkrievu un Ziemellatgales tērpu tuvā radniecība.

Līdzība ar igauṇu apg̛ērbu vērojama Vidzemes ziemel̨u daḷā, kas robežojas ar Igauniju. Šî līdzība novērojama arī Kurzemes ziemel̨ietumu daḷā, kur spilgti izpaužas lïbiešu ietekme. No otras puses, igauṇu pētnieki konstatē daudz vidzemniecisku iezīmju Dienvidigaunijas tērpos. ${ }^{865}$ Tāpat valodniecības materiāls dod liecību par to, ka igauniem ir bijusi sava nozīme Vidzemes etniskajā vêsturē. Zināms skaits igauṇu pieder pie Vidzemes senajiem iedzīvotājiem. Igauṇu ienācēji konstatējami pat līdz mūsu dienām. ${ }^{866}$

Noteikt atškirīību starp lỉbiskām un igauniskāmı iezīmēm, kas saglabājušās latviešu tautas tērpos, ir visai grūti. Apskatot atsevišķas apgeērba daḷas, konstatējams, ka Kurzemes un Igaunijas tērpus saista senākie apgêerbu gabali, turpretim jaunāka gājuma tērpa detalas - Vidzemes un Igaunijas pierobežas tērpus. Ja Ziemelvidzemē šìs radniecības pamatā ir kopīgi vēsturiskie apstākḷi, tad Kurzemē tā saistāma ar lībiešu ietekmi.

Igauṇu kreklam, tāpat kā latviešu un lietuviešu kreklam, raksturīgs tunikveida piegriezums. Igauṇu krekls līdzīgs latviešu kreklam arī pēc ornamenta un izšuvuma tehnikas - baltā izšuvuma un spodršuvuma. Vienvirziena izvilkuma tehnika, kas raksturīga Vidzemes un Ziemel̨urzemes krekliem, sastopama arī senākajos igauṇu kreklos (Hallistes).

Pēc ziliem diegiem šūtā ornamenta un izšuvuma tehnikas līdzīgi ir Kuldīgas un Igaunijas Jāni apvidus krekli. ${ }^{867}$ Igaunijā Helmes, Reuges un Vastselīnas apkārtnē valkātajiem krekliem līdzīgs pēc piegriezuma un rotājuma ir Ziemeḷlatgales krekls. ${ }^{868}$ Sie krekli rotāti ar sarkaniem diegiem ielasītā rakstā. Tomēr, ja latviešu un igauṇu krekli ir lïdzīgi pēc ornamenta izvietojuma, tad ne vienmēr pēc tā veida, jo Igaunijā pārsvarā izplatìts augu ornaments, kamēr latviešu kreklos dominē geometriskais raksts. 
Ipatnēja igauṇu apg̀ērba daḷa ir kaisets - ĩsa blūze, kas nesniedzas līdz jostas vietai, ar garām piedurknēm. Tā rotājums līdzīgs latviešu krekla rotājumam, piemēram, Kihnu kaiseta ornaments līdzīgs Rucavas krekla rotājumam grieztajā rakstā. ${ }^{869}$

Kā pēc krāsu salikuma, tā arī pēc piegriezuma visumā līdzịgi ir latviešu un igauṇu brunči. Lìdzība sevišḳi manāma pierobežas rajonos. Igauṇu vienkrāsainie brunči ar sarkanām lentēm vai svītrām apakšmalā ir līdzīgi Kurzemes brunčiem. Krasi no latviešu brunčiem atškiras horizontāli svītrotie Muhu un Sāmsalas brunči.

Pēc krāsām un raksta novietojuma atškirīịas ir latviešu un igauṇu jostas, lai gan tās pagatavotas vienādā tehnikā. Igauṇu jostās ne vienmēr ievērota latviešu jostās parastā trīsdalīgā kompo. zìcija, tomēr ornaments variē visumā tāpat kā latviešu jostām. Igauṇu jostu raksturīga iezīme ir tā, ka centrālo ornamentu pārdala kontrastainas krāsas svītra, kas latviešu jostās ir reta parādība (atskaitot Alsungas un Zemgales jostas). Igaunniem pazīstamas arī metāla jostas, bet tās izplatītas tikai atseviškłos Igaunijas rajonos, galvenokārt Igaunijas rietumu dą̣ā un salās. Latvijā metāla jostas pazīstamas ap Ventspili, Kuldīgu, Alsungu. Tātad metāla jostas uzskatāmas par zināmu lībiešu un igauṇu iezīmi.

Igauṇi vēlāk nekā latvieši sākuši valkăt jakas un ñieburus, kas pēc sava piegriezuma un materiāla līdzīgi latviešu jakām un nieburiem. Tā kā daudzos Igaunijas rajonos bija izplatits îsais kaisets, tad šeit jakas un n̦ieburi izplatījās sevišḳi plaši.

Villaines Igaunijā, tāpat kā Lietuvā, 19. gs. vidū vairs nav sastopamas. Senākie igauṇu villaiṇu varianti pēc sava rotājuma līdzīgi Kurzemes villainēm. ${ }^{870}$ Tas vēlreiz liecina par Kurzemes tērpu ciešo saistību ar igaunu tērpiem. Izzūdot villainēm, apgèèrba komplektā plaši ieviesās mēteḷi un kažoki. Bagātīgi rotātie garie igauṇu sieviešu svārki radniecīgi Ziemeḷidzemes vīriešu svārkiem.

Igaunu sieviešu galvas rotas ir daudzveidīgākas nekà latviešu. Līdzịgas latviešu sieviešu galvassegām ir tikai igauṇu sieviešu ziemas cepures ar iešūtu kažokādu un sapāna veida galvas auts. Jāpiezīmē, ka par sapānu igauni sauc no lentēm darinātu jaunavas galvas rotu. Arī Igaunijas austrumu daḷā lietotais sievu galvas auts «linik» ir līdzígs Alsungas līgavas rotai linkainim.

Diemžēl, vēl nav iespējams precizēt, kas ir Alsungas un setuku tērpu zināmu radniecības pazìmju pamatā. Jau minētais linkainis, zeḳu raksti un arī kāds loti sens Alsungas krekls (Liepājas novadpētniecības muzejā) ar stipri pagarinātām un šaurām piedurknēm ${ }^{871}$ nenoliedzami parāda šo līdzību. Arī citos setuku ornamentos (adījumu rakstos) jaušama Alsungai raksturīga kompozīcija. ${ }^{872}$ Iespējams, ka radniecīgās iezīmes Alsungas un setuku tērpos runā par labu M. Stepermaṇa izvirzītajai hipotēzei, ka lībieši dzìvojuši līdz Peipusa ezeram. ${ }^{873}$
Igauṇu jaunavas parasti nēsāja paplatināta vainaga veida cepures, kam ciets pamats. Šāda veida vainags, tikai daudz vienkāršāks, sastopams arī Kurzemē. Tā nav nejaušìba, jo arī šādas vainagveida cepures izplatītas tieši Igaunijas rietumu dạāa un salās. 18. gs. tādas valkătas arī Igaunijas ziemelaustrumu da!̣ $\bar{a}^{874}$

Liekas, ka par loti seniem kultūras un etniskiem sakariem liecina jaunavu lentveida vainags no Paistu apkārtnes, ${ }^{875}$ kas pēc savas formas un lentu saiška mugurpusē atgādina latgaḷ 12. gs. šauros auduma vainagus, ${ }^{876}$ kā arī Ziemel l- un Rietumvidzemes matauklas no 19. gs. Vienīgi pēdējo rotājums ir citāds - tās rotā izšuvumi. Lībiešu elementu ietekmi apstiprina arī antropoloğiskais materiāls $^{877}$ un daži Kurzemes celtṇu tipi, kādi sastopami arī Sāmsalā. ${ }^{878}$

Latviešu tautas tērpa izveidē zināma nozīme pieder arī zviedru tautas tērpiem. Agrākos publicējumos šì nozīme bieži vien ir pārspīlēta, sevišḳi attiecībā uz Vidzemes tērpu kompleksu. «Zviedru laikos» vidzemniekiem nebija tiešas saskares ar zviedru zemniekiem, jo zviedru civiliedzīvotāju Vidzemē bija ḷoti maz. Vienīgi Vidzemē ne pārāk plaši izplatîtās adītās cepures ar pušḳi galā varētu uzskatīt par zviedriskām, ${ }^{879}$ bet tikpat labi tās vidzemnieki varēja būt redzējuši kaimiṇiem igauniem. Kurzemes tērpos zviedru iezīmes varam konstatēt tikai senākos apğērba gabalos - jaı minētajā Kuldīgas, Alsungas un Ventspils sara. fānveida brunču piegriezumā un kniepḳena nosaukumā.

Lai gan ilgus gadsimtus latvieši atradās vācu jūgā, latviešu tautas tērpā vācu ietekme gandrīz nav saskatāma. Vācieši Latvijā piederēja pie valdošās škiras un latviešus uzskatīja par nicināmiem. Vācu muižnieki kā valdošās škiras pārstāvji dzīvoja savā noslēgtā pasaulē, kas latviešu tautī. bas cilvēkiem bija nepieejama. Vācu tautas tērpu latvieši tikpat kā neredzēja, tāpēc arī latviešu apgèrba attīstībā tam nebija kaut cik būtiskas nozìmes.

Bez tam vācieši ar dažādiem aizliegumiem centās latviešus saistīt pie viṇu «zemnieku apg̉ērba», jo feodālajā sabiedrībā, kur pastāvēja stingra kārtu atšḳirība, valdošā šḳira rūpēiās par to, lai apgèēbs būtu viena no barjerām, kas neḷautu pārkāpt kārtu robežas. Apg̣ērbs noderēja arī par pazīšanās zīmi, kas viegli lāva atrast un noḳert no muižām izbēgušos zemniekus. Par to liecina simtiem sludinājumu, kas meklēja «zemnieku apợērbos» tērpušos izbēgušos zemniekus.

Nobeigumā jāsaka, ka visas minētās kaimiṇtautu îpatnības latviešu tautas tērpā, pārnākot diezgan pārveidotā veidā, kḷuvušas par tā neatñemamu sastāvdal̨u. Tāpēc citu tautu kultūras ietekme konstatējama, tikai sīki analizējot lat. viešu tautas tērpu. S̄āda analīze rādītu tās kopējās iezīmes, kas raksturīgas visām tautām neatkarīgi no to etniskās piederības, kā arī tos elementus, kas kopēju vēsturisku apstākḷu ietekmē izvei. dojušies līdzīgi radniecīgām tautām. 


\section{LATVIEŠU TAUTAS TĒRPA IZVEIDE LİDZ MŪSU DIENĀM}

19. ğs. otrajā pusē līdz ar kapitālisma strauju attīstību latviešu kultūras dzīvē iestājās jauns periods. Latviešu nacionālā kultūra, tāpat kā visas nacionālās kultūras, kapitālisma apstākḷos nebija viengabalaina. Veidojās divas kultūras - tautas, demokrātiskā kultūra un buržuāzijas, reakcionārā - nacionālistiskā kultūra. Lìdz ar škiru cīñas saasināšanos 70.-80. gados latviešu buržuāzija visumā jau bija kḷvusi par reakcionāru spēku, tās centieni un idejas bija zaudējušas progresīvo raksturu. Reakcionārā buržuāzija, kaunoties savu senču - zemnieku, centās sev pielāgot vācu pilsoniskās modes. Tâpēc nereti tā laika presē izskan doma par modes apgēerbu negatīvo ietekmi lauku sētās. "Daudzi turīgi saimnieki iznīkst un noklīst vienīgi tik tamdēl, ka vinu sievas un meitas par savām «feinām kleitām» vairāk izdod, nekā saimniecības ienemšana to panes ... ${ }^{880}$ Lauku buržuāzija savus apgèēbus pilnīgi darināja pēc pilsētu modes: «...Mums daudzreiz izliekas, it kā mēs nemaz nebūtum uz zemēm, bet atrastumies pilsētā, jo mēs te redzam pēc jaunākās modes smalki gèerbušās jaunkundzes, kupraiṇu muguru, smalkiem drēbes zābaciniiem, galošām, saulesširmiem un, jā, pat ādas cimdiniem ... Visur dzirdam sūdzoties par grūtiem, trūcīgiem laikiem, bet, mūsu zemnieku «jaunkundzes» apskatot, ir jādomā, ka tagad valda bagātība un ka naudas ir pārāk daudz.»881

Ja 19. gs. pirmajā pusē «pēc apǵērba izskata vien jau varèja nospriest, no kura apgabala katrs cilvēks bij», tad «mūsu dienās sāk visur valdīt vienādỉba un tomēr nepastāvība. Ko vakar visì cienīja, to šodien atkal visi atmet, lai rîtdien atkal varētu griezties pie jauna. Pašu darīto drānu vietā ir stājušies fabriku ražojumi, kurus piedāvā par dārgu naudu apkārt klejojošie tirgotāji vai kurus pērk no pilsētas tirgotājiem. Mūsu dienās sāk vairāk un vairāk valdìt mode, kā apgèēba formās, tā arī vielās, iz kurām drēbes gatavo.» ${ }^{82}$

Pirkto apg̀ērbu materiālu iegādē tikai ieguldīta arī liela laukstrādnieku algas dą̣a, bet apgērbu daudzums ievērojami samazinājās: "Agrākos laikos pelnīja meitas par gadu 5 rubḷus, un, kad tās tautās gāja, bija tām dažs rublīts k̦ešā un pilna tīne visādu labu un veselīgu drēbju; bet šinīs lai- kos sniedzas meitu gada alga lìdz 40 un pat vairāk rubliem, un, ja tām precēšanās gadās, tad jaunajā dzīvē ieved lădi ar pāra plunduriem pildītu, un makā neatrodas ne kapeikas... Kur nu paliek lielā alga un ko gan meitas dara savas valas brižos? Ja tik apskatāmies svētdienās pie baznīcas, kā mūsu meitas ir izpucējušās, tad mums arī ir pilnīgi saprotami, kur viṇu rubliš̌i aizritējuši un ko tās garajos ziemas vakaros darījušas. ${ }^{883}$

Protams, raksta autors neizprot, ka nominālās darba algas paaugstināšanās izskaidrojama ar lauksaimniecības un citu masu patērina preču cenu celšanos. Faktiski reālā darba alga nepaaugstinājās. Budži atklāti izteicās, ka darbaspēku viṇi pērk, tāpēc viniem arī esot tiesības izspiest no laukstrādniekiem, cik vien tas iespējams. Līdz ar to klūst saprotams, kur palika laukstrādnieču «lielā alga», "valas brīži» un "garie ziemas vakari».

Skịiru sabiedrībā attiecībā uz gērbšanos vērojamas divas škietami pretējas tendences: no vienas puses, tieksme uz diferenciāciju, bet, no otras puses - tieksme uz imitāciju - zināma daḷ zemākās šḳiras loceklu rauga apgūt augstāko škiru paṇēmienus ārējā dzīves veidā un izskatā, kamēr augstākās šḳiras locekḷi nopūlas radìt atkal un atkal jaunas atškirības pazìmes. Tieši šĩ tendence spieda arī latviešu lauku buržuāziju ar apgeērbu rādìt savu vietu sabiedrībā, jo atsevišḳu apğērbu formu valkāšana ar likumu aizliegta netiek.

Sievietei dalẹji iesaistoties tiešajā ražošanā «vīriešu amatos», tāpat arī līdz ar sporta attīstību radās vajadzība pārveidot sieviešu apgèērbu, lai tas atbilstu dzīves prasībām. 20. gs. 20. gadi ir tas laiks, kad arī Latvijā sievietes beidz valkāt garos un neērtos brunčus, pārāk šaurās oderētās jakas u. c. darbam nepiemērotus apgeērba gabalus.

Salīdzinot ar Zemgali un dalēji arī ar Kurzemi, vidzemnieču apḡērbi tomēr ilgāk tiek darināti no pašausta materiāla. No ekspedīcijās iegūtajiem 1000 pašausta apgèrba auduma paraugiem 70\% darināti 20. un 30 . gados. ${ }^{884}$

Ja 19. gs. beigās vērojams latviešu tautas mākslai raksturīgo rotājumu iznīkšanas process, tad 20. gs. 30. gados sakarā ar plašo tautas mākslas propagandu mājturības un rokdarbu kursos 
aizvien biežāk têrpu rotājumos izmantotas tautas mākslas tradīcijas. ${ }^{885}$ Sevišḳi bagāti senās rotāša. nas tradīcijas uzplauka dažädos adījumos. ${ }^{886}$

Tā kâa pilnīgs tradicionālais tautas tērpa komplekts lielākajā Latvijas daḷā bija beidzis eksistēt jau 19. gs. 50.-60. gados, bet interese par tautas tērpu kā objektu, ko vajadzētu saglabāt nākamajām paaudzēm, radās daudz vēlāk, tad daudzi vērtīgi materiāli gājuši zudumā.

19. gs. beigās, kad latviešu nacionālā buržuāzija jau bija nostiprinājusies, tika veikti dažādi pasākumi tautas tērpu vākšanā un arī mākslīgā radī̌anā.

Lieli nopelni latviešu tautas dzīves, tai skaitā arī apg̉ērbu pētīšanā ir Krievu ǵeogrāfijas biedrībai, kä arī Maskavas Dabaszinātnuu, antropolog̣ijas un etnogrāfijas draugu biedrībai. Biedrîbu darbā, vācot folkloras un etnogräfijas materiālus, piedalījās arī latviešu buržuāziskās inteliğences pārstāvji (J. Kalējs-Kuzṇecovs, J. Sproğis, F. Brīvzemnieks u. c.).

Latviešu etnogrāfisko materiālu vạ̄kšanas darbā rosīgi iesaistījās Rīgas Latviešu biedrība un tās Zinîbu komisija. Pirmie savāktie etnogrāfiskie priekšmeti tika demonstrēti Rīgas Latviešu biedrības rīkotajā izstādē 1890. gadā.

Sākot ar 70. gadiem, latviešu buržuāzija savu interešu paušanai arvien plašāk sāka izmantot presi. It îpaši 90 . gados presē notiek veseli strīdi jautājumā, kāds ir bijis latviešu tautas tērps.

Par seno latviešu tautas apg̀ērbu pirmo reizi plašāk sāka spriest 1888. g., kad populārākajos buržuāzijas periodiskajos izdevumos - laikrakstos «Balss», «Mājas Viesis» un «Baltijas Vēstnesis» parādījās raksti par to, vai dziedātājiem gaidāmajos (III) dziesmu svētkos «nederētu ierasties tautas svētkos arī tautiskā apg̛ērbā» ${ }^{887}$ Vēlāk šis jautājums tika pārrunāts vēl plašāk. Dažos rakstos tika izteikta doma, ka latviešiem nemaz neesot sava îpaša tautas apgèrba, bet tie patapinājuši to no citām tautām, jo, piemēram, dažos Vãcijas apgabalos sastopams loti lïdzīgs apgèrbs. Jà arī latviešiem būšot bijis savs îpašs apğērbs, tad zem svešzemnieku varas tas būšot pavisam iznīcis. $^{888}$ Kādā citā rakstā izteiktas bažas, ka apgèerbs, kas «vergu laikos... piederējās latviešu kārtai», nebūs pietiekami labs «brivvai latvju tautai», 883 tāpēc autors ieteic paraugus meklēt lietuviešu varenajā pagātnē, kad tie bijuši pārāki par poḷiem. Uzskats, ka latviešu apgēerbam vajagot būt vienkāršam un vienmulam, raksta autoram liekas «nepareizs un nedaiḷ̌s».

1888. g. februārī Rìgas Latviešu biedrībā tika sasaukta speciāla sapulce, kurā tika apspriests jautājums, kādā mērā un kādā veidā dziedātāju koriem būtu jārūpējas par gēerbšanos tautiskos apg̀ērbos un kas tiem bütu jăievēro, lai sekmëtu tautas tērpu darināšanu. ${ }^{890}$ Tā kā tautas tērps esot jāšuj tikai svētkiem un tas izmaksāšot samērā dārgi (15-20 rubḷu), tad labāk būtu sastādīt speciālu komisiju, kas nodarbotos ar tautas tērpu jautājumu, vāktu materiālus, uz kuru bāzes tad vēlāk varêtu atdarināt tautas tērpus. ${ }^{891}$ Cită rakstā ieteikts dziesmu svētkos ierasties pašaustās drēbēs, jo, ar «... pirktiem drēbju gabaliem lepojoties, sacensība ir skaidri ārīga; lepnākas drēbes pierādīs tikai, ka «lielākam naudas cimdam» pieder pārsvars, turpretī, paliekot pie pašaustiem apgèrbiem, «naudas cimda» svars sarūk, kamēr zeltenes personīgā izveicība un prasme parādās jo gaiši». ${ }^{892}$ Gatavojoties III Vispārējiem dziesmu svētkiem, bija ievēlēta speciāla «tautas apgèēbu komiteja». ${ }^{893}$ Vēl pirms tās nodibināšanas laikrakstā «Dienas Lapa» bija publicēti raksti, kas ieteica pareizus tautas tērpu atdarināšanas principus, proti, vispirms savākt vajadzīgos materiālus un tikai tad domāt par tautas tērpu ieteikšanu dziesmu svëtku dalībniekiem. ${ }^{894}$

Komitejas darba gaitā «Dienas Lapa» uzstājās pret mākslīgu «vispārīga tautas tērpa» ievešanu, ieteicot pašaustus apğērbus. ${ }^{895}$ Tomēr «apgèrbu komiteja» bija sastādījusi sevišḳu «normālapg̛errbu sieviešiem», «apvienojot tanī mūsu senčı apg̀ērbu ar tagadējo laiku vajadzībām un garšu». ${ }^{896}$ Šis apgèrbs atrada diezgan daudz piekritēju, un liela dala dziedātāju svētkos bija tēr. pušies šādos apğērbos. ${ }^{897}$ Tomēr šim tērpam bija maz kopēja ar tradicionālo tautas tērpu: tas jāuzskata par pirmo māksliggi radīto «nacionālo tērpu». Pati tautas apgèerbu komiteja bija izsacījusies, ka «šis apgèerbs vēl nav galīgais, pilnīgi noteiktais un pieṇemtais. Viṇš tik kă pagaidām, kā paraugam izdots jeb sastădīits. Varbūt, ka pie viṇa ar laiku šo to pārgrozīs, ko atmetīs vai ko vēl klăt pieṇems, kad būs tuvāk iepazinušies ar mūsu senču apǵērbiem.» ${ }^{898}$

Šis pseidotautiskais tērps tomēr saglabājās arī vēl pēc 1896. g. tautas tērpu izstādes, kurā bija gan parādīti arī senie tautas tērpi, līdz pat 20. gs. pirmajiem gadu desmitiem. 20. gs. sākumā bija vêl citi mēğinājumi reformēt tautas tērpu.

Gatavojoties IV Dziesmu svētkiem (1895. g.), presē aizvien biežāk parādās raksti, kuros tiek ieteikti jauni «nacionālie tērpi» un skaidri pateikts, ka tos vajag darināt tikai «tām zeltenēm, kurām vairāk pie rokas», tās tad lai darina «samta ṇie. burus», «zīda priekšautus» un «lakatus», kā arī lielāku daudzumu sudraba saktu. ${ }^{899}$ Skaidrs, ka ar šādiem ieteikumiem reakcionārä buržuāzija gribēja nošḳirties no tautas masām. No vienas puses, sludinādama «tautas vienotību» un ar kopēja tautas tērpa darināšanu mēğinot «tautas pašapziṇu vairāk modināt», tā tomēr meklēja iespējas radìt atšḳirību pelēko baronu un buržuāzijas, no vienas puses, un strādnieku un laukstrādnieku, no otras puses, apğēerbā. Tādēl «Dienas Lapa», kas pareizi izprata, ka cīna notiek ne tikai pret vācu muižniecību, bet arī pret jauno latviešu buržuāziju, gatavojoties IV Dziesmu svētkiem, rakstīja: «Mūsu mācītiem tautas dēliem, kas dzīvo izkaisīti pa visu plašo Krieviju, vajag šad tad sapulcēties, vajag kopā papriecāties. Un kas gan šim nolūkam noderīgāks nekā šādi svētki, kur sabrauc kopā visa inteliğence un visas pārtikušãs dzimtas? S̄āda sa- 
pulcēšanās atnes labumu arî visai tautai. Un tãpēc es ar prieku apsveikšu Dziesmu svêtkus un novēlēšu tiem labākās sekmes. Bet tautas svētki viṇi nav.» ${ }^{900}$

IV Dziesmu svētkiem reakcionārās buržuāzijas pārstāvji ieteica jaunu «nacionālā tērpa» stilizējumu: nepareizi un burtiski izprazdami gleznainos tautasdziesmas vārdus, tie ieteica nieburus un priekšautus izšūt ar naturāliem ziediem. Liekas, ka šajos stilizējuma mēginājumos vairāk izpaužas vēlēšanās pielāgot toreiz plaši izplatīto vācu sīkpilsonisko «jugendstilu» tautas tērpam.

Tā kā šie stilizējumi bija pilnīgi sveši latviešu tautas mākslai, tie plašāk neieviesās.

V Dziesmu svētki (1910. g.) raksturīgi kā Rīgas Latviešu biedrības polītiska demonstrācija un tãs atlikušo piekritēju un cienītāju mobilizācija. ${ }^{901}$ «Bet, lai vairāk nevainīgu dvēsel̨u varētu dabūt šai balagāna burzmai līdz, tad bija vajadzīga tās tautiskā izkārtne.»902 Šai tautiskai izkārtnei tad arī noderēja šie «jugendstilā» izšūtie «nacionālie tērpi», kuros tērpās reakcionārās buržuāzijas pārstāvji. Viṇus nemaz neinteresēja Latviešu muzejā izstādītie tradicionālie tautas tērpi. ${ }^{903}$ Turpretī «Rīgas proletariāts nevarēja «piedalīties» šinīs svētkos. Priekš viṇa piedalīšanās šinīs varmāku dzīrēs ar pretdemonstrāciju sarīkošanu un cara izsvilpšanu nozìmētu nest jaunus smagus upurus... Jo par daudz pēdējos gados tecinātas proletāriešı asinis, par daudz ārdìtas un putinātas mūsu organizācijas, lai tagad liktu uz spēli mūsu nedaudzos spēkus, kuri patlaban sāk pamazām atkal atžirgt un gatavoties uz jaunām ciṇām.» ${ }^{904}$

Buržuāzijas varas gados Latvijas buržuāzija rīkoja dziesmu svētkus, lai saviem ārzemju saimniekiem un visai pasaulei parādītu šḳietamu dzīves un kultūras augšupeju «neatkarīgajā» Latvijā. Laikā, kad cietumos smaka brīvības cīnītāị un Komunistiskā partija no pagrīdes vadīja darbaḷaužu cīnu, reakcionārā buržuăzija pielika visas pūles, lai ḋziesmu svētki izdotos l̨oti grezni. Dziedātājus uz svētkiem aicināja ierasties tautiskos apğērbos. Piemëram, VI Dziesmu svētku (1926. g.) tērpu sekcija bija izstrādājusi 18 tautisko tērpu paraugus pēc novadiem; tie bija iespiesti atklātnēs un sakārtoti albumos. ${ }^{905}$ Protams, ka šiem mākslinieku zīmētiem nacionāliem tērpiem nebija nekā kopēja ar patieso tautas tērpu, bet tas bija tikai kārtējais mēğinājums radīt modernizētu tautas tērpu. Tā kā gaišā pamatā austos svītrainos brunčus un ar zīda diedziṇiem austās jostas ražoja fabrikās, tie ieviesās diezgan plaši.

Tādā veidā parādījās modernizêts tautas tērps: gaiši svītroti brunči, melni «sašņorējami» samta ñieburi, mazi priekšautini ar izšútiem tautas dziesmu pantiem, pirktām mežg̀inēm rotāti krekli, samta vainagi ar lecošas saules motiviem, no zīda diegiem austas jostas ar primitīvu kompozīciju. Sis apgêres tomēr bija guvis diezgan lielu piekrišanu, un VI Dziesmu svētkos liela dala dziedātāju bija tērpušās šais apgèerbos.
Blakus valdošās kliḳes reakcionārajai buržuã ziskajai kultūrai, kas kalpoja darbą̧aužu apmuḷkošanai un verdzināšanai, pastāvēja demokrātiskā kultūra. Divu kultūru cịṇa izpaudās arī tautas tērpu vākšanas un vākumu izmantošanas darbā. Lai gan buržuāzija, tendenciozi idealizējot pagātnes kultūru, vāca un krāja tikai viskrāšṇākos tautas tērpu paraugus, kas vienpusīgi parādīja vienīgi latviešu turīgo zemnieku geerrbšanās tradīcijas un apzinīgi neievēroja sociālos momentus, tomër savāktais bagātais faktu materiāls savu kultūras mantojuma nozīmi nav zaudējis arī šodien. Šo grezno paraugu radītāji galvenokārt bija darba tautas pārstāvji; ja arī daḷ no tiem ir radījuši turīgās zemniecības pārstāvji, tad tas noticis vēl tolaik, kad visa latviešu tauta cīnījās pret vācu baronu jūgu un tautas māksla bija aktīvs ierocis šai cinnā. Turpretim visi stilizētie un mākslīgi radîtie «nacionālie tērpi» kā buržuāzijas ideoloğijas izpaudums neietilpst kultūras mantojuma vềrtīgajā daḷā.

Buržuāziskās varas gados valdošā šḳira tautas tērpā saskatīja vienīgi tautas mākslas izpausmi un tāpēc izmantoja to reprezentācijas nolūkos. Sakarā ar to latviešu tautas tērpi tika eksponēti starptautiskās tautas mākslas izstādēs Stokholmā, Parīzē u. c. Arī vairākas p̉lašas šì pe. rioda publikācijas etnogrāfijā veltītas latviešı tautas mākslas krāšñākajam izpaudumam - tautiskajam apgēerbam vai atseviškāan tā sastāvdal̦ām. Lai gan šĩm publikācijām ir nenoliedzama nozīme kâ tautas mākslas popularizētājām, tās tomēr ir vienpusīgas, tendenciozi aizstāv latviešu tautas mākslas konservatīivismu, nesniedz zinātnisku analīzi, novērtējumu un noliedz kultūras sakarus ar tuvākajām kaimiṇu tautām - lietuviešiem, igauniem, krieviem u. c.

Fašistiskās diktatūras gados tautas tērpi tika izmantoti tautas «vienotības demonstrēšanai», lai parādītu strādnieku, fabrikantu, kalpu un budžu «kopējo lietu» Latvijas labā. Tầ kā bija jau pietiekami daudz savākto materiālu un plašu publicējumu par tautas tērpiem, tad vairs nenotika tautas tērpu stilizēšana tādā veidā kā agrāk. Visiem spēkiem tika meklēti līdzekḷi fašistiskās diktatūras un «vadoṇa» kulta attaisnošanai un pamatošanai, tā propagandai un popularizēšanai. Žurnālos parādījās attēli, kas rādīja, kā «vadonis» viesojās «senču kāzās», vakarēšanās utt. Sādu sarīkojumu dalībnieces bija tērpušās tautas tērpos, kuru pareizai atdarināšanai tika pieškiirta liela nozime.

Tika pārspīlēta arī tautas tērpu nozīme modernā apğērba veidošanā. Šajā laikā tika izdarīti neveiksmigi mēg̀inājumi tautas tērpa brunčus darināt no zīda auduma, kas nedeva vajadzīgo kritumu un nebūt nesaderējās ar pārējiem tautas tērpa piederumiem. Nekädus pozitīvus rezultātus nedeva arī 1943. g. Rīgas dail amatniecības vidusskolā organizētās diskusijas par to, vai pareizi valkāt prievītes kaklasaišu vietā, vai nevajadzētu «ieviest modē» pelēkos garos vīriešu svārkus, vai 
drīkst ieviest jaunas izšǔšanas metodes un tehnikas, ja mūsu senčiem tādas nav bijušas, un vai isti «tautiski» būs tikai tie modernie sieviešu apgèrbi, kuru jostas vieta pēc Alsungas tautas tērpa parauga būs "virs otrās ribas». S̄āda arhaizācija un nepareiza tautas tērpu mantojuma izpratne tikai traucēja tērpu dabisko attīstības gaitu.

Lielus zaudējumus tautas tērpu krātuvēm nodarīja nodevīgais fašistiskās Vācijas iebrukums. Lielā Tēvijas kara laikā zaudējumus cieta arī muzeja tautas tērpu kolekcija, jo daudz priekšmetu okupācijas gados noklīduši.

Līdz ar padomju varas nodibināšanos Latvijā no ekspluatācijas un kapitāla jūga atbrīvotā tauta ar nebijušu vērienu iesaistījās kultūras celtniecības darbā, izvirzīdama no sava vidus daudz talantu dažādās mākslas nozarēs. Lielā Lenina vārdi - «Māksla pieder tautai. Ar savām dzilākām saknēm tai jāieaug plašajās darbalaužu masās. Tai jābūt masām saprotamai un tuvai. Tai jāapvieno šo masu jütas, domas un griba, jāpace! tās. Tai jāaudzina masās mākslinieki un jāattīsta tie» ${ }^{906}$ - bija raduši spēcīgu atbalsi arī latviešu tautā. Kultūras un masu darbā bija iestājies revolucionārs pagrieziens. Partijas un valdības lēmumu par dziesmu svētku rīkošanu 1948. g. tautas masas apsveica ar lielu sajūsmu. Tikai tagad tie kluva par istiem tautas svētkiem un tautas tērpu atdarināšanai bija iespējams veltît vajadzīgo nozīmi.

Tāpēc pirmajos pēckara gados Centrālā valsts vēstures muzeja darbinieki uzsāka muzeja fondu kārtošanu, sistematizēšanu un samērā plašas tautas tērpu izstādes sagatavošanu. Izstāde bija veltīta Padomju Latvijas I Dziesmu svētkiem 1948. g. Tanī bija eksponēti 59 tautas tērpu komplekti un vairāki simti atsevišḳu tērpu sastāvdaḷ. ${ }^{907}$ Pēc rūpīga zinātniska darba 1948. g. muzejs kopā ar Republikānisko Em. Melngaila tautas mākslas namu publicēja divas burtnīcas ar Rỉgas un Latgales novadu tērpu paraugiem. Em. Melngaila Tautas mākslas nama vajadzībām muzejs sagatavoja albumus ar visu Latvijas novadu tērpu pa raugiem. Lai pašdarbỉbas kolektīviem, kas strauji organizējās republikas pilsētās un laukos, sniegtı palīdzību tērpu darināšanā, muzeja darbinieki vairākkārt atlasīja labākos brunču audumu paraugus, kurus ieviesa ražošanā tekstilrūpniecībā. Brunču audumi, kas bija austi no vilnas dzijām, ieguva labu kritumu un labi saderējās ar pārējām tērpa sastāvdaḷām. Tāpēc, neskatoties uz pēckara grūtībām, liela dala kolektīvu 1948. g. dziesmu svētkos bija tērpušies pareizi atdarinātos tradicionālos tautas tērpos. 1950. g. Dziesmu svētkos vēl vairāk dziedātāju bija tērpušies šādos tērpos, vienīgi pārāk maz tika ievērota atsevišḳo novadu specifika un ipatnības, rezultātā atsevišḳu novadu - Rucavas, Rīgas, Bārtas, Ziemellatgales un Lielvārdes - tērpi šodien izplatīti visā Latvijā.

Republikas pašdarbības kolektīvos vērojamā jaunrades aktivitāte, kas ir viens no spilgtākajiem komunistiskās audzināšanas momentiem, parā- dīja, ka masu iniciatīvā slēpjas liels spēks un ka pati tauta ir neizsmelamu garīgu vērtíbu radītāja un glabātāja. Vairākos koros un deju kolektīvos radās jaunas dejas un dziesmas. Jaunrades dejās izpaudās dzīvesprieks un enerğija, tās atspoguloja padomju dzives īstenību. Dabiski, ka tradicionālie tautas tērpi, kas bija radušies un veidojušies citos apstākḷos, straujajām deju kustībām un soliem bija pārāk smagi, tāpēc radās doma tos padarīt vieglākus. Vilnas brunčus sāka šūt īsākus, dažkārt no kokvilnas auduma, kreklus - no kokvilnas un zīda auduma. Pēc Republikāniskā Em. Melngaila tautas mākslas nama ierosinājuma māksliniece E. Rubene izstrādāja stilizètu tautas tērpu zīmējumus. ${ }^{908}$ Tā atsevišḳos kolektīvos radās villaines ar metāla (skārda) piekariniem, neharmoniskos tonos austi brunči un butaforiski veidoti izšuvumi. Protams, ka šie jauninājumi plašāk neieviesās. Kolektīvu dalībnieki, kuriem bija šādi tērpi, jutās tajos neērti. 1955. g. Dziesmu svētkos bija patīkami konstatēt, ka šo stilizēto tērpu bija samērā maz.

1960. g. Dziesmu svētkos vairs šādu stilizētu tautas tērpu nebija, un daudzās jaunrades dejas tika dejotas tradicionālajos tautas tërpos. Turpretī darba dejas tika dejotas darba tērpos. Liels nopelns šo stilizēto tērpu izskaušanā bija Centrālā Valsts vēstures muzeja rīkotajām tautas tērpu izstādēm. Piemēram, tautas tērpu izstādi ar 1092 eksponātiem Vēstures muzejs iekārtoja 1958. g., kad republikā gatavojās Padomju Latvijas IV Dziesmu svētkiem. Izstādi ar nolūku organizēja divus gadus pirms Dziesmu svētkiem, lai māksli. nieciskās pašdarbības kolektīvi jau laikus iepazitos ar materiāliem un paspētu pagatavot pēc šiem paraugiem sev svētku tērpus.

Tāpēc arī tik daudz pēc labiem paraugiem at. darinătu tautas tērpu kā 1960. g. Dziesmu svētkos vēl nekad vienkopus nebija redzēts. Lìdzās latviešu tautas tērpiem svētku gājienā bija redzami arī citu tautu têrpi.

Padomju Latvijā, tāpat kā visā Padomju Savienïbā, senos tautas tērpus ne tikai atdarina, tie noder arī par neizsmelamu iedvesmas avotu moderno tērpu darināšanā. Par to, ka arī citas padomju tautas interesē müsu tautas tērpi, liecina daudzās mākslinieku un zinātnisko līdzstrādnieku ekskursijas, kas apmeklējušas Vēstures muzeju, lai Etnogrāfijas nodaḷas fondos fiksētu latviešu tautas tērpus. Tātad tradicionālais latviešu tautas tërps palīdz veidot un attīstît internacionālas, vi . sām nacionālajām kultūrām kopīgas īpašỉbas un formas, kas pastāv un vēl ilgu laiku pastāvēs kopā ar nacionālajām formām harmoniskā apvienojumā un vienotībā ar tām.

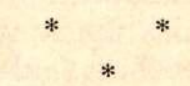

Latviešu tautas apgēēbs, tāpat kā citu tautu tērpi, ir vêrtīgs vēstures avots materiālās kultūras jautājumu pētî̌sanā un līdz ar valodniecības, 
arheoloğijas, vēstures un antropolog̀ijas datiem dod iespēju dziḷāk izprast sarežg̀itos etnoğenēzes un kultūras sakaru jautājumus. Apg̣ērba attīstība ir cieši saistīta ar ražošanas attīstību un sabiedrības vispārējo kultūras līmeni.

Latviešu tautas tērpā līdz 19. gs. sākumam saglabājušās atsevišḳas loti senas apgèēba dalas: villaines, vainagi, austās jostas, galvas auti, tunikveida krekli un nešūtie brunči, kas iepriekšējos gadsimtos bijuši lïdzīgi ar. attiecīgajiem apǵērba gabaliem kaimiṇu - lietuviešu, slāvu tautu un igauṇu - tautas tērpā un pierāda senos kultūrvēsturiskos sakarus.

Klaušu saimniecības sairuma posmā atsevišḳu novadu latviešu tautas tērps uzrāda atšḳirības, kas izpaužas tērpa darināšanas un valkāšanas tradîcijās un liecina par bagāto tautas mākslu. Pētot latviešu tautas tērpa attīstību, iespējams izsekot arī ražošanas spēku attīstības līmenim, tirdznieciskajiem un kultūras sakariem, tādējādi atklājot internacionālo momentu tautas tērpu attīstībā.

Latviešu tautas apḡērba attīstības vēsture rāda, ka visā Latvijas teritorijā apgèēba pamatelementi saglabājušies vienādi, bet katra novada vai pat pagasta robežās vērojamas variācijas apǵērba detalāās.

Jau pirmatnējās kopienas laikā, pastāvot vājiem sakariem, atsevišḳu cilšu apvienību apḡērbā vērojamas īpatnības. Feodālisma gadsimtos sakarā ar naturālo saimniecības veidu un feodālajiem spaidiem arī latviešu tautas apgeērba tālākā attīstība atseviškos novados noritēja atškirīgi, sekmējot lielas dažādības izveidošanos zemnieku tērpos.

Neskatoties uz katra sīka tērpu valkāšanas novada atškirīīām, mūsu apskatāmajā laikā (18. gs. beigas - 19. gs. sākums) latviešu tautas tērpus iespêjams iedalît piecos lielos tērpu kompleksos - Vidzemes, Latgales, Augšzemes, Zemgales un Kurzemes. Katram no tiem raksturīgs vairāk vai mazāk vienveidīgs apgēēba piegriezums, krāsu zieds un apgēerba rotāšanas principi.

Tautas apgèērbs šai laikā raksturoja valkātāja - zemnieka sociālo piederību. Kā tautas mākslas objekts tas ir visas zemnieku škiras raksturotājs, jo šajā laikā zemniecībā manẳmi vēl tikai šḳiru diferenciācijas sākumi. Latviešu zemniecība tolaik uzstājās vienota pretstatā valdošajai šḳirai. Latviešu zemnieku apgeērbs klaušu saimniecības sairuma posmā ir apspiestās un ekspluatētās zemniecības apḡērbs, kas nes labākās tautas dailrades tradícijas un atspogulo sava laika pasaules uzskatu, kultūras specifiku un māksliniecisko gaumi. 19. gs. vidū sakarā ar kapitālisma straujāku attīstību, rūpniecības ražojumu ieviešanos un pilsētas modes ietekmes pastiprināšanos laukos tautas apg̀ērbus pakāpeniski papildināja ar rūpniecības ražojumiem, un beidzot tos nomainīja pēc pilsētas modes šūti apg̛ērbi. Līdz ar kapitālisma attīstību veidojās skaitliski nelielā turīgā latviešu lauku buržuāzija, kas savā kultūrā centās atdarināt vācu muižniecību. Sakarā ar to turīgie zemnieki kã pirmie atteicās arī no pierastajiem tautas tērpiem. Kapitālisma apstāklos, kad veidojās un nostiprinājās buržuāziskā nācija, tautas tērpi tika izmantoti buržuāziskā nacionālisma propagandai, tie kalpoja par buržuāzijas tukšās reprezentēšanās un šovinistiskās ağitācijas ieroci.

Tautas tērps visā pilnībā kā tautas mākslas sastāvdaḷa novērtēts sociālistiskajā sabiedrībā. Latviešu tautas tērps kā tautas mākslas sastāvdaḷ ietver sevī labākās tradīcijas, kuras attīstās tālāk padomju mākslā, kas ir nacionāla pēc formas un sociālistiska pēc satura. Mūsu dienās latviešu tautas apgeērbs guvis citu nozimību. Lietojot to kā tautas svētku tērpu Dziesmu svētkos, valsts un starptautiskos svētkos un mākslinieciskās pašdarbỉbas priekšnesumos, tautas tērps demonstrē gadsimtos izkoptās latviešu tautas mākslas tradīcijas, to krāšnumu un bagātību.

Gatavojoties Padomju Latvijas Dziesmu svēt. kiem un ikgadējām rajonu dziesmu dienām, paš darbības kolektîvi darina tautas tērpus pēc vēsturiski pareiziem tautas tērpu paraugiem.

Latviešu tautas tērps, tāpat kā citu tautu tērpi, ir arī augstvērtīgs mākslas darbs, kurā sakoncentrētas gadsimtiem ilgi krātās estētiskās vērtības. Tautas tērps atspogulo latviešu sievietes lielo darba mìlestību, izdomas dažādību un skaistuma izpratni, kas vācu feodālu jūgā nevarēja tik pilnīgi izpausties citās mākslas nozarēs. Tautu kultūras tuvināšanās un bagātināšanās jomā arī ko. munismā tam būs sava vieta. 


\section{BIBLIOGRĀFIJA ${ }^{1}$}

\section{MARKSISMA-L̦EN̦INISMA KLASIK̦U DARBI}

\section{I}

M a rk s s K. Kapitāls, I-III. Rīgā, 1951.-1953.

M a rks s K., Eng els s F. Darbu izlase, II. Rīgā, 1950.

$M$ а ркс К. и Энгельс $Ф$. Об искусстве, I-II. M., 1957.

Eng els s Fr. Ģimenes, privātīpašuma un valsts izcelšanās. Rìgā, 1946.

Ĺ e ñ i n s par kultūru un mākslu. Rīgā, 1947.

Ĺ e ñi n s V. I. Kapitâlisma attīstiba Krievijā. - Raksti, 3. sêj . Rīgâ, 1949.

Marksistiski leniniskās estētikas pamati. Rīgā. 1961.

Padomju Savienības Komunistiskās partijas Programma. Rịā, 1961.

\section{II}

\section{HISTORIOGRÄFIJA}

Би ион А. K. Историческая наука в Латвийской ССР после XX съезда КПСС. - Проблемы истории, VI, Рига, 1962.

Buržuãziskie nacionālisti - Latvijas vēstures viltotāji. Rakstu krājums. Rīgā, 1952.

$\mathrm{Z}$ e i d s T. Senākie valstiskie veidojumi Latvijā latviešu buržuāziskās historiogrảfijas apgaismojumā. Kritisks apcerëjums. - Vēstures problēmas, V, Rỉgā, 1962.

3 у т и с Я. Очерки по историографии Латвии, 1. Прибалтийско-немецкая историография. Рига, 1949.

\section{III}

\section{AVOTI}

Latvijas PSR Vēstures muzeja Etnogrāfijas nodalas tekstiliju un rotaslietu fondi un arhīva materiāli.

Liepājas novadpētniecības muzeja tekstiliju un rotaslietu fondi.

Ventspils novadpētniecības muzeja tekstiliju un rotaslietu fondi.

Madonas novadpētniecības muzeja tekstiliju un rotaslietu fondi.

Jēkabpils novadpētniecības muzeja tekstiliju un rotaslietu fondi.

PSRS Tautu etnogrāfijas muzeja (Ľenningradā) materiāli. (Daškova muzeja austrum- un rietumslāvu, zviedru un somu kolekcijas.)

Igaunijas PSR ZA Etnogrāfijas muzeja (Tartu) tekstiliju un rotaslietu kolekcijas.

Lietuvas PSR ZA Vēstures un etnogrāfijas muzeja (Vilṇā) tekstiliju un rotaslietu kolekcijas un fototēka.

Kauñas Vēstures muzeja Etnogräfijas nodalas fondi. guloti.

1 Periodikā ievietotie raksti bibliogrāfijā nav atspo-
Kaunas Curlona Mākslas muzeja tautas mākslas nodalas kolekcijas.

Lvovas Etnogrāfijas un mākslas rūpniecības muzeja tekstiliju fondi.

Latvijas PSR ZA Valodas un literatūras institūta Folkloras sektora arhīva materiāli.

Latvijas PSR ZA Vēstures institūta Etnogrāfijas sektora arhīva materiāli.

Latvijas PSR Centrālā valsts vēstures arhīva 6810 . fonds (O. H ū n a sakopotie materiāli): Topographisch-statistische Beiträge des Gouvernements Curland (57. 1.); Kirchspiele des Tukumschen Kreises (59. 1.); Kirchspiele des Goldingenschen Kreises (60. 1.); die Kreisstadt Pilten in Curland (61. 1.); Kirchspiele des Selburgschen Kreises (62. 1).

Latvijas PSR Centrālā valsts vēstures arhīva pagasta tiesu protokoli: 879. f. - Augstrozes un Daugulu; 908. f. Grostonas; 933. f. - Grobinas; 1034. f. - Kandavas; 1073. f. - Matkules; 1111. f. - Nigrandas; 1118. f. Embūtes; 1121. f. - Lĩvbērzes; 3331. f. - Rucavas; 3356. f. - Stāmerienas; 5533. f. - Belavas; 5890. f. Jaunpiebalgas pagasta tiesa.

Gouvernements-Patente, $1760-1764 ; 1770-1774 ; 1775-1780$; glabājas Latvijas PSR Centrālajā valsts vēstures arhīvā.

Архив Географического общества СССР:

фонд 11, оп. 1, № 4, Витебская губерния. Динабургский уезд. Осунская волость. Латыши;

фонд .24, оп. 1, № 3, Программа для собирания орнаментов;

разряд 49, оп. 1, № 12, Е. Берг. Этнографические сведения об эстонцах - коренном народе Эстляндской губернии;

разряд 53, оп. 1, № 60, Г. Милевский. Литовщы;

разряд 53, оп. 1, № 75, В. Абрамович. О латышах; разряд 53, оп. 1, № 79, Сведения об эстах.

$\mathrm{B}$ a rons Kr. un Vissendorf s H. Latvju Dainas. I, Jelgavā, 1894.; II-VI, Pēterburgā, 1903.-1915.

B r a nd J. A. Reysen durch die Marck Brandenburg, Preussen, Churland, Liefland etc. Wesel, 1702.

B rotze J. Chr. Sammlung verschiedener Liefländischer Monumente, Prospecte, Müntzen, Wappen etc., I-X. (Rokraksts, glabājas Latvijas PSR ZA Fundamentālās bibliotēkas Rokrakstu un reto grāmatu sektorā.)

D z ērvīši A. un Al. un S un e pska N. Baltie darbi, II. Rīgā, 1935.

Dzērvitis A. un Suneps k a N. Baltie darbi, I. Rīgā, 1933.

D z èrvīt is A. un S un e p s k a N. Kräsainie darbi, I. Rīgā. 1934.

Eesti rahvarüete. Album. [Igaunu tautas tērpi. Albums]. Tartu, 1927.

$\mathrm{Hupe} 1$ A. W. Topographische Nachrichten von Lief- und Ehstland. Riga, I - 1774; II - 1777; III - 1782 .

Igaunu tautas mầkslas izstäde [katalogs]. Rīgā, 1933.

$\mathrm{Kel}$ ch Chr. Liefländische Historia oder kurtze Beschreibung der denckwürdigsten Kriegs- und Friedensgeschichte Ehst-, Lief- und Lettlandes. Revall, 1965. 
K o h 1 J. G. Die deutsch-russischen Ostseeprovinzen... I-Il. Dresden und Leipzig, 1841.

Krus e Fr. Necrolivonica oder Alterthümer Liv-, Esth- und Curlands. Dorpat-Leipzig, 1842.

Latviešu tautas uzvalki. Latviešu dziesmu svētku biedrības izdevums, Rịgā, 1931.

«Latvju Raksti», I-III. [Rīgā, 1924.-1931.].

«Latvijas Saule» [Rígã], 1923.-1931.

Lentilius R. Curlandiae quaedam memorabilia [Sis tas ievērības cienigs par Kurzemi]. - Latvijas Universitātes raksti, XI, Rīgă, 1924.

Livländische Reimchronik mit Anmerkungen, Namenverzeichnis und Glossar. Paderborn, 1876.

Ma n n i ne n I. Estnische Handschuhe. Tartu (Dorpat), 1927.

M ейерберг. Виды и бытовые картины России XVII века. СПб., 1903.

M e r k e l is G. Latvieši, sevišḳi Vidzemē filozofiskā gadsimtena beigās. Rīgā, 1953.

«Novadu tērpi», I-II. Rĩgā, 1949.

Ole a rius A. Vermehrte neue Beschreibung der Muscowitischen und Persischen Reise ... Schlesswig, 1656.

$\mathrm{P}$ a u ly T., de. Description ethnographique des peuples de la Russie. St-Pétersbourg, MDCCCLXII.

Plut t e V. Katalogs latviešu etnogrâfiskai izstādei va X arķeolog̣iskā kongresa laiku Rīgā 1896. [Rīgāa 1896.]

$\mathrm{S}$ j o e g r e n J. A. Reise nach Livland und Kurland zur genauen Untersuchung der Reste der Liwen und Kreewingen. St. Petersburg, 1847

Stāls A. J. K. Broces «Dažãdu Vidzemes piemineklu un skatu krājums». Zīmējumu apraksti un komentāri. Rĩgā, [1926].

Valsts arhīva raksti, IX. Rīgā, 1933

Valsts vēstures muzeja krāiumi, I un III. Rīgā, 1930.-1931.

Ziemelu muzeja izstāde. Katalogs. Rīgā, 1934.

Zviedru lietišḳās mākslas izstāde. Katalogs izstādei. Rīgā, 1934.

\section{IV}

\section{PETIJUMI}

A boli ña $M$. Klaušu saimniecība un zemnieku škiru cīna Vidzemē XVIII gs. beigās. - Disertācija. Rìgā, 1957.

A boli ñ a $M$. Vidzemes zemnieku klaušas un nodevas XVIIII gs. beigās. - Vēstures problēmas, I, Rīgā, 1957.

А ф а н а с ве в ъ-Ч у жб и н ски й. Быт малорусского крестьянна. - Вестник Императорского Географического Обшества, XII, 1855.

Aizsils A. Senās kāzas Daugavpils aprinkịi. Rīgā, 1941.

A 1 s u p e A. Audēju arodapmācība Vidzemē kapitālisma periodā. - Latvijas PSR ZA Vēstis 1959., 4.

A Is u pe A. Audumu veidi Vidzemè (19. gs. otrajā un 20. gs. pirmajā pusē). - Arheologija un etnogrāfija, II, Rìgă, 1960.

Alsu pe A. Lauku audēju darba rīki Vidzemē 19. gs. Arheologija un etnogrāfija, III, Rīgā, 1961.

Als u pe A. Mājaušana Gulbenes rajona teritorijā. - Arheoloğija un etnogräfija, IV, Rīgā, 1962.

A 1 s u pe A. Lauku audēju darinãjumi Vidzemē 19. un 20. gs. - Arheologija un etnogrāfija, V, Rīgā, 1963.

A n cît is $K$. un J a n s on s A. Vidzemes etniskās vēstures jautājumi. - Arheoloğija un etnogrāfija, V, Rīgā, 1963.

A pelgren-Kivelo H. Finnische Trachten. Helsingfors, 1907.

Ā r e nd s P. Mācītāja A. G. Boses albums. - «Senatne un Māksla». 1940., 2.

Аристов, Ригельман, Бантышь-К аменский, $\mathrm{M}$ а ф а н ски й, С а в в а и то в. Описание старинных русских утварей, одежды, орудия и пр. СПб., 1896.

A ronu $M$ atíss. Par dziparu madarăšanu un sieviešu apgeērbu agrākos laikos. - RLB ZK RK, VII, Jelgavā [1892].

Atlas polskich strojów ludowych (Polu tautas tềrpu atlants). Strój Górali Szczawnickich. Lublin, 1949; Strój szamotulski. Lublin, 1951; Strój krzczonowski. Poznań, 1952; Strój kurpiowski Puszczy Bialej. Poznań, 1952; Strój, dzierźacki. Poznań, 1953; Strój kujawski. Poznań, 1953; Strój lowicki. Poznań, 1953; Strój piotrkowski. Wroclaw, 1954; Strój pszczyński. Wrocław, 1954; Strój spiski. Poznań, 1954; Strój pyrzycki. Wroclaw, 1955; Strój rzeszowski. Wrocław, 1955; Strój międzyrzecko-babimojski (lubuski) Wrocław, 1956; Strój opoczyński. Wrocław, 1956; Strój Górali śląskich. Wroclaw, 1956; Strój jagórzan. Wrocław, 1956; Strój sandomierski. Wrocław, 1957.

A u škā p s J. Balināšana un krāsošana latvju daiṇās. LTD, III, Rigāa 1929.

Б а бе н ч и ков М. В. Народное декоративное искусствю Украины. [Москва], 1945.

Б а лл о д Ф. В. Некоторые материалы по истории латышского племени с IX по XIII столетие. М., 1910.

$\mathrm{B}$ a 1 o d is Fr. Latviešu arheoloğija. Rỉgā, 1923.

$\mathrm{B}$ a lo di s Fr. Metāls un metāla rotu lietas senatnē un tautas dziesmu atminās - LTD, V, Rigā, 1930.

Белице р В. Н. Народная одежда удмуртов. Москва, 1951.

Б ел иц е р В. Н. Методические указания к полевому сбору материалов по народной одежде. - Краткие сообщения Инст. этнографии им. Н. Н. Миклухо-Маклая, вып. XVIII., 1953.

Белицер В., М а слов а Г. Против антимарксистских извращений в изучении одежды. - «Советская этнография», $1954,3$.

Бе р езин а-Балдыре в а $M$. Русское ручное ткачество. M., 1959.

Bielenstein A. Die Grenzen des lettischen Volksstammes ... St. Petersburg, 1892.

B i e le ns te in A. Die Holzbauten und Holzgeräte der Letten, I-II. St. Petersburg-Petrograd, 1907-1918.

B i elenstein $M$. Die altlettischen Färbmethoden. Riga, 1935.

Б і ле ц к а В. Украінскі сорочки, іх типи, еволюція и орнаментація. Львов, 1929.

Болгарское народное творчество. Выставка (каталог). М., 1952.

B r a s t i ñ̌ E. Latviešu ornamentika. Rīgā, 1923.

$\mathrm{B}$ r a s t i ñ š E. Latvju raksta kompozīcija. Rīgā, 1925.

$\mathrm{Cz}$ a re ck a I. Polnische Volkskunst. Warszawa, 1957.

[D e r s ch a u E. G. und Ke y s e r ling P. E.]. Beschreibung der Provinz Kurland. Mitau, 1805.

Dzērvìtis A. Jostas un prievītes. - LTD, III, Rīga, 1929.

D z ērvîtis A. Kā latvju zeltene darinājusi un valkājusi vainagu. - LTD, VI, Rīgā, 1930.

D z ē rvît is A. Püra veltes, ziedi un knipeles. - LTD, IX, Rigā, 1931

D zērvīt is A. Sievu cepures. - LTD. VIII, Rīgā, 1931.

Dzērvitis A. Kāda Zemgales ligavas galvas sega. «Senatne un Māksla», 1937., 3.

D z è rvît is A. Latvju audumu tūkstots gadu vecas tradicijas. - «Senatne un Māksla», 1938., 2.

D z èrvît is A. Sena auduma sega no Zaubes pagasta, Rìgas apriṇkī. - «Senatne un Māksla», 1939., 4.

Eesti rahva museumi aastaraamat, I. Tartu, 1925.

Eeesti rahvarõivaid. Tallin, 1957.

Elksnite E. Gredzens. - LTD, VI, Rigā, 1930.

E 1 ks nìt e E. Rucavas krekli. - Filoloǵijas materiāli, Rīgă, 1933.

Эстонская народная одежда XIX и начала XX века. Таллин, 1960.

Etnograafia muuseumi aastaraamat, XVI. Tallin, 1959.

Г аген-Т орн Н. Женская одежда народов Поволжья. Чебоксары, 1960.

глем жай те $M$. Н. Домашняя обработка льна и шерсти в северо-восточных районах Литовской ССР. Материалы Балтийской этнографо-антропологической экспедиции (1952 г.), М., 1954.

G l e mž a i t e M. Lietuvių tautiniai drabužiai. Vilnius, 1955.

Голо в а ц к и й Я. О костюмах или народном убранстве русинов. Петроград, 1868.

Голо в а ц к и й Я. О народной одежде и убранстве русинов или русских в Галичине и сев.-вост. Венгрии. СПб., 1877.

Г ор б а че в а П. П. К вопросу о происхождении одежды. - «Советская этнография», 1950, 3. 
Grunvalde P. Kā senā zeltene adijusi cimdus un zekes. - LTD, III, Rīgā, 1929.

Gi in te rs V. Rīgā atrastās vēstures laikmeta latviešu rotu lietas. - «Senatne un Māksla», 1936., 2.

Gi inters V. Dažas Zemgales 17.-18. gs. sudraba saktis. - «Senatne un Māksla», 1937., 3.

Heikel A. O. Die Volkstrachten in den Ostseeprovinzen und in Setukesien. Helsingfors, 1909.

Hurt J. Uber die Pleskauer Eesten oder die sogenannten Setukesen. Helsingfors, 1904.

Ievads latviešu tautas tērpu vēsturē. Rīgā, 1936.

Iš Lietuvių kultūros istorijos. Vilnius, I - 1958; II - 1959

Jā k obsons F. Dzintars mūsu senlietãs un tautas dziesmās. - LTD, IV, Rīgã, 1929.

$\mathrm{J}$ a n š e v s k i s J. Nìca. Rỉgā, [1928.]

Jende E. Kā senāk šũdinājuši un rakstijjuši kreklus. LTD, IV, Rīgā, 1929.

J e n š s J. Kapitālistiskā manufaktūra Vidzemē XVIII gadsimta beigās un XIX gadsimta sākumā. Rīgā, 1951.

J e n šs J. No Latvijas rūpniecības attīstības vēstures 18 . gs. beigās - 1860. g. - Vēstures problēmas, V, Rīgā, 1962.

J ü r g en s K. Mana vectēva nostâsti. Rīgā, 1934.

Juškevičs J. Hercoga Jēkaba laikmets Kurzemē. Rīgā, 1931.

K a rnups $\AA$. Kāda 1000 gadu sena tradīcija latviešu rakstos. - «Senatne un Mäksla», 1936., 2.

K a rnups $\AA$. Līkuloks latviešu audumos. - «Senatne un Māksla», 1937., 1 .

Ka rnups $\bar{A}$. Kurzemes tautas tērpi. - «Senatne un Māksla», 1937., 2.

Karnups $\AA$. Senãs ziñas par Zemgales tautas tērpu. «Senatne un Māksla», 1937., 3.

Ka udzite $M$. Vecpiebalga. - Latvijas novadi, Rīgã, [1926].

Ke m p s F. Latgalieši. Kultürvēsturiska skice. Rīgā, 1910.

K i vi ck a E. Aušanas pašmācība. Rīgā, 1934

Коз а че н ко А. И. Древнерусская народность - общая этническая база русского, украинского и белорусского народов. - «Советская этнография» $1954,2$.

$\mathrm{Kr}$ a sti ñ š J. Latvija straujas kapitālisma attīstības un imperiālisma sākumā. Rīgā, 1948.

K r a u s s T. Kā senāk šūđināiuši, pušḳojuši un valkājuši cepures. - LTD, IV, Rīgā. 1929.

Krišjāna B a r o n a atminas. Sakārtojúsi Līna Barone. Rìgā, 1924.

Kruse Fr. Ur-Geschichte des Ehstnischen Volksstammes und der Kaiserlich-Russischen Ostseeprovinzen LivEhst- und Curland überhaupt, bis zur Einführung der Christlichen Religion. Moskau, 1846.

Ку ф ти н Б. А. Материальная культура русской мещери. M., 1926.

K u n d z i ñ š K. Smiltene. Rīđã, [1926].

Latviešu tautas māksla. I, II. Rīgāa, 1961., 1962

Latviias PSR vēstıre, I-III. Rīgā, 1953.-1959.

Л е бе де в а Н. И. Народный быт в верховьях Десны и верховьях Оки. М., 1927

Л е бе д е в а Н. И. Очередные вопросы изучения прядения и ткачества. М.. 1999

Л ебед ев а Н. И. Материалы по народному костюму Рязанской губернии. Рязань, 1929.

Л е бе де в а Н. И. Прядение и ткачество восточных славян в XIX - начале XX в. - Восточно-славянский этнографический сборник. М., 1956.

Л е бе де в а Н. И. и М а сло в а Г. С. Русская крестьян. ская одежда XIX - начала XX века как материал к этнической истории народа. - «Советская этнография», 1956, 4

Le i n b o c k F. Die materielle Kultur der Esten. Tartu, 1932.

L e pold i H. Mecklenburgische Volkstrachten, I. Leipzig, 1957.

Le p ner Th. Der preussische Lithauer. Danzig, 1744.

Л е в и н М. Г. и Че бок с а ров Н. Н. Хозяйственнокультурные типы и историко-этнографические области. - «Советская этнография», 1955, 4.

Lietuviu liaudies menas. Audiniai, I, II. Vilnius, 1957, 1962.

Lietuvių liaudies menas. Senovès lietuvių papuošalai, I. Vilnius, 1958.
L ü cking W. Trachtenleben in Deutschland. I - Schaumburg-Lippe (Berlin, 1958); II - Die Lausitz. Sorbische Trachten (Berlin, 1956); III - Hessen (Berlin, 1959).

M a de rn i e k s J. Ornaments. Raksti, I. Rīgā, 1911.

М а ков ски й С. Народное Искусство Подкарпатской Руси. Прага, 1925.

M a n n in en I. Die Sachkultur Estlands, 1-2. Tartu, 1931.1932.

M a n ninen I. Die Kleidung. - Kansatieteellinen arkisto, 13, Helsinki, 1957.

[M a n t e u f f e l G.] Polnisch-Livland Riga, 1869.

$M$ a n t e uf $f$ el G. Inflanty Polskie. Poznań, 1879.

$M$ a rk ov J. Slowakische Volkskleidung der Vergangenheit. Praga, 1956.

М а сло в а Г. Выставка «Польское народное искусство и художественные ремесла». - «Советская этнография», $1949,2$.

М а слов а Г. С. Народный орнамент верхневолжских карел. М., 1951.

М а слова Г. С. Историко-культурные связи русских и украиншев по данным народной одежды. - «Советская этнография», 1954, 2.

М а сл о в Г Г. С. Народная одежда русских, украинцев и белорусов в XIX - начале XX вв. - Восточнославянский этнографический сборник, М., 1956.

Материалы Балтийской этнографо-антропологической экспедиции (1952). М., 1954.

Merkel G. Wannem Imant. Eine lettische Sage. Leipzig, 1802.

Mi e ri ña A. Par zemnieku sociālekonomisko stāvokli Kurzemē XIX gs. 60. gados. - Vēstures problēmas, I, Rīgā, 1957.

Моора А. Х. Об историко-этнографических областях Эстонии. - Вопросы этнической истории эстонского народа, Таллин, 1956.

Mo or a H. Die Eisenzeit in Lettland bis etwa $500 \mathrm{n}$. Chr. Tartu, 1938.

Moora H. Pirmatnējā kopienas iekārta un agrā feodālā sabiedrība Latvijas PSR teritorijā. Rīgā, 1952.

Моо р а X. А. и А. Х. К вопросу об историко-культурных подобластях и районах Прибалтики. - «Советская этнография», 1960, 3.

Народнае і прыкладное мастацтва Савецкай Беларусі. Мінск, 1958.

Mützel H. Vom Lendenschurz zur Modetracht. Berlin, [1925].

$\mathrm{N}$ a vi ck is S. Par latviešiem Ilūkstes apriṇkīi. - RLB ZK RK, XI, 1897.

N i e d r e J. Brunči. - LTD, IV, Rīgā, 1929.

$\mathrm{Ni}$ edre J. Krustpils apvidus jostas. - Valsts vēsturiskă muzeja krājumi, I, Rīgā, 1930.

$\mathrm{N}$ i e d r e J. Latviešu cimdi. - Valsts vēsturiskā muzeja krājumi, III, Rīgā, 1931.

$\mathrm{Ni}$ e d re J. Sievietes apgērbs Latvijas atseviškos novados. Rīgā, 1931. (Zurn. «Zeltene», 16.-19. nr. ievietotā raksta novilkums atsevišḳā brošūrā.)

$\mathrm{N}$ i edre J. I - Villaines; II - Latviešu sievietes galvas segas. Jostas un prievītes; III - Sieviešu svārki (brunči). - Latvju Raksti, Rīgā, 1946.

Н о в осе ло в Ю. Латыши. [Рига], 1911.

Н о в о с е лов Ю. Русский народный орнамент. Рига, 1928.

Нукшинский могильник. Рига, 1937.

Очерки по истории русской деревни X-XIII вв. Под ред. Б. Н. Рыбакова, 1959.

$P$ a e g l e Ed. Latviešu tautas māksla. Rīgā, 1935.

Pā vuli ñ a K. Krustpils. - «Latvju Raksti», II [Rīgā, b.g.].

Pāvuli ñ a K. Cesvaine. - «Latvju Raksti», II [Rìgā,b.g.].

Pā v u li ñ a K. Laudona. - «Latvju Raksti», II [Rigā, b.g.].

Pāvuli na K. Puški un puškojumi tautas tradīcijās. LTD, VIII, Rìgā, 1931.

P e lš e R. Ievads mākslas vēsturē. Rīgā, 1946

P el š e R. Latviešu un krievu kultūras sakari. Rīgā, 1951.

Pēter sons K. Gērbs. - RLB ZK RK, XVII, Rìgā, 1914

Petri J. Chr. Ehstland und die Ehsten oder historischgeographisch-statistisches Gemälde von Ehstland, II. Gotha, 1802. 
П и с а р е в С. Н. Древнерусский орнамент с X по XVII в. включительно. СПб., 1903.

Позн а н ски й Б. С. Одежда малороссов. - Труды XII Археологического съезда в Харькове, М., 1905.

R e t z i u s G. Finnland. Berlin, 1885.

Р ы ба ко в Б. А. Древние элементы в русском народном творчестве. М., 1948.

Р и х те p Е. K вопросу об этнической истории сету. Известия Академии наук Әстонской ССР, т. VII, $1959,4$.

Рязанская народная вышивка. М., 1959.

R ū ķi ts H. Latvju raksti (izšuvumi). Rīgā, 1936

Румынское народное искусство. Бухарест, 1955.

Сборник антропологических и этнографических статей о России и странах ей принадлежащих, II. М., 1873.

С еме н то в ски й А. Этнографический обзор Витебской губернии. СПб., 1872

S i 1 i ñ š M. Alšvanga. - «Latvju Raksti», II [Rīgā, b.g.] S k ruzīts $M$. Sēli, Kurzemes augšgala senči. Rỉgā, 1889.

С л а в а $M$. К. Крестьянская одежда латышей и орнамент на предметах домашнего убранства (Неретский и Акнистский район Латвийской ССР). - Материалы Балтийской этнографо-антропологической экспедиции (1952 г.). M., 1954.

С л а в а $M$. K. Латышская женская одежда и орнаментация (XVIII-XX вв.). Автореферат диссертации. M. 1955.

S I a va M. Zemnieku apgēerbs Valkas rajonā. - Referātu tezes zinātniskai sesijai, veltîtai 1958 . g. arheoloğiskiem izrakumiem un etnogrâfiskai ekspedīcijai Latvijas PSR teritorijā. Rīgā, 1959.

С л а в а M. К. Комплексы женской народной одежды латышей в конце XVIII и первой половине XIX в. Вопросы этнической истории народов Прибалтики, 1, 1959.

Sl a v a $M$. Daži adīto cimdu rotâšanas veidi. - Arheoloǵija un etnogrāfija, II, Rīgā, 1960.

S I a v a $M$. Latviešu zemnieku kreklu veidi (18. gs. beigãs un 19. gs. pirmajā pusē). - Arheologija un etnogrāfija, III, Rịgā, 1961.

S 1 a v a M. Zemnieku apgēerbs Gulbenes rajonā. - Arheologija un etnogrāfija, IV, Rīgā, 1962.

S 1 a v·a M. Zemnieku apgèros Vidzemē (18. gs. beigās 20. gs.). - Arheolog̣ija un etnogrāfija, V, Rīgā, 1963.

Словацкое народное искусство. Братислава, 1953.

С обол в Н. Н. Очерки по истории украшения тканей. M., 1934.

С обол е в Н. Н. Русский орнамент. М., 1948.

Sodžiaus Menas, 7-8. Lietuvių moterų tautiniai drabužiai. Kaunas, 1939.

S p e kke A. Vecākie latvju tautas apgērba zīmējumi. [Rĩgā, 1934.]

С та со в а В. Русский народный орнамент. СПб., 1872.

$\mathrm{S}$ t e p e r m a $\mathrm{n}$ is $M$. Zemnieku nemieri Vidzemē $1750 .-1784$. Rìgā, 1956.

С т е п е р м а н и с $M$. Некоторые итоги последних экспедиций этнографов Академии наук Латвийской ССР в северной Видземе - Etnograafia muuseumi aastaraamat, XVII, Tartu, 1960

S tra u bergs J. Alūksnes mācītāja Dāvida Celaka ziṇojums konsistorijai par latviešu bēru paražām 1664. g. «Senatne un Māksla», 1936., 2.

S tra u bergs K. Limbaži un Lēdurga 19. gs. trīsdesmitajos gados. - «Senatne un Māksla», 1936., 4.

Stra u berg s J. Senā Rĩga un Rīgas koniṇi. - «Senatne un Māksla», 1936., 4.

Straubergs J. Džūkste. Pagasta un draudzes vēsture. Rìgā, 1939.

Straubergs J. Latviešu saktu kalēju amats un Rīgas latviešu rotas. - «Senatne un Māksla», 1939., 2.

S tr a u b e rg s K. Rīgas vēsture. Rignā, [b.g.].

$\mathrm{S}$ trods H. Kurzemes krona zemnieku klaušas XIX gs. pirmajā pusē. - Vēstures problēmas, III, Rìgā, 1960.

$\mathrm{Strods} \mathrm{H}$. Vidzemes etnogrāfijas avotu un pētījumu apskats. - Arheologija un etnogrãfija, V, Rīgâa, 1963.

S u d m a li s J. Latvju raksti (ornamenti). Rìgā, 1923.

S u d r a b s A. Puku vainags. - LTD, III, Rīgā, 1929.
С уп и нски А. К. «Панова» и «встовка» в белорусской женской одежде. - «Советская этнография», 1932, 2.

$\mathrm{S} v$ enne $\mathrm{O}$. Vecā un jaunā Latgale un viṇas ipatnỉbas. Rịgā, 1923.

Ш м еле в а M. Н. Народная одежда украинцев Закарпатской области. Автореферат диссертации. М., 1949.

S mi t s P. Par seno latviešu apgèrba krāsu. - Filologu biedrības raksti, III, Rīgā, 1927.

S m i t s P. Kā senāk jaunieši kājas āvuši. - LTD, IV, Rīgā, 1929.

S mits P. Vērpšana un aušana tautas dziesmās. - LTD III, Rīgā, 1929.

So u rek K. Volkskunst in Bildern. Prag, 1956.

Т ар акан ов а С., Т ерентьева Л., Че боксаров Н. Некоторые вопросы этногенеза народов Прибалтики. «Советская этнография», 1956, 2.

Тараканов С. А. и Т ерентьева Л. Н. Вопросы этнической истории народов Прибалтики по данным археологии, этнографии и антропологии. М., 1959.

$\mathrm{T}$ a u b e M. Greznibas noliegums Rigā XVI un XVII gadsimtā. - Latvijas PSR ZA Fundamentālās bibliotêkas raksti, I, Rīgā, 1960.

Tetzner F. Die Slaven in Deutschland. Braunschweig, 1902.

Tilke $M$. Osteuropäische Volkstrachten in Schnitt und Farbe. Berlin, 1925.

Т ок а ре в С. А. О культурной общности восточнославянских народов. - «Советская этнография», 1954, 2.

Т ок а ре в С. А. К постановке проблем этногенеза. «Советская этнография», 1949, 3.

Т олстов С. П. К проблеме аккультурации. - «Этнография», 1930, 1-2.

Т ретьяков П. Н. Восточнославянские племена. М., 1953.

Українські народні вишивкі. Київ, 1959.

Українське народне мистецтво. Тканини та вишивки. Київ, 1960.

Українське народне мистецтво. Вбрання. Київ, 1961.

$\mathrm{V}$ ā rs bergs J. Lini un kaṇepes latvju daiñās. - LTD III, Rīgầ, 1929.

Veil a nd s E. Senais vĩriešu apgērbs. - LTD, V, Rīgã, 1930.

В ей м а р н Б. В. и С ы с ое в П. М. Народное декоративное искусство СССР М., 1949.

В е р ш и н с к и й А. Н. Материалы по истории древнерусских одежд. Старинные наряды и головные уборы Тверской губ. - «Старица», 1913.

$\mathrm{W}$ i e d e m a n n F. J. Die Esteninseln in den lettischen Kirchspielen Marienburg und Schwanenburg. - Bulletin de l'Académie Impériale des Siences de St. Pétersbourg XIII, 5 (1869)

Выставка польского народного искусства и художественных ремесел. М., 1948.

В и т о в М. В. Антропологическая характеристика населения восточной Прибалтики. - Вопросы этнической истории народов Прибалтики, I, М., 1959.

В и т о в $М$. В., М а р к К. Ю., Ч е б о к с а ро в Н. Н. Этническая антропология восточной Прибалтики, 1,2 . М 1958, 1959.

В олков Ф. Украинский народ в его прошлом и настоящем, т. II. Петроград, 1916.

Volkstrachten in der Tschechoslowakei. [Prag, 1956].

В ол тер Э. Н. Материалы для этнографии латышского племени Витебской губернии, II. СПб., 1890.

[V olters E.]. Programa tautas gara mantu krājējiem, sastādīta privātdocenta E. Voltera vadībā no dažiem Pēterburgas latviešu studentiem. Jelgavā, 1892.

Вопросы этнической истории эстонского народа. Таллин, 1956.

3 ари н я А. Э. Материалы по одежде древних латга. лов. - Тезисы докладов на объединенной конференции по археологии, этнографии и антропологии Прибалтики. М., 1955.

3 а р и н я А. Э. Одежда латгалов по материалам археологических раскопок последних лет. - Вопросы этнической истории народов Прибалтики, 1, М., 1959. 
3 а р и н я А. Э. Виллайне латгалов VII-XIII в. - «Советская археология», 1960, 3.

3 а ри н я А. Отражение развития производительных сил и производственных отношений в одежде латгалов VII-XIII вв. Автореферат диссертации. Рига, 1962.

$\mathrm{Z}$ a r i ña $\mathrm{A}$. Latgalu vainagi laikà no 6 . lídz 13. gs. - Arheoloǵija un etnogrāfija, II, Rīgā, 1960.

Z a r i ñ š R. Villaine. - LTD, III, Rigā, 1929.

Z a ri ñ š R. Piebalga. - «Latvju Raksti», II, [Rīgā, b.g.].

$\mathrm{Z}$ ei a $\mathrm{A}$. un $\mathrm{Z}$ e ids $\mathrm{T}$. Amatniecības attīstíba Césīs feodālisma laikmetā. - Vēstures problēmas, IV, Rīgā, 1961.

Z e i d s T. Feodālisms Livonijā. Rīgā, 1951.

$\mathrm{Z}$ eids $\mathrm{T}$. Dažas Latvijas lauku amatniecỉbas vēstures problēmas feodālisma laikmetā. - Vēstures problēmas, IV, Rīgä, 1961.

Zelenin D. Russische (ostslavische) Volkskunde. Berlin und Leipzig, 1927.

$\mathrm{Z}$ e mz a re D. Valodas liecïbas par Lejasciema novadu. Rìgä, 1940.
Z i l a is [Blaus, Pēteris]. Par dzīparu madarošanu un sieviešu apgēēbu agrākos laikos. (Iz Ërglu un Liepkalnes draudzes apgabala). - RLB ZK RK, III, Rīgā, 1885.

$\mathrm{Z}$ ö 11 e r E. Schweden. Land und Volk. Lindau und Leipzig, 1882.

Z ut is J. Cīṇa par agrārām reformām XIX gadsimteṇa pirmā pusē. Rỉgā, 1945.

Z u t i s J. Livonijas karš. Rigaā, 1949.

Zut is J. Vidzeme kā polu un zviedru ciñas objekts. Rĩgā, 1949.

Z u t is J. Baltijas jautājums XVIII gs. Rìgā, 1951.

$\mathrm{Z}$ u t i s J. Latvija klaušu saimniecības sairšanas periodā un Kauguru nemieri 1802. gadā. Rīgā, 1953.

$\mathrm{Z}$ u t is J. Vidzemes un Kurzemes zemnieku likumi XIX gadsimta sākumā (1804.-1819.). Rīgā, 1954.

$\mathrm{Z}$ u t is J. Vidzemes un Kurzemes zemnieku brīvlaišana XIX gs. 20. gados. Rīgā, 1956. 


\section{PARINDES}

1 M. Kozins. Zemnieku kustība Latvijā XIX gs. 60. gados. Rīgā, 1958., 56. lpp.

2 Kapitālisma apstāklos jauno, progresīvo tradīciju vejdotājs ir pilsētu un lauku proletariāts, bet šā perioda apskats neietilpst monogräfijas ietvaros.

3 L e ñ i n s par kultūru un mākslu. Rĩgã, 1947., 329. lpp.

1 Padomju Savienibas Komunistiskăs partijas Programma. Rīgā, 1961., 120. lpp.

5 Turpat, 103. lpp.

${ }^{6}$ Latvijas PSR Vēstures muzeja Etnogrāfijas nodalas fondu signatūra - CVVM.

7 Dažas Kurzemes un Austrumvidzemes villaines.

8 Latvijas PSR Vēstures muzeja Etnogrāfijas nodalas arhīva materiāli (turpmāk - VM E).

${ }^{9}$ Iznēmums ir Latgales ekspedíciju materiāli.

10 Skat. H. St rod s. Vidzemes etnogrāfijas avotu un pētījumu apskats. - «Arheologija un etnogrăfija», V, Rịgā, 1963., 17. 1pp.

ii 24 fotouznēmumu kopijas glabājas Latvijas PSR ZA Vẽstures institūta Etnogrāfijas sektora arhīvā (turpmāk - E)

12 Turpmãk saīsināti - NM.

${ }^{13}$ Latvijas PSR ZA Valodas un literatūras institūta Folkloras sektora materiāli (turpmāk - F). Tā kā bij. Folkloras krātuves darbinieki bieži vien vāca materiālus kopā ar muzeja darbiniekiem, tad dala uzrakstījumu muzeja arhīvā ir dublēti, sevišḳi tas attiecas uz materiāliem par Vidzemi.

14 Latvijas PSR Centrālais valsts vēstures arhivs (turp. māk - LCVVA), 879. fonds (f.), Augstrozes un Daugulu pagasta tiesas protokoli, 1848.-1880. g.; 1118. f., Embūtes pag., 1828.-1892. g.; 589n. f., Jaunpiebalgas pag., 1834.-1880. g.; 1121. f., Livbērzes pag., 1886. g.; 908. f., Grostonas pag., 1830.-1886. g.; 1111. f., Nigrandas pag., 1833.-1885. g.; 1034. f., Kandavas pag., 1825.-1880. g.; 3331. f., Rucavas pag., 1857.-1860. g.; 1073. f., Matkules pag., 1819.-1890. g.; 933. f., Grobinas pag., 1833.-1890. g.; 5533. f., Belavas pag., 1890. g.; 3356. f., Stāmerienas pag., 1849.-1900. g.

is LCVVA, Gouvernements-Patente, 1760-1764; 1770$1774 ; 1775-1780$.

16 Rigische Anzeigen von allerhand Sachen, deren Bekanntmachung dem gemeinen Wesen nöthig und nützlich ist, 1761-1852 (turpmāk - Rigische Anzeigen...). Pielikumā ziñas par izbēgušajiem dzimtcilvēkiem.

${ }_{17}$ Valsts arhīva raksti, IX. Rīgā, 1933. - Grobinnas, Griezes un Kalnamuižas draudžu hronikas.

${ }^{18}$ Архив Географического общества СССР, фонд А 36 1/25 (J. A. Segrēna ekspedīcijas materiāli); Ekspedīcijas atskaites materiāli un pētījumi publicēti 1847. g. Skat. J. A. S joegren. Reise nach Livland und Kurland zur genauen Untersuchung der Reste der Liwen und Kreewingen. S.-Petersb., 1847.

19 Архив Географического общества СССР, фонд 11, оп. 1 , № 4.

$20 \mathrm{~J}$. Chr. B rotz e. Sammlung verschiedener Liefländischer Monumente, Prospecte, Müntzen, Wappen etc., I-X (turpmāk - J. Chr. B r o t z e. Monumente...). Rokraksts, glabājas Latvijas PSR ZA Fundamentālās bibliotēkas Rokrakstu un reto grāmatu sektorā.

${ }^{21}$ Gegenüberstehende Vorstellung einer Liefländischen Bauerhochzeit ist aus einem grossen Gemälde genommen. Die Gegend, wo die hier zu sehenden Trachten zu finden sind, ist ohne Zweifel Ehstländisch. Die am Tisch verhüllte Weibsperson ist die Braut, die Weibspersonen, welche Mützen oder weisse Tücher um den Kopf gewickelt haben, sind verheyrathet, die andern sind Dirnen; die 2 mit Hämmern in den Händen am Tisch sitzende Bauern geben beym Gesange den Takt durch Schlagen auf den Tisch an; diese Hämmer, an deren Griff einige lose Ringe befind[lich], mennt der Lette Tschaggans (J. Chr. B rotz e. Monumente..., III. 9.10. lpp.).

${ }_{22}$ Skat. Эстонская народная одежда, Таллин, 1960; A. Х. Моора. Об историко-этнографических областьях Эстонии. - Вопросы этнической истории эстонского народа. Таллин, 1956.

${ }^{23}$ L. S c h roeder. Die Esten als Bewahrer altindogermanischer Hohzeitsbräuche. Dorpat, 1886, 13. lpp.; A. O le a$\mathrm{r}$ i us. Vermehrte neue Beschreibung der Muscowitischen und Persischen Reyse ... Sollesswig, 1656, 108.-109. 1pp.; $\mathrm{Kr}$. B a r o n s norāda, ka ligavai kāzās «ietin galvu un gìmi villainē» (Erglu draudze; 28. 1pp.); «Precībās ved jaunavas ar aizsietām acīm» (Dzērbenes draudze, 38. 1pp.); «Brūtei aizsien acis ar biezu lakatu, lai nebēg atpakal» (Gulbenes draudze, 53. lpp.) u. tml. Piemēram dažas tautasdziesmas:

Ai dieving, ai dieviñ,

Nekauniga vedeklina:

Ne pie vărtu nepiebrauca,

Jau actinas parāinija.

LD 18572 (Ergli, Bērzaune, Aderkaši, Suntaži)

Bez kaunina, bez kauniņa

Sovakar vedeklina:

Pirmajā vakarā

Deguntiṇu parādija.

LD 18572, 2 (Sauka, Dzērve, Susēja, Dignāja)

24 Эстонская народная одежда. 14., 24. att. un 43. 1pp. $25 \mathrm{~J}$. N i e d r e. Brunči. - Latvju tautas daiṇas, IV, Rīgā, 1929, 442. lpp., 1. att.

26 Әстонская народная одежда. 25., 36., 47. Ipp.

27 Topographisch-statistische Beiträge des Gouvernements Curland (LCVVA, 6810. f., 1. apr., 57. 1.); Kirchspiele des Selburgschen Kreises (turpat, 62. 1.); Kirchspiele des Goldingenschen Kreises (turpat, 60. 1.); Kirchspiele des Tukumschen Kreises (turpat, 59. 1.); die Kreisstadt Pilten in Curland (turpat, 61. 1.).

${ }_{28}$ Origgināltekstus un to tulkojumus publicējis A. Spekke darbā «Vecākie latvju tautas apgèrba zīmējumi» [Rĩgā, 1934.]. 
${ }^{29}$ Laurentius $M$ üller. Septentrionalische Historien (kopš 1595. g. piedzīvojis vairākus izdevumus); Dionysius F a b ricius [Vilandes prāvests]. Livonicae Historiae Compendiosa Series. - Scriptores rerum Livonicarum, II (17. gs. sāk., skat. A. S p e k k e. Vecākie latvju tautas apgèreba zīmējumi. 28.-30. 1pp.); Dobeles novada ārsta un skolotāja Rozina Le ntili a raksts «Curlandiae quaedam memorabilia» (1692.), kas ievietots Latvijas Universitātes rakstu XI sēj. (Rīgā, 1924.); Chr. Kelch. Liefländische Historia etc. Reval, 1695

30 J. A. B r a n d. Reysen durch die Marck Brandenburg. Preussen, Churland, Liefland etc. Wesel, 1702; skat. $72 .-74$. un 137.-141. lpp.

${ }^{31}$ A. W. Hu p e l. Topographische Nachrichten von Liefund Ehstland, I-III. Riga; I - 1774, II - 1777, III - 1782.

${ }^{32} \mathrm{G}$. M e r k eli s. Latvieši, seviški Vidzemē filozofiskā gadsimteña beigās. Rīgā, 1953.; t. p. Die Vorzeit Livlands, I II. Berlin, 1798-1799, 45. lpp.; t. p. Wannem Imant. Leipzig, 1802 ; skat. darba ievadu.

${ }^{33}$ Skat. «Baltische Monatsschrift», XXXIV, 1888, 39., 40. $1 \mathrm{pp}$.

${ }_{34} \mathrm{~J}$. Chr. B r a ndes. Meine Lebensgeschichte, I-111. Berlin, 1799-1800.

${ }^{35}$ [E. G. Dersch a u und P. E. Keyserling]. Beschreibung der Provinz Kurland. Mitau, 1805.

${ }^{36}$ J. G. Kohl. Die deutsch-russischen Ostseeprovinzen ..... I-II. Dresden und Leipzig, 1841.

${ }^{37}$ Fr. Kr u s e. Necrolivonica oder Alterthümer LivEsth- und Curlands. Beilage. C. Dorpat-Leipzig, 1842.

$38 \mathrm{~A}$. С е ме н тов в кий. Этнографический обзор Витебской губернии. СПб., 1872.

${ }_{39}$ Сборник антропологических и этнографических статей о России и странах ей принадлежных, II. М., 1873

${ }^{40}$ Programma tautas gara mantu krājējiem, sastādīta privātdocenta E. Volte r a vadībā no dažiem Pēterburgas latviešu studentiem. Jelgavā, 1892. Rīgā.

${ }^{1}$ Zimējumi glabājas Latvijas PSR Vēstures muzejā

42 Kādā apg̛ērbā un rotā lai nākam uz saviem gaidāmiem diženajiem tautas svētkiem. - «Balss», 1888., 17.

${ }^{43}$ Rigas Latviešu biedrïbas vīri bija «sākuši domāt uz vispārīga un priekšzīmīga tautiska apgeèrba nodibināšanu priekš latviešu tautas», tādē] tika sastādīta «Latviešu apgeērbu komisija», kas izstrāđāja «priekšzỉmi priekš vispārīga latvju sieviešu apgèerba un šo priekšzīmi seviškā krāsainā zīmējumā likusi nodrukāt uz sevišķas lapinas lìdz ar izskaidrojumu. Mēs ievēlam ik katram, kam tautas apgēèrba lieta rūp, iegādāt izdoto lapinu ar vispārīga latvju sieviešu apgeērba priekšzìmi» («Balss», 1888., 17.). Protams, ka šeit propagandētajam «vispārīgam latvju sieviešu apgeērbam» nav nekā kopēja ar vēsturiski pareizu latviešu tautas tērpu, bet tas ir (kā rakstā teikts) «pēc tagadējo laiku garšas sakārtots» ar «šnorētiem» nieburiem, gaišiem brunčiem, ar izšūtām drēbju iostām utt. Pret šādām bezjēdzībām uzstājās progresīvā inteliłgences dala, kas ieteica, kamēr nav vēl izpētīts latviešu tautas tērps, labāk to neatdarināt, un pareizi secināia: «ka tautisks apḡērbs nav nosakāms, nedz ievedams» («Dienas Lava», 1888., 55.)

${ }^{44} \mathrm{~A}$. B i elenstein. Die Holzbauten und Holzgeräte der Letten, I-II. St. Petersburg-Petrograd, 1907-1918.

${ }^{45} \mathrm{M}$. B i elenstei n. Die altlettischen Färbmethoden. Studien zur idg. Altertumskunde. Riga, 1935.

${ }^{46}$ A. O. H e i kel. Die Volkstrachten in den Ostseeprovinzen und in Setukesien. Helsingfors, 1909.

${ }^{47}$ Latvju Raksti, I-III. [Rīgā, 1924.-1931.].

48 E. Pä v 11 li ña. Krıstnils. - «Latviı Raksti», II, 4172. Inp.; Cesvaine. - Turpat, 1.-27. Inn.: Laudona. - Turpat, 1.-39. lpp.; Tirzas draudzes tautiskais apgēerbs ap 1850. gadu. - Turpat, 1.-8. lpp.

49 M. Sili ňs. Alšvanga. - «Latvju Raksti», I, 156. Ipp.: R. Z a r i ňs. Piebalga. - Turpat. II, 1.-11. lpp. Rakstu kritisku nnvērtēiumu skat. $M$. К. С те пп п м ан и с. Развитие этногпафической науки в Сппетской Латвии. «Советская этнография» (turpmāk - СЭ), 1960, 3, 140.141. Inn

${ }^{50}$ Valsts vēsturiskā muzeja krājumi (turpmāk - VVM). 1, III. Rīgā, 1930.-1931.
51 M. S i 1 i ñ. š. Ievads. - VVM, I, 7. lpp.

${ }^{52}$ M. S i 1 i ñ š. Ievads. - VVM, III, 7.-8. lpp.

${ }^{53}$ Latviešu tautas uzvalki, I-XII. Rīgā, 1931.

54 Jäpiezìmē, ka šis ir viens no nedaudzajiem folklorista K. Strauberga rakstiem etnogrāfijā.

${ }^{55}$ Latviešu tautas tērpi, 1-4. Rīgā, 1936. Atseviškās burtnīcas kopējā iesējumā saucas «Ievads latviešu tautas tērpu vēsturē».

${ }^{56}$ Ievads latviešu tautas tērpu vēsturē. 5 . lpp.

57 Turpat, 6. 1pp.

${ }^{58}$ Novadu tērpi. Jelgavā, 1939. (15 burtnīcas.)

59 P. S mit s. Vērpšana un aušana tautas dziesmās. LTD, III, 1.-24. Ipp.; J. A u š k ā p s. Balināšana un krāsošana Latvju dainās. - Turpat, 25.-40. 1pp.; J. Vā r s b e r g s. Lini un kañepes latvju daiñās. - Turpat, 41.-54. lpp.; R. Z a r i n š. Villaine. - Turpat, 107.-116. lpp.; A. D z ërvitis. Jostas un prievites. - Turpat, 153.-181. 1pp.; P. Grunval die. Kă senā zeltene adījusi cimdus un zekies. Turpat, 201.-221. 1pp.; J. S u d r a b s. Puku vainags. - Turpat, 425.-428. Ipp.; P. S mits. Kā senāk jaunieši kājas āvuši. - LTD, IV, 404.-424. Ipp.; T. K r a u s s. Kā senāk šūdinājuši, puškojuši un valkājuši cepures. - Turpat, 425.438. Ipp.; J. Ni e d r e. Brunči. - Turpat, 439.-450. lpp.; E. J e n d e. Kā senāk šūdinājuši un rakstījuši kreklus. Turpat, 451.-472. 1pp.; F. J ā k o b s o n s. Dzintars mūsu senlietās un tautas dziesmās. - Turpat, 473.-484. 1pp.; Fr. B alo dis. Metāls un metāla rotu lietas senatnê un tautas dziesmu atminās. - LTD, V, 309.-320. 1pp.; A. D z ēr vīt i s. Kā latvju zeltene darinājusi un valkājusi vainagu. - LTD, VI, 207.-224. Ipp., E. E $1 \mathrm{ks} n$ it e. Gredzens. - Turpat, 263.-300. Ipp.; A. D z ērviti s. Sievu cepures. - LTD. VIII, 327.-344. Ipp.; t. p. Pūra veltes, ziedi un knipeles. LTD, IX, 11.-35. lpp. u. c.

${ }_{60} \mathrm{E}$. Veil a nds. Senais vīriešu apgērbs. - LTD, V, 237.-307. Ipp.

${ }^{61}$ Sai sakarā minami vairāki Ā. Karnupa, K. Pāvuliṇas un J. Niedres raksti.

62 Rakstu autori: P. Smits, J. Niedre, Z. Ventaskrasts u. c.

${ }^{63}$ E. E 1 ks nit e. Rucavas krekli. - Filolog̀ijas materiāli, Rīgā, 1935., 122.-135. lpp.

${ }_{64}$ J. M a der n i eks. Ornaments, I-IV. Rïgā, 1911 1923.

${ }^{65} \mathrm{~J}$. S udmalis. Latvju raksti (ornamenti). Rìgā,

${ }^{66}$ E. B r a s ti ñ š. Latyiešu ornamentika. Rīgã, 1923.; t. p. Latvju raksta kompozīicija. Rỉgā, 1925.

${ }^{67}$ Lìdzīgus uzskatus autors pauž arī citos savos darbos.

68 Darbs izdots 1957. gadā Vẫcijā.

${ }^{69}$ Latviešu nacionālistisko emigrantu raksti faktiski nav nekas cits kā 30 . gados publicēto rakstu isi konspekti.

${ }^{70}$ Skat. Г. Т. С тр од. Фальсификация истории Латвии в современной реакционной западногерманской и латышской эмигрантской историографии. - История СССР, 1962, 4, 192. Ipp.

${ }^{71}$ Piemēram, V. Gintera rakstā «Latviešu tautas tērps» minēts, ka sievu cepures - aubes ir darinātas pēc svešiem paraugiem, tās gan ieviesãs jo dienas, jo vairāk, bet tomēr nesakusa ar tautas tērpiem. Turpretim nedaudz tālāk autors apgalvo, ka sievu cepurēm, vainagiem un sagšām latviešu sieviešu tautas tērpā arvien bijusi izcila nozīme. Aprakstot 15. gs. Makašēnu pagastā sievietes kapā atrastu cepuri, autors šai sakarā norāda uz 16. gs. Grasi albumā zīmēto Livonijas sievietes attēlu ar vertikālās joslās rotātu cepuri. Līdzìgas pretrunas sastopamas arī citu materiālu apskatā (par kaspinēm, rotaslietām u. c.).

$72 \mathrm{~J}$. S tra uberg s. Latviešu saktu kalēju amats un Rīgas latviešu rotas. - «Senatne un Māksla», 1939., 2.

${ }^{73}$ Skat. arī J. S t r a u b e r g s. Jumpravmuižas depozīts un tā īpašnieks. - «Senatne un Māksla», 1939., 1.

74 Sīkāk skat. T. Z e i ds. Senākie valstiskie veidojumi Latvijā latviešu buržuāziskās historiogrāfjias apgaismojumā. - Vēstures problēmas, V, Rīgā, 1962., 6.-48. lpp.

75 Pārskatu par padomju laikā notikušajām ekspedīciiām un rakstiem, kuros atspoguloti šo ekspediciju vākumi līdz 1956. g., skat. M. S 1 a v a s rakstā «Latvijas PSR Zinātnı akadēmijas etnogrāfu ekspedīcija Gulbenes rajonā 1956. 
gadā». (Manuskripts Latvijas PSR ZA Vēstures institūta Etnogrāfijas sektora arhīvā.) Par ekspedīcijām Vidzemē skat. minēto $\mathrm{H}$. S t r o d a rakstu «Vidzemes etnogrāfijas avotu un pētijumu apskats». Par 1961. un 1962. g. ekspedīijām skat. ZA Vēstis, 1963., 9.-10.

Etnogrāfijas sektora arhīvā 1962. g. sākumā atradās 12192 vienības par apgēerbiem un citām tekstilijām.

${ }_{76}$ Baltijas kompleksās ekspedīcijas materiāli. glabājas PSRS ZA Etnogrāfijas institūtā (Maskavā) un Latvijas PSR ZA Vēstures institūta Etnogrāfijas sektorā.

77 Ekspedīcijās savāktais materiāls tiek publicēts «Baltijas ekspedīciju krājumos», žurnālā «Советская этнография», kā arī rakstu krājumos «Arheoloğija un etnogrāfija». 78 «Latvju Raksti», I-III. Rīgā, 1946. J. Niedres apcerējumi: I - Villaines; II - Latviešu sievietes galvas segas. Jostas un prievītes; III - Sieviešu svārki (brunči). Segas. ${ }^{79}$ Novadu tērpi, I, II. Rīgā, 1949.

80 Latviešu tautas tērpi, 1.-30. (Rịgas, Lielvārdes, Krustpils, Zemgales, Vainodes, Abrenes, Alsungas, Kuldīgas, Nicas, Vidzemes vidienes.)

${ }_{81}$ M. К. С ла в а. Крестьянская одежда латышей и орнамент на предметах домашнего убранства (Неретский и Акнистский район Латвийской ССР). - Материалы Балтийской этнографо-антропологической экспедиции (1952 г.), M., 1954, 114.-125. lpp.

${ }_{82}$ M. К. С ла в а. Комплексы женской народной одежды латышей в конце XVIII и первой половине XIX в. - Вопросы этнической истории народов Прибалтики. 1, M., 1959; M. S l a v a. Izšuvumi. - Latviešu padomju lietišǩā māksla, Rīgā, 1960; t. p. Daži adīto cimdu rotãšanas veidi. - Ârheoloğija un etnogrāfija, II, Rīgā, 1960; t. p. Latviešu zemnieku kreklu veidi (18. gs. beigās un 19. gs. pirmajā pusē). - Arheologija un etnogrāfija, III, Rīgā, 1961.; t. p. Zemnieku apgēèbs Gulbenes rajonā. Arheolog̀ija un etnogrāfija, IV, Rīgā, 1962.: t. p. Zemnieku apǵērbs Vidzemē (18. gs. beigās - 20. gs.). - Arheologijia un etnogrāfija, V, Rìgâ, 1963.

83 А. 3 а р и н я. Одежда. - Нукшинский могильник, Рига, 1957, 31.-38. lpp.; t. p. Одежда латгалов по материалам археологических раскопок последних лет. - Вопросы этнической истории народов Прибалтики, 1, M., 1959, 510.-552. lpp.; t. p. Виллайне латгалов VII-XIII вв. - «Советская археология» (turpmāk - CA), 1960, 3, 203.216. lpp.; t. p. Latgalu vainagi laikā no 6. līdz 13. gadsimtam. - Arheoloğija un etnogrāfija, II, Rīgā, 1960.; t. p. Отражение развития производительных сил и производственных отношений в одежде латгалов VII-XIII вв. Автореферат диссертации. Рига, 1962.

${ }^{84} \mathrm{~A}$. A $1 \mathrm{~s}$ u pe. Audēju arodapmācība Vidzemē kapitālisma periodā. - Latvijas PSR ZA Vēstis, 1959., 4.; t. p. Audumu veidi Vidzemē (19. gs. otrajā un 20. gs. pirmajä pusē). - Arheolog̀ija un etnogrāfija, II, Rīgã, 1960; t. p. Lauku audēju darba rîki Vidzemẽ 19. gs. - Arheoloǵija un etnogrāfija, III, Rīgā, 1961.; t. p. Mājaušana Gulbenes rajona teritorijā - Arheolog̣ija un etnogrāfija, IV, Rīgā, 1962.; t. p. Lauku audēju darinājumi Vidzemē 19 . un 20 . gs. - Ärheoloğija un etnogräfija, V, Rĩgà, 1963.

85 Л. Н. Т е ре н т в в а. Колхозное крестьянство Латвии. Историко-этнографическая монография по материалам колхозов Екабпилсского района Латвийской ССР. М., 1960 , 66.-77., 160.-167., 290.-298. Ipp.

86 О. А. Ганцкая, Н. И. Л ебедева, Л. Н. Ч иж и ко в а. Материальная культура русского сельского населения западных областей (во второй половине XIX и начале XX в.). - Материалы и исследования по этнографии русского населения Европейской части СССР. М., 1960.; Н. И. Л е б е д е в а. Одежда. - Материалы и исследования по этнографии русскоro населения Европейской части CCCP, M., 1960.

${ }^{87}$ H. Mo o r a. Pirmatnējā kopienas iekārta un agrā feodālā sabiedrība Latvijas PSR teritorijā. Rìgā, 1952., 66. Ipp.

${ }^{88} \mathrm{Par}$ latgalu têrpiem pēdējos gados plašus pētījumus veikusi A. Zarina: A. Э. 3 а р и н я. Материалы по одежде древних латгалов. Тезисы докладов на объединенной конференции по археологии, этнографии и антропологии Прибалтики. М., 1955: t. р. Одежда латгалов по материалам археологических раскопок последних лет (turpmāk -
А. Э. 3 а р и н я. Одежда латгалов) - Вопросы этнической истории народов Прибалтики, 1, M., 1959; t. p. Latgalu vainagi laikā no 6. lìdz 13. gs. - Arheoloğija un etnogrā. fija, II, Rìgā, 1960. aušana Latvijas teritorijā bija pazistama jau līdz mūsu êras sākumam (skat. Pirmatnējā kopienas iekārta un agrā feodālā sabiedrība Latvijas PSR teritorijā. 57. 1pp.).

90 А. Э. 3 а р и н я. Одежда латгалов. 511. 1pp.

${ }^{91}$ Turpat, 519. Ipp.; V. U rtāns. Tīras purva depozīts. - Latvijas PSR Vēstures muzeja raksti, Arheologija, Rìgā, 1962., 83. lpp.

${ }^{92}$ H. M o o r a. Pirmatnējā kopienas iekārta. 89. lpp.

93 J. Z u t i s. Latvijas aizvēstures problēmas. Rĩgā, 1948.

22.-23. lpp.; t. p. Agrie viduslaiki Latvijā. Rīgā, 1948., 6. lpp.

${ }^{94} \mathrm{~T}$. Z e i d s. Feodālisms Livonijā. Rịgā, 1951., 61. lpp.

95 A. Zarina sniedz svarigus datus par mantisko nevien-

līdzību pēc Nukšu kapulauka materiāliem: no 78 sieviešu kapiem 29 kapos bijušas villaines ar bronzas rotājumiem. bet loti grezni rotātas villaines bijušas tikai 3 (skat.

А. Э. 3 а р и н я. Одежда латгалов. 521. 1pp.).

${ }_{96} \mathrm{~J}$. Z u ti s. Agrie viduslaiki Latvijā. 10.-11. Ipp.

97 А. Э. 3 а р и н я. Одежда латгалов. 518. lpp.

98 Ф. В. Б а л ло д. Некоторые материалы по истории латышского племени с IX по XIII столетие. М., 1910, 85. Ipp.

${ }_{99}$ Turpat, 85.-86. Ipp.

100 Tērpa rekonstrukciju skat. krājumā «Latviešu tautas tērpi» 1. burtnīcā.

101 Ф. В. Б а лло д. Minētais darbs. 89. lpp.

102 D. Z e le n in. Russische (ostslawische) Volkskunde.

Berlin, 1927, 208. lpp.

103 Эстонская народная одежда. 15. 1pp.

104 А. Э. 3 а р и н я. Одежда латгалов. 520. Ірр.; Эстонская народная одежда. 18. Ірp.

105 Sĩku villainu tipolog̣iju un raksturojumu analizi skat. А. Э. 3 а р и н я. Виллайне латгалов VII-XIII в. - CA, $1960,3$.

106 А. Э. 3 а р и н я. Одежда латгалов. 519. 1pp.

107 Turpat, 520. lpp.

108 Turpat.

109 A. Z a r i ña. Latgalu vainagi laikā no 6. līdz 13. gs.

79. 1pp.

110 А. Э. 3 а р и н я. Одежда латгалов. 518. 1pp.

111 Turpat.

112 Turpat, 519. lpp.

113 A. Z a r i na a. Latgalu vainagi laikā no 6. lỉdz 13. gs. 92. 1 pp.

114 Sai laikā pirmās zinas par galvas autu valkāšanu ir gandrīz no visas Latvijas.

115 Эстонская народная одежда. 16. Ipp.

116 Vĩlandes prāvesta Dionīsija Fabrīcija aprakstā (17. gs. sākums) lasām: «Galvas vinas apsedz ar linu lentām, kas izaustas daudzkräsainos pavedienos un ar adatu izšũtas» (skat. A. S p ek ke. Vecākie latvju tautas apgērba zīmējumi. 29. Ipp.). Tāpat J. Brands savā celoiuma aprakstā stāsta «Die Weiber aber umbwickeln ihre köpff mit weissem feineren Leinwandt» (J. A. B r a n d. Minētais darbs. 73.74. lpp.).

117 А. Э. 3 а р и н я. Одежда латгалов. 521. 1рр.

118 V. Urt ā n s. Tìras purva depozìts. 91. lpp.

119 А. Э. 3 а р и н я. Одежда латгалов. 520., 521. 1рp.

120 Ф. В. Б а л ло д. Minētais darbs. 97. Ipp.

121 T. Z e i d s. Feodālisms Livonijā. 63. Ipp.

$122 \mathrm{~K}$. S t r a z d i ñ š. Latviešu sociālistiskā nācija. Rīgā, 1961., 15. 1pp.

123 12. gs. beigãs par Livoniju dēvēja tikai lỉbiešu apdzīvoto teritoriju: $\mathrm{Ar}$ 13. gs. pirmo ceturksni šo nosaukumu sāka lietot plašākā nozīmē, un viduslaikos par Livoniju parasti sauca visu vācu iebrucējiem paklauto Latvijas un Igaunijas teritoriju (Latvijas PSR vësture, I. 88. lpp.).

${ }_{124} \mathrm{~T}$. Z e i d s. Feodālisms Livonijā. 81. Ipp.

125 Turpat.

126 Skat. A. S pek ke. Vecākie latvju tautas apgērba zīmējumi. 
127 Sīkāk šos zīmējumus no latviešu apgērba vēstures viedokla analizējis $\bar{A}$. Karnups savā rakstā «Latviešu tērps pēdējos 350 gados» (skat. krăj. «levads latviešu tautas tērpu vēsturē». 101.-106. lpp.).

${ }_{128}$ V. U r tā n s. Vinakalna kapulauks pie Stukmaniem (13.-17. gs.). - Arheoloğija un etnogrāfija, IV, Rīgā, 1962., 17. $1 \mathrm{pp}$.

${ }_{129}$ T. Z e i d s. Feodālisms Livonijā. 131. Ipp.

$130 \mathrm{~K}$. S t r a u ber g $\mathrm{s}$. Liecỉbas par latviešu tērpa attīstỉbu vēsturiskos laikos. - Ievads latviešu tautas tērpu vēsturē, 96. lpp.

131 G. Mer k़eli s. Latvieši ... 21. Ipp.

132 R. Lentilius. Curlandiae quaedam memorabilia. 3.-73. Ipp.; J. Chr. B r ot z e. Monumente..., III. 55. Ipp.; J. G. K o h 1 . Minētais darbs. S. N a vi c k i s. Par latviešiem Ilūkstes aprinkī. - RLB ZK RK. XI, 67. lpp.

${ }_{133}$ Krievini bija Livonijas ordena karagūstekṇi, kurus 1445. g. pēc ordena karapulku iebrukuma Novgorodas votu zemē novietoja Latvijā, Bauskas apkaimē. Literatūrā krievinus pirmais piemin P. Einhorns (1636. -1643.), kas atzīmē arī, ka krieviṇi savā starpā sarunājušies igauniski. Pamatīgākus pētijumus par krieviniem izdarījis J. Vĩdemans (1871.), secinot, ka valodas zinā krievini vistuvāki votiem (vodiem). kas dzīvoja Pēterhofas un Jamburgas apriṇkos. 1805. g. krievinu aprakstu sniedz P. Keizerlings un E. Deršaus. Pilnīgāku krievinu apg̀ērba aprakstu ar Pecolda zimējumiem devis J. A. Segrēns (1846.); skat. arī Latviešu konversācijas vārdnīcas (1.-21., 1928.-1940.) IX sēj., 18339.-18340. sl.

${ }_{134} M$. A b o li n a. Vidzemes zemnieku klaušas un node. vas XVIII gadsimta beigās. - Vēstures problēmas, I, Rĩgā, 1957. 87. Ipp.; $M$. S t e perm a nis. Zemnieku nemieri Vidzemē 1750.-1784. Rīgā, 1956., 95.-100. 1pp.; Z. K a r ls o n s Lielais mēris Kurzemề (1709.-1711.). Jelgava, 1936. Nostāstus par svešu tautu pārvietošanu Latvijas teritorijā dažādās va riāciiās vēl šodien atceras gados vecāki teicēji.

${ }_{135} \mathrm{G}$ Merkelis. Latvieši ... 52. lpp.

136 Kartes nosaukums «Latviia etnogrāfiski pēc tautisko uzvalku un rotas lietu līdz šim ievāktiem materiāliem», tā sastādīta 1930. g.; $\bar{A}$. K a rnu p s savā rakstā «Matīss Silinš norāda. ka pirmo etnogrāfisko novadu karti $M$. Silinnš sastādīiis 1928. g., karšu kopijas glabājas Latvijas PSR ZA Vēstures institūta Etnogrāfijas sektorā.

${ }_{137} M$. S i 1 i ñ š. Ievads. - VVM, III, 7. lpp.

138 Turpat, 6 lpp.

139 A. D z ērvitis. Vēsturisko laiku latviešu tautas tērpi. Saǧ̌as, villaines un snātnes. - Ievads latviešu tautas tērpu vēsturē, 206. lpp. 1946.

140 J. N i e d r e. levads. - «Latvju Raksti», I-III, Rīgā,

141 А. Э. 3 а р и н я. Виллайне латгалов VII-XIII вв. 205. $1 \mathrm{pp}$

${ }_{142}$ Termins «novads» šai darbā apzìmē teritoriju, kurā izplatīts vairāk vai mazāk vienveidīgs tērps, un tas nav saistāms ar administratīvi teritoriālo iedalijjumu.

143 Skat. Valsts vēsturiskā muzeia vadoni, II, Etnogrāfija. Rīgā, 1939., 87.-89. 1pp.; arī 1958. g. Latgales kultūras nedēlai veltīitajā izstādē pie Latgales bija pieskaitīts Krustpils novads

${ }_{144} \mathrm{~J}$. J u š kē vi čs. Hercoga Jēkaba laikmets Kurzemē. Rīgā, 1931., 187.-188. lpp.; Latvijas PSR vēsture, I. 194. 'pp.

$145 \mathrm{~J}$. J e n š s. No Latvijas rūpniecības attīstības vēstures 18. gs. beigās - 1860. g. - Vêstures problēmas, V, Rīgā, 1962., 188. lpp.

146 Turpat.

147 Очерки истории СССР XVIII в., вторая половина. M., 1956, 690. lpp.

${ }_{148} M$. $\bar{A}$ b oli n a. Vidzemes zemnieku klaušas un nodevas XVIII gadsimta beigās. 9., 26.-29., 41. 1pp.; Krišjāna B a r o n a atminas. Sakărtojusi Līna Barone. Rīgā, 1924., 28. 1pp. [apraksts no Valpenes muižas pie Dundagas]; Latvijas PSR vēsture, I. 323. lpp.

$149 \mathrm{H}$. S trods. Kurzemes krona zemnieku klaušas 19. gs. pirmā pusē. - Vēstures problēmas, III, Rīgā, 1960., 67. lpp.

${ }_{150}$ Piemēram, kādas Kurzemes muižas ienēmumi par pārdotajiem linu diegiem un audeklu sastādīja $15-39 \%$ no muižas kopējiem ienākumiem (Latvijas PSR vēsture, I. 323. 1pp.).
${ }^{151} \mathrm{M}$ Koz ins. Zemnieku kustiba Latvijā XIX .gs.

60. gados. 52. 1pp.

${ }_{152} \mathrm{~J}$. Z u t i s. Latvija klaušu saimniecības sairšanas periodā un Kauguru nemieri 1802. gadā. Rīgā, 1953., 59. lpp.

${ }^{153}$ T. Z e id s. Dažas Latvijas lauku amatniecibas vēstures problēmas feodālisma laikmetā. - Vēstures problēmas, IV, Rīgā, 1961., 56. lpp.

${ }^{154}$ Turpat, 57. $1 \mathrm{pp}$.

155 Turpat, 57.-58. 1pp.

${ }^{156}$ Latvijas PSR vêsture, I. 323. lpp. J. Broce fiksējis vairākus Rỉgas tuvumā dzīvojošus zemniekus, kuru apgeērbs jau šajā laikā atšḳīās no pārējo zemnieku apğērba (Monumente..., III. 74., 77. Ipp.).

${ }_{157} \mathrm{Par}$ aužamo stāvu attīstību Vidzemē skat. A. A 1. s u p e. Lauku audēju darba rỉki Viḋzemē 19. gs. 97.-111. 1pp.

158 Latvijas PSR vēsture, I. 424. Ipp.

${ }^{159} \mathrm{M}$. Koz ins. Zemnieku kustība Latvijā XIX gs. 60. gados. 48. lpp.

${ }_{160}$ Latvijas PSR vēsture, I. 450. 1pp.

${ }^{161} \mathrm{~J}$. Z u t i s. Latvija klaušu saimniecíbas sairšanas periodā un Kauguru nemieri 1802. gadā. 53. lpp.

162 K. S t r a z d i ñ š. Latviešu sociālistiskā nācija. 19. 1pp.

${ }^{163}$ Latvijas. PSR vēsture, I. 406. Ipp.

164 Mērenais sīkburžuāziskais žurnāls «Austrums» vēl 20. gs. sākumā nevarēja samierināties ar šĩm pārvērtībām: «... Bet līdz ar labākiem saimnieciskiem apstākliem spiežas tautā stiprāks vācu iespaids nekā pa visu dzimtbūšanas laiku. Pirmie latvieši sāk studēt. Iz tēva zemnieku māiām izgãjis, mūsu «literāts» ieklūst pavisam citā pasaulē... Lì̃dzība dzīvoklī un apłēēbā it kā izlỉdzina starpību starp «kungu» aprindām un jauno latviešu «literātu». («Austrums», 1904., 1., 67. lpp.)

165 K. Blaus turīgo zemnieku apg̀ērbu 19. gs. beigâs raksturo šādi: «Mums daudzreiz izliekas, it kā mēs nemaz nebūtum uz zemēmn, bet atrastumies pilsētā, jo mēs te redzam pēc jaunākās modes smalki ġērbušās jaunkundzes, kupraiṇu muguru, smalkiem drēbes zābaciniem, galošām, saulesširmiem un, jāa, pat ādas cimdiniem» («Balss», 1887., 47.).

166 LCVVA, 3356. f., 1. apr., 2. 1., 38. 1p., 1854. g. Stāmerienas pag.; turpat, 3. 1., 104. 1p., 1876. g. u. c.

167 «2 pirkti brunči» (LCVVA, 879. f., 1. apr., 43. 1., 61. Ip., 1869. g.), «1 pirkti krustaini vamži» (turpat, 47. lp., 1863. g.), u. c.

168 Saimnieka Jāña Lamstera mirušās sievas mantība:

\section{1 liels tūka lakts}

1 katūna brunči

1 brūni zili pirkti brunči ar jaku

1 gaiši strīpaini pirkti brunči ar jaku

1 drikēti brunči

1 dubultštofs

1 galvas lakatiňš (atlasa)

1 katūna galvas lakatiṇs

$3,-\mathrm{rbl}$

0,25 ,

$3,-\cdots$

$3,-\cdots$

$2,-\cdots$

$1,-\cdots$

$0,30 "$

(LCVVA, 879. f., 1. apr., 52. 1., 158.-159. 1p., 1880. g. Daugulu pagasta tiesa).

Pie Margrietas Vabules māsas Lizes Stats bijušas šãdas mirušās Vabules mantas:

\section{3 katūna jakas}

1 bukstinumētelis

1 pirkts apgèerbs

Pēc pārējàm mantām spriežot, mirušajai ir bijuši lieli apgèré krājumi, tāpēc jādomā, ka tā bijusi bagāta saimniece (LCVVA, 1118 f., 1. apr., 37. 1., 3., 4. 1p., 1884. g. Embūtes pagasta tiesa).

${ }^{169}$ Rekrūša Pētera Cīrula gada algas dala, kas no saimnieka nav sañemta: 1 villainas bikses, 1 nātnas bikses, 3 krekli, 3 pāri zeku, 3 päri cimdu, 1 villains mētelis (LCVVA, 879. f., 1. apr., 47. 1., 2.-3. 1p., 1870. g. - Augstrozes-Daugulu pagasta tiesa. Lìdzīgas ziñas turpat, 5. lpp. u.c. protokolos). Iznēmumi ir pirktie galvas lakatini un citi sīki priekšmeti, kas sastopami arī mazturīgo mantu sarakstos 80 . gados.

$170 \mathrm{~J}$. K r a s t i ñ š. Latvija straujas kapitālisma attīstības laikā un imperiālisma laikmeta sākumā. Rīgā, 1948., 11.12. lpp. 
171 Zemnieces lielo darba slodzi un vispusīgäs zināšanas raksturojis $\mathrm{K}$. Jirgens: «Bez parastiem mājas darbiem māte vēla vadmalu, krāsoja audeklus un dzijas ar dabiskām krāsām un ar tautas medicinnu ārstēja cilvēkus un mājas kustonus. Viña labi pazina kokus, krümus, pukes, zāles un viṇu krāsošanas un dziednieciskās ipašỉbas. Vasarā un rudenī vina savāca augu materiālus visām vajadzībām. Apkārtne slavēja vinu vairāk kā krāsotāju, bet savu dalu arī kā ārstētāju» (K. J ü r g e n s. Mana vectēva nostāsti. 23. lpp.).

172 А. Э. 3 а риня. Отражение развития производительных сил и производственных отношений в одежде латгалов VII-XIII вв. 15. lpp.

173 Turpat, 14. lpp.

$174 \mathrm{~A}$. Zarinas pētījums pilnībā atspēko A. Bīlenšteina uzskatu, ka tehnikas uzlabojumi saistämi tikai ar aizguvumiem no citām tautām - pirmām kārtām no «kultūrtrēgeriem» vāciešiem (skat. $\mathrm{A}$. B i elen ste in. Die Holzbauten und Holzgeräte der Letten. 367.-368. 1pp.). 106. $1 \mathrm{pp}$.

${ }_{75}$ A. A l s u p e. Lauku audēju darba rīki Vidzemë 19. gs.

${ }_{176}$ CVVM, 10704

177 CVVM, 11905.

178 «Audeklu balina pavasaros, kad sāk ziedēt baltie vizbuli. Tad izvelk audeklus uz zāles un pa brižiem aplaista ar üdeni un apgriež otru pusi, tã audekliem jāstāv loti ilgi, pat lìdz 2 mēnešiem un vēl ilgāk, kamēr paliek balti ...» (F 438, 454 Rucavā).

${ }_{179}$ Ar tādiem pašiem panēmieniem balināja linu audumus austrumslāvi (skat. D. Z e l e n i n. Russische (ostslawische) Volkskunde. 169.-170. lpp.) un igauni (skat. Эстонская народная одежда. 195. lpp.)

180 1962. g. ekspedīcijas materiāli Daugavpils rajonā.

181 «Turpat skaidienē uz nobrauktas ecēšas slapja vadmala, kuru saimniece vel, nurcĩdama un apliedama ar karstu ūdeni» (K. J ür g e n s. Mana vectêva nostāsti. 19. lpp.).

182 E 21,5678.

183 K. P ā v u 1 i n a. Krustpils. 48. 1pp.

184 E 15, 367; F 145, 1178; sal. šãdu veltni ar igaunu veltni (skat. Эстонская народная одежда. 197. lpp., 314. att.). 185 F 89, 2807.

${ }^{186}$ M. B i ele nstein. Die altlettischen Färbmethoden. 81. lpp.

87 F 89, 2806 un 89, 1958.

188 P. Hepnera vadmalas manufaktūras inventārā, starp citu, minēta viena vilnas velamā mašiña -1 заведение для наведения на сукно ворса (Центральный государственный исторический архив в Ленинграде (turpmāk - ЦГИАЛ), Ф. 18 , оп. 2, д. 117 , л. 206). 1821. g. Zasulauka manufaktūrā bija zirga dzirnavas ar 3 ganğiem vilnas velšanai (J. J e n šs. No Latvijas rūpniecības attīstības vēstures. 208. Ipp.) 200. $1 \mathrm{pp}$.

${ }_{89}$ J. J u š kē vi čs. Hercoga Jēkaba laikmets Kurzemē.

190 1812. g. Kiršfelda vadmalas fabrikā Rīgā krāsoja ar indigo, pernambukkoku un sandalkoku (ЦГИАЛ, ф. 18, оп. 2 , д. 63 , л. 21500$)$. Krāsojamo koku sasmalcināšanas ierīces minētas P. Hepnera vadmalas fabrikā 1815. g. (ЦГИАЛ, ф. 18 , оп. 2 , д. 117 , л. 193-206)

191 «Витебские губернские ведомости», 1863, 43 (A. Sementovska raksts).

${ }_{192}$ Turpat. (Arī Latvijas PSR Vēstures muzeja arhīvos glabājas daudz aprakstu un krāsu paraugu.)

${ }^{193}$ Pirmās sintētiskās krāsas ieguva no anilīna. Līdz 19. gs. vidum (1856.) bija pazīstamas tikai dabiskās organiskâs krāsas (Latviešu konservācijas vārdnīca, IX sểj., 17 923. sl.).

194 K. P ā v u li na. Krustpils., 148. lpp.

195 J. G. Ko h l. Minētais darbs, II. 68. 1pp. 124. $1 \mathrm{pp}$

${ }^{197}$ Latviešu tautas apgērbs savā vēsturiskajā attīstībā un nozìmē. - «Austrums», 1895., 12. 1pp.

198 Н. И. Ле беде в а. Прядение и ткачество восточных славян в XIX - начале XX в- - Восточно-славянский этнографический сборник (turpmāk - ВЭС), М., 1956, 522. Ipp.
199 Sis termins lietots Krustpils novadā (skat. J. N i e d. r e. Krustpils apvidus jostas. - VVM, I, 11. lpp.)

${ }^{200}$ Sīkāk par atseviškiiem terminiem skat. $M$. Bỉlenšteinas minētā darba 83.-85. lpp.

${ }^{201}$ Skat. Ā r o n u Matīss. Par dzīparu madarāšanu un sieviešu apgēenbu agrākos laikos. - RLB ZK RK, VII, Jelgavā, [1892.], 34. lpp.

${ }^{202}$ Arī Austrumslāvi sarkanas krāsas iegūšanai lietoja madaras (skat. D. Z elenin. Russische (ostslawische) Volkskunde. 186. lpp.).

${ }^{203}$ Dzeltes - Lycopodium.

204 Latviešu apğērbos isti melns tonis gandrīz nav sastopams, izplatītākais ir zilais vai melnpelēkais tonis.

205 K. J ür g e n s. Mana vectēva nostāsti. 23. lpp.

${ }^{206}$ F 891, 2795, Märcienas pag.; 891, 2781, Kalsnavas pag.;

891, 2067, Vecpiebalgas pag.; 891, 1929, Druvienas pag.

${ }^{207}$ F 891, 2786, Kalsnavas pag.; 891, 2803, Viesienas pag.

208 Šie augi deva stipri pelēkzilu krāsu.

${ }^{209} \mathrm{~J}$. A u š kā p s. Balināšana un krāsošana Latvju daiñās. 30. lpp.

${ }^{210} \mathrm{Par}$ to sīkāk skat. $M$. Bīlenšteinas minētā darba 111.-119. lpp.

${ }^{211}$ Lai krāsa nenoietu, tad nokrāsoto audumu vai dziju skaloja pilna mēness laikā upē vai ezerā (F 781, 166). Krāsošanai par labāko skaitījās lietus ūdens, jo, tanī krāsojot, krāsas labi pieķeras un audums klūst mīksts (F 23, 4357). ${ }^{212} \mathrm{~K}$. J ü r g e n s. Mana vectēva nostāsti. 24 . lpp. ${ }^{213}$ F 794, 156, Ventspils.

214 F 891, 277.

${ }^{215}$ Krekla atdarinājums pēc A. Dzērvīša materiāliem glabājas Rīgas Lietiškāās mākslas vidusskolas muzejā. CVVMM, 12741,12742

218 Skat. Arheologija un etnogrâfija, III, 90. Ipp.

217 Sodžiaus Menas, 7.-8. Lietuvių moterų tautiniai drabužiai. Kaunas, 1939., 54. 1pp.

218 CVVM, 12756

219 Izšuvuma tehnika savu nosaukumu dabūjusi no Hardangera fjorda (arī apgabala) Norvēgijâa, kur šî tehnika bija seviški izplatīta.

${ }^{220}$ Lvovas Etnogrāfijas un mākslas rūpniecības muzejs, ЕП, 36597, 36620, 36633, 36643-36656.

${ }^{221}$ CVVM, 7767, Krustpils pag.

${ }^{222}$ CVVM, 7996, Cesvaines pag.

${ }^{223}$ CVVM, 13678, Lēdmanes pag.; 13876, Cesvaines pag

${ }^{224}$ CVVM, 12744; J. Chr. B r o t $\mathrm{z}$ e. Monumente ..., III 57. 1pp., 20. att.

${ }^{225} \mathrm{~S}_{\mathrm{i}} \mathrm{t}$ tehnika sastopama jau 12. gs. villainēs (skat. A. $Z$ a ri ñ a s iepriekš minēto autoreferātu, 20. lpp.).

${ }^{226}$ Stikla zīliš̌u rotājumi sastopami arheolog̣iskā materiāla vainagos un 15 . gs. villainēs (A. $Z$ a r i ṇ a. Latgalu vainagi laikā no 6. lỉdz 13. gadsimtam. 87.-88. lpp.).

${ }^{227}$ Ziedu rakstus izplatīja apkārtcelojošie tirgotāji kas par atlīdzību-meitām uz auduma «uzzīmēja pukes». Šādus zīmētājus sauca par «daildārzniekiem». 19. gs. beigãs zīmētos «musturus» varēja dabūt pirkt pilsētās un gadatirgos. Tâ kā šĩ izšušanas tehnika ir stipri vienkārša, tā ieviesās visai plaši.

${ }^{228}$ CVVM, 18956, 18959; vīriešu krekli ar «pukēm».

${ }^{229}$ Skat. A. Z a r i n a s iepriekš minēto autoreferätu.

$230 \mathrm{~T}$. $Z$ e i d s. Dažas Latvijas lauku amatniecības vēstures problēmas feodālisma laikmetā. $57.1 \mathrm{pp}$.

231 J. Chr. B rotz e. Monumente..., III. 77. 1pp.

232 VM E 1970. mape, Džükstes pag.

${ }^{233}$ «Drānas visas šuva ar adatu (ar rokām). Vairāk šuva pēc pelestaka (mašindūriena). Kad skroderis atnāca, tad tam kulē bija piṇgerūts, šḳēres, vasks, plekste, ko uz šḳēru galiem uzmaukt. Tas bija priekšā. Pakalā bija prāgas (dzelzs gabals, ko ielikt ugunī), kad sasila, tad pletēja. Rokā paṇēma olekti. Adatas bija sadurtas drēbes gabalā» (F 438, 545, Rucavā).

234 Drēbnieka darbs labi attēlots R. Blaumaṇa lugā «Skroderdienas Silmačos».

235 Stāmerienas pag. drēbniekam Bombānam pēc vina nāves 15 darba devêji palikuši parādā par darbu kopsumā 28,85 rbl. (LCVVA, 3356. f., 8. 1., 190.-191. 1p., 1885. g.). 
236 LCVVA, 3356. f., 1. apr., 6. 1., 49.-50. lp., 1881. g. 237 Kalpa alga:

$\begin{array}{ll}\text { naudā } & 14,- \text { rbl. } \\ \text { skroderim šūšanai } & 1,- \text { " } \\ \text { par zābaku galvām } & 3,-, " \\ 1 \text { pāris kurpju } & 2,-, "\end{array}$

LCVVA, 3356. f., 1. apr. 8. 1., 15. 1p., 1885. g. - Stāmerienas pagasta tiesa). Kầã citã protokolâ minēts, ka saimniekam par kalpa kažoka šūšanu jāmaksã 1 rublis (turpat, 29. 1p.), vēl citā, ka saimniekam par kalpa drēbju šǔšanu bija jādod skroderim pārtika (turpat, 31 . lp.).

${ }_{238} \mathrm{~S}$. $\mathrm{N}$ a vi cki s. Par latviešiem Ilūkstes aprinkīi 66. lpp.; lidzigas zinas atrodamas LCVVA, 879., 1118., 214 ., 5676. u. c. fondos

${ }^{239}$ Rekrūtis Juris Cielava ar saimnieku Jāni Ulmu saderējis «šādu loni» gadā:

$\begin{array}{ll}4 \text { krekli vai } & \\ 4 \text { bikses, nātnas, } 80 \text { kap. gab. } & 3,20 \text { rbl. } \\ 1 \text { vilnas bikses vai } & 7,-\overline{\text { " }} \\ 1 \text { vilnas mantelis } & 0,60 \text { ", } \\ 4 \text { pāri zeḳu, } 15 \text { kap. pāri } & 1,50 \text { ", }\end{array}$

3/4 pūrvietas linu, no kuriem izaudzis līdz 1900 sauju. (LCVVA, 879. f., 1. apr., 47. 1., 90. 1p., 1873. g. - Augstrozes un Daugulu pagasta tiesa); līdzìgas algas minētas arī 50 , 60., 91., 92. un 184. lp.

Saimnieks Pēteris Sarmulis solijjis kalpam Pēterim Dreimanim uz 1 gadu šādu algu:

$\begin{array}{lc}\text { naudā } & 30,- \text { rbl. } \\ \text { par kažoku pielāpišanu } & 0,50 " \\ 3 \text { kreklus } & 3,-\overline{\text { " }} \\ 3 \text { bikses (nātnas) } & 1,50 \text { ", } \\ 2 \text { pārus cimdu } & 0,40 \text { ", } \\ 1 \text { čabatus } & 3,- \text { ", }\end{array}$

Liecinieks vēl min, ka bijuši līgti 1 svārki un 1 bikses (LCVVA, 3356. f., 1. apr., 8. 1., 39. lp., 1885. g. - Stāmerienas pagasta tiesa)

Kristīne Papēde sūdz Ozolu māju rentnieku Gotlību Lapinu, ka tas vinaai nav samaksājis visu algu, kas bijusi norunāta šãda:

$\begin{array}{lc}\text { naudā } & 10,- \text { rb|. } \\ 1 \text { pāris zābaku } & 3,- \text { " } \\ 1 \text { lakats } & 1,-", \\ 4 \text { pāri pastalu } & 2,-" \\ 11 \text { mārc. linu } & 4,-", \\ 2 \text { aitu izmitināšana } & 6,-",\end{array}$

(LCVVA, 3356. f., 1. apr., 7. 1., 20. 1p.; 1884. g. - Stāmerienas pagasta tiesa).

240 Gana noliggta alga: 5 rubli naudas un visas drēbes 2 bikses, 1 svārki, 2 pāri cimdu, 2 krekli, 2 pāri zeķu un apavu tik, cik noplēš (LCVVA, 908. f., 1. apr., 58. 1., 51. lp., 1860. g. - Grostonas pag.). 214. $1 \mathrm{pp}$

${ }^{241}$ J. J e n šs. No Latvijas rūpniecības attīstības vēstures.

${ }_{242}$ LCVVA, 879. f., 1. apr., 43. 1., 1863. g. - Augstrozes un Daugulu pagasta tiesa.

${ }^{243}$ Kāds Stāmerienas pagasta saimnieks sūdzēja kurpnieku, ka tas sabojājis kurpes. Norunātā cena:

$\begin{array}{ll}\text { par } 1 \text { pāri jaunu zābaku } & 3,50 \text { rbl. } \\ \text { par } 2 \text { pāriem mājas zābaku } & 2,-\overline{\text { " }} \\ \text { par puszābakiem } & 1,75 \text { " }\end{array}$

(LCVVA, 3356. f., 1. apr., 6. 1., 83. 1p., 1881. g.)

244 Bèrnu apḡèrbi netiks sīkāk iztirzāti.

245 Vēl šodien gados vecāki teicēji atceras, ka vini bērnībā staigãjuši visu ziemu vienā kreklā, tāpēc visu dienu bija jāsēž istabā; ja gribējuši izskriet ārā, tad uzvilkuši vecāku novalkātās drānas; izskriet ārā sniegā ar kailām kājām nebijusi nekāda varonība.

246 Sādās grupās pađomju pētniece G. Maslova iedala arī austrumslāvu apgēērbus. Skat. Г. С. М а с ло в а. Народ- ная одежда русских, украинцев и белорусов в XIX - начале ХХ вв. - ВЭС, 556. lpp.

247 Ŝis grupas apḡērbi monogrāfijā izmantoti tādā mērā, cik tas nepieciešams tipologiijas vai etniskãs specifikas parādīšanai, bet kā atsevišķa apgēerbu grupa apskatīta netiks. 248 Sajā grupā ietilpst speciāli darba apłērbi mežiniekiem, vasaras lauku darbu apgēerbi, amatnieku, kalēju u. c. priekšauti utt. Pie šîs grupas apgeērbiem būtu jảpieskaita arī J. Broces minētie linu svârki («uswalk»), ko Vidzemes zemnieki vilka virs grezniem aitādas kažokiem un svārkiem, lai tos pasargātu no novārtišanās, dodoties tālākā celā (Monumente..., III. 65. lpp., 67. attēla apraksts; lïdzìgas ziṇas turpat, 67. 1pp., 53. attēla apraksts.).

${ }_{249}$ Baltijas ekspedícijas materiāli Ziemellatgalē 1956. g.

250 История Эстонской ССР, 1. Таллин, 1961, 838. lpp.

$251 \mathrm{~A}$. W. H u p e l. Minẽtais darbs, II. 153. lpp.

252 Turpat, 150 . lpp.

${ }^{253}$ Skat. J. Chr. B r o t z e. Monumente ..., VIII. 165. Ipp.

254 Turpat, III. 63 . lpp.

255 Turpat, III. 63. Ipp.; V. 102. lpp.; VIII. 165. Ipp.

256 LCVVA, 6810. f., 1. apr., 62. 1., 183. 1p.

257 G. M e r ke li s. Latvieši ... 19. lpp.

258 Indrika S t r a u mīš a raksti. Rīgā, 1906. g., 25. lpp.

259 Baltijas ekspedīcijas materiäli Ziemellatgalë 1956. g.

260 S̄à darba tematikā ietilpst tikai zemnieku apgèrbs, bet pilsētnieku apgērbs tiks apskatīts tîkai tādā mērâ, kādā tas saistīts ar jaunu formu ieviešanos zemnieku apgērbā.

261 Par vācu muižnieku kultūras līmeni mums bagātas ziñas sniedz G. Merḳela darbs «Latvieši». Deg̀enerêto văcu muižniecību (19. gs.) labi atspogulo $\mathrm{Z}$ e i b o 1 t u Jēkabs savā romānā «Barons Bundulis» (Kopoti raksti, III. Rīgā, 1956.) $\mathrm{R}$ a i n is savās piezīmēs raksta, ka: «Bargā, nemitīgu karu un sīku intrigu pilnā Baltijas vēsture nelầva attīstīties kultūras pasākumiem un atspogulojās valdošās muižnieku škiras zemajā kultüras lïmenì» (J. R a i n is. Kopoti raksti, XIV. Rīgā, 1951., 702. lpp.).

${ }^{262} \mathrm{Par}$ šiem jautājumiem tuvāk skat. $M$. T a u b e. Greznïbas noliegums Rịgā XVI un XVII gadsimtā. - Latvijas PSR ZA Fundamentālās bibliotēkas raksti, I, 1960., 287.308. lpp.

263 Turpat, 307. 1pp.

264 J. S t r a u b e r g s. Rìgas vēsture. Rīgā, 1937., 430. lpp.

265 Skat. M. T a u be. Minētais darbs. 307. lpp.

266 J. Chr. B r ot z e. Monumente ..., III, 57. Ipp., 1. att.; 55. lpp., 4. att.

267 Turpat, 55. 1pp., 4. un 5 . att.

268 Turpat, 56. lpp., 14. att.; 57. lpp., 16. att.

269 Turpat, 63. lpp., 58. att. (kādas augstākas kārtas sieviete pastaigājoties); 56. lpp., 7., 9., 11. un 12. att. (vidus šķiras pārstāvju apgềrbi).

$270 \mathrm{M}$. T a u b e. Minētais darbs. 307. Ipp.

${ }^{271}$ Latvijas PSR vēsture, I. 313. lpp.

272 J. Chr. B r ot $\mathrm{z}$ e. Monumente ...., III. 62. 1pp., 53. att.

273 «Pilsētas tuvumā dzīvojošs turīgs zvejnieku zemnieks. Jau viña apgēerbs liecina, ka viṇš ir labāk pārticis nekā lauku amatnieki. Zem zilā mētela vinam ir kažoks un zem tā vêl sarkans kamzolis» (J. Chr. B r ot z e. Monumente ..., III. 74. lpp., 97. att.).

$274 \mathrm{~K}$. J ü r g e n s. Mana vectēva nostāsti. 129. lpp.

275 «Das Inland», 1845., 451. Ipp.

276 Skirstinu muižâ 1815 . g. (Limbažu draudze) muižas kalps savā algas dalā sanēma 2 podus linu, 10 mārciñas vilnas (vai tās vietā $3^{3} / 4 \mathrm{rb}$. vara naudā), 1/2 pastalādas. Sāda kalpa sievai 8 mēnešus gadā vajadzēja vērpt muižas dotu vērpjamo, bet pārējos 4 mēnešus no vêrpšanas tā bija atbrīvota, lai varētu sagādāt drānas sev un savai ǵimenei (skat. J. Z u t i s. Latvija klaušu saimniecības sairšanas periodā un Kauguru nemieri 1802. gadā. 57. Ipp.).

277 Pēc 1809. g. papildinātiem likumiem neprecējies kalps sañēma no saimnieka ik pēc 4 gadiem 1 kažoku, ik pēc 2 gadiem vadmalas meteli, 1 vilnas apakšbikses, vadmalas vesti un pāri autu, bet katru gadu 3 kreklus, 3 pārus nātnu apakšbikšu, 1 audekla priekšautu, 3 pārus pastalu 2 pārus garo un 1 pārī iso vilnas zeķu... Meita sañēma $25^{\circ}$ mārciṇas linu, mitinâja pie saimnieka 2 aitas vai arī sanēma 5 mārcinas vilnas. Săkoties «brīvo līgumu» periodam, kalpu atalgojums 
graudā nemainījās, bet saimnieki centās samazināt niecīgo atalgojumu naudā. (Latvijas PSR vēsture, I. 395. Ipp.)

Teiktā raksturošanai sniedzam dažus piemērus par Vidzemes laukstrādnieku algām 19. gs. otrajā pusē. Rekrūtim Spricim Riekstiñam pienākas no saimnieka šãda alga:

$\begin{array}{lr}\text { naudā } & 33,75 \text { rbl. } \\ \text { pastalu pāris } & 1,12 \text { ", } \\ \text { par vilnas drēbēm } & 4,26 \text { ", } \\ 3 \text { nātni krekli, 80 kap. gab. } & 2,40 \text { ", } \\ 2 \text { nātnas bikses, 50 kap. pärī } & 1,- \text { ", }\end{array}$

(LCVVA, 879. f., 1. apr., 45. 1., 3. 1p., 1869. g. - Augstrozes un Daugulu pagasta tiesa).

Laukstrādnieces alga:

$\begin{array}{lc}\text { naudā } & 12,- \text { rbl. } \\ \text { 1 kurpes } & 1,50, " \\ \text { vai 1 lakats } & 0,50, " \\ 18 \text { mārc. linu } & 1,50, "\end{array}$

(LCVVA, 879. f., 1. apr., 47. 1., 210.-211. 1p., 1873. g. Augstrozes un Daugulu pagasta tiesa).

Laukstrādnieču algās tieši apgeērbi, atskaitot apavus un kažokus, nav minēti, bet algai vienmēr pielïgti lini un vilna vai arī atlauja turēt aitas. Laukstrādnieces auda un gatavoja apgēēbu brivajā laikā - vēlu vakaros, pusdienas laikā u. tml. Plašāk jautājums par kalpu algām dalēji skarts speciālos pētijumos par kalpu stāvokli (skat. S. Cimermanis. Laukstrādnieku dzīves veids Kurzemē un Zemgalē 19. gs. otrajā pusē. Rịgā, 1959.; E. Ċivkule. Muižas kalpi Vidzemē 19. gs. otrajā pusē. - Arheologiija un etnogräfija, II, Rīgā, 1961.).

${ }_{278}$ Teiktä analizei noder šãds piemërs: Ja šodien aplūkosim divu sieviešu apgērbu krājumus, kuras saṇem vienādu atalgojumu, dzīvo vienādos apstāklos un ir ar vienādu izglītĩbu, redzēsim, ka to apgērba krājums nebūt nav vienāds. Iespējams, ka viena savu brīvo laiku pavadiss, izstrādājot dažādus papildinājumus vai rotājumus savam apg̉ērbam, turpretī otra savu laiku izmantos citādi. Tăpat viena no sievietēm varbūt apgeērba iegādei iztērēs pusi no algas, kamēr otra tam atlicinās tikai ceturto dalu vai mazāk. Tieši šajos apstākḷos izpaužas individuālais moments, ko nedrīkstam aizmirst, arī analizējot apgēērbu pagātnē.

${ }_{279}$ Marksistiski leniniskās estētikas pamati. Rīgā, 1961. 269. Ipp.; K. Markss. Par politiskās ekonomijas kritiku. Rìgā, 1952., 217. lpp.

280 Turpat.

281 J. A. J a n s ons. Brîvs, radošs darbs un ciña par to - darba tautas morālās dzives pamats. - Darba vara lielu dara, Rīgā, 1960., 9.-80. lpp.

${ }_{282}$ Tautasdziesmās vārdi «bārene» un «kalpone» palaikam ir sinonīmi, jo bārene, tāpat kā bezzemniece, gāja pie saimniekiem pelñâs.

${ }^{283}$ Jāpiezìmē, ka vēl 1954. g. Baltijas ekspedīcijā Alsungā izdevās sastapt $70 \mathrm{~g}$. v. Annu Bērzinu, kas vēl šodien nevalkā zīda lakatu, kuru tai uzdāvinājusi kāda saimniece, jo viṇa jau neesot «to laužu» (t. i., turīgo), kas var valkāt zīda lakatus.

${ }^{284}$ V. P l u t t e. Katalogs latviešu etnogrāfiskai izstādei pa X arķeologiskā kongresa laiku Rīgā, 1896. [Rîgā, 1896.], 63. lpp.

${ }_{285}$ Latvijas PSR vēsture, II. Rīgā, 1955., 62. lpp.

280 Atkarībā no pamatuzdevuma, kādam apgèrbs kalpo, tas dalāms: velā (krekli, apakšbikses u. tml.) un virsdrānās, pie kam pie virsdrānām pieskaitāmi gan brunči, jakas, virs. bikses, gan arī svārki, mēteḷi, kažoki, kurus valkā aukstā laikā, izejot no telpām.

Pêc vietas, ko apgēerbs sedz, tas dalāms gurnu un plecu apgêerbā (Pie šãda dalījuma pieturas krievu padomju etnogrăfe G. Maslova, skat. Народная одежда русских, украинцев и белорусов. - ВЭС, 566.-567. lpp.). Pie gurnu apgērba pieskaitijaàm - sieviešu nešūtos jeb apliekamos brunčus, šūtos brunčus ar nieburu (sarafãnveida), jostas un priekšautus; vĩriešu bikses (ūzas) un jostas. Pie plecu apgẽrba pieskaitījām villaines, pussvärčus, svārkus, ñieburus, jakas. Pie šĩs pašas grupas pieskaitāmas arī virsdrānas virssvārki, mēteḷi, kažoki. Pie apğërba komplekta pieder arī galvassegas, cimdi, zekses, apavi.
${ }^{287}$ E. E 1 k s n it e. Rucavas krekli. 122. Ipp.; E 1959. " ekspedicijas materiāli Krustpils un Madonas rajonos; VM E 2454. mape, 368., 494. dok. - Vecpiebalgas pag.; 2541. mape, 381. dok. - Praulienas pag.; 2544. mape, 19. dok. - Laudonas pag.; turpat, 373. dok. - Vestienas draudze; turpat, 91. dok. - Kalsnavas pag.; 2862. mape, 179. dok. - Rudzētu pag.; Baltijas ekspedīcijas materiāli - 1954. g. Ventspils un Liepājas rajonos, 1956. g. Ludzas un Dagdas rajonos, 1960. g. Kuldigas un Saldus rajonos.

${ }_{288}$ J. Chr. B r ot $z$ e. Monumente..., III. 91. 1pp.

289 J. Broces akvarela kopija publicēta krājumā «Arheoloğija un etnogrāfija», IIII, 84. lpp.

290 I. M a n n in en. Die Kleidung. - Kansatieteellinen arkisto, 13, Helsinki, 1957., 112. Ipp.

${ }_{291} \mathrm{Par}$ kreklu materiălu un formām skat. M. S l a v a. Latviešu zemnieku kreklu tipi. 83.-84. lpp.

292 Skat. rakstu krājumu «Нукшинский могильник». Рига, 1957, 31., 34., 36., 37. lpp.; M. S il i ñ š. Alšvanga. 32. lpp.

${ }^{293}$ Б. А. Ку фтин. Материальная культура русской Мещеры. М., 1962, 22. Ірp.

294 So terminu pirmo reizi lieto B. Kuftins (Б. A. K y фт и н. Minētais darbs. 23. lpp.). Polu etnogrāfs N. Mošinskis šādu krekla veidu sauc par «pončo» (N. Mos z y ń s k i. Kultura ludova slowian, I. Kraków, 1929., 425.-426. lpp.).

295 Kreklu pamattipu un to variantu izplatība parādìta kartē krājumā «Arheologija un etnogrāfija», III, 85. lpp.

${ }_{296}$ M. К. С ла в а. Латышская женская одежда и ее орнаментация (XVIII-XX вв.). Автореферат диссертации. М., 1955, 5. Ірр.; А. Х. М о о р а. Об историко-этнографических областях Эстонии. 147. Ipp.

297 Kurzemē šis senākais krekla veids saglabājies tāpēc, ka Kurzeme ar citām tautām geogrāfiski un ekonomiski bija mazāk saistîta kultūras sakariem; bez tam źinäma nozīme bija šeit dzīvojošo lībiešu lēnajam asimilācijas procesam. Zemgalē, kur tautas tērps izzuda daudz āträk nekā pārējā Latvijā, senais krekla veids tālāk neattīstījās, bet saglabājās savã pirmatnējā veidā.

298 Skat. A. X. M о о р а. Об историко-этнографических областях Эстонии. 252. lpp., 57. att.; Эстонская народная одежда. 46. lpp., 38. att.; Latvijā pirmā varianta tunikveida kreklam vienmër ir apkakle, kuplas piedurknes un aproces. 299 IEM, 4042, 4142, 447: 270, 19350 (Halliste).

300 M. G l e m ž a i tè. Lietuvių tautiniai drabužiai. Vilnius, 1955., 117. lpp.; skat. arī «Sodžiaus Menas», 7.-8., 167.-169. lpp.

301 Г. С. М а сл о в а. Minētais darbs. 611. 1pp.

302 С. П. Т олстов. К проблеме аккультураций. «Этнография», 1930, 1-2, 74. lpp. S. Tolstovs izsaka domu, ka dienvidlielkrievu krekla tips ar slīpiem uzplečiem cêlies no tunikveida krekla tipa, kāds zināms Pievolgas somu valodas grupu tautām un čuvašiem. Konkrētus materiālus šai jautājumā varam atrast darbā Н. Г а ге н-Т о р н. Женская одежда народов Поволжья. Чебоксары, 1960.

18. $1 \mathrm{pp}$.

${ }^{303}$ Б. А. К у ф т ин. Minētais darbs. 8., 10., 14.-16.,

304 Г. С. Маслов а. Minētais darbs. 611. 1pp.

305 «runkainais krekls» (VM E, 2454. mape, 368., 380. dok., Vecpiebalgas pagasts); CVVM, 12636, 12637. ${ }_{306}$ CVVM, 12738, Vipes pag. Sis muzeja kolekcijā ir vienīgais krekls ar rotātu apakšmalu.

307 Skat. 3. att. (karti) «Latviešu valodas izloksnes Vidzemē» H. S tro d a rakstā «Vidzemes etnogrāfijas avotu un pētījumu apskats», 13. lpp.

308 CVVM, 12845, Džutustes pag.

309 Liepājas NM 251, 273, Rucavas pag.

310 CVVM, 12639.

311 Sie krekli dažkārt tiek nepareizi uzskatīti par Zemgales un Piebalgas kreklu vecāko veidu (skat. M. S l a v a. Latviešu zemnieku kreklu tipi. 87. 1pp.).

${ }^{312}$ Baltijas ekspedīcijas materiāli 1956. g.

313 Г. C. M а сл о в а. Minētais darbs. 605. lpp.

314 Б. А. К у ф т и н. Minētais darbs. 24. Ipp.

315 Lietuvas PSR ZA Vēstures un etnogräfijas muzeja fondiem bieži nav aprakstu par vietu un laiku, no kurienes priekšmets iegūts; šâ tipa krekli (no Austrumlietuvas) atzīmēti kā baltkrievu (EMO, 98, Polesje). Tā kā pārējie šā tipa 
krekli (EMO, 97, 751, 1677) muzeja inventāra grāmatā minēti to priekšmetu sarakstā, kas nākuši no Rietumlietuvas, tad nav šaubu, ka arī šie krekli ir no Klaipēdas novada.

316 A r o n u Matīss. Par dzīparu madarāšanu un sieviešu apg̉ērbu agrākos laikos. 38. lpp.

317 So terminu vēl ekspedícijas laikā atcerējās 70 g. v. teicēja Marija Purene bij. Neretas rajonā (E 2, 607).

${ }_{318}$ Б. А. К у фт и н. Minētais darbs. 27. lpp.

319 Atłas polskich strojów ludowych: Strój piotrkowski. 1954, 37., 45. lpp.; Strój kurpiowski Puszczy Bialej. 1952, 15. 24. Ipp.; Strój kujawski. 1953, 16., 29. 1pp.; Strój rzeszowski. 1951, 19., 27. 1pp.; Strój krzczonowski. 1952, 13., 33. lpp.; Strój pszczyński. 1954, 48. lpp. muzejā.

${ }^{20}$ Krekls glabājas Rỉgas Lietišķās mākslas vidusskolas 321 28. 1pp. Tādā pašā tehnikā izstrādāti lietuviešu sieviešu kreklu dūrgali (skat. «Sodžiaus Menas», 7.-8., 54. 1pp.).

${ }^{322}$ Г. С. $\mathrm{M} \mathrm{а} \mathrm{с} \mathrm{ло} \mathrm{в} \mathrm{а.} \mathrm{Minētais} \mathrm{darbs.} \mathrm{27.} \mathrm{att.;} \mathrm{30.} \mathrm{att.,} \mathrm{1;}$ 35. att., 2 .

${ }^{323}$ Liepājas NM, 251, 273, Rucavas pag.; CVVM, 16785, 16794, Rucavas pag.

324 «Sodžiaus Menas», 7.-8., 167.-169. 1pp.; M. G 1 e mž a i tè. Lietuvių tautiniai drabužiai. 117.-120. lpp.; G. M a slo v a šo tipu kreklus sauc par «бесполиковую» (Г. С. M a cл о в а. Minētais darbs. 607. lpp.).

${ }_{325}$ M. Н. Ш м е ле в а. Народная одежда украцнцев Закарпатской области. Автореферат диссертации. М., 1949, 94. lpp.; prof. S. Tok a r e v s šo kreklu tipu sauc par Karpatu tipu. (Skat. Г. С. M а с л о в а. Minētais darbs. 609. lpp.). 326 Б. А. К у ф т и н. Minētais darbs. 45 . 1pp.; Г. С. M а cл о в а. Minētais darbs. 607. lpp.

327 О. В. Пчелин а. Польская народная одежда. Автореферат диссертации. М., 1951, 56. 1рр.

328 Vĩriešu kreklus Rucavā un arī pārējā Latvijas teritorijā šuva tunikveida piegriezumā ar vai bez uzplečiem. Tikai 19. gs. otrajā pusē biežāk parādãs vīriešu krekli ar atsevišku plecu dalu - «teilīti». Sāda piegriezuma kreklu krievu padomju etnogrāfijā pieņemts apzīmēt ar terminu «рубаха на какетку».

${ }^{329}$ VM E, 2862. mape, 213. dok., Rudzētu pag.; turpat, 113. dok., Dagdas pag.; 2457. mape, 173. dok., Lizuma pag.; turpat, 141. dok., Vaives pag.; 2542. mape, 389. dok., Vestienas pag.; turpat, 508. dok., Laudonas pag. Tādas pašas ziṇas ir par Kurzemes (E. Elks nīt e. Rucavas krekli. 130. lpp.) un Latgales (A. С е ме н то в ски й. Этнографический обзор Витебской губернии) vīriešu krekliem.

$330 \mathrm{~K}$. St $\mathrm{r}$ a u b e r g s. Latviešu tērps un vina raksta ornamentika. 349. $1 \mathrm{pp}$.

331 VM E, 2542. mape, 382. dok., Praulienas pag.

332 E $17,8099-8100,8128,8382,8396$.

${ }^{333}$ Sis termins visplašāk izplatìts un sastopams gandrīz visā Latvijā, mazāk pazīstams Latgalē.

334 Ceremoniju krekli no viena auduma gabala pazīstami arī slāvu tautām ( $Г$. С. М а слов а. Minētais darbs. 602. 1pp.).

335 J. R a in is. Kāzu parašas Višku pagastā. 319. lpp. 336 Kreklu piegrieztnes skat. M. S. I a v a. Latviešu zemnieku kreklu tipi. 85.-87. lpp.

${ }^{337}$ Skat. J. Chr. B r o t z e. Monumente ..., III, 89. 1pp., 1. att.; O. Hūna zìmējumi - LCVVA, 6810. f., 1. apr., 62. 1, 175. $\mathrm{lp}$.

${ }_{338}$ Ф. В. Б алл о д. Minētais darbs. 86. lpp.

${ }^{339} \mathrm{~K} . \mathrm{P}$ à v u li ña. Krustpils. 153. lpp.

${ }^{340}$ F 891, 1988; Baltijas ekspedīcijas materiāli 1960. g. Kuldīgas un Saldus rajonos.

${ }^{341}$ Baltijas ekspedicijas materiāli 1956. g. Ludzas un Krāslavas rajonos.

342 F 23, 6343 un 6365.

${ }^{343}$ E ekspedīcijas materiāli 1958. g. Valkas rajonā.

344 Tautās aizejot, lĩgava dāvāja vĩra mātei garo kreklu.

Dāvājamo kreklu šuva bez pierietña, visu no viena gabala.

(J. R a i n i s. Kāzu parašas Višḳu pagastā. 320. lpp.).

345 Krekla rotājumu izplatības kartogrammu un rotājumı tehnikas skat. krājuma «Arheoloğija un etnogrāfija», III, 89.94. Ipp.

J. A. B r a nd. Minētais darbs. 73.-74. Ipp.
347 Iespējams, ka·tã ir plata josta, kas gandriz jau lĩdzinās ñieburam un ir līdzīga J. Branda aprakstītajai jostai, caur kuru «izvelk rupju, nebalinātu linu audeklu vai rupjas vadmalas gabalu» (J. A. B r a n d. Minëtais darbs. 73. 1pp.).

${ }^{348}$ Th. Le pner. Der preussische Lithauer. Danzig, 1744,68 . 1pp.; J. A. B r a n d. Minētais darbs. 58., 63. 1pp.; $\mathrm{H}$. M üt z el. Vom Lendenschurz zur Modetracht. Berlin, [1925], 60. 1pp.

${ }^{349}$ A. W. Hupel. Minētais darbs, II. 179. lpp.; Fr. K r u s e. Necrolivonica. 32.-33. Ipp. Эстонская народная одежда. 47.-48. 1pp.; А. Х. Моор а. Об историкоэтнографических областях Әстонии. 250. lpp.

${ }_{350}$ A. O. Heikel. Minētais darbs. 13. lpp., 11. att.; Б. А. К у ф т и н. Minētais darbs. 81.-82. $1 \mathrm{pp}$.

351 VM E, 170. dok., Daugavpils apr. Vipes pag. Termins «prošava» ir līdzịgs krievu vārdam «прошва», kas apzìmē ielaidumu starp abām brivajäm «panovas» («понева») malām (skat. Б. А. К у ф т и н. Minëtais darbs. 50. 1pp.). «Vestienā kā izgreznojumu pie brunčiem [valkāja] tā sauktās «prošaves», «prošavas». Augšā viñas bija savilktas kā priekšauts, bet garākās malas krāsainas un viscaur nošūtas ar a pa|ām vai garenām smelcēm» («Austrums», 1904., 379.380. 1pp.).

${ }^{352} \mathrm{~K} . \mathrm{P} \overline{\mathrm{a}} \mathrm{v} \mathrm{u} \mathrm{l}$ i n a. Krustpils. 155. lpp.

${ }^{353} \mathrm{~F} 446,204$, Bèrrzaune, Viesiena.

354 E 43, 1351; liekas ka materiāls attiecas uz Latgali.

355 Termins «snātene» tomēr parasti tiek lietots no linu auduma darinātu vasaras villainu apzìmēšanai. Tãdā nozīmē tas pazîstams arī speciālajā literatūrā. Par apliekamajiem brunčiem iegūtas ziñas Baltijas ekspedīcijā 1956. g. Dagdas rajonā.

${ }^{356}$ J. N i e d r e. Sieviešu svārki (brunči). - «Latvju Raksti», III, (1946.), 3. lpp.

357 Turpat, 4. lpp.

358 J. A. B r a n d. Minētais darbs. 58., 63. 1pp.

359 Н. И. Л е бе де ва. Прядение и ткачество восточных славян в XIX - начала XX в. 522. lpp., 30. att., 1.

360 Vienai no Liepãjas novadpētniecības muzeja fondos esošajām mārờenēm (Liepājas NM, 7) zalās lentes vietā uzšūtas krāsainas mestas bārkstis. Bārkstis pa $1,5 \mathrm{~cm}$ platiem posmiem liktas šādā krāsu secībà: sarkanas, dzeltenas, sarkanas, zalas, sarkanas, dzeltenas utt.

361 J. Chr. B r ot z e. Monumente ..., III. 10. 1pp.

362 A. S p e k k e. Vecākie latvju tautas apgēerba zìmējumi. 10. att. (apakšejjās rindas 4 . figūra).

363 Termins lindraki un rinduki biežāk dzirdams Kurzemē un Zemgalē, lindraki - Latgalē, bet Vidzemē un Augšzemē - brunči.

${ }^{364}$ F 891, 1962 un 1963; VM E, 2454. mape, 207., 239. dok., Jaunpiebalgas pagasts.

${ }^{365} \mathrm{~J}$. N i e d r e. Sieviešu svārki (brunči). 4. lpp.

${ }^{366} \mathrm{~A}$. Olearius. Vermehrte neue Beschreibung der Muscowitischen und Persischen Reise ... 107. lpp.

${ }^{367}$ VM E, 2454. mape, 214. dok., Druvienas pag.

${ }^{368}$ LCVVA tiesu protokolu mantu sarakstos brunči nav sīkāk aprakstīti, vienīgi minēti svītraini, rūtaini un pat zali brunči. Piemēram, Belavas pagasta iedzīvotājai Zuzei Eglītei «aukcionā» pārdoti šădi brunči:

$\begin{array}{ll}1 \text { apakšbrunči } & 0,45 \mathrm{rbl} \\ 1 \text { diedziñu brunči } & 0,60 \text { ", } \\ 1 \text { brunči } & 0,20 \text { ", } \\ 1 \text { diedziṇu brunči } & 1,05 \text { ", } \\ 1 \text { diedziñu brunči un jaka } & 0,65 \text { ", } \\ 1 \text { brunči } & 0,85 \text { ", }\end{array}$

(LCVVA, 3356. f., 1. apr., 8. 1., 211. 1p., 1885. g.) Stāmerienas pagasta iedzīvotājai Annai Sildei bijuši 1 zali un 1 sarkani brunči (LCVVA, 3356. f., 1. apr., 4. 1., 79. lp., 1879. g.).

Citā mantu sarakstā minēti:

1 nātni brunči

1 pusvillāni strīpaini brunči

$1,50 \mathrm{rbl}$.

1 strīpaini brunči

1,75 "

1 rütaini brunči
$2,-"$

$2,-\quad$ 
(Liekas, ka pēdējie, spriežot pẹc cenas, būs bijuši austi no vilnas dzijām. LCVVA, 3356. f., 1. apr., 4. 1., 41. lo., 1879. g.).

Bez brunčiem mantu sarakstos minēti arī «kapati», t. i., brunči ar piešūtu ñieburu vai «jaku». Sevišḳi bieži kapati minēti Ziemelvidzemè. Kapatu materiāls un cena bijusi dažãda, un tie mantu sarakstos minēti kopả ar brunčiem:

$\begin{array}{ll}1 \text { kapats } & 4,- \text { rbl. } \\ 1 \text { diedziṇu kapats } & 4,-, " \\ 1 \text { sarkani strīpaini brunči } & 4,50 \text { " } \\ 1 \text { rũtaini brunči } & 2,-, " \\ 1 \text { sarkani strīpaini brunči } & 2,- \text { " } \\ 1 \text { strīpaini brunči } & 1,- \text { " }\end{array}$

(LCVVA, 5890. f., 1. apr., 10. 1., 105. 1p. 1856. g. - Jaunpiebalgas pag.).

369 VM E, 2454. mape, 238. dok., Jaunpiebalgas pag.; kā konstatēts 1959. g. ekspedīcijā, Valkas rajonā vêl šodien saglabājies sakāmvārds, kas plāpīgu cilvèku lielo runāšanu salīdzina ar seno brunču plato apakšmalu — «Tev mute kä mātei brunču apakša».

370 F 891, 1972.

${ }^{371}$ F 891, 1978; VM E, 2454. mape, 395. dok., Taurenes pag.; turpat, 707. dok., Jaunpiebalgas pag.; turpat, 214. dok., Druvienas pag.

${ }^{372}$ F 891, 1978; arī Vidzemē atsevišķos gadijjumos brunči šüti no 7 vai 8 auduma platumiem.

${ }_{373}$ Skat. O. Hū n a zimējumus (LCVVA, 6810. f., 1. apr., 62. 1., 183. un 175. lp.); VM E, 2454. mape, 143. dok., Jaunpiebalgas pag.

${ }_{374}$ J. Ni e dre. Sieviešu svārki (brunči). 4. lpp.

375 Mūsu tautas uzvalks. - «Austrums», 1904., 379. 380. 1pp.

${ }_{376}$ VM E, 2454. mape, 143. dok., Jaunpiebalgas pag.; Baltijas ekspedicijas 1960. g. materiāli Kuldigas un Saldus raj.

${ }_{377}$ Kāzās liggava uzvilka vairākus brunčus, lai būtu siltāka un bagātāka dzīve (J. Ni e d r e. Sieviešu svārki (brunči). 4. 1 pp.).

vas pag.

891, 1985; VM E, 2544. mape, 92. dok., Kalsna-

F 891, 1977; Ā r o n u Matīss. Par dzīparu madarāšanu un sieviešu apgèrbu agrākos laikos. 38. lpp.

380 Skat. «levads latviešu tautas tērpu vēsturē», 105. lpp.; jāatzīmē, ka vīrieši ādas somas vai auduma kulîtes piestiprināja zem virsējiem svārkiem pie jostas, iespējams, ka 16. gs. arî sievietes kabatu-kulīti sēja pie jostas, redzamā vietā.

381 Termins «sarafāns» pazîstams Latgalē un Augšzemē, kur sarafāni parādās tikai 19. ưn 20. gs. mijā.

${ }^{382}$ Lielvārdes novadā (Etnogrāfiskās zinas par latviešiem, «Dienas Lapas» pielikums, 1894., IV. 108. Ipp.).

${ }^{383}$ Ziemelrietumkurzemē. (M. S i 1 i ñ š. Alšvanga.35.lpp.). 384 E 1953. g. ekspedīcijas materiāli par Alūksnes rajonu. 385 Par kapatu gan biežāk sauc brunčus kopā ar jaku, bet Ziemelvidzemē tā sauc arī ar nieburu kopã šūtus brunčus. Atseviškos gadījumos par kapatu sauc arī vīriešu svārkus. 386 «Kuršu koniṇi» dzīvoja tagadējā Alsungas rajona dienvidrietumu dalā: konini bija brīvi, maksāja tikai nelielus nodoklus (skat. Latvijas PSR vēsture, I. 213.-214. 1pp.).

${ }^{387}$ Arì A. Pecolda libiešu gimenes zìmējumā redzami šādi brunči (Akvarelis «Семейство ливов из с. Колкен» glabājas Krievu geogrāfijas biedrības arhīvā Leṇingradā, A 36 15/25).

${ }^{388}$ K. P à v u li ña. Cesvaine. 8. 1pp.

${ }^{389}$ Tag. Valmieras raj. teritorijā.

390 Orighināls glabājas Krievu geogrāfijas biedrības arhīvā Leningradā, A 36. Paraksts zem akvarela «Окрестность имения Нейсалис».

391 VM E, 2544. mape, 83. dok., Praulienas pag.; 2454. mape, 352. dok., Dzërbenes pag.; F 69, 1177, Saukas pag.

${ }^{392}$ LCVVA, 5890. f., 1. apr., 10. 1., 105. 1p., 1856. g. Jaunpiebalgas pag.; 3356. f., 1. apr., 2. 1., 70. lp., 1854. g. Stāmerienas pag.; 1262. f., 10. apr., 5. 1., 78. 1p., 1856. g. Valkas pag.

${ }^{393}$ Б. А. К у ф т и н. Minētais darbs. 116. lpp.
394 Skat. J. N i e dre. Sieviešu svārki (brunči). 3. Ipp.: K. S t r a ub ergs. Latviešu tērps un vipa raksta ornamentika. 341. lpp.

395 Skaidrïbas labad sniedzam J. Branda tekstu: «... Der Weiber und Mariellen tracht ist sehr possierlich / und der Zygeuner-kleydung nicht ungleich; d a n / u m b den Leib binden sie nur einen wüllenen gürtel/durch diesen stecken sie ein tuch von grobem ungebleichten Leinwandt / oder anderem groben wüllenen tuch / womit sie kaum ihren untern Leib biss a uff die waden bedecken; den obern Leib bedecken sie mit einem andren dergleichen tuch / welches sie mit zweyen endten durch eine hefft über der rechten schulter zusammen halten / also dass es unter den lincken arm hingehe / un die brust und rücken decke; lassen die arme nur im blossen hembde gantz frey; so es aber grosse kälte ist / hefften sie über den lincken schulter noch ein zweytes tuch / wie voriges / welches ihnen unter dem rechten arm hergehet. Die füsse bewinden sie mit alten durch handt umbwickelten lumpen biss auff die encklauwen / gehen im übrigen barfuss / oder tragen auch wohl / wie die Männer Pareyscher: die Weiber aber umbwickeln ihre köpff mit weissem feineren Leinwandt / und die Mägder setzen auff denselben eine Wronge über die zusammen geflochtene haare (wie bey uns das gesinde trägt) mit allerhand-färbigen corallen besetzet / von zwei biss drey finger breit / nur dass selbiger ihnen oben rings umb den kopff gehe; etliche tragen zum zierath mitten umb den Leib einen gürtel von weissen schlangenköpffen / und andrem mischmasch; wan sie aber in die Kirchen gehen (wiewohl ihnen mehrentheils bey ihren Herren / und sonst bey den Ambtsmännern in seinem gemach auss der Bibel oder Postillen etwas vorgelesen wird /) bedecken sie ihre beyde schultern mit einem weissen leinwandt welches sie vor der brust mit beyden endten zusammen halten»... (J. A. B r a n d. Minētais darbs. 73.-74. 1pp.). Aprakstītais kermena augšdalas tērps nekādā gadījumā nav uzskatāms par brunču augšdalu, bet tâs ir divas villaines ar Kurzemei raksturigo valkāšanas veidu - sastiprinot uz viena pleca.

${ }^{396}$ Sal. zviedru brunčus. A. Heikela minētā darba IV tabulä (3. un 8.) ar Alsungas brunčiem.

397 E. V e il a n d s terminu «paslavas» uzskata par senāko latviešu «kāju stilbu apgēerba nosaukumu» (Senais vīriešu apgēerbs. - LTD, V, 298. Ipp.).

398 «Ozas» - garas bikses, apakšbikses, kuras ar auklu viducī saturētas kopā. Par ūzām sauc tās bikses, kas sniedzas lidz celiem (skat. V. Plut t e. Katalogs latviešu etnogräfiskai izstādei pa $\mathrm{X}$ arķeolog̀iskā kongresa laiku. 75. lpp.; K. $M$ ül e n b ahs un J. Endzelīns. Latviešu valodas vārdnīca, V. 410.-411. lpp.

${ }^{399}$ Plašāk izplatīts Latgalē.

400 Publicētos bēglu sarakstos minēts, ka ādas bikses valkätas ar tumši za|̣iem svārkiem, kuri aizpogāti ar dzeltenām (liekas, misina) pogäm. (Beilage zur 20-sten Stück Rigischer Anzeigen, $20 \mathrm{~V}, 1801,248$. lpp.)

401 Sal. ar igaunu vīriešu biksēm (Эстонская народная одежда, XXV, XXXIV, XXXVI tab.; Baltijas ekspedicijas 1954. g. materiāli bij. Dundagas rajonā).

${ }^{402} \mathrm{Z}$ e i b o lt u Jēkabs savā romānā "Barons Bundulis» sniedz šādu sulaina apḡêrba aprakstu: «... Pêterim... pa sulaiṇu modei bija jāgẹerbjas jaunās, smalkās, garās diegu zeḳēs, sudrabsprādzainās kurpẹs, cieši piegulošầs, îsās biksēs, kuru stilbu gali sniedzās tikai lī̉z celiem, un zilos svārkos spožām sudraba pogām (Raksti, III, 223. lpp.).

${ }^{403}$ Novadu tērpi. 86. lpp.

404 VM E, 2457. mape, 188. dok., Vaives pag.; 2542. mape, 399. dok., Viesienas pag.; metāla pogu priekšteči ir koka «sprūdzenīši» - apaḷi nodrāzti koka pulkîši vai arī no diegiem šūtas pogas.

405 Sāda veida bikses plašāk izplatītas Igaunijas salu apgèerbos (Эстонская народная одежда. 154. 1pp., 240. att.); tās atrodamas arī nelielajā tautas tērpu kolekcijā PSRS Tautu etnogrāfijas muzejà Leñingradā (3217, Vỉborgas guberñas Lavansāri salas); austrumslāvu vīriešu tērpā šis bikšu veids nav sastopams (skat. Г. С. М а с лов в. Minētais darbs. 590.-594. lpp.).

${ }^{406}$ E. V e il a n d s. Minētais darbs. 306. lpp. 

8120.

${ }^{407}$ Baltijas ekspedicijas 1954. g. materiāli; E 17, 8119-

408 J. Chr. B r ot z e. Monumente ..., VII. 66. lpp.: «... An den Beinen hangen blaue od. schwarze weite Unterhosen herab.»

${ }_{409}$ V. G i in t e r s. Latviešu tautas tērps. - Latviešu tautas dziesmas, II, Kopenhāgenā, 1953., 279.-321. lpp.

410 Turpat.

411 Sal. M. G l e mž a i tè. Lietuviu tautiniai drabužiai. 52. lpp.; «Sodžiaus Menas», 7.-8., 28., 29., 32.; «Latvju Raksti», I-II; Novadu tērpi, 15.-16., 56., 128., 164.-165., 207.-209., 249.-256., 284., 443.-446. lpp.; J. N i e d r e. Krustpils apvidus jostas - VVM, I, 12. lpp.; igaunu, latviešu un lietuviešu jostas ir stipri lîdzīgas, vienigi igauṇu jostâm raksturīgi lieli ornamenta raksti, kuri atkărtojas, un krāsas velku virzienā mainās. Lietuviešu jostām raksturīgi lieli pušḳi galos no rupjas dzijas vai arì audu diegiem.

$412 \mathrm{~J}$. Ni ed.re. Krustpils apvidus jostas. 8. lpp.; celu aušanas tehnika plaši izplatīta visā pasaulē. Skat. A. D z ē r. viti s. Jostas un prievites. 163. lpp.

${ }^{413}$ Interesanti atzīmēt, ka tautasdziesmas, kurâs minētas celu jostas, pierakstītas gandrīz vienīgi tikai Latgalē (skat. Kr. B a ro n a «Latvju Dainu» rādītājus); celos austo jostu paraugus skat. VVM, I; XIII un XIV tab.

${ }_{414} \mathrm{~A}$. D z ë r vi t i s. Jostas un prievites. 160. 1pp. nikā.

415 Latgales svītrainās jostas vienmēr austas celu teh-

416 VVM I; V-XII tab.

417 Turpat, XI tab.

418 Novadu tērpi, 249.-252. lpp.

419 A. D z ērvîtis. Jostas un prievītes. 162. lpp.

$420 \mathrm{~J}$. $\mathrm{N}$ i e d r e. Jostas un prievítes. 8. 1pp.

421 LTD, III, 163. lpp.

${ }_{422}$ Baltijas ekspedicijas 1954. g. materiâli (Madona, Cesvaine); VM E, 2550. mape, 57., 58. dok., Praulienas pag.; turpat, 227. dok., Laudonas pag.; 2549. mape, 205. dok., Galgauskas pag.; turpat, 107. dok., Grostonas pag.

${ }^{423}$ 19. gs. Lietuvā priekšautus pie goda tērpa valkāja tikai jaunavas, bet Igaunijā galvenokārt tikai precētas sievietes.

${ }^{424}$ Skat. krāj. «Ievads latviešu tautas tērpu vēsturē», «Novadu tērpi» u. c.

425 Skat. J. Chr. B r o t $z$ e. Monumente..., III. 55. Ipp., 4. att.; 57. 1pp., 21. att.; 63. 1pp., 55. att.; 77. 1pp., 106. att.; O. H ū n a zìmējumi LCVVA, 6810. f., 1. apr., 62. 1., 175., 177., 181. lp.

${ }^{426}$ Priekšauti bieži minēti vecākajās tautasdziesmās; tas liek domāt par priekšautu senumu.

427 Эстонская народная одежда. I, X, XII, XXI, XL, XLIII, XLII, LXI, LXII, LXVII tab.

${ }_{428}$ Skat. «Sodžiaus Menas», 7.-8., 25.-26. Ipp., 30., 31. att.

429 Г. С. М а сл о в а. Minētais darbs. 650. lpp.

${ }^{430}$ F 891 , 1894; Baltijas ekspedícijas 1956. g. materiāli Latgalë un Jëkabpils rajonā.

431 «Latvju Raksti», II; XXV, 241, Pilskalnes pag. Sāds kompozīcijas princips ar kvadrātiem «uz malu» un šaurākām starpformām sastopams vēl Bārtas sievu cepurēs; citos novados tas nav raksturīgs, un liekas, ka mūsu tautas tērpos tas būs pārnācis no lietuviešiem, kur tas sastopams biežāk. (Sal. «Sodžiaus Menas», 7.-8., 14., 60., 85., 114., 117., 118. lpp.).

$432 \mathrm{~J}$. Chr. B rotze. Monumente... III. 89. Ipp.; Lielvārdes sieviešu priekšauti loti līdzīgi igaunu sieviešu priekš. autiem (Sal. A. O. Hei kel. Minētais darbs. V tab., 16.; Эстонская народная одежда. I, LXXVI tab.).

433 Skat. R. Z a ri ňš. Villaine. 107. lpp.; V. U r tān s. Tìras purva depozīts. 90. lpp.

${ }_{434} \mathrm{~A}$. D $\mathrm{z}$ ë r vît i s. Vêsturisko laiku latviešu tautas tērpi. 199.-256. lpp.; J. N i e d r e. Villaines. 3. lpp.; «Novadu tērpi» u. c.

435 G. Fr. Stender. Lettisches Lexicon, I-II. Mitau, [1789], 236., 361. lpp.

436 Jakob L a n ge. Vollständiges deutsch-lettisches und lettisch-deutsches Lexicon. Lettisch-deutscher Theil. Schlon Ober-Pahlen, 1773, 263. Ipp. ( $\ll$ Sakscha ta, eine Staatsweepe, denn Willanas sind die schlechten».)
${ }^{437} \mathrm{~K}$. Mülen bahs un J. Endzelīns. Latviešu valodas vãrdnīca, III. 631. lpp.

${ }^{438}$ Sal. J. A. B r a n d. Minētais darbs. 140. 1pp.; LCVVA, 6810. f., 1. apr., 60. 1., 69. 1p.; J. Chr. B r ot $z$ e. Monumente... VII. 66. Ipp. u. c.

${ }^{439}$ Tikai Rucavā, Nīcā un Bārtā.

440 1959. un 1960. g. ekspedīciju materiāli Madonas, Jèkabpils un Krustpils raj.

${ }^{441}$ F 11647, 12177; VM E, 2459. mape, 212. dok., Vecpiebalgas pag.

${ }^{442}$ CVVM, 7041 (Cesvaine).

$443 \mathrm{VM} \mathrm{E}$ ir daži dokumenti kuros norâdíts par villainu valkāšanu uz viena pleca (VM E, 5546. mape, 1225. dok. Aizkraukles pag.; 1995. mape, Kastrānes pag.). Tā kā visi părējie materiāli liecina par villainu valkāšanu uz abiem pleciem, jādomā, ka uzrakstītājs k|ūdījies vai arī teicējas savās jaunības dienās dzīvojušas Dienvidkurzemē.

60. lpp.

${ }^{44} \mathrm{H}$. M ü t $\mathrm{z}$ el. Vom Lendenschurz zur Modetracht.

${ }_{445}$ Skat. 54. Ipp.

446 Sal. attēlus krāj. «Latvju Raksti», I; XXXII, 312; Эстонская народная одежда. VI, VII tab.

${ }_{447}$ VM E, 1995. mape, Kastränes un Skrīveru pag.; Baltijas ekspedīcijas 1954. g. materiāli Kurzemē.

${ }^{448}$ Ziemera, Lizuma, Tirzas pag.

449 VM E, 2459. mape, 73. dok., Vaives pag.

${ }^{450}$ Baltijas ekspedícijas materiāli Jēkabpils rajonā un 1952. g. ekspedīijas materiāli bij. Neretas un Aknistes rajonos.

${ }^{451}$ Baltijas ekspedīcijas materiāli 1954. g.

452 Janina K rajewsk a. Stroj opoczyński. - Atlas polskich strojów ludowych. Mazowsze i Sierạdźkie. Wrocław, 1956., 7., 9. lpp., I un II tab.

453 VM E, 2454. mape, 71. dok.; 2544. mape, 374. dok.

454 A r o n u Matīss. Par dzīparu madarāšanu un sieviešu apgēērbu agrākos laikos. 37. lpp.

455 Turpat, 36. lpp. VM E, 2454. mape, 120. dok.; 2541. mape, 426. dok.

${ }^{456}$ VM E, 2542. mape, 379. dok., Vestienas pag.

457 LCVVA, 6810. f., 1. apr., 62. 1., 175., 177., 181. 1p.; skat. arī krãj. «Latviešu tautas têrpi», 131., 134. Ipp.

458 VM E, 2542. mape, 82. dok.

459 VM E, 2457. mape, 395. dok.; 2862. mape, 125. dok.; 2788. mape, 4. dok

460 LCVVA, 6810. f., 1. apr., 62. 1., 181. 1p. attēlā redzami vīriešu kažoki, bet tādi paši bija arī sieviešu kažoki (VM E, 2863. mape, 125. dok., Jāsmuižas pag.).

${ }^{461} \mathrm{~F} 23,4572$; Baltijas ekspedícijas 1954., 1956. un 1960. g. materiāli.

${ }_{462}$ Termins plašāk izplatīts Kurzemē un Zemgalē, Vidzemē - tikai Cềsu un Rịgas apkārtnē

${ }^{463}$ Sādu svārku dalījumu lieto arī E. V e i l a n d s (skat. LTD, V, 267. lpp.).

${ }^{464}$ Līdz 19. gs. 40. gadiem Tērvetē valkāti tumši zili, bet Aucē - gaiši zili svārki (Valsts arhīva raksti, IX, 184. lpp.). 465 A. W. H u pel. Minētais darbs, II. 163. Ipp.; J. G. Ko h l. Minētais darbs. 65., 66. 1pp.

${ }_{466} \mathrm{~J}$. Chr. B r ot z e. Monumente ..., III. 74. 1pp., 97. att. Zilo svārku divkāršã apkakle vai rotājums, pogas un platās aproces ir darinātas atbilstoši tā laika modes prasībām. 467 VM E, 3097. mape, 218. dok., Snēpeles pag.

468 J. Chr. B r ot z e Monumente ..., III. 55. 1pp., 3. att.; 62. 1pp., 53. att.; 76. 1pp., 105. att.

${ }_{469}$ PSRS Tautu etnogrāfijas muzejs Leningradā, 2991.64.; 3054.-52.

470 Tāpēc liekas, ka vienpusīgi tautasdziesmās minētos raibos svârkus izskaidrojis E. Veilands, velkot paralēles ar 16. gs. franču un vācu dižkungu, galminieku un karavīru raibajiem svārkiem, vamžiem un biksểm (E. Ve il a n d s. Senais vĩriešu apgēerrbs. 266. lpp.).

471 Zemnieks no Drustiem Dzērbenes draudzē. Virs kažoka vinam ir linu svårki, ko latviski sauc par uzvalku («uswalk»). (J. Chr. B rotz e. Monumente ..., III. 65. lpp., 67. att.) Lìdzīgi virssvārki ir arī vienam Älūksnes zemniekam (turpat, 68. 1pp., 77. un 78. att.).

Linu mēteli minēti arî nozagto mantu sarakstā no Smil. tenes (Rigische Anzeigen, 25. XI 1801, 568. 1pp.). 
${ }^{472}$ F 707, 79; E 17, 8349; VM E, 2542, mape, 306. dok., Laudonas pag.

473 VNi E, 2542, mape, 82. dok., Lazdonas pag.

474 Jèkaba Lèrmes alga bija ieskaititas arì 4 aitādas kažokam (LCVVA, 5890. f., 1. apr., 10. 1., 1856. g. u. c.; Baltijas ekspedicijas 1960. g. materiäli Kuldigas un Saldus rajonos). Puisim saimnieks devis pa 3 gadi kažocin̨u (VM E, 2542. mape., 306. dok., Laudonas pag.).

475 A. Gua g n in i. Sarmatiae Europae descriptio, quae Regnum Poloniae, Lituaniam, Samogitiam, Russiam, Masouiam, Prussiam, Pomeraniam, Liuoniam et Moschouiae, Tartariaeque partem complectitur... 1578. (Skat. A. S p e kk e. Vecấkie latvju tautas apgēêrba zimējumi. 26., 27. lpp.)

${ }^{476} \mathrm{Sal}$. A. S p e k k e. Vecākie latvju tautas apġērba zimējumi. 1., 2. att.

477 levads latviešu tautas tērpu vēsturē. 111. lpp.

478 Zimējums publicēts krāj. «levads latviešu tautas tērpu vēsturề, 106. lpp.

$479 \mathrm{~A}$. O l e a ri u s. Minētais darbs. 107.-108. 1pp.

480 J. A. B r a n d. Minētais darbs. 73.-74. 1pp.; A. W. H u p e l. Minētais darbs, II. 178. lpp.

${ }^{481}$ F 438, 539, Rucavas pag.; 1954. g. Baltijas ekspedicijas materiāli; Эстонская народная одежда. 76. lpp., 96. att.; Latviešu tautas uzvalki, IX. 3. lpp., 8. att.

${ }^{482}$ J. Chr. B r o t z e. Monumente..., III. 62. Ipp., 53. att.; 63., Ipp., 55. att.; 68. lpp., 73., 77., 78. att.

${ }_{83}$ K. J ü r g e n s. Mana vectēva nostästi. 21. Ipp., arī 25. 27. un 31. lpp.

${ }^{484}$ Latgalu teritorijā senākais ir bronzas lentes vainags ar starpskārditi. Sis vainags eksistē no 6. lỉdz 12.-13. gs. mijai. (Skat. A. Z a r i ṇa. Latga|u vainagi laikā no 6. lìdz 13. gadsimtam. 92. lpp.)

485 V. Gi inters. Latviešu tautas tērps. 299.-300. lpp. 486 A. Z a r i ñ a. Latgalu vainagi laikā no 6 . lìdz 13. gadsimtam. 84.-89. Ipp.

${ }_{487}$ \&Jaunpiebalgas vainagi ir tik vienādi, ka liekas, tos bûtu darinājis viens un tas pats cilvēks. Vinu vecumu neviens neatceras, kur tādi cēlušies. Domā, ka tie pirkti. It kā pašā Piebalgā bijis kāds, kas vainagus darinājis. Citi domā, ka tie vesti no Rigas» (VM E, 2456 mape, 434. dok., Druvienas un Lizuma pag.). Par Piebalgas vainagu meistarēm iegūtas ziñas arì ekspedícijā (1954. g. Baltijas ekspedicijas materiāli).

488 VM E, 2454. mape, 60. dok., Vaives pag.; E 17, 8403 , 8378, Madonas un Krustpils raj.; F 41, 690; Vietalvas un Kalsnavas pag. bijuši vainagi ar «četrkantīgiem skārda spieǵelīšiem» vai plānām vizlas plāksnìtēm (VM E, 2545. mape, 179. dok., Kalsnavas pag.).

189 Skat. A. S p e k k e. Vecākie latvju tautas apgērba zīmējumi. 1. att., 1. fig.; Barnikela karšu detalās grāmatāa «levads latviešu tautas tērpu vēsturē», 115.-117. 1pp.

490 J. Chr. B r ot z e. Monumente ..., VIII. 8. 1pp.

491 A. $Z$ a r i n a. Latgalu vainagi laikā no 6 . līdz 13. gadsimtam. 83.-84. 1.pp.

${ }^{492} \mathrm{~F} 891,1974$

493 Baltijas ekspedícijas 1960. g. materiāli.

194 Ã r o n u Matīss. Par dzîparu madarāšanu un sieviešu apgēēbu agrākos laikos. 36. lpp.

495 F 41, 690 .

496 J. R a i nis. Kāzu parašas Višku pagastā. 315.316. Ipp.; sal. Г. С. М а слов а. Minētais darbs. 676.682. Ipp.

${ }_{497}$ VM E 2714. mape, Zvirgzdienes pag.; Baltijas ekspedīcijas 1956. g. materiāli Ludzas un Kārsavas raj.

${ }_{498}$ J. Chr. B r ot z e. Monumente ..., III. 10. lpp. - «Vidzemes kāzu skats».

499 Эстонская народная одежда. 15.-16. 1pp.

500 А. Х. М о р а. Об историко-этнографических областях Эстонин. 247. 1pp.

501 I. M a nn in en. Die Kleidung. 76. 1pp.

502 «Inflantijā nēsāja tā saukto «garo autu», kuru aplika ap galvu, sasēja pakausī lielā mezglā, pie kam garā auta dažreiz izrakstītie gali nokarājās uz muguru.» - «Austrums», 1904., 790. 1pp.

503 CVVM, 889; J. A. S joegren. Minētais darbs. 48. -50 . Ipp.

504. CVVM, 14324, 14330
505 CVVM, 14393, 14400, 14410.

506 LCVVÄ, 6810. f., 1. apr., 59. 1., 33. Ip.; zem zimējuma paraksts: «Curländische Bäuerin in der Gegend von Ploenen» (Plienu ciems Tukuma apr.).

5ü «Latvju Raksti», II. 18. Ipp.

${ }^{508}$ A. S p e k ke. Vecākie latvju tautas apgèrba zīmêjumi. 1. att.

${ }_{509}$ K. P āv u li n a. Cesvaine. 18. lpp.; CVVM, 13942 un 13965, Valmieras apvidus; šì cepures sauktas arì par «benìtēm» (VM E, 2455. mape, 338. dok., Kuduma pag.).

510 F 891, 2834. «Veclaiku rakstitu mici nesaja tikai sievas. Anna Bebre bijusi speciâliste šai arodā un šâdu mici pagatavojusi par 5 kvartiem.» (F 43, 68, 181. 1pp., Krauklu pag.) Specialas knipelu pinējas bijušas arî citos pagastos (VM E, 2545. mape, 385. dok., Vestienas pag.).

62. 1.)

'11 Skat. O. H ü n a zimêjumu (LCVVA, 6810. f., 1. apr.

${ }_{512}$ K. P ā v u 1 i ṇa. Krustpils. 161. lpp. nas pag.

891, 2834; VM E, 2545. mape, 385. dok., Vestie-

1. Ma nni ne n. Die Kleidung. 77., 78. Ipp.; sal. A. O. He ike l. Minètais darbs. XXII tab., 3., 6.

${ }^{515}$ F 17, 1443, 23, Vecpiebalgas pag.; VM E, 2456. mape, 227., 291., 427. dok., Vecpiebalgas pag.; turpat, 430. dok., Velku pag

${ }_{516} \mathrm{~K}$. J ür g ens. Mana vectēva nostāsti. 122. 1pp.

517 J. Chr. B r ot z e. Monumente ..., VIII. 8. att.

518 «Lavju Raksti», II; XXVII tab., 2660. e.

519 Jāpiezimēe, ka neviena no tautasdziesmaàm, kurās minēta krievu cepure, nav uzrakstīta Piebalgã; lielākā dạa ir no Latgales un daži varianti no Lubānas. Tapèc jãdomâ, ka šîs cepures ir bijušas plašâk izplatîtas. 19. gṣ. otrajầ pusē par krievu cepurèm sauktas cepures ar ādas nagu (VM E, 2864. mape, 287. dok., Kalupes pag.).

520 J. Chr. B rotz e. Monumente ..., II. 65. Ipp., 67. att.

79. 1pp., 5. att.; VM E, 2712. mape 53., 62., 194. dok.

${ }_{521}$ T. K r a u s s. Kā senāk šūdinājuši, pušḳojuši un valkājuši cepures. 425 . lpp.

522 J. Chr. B r o tz e. Monumente ..., III. 55. lpp., 3. att.; 62. Ipp., 53. att.; 65. lpp., 61. att. (vīriešu fig.); 68. lpp., 77., 78. att.; 74. 1pp., 97. att.

${ }_{523}$ Turpat, 65. lpp., 61. att. (zēna fig.); 71. 1pp., 85. att. (sievietes fig.); 75. Ipp., 99. att.; 79. Ipp., 3. att., 3. fig.

$524 \Phi$. В. Б а л л о д. Minētais darbs. 81.-83. lpp.

${ }_{525} \mathrm{~T}$. K r a us s. Kā senāk šüdinājuši, pušķojuši un valkājuši cepures. 428.-429. 1pp.

526 J. Chr. B rotze. Monumente ..., III. 55. Ipp., 1., 2. att.; 61 . lpp.

kãjuši cepures. 438 . lpp.

528 Sãdas cepures J. Broces zìmējumos un kartēs redzamas zviedru karavīriem Ziemelu kara laikā un holandiešu jürniekiem (J. Chr. B rotz e. Monumente ..., III. 61. Ipp., 43., 44. att.; VI, 154. lpp.).

529 Rigische Anzeigen, 20. V 1801, 248. 1pp.

530 LD 20522.

531 J. Chr. B rotz e. Monumente ..., III. 63. 1pp., 56. att.

532 Turpat, 63. Ipp., 55. att.; 68. lpp., 73. att.; 71. Ipp., 85. att.; 76. 1pp., 105. att.

533 Turpat, 75. 1pp., 100. att.; Novadu têrpi. 69. Ipp.

534 Novadu tērpi. 68., 81., 96. lpp.

535 1954. un 1956. g. Baltijas ekspedīcijas materiāli. Latgalē salmu cepures sauc par «brilām» (VM E, 2712. mape, 30. un 35. dok., Ciblas pag.; 107. dok., Nautrënu pag.; 2864 mape, 276. dok., Rudzētu pag.

536 1958. g. ekspedicijas materiāli Valkā.

537 A. O. H e i k el. Minētais darbs. XIX tab., 5.

538 Эстонская народная одежда. 165. un 175. lpp.

LXV tab.; A. O. Heikel. Minêtais darbs. XIX tab., 9.-15.

539 1954. g. Baltijas ekspedícijas materiāli Ainažu rajonā.

540 VM E 2549. mape, 576. dok.

541 16. un 17. gs. autoru (Dž. Lipomani, A. Gvanini, L. Millera, D. Fabricija un R. Lentilija) zin̄ās atrodami norădỉjumi tikai par vīzēm un pastalâm; arī J. A. B r a n da a rakstos sastopami tikai vižu un pastalu apraksti.

${ }^{542}$ Pirmie norādījumi par kurpju valkāšanu atrodami

A. Hu pela igauṇu apgēerba aprakstā; autors, salīdzinot 
igaunu apgerbu ar latviešı apgērbu, saka: «Apavu vietā zemnieki nēsā pastalas, kas istenibā ir tikai zoles no nemiecêtas, latviešiem arì no miecētas adas: viṇi nokasa spalvas un ar auklu, kuru aptin ap lieliem, pastalas savelk tā, ka tās nedaudz aptver pēdu sānus...

. Tikai svètdienās un godos igaunietes, retāk latvietes, staigā îstās kurpès (pasvîtrojums $-M . S$.); tad viṇām, nepieradušâm, ir smiekliga gaita ... Lai ilgāk savas kurpes taupitu, vinas tās nes rokas un labāk iet kailām kājām līdz nonāk baznīcas priekšā. No lepnuma vāciešiem paka! darīdami, daži zemnieki svētdienās valkā zābakus vai kurpes. Vasarā, darbā iedami, viṇi visi staigā kailām kājām vai arī valkã vīzes...» (Minētais darbs. II, 152. un 153. 1pp.).

Ari j. B roces zimmējumos tikai retumis redzamie latvieši ar zābakiem vai kurpēm ir no Rigas vai tās apkārtnes (J. Chr. B rotz e. Monumente..., III. 60. lpp., 36. att.). Pat vidzemnieku kāzu skatā kāzinieki redzami tikai pastalās; citos aprakstos J. Broce pasvītro, ka tieši pastalas liecinot, ka to valkātāja ir latviete: «Latviešu dzimtlaužu meita, kas pilsētā ir par kalponi. Ka tā nav vāciete, redzams no pastalām un no viṇas neapsegtajiem matiem, ap kuriem apsieta lente» (turpat, 55. 1pp., 4. att.); arī 57. Ipp., 21. att. redzamajai kuršu sievietei, kas kalpo par aukli Rịgā, kājās ir pastalas pat pie goda apgēēba (turpat, 87. lpp., 4. att.; 89. lpp., 1. att.; 91. lpp., 1. att. u. c.).

543 LCVVA, 3356. f., 7. 1., 1. apr., 20. 1p., 1884. g. -

Stāmerienas pag.; 908. f., 58. 1., 1. apr., 51. un 64. 1p., 1850.1861. g. - Grostonas pag.

544 F 23, 407, Valinieras. Vaidavas, Velku pag.; VM E, 2872. mape, 267. dok., Asūnes pag.

68. $1 \mathrm{pp}$.

${ }^{545} \mathrm{~S}$. $\mathrm{N}$ a vickis. Par latviešiem Ilūkstes apriṇkī.

546 Etnogrāfiskas ziñas par latviešiem. «Dienas Lapas» pielikums, 1891., I, 144. Ipp.

${ }^{547}$ VM E, 2553. mape, 382. dok., Vestienas pag.

548 Г. С. $M$ а с лов а. Minētais darbs. 717. Ipp.

549 I. Ma nninen. Die Sachkultur Estlands, 1.-2.

Tartu: 1931.-1932., 454., 458. Ipp.; A. X. Mоop a. O6 историко-этнографических областях Эстонии. 257. Ipp.

550 F 781, 1026. Lìdzịgas ziñas iegūtas 1960. g. Baltijas ekspedīcijā Kuldīgas raj.

551 Tírzas draudzes tautiskais apgērbs ap 1850. gadu. «Latvju Raksti», II, 7. lpp. Vienā no J. Broces zīmējumiem redzamas pastalas ar pušķiem (Monumente ..., III. 68. lpp., 78. att.).

552 VM E, 2553. mape, 382. dok., Vestienas pag.

553 19. gs. pirmajả pusē pat saimniekiem zăbaki bija retos gadijumos: «Tos laikus zäbaki bija retam saimnieku tēvam un izdıenējušam zaldātam, kuros viṇš pārnāca no dienesta mājā. Brencim likās, ka tikai zábakos cilvēks ir isti cilvēks, diezgan stalts un cienīgs,» Tēvs runā ar dēlu: «... Nē, dēls, zābakus nevar pirkt; ko tad muiža sacis, kad puikas sāks zābakos iet? Jau tā muiža èd zemniekus nost. Nē, nē zābakus nevar pirkt!» (Kad zābaki tomēr nopirkti.) ...« Drīz vien viss pagasts un muiža zināja, ka Medṇu Putna dēls Brencis staigã staltos zābakos. Muiźai tas nepatika. Vina ieskatija to par zemnieka necienigu lepnibu un sodāmu izlaidību.» (K. J ü r g e n s. Mana vectēva nostāsti. 96.-97. lpp.).

554 «Pirmās kurpes man nopirka, kad man bija 7 gadi un mani sāka vadāt uz baznīcu», stãsta 76 g. v. Berta Kalniña Gulbenes rajonā $(E$ 11, 2671); «Kurpes man bija, kad es gāju skolā, bet citi bērni gãja ar pastalãm. Kad es gãju ganos, tad valkāju lūku vĩzes. Vĩzes visi paši mäcēja pît no kārklu un liepu lūkiem. Pastalas arī puiši paši taisijja, pat uz balli daži gãja ar pastalăm», stāsta 76 g. v. Jūle Pinka Gulbenes raj. Litene (E 11, 2930); «Kalpu bērni pirmos zābakus dabūja vêl vêlāk», stāsta $86 \mathrm{~g}$. v. Kärlis Skrīvelis Valkas raj. Jērcēnos. «Pirmos zābakus es dabūju pēc skolas beigšanas, kad man bija kadi 14 gadi un es, noligdams pie saimnieka uz visu gadu, pie algas pielígu zābakus. Jaunus zābakus jau saimnieks nepirka, bet pie vecām čabām piešuva jaunas galvas» (E 13, 4855). Lidzigas ziṇas (F 91, 116) no Ungurmuižas pag. Bèrniem $2-10$ g. v. kāiās velk no pakulu auklām pîtus «bokīininus», skat. VM E, 2716. mape, 106. dok., Nautrēnu pag.

555 J. Chr. B rotz e. Monumente..., III. 57. 1pp., 21. att.
556 «Ziemas zābaks bija čabas ar platu purnu un gariem stulmiem pāri celitni. Cả̉s taisija no zirga ādas un zieda ar degutu. Cavas taisıja Pečoru kỉievi, kuri atbrauca pie mums, uLpirka beigtos un vecos zirgus, pārstrādāja un pềc tam pārdeva Vidzemē tirgos. Vēlāk čabas pārdeva arī lauku veikalos, kur tãs maksāja 8-10 rublu. Cabu pazoles bija apkaltas ar lielām naglām. Cabas pirka lielas un tās sabāza pilnas ar salmiem, lai ziemā būtu siltāks», stāsta 61 g. v. Jülijs Dalǵgis Valkas raj. Jērcēnos (E 13, 4671, 4672).

${ }^{557} \mathrm{~F} 91,116$, Ungurmuižas pag.

558 Ipatnējs î vecākā zemnieka kāju aptinums - no potītēm līdz celiem, bet kāju pēdas ir palikušas kailas (J. Chr. B r o tz e. Monumente..., III. 79. 1pp., 59. att.); kādā zīmējumā, liekas, redzamas arī sietavas (turpat, 64. lpp., 3. att.).

559 Skat. 31. att.; jāaizrāda vël, ka J. Broces. attēlā sievietei (pa kreisi) zem sietavām ir skaidri redzamas. baltas zeķes, un arī tas rāda, ka zilās nav vis bikses, bet sietavas. Bez tam jānorāda, ka Piebalgā nav saglabājies neviens nostāsts, ka šai novadā agrāk būtu valkātas bikses. 70 g. v. Otīlija Zeltiṇa atcerējās, ka viṇas vecã māte stāstĩjusi, ka bikses sievietes agrāk nav valkājušas, bet valkājušas gan vilnas drēbes sietavas, kuras tika piestiprinātas jostas vietā (1954. g. Baltijas ekspedīcijas materiāli). Tāpēc liekas, ka līdzīgu kâju apgeêrbu J. Broce būs uzskatījis par biksēm. Par tumšām sietavām ir zinas arî no Vestienas draudzes. VM E, 2553. mape, 381. dok.

${ }^{560}$ Г. С. M а слов в. Minētais darbs. 715 . Ipp. A. $\mathrm{Hu}$ p els to novērojis igaunietēm Tērbatas un Vīlandes apvidū. (Minētais darbs, II. 152. lpp.).

561 Г. С. М а слов а. Minētais darbs. 716. 1pp. un Ф. К. В олков. Этнографические особенности украинского народа. - Украинский народ в его прошлом и настоящем, II, СПб., 1916, 574. lpp.

562 J. Chr. B rotz e. Monumente ..., III. 61. Ipp., 47. att. Jāpiezīmē, ka šis ir vienīgais gadījums kad latviešu zemnieks redzams ar zekēm līdz celgaliem, lai gan P. Smits pēc tautasdziesmu materiāliem garo zeḳu valkāšanu min Tirzas, Laicenes, Apes, Lizuma, Mēdzulas un Lazdonas pag. (skat. P. S mit s. Kã senāk jaunieši kãjas āvuši. 424. lpp.). ${ }^{563} \mathrm{~F} 891,1976$.

564 G. M a s lov a zekes bez papēžiem sauc par krievu tipa, bet ar papẽžiem - par vācu tipa zekēm. Liekas, ka šie termini nav precizi; Latvijas apstāklos tie nav divu dažāả zeku tipi, bet dažãdas zeku attistības stadijas. Bez tam zekุes bez papēža bija praktiskākas, jo tās varēja valkāt, papēža vietu pakāpeniski mainot, un tās tik àtri nenoplisa (Г. С. М а сл о в а. Minētais darbs. 716. Ipp.). XXVII tab.

566 Raibo rakstu adišana bieži apdziedāta tautasđziesmās. Tautasdziesmās minēto rakstu sacerēšanas veidu - dabā novērotā pārnešanu ornamentālā kompozịcijā - atkārtoti nảcies dzirdēt no gados vecakām teicējām. Sniedzam vienu no šiem nostāstiem, kas pierakstîts Lielvārdes invalīdu namā: «Senos laikos lauku laudìm tãdi musturi, kādi tagad iraid, nemaz neesot bijuši. Tādēl arī katra adìtâja, ko nu bija varējusi iedomāties, - to arī adijusi. Гã reiz kãda veca večina, lopus ganīdama, esot sākusi adīt cimdus. Domājusi domãjusi, kảdu gan rakstinuu varētu ieadît, jo cik tai bija bijuši prātā, tos jau daudz reiz bija no vietas adijusi. Tã večina prātojusi un gudrojusi. Tā domājot. uznacis pērkons un zibens, un večișa uz zibeni noskatījusies. Tai iešảvảs prātā, kả būtu, ja es tādus zibens krustus un liěus ierakstītu šai cimdu pãrî. Viṇa sākusi adīt, un raksti patiesi bijuši jauki, un tãdi vēl nekad nevienam nav rakstiti. Tos rakstus tad cits no cita noadijis, kurus vēl šo baltu dienu redz adām.

Senāk, kad sievas vai arī meitieši gājuši uz citu māju ciemā, tad pastāvīgi nēmuši lỉdz darāmās [adāmās] adatas un dziju un, ja tai mājā bijuši kãdi jauni raksti, tad tos izadījuši. Uz citu māju iedami, ñēmuši jau iesākto rakstu slejas lỉdz un adījuši atkal citu musturi. Citreiz lielā rakstus sleja (tã tur sauca) bija tik gara kā josta, kuru tad sējuśi ap vidu un nēsājuši uz ciemu lìdz un rakstus vēl adījuši klāt. Kurām tādas rakstu slejas bijušas, tās traki godātas» (F 739, 5514).

67. J. R a i n i s. Kāzu parašas Višḳu pagastā. 317. 1pp. 
${ }^{568} \mathrm{~F} 523,697$. Uz lielo cimdu daudzumu 19. gs. vidū jau norādījis J. K o ls (Minētais darbs. 69.-70. lpp.).

569 S. N a v i c k i s. Par latviešiem Ilūkstes apriṇki. 78. lpp.

570 J. R a in is. Kàzu parašas Višķu pagastâ. 324. lpp. $571 \mathrm{~F} 214,1040$.

572 J. Chr. B r ot z e. Monumente ..., III. 58. 1pp., 3. att. 573 Aitu turēšana vienmēr tika pielīgta pie algas; muižu kalponēm vilna un lini ietilpa algā (J. Z u t is. Latvija klaušu saimniecíbas sairšanas periodā un Kauguru nemieri 1802. gadā. 57. Ipp.).

$74 \mathrm{~J}$. S t r a u ber'g s. Latviešu saktu kalēju amats un Riggas latviešu rotas. - «Senatne un Māksla», 1939., 2., 103. Ipp.

575 Turpat, 104. Ipp.

576 J. A. B r a n d. Minētais darbs. 73. 1pp.

577 A. W. H u p e l. Minētais darbs, II. 153. lpp.

578 Grobinas draudzes hronika (Valsts arhiva raksti, IX,

2. lpp.)

579 J. A. S j o e gre n. Minētais darbs. 49.-50. Ipp.

580 J. Chr. B r otz e. Monumente ..., III. 89. 1pp.

581 A. W. H u pel Minētais darbs, II. 153. lpp.

582 Autora lauku materiāli 1951. g. no Ogres un Kuldigas rajoniem

583 В. Н. Бе ли це р. Народная одежда удмуртов. M.

1951, 58., 62., 71., 83. lpp.; A. O. Heikel. Minētais darbs. 57. Ipp. $_{584}$

684 г. С. Маслова. Minētais darbs. 734. lpp.;

Ф. К. В ол ко в. Minētais darbs. 550.-551. Ipp. Jāpiezimē, ka Kurzemes lỉbieši vēl lỉdz 19. gs. vidum valkāja ipatnēju važinu rotu ar adatām.

585 Novadu tèrpi. 3. lpp.

586 J. A. S joegren. Minētais darbs. 33.-34. Ipp.; VM

E, 172. mape

587 Ф. В. Б а л ло д. Minētais darbs. 109. lpp.

588 VM E, 445. mape; saktas kreisajā pusē iegravēts \&les $1792 \%$.

${ }^{589}$ LCVVA, 6810. f., 1. apr., 62. 1., 175., 181., 183. 1p.

$590 \mathrm{~J}$. Chr. B r ot z e. Monumente .... III. 89. 1pp.

591 Novadu tērpi. 208. att.; VM E, 2548. mape, 496. dok.,

Sausnējas pag.

${ }_{592}$ Sal. XXIV tab., 7., 8., 9. A. H e i k e l a minētajā darbā.

593 Turpat, 90. 1pp.

594 VM E, 90. dok., Mārcienas pag.

595 Fr. K r u s e. Necrolivonica. 12. Ipp.

596 Termins «novads» lietots, apzīmējot tērpa noteikta lokäla varianta valkãšanas vietu, un tas nav saistîts ar teritorijas administrativo iedalījumu.

${ }^{597} \mathrm{~K}$. S t r a z di ñ š. Par latviešu buržuāziskās nācijas izveidošanos. - Buržuãziskie nacionālisti - Latvijas vēstures viltotāji, Rīgā, 1953., 103. Ipp.

${ }^{598} \mathrm{~K}$. S t r a z d i n š. Latviešu sociālistiskā nācija. 16. lpp. ${ }^{599}$ Apriṇki pēc 19. gs. pirmâs puses administrativā iedalijuma.

${ }^{600}$ Rìgas raj. lìdz Daugavai, Cēsu un Valmieras raj. rietumdalā.

${ }^{601} \mathrm{~J}$. Chr. B rotz e. Monumente ..., III. 71. 1pp., 85. att. (Krimuldas draudze); 83. lpp., 5. att. (Ikškiles un Vangažu draudze); 91. lpp. (Bïrinu un Straupes draudze); VI, 172. lpp. (goda un darba apgēerbi Madlienas draudzē).

${ }^{602} \mathrm{Par} \mathrm{H}$. Brigenas albumu skat. K. S tra ubergs. Limbaži un Lëdurga 19. gs. trísdesmitos gados. - «Senatne un Māksla», 1936., 4., 127.-134. 1pp. Krāsaini un vienkrāsaini attēli publicēti darbā «levads latviešu tautas tërpu vēsturẽ». ${ }^{603}$ VM E glabājās T. G e l h ā r a zīmējums kLimbažnieki pie baznicas».

604 A. P e colda zīmējums «Limbažu zemnieki svētku apgèerbã» pārzīmēts un ievietots darbā. T. de $\mathrm{P}$ a u $1 \mathrm{y}$. Description ethnographique des peuples de la Russie. St. Pétersbourg, 1862

${ }^{605} \mathrm{~J}$. K rēs li ṇa zīmẽjums «Salacas zvejniece» glabājas - VM E.

${ }^{606}$ Skat. karti Latvijas PSR vēstures I sējumā (starp 67. un 68. 1pp.).

${ }^{607}$ П. С е мено в. Географическо-статистичеекий сло-

варь Российской империи, т. III. СПб., 1866 («Ливы»).

$608 \mathrm{~J}$. A. S j o e g r e n. Minētais darbs. 24. un 35. lpp.

${ }^{609}$ A. W. H u p e l. Minētais darbs, I. 135. Ipp.
610 A. $\$$ tāls. J. K. Broces \&Dažādu Vidzemes piemineklu un skatu krâjums.» Zimejumu apraksti un komentāri. Rigä, [1926.], 5. lpp.

611 J. Chr. B r ot z e. Monumente ..., III. 77. 1pp.

612 Turpat, 74. lpp., 97: att.

613 1954. .g Baltijas ekspedīcijas materiāli (Kurzeme).

614 J. Chr. B r o t z e. Monumente .... III. 87. lpp.

615 Turpat, 63. lpp., 55. att.; 71. lpp., 85. att.; 77. 1pp.,

106. att.; 87. 1pp., 4. att.

616 Turpat, 55. 1pp., 4. att.; 59. 1pp., 33. att.

97, att.

617 Turpat, 55. lpp., 3. att.; 71. lpp., 85. att.; 74. 1pp.,

${ }_{618}$ Visā Valkas raj., Valmieras raj. austrumu dạā un gandrīz visa Gulbenes raj., iznnemot tā rietumu stūri.

619 LCVVA, Gouvernements-Patente, 1760-1764; Rigische

Anzeigen, 1801, 122 un 248. 1pp.; 1803, 469. lpp.

620 Rigische Anzeigen, 1803., 572. Ipp.

621 Skat. H. S trods. Vidzemes etnogrăfijas avotu un pētījumu apskats. 10. lpp.

${ }_{622} \mathrm{~A}$. B i e len st ei n. Die Grenzen des lettischen Volksstammes und der lettischen Sprache in der Gegenwart und im 13. Jahrhundert. St. Petersburg, 1892, 19.-20. Ipp.

${ }^{623}$ Etnogrāfijas sektora ekspedīcijās uzzìmētas vairākas jostas un matauklas (E 13, 939, 940, 3287).

624 Эстонская народная одежда. 38. Ipp., 25. att.

625 A. B i e le n stein. Die Grenzen des lettischen Volksstammes ...20. Ipp.

${ }_{626}$ LCVVVA, 3356. f., 1. apr., 4. 1., 41. 1p., 1879. g. - Stāmerienas pag.; turpat, 879. f., 1. apr., 48. 1., 187 . lp., 1875. g. - Augstrozes un Daugulu pagasta tiesas protokoli; līdzịgas ziñas iegûtas vêl no citiem pagastiem ekspediciju laikă.

${ }_{627}$ A. K u n d z i ñ š. Smiltene. Rĩgā. [1926.], 35.-36. Ipp.

${ }^{628} \mathrm{Par}$ zilu vainagiem Ziemalvidzemê skat. $M$. S l a v a.

Zemnieku apgéêrbs Gulbenes rajonā.

${ }_{629}$ J. Chr. B r ot z e. Monumente ..., VIII. 156. Ipp.

630 Turpat, III. 62. Ipp., 52., 53. att.; 68. lpp., 73., 77., 78. att.; 79. Ipp., 1. att.; lídzígi vîriešu apgèrbi redzami jau iepriekš minētajos J. Broces Rũjienas un Gaujienas zemnieku zìmējumos.

631 Turpat, III. 68. 1pp., 77., 78. att.

${ }^{632} \mathrm{E} 13,4678,4718$. «Jostas bija 5 metrus garas, un tās auda speciâli audēji, jo katrs jau tảdas izaust nemäcēja» (E 13, 46839).

6з3 Эстонская народная одежда. VI, X, XII, XIII, XIV tab.

634 Turpat, 33. Ipp.

635 F. Lein ock. Die materielle Kultur der Esten. Tartu, 1932, 55. Ipp.

636 Cēsu raj. austrumu, Gulbenes raj. rietumu stūris. M. Kaudzīte par Vecpiebalgas apgērbtem lìdz 19. gs. 60. gadiem izsakās šādi: «Tolaik valdīja vēl tik liela vienādība pie apg̀ērbiem, ka katrs, kas iegadijjās baznīcâ vai citur pulkā citădi geērbies, izskatījās visiem kā tảds brīnumnieks, kas velk uz sevi citu acis un par kuru vēlāk mājā citiem stāstāms, kas paši tāda nav redzējuši. Viss tur bija vienīgi mãjās pašu darināts pēc lielākâs vienādības.» $M$. K a u d z ìt e. Vecpiebalga. Rigā. [b. g.], 38. lpp.

${ }^{637}$ Lỉdzšinējā etnografiskajā literatūrā Piebalgas novadam tiek pieskaititi tikai Vecpiebalgas. Jaunpiebalgas un Velku pagasti. Mūsu vāktie ekspedicijas materiāli un VM E arhiva dckumenti (2454. mape, 24., 172., 219. dok., Druvienas pag.; 2457. mape, 175., 385., 446. dok., Lizuma pag.; turpat, 386., 387. dok., Rankas pag.) rāda, ka Piebalgas novada tērpa iezimes atsevišķos gadijumos vērojamas Ziemelvidzemē Trikātas pagastā: «Trikātiešos valkāja tallassvārkus ar streijām sānos. Trikātieši vispār gērbās atškirigi no visas apkārtnes» (E 13, 4665).

${ }_{638}$ Valsts vēsturiskā muzeja vadoni: I. Etnogrāfija Rīgā, 1939., 76. lpp.; R. Z a ri ñ š. Piebalga. - «Latvju Raksti», II, 1.-11. Ipp.

${ }^{639}$ A. D z ē r vīti s. Latviešu tautas uzvalki. Rīgā, 1931. $\mathrm{V}, 2 ., 3$. lpp.

640 Ziemelvidzeme bija hernhūtiešu kustības centrs Latvijā (skat. Latvijas PSR vēsture, I, 234.-239. Ipp.).

Brālu draudżu ietekme vērojama arī Trikātas pagasta tautas tērpos, jo arī te brunčos dominē melnā krāsa, krekli 
maz rotāti, tāpat Trikātas vīriešu tērpi līdzinās Piebalgas tērpam un saglabājušies te daudz ilgāk nekā pārējā Ziemelvidzemē (E 1958. g. ekspedīcijas materiāli Valkas rajonâ). 641 CVVM, 12636, 12640.

642 19. gs, vidū valkāti «mellie» brunči, kurus 60.70. gados nomainìja «strīpaiṇi» vai «bantainıı - austi melnā pamatā ar krāsainām svītrām. Pēc tam valkāja rūtaiṇus, kas zināmu laiku tika valkāti reizẽ ar bantainiem. 19. gs. beigās Piebalgas novađā atkal valkāja vienkrāsainus pelēkus brunčus (VM E, 2454. mape, 238.-241. un 143. dok., Jaunpiebal. gas pag.)

${ }_{43}$ CVVM 13759, 13765, 13775, 13787; Piebalgas vainagi visi ir tik loti vienādi izstrādāti un no viena materiāla, ka liekas, tos visus darinājis viens meistars.

644 J. Chr. B r ot z e. Monumente ..., VII. 66. lpp., 1. att. $645 \mathrm{VM}$ E, 2457. mape, 389. dok., Jaunpiebalgas pag.; 413. dok., Vecpiebalgas pag.; J. Chr. B rotz e. Monumente..., III. 63. lpp., 56. att., Liezeres zemnieki.

${ }_{646}$ VM E, 2455. mape, 42. dok., Vecpiebalgas pag.

647 J. Chr. B r o t $z$ e. Monumente ..., III. 63. Ipp., 56. att., Liezeres zemnieki.

648 Turpat, 61. 1pp., 47. att.; 62. 1pp., 52. att. u. c

649 Ogres raj. dạ̄a Daugavas labajā krastā bez rajona ziemelaustrumu un ziemelrietumu dalas.

650 J. Chr. B r ot z e. Monumente ..., III. 89. 1pp.

651 Etnogräfiskas ziñas par latviešiem. «Dienas Lapas» pielikums, IV, 1894., 108. lpp.

${ }^{652}$ CVVM, 12635, 12649. Skat. M. S l a v a s rakstu «Zemnieku kreklu tipi»... (Arheologija un etnogrāfija, III).

${ }^{653}$ Baltie darbi. A. D z ē r vi iš a redakcijā. Rígā, 1932. 78. $1 \mathrm{pp}$.

Etnogrāfiskas zinas par latviešiem. «Dienas Lapas» pielikums, IV, 1894., 108. 1pp.

655 Turpat, 109. lpp.

656 Turpat, 108, lpp.

657 CVVM, 13577, 13697, 13715

$658 \mathrm{~J}$. Chr. Petri. Ehstland un die Ehsten oder historisch-geographisch-statistisches Gemälde von Ehstland, II Gotha, 1802., 181. 1pp.; Fr. K r u s e. Ur-Geschichte des Ehstnischen Volksstammes und der Kaiserlich-Russischen Ostseeprovinzen Liv- Ehst- und Curland überhaupt, bis zur Einführung der Christlichen Religion. Moskau, 1846, 38. lpp. ${ }_{659} \mathrm{~J}$. Chr. B r ot z e. Monumente ..., III. 79. lpp., 3. attēla vidējā figūra.

660 E. D u n s d o r f s paskaidrojošā kartē norāda, ka iecelotāji Vidzemē bijuši latvieši un nãkuši no Latgales. Pilnīg nav noskaidrots mēra upuru skaits Latgalē, zināms tikai, ka tas, salídzinot ar Rietumvidzemi, bijis daudz mazāks. Jāievêro arī, ka Latgale vienmēr ir bijusi biežāk apdzīvota nekā pārējā Latvija.

661 Skat. H. Strods. Vidzemes etnogräfijas avotu un pētijumu apskats. 13. lpp., 3. att.; K. A n c it is un A. J a ns o n s. Vidzemes etniskâs vēstures jautājumi. - Arheoloǵija un etnogrāfija, V, 25.-66. lpp.

662 Jēkabpils raj. ziemelu dala Daugavas labajā krastā rietumos līdz Gostiniem, bet austrumos - lỉdz Atašienai un Preilu raj. rietumu dalai (ap Lĩvāniem).

663 Skat. 15., 20. $1 \mathrm{pp}$

664 Kã iznēmums jămin viens Cesvaines un viens Piebalgas krekls, kuriem ir vienāds piegriezums ar Krustpils kreklu piegriezumu. Skat. M. S l a v a. Latviešu zemnieku kreklu tipi ... 86. lpp.

665 Krekla sarkanais un baltais izšuvums pārējā Vidzemē nav raksturigs, bet tas radniecigs ar Latgales un Augšzemes kreklu izšuvumu.

666 CVVM, 12744.

667 CVVM, 12736.

668 CVVM, 10820, 10821; E $17,8149,8163-8165$

669 E $17,8126$.

670 CVVM, 1243, 1269; Etnogrāfijas sektora ekspedicijā izdevās iegūt vairākus senus Krustpils jostu paraugus (E 17, 3693,3697 ; E 21, 1746).

671 E $21,4593$.

${ }^{672}$ Cēsu raj. austrumu daḷā un gandrīz visā Madonas rajonā, atskaitot tā dienvidaustrumu stūri ap Varaḳ̄aniem.

${ }^{673}$ Cesvaines krekli ar krāsainām apkaklēm (1954. g. Baltijas ekspedīcijas materiāli).
674 CVVM, 18961, 18967.

$675 \mathrm{~K}$. P ā v u 1 i n a. Cesvaine. 36. Ipp.

676 J. Chr. B rot z e. Monumente ..., III. 61. Ipp., 47. att.; 63. Ipp., 56. att.; 65. 1pp., 61., 62. att.

677 Turpat, 65. 1pp., 67. att. un teksts.

${ }^{678}$ «Zemnieks no Sausnējas, Kalsnavas draudzē ar savu dēlu. Abiem ir «johsta» blāvi sarkanā krāsā. Kāju lieli viniem aptīti ìpatnējā veidā» (J. Chr. B rotze. Monumente ..., III. 65. lpp., 61. att. teksts).

${ }^{679}$ «Dzērbenes zemnieks. Tas seviški izcelas ar saväm zilajām zeķēm, ko uzvilcis pāri celgaliem» (J. Chr. B r ot z e. Monumente ..., III. 61. Ipp., 47. att. teksts).

680 Par zilo zeḳu valkāšanu vēl ir zinas no Zemgales novada; atsevišḳos gadijjumos tās valkājuši arī Kurzemes lïbieši.

681. Arī antropolog̣iskie materiāli rāda Alūksnes rajona iedzīvotāju lỉdzību ar Tartu apkārtnes igauniem un setukiem. Skat. M. В. В и то в. Антропологическая характеристика населения восточной Прибалтики. - Вопросы этнической истории народов Прибалтики, 1, М., 1959, 562. Ipp.

${ }^{682}$ Latvijas PSR Vēsture, I. 264. lpp.

683 А. А. 3 а в а р и на. Семья и семейный быт русского старажильческого населения Латгалии во 2-ой половине $\mathrm{XIX}$ и начале XX веков. Автореферат диссертации. М., 1955 3. lpp.

684 Varaḳ̄ānu pagastā 1/10 iedzīvotāju 1863. g. runāja baltkrievu valodā, baltkrievu valodā runāja arī Ozolaines pag. Skat. Архив Географического общества СССР, ф. 11. оп. 1, № $24,6 .-14$. Ipp.

${ }^{685}$ Latvijas PSR vēsture, I. 267. lpp.

686 Skaistas pagastā 1869. g. vidêja zemnieka saimniecỉbā bijuši 3 zirgi; Ciblas pag. vidējā saimniecíbā -2 zirgi; Nautrēnu pag. - 3 zirgi; Varaklănu pag. - 4 zirgi (turīga), 2 zirgi (vidēja); Andrupenes pag. turīgam saimnie. kam bijuši 4 zirgi, vidējam - 2 zirgi (Архив Географического общества СССР, ф. 11, оп. 1, № 4, 6.-14. Ірp.).

687 Л. Е ф ре мо в а. Семья и семейный быт латгальских крестьян во второй половине XIX-XX веков. Диссертация. Рига, 1960, 204.-205. Ipp. (Latvijas PSR ZA Vēstu. res institūta bibliotēkā)

688 «Das Inland», 1845, 451. Ipp.; [G. M a n t e uff el]. Polnisch-Livland. 34., 35. lpp.; J. Kalējs-Kuznecovs atzìmē, ka Andrupenes pagastā tirgos daudz pārdodot zābakus un ka vīzes tur vairs nevalkājot. Zemnieki paretam pērkot vilnas un kokvilnas audumus. Tagadējie (1863. g.) zemnieki jau nēsājot drapa mētelus ar bebrādas apkaklēm (Архив Географического общества СССР, ф. 11, оп. 1, № 4, 6.14. Ipp.).

${ }^{689}$ Atškirīibā no pārējās Latvijas Latgalē apgērbs kalpu algā ietilpa tikai loti retos pagastos. No J. Kalēja-Kuznecova 1869. g. apsekotajiem 9 pagastiem tikai Andrupenes un Varak lānu pagastos apgērbu kalpam devis saimnieks (Архив Географического общества СССР, ф. 11 , оп. 1, № 4 , 6.-14. lpp.)

${ }^{690}$ Latvijas PSR vēsture, I. 399. Ipp. J. Kalējs-Kuzñecovs sniedz sekojošus datus par pelnās gājējiem: Asūnes pag. uz dzelzcela un zemes darbos strầdā 8-10 cilvēki; Varak|ānu pag. zemes darbos - 35-50 cilvēki; Andrupenes pag. 300 roku nodarbojas ar zvejniecỉbu (Архив Географического общества СССР, ф. 11, оп. 1, № 4, 6.-14. Ірp.).

691 Latvijas PSR vēsture, I. 400. lpp.

692 V. I. L e n i n s. Raksti, 3. sēj., 512. Ipp.

${ }^{693}$ Ludzas, Rēzeknes, Preilu un Krāslavas raj.; Daugavpils raj. ziemelu dạā Daugavas labajā krastā.

$694 \mathrm{Uz}$ šo novada dalu, liekas, attiecināmi A. Sementovska apraksti: «Мужчины и женщины носят рубахи из белого толстого льняного холста, без всяких украшений, какие встречаются у малороссиян и даже у велико-руссов. Покрой их совершенно одинаков; женская рубаха только несколько длиннее мужской, нижняя часть ея (от пояса) делается из самого грубого холста, из которого мужчины носят летние панталоны - ивзес. Каждый взрослый член семейства снашивает в год от 3 до 4 рубах. Мужская рубаха ценится в 50, а женская в 25 копеек» (Витебские губернские ведомости, $1863, \mathrm{Nr} .43$.$) .$ 
${ }^{605}$ CVVM, 12760, 12765, 12790; VM E, 2862. mape, 251 un 179. dok., Rudzētu pag.; 2865. mape, 201. dok.; Asūnes pag.

${ }^{696}$ E 1962. g. ekspedīcijas materiāli.

697 CVVM, 10729, 10750, 10763, 10768 u. c.

698 «Brunči - «lindraki» šūti no vilnas vadmalas, kas austa «streipām» un «kristā». Papriekš esot nēsājuši vairāk krustainus lindrakus, pēc nāca «mūde» uz strīpainiem. Strīpas lindrakiem noteiktas un nenoteiktas, vairāk sarkanas (dominējošã krāsa), tad zilas, baltas, melnas, zalas un dzeltenas, līdz $3 \mathrm{~cm}$ platas. ... Lindrakus piestiprināja augšā pie viduča, izverot cauri vîlei auklinu, kuru savilka un sa. sēja kreisos sānos un kuras galus aizbāza aiz vĩles.» VM E, 2865. mape, 201. dok., Asūnes pag.; lỉdzīgas ziñas arī 227. dok. A. S e m e n tovs k is min tikai svitrainus goda brunčus (skat. Витебские губернские ведомости, 1863, № 43.).

${ }_{699}$ Vẽstures muzeja fondos ir vairāki simti jostu paraugu un zimējumu no Dienvidlatgales.

700 Rudzētu, Vidsmuižas, Preilu, Livānu, Kalupes pag.

701 CVVM, 7259, 147095.

702 «...vecmāte sagšu pagatavojusi jaunībā, pie kam izšuvumus izpildījusi sestdienas vakaros pirtī pie skalu gaismas un svētdienãs, jo darbdienās bijis jāiet klaušās. Pirtinaa palaikam strādājusi kopā ar citām jaunām sagšu rakstītājām, jo tad dziedot îsāks bijis laiks». VM E, 2867. mape, 249. dok., Rudzētu pag.

${ }^{703}$ CVVM, 13839 13844. Tradicija vainaga mugurpusi rotāt ar lentveida piekariniem vai pagarināt pašu vainagu ir loti sena (skat. A. Z a ri ñ a. Latgalu vainagi laikā no 6 . lìdz 13. gs. 79.-94. Ipp.; arī J. Chr. B r o't z e. Monumente ... VII. 126. Ipp., Vilakas jaunavas).

704 [G. M a n t e u f f e l]. Polnisch-Livland. 35. 1pp. Ziedu vainags ir redzams arî Ludzas jaunavai PSRS Tautu etnogrăfijas muzejā - Leṇingradā.

705 CVVM, 14044, 14050, 14528; [G. M a n te uffel]. Polnisch-Livland. 35. Ipp.

706 VM E, Ludzas un Rēzeknes apr. (mape un dok. bez nr.); J. Chr. B r ot z e. Monumente..., VIII. 57. lpp. Ludzas pilsêtas zîmējuma priekšplānā redzamā vîrieša un zēna figūra.

707 VM E 2627. mape, 297. dok., Stirnienes pag.; 2628. mape, 167. dok̀., Silajāṇu pag.

708 CVVM, 13807, Silajānu pag.; 11273, Daugavpils apr.; 10772, Andrupenes pag.; 10775, Ludzas pag.; 10776, Vidsmuižas pag.; 10777, Dagdas pag.; 10771, Rēzeknes pag.

709 Витебские губернские ведомости, 1863, № 43.

710 Ludzas apr. latviešu apgéerbs - PSRS Tautu etnogrāfijas muzejā, 5273. nr.

711 Turpat.

712 J. Chr. B rotze. Monumente ..., V. 70. lpp.; VII. 126. un 128. lpp.; arî Viḷakas muižas pagalma skatâ redzamās 3 figūras (V'IIII. 76. lpp.).

713 Tag. Balvu rajonā.

714 Эстонская народная одежда, XVII, XIX, XXI, XXII tab.; E. Р и х те p. K вопросу об этнической истории сету. - Известия Академии Наук Эст. ССР, том. VII, 1959, № 4, 407. lpp.

715 CVVM, 12758, 12763, 12776.

716 CVVM, 10825.

717 J. Chr. B r ot $z$ e. Monumente .., VII. 126. lpp.

718 Turpat, VIII, 76. lpp.

719 Sal. Г. С. М а сло в а. Minētais darbs. 608. Ipp., 30. att. -1 . un 2 .

${ }^{720}$ Novadu tērpi. Sķilbēnu pag., 225. lpp.

721 CVVM, Baltijas ekspedicijas materiāli 1956. g.

722 Jēkabpils un Daugavpils raj. dienvidu dala Daugavas kreisajā krastā.

${ }^{723}$ LCVVA, 6810. f., 1. apr., 62. 1., 183. un 175. 1p.

${ }^{724} \mathrm{~S}$. $\mathrm{N}$ a vi cki s. Par latviešiem Ilūkstes apriṇkī.

725 CVVM, 12827. Sal. Г. С. М а с лов а. Minētais darbs. 35. att., 617. Ipp.

${ }^{226}$ CVVM, 12823, 12824; VM E, 2788. mape, 25. dok., Gãrsenes pag. 19. gs. beigâs krekli izšūti baltiem diegiem; VM E, 1912. mape, 111. dok., Aknistes pag.
${ }^{727}$ CVVM, 12741, 12742; LCVVA, 6810. f., 1. apr., 62. 1., 183. un 175. lp.; liekas, ka šis ir senākais Augšzemes krekla veids.

${ }^{728}$ VM E, 2788. mape, 5., 86. un 110. dok., Bebrenes pag. 77. dok., Prodes pag.

${ }^{729}$ CVVM, 10770, 10779.

730 CVVM, 6246.

${ }^{731}$ LCVVA, 6810. f., 1. apr., 62. 1., 175. un 183. 1p.

732 В. А бр а м о в и ч. О латышах. Архив Географического общества СССР, разряд 53, оп. 1, 5.-11. 1рp.

${ }_{733}$ VM E, 2788. mape, 109. dok., Bebrenes pag.; [E. G

Ders cha und P. E. Keyserling]. Beschreibung der Provinz Kurland. 198. lpp.

${ }_{734}$ VM E, 2788. mape, 77. dok., Prodes pag.; 2790. mape, 203. dok., Prodes pag.

${ }_{735}$ VM E, 2788. mape, 77. dok., Prodes pag.; 243. dok. Bebrenes pag.

${ }^{736}$ VM E, 2788. mape, 77. dok., Prodes pag.

${ }^{737}$ VM E, 2787. mape, 111. dok., Bebrenes pag. un Prodes pag.

VM E, 2785. mape, 116. dok., Bebrenes pag.; [E. G. Ders ch a und P. E. Ke y serling]. Beschreibung der Provinz Kurland. 197. lpp.

${ }_{739}$ Bauskas un Dobeles raj., Tukuma un Saldus raj. austrumu dalāâ, Rīgas un Ogres raj. dalā Daugavas kreisajā krastā.

${ }_{740}$ VM E, 1952. mape, 696. dok., Bukaišu pag.

741 CVVM, 12853

742 Turpat, 10700,10708

743 «Bez tam (Zemgales) tautas apgērbu jaunākos laikos iespaido šâs hercoga Jêkkaba darbnīcu «modes». Vēl daži vecāki cilvēki atceras laikus, kad darbnīcās pienēmuši latviešu strādniekus, kuri, mãjās pārnākuši, netautiskos panēmienus lūkojuši izlietot savos darinājumos (Pēc O. Stendera materiāliem, 1930. g.)» (J. N i e d r e. Sieviešu apḡērbs Latvijas atsevišķos novados. Rīgā, 1931., 13. lpp.).

744 Novadu tërpi. 3. lpp.

$745 \mathrm{~J}$. G. K o h l. Minētais darbs, II. (Latviešu un igaunu apgèērbu tabulas 8. un 9. figūra).

${ }^{746}$ CVVM, 76856

747 Vēstures muzeja fondos ir tikai viena villaine ar grezno celu apaudu, kas vedina domāt, ka šādas villaines nebūs bijušas pārāk plaši izplatītas; spriežot pēc celaines sarežgìtā tehniskā izpildījuma, jādomā, ka tâs audušas labas amata zinātājas.

${ }_{748}$ J. G. K o h 1 . Minētais darbs, II. 8., 9. figūra. Jäpiezīmē, ka pēc mūsu domām nepareizs ir Â. Karnupa šîs galvassegas salīdzinājums ar $\mathrm{O}$. Hūna Plieñu ciema sievietes galvas autu. Kola zīmējumā redzamais matu kārtojums vienā bizē ir raksturīgs tikai jaunavām, bet $\mathrm{O}$. Hūna zīmējumā parādìta precētas sievas galvassega (skat. $\bar{A}$. K a rn u p s. Senās ziñas par Zemgales tautas têrpu. - «Senatne un Māksla», 1937., 3. 106. lpp.).

${ }_{749}$ Hipotētisks ir A. D z ē r vi š a raksts: «Kāda Zemgales līgavas galvas sega» («Senatne un Māksla», 1937., 3., 97.-100. lpp.), kurā aprakstīts dvielveida apgêrba gabals no Lambertes draudzes. Pēc priekšmetam pievienotã visai apšaubāmā apraksta A. Dzērvĩtis secina, ka minētais apḡērba gabals ir ligavas galvassega. Pēc formas un kompozīcijas veida šis apgērba gabals tomēr vairāk atgãdina gurnu autu, käds pazîstams Dienvidigaunijā un setukiem (Sal. А. Моор а. Об историко-этнографических областях Эстонии. 252.-253. lpp., 59. att.; Эстонская народная одежда. XVII tab., 36. lpp., 35. att.). Tāpēc šajā darbā tas pie galvassegăm netiek pieskaitìts.

750 Tãdas pašas kurpes ar sprādzēm, tikai ar augstākiem papēžiem J. Broce uzzimējis kādai turīgai Rĩgas apkārtnes zemniecei (J. Chr. B rotz e. Monumente..., III. 77. lpp., 106. att.).

${ }_{751}$ J. Chr. B r o tz e. Monumente ..., III. 75. 1pp., 99. un 100. att.; 80. lpp., 2. att.

752 «Kurzemes zemnieks no Saules muižas. Viňš ir no šajā aprinkîi dzīvojošiem krieviniem, kas, domājams, senākos laikos uz šejieni atvesti kā kara güstekṇi no Igaunijas. Savā starpā vini sarunājas igauniski, bet ar citiem - latviski. No kurienes vini dabūjuši nosaukumu krievini, kas nozīmē krievus, nav zināms; domājams, viṇu izvešana notikusi vēl or- 
deña mestra laikos no tās Igaunijas dalas, kas toreiz bija paklauta krievu knaziem, proti, Unganijas» (J. Chr. B r ot z e. Monumente .... III. 75. lpp., 100. attêla apraksts.). 753 Novadu tērpi. 349. lpp.

754 Kurzemes draudžu hronikas, II. - Valsts arhīva raksti, IX, 184. lpp.

$755 \mathrm{~J}$. J e n š s. No Latvijas rūpniecības attīstības vēstures. 295. lpp.

${ }_{756}$ Pārspīlēts liekas apgalvojums, ka Kurzemes têrpos ir tik liela dažādība, ka nav iespējams runāt par vienotu Kurzemes tautas tērpu. (Skat. [E. G. D e r s ch a u und P. E. Keyserling]. Beschreibung der Provinz Kurland. 191. lpp.).

${ }_{757}$ Talsu rajona ziemelu dalā.

758 Skat. «Latvju Raksti», I. (1946.), 8. lpp., karte.

$759 \bar{A}$. K a r n u p s. Kurzemes tautas tērpi. - «Senatne un Māksla», 1937., 2., 144. lpp.

760 Latvijas PSR vēsture, I. 269. 1pp.

${ }^{761}$ A. O. H e i k e l. Minētais darbs. 109.-113. 1pp., 68.71. att.

${ }_{762} \mathrm{Par}$ lïbiešu antropolog̣isko tipu un tā īpatnībām skat. Р. Я. Д е н и сов а. Антропологический тип ливов. - Балтийский этнографический сборник, М., 1956, 230.-251. 1pp.; M. В. В и тов, Р. Ю. Ма рк, Н. Н. Ч е бок с а ров. Этническая антропология восточной Прибалтики. М., 1959, 83. - 84. lpp.

${ }_{763} \mathrm{~A}$. Dzērvītis šo kreklu nepareizi nosauc par radniecīgu ar Krustpils kreklu, jo Krustpils kreklam ir iekšã laistais uzplecis. Vienigi va|ējie piedurknu dūrgali šiem krekliem līdzīgi (sal. A. D z èrvītis. Latviešu tautas uzvalki, VI. 2. lpp.). $_{764}$.

${ }_{764}$ Baltijas ekspedīcijas materiāli 1954. g. Tādas pašas ziṇas par lỉbiešu apğērbu dod J. A. Segrēns iepriekš minētajā darbā.

${ }^{765}$ CVVM, 16857, 16859.

${ }^{766}$ Turpat, 10618, 10653, 10664, 10666.

767 Turpat, 7333.

768 Turpat, 7345, 7367, 7370 .

769 Turpat, 14003, 14097, 14098, 14107.

2. att.

770 A. D z ē r viti s. Latviešu tautas uzvalki, VI. 2. Ipp.,

${ }_{771}$ A. O. Heike l. Minētais darbs. 69., 70. un 71. att. 772 LCVVA, 6810. f., 59. 1., 1. apr., 32. un 33. 1p.

${ }^{773} \mathrm{~A}$. K a rnu ps sievas tērpu pieskaita Zemgales tērpiem. Tomēr jāpiezīmē, ka Zemgalē nav pazīstamas tumšzilās villaines, melni brunči un linkainim radniecīgs galvas auta sējuma veids.

774 LCVVA, 6810. f., 1. apr., 59. 1., 31. 1p. Ā. K a r n u p s savā rakstā «Senās ziṇas par Zemgales tautas tërpu» zīmējumā redzamo tērpu pieskaita pie Zemgales tērpiem (skat. «Senatne un Māksla», 1937., 3., 107. lpp., 7. att.), turpretim «Novadu tērpos» šis pats tērps iztirzāts kä Ziemelkurzemei piederīgs («Novadu têrpi», 85.-86. 1pp., 168. att.).

${ }^{775} \mathrm{Fr}$. Kr u s e. Necrolivonica ... Krāsainie attēli.

776 Talsu rajona rietumdạāa un Kuldīgas rajona ziemelrietumu stūrī.

777 CVVM, 16434, 16436, 16437. Pēc Vëstures muzeja materiāliem un «Novadu tērpos» publicētajiem Ventspils kreklu paraugiem spriežot, apkakles sieviešu krekliem ir stāvas, bet nevis atlocitas, kā tas minēts $\tilde{A}$. Karnupa rakstā «Kurzemes tautas tērpi (skat. «Senatne un Māksla», 1937., 2., 136. lpp.).

778 CVVM, 10498, 10529. Loti līdzīgs brunču audums ir sastopams Sămsalā Mustjalā (skat. Эстонская народная одежда. 148.-149.).

779 Sãds brunču krokojuma veids ir raksturīgs Igaunijas salu iedzīvotājiem (skat. Эстонская народная одежда. 148. un 155. lpp.). J. Broce sniedz vienu Roṇu salas sievietes tērpa zìmējumu, kurā redzams tāds pats brunču krokojuma veids (J. Chr. B r ot z e. Monumente..., III. 82. lpp). Šādā veidā ir krokoti arī senākie Kuldīgas, Alsungas, Nīcas, Bārtas un Rucavas brunči.

780 Skat. 51. lpp.

${ }^{781}$ Fr. K r u z e s zīmējumā redzamajām sieviešu figūrām ir īpatnējs krūšu rotājums no metāla važiñām, kas līdzīgas sleṇgenu važinām. Lentilijs (17. gs.) raksta, ka misina jostas valkātas visā Kurzemē (Latvijas PSR vēsture, I. 299. lpp.).
${ }_{782}$ CVVM, 7519, 7543 (saglabājusies tikai viena kārta).

${ }_{783}$ Vēl 1954. g. Baltijas ekspedīcijas laikā gados vecākas teicējas atcerējās savu vecmāmiṇu nostāstus par villainēm ar bronzas rotājumu. Villaines ar metāla rotājumu Ventspilī minētas arī Kurzemes aprakstã 19. gs sākumā (skat. [E G. Dersch a u und P. E. Keyserling]. Beschreibung der Provinz Kurland. 195. lpp.).

${ }^{784}$ CVVM, 7502.

785 Turpat, 14133, 14120. Tas ir bijis platāks nekā Kuldigas spangu vainags.

786 Turpat, $14324,14330$.

${ }^{787}$ [E. G. Der s ch a u und P. E. Keyserling]. Beschreibung der Provinz Kurland. 195. Ipp.

${ }_{788}$ Sal. «Novadu tērpi». 151. un 166. att.

${ }^{789}$ Vēl 1954. g. Baltijas ekspedīcijā konstatēti vairāki tērpu komplekti, kurus vecākās sievietes godos valkā vēl šodien.

${ }_{790}$ Kuldĩgas rajona rietumdalā.

$791 \mathrm{~J}$. J u šk ē vi čs. Hercoga Jēkaba laikmets Kurzemē. 381. -382 . lpp.

${ }_{792}$ Turpat, 437. lpp. 1952.

${ }^{793}$ Atlas polskich strojów ludowych: Strój krzczonowski.

${ }_{794}$ CVVM, 16451, 16677, 16682, 16685.

795 1954. g. Baltijas ekspedīcijas materiāli.

796 Atlas polskich strojów ludowych: Strój lowicki. 1953.

797 CVVM, 4123, 4148.

798 CVVM, 7577, 7579, 7583.

799 IEM, 546, 4124.

800 Kuldīgas raj. austrumu dala līdz Skrundai.

801 Kurzemes provinces aprakstā par k̦oniṇiem teikts: «Viṇi bauda retas un plašas brīvtiesības, vārdu sakot, muižnieku privilēğijas» (skat. [E. G. D e r s ch a a und P. E. Keyserling]. Beschreibung der Provinz Kurland. 184. lpp.). «Fakti, kas līdz šim zināmi par ķoniniem, ir šādi: ķoninii vêl 18. gadsimtenī atšķīās no apkärtnes latviešiem etnogrăfiskā ziñā diezgan spilgti ar augumu, matiem un apgeērbu. Viṇi bija loti pašapzinīgi, dažkārt iedomīgi, mīlēja dzîvot pāri saviem līdzekliem, saimniecỉbu caurmêrā vadīja sliktāk par kaiminiem latviešiem, savās runās un nostāstos sevi turêja par pārākiem cilvēkiem visā apgabalā» (J. J u šk ë v i č s. Hercoga Jēkaba laikmets Kurzemē. 394.-395. lpp.). 2. att.

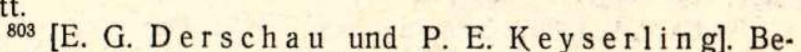
schreibung der Provinz Kurland. 193.-195. lpp.

${ }^{804}$ «Brunči ... bijuši pelēki, vienādi gludā audumā, gludās krokās salikti, virs kurām apakšējā mala nošūta sīkiem rakstiem «repiñām», baltā linā, ar sarkanu pīnīti apakšējā malā. Brunči valkāti augstu lỉdz krūtīm, tie turējušies seviška svïtrota auduma lencês» (skat. A. D z ër vi it is. Latviešu tautas uzvalki, VII, 2. Ipp., 10. att.). Arī O. Hūns min, ka Kuldīgā valkāti pelèki brunči (LCVVA, 6810. f., 1. apr., 60. 1., 69. 1p.); tātad skaidrs, ka iespējams runāt par vienu tērpa variantu.

${ }_{805}$ CVVM, 16611, 16612, 16614.

${ }^{806}$ [E. G. De r s ch a u und P. E. K e y ser ling]. Beschreibung der Provinz Kurland. 193.-194. 1pp.

807 Turpat, 193. lpp.

808 CVVM, 10592.

809 CVVM, 7299.

810 CVVM, 7293.

811 CVVM, 7313.

812 CVVM, 14114, 14123, 14124, 14128.

813 Vainagu katra meita sev nemācēja izšūt, pagastā vienmēr bija kāda sieva speciāliste, kas tos taisīja. Raṇku pagastā viena tāda bijusi, un to saukuši par «vainagu Ilzi», viña bijusi vainagu darinātāja. Tāpēc Raṇku pagasta vainagiem bijis gandrìz vienāds raksts, tikai ar dažām variācijām un citiem smeldžu krāsu kopojumiem (VME, 3100. mape, 362. un 407. dok., Raṇku pag.).

814 VME, 3100. mape, 345. dok., Snēpeles, Turlavas, Rankku un Skrundas pag. «Ja kādai nabagākai liggavai nebijis vainadziṇa, tad tā gājusi no citiem aizṇemties» (VME, 3100. mape, 109. dok., Plānīcas pag.).

${ }_{815}$ [E. G. Der s ch a u und P. E. Keyserling]. Beschreibung der Provinz Kurland. 194. Ipp. 
816 Turpat, 194. lpp.

${ }^{817}$ Novadu tērpi. 70.-73. Ipp.; tas ir greznākais vīriešu krekla paraugs. Snēpeles pag. bijuši arī vienkāršāki krekli (VME, 3097. mape, 220. dok.).

${ }^{818}$ [E. G. Dersch a und P. E. Keyserling]. Beschreibung der Provinz Kurland. 193. lpp.

819 Turpat.

820 «Senos laikos, vēl pirms 1860. g., mētelim ap jostas vietu apnēma misiña jostu» - tas bija «dižais apgērbs» (VME, 3097. mape, 352. dok., Turlavas pag.).

821 VME, 3097. mape, 219. dok., Snêpeles pag.

${ }^{822}$ Tagad Kuldigas un Liepājas raj. austrumu daḷā, Sal-

dus un Tukuma raj. rietumu dalā.

${ }_{823}$ Novadu tērpi. 416. lpp.

824 Novadu tērpi. 402.-407. lpp., Kuldīgas NM, 1718

825 \&Jaunavas vainagu nēsāja ap 1860. g. - pềc tam vainagi drīz izzuda. Bijuši arī vainagi melnā pamatā šũti» (VME, 3100. mape, 310. dok., Pampâlu pag.).

${ }^{826}$ «Aubi katrs vis nemācēja pašūt, un arī aubes šuvējas bijušas viena par otru labākas, mācējušas fasonīgāk uzšūt, tãpēc aubi šūt brauca kādreiz vairākas verstis tālu pie šuvējas. Aubi valkāja, ziemā un vasarā baznīcā ejot, labi to glabājot; pa celam galvā nelika, bet nesa drāninā iesietu un, kad pienāca pie baznīcas, tad tikai uzlika» (VME, 3100. mape, 489. dok., Skrundas pag.).

827 VME 3100. mape, 217. dok., Kabiles pag.

828 «Arī vīriešu krekli sasprausti ar kniepkeniem. Kniepkenus gatavoja uz vietas, tos pa lielākai dalai lēja ganu puikas no alvas, izgriežot formu kādā rācenī jeb citā augā» (VME, 3097. mape, 168. dok., Lutrinu pag.). Par alvas pogu izgatavošanu un lietošanu skat. X. М о о р а. Об оловянных украшениях и их изготовлении в Прибалтике. (Atsev. novilkums. - Munera Archaelogica Iosepho Kostrzewski. 365. Ipp.).

620 VME, 3097. mape, 224. dok., Pampālu pag. pag.

sao Turpat, 157. dok., Pampālu pag.; 168. dok., Lutriṇu

831 Turpat, 168. dok., Lutriñu pag.

${ }^{832}$ Liepājas rajona rietumdalā.

${ }_{833} \mathrm{~A}$. Ka rn ups pareizi apvieno Nìcas, Bârtas un Rucavas pagastus Dievidrietumkurzemes apgērbu apgabalā ( $\bar{A}$. K a r n u p s. Kurzemes tautas tērpi. 137. Ipp.). Liekas, ka šo îpatnỉbu loku iespẽjams vēl vairāk paplašināt - tas sniedzas aiz Liepājas robežām, kamēr pāriet Alsungas, Kuldīgas un Austrumkurzemes tērpos. Izdalīt šo pārejas joslu atsevišķā variantā nav nepieciešams.

${ }_{834}^{8}$ [E. G. Der S Ch a und P. E. Ke y serling]. Beschreibung der Provinz Kurland. 195.-196. 1pp.

${ }^{835}$ No lietuviešu vārda perpetis «pāri plecam» (E. E 1 ks nīt e. Rucavas krekli. 126. lpp.).

${ }_{836}$ Lvovas Etnogrăfijas un mākslas rūpniecỉbas muzejs.

837 E. E 1 ks nit e. Rucavas krekli. 131. lpp. Nezinot Zviedrijas, Norvēgijas un Somijas muzeju fondus, bet spriežot vienīgi pēc literatūras materiāliem, liekas, ka grieztais raksts tādā variantu dažādībā, kādā tas redzams Lvovas muzejā, diez vai kädā zviedru, norvēłu vai somu muzejā būs. Bez tam tehnikas nosaukums «hardangers» tautā nav pazīstams; grieztā raksta nosaukums, tāpat kā ukraiṇu «вирізування», radies no paša izšǔšanas procesa (rakstu veidojot, auduma diegus pārgriež)

${ }^{838}$ Lvovas Etnogrāfijas un mākslas rūpniecības muzeja materiāli - EП 68404, Poltava; 20734, Aizkarpati u. c.

${ }_{839} \mathrm{~J}$. J a n š evs ki is. Nica. 42. lpp.

${ }_{840}[\mathrm{E}, \mathrm{G}, \mathrm{D}$ e r s ch a und P. E. Keyserling]. Beschreibung der Provinz Kurland. 196. 1pp.

${ }_{841} \mathrm{~J}$. J a n š e v s k i s. Nìca. 42. lpp.

842 Turpat, 43. 1pp.

$843 \bar{A}$. K a r n u p s. Kurzemes tautas tērpi. 141. lpp.

844 [E. G. Ders ch a und P. E. Keyserling]. Beschreibung der Provinz Kurland. 196. lpp.

${ }^{845}$ Skat. «Sodžiaus Menas», 7.-8., 11., 12., 184. u. c. 1pp. 846 Skat. 28. tab., 3.

${ }^{847}$ [E. G. Der s ch a u und P. E. Keyser ling]. Beschreibung der Provinz Kurland. 195. 1pp.

${ }_{848}$ Turpat.

849 Turpat.
850 М. В. В и то в. Антропологическая характеристика населения восточной Прибалтики. 562.-563. lpp.; М. В. В итов, К. Ю. М а рк, Н. Н. Че бокс а ров. Этническая антропология Восточной Прибалтики. 110.-111. 223. u. c. lpp.

${ }^{851}$ 1954. g. Baltijas ekspedīcijā Kuršu kāpās, sarunājoties ar turienes iedzīyotāiem, konstatēts, ka tiem latviešu termini «apgēērbs» vai «têrps» bija pilnīgi sveši, turpretim vārds «drēbes» bija pazīstams visiem.

${ }^{852} \mathrm{R}$. M a l ve s s. Jelgavas ostas liktengaitas. - «Senatne un Māksla», 1937., 3., 25., 29. lpp.

${ }_{853}$ Luijs XVIII ar savu galmu un apmēram 200 franču emigrantiem dzīvoja Jelgavas pilī no 1798. līdz 1800. un no 1804. līdz 1807. gadam. Skat M. S t e p e r m a n i s. Francijas burboni Jelgavā. - «Senatne un Māksla», 1937., 3., 55.62. lpp.

854 М. В. В и то в, К. Ю. М а рк, Н. Н. Че бокс а ров. Этническая антропология Восточной Прибалтики. 111., 229. -230. 1pp.

855 История Польши, т. 1. 1956, 19. lpp.; П. Н. Т рет в я к в. Восточнославянские племена. М., 1953, 80. lpp., 17. att.

${ }_{856}^{85}$ М. В. В и то в, К. Ю. М а р к, Н. Н. Ч е бокс аров. Этническая антропология Восточной Прибалтики. 229. - 230. 1pp.

${ }^{857}$ E. B l e s e. Seno kuršu etniskā piederība. 67. lpp.

$858 \Gamma$ е н р и х Л а т в и й с к й й. Хроника Ливонии. Пер. и коммент. С. А. Аннинского. М.-Л., 1938, 292. lpp. Tuvāk par vendu pārvietošanos skat. K. A n c ît is un A. J a n s on s. Vidzemes etniskās vêstures jautājumi. 59.-60. 1pp.

${ }^{859}$ Lvovas Etnogrāfijas un mākslas rūpniecỉbas muzeja materiāli - EП 21271.

${ }_{860}$ Lvovas Etnogrāfijas un mākslas rūpniecības muzeja materiāli - EП 21101

${ }_{861} \mathrm{~J}$. J u šk ēvičs. Hercoga Jēkaba laikmets Kurzemē. 380. lpp.

$\log _{862}$ Turpat, 382. lpp.

863 Х. А. и А. Х. М о р а. К вопросу об историкокультурных подобластях и районах Прибалтики. - СЭ, 1960, 3, 33. 1pp.

864 Turpat.

865 Эстонская народная одежда. 34 . 1pp. А. Х. М о о р а. Об историко этнографических областях Эстонии. 255.256. $1 \mathrm{pp}$.

${ }_{860}$ K. A n cît is un A. J a n s ons. Vidzemes etniskās vēstures jautājumi. 45. lpp. 867 IEM, Jaani, H 290: 426.

868 IEM, Helme - 18444, Reuge - A 168:57, 7152,

$7164,7232-7234$; Эстонская народная одежда. 21. att. (sieviešu krekls no Vastselinnas). ${ }^{869}$ IEM, Kihnu - A $290: 430$

870 А. Х. Моора. Об историко-этнографических областях Эстонии. 255. 1pp.

${ }_{871}$ M. S I a v a. Latviešu kreklu tipi, 90 . 1pp.

872 Skat. Mulgi kirikindad ja kirisunad, (Mulgi novada cimdi un zekes). Tallin, 1960., 36., 39., 48. u. c. lpp.

${ }_{873} M$. С те пе р м а н и с. Некоторые итоги последних экспедиций этнографов Академии Наук Латвийской ССР в Северной Видземе. - Etnograafia muuseumi aastaraamat, XVII, Tartu, 1960, 227. lpp.

874 Эстонская народная одежда. 13., 14. att.

875 А. Х. Моо ра. Об историко-этнографических областях Әстонии. 256. lpp.

876 Sal. A. Z a r i na a. Latgalu vainagi laikā no 6. līdz 13. gadsimtam. 85.-87. 1pp.

$877 M$. В. В и т о в, К. Ю. М а р к, Н. Н. Ч е бо к с аров. Этническая антропология Восточной Прибалтики. 112. lpp.

878. Х. А. и А. Х. Моо р а. К вопросу об историкокультурных подобластях и районах Прибалтики. 48. Ірр

879 Sal. Rietumvidzemes cepures (CVVM) ar zviedru cepurēm; skat. P. G. W i s t r a n d. Svenska folkdräkter. Stockholm, 1907, 62. att.

880 K. B l a u s. Mūsu apgērbs. - «Balss», 1887., 47.

881 Turpat.

882 Turpat.

${ }_{883}$ Turpat. 
884 Skat. A. A 1s u p e. Lauku audēju darinājumi Vidzemē 19. un 20. gs. - Arheologija un etnogrāfija, V, Rīgā, 1963. 885 E 13, 982.

886 Skat. $M$. S l a v a. Daži adīto cimdu rotāšanas veidi. - Arheologija un etnogrāfija, II, Rìgāa 1960.

${ }_{887}$ Kādā apgèrbā un rotā lai nākam uz saviem gaidāmiem diženajiem tautas svētkiem? - «Balss», 1888., 17. 18., 21.; S. H. [Z ā lī t e H.]. Par latviešu tautas apgeērbu. «Mājas Viesis», 1894., 10., 11.; P. Kl. [Nik. P u ri n šs. Kāds vārds par latvju tautisko apgēēbu. - «Baltijas Vēstnesis», 1888., 70 .

888 «Balss», 1888., 14.

${ }_{889}$ P. Kl. Kāds vārds par latvju tautisko apgêrbu. «Baltijas Vēstnesis», 1888., 70.

${ }_{890} \mathrm{R} u \mathrm{~d} z \bar{i}$ š u Pēteris. Tautiskie apgērbi III latviešu vispārīgos dziedāšanas svētkos. - «Dienas Lapa», 1888., 35.

891 Turpat.

${ }^{892}$ Pašausti apgērbi Latviešu trešos vispārīgos dziedamos svētkos. - «Dienas Lapa», 1888., 55.

${ }^{893}$ Par tautisku apǵērbu. - -Dienas Lapa», 1888., 147.

894 «Ja tiešãm rastos laudis, kam pie šã jautājuma būtu lielāka interese nekā tik ar vārdiem un uz papīra, tad vajadzētu tādiem, kam apgêerba lietā prašana, sastādīties îpašã komisijā un ar lietas prašanu krāt uzvalkus, uzvalku nozīmējumus un aprakstus, šos pētīt, salīdzināt, likt priekšā vairākiem lietas pratējiem uz apspriešanu. Siem vajadzētu apgērbus kārtot pēc apgabaliem un laikmetiem. Kad šāds darbs būtu iepriekš vairāk gadus turpināts, kad lietai būtu cik necik zināms sistēms, tad arī būtu iespējams ko patiesi vērtīgu laikmetam piemērotu uzrādīt» («Dienas Lapa», 1883., 35.).

${ }^{895} \mathrm{Pašausti} \mathrm{apgērbi} \mathrm{latviešu} \mathrm{trešos} \mathrm{vispārīgos} \mathrm{dziedamos}$ svētkos. - «Dienas Lapa», 1888., 55.

${ }^{896} \mathrm{Par}$ tautisku apgeērbu. - «Dienas Lapa», 1888., 147. 897 «Latviešu apgēerbu komiteja līdz šim izstrādājusi priekšzīmi priekš vispārīga latvju sieviešu apgeērba un šo priekšzīmi seviškā krāsainā zīmējumā likusi nodrukāt uz sevišķas lapiṇas lïdz ar izskaidrojumu...»

«Kā pieliktā izskaidrojumā lasāms, tad šis vispārīgais latviešu sieviešu apgēēbs izskatās šāds: 1) Galvas rota: zīlu vainags, puḳu vainadz. vai arī kảda puke. Mati - divās bizēs, ap galvu aplikti vai karājošies; galos iepītas lentes vai sasietas cilpās, vai arī izlaistas. 2) Kakla rota: sakta (brošas vīzē) un krelles divăs vai trijās kārtās. 3) Krekls: ar knipelu apkakli; uzpleči (laidiñi) un aproces raibi izrakstīti. 4) Nieburs: (knēpe) vienkrāsains bez piedurknēm vai apalı, vai stūraini izgriezts un priekšā saâkêjams; arī atlauts to nošūt divām no augšas uz leju ejošăm pogu rindām; kas škērsu savienojamas šņorēm. 5) Brunči: (svārki) krokaiṇi, gan vienkrāsaini, gan gareniski strīpaini; ja vienkrāsaini, tad apakšā škērsu strīpas ietaisāmas: brunčiem der būt gaišãkiem par ñieburu. 6) Priekšauts: balts, apakšā raibi izrakstīts, izrakstījumi balti, zili vai sarkani - tikai vienā krāsā. 7) Ja brunči un priekšauts sienami virs niebura, tad arī josta ievēlama; josta var būt iz ādas vai izšūtas drēbes ar metāla sprādzi. 8) Apavs: seklas kurpes un gaišas vienkrāsainas, vislabāki baltas zekces. Citādi krāsas var izvēlēt, kādas katram patīk. Latviešu tautas mī|ākās krāsas ir bijušas un ir vēl tagad: balta, zila, sarkana.

Tädi ir tie priekšraksti, kurus izdevusi «Latviešu apgẽrbu komisija» priekš vispārīga latviešu sieviešu apgēerba. Komisija izskaidro, ka visas nupat aprakstītās apgèrbu un rotu dalas it nebūt neesot kāds bezpamatīgs vinas sadomājums, bet nemtas no latviešu tautā agrāki un pa dalai arī vēl tagad šur tur lietotiem apgēerbiem un tikai pēc tagadējo laiku garšas sakārtotas.»

${ }_{898}$ «Dienas Lapa», 1888., 147.

${ }^{899} \mathrm{~S}$. H. [Z äli te H.] Par latviešu tautas apgērbu. «Mājas Viesis», 1894., 10.

900 «Dienas Lapa», 1894., 42. 63. $1 \mathrm{pp}$.

901 K. M e d i ṇ š. Latviešu dziesmu svētki. Rīgā, 1955.,

${ }_{902}$ Em. Mel ng a ilis. Būt vai nebūt dziedāšanas svētkiem. - «Jaunā Dienas Lapa», 1909., 165.

${ }^{903}$ Muzeja ekspozīcija tajā laikā komplektējās galvenokārt no priekšmetiem, kas bija savākti, gatavojoties 10. arheologu kongresam Rīgā. 1894. un 1895. g. tika sūtītas vairākas ekspedīcijas uz dažādiem Latvijas novadiem materiālu vākšanai. Viena šāda ekspedīcija apmeklēja Ziemel- un Rietumvidzemi, otra - Liepāju un Alsungu, trešã - Latgali un ceturtā - Ilūksti.

904 «Cīna», 1910., 108.

905 K. M e d i ñ š. Latviešu dziesmu svētki. 76. -77. lpp.

${ }^{906}$ L e ñ i n s par kultūru un mākslu. Rīgā, 1947., 330. lpp. nova.

907 Żinas sniegusi Etnogrāfijas nodalas vadītāja G. Iva-

${ }_{908}$ [E. R u be n e]. Tautas tērpi mākslinieciskās pašdarbības kolektiviem. - «Padomju Latvijas Sieviete», 1954., 9. 


\title{
ЛАТЫШСКАЯ НАРОДНАЯ ОДЕЖДА
}

\author{
КРАТКОЕ ИЗЛОЖЕНИЕ
}

Народная одежда вместе с присущей ей орнаментикой, как и вся материальная культура народа, развивается не изолированно. Она формируется в процессе взаимодействия различных этнических групп, входящих в состав данного народа, видоизменяясь с развитием экономики и расширением взаимосвязей с другими народами. Народная одежда ярко отражает этническую специфику и вкус народа и, сопоставленная с одеждой соседних народов, позволяет выявить самобытные черты культуры латышей, а также проследить их внешние этнические и культурные связи.

Несмотря на то что одежда, как и другие элементы народной культуры, с развитием общества постоянно изменяется, она все же отличается большой устойчивостью.

При написании монографии использованы полевые материалы этнографических экспедиций, архивные и музейные материалы, а также данные специальной литературы.

Во введении дается обзор источников и специальной литературы, а в картах (рис. 1-3) отражаются материалы, собранные в ходе экспедиций и почерпнутые из источников. Для сравнительного анализа были использованы также соответствующие материалы, характеризующие одежду соседних народов. В этих целях автором, в частности, были изучены фонды этнографических и исторических музеев в Ленинграде, Тарту, Вильнюсе, Каунасе и Львове.

Коллекции и описания народной одежды Латвии относятся главным образом к XIX в., и лишь небольшая часть их восходит к концу XVIII в. Поэтому констатируемые на основании этих материалов явления, в том числе культурные области и их особенности, выступают перед нами по существу в том виде, в каком они сложились к прошлому веку. При этом характерно, что многие новые явления распространялись не в новом ареале, а обычно в пределах старых культурных областей со всей присущей им общностью тради- ций. Конечно, кое-где древние границы стерлись или сместились, в отдельных случаях произошло образование новых этнографических подразделений, но и последние дают возможность проследить связи с более ранними группировками. Поэтому здесь исходным пунктом для сравнительного анализа является народный костюм XIX в., но по мере надобности делајются и экскурсы в прошлое.

О характере одежды древнейшего населения, жившего на территории современной Латвийской ССР, дают представление археологические материалы. Анализ этих материалов позволяет восстановить историю народной одежды предков латышей примерно начиная с VII в. н. э. Но отдельные элементы латышской народной одежды, которые в несколько измененном виде бытовали вплоть до начала XIX в., уводят нас в еще более отдаленное прошлое.

Латышская женская одежда в XII в. состояла из льняной рубахи, шерстяной или полушерстяной поясной одежды, шерстяного покрывала «виллайне» и головного убора. Виллайне обычно украшалась бронзовыми колечками и каймой «целайне». Подобного типа виллайне была обнаружена уже в погребениях латгалов VII в. Как составная часть женской одежды виллайне сохранялась вплоть до XX в., менялся только характер ее украшения. В XII в. в качестве головных уборов появляются венки из ткани, вышитые бисером; они постепенно сменяют прежние венки из бронзовых спиралей и колечек, которые часто встречаются в могильниках до XII в. Погребения женщин, принадлежавших, по-видимому, к социальной верхушке, отличаются более богато орнаментированными виллайне и бо́льшим количеством металлических украшений.

Мужская одежда состояла из льняной и шерстяной рубахи, штанов, шапки и такой же, как у женщин, кожаной обуви или лаптей. Украшения были близки по форме к тем, которые обнаружены археологами в Литве и Эстонии, однако в 
деталях и в отношении излюбленных форм существовали различия даже на территориях различных объединений древнелатышских племен.

Сопоставляя археологические данные с рисунками XVI-XVIII вв. и описаниями путешественников, можно заключить, что народная одежда латышей до XVIII в. состояла из тех же частей, что и в древние времена. Только на смену богатой орнаментации металлическими украшениями приходят стеклянный бисер, нитяные кисти и вышивка.

Классических форм латышская народная одежда достигла в период позднего феодализма. В конце XVIII - первой половине XIX в. на территории Латвии существовало несколько различных комплексов народной одежды. Особенности их в известной мере восходили к различиям в материальной культуре отдельных племенных объединений, населявших данную территорию и вошедших позднее в состав латышского народа Натуральный способ ведения хозяйства и слабость культурных связей в период феодализма способствовали сохранению и развитию местных особенностей народной одежды. Лишь в середине XIX в., в связи с развитием капитализма, расширением местного рынка и распространением в деревне фабричных тканей, создались условия для нивелировки этих особенностей.

В латышском народном костюме можно выделить пять главных комплексов: видземский, латгальский, аугшземский, земгальский и курземский (рис. 6). Для каждого из них характерен своеобразный покрой, оттенки красок и принципы украшения одежды.

После обзора и характеристики разных форм одежды в работе рассматривается материал и изготовление одежды, а также традиции ее ношения.

Одежда в Латвии изготовлялась преимущественно из шерсти и льна. Обработка шерсти и льна у латышских крестьян вплоть до XX в. носила характер домашней промышленности. В районах, отсталых в хозяйственном отношении и отдаленных от городов, домашнее производство тканей сохранялось и при капитализме. Техника ткачества отражена на рис. 8 .

Для окраски тканей использовались растительные красители, добываемые на месте, поэтому расцветка тканей в различных местах в большой степени зависела от характера местной растительности. В монографии описываются различные приемы окраски тканей, вырабатывавшиеся на протяжении веков. С распространением химических красителей во второй половине XIX в. расцветка тканей стала меняться.

Помимо покроя и основного материала серьезную роль в народном костюме играет его украшение. Довольно высокий уровень развития форм украшений одежды наблюдается уже в период феодализма (всякого рода обшивки из цветных материалов, окаймление цветным шнуром, сбор- ки, бахрома, вышивки и т. п.). Среди различных декоративных приемов наиболее богатой в латышском народном костюме является вышивка, часто переплетающаяся с другими видами украшения - бахромой, ткаными узорами, каймами. По технике выполнения народные вышивки можно подразделить на две основные группы. К одной группе следует отнести разные белые мережки и счетную гладь (рис. 10-12), к другой цветные счетные вышивки, находящиеся в тесной зависимости от структуры полотна (цветные таблицы 1,2 , рис. 11,14$)$. Счетная вышивка с геометрическими мотивами является более старинной по своему происхождению.

В народных костюмах вышивка как украшение применяется в весьма различных формах Однако во всех случаях размеры, расцветка и композиция узоров тесно связаны с формой и материалом украшаемой части одежды. Вышивка встречается на воротнике, наплечниках, манжетах и застежках рубах (цветная таблица 2), по краям наплечного покрывала-виллайне (рис. 16, 17, цветные таблицы 16-19), на женских чепцах (цветная таблица 29). Богатая вышивка рубах бытовала в Латвии повсюду, за исключением северной части Видземе. Наиболее распространена вышивка, выполненная белыми нитками (Видземе, за исключением района Крустпилса и, частично, восточной Видземе; Земгале и северо-восточная часть Курземе). Вышивка красными нитками характерна для Латгале и Аугшземе, в быту населения которых проявлялось больше славянских черт. В юго-западной части Курземе и юго-восточной части Видземе распространена многоцветная вышивка.

Особое место занимают вышивки по тюлю, родственные кружевам (рис. 20). Узорчатые нашивки из бус и бисера (иногда - на золотой тесьме) делаются главным образом на венках, воротниках и мужских поясах (рис. 34, цветная таблица $2,1-3)$.

В книге рассматриваются вопросы, связанные с социальными, семейными и возрастными различиями, которые отражаются в одежде. Дается и описание рабочей одежды (цветная таблица 3).

Далее подробно описаны основные элементы одежды и, насколько это удалось проследить, показаны их изменения.

Основной элемент латышской одежды - рубаха (krekls). Она встречается двух типов - туникообразная и с прямыми поликами.

Туникообразная рубаха представлена тремя вариантами: без наплечников, с нашитыми наплечниками и с прямыми плечевыми вставками. Туникообразную рубаху без наплечников (первый вариант) можно считать наиболее древним на территории Прибалтики видом рубахи. Рубахи такого покроя встречались по всей Латвии. Туникообразная рубаха с нашитыми наплечниками (второй вариант) является самым распространенным в Прибалтике видом рубахи. Такого 
рода рубахи характерны для всех областей Латвии, за исключением Аугшземе. Туникообразная рубаха с прямыми плечевыми вставками (третий вариант) встречается в Видземе.

Рубахи второго типа - с прямыми поликами - характерны для Аугшземе и окрестностей Лиелварде в Видземе. Помимо того, они встречаются в отдельных селениях южной части Курземе и Земгале (рис. 26). Рубахи этого типа встречаются двух вариантов. Первый вариант - длинная рубаха с прямоугольными плечевыми вставками, которые пришиты по утку к основным полотнищам рубахи, доходя до их краев; рукав пришивался к этой вставке. Второй вариант отличается от первого тем, что плечевые вставки пришиваются к основным полотнищам не по утку, а по основе (рис. 27). Такого рода рубахи носили только в районе Руцавы (юго-запад Курземе).

Рубаху обычно шили из двух тканей разного качества: верх - из тонкой отбеленной льняной ткани, а нижнюю часть - приставку или подставку (pierietnis), идущую от пояса до колен или ниже колен, - из грубой льняной ткани.

Рабочие рубахи почти не украшали, зато праздничные были богато отделаны вышивкой (цветные таблицы 1 и 2). Мужские рубахи шили туникообразного покроя с нашитыми наплечниками.

Женскую поясную одежду составляли юбка (brunči), передник (priekšauts) и пояс (josta), а мужскую - штаны (bikses, üzas) и пояс.

Юбки изготовляли из клетчатой, полосатой или однотонной шерстяной, полушерстяной или льняной ткани. Шили юбку из одного куска ткани длиной от 2 до 5 м. В талии юбку собирали или укладывали в складки и пришивали поясок из той же ткани. Юбка, сшитая из нескольких полотнищ, представляла собой более новый вариант (середина XIX в.). По длине юбка обычно доходила до щиколотки, но в некоторых районах Курземе носили несколько более короткие юбки.

Во всех областях Латвии юбки были почти одинакового покроя, но они сильно различались по расцветке и сочетанию полосок и клеток (рис. 30, цветные таблицы 5-11). Полосатые и клетчатые юбки, сшитые из одного куска ткани, можно считать характерными для всей Прибалтики первой половины XIX в. Судя по рисункам XVI в. и описаниям XVII в., в Латвии, так же как и Литве и Эстонии, юбки не сшивали, а запахивали ткань и закрепляли ее в талии поясом, т. е. носили несшитую поясную одежду (рис. 28,29 , цветная таблица 4).

Штаны, как одну из основных частей мужской одежды, латыши носили с глубокой древности. Они шились из холста или сукна. Характерны для латышей так наз. «узкие штаны», различавшиеся по покрою и длине (рис. 32 ).
Пояса были тканые, бисерные и металлические. Тканые пояса, длиной от 3 до 5 м и шириной 3-10 см, типичны для всей Прибалтики (рис. 35-37, цветные таблицы 13-15). Металлические пояса (slengenes), встречающиеся в западной части Курземе и Эстонской ССР, можно считать характерными в прошлом для ливов (рис. 33). Пояса, вышитые бисером, носили в XIX в. только зажиточные мужчины (рис. 34 ).

B XVIII в., как можно судить по рисункам того времени, обязательной частью женского праздничного костюма латышей был передник. B середине XIX в. в Латвии передник с праздничным костюмом уже не носили, за исключением Аугшземе и Латгале (рис. 38,39 ).

Самой древней самобытной частью латышского женского костюма является виллайне. Такие покрывала, называемые в некоторых районах также «сагша», можно считать типичной наплечной одеждой народов Прибалтики. Виллайне представляет собой прямоугольный кусок шерстяной или полушерстяной ткани длиной от 120 до 250 и шириной от 80 до $150 \mathrm{~cm}$. Обычно виллайне накидывали на оба плеча и спереди застегивали пряжкой (sakta) или оставляли свободно висеть оба конца. Только в районе Ницы, Барты и Руцавы (юго-запад Курземе) виллайне застегивали на одном плече (рис. 43).

Летом носили «снатене» (snātene) - белое или клетчатое льняное покрывало (рис. 48). К праздничному костюму надевали снатене с богатой отделкой. Снатене наиболее характерна для Латгале, Аугшземе и Руцавы (Курземе).

По форме, расположению вышивки, расцветке и особенностям композиции узоров нами выделены четыре основных типа виллайне (рис. 42): 1) восточнолатвийский, распространенный в юговосточной части Видземе, западной части Латгале и северной части Аугшземе (цветная таблица 16); 2) южнокурземский, встречающийся в южной части Курземе (цветная таблица 17); 3) северокурземский, характерный для северо-западной части Курземе (цветная таблица 18 ); 4) земгальский (рис. 42). Белые виллайне с роскошной вышивкой и разноцветными ткаными узорами надевали лишь в очень торжественных случаях, и они являлись признаком зажиточности. Еще в XIX в. в западной Курземе встречались синие виллайне, украшенные бронзовыми колечками и спиралями. Это древний тип виллайне, известный еще в VIII в. Клетчатые виллайне (lielais lakats) появились довольно рано, но более широкое распростра̊нение получили в первой половине XIX в.

На одном из рисунков XVI в. изображена своеобразная наплечная одежда - пелерина из шерстяной полосатой ткани в виде юбки с завязками спереди (pussvārcis). Наплечную одежду такого вида и в настоящее время можно встретить в северной части Курземе и северо-западной части Видземе (рис. 50, 51, цветная таблица $36,4)$. 
В состав женской одежды в ХІХ в. входили безрукавка-жилетка (nieburs) и кофта (jaka). Эти части одежды особенно характерны были для населения Курземе и северной Видземе. Безрукавки и кофты шили из одноцветной ткани и украшали вышивками, лентами и пуговицами (рис. 52-54).

Мужская и женская верхняя одежда латышей отличались одна от другой не столько покроем, сколько деталями, главным образом длиной, отделкой и украшениями (цветная таблица 21). Нередко в будни женщины надевали мужскую одежду, и наоборот. В XVIII в. и первой половине XIX в. в крестьянской среде оставалась обычной одежда домашнего изготовления (суконная или холщовая для осени, весны и лета, овчинная - для зимы). С развитием капитализма одежда из фабричного сукна и других тканей постепенно заменяла домотканую, вначале лишь в среде наиболее зажиточных слоев деревни. Изменялся под влиянием города также и покрой одежды (цветная таблица $30,2,3$ ).

Қафтаны (svārki, muduraini) преимущественно шили однобортные, только некоторые виды курток (īsie svärki) были двубортными (рис. 59, 1). Кафтаны с целой спинкой и клиньями - повсеместно более старый покрой, чем с отрезной спинкой и сборками сзади, а иногда и вокруг всего корпуса (рис. 55-59).

В Восточной Латвии, включая Аугшземе и Земгале, мужские кафтаны изготовляли большей частью из белой или светло-серой шерстяной ткани. Қафтан перепоясывался полосатым поясом, иногда тканым на дощечках, который был почти единственным украшением одежды. Старинные кафтаны шили совсем без воротников или с очень низким стоячим воротом. Помимо белых известны также густо-синие и темно-серые кафтаны; выделяются богатством отделки мужские кафтаны из окрестностей Мазсалацы и Алуксне (рис. 56).

На западе Латвии мужские кафтаны изготовляли большей частью из белой шерстяной ткани (исключение представляют алсунгские черные кафтаны с двумя рядами перламутровых пуговиц). Западнолатвийские (Ница, Барта, Руцава) мужские кафтаны (рис. 59) были богаче украшены шнуровым орнаментом или вышивкой, чем восточнолатвийские. Мужские рубахи на западе Латвии также украшались белой или черно-белой вышивкой.

Шубы (kažoki) из овчины были одинаковыми у мужчин и женщин. Украшались шубы так же, как кафтаны (рис. 60, цветная таблица 21).

Головные уборы у девушек и замужних женщин различались по внешнему виду и способу ношения (рис. 64, 65). Наиболее распространенным девичьим головным убором был венок (vainags) из красной шерстяной ткани, вышитый цветным бисером (цветные таблицы 24, 26-28). В древности носили металлические венки, известные по археологическим материалам. В некоторых районах Курземе металлический венок как девичий головной убор сохранялся вплоть до XIX в. (цветная таблица 27). В центральной и северной частях Видземе в начале XIX в. встречались венки из конского волоса (цветная таблица 24,6 ). Летом часто носили венки из полевых цветов. В некоторых местах (в районе Руцавы в Курземе и в северо-западной части Видземе) место венков занимали шелковые или шерстяные ленты (matauklas), длинные концы которых спускались на спину (цветная таблица 25). Головным убором замужних женщин в древности был наматс (nāmats) особого рода длинное полотенце, которым обматывали голову (рис. 66-68). Позднее вошли в употребление чепцы. В XIX в. наматс сохранялся только в Латгале и Аугшземе и в районе Руцавы в Курземе. Чепцы (cepures) различались по форме. На территории Латвии было известно три вида их: башнеобразный, круглый и с отогнутыми вверх полями (рис. 69, цветные таблицы $28,2,29)$. С середины XIX в. наиболее распространенным головным убором стал платок (рис. 63).

Мужчины на голову надевали черную или серую шляпу - так наз. ратене (ratene) (рис. 72), которая в западной части Латвии украшалась шелковой лентой или ниткой бисера. Зимою носили меховые шапки (рис. 71).

Старинной обувью латышей являлись кожаные постолы (pastalas) и лапти из лыка (vizes) (рис. 73,74$)$. В конце XIX в. во всех областях Латвии многие женщины к праздничному наряду стали носить кожаные туфли на низких каблуках с широкими носками (рис. 75), а мужчины сапоги (рис. 76,12 ). Постолы и лапти сохранялись как повседневная рабочая обувь.

В конце XVIII в. получили широкое распространение вязаные чулки (до этого времени ноги обматывали портянками) - летом к праздничному костюму белые льняные, а зимой - шерстяные чулки ажурной вязки. В некоторых районах носили шерстяные чулки с цветными узорами (цветная таблица 22).

Рукавицы, перчатки и чулки вязали в большом количестве. Более зажиточные девушки имели их до пятидесяти пар. Рукавицы дарили за разного рода услуги. Кроме того, по обычаю на свадьбе молодая дарила рукавицы родственникам мужа. Для невесты и жениха вязали белые свадебные перчатки с широкой резинкой, украшенные цветными полосами (цветная таблица 23). Мужчины, выходя из дому, в любое время года брали с собой перчатки, которые в холод надевали, а в жару затыкали за пояс.

В восточной части Латвии рукавицы и перчатки богато украшали бахромой, располагая ее в несколько рядов. По узору и сочетанию цветов рукавицы напоминали виллайне. В западной 
части Латвии вязали преимущественно зубчатые резинки без полос, со сплошным узором.

Из древних украшений в праздничном наряде XIX в. сохранялись только пряжки «сакты» (рис. 79-83). Форма их упростилась, но зато они были обильно украшены орнаментом. Рубахи застегивали маленькими сактами, а покрывала большими (burbulsakta, dižsakta). Серебряные сакты, которые могли приобретать только зажиточные люди, передавались в семьях по наследству. Бедные завязывали рубаху ленточками или застегивали нитяной пуговицей. В западной части Курземе, на побережье Балтийского моря, чаще носили янтарные брошки и пряжки (рис. 85).

В Земгале и Латгале к праздничному костюму в середине XIX в. надевали стеклянные и серебряные бусы (рис. 77). В северной Курземе сохранились старинного вида нагрудные украшения с цепочками. Эти украшения встречаются только у потомков ливов.

Как уже говорилось выше, в латышском народном костюме выделяются пять главных комплексов: видземский, латгальский, аугшземский, земгальский и курземский, отличающихся один от другого покроем, расцветкой и принципами украшения их отдельных деталей.

В и дз е м с к й комплекс народного костюма был распространен на территории, населенной в древности латгалами и ливами. Для него характерна туникообразная рубаха с нашитыми наплечниками, а в восточной части Видземе - c прямыми плечевыми вставками, украшенная мережкой из белых ниток (в отдельных случаях В восточной части Видземе - воротник украшается цветной вышивкой); юбка - продольнополосатая либо клетчатая, в отдельных районах с пришитым лифом; наплечные покрывала виллайне и белые, в некоторых районах с богатой вышивкой (например, восточнолатвийский тип). Девичий головной убор - красный венок, вышитый стеклянным бисером (в северной Видземе - красные шерстяные ленты для волос). Головным убором замужних женщин служили белые вышитые чепцы башнеобразной формы и зимние шапки (цветные таблицы $31-33$ ).

Л а т г а в ски й комплекс сформировался на территории, которую в древности населяли латгалы. В отличие от видземского, он испытал сильное влияние соседних народов - русских, белорусов, поляков. Основные отличительные черты латгальского комплекса: туникообразная рубаха с нашитыми наплечниками с красным браным узором или красной вышивкой, клетчатая (в северной части Латгале - белая) юбка, виллайне - восточнолатвийского типа, но с синезеленой цветовой гаммой. Широкое распространение имели льняные наплечные покрывала «снатене» (snātene). На голове латгальские девушки носили красный вышитый бисером венок, замужние - полотенчатый головной убор, кото- рый в Латгале назывался galvas auts (цветная таблица $34,1-3)$.

Третий комплекс - аугш зе м ск и й - характерен для территории, на которой прежде обитали селы. Отдельные элементы аугшземского комплекса обнаруживают сходство с латгальским, видземским, а в иных случаях - земгальским комплексами. Тем не менее аугшземский комплекс следует выделять как особый тип, так как только на этой территории распространена рубаха с прямыми поликами. Туникообразные рубахи встречаются лишь на границе с Видземе. Рубахи украшались цветной, обычно красной вышивкой. Юбка была клетчатая или со светлыми полосами и крапинками, получавшимися при тканье благодаря особому способу окраски пряжи (при крашении пряжу туго перетягивали в определенных местах бумажными нитками, в результате чего эти места оставались неокрашенными). На праздники обязательно носили передник. Виллайне в Аугшземе - восточнолатвийского типа, но с более яркой вышивкой. Головным убором замужних женщин служил «наматс» (namāts) (цветная таблица $34,4-6$ ).

Распространение четвертого - земгальского-комплекса совпадает в основном с территорией расселения древних земгалов (цветная таблица 35). Его характерные признаки: туникообразная рубаха с наплечниками или без них, со своеобразной белой вышивкой; юбка клетчатая или полосатая с особым браным узором («цветочным»); виллайне - с богатой тканой каймой, без вышивки; головной убор шелковый платок, который девушки и замужние женщины носили по-разному: женщины завязывали под подбородком, а девушки - сзади.

Пятый - курз е м с к й - комплекс характерен для территории, которую прежде населяли курши и ливы. Следует отметить, что курземские ливы в процессе ассимиляции значительно дольше сохраняли присущую им специфику, чем видземские, что нашло отражение в народной одежде. Кроме того, в Курземе дольше сохранялись очень древние традиции народной одежды, так как эта часть Латвии по сравнению с другими меньше подвергалась военным опустошениям. Курземский комплекс народного костюма характеризуют украшения рубах, густо-синие виллайне, декорированные металлом, металлические пояса, металлические венки или венки из ткани на твердом каркасе, вышитые бисером, юбки с яркой гаммой красок. Курземский комплекс одежды сохранялся особенно стойко, в некоторых районах - вплоть до середины XX в. (цветные таблицы 36-38).

Мужская одежда на всей территории Латвии по сравнению с женской была гораздо более однообразной. Она состояла из кафтана - короткого, полудлинного или длинного, рубахи, штанов, носков, постол или сапог, пояса, шапки, шарфа и перчаток. 
Начиная со второй половины XIX в. женская народная одежда (мужская - еще раньше) заменяется одеждой, сшитой из покупных тканей по городской моде. В виде исключения можно назвать Ницскую, Бартскую, Руцавскую и Алсунгскую волости на юго-западе и западе Курземе, где народный костюм сохранялся кое-где даже в середине XX в.

Автор делает попытку на материалах одежды проследить культурно-исторические связи латышей с соседними народами (литовцами, эстонцами, восточными и западными славянами). В первую очередь такие связи можно наметить на примере туникообразной рубахи с тремя ее вариантами - без наплечников, с нашитыми наплечниками и с прямыми плечевыми вставками.

Туникообразная рубаха без наплечников, являющаяся самым древним видом рубах, в XIX в. сохранялась в Курземе и Земгале, встречалась также в южной части Эстонии (Халлисте) и на острове Муху. В Литве рубаха такого рода в XIX в. встречалась реже. Туникообразные рубахи с нашитыми наплечниками, являющиеся самым распространенным видом, встречаются в Прибалтике повсюду, но имеют значительные различия по отдельным областям. Например, у латышских рубах в Видземе - большой отложной воротник, отделанный белой мережкой, в Латгале-стоячий воротник и красный браный узор и т. д. Этот вариант рубах характерен также и для эстонской народной одежды, а в Литве он являлся почти единственным до конца XIX в. (за исключением Клайпедского округа и некоторых мест Аукштайтии) .

Туникообразная рубаха с прямыми плечевыми вставками (третий вариант) встречается только в Латвии - в южной части Видземе и прилегающей к ней Аугшземе. Автору не удалось найти аналогий этому варианту у соседних народов, за исключением нескольких финских мужских рубах из коллекций Этнографического музея народов СССР в Ленинграде. Вариант с прямыми плечевыми вставками является более новой формой по сравнению с двумя предыдущими. По-видимому, его можно считать переходной формой от туникообразной рубахи к рубахе с прямыми поликами. На это указывает прикрепление плечевых вставок в рубахе Крустпилсского округа и соединительный шов-узор на рубахах с прямыми поликами в Аугшземе. На вероятную близость третьего варианта к рубахе с косыми поликами указывает покрой рукава с большим клином, характерный для крустпилсской рубахи и русских женских рубах с косыми поликами из Мещерского края и южнорусских областей. Не случайно этот вариант туникообразной рубахи встречается именно в тех районах, которые лежат между Видземе и Латгале и население которых общалось со славянами.

Рубаха с прямыми поликами в Прибалтике характерна для населения юго-восточных частей территории - Аугшземе и Аукштайтии, а также для жителей части побережья - района Руцавы и Клайпедского края. Рубахи такого типа известны у поляков, украинцев, белорусов и русских; Б. А. Куфтин считает этот тип характерным для русской женской рубахи. В латышских народных песнях прямые полики называются «польскими ластаугами». Термин «ластауги» похож на русское слово «ластовицы», которое является синонимом термина «полики». В польском языке констатировать этот термин не удалось, но рубаха с прямыми поликами является одной из наиболее распространенных в Польше. Надо полагать, что название «польские ластауги» в Аугшземе появилось не случайно, а перешло вместе с покроем рубахи. Близость к польской рубахе обнаруживается и в такой детали, как сборчатый ворот с узором. В Латвии такие вороты носили только в Аугшземе. Однако по расположению орнамента аугшземская рубаха ближе к белорусской и украинской.

В Прибалтике рубахи с прямыми поликами встречаются в двух вариантах. У первого варианта плечевая вставка пришивается к основным полотнищам по утку, а у второго - по основе. «Утковый». вариант является единственным видом женских рубах Аугшземе и района Лиелварде, а вместе с туникообразной рубахой он встречается в восточной части Литвы. Возможность четкого выделения ареала распространения рубах этого типа в Латвии дает основание полагать, что они появились у латышей в результате общения со славянами и представляют более новый тип по сравнению с туникообразной рубахой. Второй вариант рубахи с прямыми поликами в Латвии был известен в районе Руцавы. Но он встречался также и на Западной Украине, у южных славян и у поляков юго-восточной части Краковского воеводства. Известен он и в Литве, в Клайпедском крае, но здесь полик иногда выкраивается вместе с рукавом, однако плечевой узор остается на обычном месте-там, где прежде проходил шов. Рубахи такого рода называются «бесполиковыми». Судя по виду ткани и технике вышивки, можно предположить, что в окрестностях Руцавы рубаха с прямыми поликами второго варианта бытовала одновременно с туникообразной рубахой первого варианта, которая во второй половине XIX в. сменилась туникообразной рубахой второго варианта. Вопрос о том, как мог здесь появиться этот тип рубахи (рубахи с прямыми поликами, пришитыми по основе) и почему он бытовал только в пределах этой весьма ограниченной территории, пока выяснить не удалось, но возможно, что он связан с одеждой лужицких славян.

Несшитая поясная одежда была зафиксирована в Латвии И. Брандом в XVII в., она встречалась и в XVIII в., а некоторые пережиточные формы ее - и в XIX в. Аналогичной формы поясная одежда была известна в XVII-XVIII вв. под 
названием «маргине» (marginè) у литовцев, «сыба» (sõba), «кырик» (kõrik) и «паллапооль» (pallapool) - у эстонцев и «хурстут» (hurstut) или «урск» (ursk) у прибалтийских финнов. В латышском языке особого термина для обозначения несшитой одежды до наших дней не сохранилось, но аналогичной формы женскую одежду в конце XIX в. в Випской волости под Крустпилсом называли «прошавой». Прошаву носили молодые девушки и даже невесты. Она была синего цвета и состояла из двух кусков ткани. Каждый кусок наполовину прикреплялся складками к поясу, а оставшиеся свободные концы обоих кусков, так наз. «ножницы»- «шкерес» (šḳēres), запахивались и застегивались на боках; кроме тoro, их расшивали бисером. Таким образом, хотя прошава и не была сшита на боках, ее полотнища не распахивались, а вшитые «шкерес» служили также и украшением. Несшитая поясная одежда несколько иного типа видна на рисунке И. Бротце, изображающем свадьбу в Видземе. У этой одежды спереди - закругленные углы, а по краям она, по-видимому, обшита бахромой. Только сзади она достигала длины рубахи, тогда как спереди большая часть рубахи оставалась незакрытой. Сходного типа поясная одежда встречается и на рисунках XVI в.

Литовский термин «маргине», обозначающий несшитую поясную одежду, о которой говорит Бранд - автор XVII в., встречался в Латвии еще в XIX в. в окрестностях Руцавы как название особого типа покрывала. Кроме того, в Руцаве, как и в некоторых районах Литвы, термином «маргине» («маргене») обозначается покрывало, которое носят на бедрах, перебрасывая концы его через левую руку и застегивая их круглыми пряжками - сактами. Следует полагать, что такой способ ношения покрывала сохранился со времени бытования несшитой поясной одежды. На эстонском материале мы также можем убедиться в том, что несшитая поясная одежда и наплечное покрывало носили одинаковые местные названия. Это подтверждают другие факты: тип ткани «маргене» очень сходен с темно-синей в цветную клетку тканью понев южных великорусов. Понева является несшитой поясной одеждой, известной у вятичей и кривичей уже в XII в. О том, что руцавская маргене была несшитой юбкой, свидетельствует особая нашивка из зеленых лент по подолу маргене с небольшой прорехой в конце шва. Узорами и отделкой (лентой) маргене очень похожа на несшитую поясную одежду, которая в середине $\mathrm{XIX}$ в. зафиксирована экспедицией А. Шегрена в окрестностях Бауски у так наз. криевиней потомков вотяков или ижорцев, поселенных здесь B XV B.

Ограниченность материалов не позволяет выделить отдельные типы и выявить локализацию несшитой поясной одежды в Латвии. Однако. несомненно, что такая одежда предшество- вала юбке и постепенно исчезала из обихода, но довольно долго сохранялась в качестве праздничной одежды.

Общей для народов Прибалтики наплечной одеждой является покрывало - «сыба» (sõba) или «кырик» (kõrik) у эстонцев, «дробуле» (drobulè) или «скара» (skara) у литовцев, «виллайне» (villaine) или «снатене» (snātene) у латышей. Археологические материалы показывают, что наплечные покрывала были известны народам Прибалтики уже в VIII в. Старинные украшения покрывал делались из бронзовых спиральных пронизок. Бронзовые пронизки были характерным украшением одежды балтийских и финских народов в эпоху первобытнообщинного строя. Развитие форм и украшение покрывал в начале XIX в. также являются обшими для всей Прибалтики, хотя мотивы орнаментики и техника вышивки в разных местах различны.

Переходной формой от несшитой наплечной одежды к сшитой можно считать своеобразные латышские покрывала-пелерины «пуссварцис» (pussvārcis) в виде юбки из шерстяной домотканой ткани. Термин «пуссварцис» показывает, что эта одежда когда-то была длинной и, по всей вероятности, покрывала всю фигуру, но в настоящее время ею покрывают только верхнюю часть тела. Время появления и распространения такого вида наплечной одежды пока сколько-нибудь точно установить не удалось. Некоторые данные позволяют предполагать, что пуссварцис в Латвии был известен уже в XVI в. Ношение такой одежды в конце XVIII и середине XIX в. зафиксировано на рисунках И. Бротце и Т. Гельхара. В настоящее время пуссварцис бытует в северной части Курземе, где его носят вместо плаща в дождливую погоду. По рассказам информаторов, такого рода одежда еще в начале XX в. была известна и в северной части Видземе. Таким образом, в XIX в. пуссварцис носили в некоторых районах Курземе и Видземе - в тех местах, где жили предки ливов. На остальной территории Латвии пуссварцис неизвестен. Можно было бы предположить, что такая одежда была типичной составной частью ливского костюма. Однако аналогичная наплечная одежда имеется в польском народном костюме. Она типична для центральных и западных областей Польши. Польское название такой накидки (zapaska) обозначает также и поясную одежду. Польская «запаска» отличается от пуссварциса тем, что она похожа на передник, тогда как пуссварцис имел вид юбки. Пока не удалось установить, была ли такого рода одежда у литовцев, но все же надо полагать, что район ее распространения охватывал побережье Балтийского моря; по-видимому, это был древний вид одежды.

Следует отметить, что одежда народов Прибалтики во многих своих формах и наименованиях близка к одежде их соседей, в особенности 
русских и белорусов. Это можно сказать, напрнмер, о полотенчатом головном уборе типа белорусской «наметки» («наматс»у латышей, «нуометас» у литовцев, «лынник» у эстонцев). Бытуют русские термины: армяк, сермяга и др. Особенно много черт, общих с русской одеждой, обнаруживает одежда сету (население юго-востока Эстонии) и латгальцев, а с одеждой белорусов - одежда южных и восточных литовцев.

Определенное значение для развития народной одежды в западной части Латвии и Эстонии имели связи со Скандинавией. Шведские элементы проявляются главным образом в одежде на эстонских островах и в северо-западной части Эстонии (головные уборы и некоторые виды орнамента), а также в Курземе (юбки с глухим лифом и пряжки «книепкенс»). Немецкие элементы проникли в латышскую и эстонскую народную одежду в более позднее время, причем они исходили главным образом из имений и, соответственно, были связаны с одеждой городского типа, а не с одеждой немецких крестьян.

Таким образом, можно констатировать, что в одежде и ее орнаменте прослеживается древнее родство латышей и литовцев. Особенно ярко это видно на примерах литовских костюмов из Жемайтии и Аукштайтии и латышской одежды из южной Курземе, Земгале и Аугшземе. У латышей и литовцев много общих черт в материале, покрое и расцветке народного костюма, встречаются одни и те же элементы одежды, есть общность в расположении и характере вышивок. Общие черты в одежде латышей и литовцев обусловливаются не только этнической общностью этих двух народов, но и смешанностью населения пограничных районов.

Родственный характер латышской и эстонской одежды прослеживается в двух районах во-первых, в северной Видземе и южной части Эстонии и, во-вторых, в западной Курземе и западной части Эстонии и на островах. Если связи северной Видземе и южной части Эстонии возникли вследствие общности исторических судеб, то в курземском народном костюме прослеживаются остатки влияний ливов, наиболее близких к древним эстонцам племен, частично влившихся потом в состав как латышского, так и эстонского народа.

Латышско-славянские культурные связи наиболее ярко проявляются в комплексах народных костюмов Латгале и Аугшземе. Эти связи - результат сравнительно позднего контакта. Однако отдельные элементы одежды - несшитая поясная одежда, узкие тканые пояса, женские головные уборы и лапти - свидетельствуют и о более древних культурных связях между славянскими, балтийскими и финно-угорскими народами.

В заключении монографии рассматриваются изменения, происшедшие в латышском народном костюме во второй половине XIX и первой половине XX в.
В условиях быстрого роста капитализма в Латвии, начавшегося после отмены в России крепостного права, традиционный народный костюм стал выходить из употребления. Проникновение капиталистических отношений в деревню изменило роль женщины в производственном процессе. В связи с развитием животноводства, молочного хозяйства, а также с расширением производства технических культур в сельском хозяйстве возникла большая потребность в женской рабочей силе. Женщины уже не имели возможности тратить время на изготовление праздничной одежды домашним способом и предпочитали фабричные изделия. В связи с этим возросло значение сельских портных (их труд оплачивался большей частью продуктами), которым заказывали праздничную одежду из тканей фабричного производства. Однако будничную одежду вплоть до середины ХХ в. в отдельных местностях (Латгале и Курземе) продолжали шить дома из домотканого материала. При этом подготовка материала - обработка шерсти, сукноваляние, чесание и крашение - часто производилась на фабриках. Все большее общение с городским населением способствовало распространению в латышской деревне городской одежды.

Национальный костюм выходил из употребления не одновременно повсюду, а постепенно, по отдельным районам в зависимости от их экономического развития и связи с городом. В конце XIX в. традиционный национальный костюм еще встречался в западной части Курземе, в Аугшземе и Латгале. Но и в областях, где национальный костюм сохранялся дольше, он все же не оставался без изменений. Изменялся главным образом материал (кофта из окрестностей Алсунги), другим стал цвет одежды вследствие применения химических красок (юбки в районе Ницы, Алсунги и др.), появился новый покрой (северовидземские платья-сарафаны), изменилась отделка (рубашки с покупными кружевами).

Иной характер носили изменения, связанные с попытками стилизации народного костюма для хоровых и танцевальных коллективов к праздникам песни. Таким образом возник модернизнрованный народный костюм: юбки и жилетки из черного бархата, маленькие передники, на которых вышивались куплеты народных песен; рубашки, украшенные кружевами; бархатные венки со слащавым изображением восхода солнца; пояса, вытканные из шелковых ниток, с упрощенной композицией орнамента. Этот псевдонародный костюм сохранился и после этнографической выставки 1896 г., на которой экспонировались подлинные образцы традиционного латышского народного костюма. После 1905 г. латышская буржуазия пыталась приспособить традиционный национальный костюм к господствовавшей тогда моде на сентиментальный немецкий стиль. Но эта попытка имела гораздо мень- 
ший успех. В печати стали появляться статьи и рисунки, пропагандировавшие подлинные этнографические музейные материалы по народной одежде латышей.

Далее автор подробно останавливается на использовании форм и узоров традиционной народной одежды в годы существования буржуазной Латвии и в советский период. Рассматриваются также попытки стилизации традиционного народного костюма. Автор не дает подробного описания и анализа современной городской одежды, которая бытует в Латвии, потому что этот вопрос требует специального изучения, что не входит в задачи данной монографии.

Стремление модернизировать и стилизовать народный костюм особенно настойчиво проявлялось в Латвии в годы буржуазной диктатуры. В 1929 г. на VI празднике песни среди традиционных народных костюмов были представлены костюмы со шнурованными жилетками, вышитыми передниками. Появились покрывала, украшенные большими грубыми узорами, расшитые цветными нитками кофты, короткие юбки с цветными полосами на белом фоне (чего никогда не было в традиционном латышском костюме), низко повязанные пояса, бархатные лентообразные венки. Получила также распространение новая манера ношения виллайне на одном плече. Что касается использования национальных традиций в одежде, то при капитализме это сводилось к воспроизведению отдельных элементов орнамента традиционного народного костюма на вязаных изделиях, причем в этих рисунках отражались особенности узоров старинной одежды отдельных областей Латвии.

Современная латышская одежда сельского населения мало отличается от той, которую носят в Риге и в других городах Латвийской ССР, но «последние крики» моды на селе, естественно, распространяются с некоторым запозданием. Изучение современной одежды показывает, что в основных ее элементах сохраняются традиционные национальные черты, которые возрождаются теперь в новой форме. Наиболее стойко национальные традиции сохраняются в орнаментировке и расцветке тканей. Народный костюм служит неисчерпаемым источником для моделирования современной одежды. Орнамент народного костюма широко используется для украшения одежды, для подбора цвета и рисунка при изготовлении фабричных тканей. Подобным же образом традиционный народный костюм используется в Эстонской и Литовской ССР.

Традиционный народный костюм надевают участники праздников песни. Однако нельзя не отметить новой попытки стилизации, которую допустил Дом народного творчества Латвийской ССР при подготовке к празднику песни Советской Латвии в 1955 г. Костюмы, созданные художниками к этому празднику, не отвечали народным традициям; в этом сказывалась недооценка художественного значения традиционного народного костюма. Благодаря более тщательной подготовке выставки народной одежды в 1958 г. и усиленной пропаганде правильного использования народного костюма на празднике песни в 1960 г. в последнее время тенденция к стилизации народной одежды значительно ослабла. В 1965 г. на праздник песни в честь 25летия Советской власти в Латвии костюмы были изготовлены в соответствии с традиционной народной одеждой. Богатейшее наследие народного творчества, которое мы находим в народной одежде, не только используется при изготовлении праздничных костюмов для участников художественной самодеятельности, но и способствует обогащению современного прикладного искусства и успешно применяется при моделировании и украшении современной одежды. Здесь не только возможно, но даже необходимо предоставить полную свободу в деле использования старых народных мотивов, в искусном и смелом их развитии.

\section{СПИСОК ИЛЛЮСТРАЦИИ В ТЕКСТЕ}

1. Районы, в которых автор собирал материалы (1951-1963 гr.).

2. Экспедиции, организованные Музеем истории Латвийской ССР.

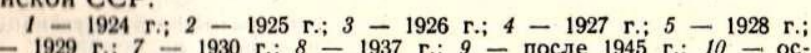
тальные (отдельные выезды и т. п.).

3. Места зарисовки одежды латышей в работах авторов XVIII и первой половины XIX в.

4. Одежда латышских крестьян первой половины XVIII в. (деталь на карте Барникеля 1747 г.).

5. Реконструкция одежды латышской (латгальской) женщины XII в. Музей истории Латв. ССР.

6. Комплексы одежды латышей и их локальные варианты в начале XIX в.

1 - западная Видземе; 2 - северная Видземе; 3 - Пиебалга; 4 - Лиелварде; 5 -. Крустпило; 6 - востонная Видземе; 7 - юж-
11 - северная Курземе; $12-$ Вентспилс; 13 - Алсунга; $14-$ КулНица, Барта, Руцава)

7. Мануфактуры и фабрики в Латвии в XVII - первой половине XIX в.

1 - сукноткацкие; 2 - льноткацкие; 3 - хлопчатобумажные; 4 - мастерскне по обработке янтаря; 5 - сукновальни; 6 - сте кольные; 7 - мастерские по производству обойных тканей; 8 - кожевенные.

\section{8. Техника изготовления тканей}

1 - полотняное переплетение; 2 - репсовое переплетение; 3 - саржевое переплетение; 4- -узорчатый сарж; 5 - переплете ние типа букле; 6 - атласное переплетение; 7 - узорный атласдрелль.

9. Орудия прядения и ткачества. $1-4-$ мотовила; 5 - орудия труда сельского портного;
$6-7-$ прялки; $8-$ ткацкие станки. 
10. Образцы мережки.

1 - наплечник (Земгале); 2 - воротник рубахи (Земгале); 3 - воротник рубахи (Вентспилс); 4 - манжет рубахи (Вентсрубахи (Лутрини); 7 - рубаха (Талсы); 8 фрагмент наплеч. ника (Аугшземе).

11. Образец браного узора.

1,2 - узор кромки полотенчатого головного убора замужней женщины (Аугшземе) (материалы сектора этнографии Ин-та истории АН Латв. ССР); 3, 4- узор виллайне (южная Курземе) (Лиепайскнй краеведческий музей).

12. Образцы перевитого узора (материалы Рижского училища прикладного искусства — РУПИ).

1 - манжет рубахи (Земгале); 2 - фрагмент узора мужской рубахи (Ренда); 3,4 - перевить в рукавах рубахи (Земгале).

13. Образец техники вырезом (рубаха из Руцавы) (Лиепайский краеведческий музей).

14. Образцы узора крестом.

1 - руцавский жкрумс»; 2 - орнамент воротника рубахи из Кулдиги (материалы рУПИ).

15. Головной убор замужней женщины из Видземе в начале XVII в. (по карте 1612 г., см. J. Chr. Brotze. Monumente..., III, 83).

16. Виллайне из Вентспилса (материалы Музея истории Латв. ССР).

17. Виллайне из Талсы (материалы Музея истории Латв. ССР).

18. «Машинная строчка» в орнаменте мужских кафтанов из Курземе (материалы Музея истории Латв. ССР)

19. Узоры из бисера и блесток на венках.

20. Тюлевые украшения на женских головных уборах

21. Цветочный орнамент в вышивках рубах. пилс.

1 - Руцава; 2 - северная Латгале (Шкилбены); 3 - Круст-

22. Образцы украшений шнуром.

23. Рабочая одежда (J. Chr. Brotze. Monumente.... III, 91).

24. Крестьянки из имения Мазсалаца на уборке сена (по материалам из фондов Русского географического общества).

25. Типы покроя рубах.

1 - туннкообразная без наплечников; 2 - туникообразная с на шитыми наплечниками; 3 - туникообразная с прямыми наплеч ными вставками; 4 - рубаха с прямыми поликами, пришитым по утку; $5-$ рубаха с прямыми поликами, пришитыми по основе

26. Типы сборок на воротниках и манжетах.

1. Аугшземская рубаха с вышивкой по присборенному вырезу

(материалы руПИ).
2. Сборки на манжетах занавикской рубахи из Литвы (Sodžiaus menas, 7-8. Kaunas, 1939 , рис. 79,80 ).

3. Присборенный нижний конец рукава из Люблина (Hafty zdobienie stroju ludowego. Warszawa, 1955, Nr. 66).

27. Рубахи с прямыми поликами, пришитыми по основе.

1. Рубаха из Руцавы (Лиепайский краеведческий музей, №167) 2. Литовская рубаха из окрестностей Клайпеды (Sodžiaus menas, 7-8. Kaunas, 1939, рис. 409).

3. Украинская рубаха (Музей этнографии и художественного промысла в Львове, ЕП, 20734)

28. Сцена видземской свадьбы (J. Chr. Brotze. Monumente ..., III, 10).

Нижняя деталь - свадебная гостья в несшитой поясной одежде.

29. Зарисовки ливонской женской одежды XVI в. (из альбома Брейна).

30. Распространение типов юбок (по материалам Мyзея истории Латв. ССР).

1 - полосатые; 2 - клетчатые; 3 - узорчатые; $4-$ в орнаментированную полоску (Земгале, Ница); 5 - алсунгский; 6 узорчатой каймой (северная Латгале, Барта, Руцава).

31. Женщины из Пиебалги (J. Chr. Brotze. Monumente..., VII, 66).

32. Типы покроя мужских штанов.

1 - штаны с отдельно кроенной и собранной в сборку спи ной; 2 - штаны с застегивающимся клапаном; 3 - штаны с цельной, 2 - штаны с застегвающимся клапаном, з - штаны с цел ным полем и разрезом спереди, 4- штаны с разделенным поя сом, завязываемые сзади шнурком; 5 - штаны с большим клином 6- жланы с малым клином, 7 - штаны с калошами, сшитыми из 9 - полудлинные штаны.
33. Пояса (материалы Музея истории Латв. ССР).

1 - металлические пояса; 2-4 - кожаные пояса с металлическими пряжками.

34. Бисерные пояса (материалы Музея истории Латв. CCP)

35. Тканые пояса латышей, литовцев и эстонцев.

Латышские пояса: 1 - Аулея; 2 - Қапини; 3 - Макашены; 4 - Крустпилс. 5, 6 - литовские пояса (материалы Вильнюсского музея истории и этнографии). 7 - эстонские пояса (Эстонская на родная одежда. Таллин, 1960, табл. 55)

36. Пояса, тканые на дощечках.

1 - кайма; 2 - пояса, предназначенные для подарков.

37. Тканье поясов:

1 - на бердечке, 2 - на пруте.

38. Женская одежда XVI в. с передником.

39. Аугшземский передник (материалы сектора этнографии Ин-та истории АН Латв. ССР).

40. Виды наплечных покрывал (виллайне) первой половины XIX в. (по материалам Музея истории Латв. ССР).

1 - восточнолатвийский; 2 - земгальский; 3 - западнокур земский; 4 - южнокурземский; 5 - белые виллайне; $6-$ синие виллайне; 7 - талсинские виллайне; 8- льняные покрывала «snatenes*.

41. Наиболее распространенные виды виллайне и их названия в первой половине XIX в. (по материалам Музея истории Латв. ССР).

42. Схемы типов виллайне.

1 - восточнолатвийский; 2 - южнокурземский; 3 - северокурземский; $4-$ земгальский.

43. Южнокурземские виллайне (материалы Лиепайского краеведческого музея).

$I$ - способ ношения; 2, 3 - Перконе; $4-$ Медзе; 5 - Руцава.

44. Крустпилсское наплечное покрывало с орнаментом в углу (материалы РУПИ).

45. Кабильские виллайне (Лиепайский краеведческий музей)

46. Пиебалгская виллайне (материалы РУПИ).

47. Белая виллайне с бахромой (материалы РУПИ).

48. Льняные наплечные покрывала (snātenes) (материалы РУПИ).

1 - Прейли; 2 - Видсмуйжа; 3 - Праулиена; 4 - Ясмуйжа.

49. Клетчатые виллайне (материалы Балтийской экспедиции).

1 - Вентспилс; 2 - Видземе; 3 - Аугшземе; 4 - Скрунда; 5 - Земгале; 6 - Алсунга

50. Наплечная одежда в виде юбки «pussvārcis».

1. Толока в Страупском приходе (J. Chr. Brotze. Monumente.... VIII, 4). Женщина на переднем плане, женщина, стоящая за телегой, и женщина слева носят «pussvärcis»

2. Крестьяне Бириньской волости (J. Chr. Brotze. Monumente...

91). «Pussvärcis» носят две женщины справа.

3. Ливская наплечная одежда (акварель А. Пецольда из архива Русского географического общества).

51. Наплечная одежда «pussvärcis»

(материалы Балтийской экспедиции 1954 г.).

1 - схема; 2 - узор (черными полосами обозначена темнокоричневая окраска, поперечной штриховкой - темно-желтая, белыми полосами - светло-серая).

52. Кофты.

1 - земгальская женская кофта, безрукавка (nieburs), пуговицы; 2 - видземская кофта, внизу - покрой «ушек» на спине.

53. Курземские кофты (материалы Лиепайского краеведческого музея).

1 - Ница; 2, 3 - Алсунга.

54. Безрукавки (nieburi) из южной Курземе (материалы Лиепайского краеведческого музея).

55. Мужское пальто из Ясмуйжи (РУПИ).

56. Видземские мужские кафтаны.

1, 4 - Крустпилс; 2, 5 - Ляудона; 3 - Лиезере; 6 - Пиебалга; 7 - Браслава; 8 - Мадлиена; 9 - Цесвайне; $10-$ Эргеме; 11,14 - Мазсалаца; 12 - Алуксне; 13 - Гулбене; 15 - Вецсалаца; 16,17 - Рунена. 
57. Латгальские мужские кафтаны.

1 - Лудза; 2 - Рундены (синие), 3 - Рундены (белые);

4 - Рундены (темно-синие); 5 - северная Латгале.

58. Мужские кафтаны из центральной и восточной части бывш. Курляндской губернии.

1, 2 - Аугшземе; 3, 4 - Земгале.

59. Курземские мужские кафтаны.

1 - Алсунга; 2 - Тукумс; 3, 4 - Талсы; 5, 6 - Вентспилс;

60. Короткая шуба из окрестностей Екабпилса (по зарисовке О. Гуна - ЦГИА Латв. ССР, ф. 6840 , оп. 1 , д. 62 , л. 230$)$

61. Девичьи прически.

Слева - рисунок Х. Брюгген «Мария из Ледурги», справа рисунок И. Бротце (Monumente..., III, 87).

62. Мужские прически.

1-3 - акварели А. Пецольда из архива Русского географического общества; 4 - рисунок Х. Брюгген «Ян Индриксон».

63. Способы повязывания платков.

I - акварель А. Пецольда; 2 - по эскизу художника А. Алксниса; $3-5-$ повязывание платков в Курземе (материалы Лиепайского краеведческого музея)

64. Распространение разных типов головных уборов девушек.

1 - красные твердые венки; 2 - шерстяная лента «mataukla», шелковые ленты «kaspines», ленты; 3 - красные мягкие венки; 4 - черные мягкие венки; 5 - синие или серые мягкие венки; 6 - металлические венки «spangu vainagi»; 7 - венки из конского волоса; 8 - шелковые платки.

65. Схемы венков.

I - металлические венки «spangu vainagi», Кулдига, Алсунга, Вентспилс; 2 - Крустпилс; $3-$ южная Латгале; $4-$ Цесвайне; 5 - Юмурда; 6 - Праулиена; 7 - Вецдрусты; 8 - Цесис - Вайве; 9 - Яушпиебалга: 10 - Дигная: 11 - Тылжа; 12 - Лиелварде; 13, 14 - Илуксте; 15 - шерстяная лента \&mataukla», Рунена; 16 - пенок из конского волоса, Руиена; 17 - Аугшземе; 18 Талеы; 19 - Скрунда - Айзпуте; 20 - Алуксне; 21 - северная видаес 22 - шелковая лента кkaspine» рущава: 23 - венок непесты, украшенный блестками, Попе; 24 - Вайнёде; 25 - венок невесты, украшенный блестками, Лиепая; 26 - Ница - Барта.

66. Женские полотенчатые головные уборы.

1 - схема головного убора из Аугшземе; 2 -- орнамент и кайма головного убора из Аугшземе; 3,4 - кайма головного убора из Ясмуйжи.

67. Способы повязывания полотенчатых головных убоpоB.

I-3 - Латгале; 4 - налобник; 5 - Аугшземе.

68. Способы повязывания платка и полотенчатого головного убора в Курземе.

1 - Алсунга; 2 - Кулдига; 3 - Земгале; 4 - Вентспилс; 5 - восточная Курземе; 6 - Руцава.

69. Чепцы и шапки замужних женщин.

I - Земгале; 2 - Алсунга; 3 - Крустпилс; 4 - Варкава; 5 - северная Курземе; 6 - Нурмуйжа; 7 - Цесис; 8 - Лиелварде; $9-$ Вецпиебалга; $10-$ Рига; 11 - Валмиера; 12 - восточиаи Видземе: 13 - Смилтене; 14 - Кабиле; 15 - Сайкава; 16 - Барта; 17 - Ница; 18 - Приекуле.

70. Женские головные уборы из Гауиены (J. Chr. Brotze. Monumente...,VI, 5).

71. Мужские зимние шапки.

I - Дундага; 2 - Латгале; 3 - Друсты; 4 - Сауснея; 5 - Алсунга; 6 - Пиебалга.

\section{2. Мужские шапки.}

1 - Видземе (также и Земгале); 2 - Лиезере; 3 - Земгале; 4 - соломенные шапки (по всей Латвии); 5 - Рига; 6 - Алсунга; 7 - Пиебалга.
73. Повязывание обор.

1 - Друсты; 2 - постолы из недубленой кожи с кистями 3- Эргеме; 4 - Сауснея; 5 - Тирза; 6 - лапти.

74. Типы лаптей.

1 - распространенные по всей Латвии; 2 - только в Латгале.

75. Женские туфли во второй половине XIX в.

76. Обувь.

1 - женские туфли из Латгале, Видземе и Аугшземе; 2 женские туфли из Земгале; 3 - женские туфли из северной Видземе; 4 - женские туфли из Латгале и Видземе; $5-$ женские земе, 4- женке туфли из Латале и Видеме; 5 - женские туфли и цавы; б мужские туски

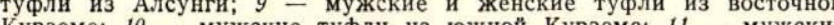

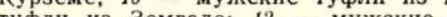

77. Шейные украшения.

1 - бусы из Земгале; 2 - ожерелье из монет из Печор (материалы Музея истории Латв. ССР) (такое же ожерелье из монет упоминает И. Бротце в описании лиелвардского костюма).

78. Видземские сакты.

1-3 сакты для рубах из Крустпилса; 4, 5 - сакты для виллайне из Крустпилса $(1: 2) ; 6,7-$ восточная Видземе; $8-$ Крустпилс; 9 - Лиелварде.

79. Земгальские и аугшземские сакты.

1, 2 - сакты для рубах из Земгале; 3, 4-сакты для рубах из Аугшземе; 5, 6 - сакты для виллайне из Земгале; 7 - реконструкция сакты из Екабпилса по зарисовке О. Гуна; 8 - сакта для виллайне из Аугшземе.

80. Курземские сакты.

$1-3$ - сакты для рубах из Вайнёде; 4-6 - сакты для рубах из Лиепаи; $7-9-$ сакты для рубах из северной Курземе; 10 - Алсунга; 11 - Сака; 12 - Айзпуте; 13,14 - окрестности Лиепаи.

81. Курземские сакты. путе.

1 - восточная Курземе; 2 - Скрунда; 3 - Руцава; 4 - Айз-

82. «Сакта с пузырями» из Крустпилса (материалы РУПИ) .

83. Латгальские сакты.

1 - «сакта с венками»; 2 - сакты для рубах.

84. Сакта с подвесками из Крустпилса (материалы РУПИ)

85. Янтарные сакты (материалы музея истории Латв. $\mathrm{CCP})$

86. Эстонские сакты.

1 - Северная Эстония; 2 - островная часть; 3 - Западная

87. Латгальская одежда.

1, 2 - Виляка (J. Chr. Brotze. Monumente ..., VIII, 76; VII, 128); 3 - окрестности Даугавпилса ([G. Manteuffel]. 'Polnisch Livland. Riga, 1869, S. 34).

88. Мужская одежда из Алсунги.

89. Мужская одежда из южной Курземе (фото Ф. Бривземниека).

1 -3 - окрестности Лиепаи, около 1869-1870 гг.; 4 - Ница, около $1869 \mathrm{r}$.

90. Женщины из Руцавы (фотография сделана на празднике песни 1910 г. в Риге).

91. «Латышская девушка из Ницы в 1896 г.» (копия с фотографии В. Сизова, подаренная Дашковскому этнографическому музею). XIX B.

92. Прибалтийский женский костюм первой половины

1 - женщина из Южной Эстонии; 2 - латышская девушка из Видземе; 3 - литовская женщина из Аукштайтии. 


\section{T A B U L A S ТА Б ЛИЦЫ}

\section{1. tabula}

Izšuvumi krāsaino darbu tehnikās. Svītru dūriens un spodršuvums: 1 - Cesvaines villaine (CVVM). Svītru dūriens un krustdūriens; 2 - Nautrēnu villaine (CVVM). Svìtru dūriens; 3 - Balvu mutauts (ZA Etnogrāfijas sektora materiāli); 4 - Dignājas krekla piedurknes gals (CVVM); 5 Cesvaines krekla piedurknes gals (CVVM);6-Cesvaines krekla apkakle (CVVM); Dignājas krekla piedurknes gals (CVVM).

\section{2. tabula}

Krekla apkaklu un aproču rotājumi ar krāsaina diega un stikla zillišu izšuvumu: $1-3-$ Alsungas krekla apkakles (RLMV); 4-Alsungas krekla aproce (RLMV); 5 - Krustpils krekla apkakle (RLMV); 6 - Augšzemes krekla apkakle (RLMV); 7 - Kuldīgas krekla apkakle (RLMV).

\section{3. tabula}

Darba apgēèrbi: 1 - nerotāts darba apgeërbs (J. Chr. B r o tz e. Monumente..., III. 63. 1pp.); 2 - strādnieki pilsētas tuvumā (J. Chr. B r o t z e. Monumente..., III. 64. lpp.); 3-4 - dzimtlaužu meitas, kas pilsētā strädä par kalponēm (J. Chr. B r otz e. Monumente..., III. 57., 67. lpp.); 5 «vãcu kalpone ar zalo sedzeni» (J. Chr. B rotz e. Monumente..., III. 57. lpp.).

\section{4. tabula}

Nešūtie brunči: 1 - mārg̀enes malu noslëgums un sānu šuves apstrādājums (CVVM); 2 - Jaunsaules krieviṇi: sievietēm mugurā nešūtie brunči «ursk» (A. P e c old a akvarelis Krievu geogrāfijas biedrības arhīvā); 3 - rucaviete ar mārğeni (pềc Latvijas PSR Vēstures muzeja materiāliem zīmējusi R. Kalnina); 4 - lietuviešu mārğene $(\mathrm{H}$. M ü $\mathrm{z}$ e l. Vom Lendenschurz zur Modetracht. Berlin, 1925, 60. Ipp.).

\section{5. tabula}

Vidzemes brunču audumi (CVVM): 1 - Lejasciema; 2 Valmieras; 3 - Tũjas; 4 - Drustu; 5 - Tũjas; 6 - Viskā|u.

\section{6. tabula}

Vidzemes brunču audumi (CVVM) : 1 - Augulienes; 2 Liezeres; 3 - Trikātas; 4 - Vidzemes vidienas; 5 - Praulienas; 6 - Vecpiebalgas; 7 - Tūjas; 8 - Galgauskas; 9 Sērmūkšu; 10 - Lizuma; 11 - Praulienas.

\section{7. tabula}

Latgales brunču audumi (CVVM): 1 - Kalupes; 2 Aulejas; 3 - Vilzēnu; 4 - Līvānu; 5 - Bukmuižas; 6 Škilbēnu; 7 - Zieme|latgales brunču atdarinājums (RLMV).

\section{8. tabula}

Augšzemes brunči: 1 - Bebrenes (CVVM); 2 - Jēkabpils brunču atdarinājums pēc Jēkabpils novadpētniecības muzeja materiāliem (RLMV); 3 - Bebrenes (E, 7); 4-Zemgales (CVVM).

\section{9. tabula}

Zemgales brunči (CVVM): $1-3-$ Zemgale; $4-$ Zalenieki; 5 - Zemgale; 6 - Jelgava; 7 - Jēkabnieki; 8 Zemgale; $9-$ Zalenieki; $10-$ Bauska.

\section{0. tabula}

Kurzemes brunču audumi (CVVM): 1 - Kursī̌̌u; 2 Zvārdes; 3-4 - Nogales; 5 - Skrundas; 6-7 - Aizputes; 8 - Kandavas; 9 - Mürmuižas.

\section{1. tabula}

Pie brunčiem piestiprināmās kulītes $($ CVVM): 1 - Skrundas; 2 - Rembates; 3 - Jaunjelgavas; 4 - Rucavas brunči; 5 - Priekules brunči.

\section{2. tabula}

1 - Ventspils novada iedzīvotāji 19. gs. pirmajā pusē (pēc F. Kruzes darbā «Necrolivonica» ievietotā attēla zìmējis U. Zemzaris); 2 - Mazirbes lïbiešu vīriešu apgēerbs (pēc F. Kruzes darbā «Necrolivonica» ievietotā attēla zìmējis U. Zemzaris); 3 - Kuršu ķoniṇienes (R. Kalniṇas kopija pēc darbā «Ievads latviešu tautas tērpu vēsturē» ievietotā zīmējuma; oriğināls $\mathrm{O}$. Hūna manuskriptā LCVVA, 6810. f.).

\section{3. tabula}

Rakstainäs jostas (RLVM); 1 - Alsungas; 2 - Zemgales; 3 - Krustpils.

Svītrainās jostas (CVVM): $4-$ Matī̌su; 5 - Rūjienas; 6 - Mazsalacas.

\section{4. tabula}

Ziedainās jostas (CVVM): 1 - Jaunpiebalgas; 2 - Tirzas; 3 - Gulbenes; 4 - Vecpiebalgas; 5 - bez vietas norādes.

Rakstainās jostas (CVVM) : 6-7 - Ārlavas; 8 - Saukas; 9 - Alsungas; 10-11 - Vecgulbenes.

\section{5. tabula}

Celaines (CVVM): 1 - Sëlpils; $2-3-$ Slates; $4-$ Załmuižas; 5 - Vidsmuižas; 6 - Līksnas; 7 - Kaunatas.

Pìtās jostas (CVVM): 8 - Škilbēnu; 9 - bez vietas norādes; 10 - Vecpiebalgas; 11 - bez vietas norādes.

\section{6. tabula}

Austrumlatvijas tipa villaines (CVVM): 1 - Cesvaines; 2 - Lubānas; 3 - Augšzemes. 
17. tabula

Dienvidkurzemes tipa villaines (CVVM) : $1-2-$ Rucavas; 3-5 - Nícas; $6-7-$ Bārtas viliainu rotājuma fragmenti.

18. tabula

Ziemelkurzemes tipa villaines (CVVM): 1 - Ventspils un Sarkanmuižas; 2 - Ventspils; 3 - Alsungas; 4 - Turlavas; $5-7$ - Kuldiggas villaiṇu izšuvumu fragmenti.

\section{9. tabula}

Kurzemes villaines: 1 - Talsu kristību villaines shēma un rotājuma fragments (Liepājas novadpētniecības muzeja materiāli); 2 - Kabiles; 3 - Sakaslejas; 4 - Turlavas mēlenes fragments (CVVM).

\section{0. tabula}

Rūtotās un vienkrāsainās villaines: 1 - zalā «kuča» (J. Chr. B r ot z e. Monumente ..., III. 55. lpp.); 2 - Rudbāržu austene; 3 - Bārtas; 4-5 - Alsungas (CVVM).

\section{1. tabula}

Zemnieku apgèēbs: 1 - Dundagas zemnieks ziemas drānās (J. Chr. B r ot z e. Monumente..., III. 79. lpp.); 2 - vîriešu svārki (J. Chr. B r ot z e. Monumente..., III. 62. lpp.); 3 - vīriešu svārki ( $\mathrm{J}$. Chr. B r ot z e.-Monumente.... III. 74. Ipp.); 4 - raibie svãrki (J. Chr. B rotze. Monumente... III. 79. lpp.); 5 - zemnieks kažokā no Sesavas (J. Chr. B rotz e. Monumente..., III, 81. 1pp.); 6 - Liezeres zemnieki kažokos (J. Chr. B r ot z e. Monumente..., III. 63. lpp.); 7 - Saules muižas zemnieki kažokos (J. Chr. B rotze. Monumente..., III. 75. lpp.).

\section{2. tabula}

Garās zekes (CVVM): 1 -.. Blīdenes; 2 - Zalenieku; 3 Zemgales; 4 - Turaidas; 5 - Jaunpiebalgas; 6 - Vecpiebalgas; 7 - Ventspils; 8 - Alsungas.

Isās zekses (CVVM): 9 - Ungurmuižas; 10 - Kalsnavas; 11 - Austrumzemgales; 12 - Ceraukstes; 13 - Izvaltas; 14 - Atašienes; 15 - Kuldīgas; 16 - Düres.

23. tabula

Cimdi (CVVM): 1 - Rucavas; 2 - Kuldigas; 3 - Tadaiḳù; 4 - Valmieras; 5 - Preilu; 6 - Ilūkstes; 7 - Rucavas; 8 - Alsungas; 9 - bez vietas norādes; $10-$ Ceraukstes; 11 - Bauskas; 12 - Izvaltas; 13 - Upesgrīvas; 14 - Pērkones; 15 - Užavas; 16 - Rucavas; 17 - bez vietas norādes; 18 - Auces.

\section{4 tabula}

Vidzemes vainagi (CVVM): 1 - Laudonas; 2 - Jumurdas; 3 - Tirzas; 4-Lēdmanes; 5 - Austrumvidzemes (sienamais); 6 - Rūjienas - zirgu astru vainags; 7 - Piebalgas; 8 - Vidzemes.

\section{5. tabula}

Vidzemes matauklas (CVVM): $1-2$ - Valmieras; 3 Trikātas; 4 - Rūjienas; 5 - Drabešu; 6 - Umurgas.

\section{6. tabula}

Augšzemes un Latgales vainagi: 1 - pärpieris (CVVM); 2 - Balvu līgavas vainags (E, 145); 3 - Rugāju; 4-5 Ilükstes (CVVM).

\section{7. tabula}

Kurzemes vainagi (CVVM). Zīlu: 1 - Aisteres; 2 Skrundas; 3 - Ranku. Spangu: 4 - Turlavas; 5 - bez vietas norādes; 6 - Alsungas; 7 - bez vietas norädes.

\section{8. tabula}

Dienvidkurzemes sieviešu galvas segas (CVVM): $1-\mathrm{Ni}-$ cas vainags; 2 - Nîcas sievu cepure; 3 - Krotes lĩgavas vainags; 4 - Pērkones vainags.

\section{9. tabula}

Sievu cepures (CVVM): $1-3-$ Lēdmanes; 4 - Cesvaines; 5 - Bārtas; 6 - Vaives torṇa cepures.

\section{0. tabula}

Zemnieku apg̀ērbs un apavi Rĩgas tuvumā: 1 - nevācu piena pārdevêja (J. Chr. Brotz e. Monumente..., III.
65. lpp.); 2 - turīgs zemnieks - zvejnieks (J. Chr. B r o t z e. Monumente..., III. 74. lpp.); 3 - kurpes ar sprādzēm (J. Chr. B r ot z e. Monumente..., III. 77. lpp.).

\section{1. tabula}

Zemnieču apgiērbs: 1 - Rietumvidzemes sievietes apgeērbs (J. Chr. B r ot z e. Monumente..., III. 83. lpp.); 2 - Rỉgas apkārtnes sievietes apğērbs (J. Chr. B r ot z e. Monumente..., III. 59. lpp.); 3 - Rietumvidzemes sievietes apğērbs (J. Chr. B r o t z e. Monumente..., III. 91. lpp.); $4-$ Rietumvidzemes sieviešu apḡērbs (J. Chr. B rotze. Monumente..., III. 87. lpp.).

\section{2. tabula}

Vidzemes sieviešu tērpi: 1 - Gaujienas sievas apgēerbs (CVVM); 2 - Rietumvidzemes jaunavas tērps (rekonstrukcija pēc Latvijas PSR Vēstures muzeja materiāliem); 3 Lielvärdes sievas goda apgēerbs (rekonstrukcija pēc Latvijas PSR Vēstures muzeja materiāliem); 4 - Lielvārdes jaunavas apğērbs (rekonstrukcija pēc Latvijas PSR Vēstures muzeja materiāliem); 5 - Lielvärdes darba apgēêrbs (pēc K. Hūna akvarela); 6 - Ziemelvidzemes jaunavas tērps (rekonstrukcija pēc Latvijas PSR Vēstures muzeja materiāliem).

\section{3. tabula}

Austrumvidzemes un Krustpils sieviešu tērpi un Vidzemes vīriešu tërpi: 1 - Krustpils jaunavas tērps (rekonstrukcija pēc 1959. g. ekspedīcijā iegūtajiem materiāliem); $2-$ Cesvaines sievas apğērbs (pēc Latvijas PSR Vēstures muzeja materiāliem; 3 - Austrumvidzemes jaunavas tërps (rekonstrukcija pēc Madonas novadpētniecibas muzeja un 1959. g. ekspedīcijā iegūtajiem materiāliem); 4 - zemnieks svētku apgèerbā no Belavas (J. Chr. B rotze. Monumente..., III. 56. 1pp., 6. att.); 5 - Kalsnavas zemnieku apg̀ērbs (J. Chr. B r ot z e. Monumente..., III. 65. 1pp.); 6 - Lielvärdes vīriešu apgèrbs 19. gs. sākumā (rekonstrukcija pēc Latvijas PSR Vēstures muzeja materiāliem.)

\section{4. tabula}

Latgales un Augšzemes apḡērbi (pēc Latvijas PSR Vēstures muzeja materiăliem): 1 - Preilu jaunavas goda apg̀eerbs; 2 - Dienvidlatgales sievas apgèrbs; 3 - Ziemellatgales sievas apgēerbs; 4 - Gārsenes jaunavas apgèerbs; 5 - Ilūkstes sievas apğērbs; 6 - Augšzemes vīriešu apḡērbs.

\section{5. tabula}

Zemgales apġērbi: 1 - Sīpeles tērps (pēc F. Kruzes darbā «Necrolivonica» ievietotā zîmējuma); 2 - Rietumzemgales sievas tērps (pēc Latvijas PSR Vēstures muzeja materiāliem); 3 - Bauskas apkārtnes sievas tērps (pēc Latvijas PSR Vēstures muzeja materiāliem); 4 - vïrieša apḡérbs (J. Chr. B r ot z e. Monumente..., IIII. 80. 1pp.); 5 - vīriešu apgèrbs (pēc CVVM arhīvä esošā akvarela); 6 - Zemgales vîriešu apgẹērbs (pēc Latvijas PSR Vēstures muzeja materiāliem).

\section{6. tabula}

Kurzemes apg̣ērbi (pēc Latvijas PSR Vēstures muzeja materiāliem): 1 -Skrundas-Saldus sievas apgērbs; 2 - Talsu jaunavas apgèērbs; 3 - Kolkasraga lībiešu sieva un meitene (A. Pecolda zīmējums, 1864. g.); 4 - apgèērba komplekts ar pussvārci (rekonstrukcija pēc 1954. g. Baltijas ekspedīcijā iegūtajiem materiāliem); $5-6-$ Ventspils un Puzes jaunavu apgërbi.

\section{7. tabula}

Kuldīgas un Alsungas tērpi: 1 - Kuršu konininiene (pēc F. Kruzes darbã «Necrolivonica» ievietotā zimējuma); 2 Kuršu koniñš (turpat); 3 - Kuldīgas jaunava (turpat); 4 Alsungas jaunava (pëc Latvijas PSR Vēstures muzeja materiāliem)

\section{8. tabula}

Dienvidkurzemes apḡērbi (pēc Latvijas PSR Vēstures muzeja materiāliem): 1 - Rucavas sievas apgēerbs; 2 - Nīcas jaunavas apgèērbs; 3 - Bärtas sievas apgēērbs; 4 - Rucavas jaunavas apg̀ērbs. 
Таблица 1

Цветная вышивка-роспись, крест и гладь. 1. Виллайне, Цесвайне (CVVM*). 2. Виллайне. Наутрены (CVVM). 3. Носовой платок. Балвы (материалы сектора этнографии Института истории АН Латв. ССР). 4. Нижний конец рукава рубахи. Дигная (CVVM). 5. Нижний конец рукава рубахи. Цесвайне (CVVM). 6. Ворот рубахи. Цесвайне (CVVM). 7. Нижний конец рукава рубахи. Дигная (CVVM).

\section{Таблица 2}

Украшение ворота и манжета рубахи нитками и бисером (РУПИ). 1-3. Ворот рубахи. Алсунга. 4. Манжет. Алсунга. 5. Ворот рубахи. Крустпилс. 6. Ворот рубахи. Аугшземе. 7. Ворот рубахи. Кулдига.

\section{Таблица 3}

Рабочая одежда (J.Chr. Brotze. Monumente...). 1. Рабочая одежда без украшений (III, 63). 2. Жители окрестностей Риги в рабочей одежде (III, 64). 3, 4. Крепостная девушка, работающая служанкой в городе (III, $57,67)$. 5. Немецкая служанка с зеленым покрывалом (III, $57)$

\section{таблица 4}

Несшитая поясная одежда. 1. Кайма «маргене» и обработка бокового шва (CVVM). 2. Криевини из Яунсауле; женщина в несшитой поясной одежде «урск» (акварель А. Пецольда из архива Русского географического общества). 3. Женщина из Руцавы с «маргене» (рисунок P. Калнинь по материалам Музея истории Латв. ССР). 4. Литовская «маргине» (H. Mützel. Vom Lendenschurz zur Modetracht. Berlin, 1925, S. 60).

\section{Таблица 5}

Юбочные ткани из Видземе (CVVM). 1 - Леясциемс; 2 - Валмиера; 3 - Туя; 4 - Друсты; 5 - Туя; 6 - Вискали.

\section{Таблица 6}

Юбочные ткани из Видземе (CVVM), 1 - Аугулиене; 2 - Лиезере; 3 - Триката; 4 - центральная Видземе; 5 - Праулиена; 6 - Вецпиебалга; $7-$ Туя; $8-$ Галгауска; 9 - Сермукши; 10 - Лизумс; 11 - Праулиена.

\section{Таблица 7}

Юбочные ткани из Латгале (CVVM). 1 - Калупе; 2 - Аулея; 3 - Вилзены; 4 - Ливаны; 5 - Букмуйжа; 6 - Шкилбены; 7 - юбка из северной Латгале. Реконструкция (РУПИ).

\section{Таблица 8}

Аугшземские юбки. 1. Бебрене (CVVM). 2. Екабпилсская юбка. Реконструкция по материалам Екабпилсского краеведческого музея (РУПИ). 3. Бебрене (материалы сектора этнографии Ин-та истории АН Латв. ССР, инв. № 7). 4. Земгале (CVVM).

\section{таблица 9}

Земгальские юбки (CVVM). 1-3 - Земгале; 4 - Залениеки; 5- Земгале; 6 - Елгава; 7 - Екабниеки; 8 - Земгале; 9 - Залениеки; 10 -Бауска.

\section{таблица 10}

Юбочные ткани из Курземе (CVVM). 1 - Курсиши; 2 - Зварде; 3, 4- Ногале; 5 - Скрунда; 6, 7 - Айзпуте; 8 - Қандава; 9 - Мурмуйжа.

\section{таблица 11}

Подвесные карманы к юбкам (CVVM). 1 - Скрунда; 2 - Рембате; 3 - Яунелгава; 4 - юбка. Руцава; 5 юбка. Приекуле.

* Сигнатура единиц хранения (этнографических предметов) в фондах Музея истории Латвийской ССР.

\section{таблица 12}

Одежда из западной Курземе. 1. Жители Вентспилсского края в первой половине XIX в. (Fr. Kruse. Necrolivonica. Dorpat, 1842). 2. Мужская одежда ливов из Мазирбе (Fr. Kruse. Necrolivonica. Dorpat, 1842). 3. Женщины из селения «куршских королей» (Ievads latviešu tautas tērpu vēsturē. Rịgā, 1936, 104. lpp.).

\section{Таблица 13}

Пояса. Узорчатые пояса: 1 - Алсунга; 2 - Земгале; 3 - Крустпилс (РУПИ). Полосатые пояса: 4 - Матиши; 5 - Рунена; 6 - Мазсалаца (CVVM).

\section{Таблица 14}

Пояса (CVVM). Тканые пояса «ziedainās jostas»: 1 - Яунпиебалга; 2 - Тирза; 3 - Гулбене; 4 - Вецпиебалга; 5 - без указания места. Узорчатые пояса: 6, 7 Арлава; 8 - Саука; 9 - Алсунга; 10, 11 - Вецгулбене

\section{Таблица 15}

Пояса (CVVM). Пояса, тканые на дощечках («celaiпеs»):1 - Селпилс; 2, 3 - Слате; 4 - Зальмуйжа; 5 Видсмуйжа; 6 - Ликсна; 7 - Кауната. Плетеные пояса: 8 - Шкилбены; 9 - без указания места; 10 - Вецпиебалга; 11 - без указания места.

\section{Таблица 16}

Виллайне восточнолатвийского типа (CVVM). 1 Цесвайне; 2 - Лубана; 3 - Аугшземе.

\section{таблица 17}

Виллайне южнокурземского типа (CVVM). 1, 2 - Руцава; 3-5 - Ница; $6,7-$ фрагменты украшения виллайне из Барты.

\section{Таблица 18}

Виллайне северокурземского типа (CVVM). 1 - Вентспилс и Сарканмуйжа; 2 - Вентспилс; 3 - Алсунга; 4 Турлава; 5-7 - фрагменты вышивки виллайне из Кулдиги

\section{Таблица 19}

Виллайне из Курземе. 1 - схема «виллайне для крестин» и фрагмент ее украшения. Талсы (материалы Лиепайского краеведческого музея); 2 - Кабиле; 3 - Сакаслея; 4 - фрагмент синей виллайне «мелене». Турлава (CVVM).

\section{Таблица 20}

Клетчатые и одноцветные виллайне. 1 - зеленый платок (J. Chr. Brotze. Monumente..., III, 55); 2 - платок. Рудбаржи; 3 - Барта; 4, 5 - Алсунга (CVVM).

\section{таблица 21}

Мужская одежда (J. Chr. Brotze. Monumente...). 1. Зимняя одежда крестьянина из Дундаги (III, 79) 2. Мужской кафтан (III, 62). 3. Мужской кафтан (III, 74). 4. Пестрый кафтан (III, 79). 5. Крестьянин из Сесавы в шубе (III, 81). 6. Крестьяне из Лиезере в шубах (III, 63). 7. Крестьяне из Сауле в шубах (III, 75).

\section{таблица 22}

Чулки и носки (CVVM). Чулки: 1 - Блидене; $2-3 \mathrm{a}$ лениеки; 3 - Земгале; 4 - Турайда; 5 - Яунпиебалга 6 - Вецпиебалга; 7 - Вентспилс; 8 - Алсунга. Носки: 9 - Унгурмуйжа; 10 - Калснава; 11 - восточная Зем гале; 12 - Церауксте; 13 - Извалта; 14 - Аташиене; 15 - Кулдига; 16 - Дуре.

\section{таблица 23}

Рукавицы (CVVM). 1 - Руцава; 2 - Кулдига; 3 Тадайки; 4 - Валмиера; 5 - Прейли; 6 - Илуксте; 7 - Руцава; 8 - Алсунга; 9 - без указания места; 10 - Церауксте; 11 - Бауска; 12 - Извалта; 13 - Упесгрива; $14-$ Перконе; $15-$ Ужава; $16-$ Руцава; $17-$ Видземе; 18 - Ауце. 


\section{таблииа 24}

Видземские венки (CVVM). 1 - Ляудона; 2 - Юмурда; 3 - Тирза; 4 - Ледмане; 5 - восточная Видземе (венок с завязками); 6 - Руиена (венок из конского волоса); 7 - Пиебалга; 8 - Видземе.

\section{Таблища 25}

Ленты для волос (CVVM). 1, 2 - Валмиера; 3 - Триката; 4 - Руиена; 5 - Драбежи; 6 - Умурга (концы ленты).

\section{Таблица 26}

Аугшземские и латгальские венки. 1 - налобннк $(\mathrm{CVVM}) ; 2$ - венок невесты из Балвы (материалы сектора этнографии Ин-та истории АН Латв. ССР, инв. № 145); 3 - Ругаи; 4, 5 - Илуксте (CVVM).

\section{Таблица 27}

Курземские венки (CVVM). Венки с бисером: 1 Айстере; 2 - Скрунда; 3 - Раньки. Металлические венки «spangu vainagi»: 4 - Турлава; 5 - без указания места; 6 -Алсунга; 7 - без указания места

\section{Таблица 28}

Южнокурземские венки (CVVM). 1 - Ница; 2 - головной убор замужней женщины из Ницы; 3 - Кроте 4 - Перконе.

\section{Таблица 29}

Головные уборы замужних женщин (CVVM). 1-3Ледмане; 4 - Цесвайне; 5 - Барта; 6 - башнеобразный чепец. Вайве.

\section{Таблица 30}

Одежда и обувь жителей окрестностей Риги (J. Chr. Brotze. Monumente...). 1 - молочница (III, 65); 2 зажиточный крестьянин-рыбак (III, 74); 3 - туфли с пряжками (III, 77).

\section{Таблица 31}

Женская одежда из Видземе (J. Chr. Brotze. Monumente...). 1 - западная Видземе (III, 83); 2 - окрестности Риги (III, 59); 3 - западная Видземе (III, 91); 4 западная Видземе (III, 87).

\section{Таблица 32}

Женская одежда из Видземе. 1. Одежда женщины. Гауиена. 2. Костюм девушки из западной Видземе (реконструкция по материалам Музея истории Латв. ССР) 3. Праздничная женская одежда из Лиелварде (реконструкция по материалам Музея истории Латв. ССР) 4. Костюм девушки из Лиелварде (реконструкция по материалам Музея истории Латв. ССР). 5. Рабочая одежда из Лиелварде (по акварели К. Гуна). 6. Костюм девушки из северной Видземе (реконструкция по материалам Музея истории Латв. ССР).
Таблица 33

Женская одежда из восточной Видземе и Крустпилса, мужской костюм из Видземе. 1. Костюм девушки из Крустпилса (реконструкция по материалам экспедиции 1959 г.). 2. Женская одежда из Цесвайне (по материалам Музея истории Латв. ССР). 3. Костюм девушки из восточной Видземе (реконструкция по материалам Мадонского краеведческого музея и экспедиции 1959 г.). 4. Крестьянин из Белявы в праздничной одежде (J. Chr. Brotze. Monumente..., III, 56, 6). 5. Одежда крестьянина из Калснавы (J. Chr. Brotze. Monumente..., III, 65). 6- Мужская одежда начала XIX в. из Лиелварде (реконструкция по материалам Музея истории Латв. ССР).

\section{Таблица 34}

Одежда из Латгале и Аугшземе (по материалам Музея истории Латв. ССР). 1. Праздничная одежда девушки из Прейли. 2. Женская одежда из южной Латгале. 3. Женская одежда из северной Латгале. 4. Одежда девушки из Гарсене. 5. Женский костюм из Илуксте. 6. Аугшземский мужской костюм

\section{Таблица 35}

Земгальская одежда. 1. Костюм из Сипеле (Fr. Kruse. Necrolivonica. Dorpat, 1842). 2. Женский костюм из западной Земгале (по материалам Музея истории Латв. ССР). 3. Костюм женщины из окрестностей Бауски (по материалам Музея истории Латв. ССР). 4. Мужская одежда (J. Chr. Brotze. Monumente..., III, 80). 5. Мужская одежда (по акварели из архива Музея истории Латв. ССР). 6. Земгальская мужская одежда (реконструкция по материалам Музея истории Латв. ССР).

\section{Таблица 36}

Курземская одежда. 1. Женская одежда из района Скрунда - Салдус (по материалам Музея истории Латв. ССР). 2. Одежда девушки из Талсы (по материалам Му зея истории Латв. ССР). 3. Ливские женщина и девочка с мыса Колка (рисунок А. Пецольда 1846 г., архив Музея истории Латв. ССР). 4. Комплект одежды из северной Курземе с наплечным покрывалом «pussvārcis» (peконструкция по материалам Балтийской экспедиции 1954 г.) 5 , 6. Одежда девушки из района Вентспилс - Пузе (по материалам Музея истории Латв. ССР).

\section{таблица 37}

Кулдигский и алсунгский костюмы. 1, 2. Одежда «куршских королей» (Fr. Kruse. Necrolivonica. Dorpat, 1842). 3. Девушка из Кулдиги (Fr. Kruse. Necrolivonica. Dorpat, 1842). 4. Девушка из Алсунги (по материалам Музея истории Латв. ССР)

\section{Таблица 38}

Южнокурземская одежда (по материалам Музея истории Латв. ССР). 1 - одежда женщины из Руцавы; 2 одежда девушки из Ницы; 3 - одежда женщины из Барты. 


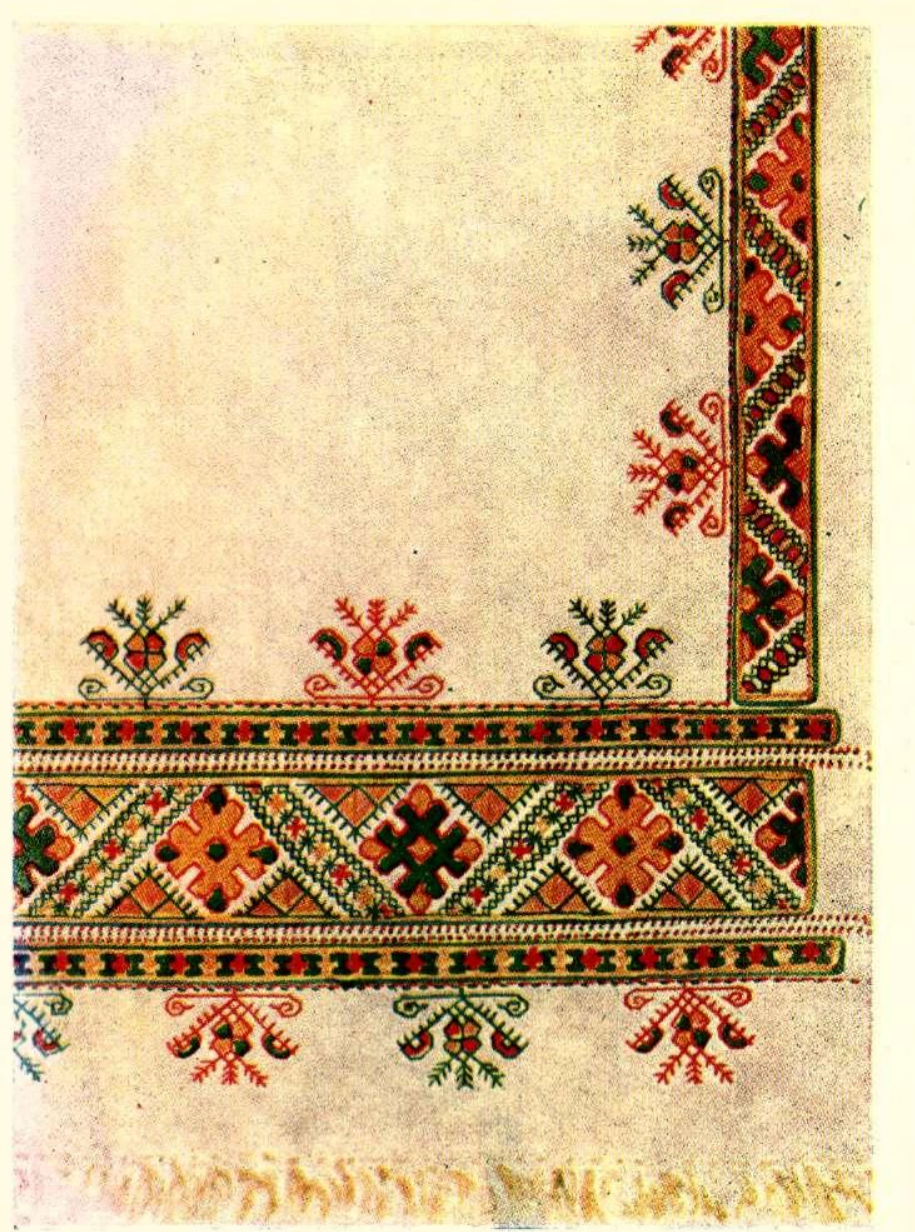

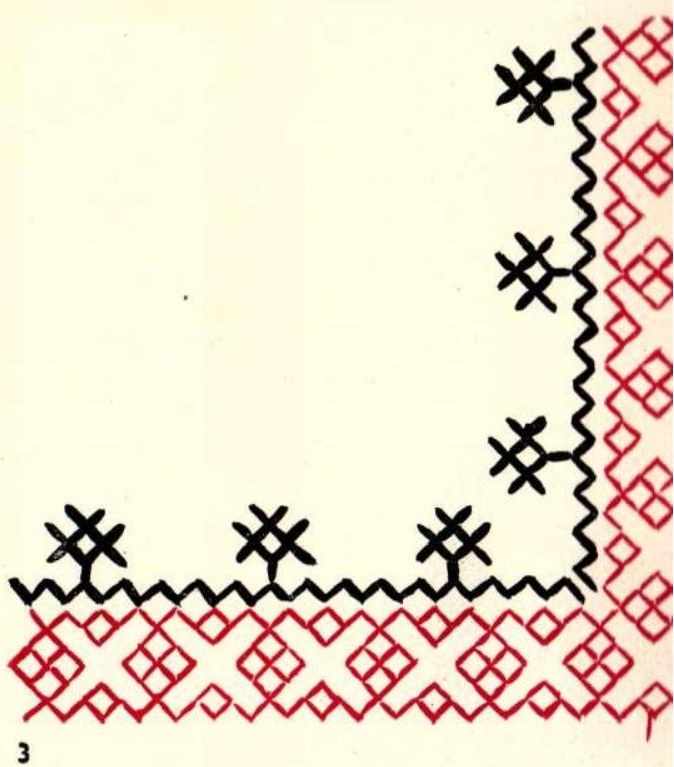

4
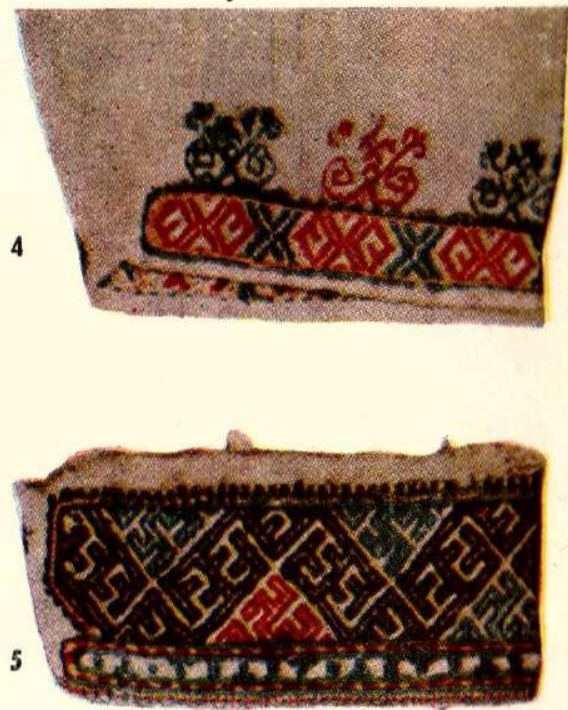

6
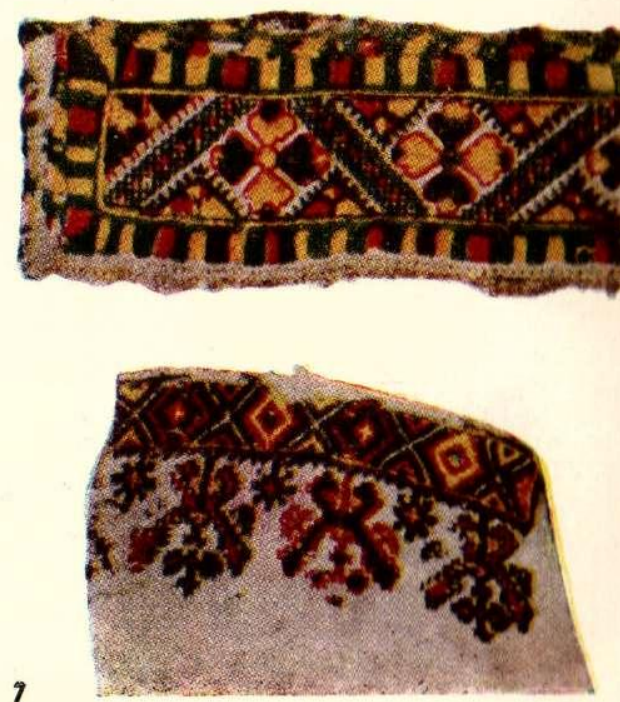
2. TABULA

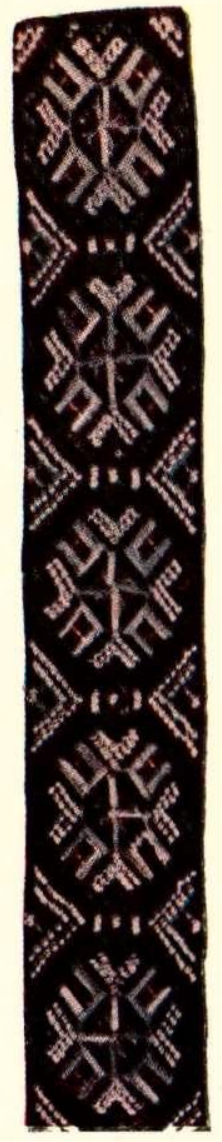

1

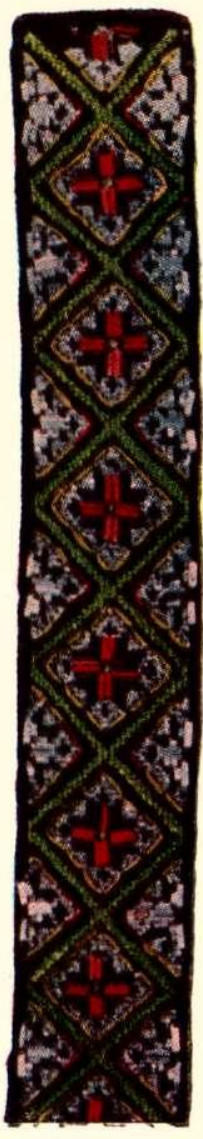

2

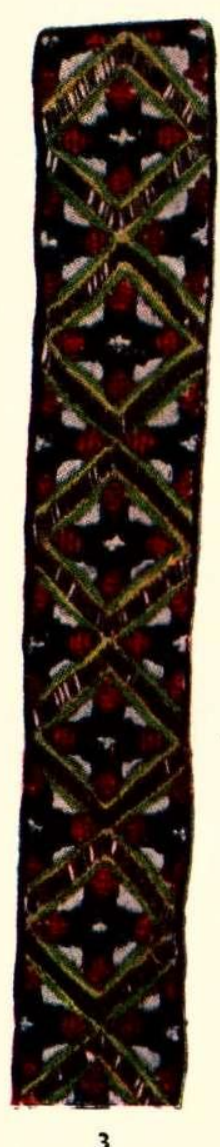

3

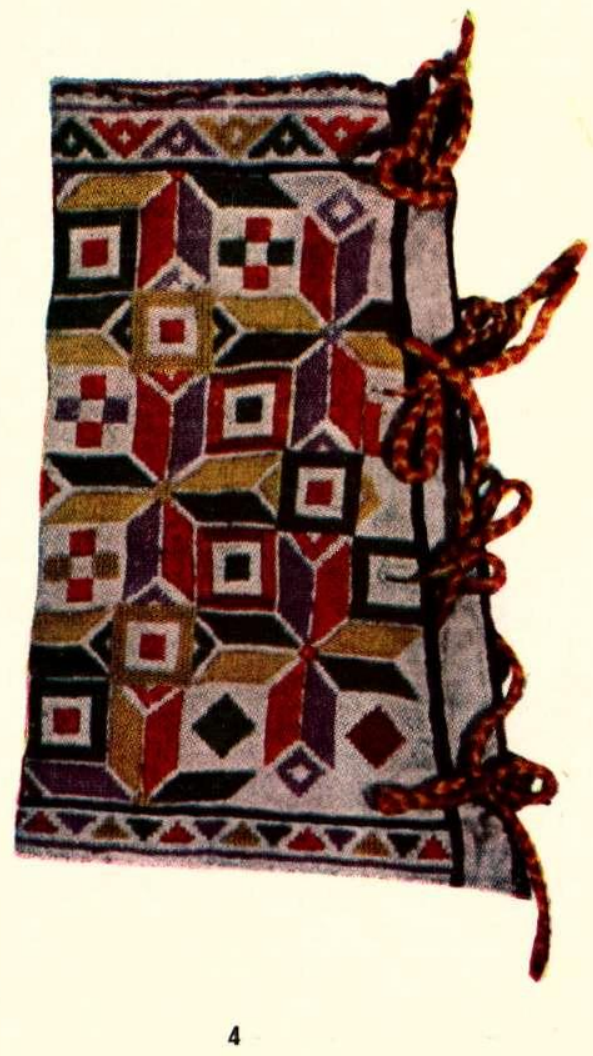

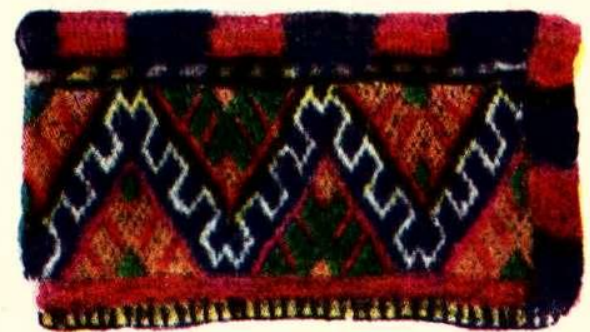

5

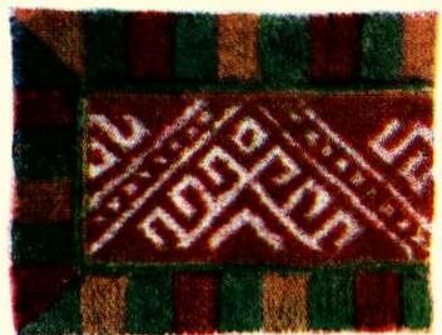

6

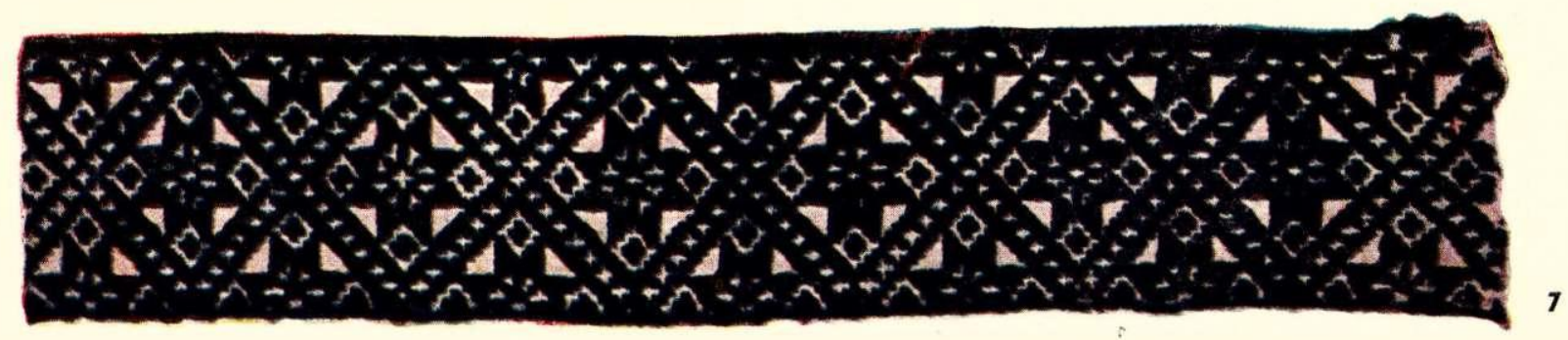




$$
\frac{11}{10}
$$


5. TABULA
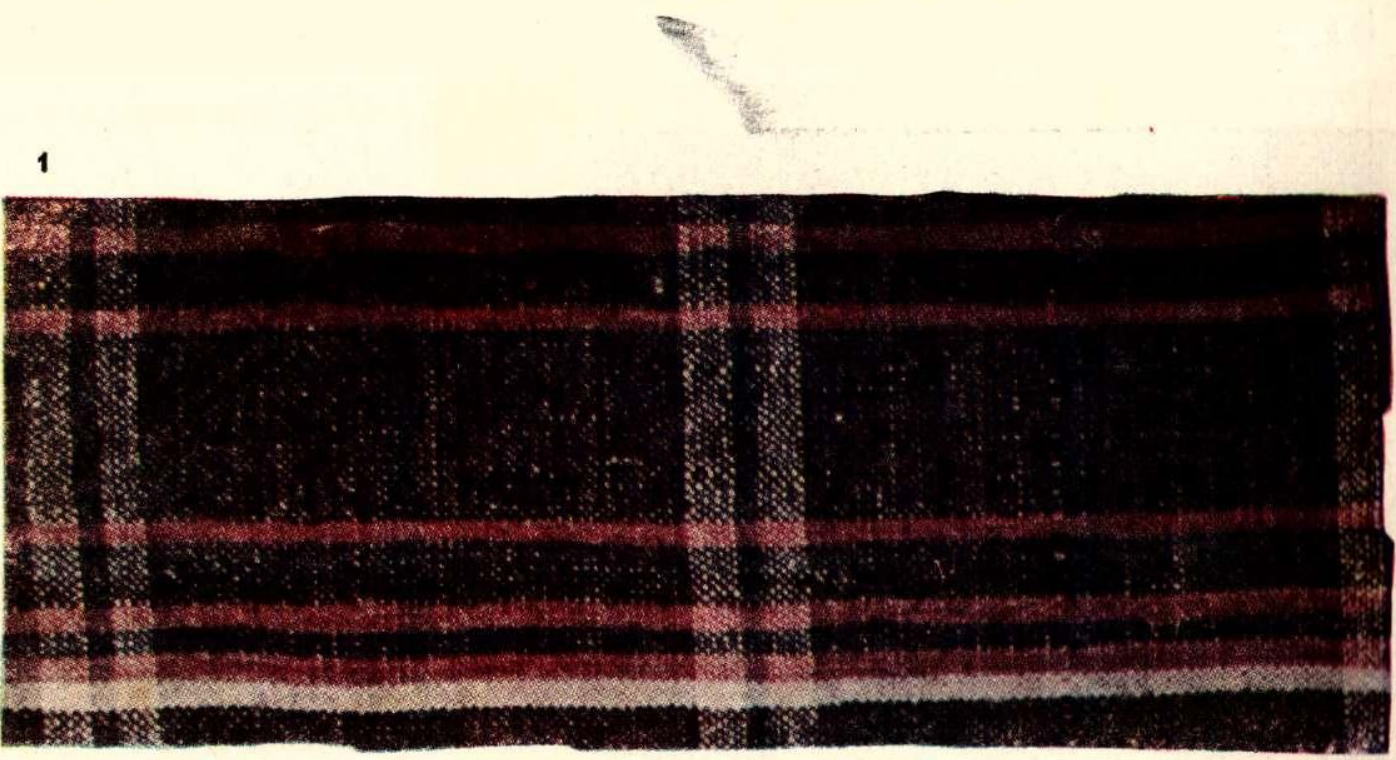

2
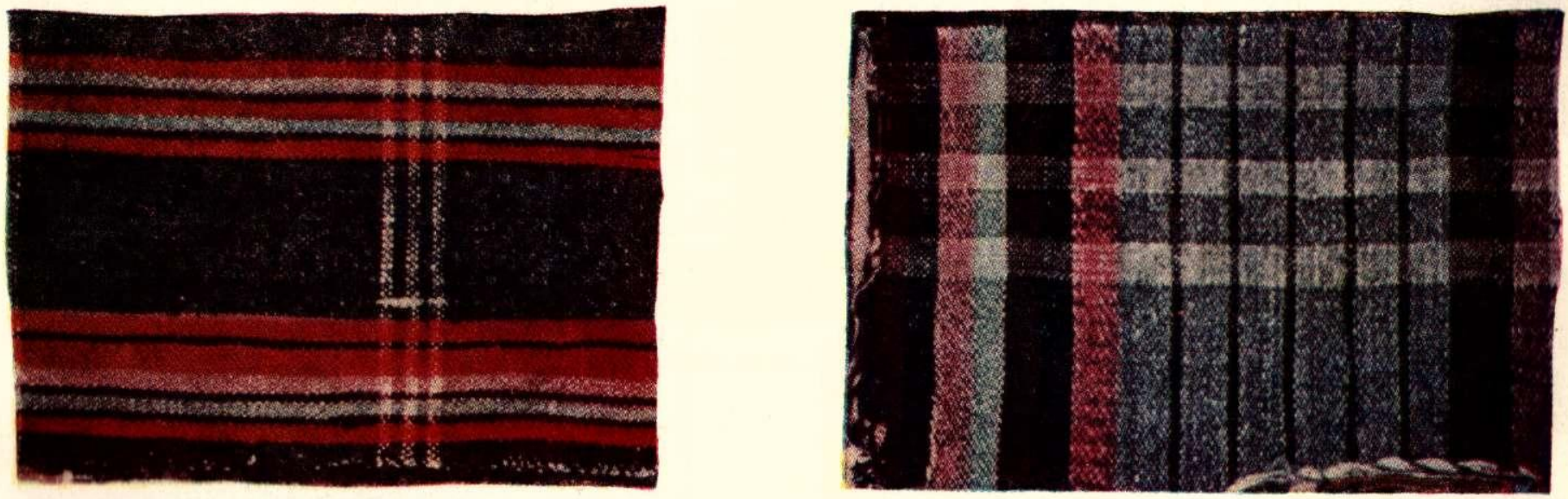

5
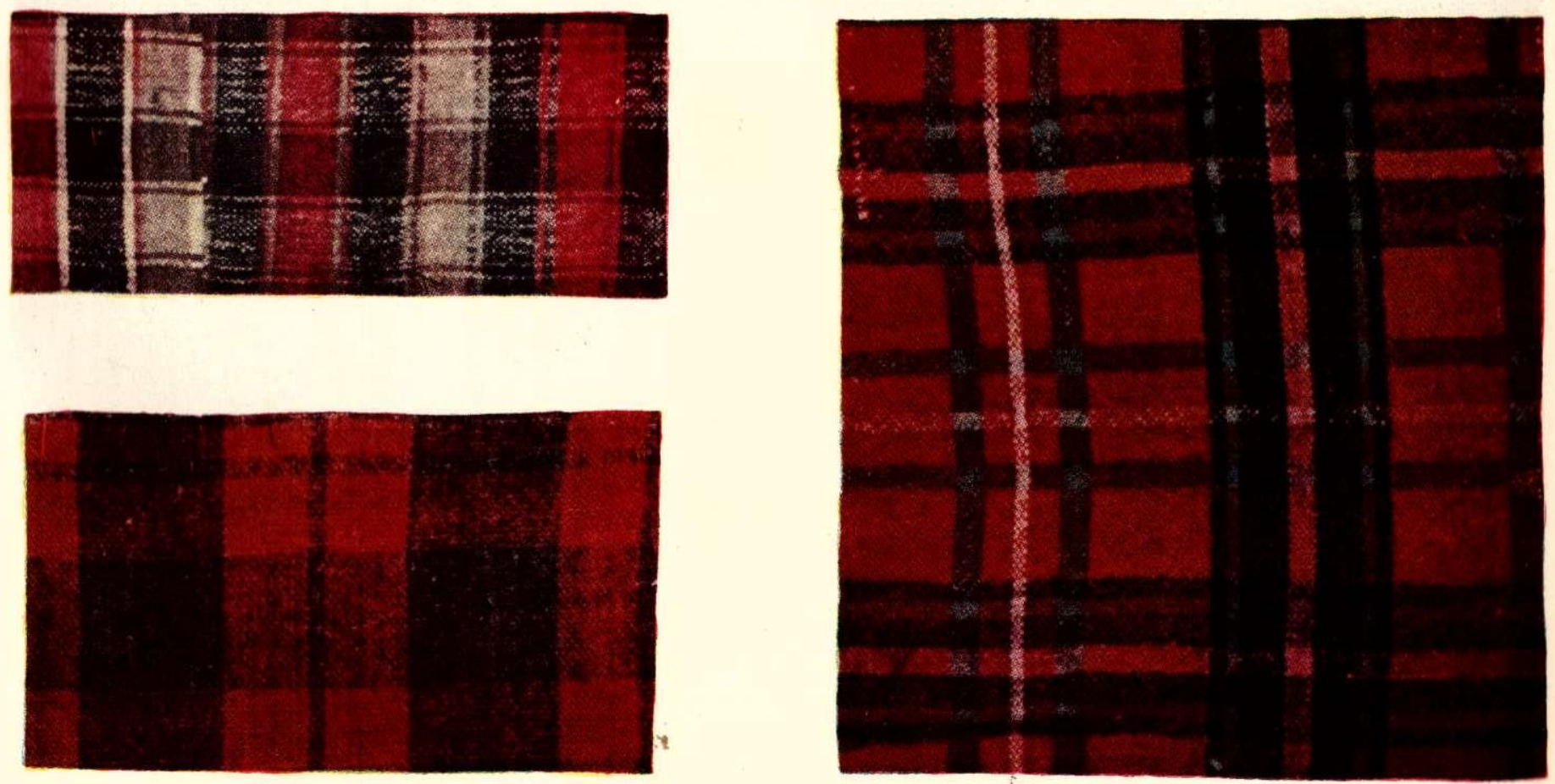
6. TABULA
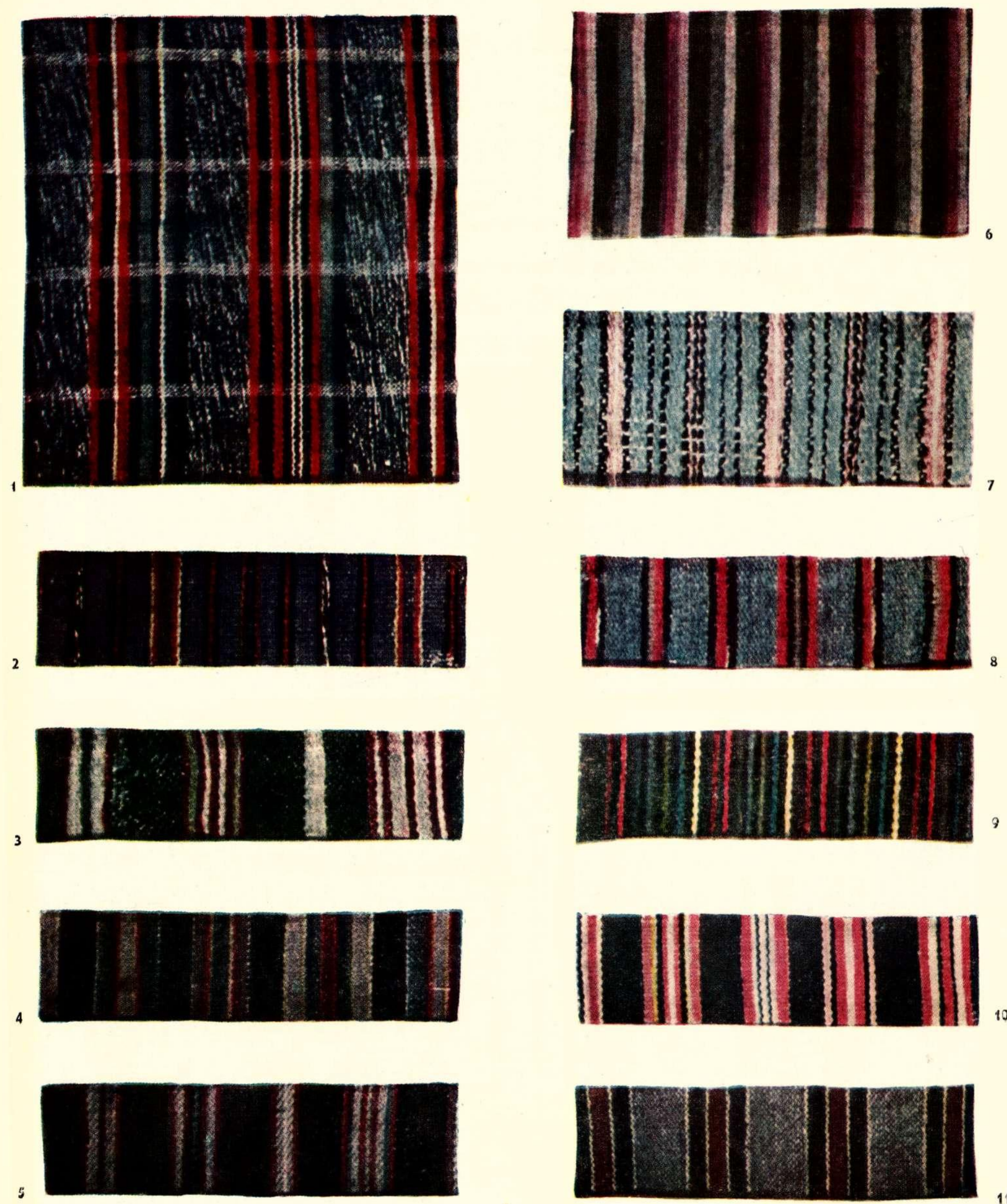

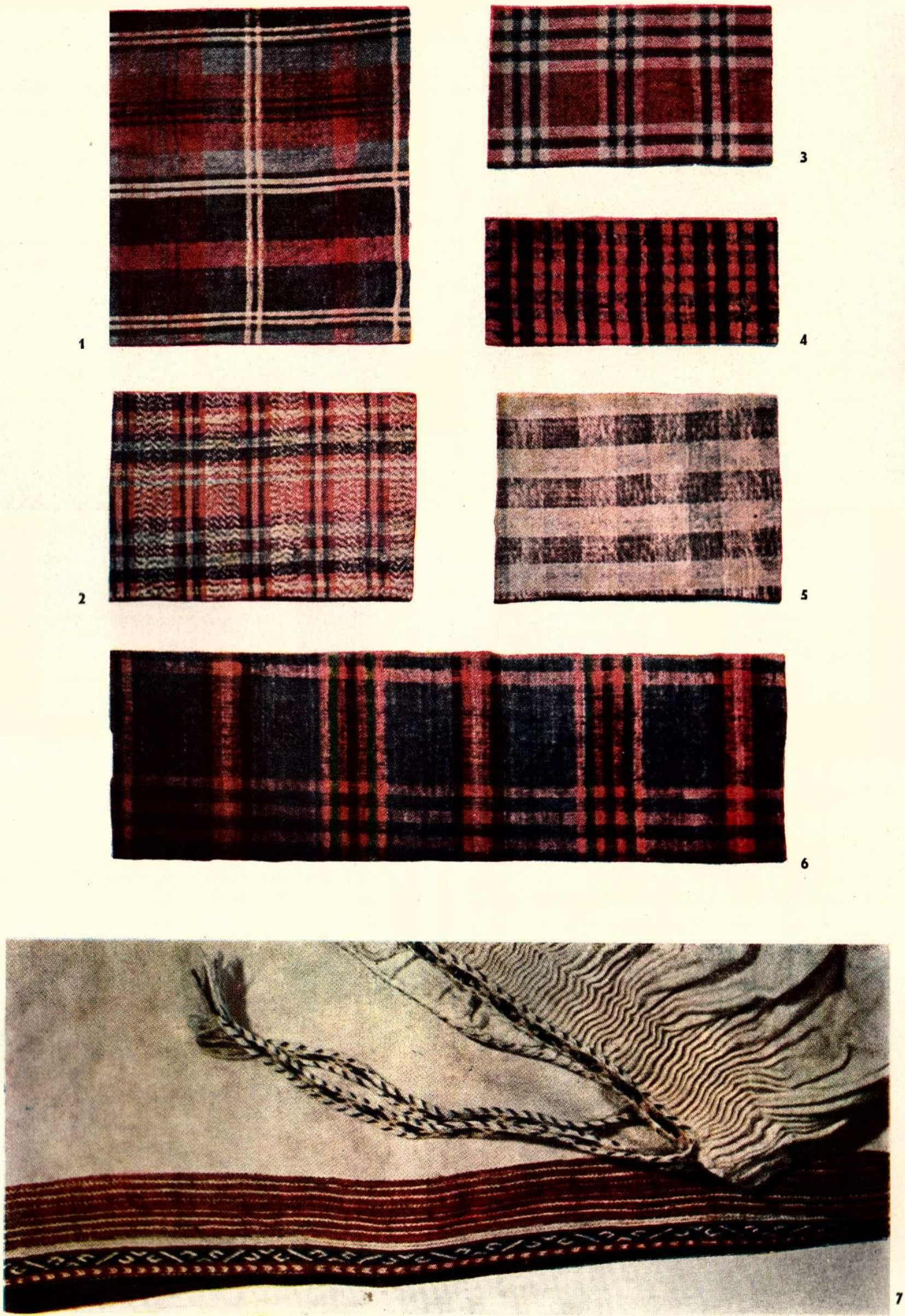


\section{TABULA}

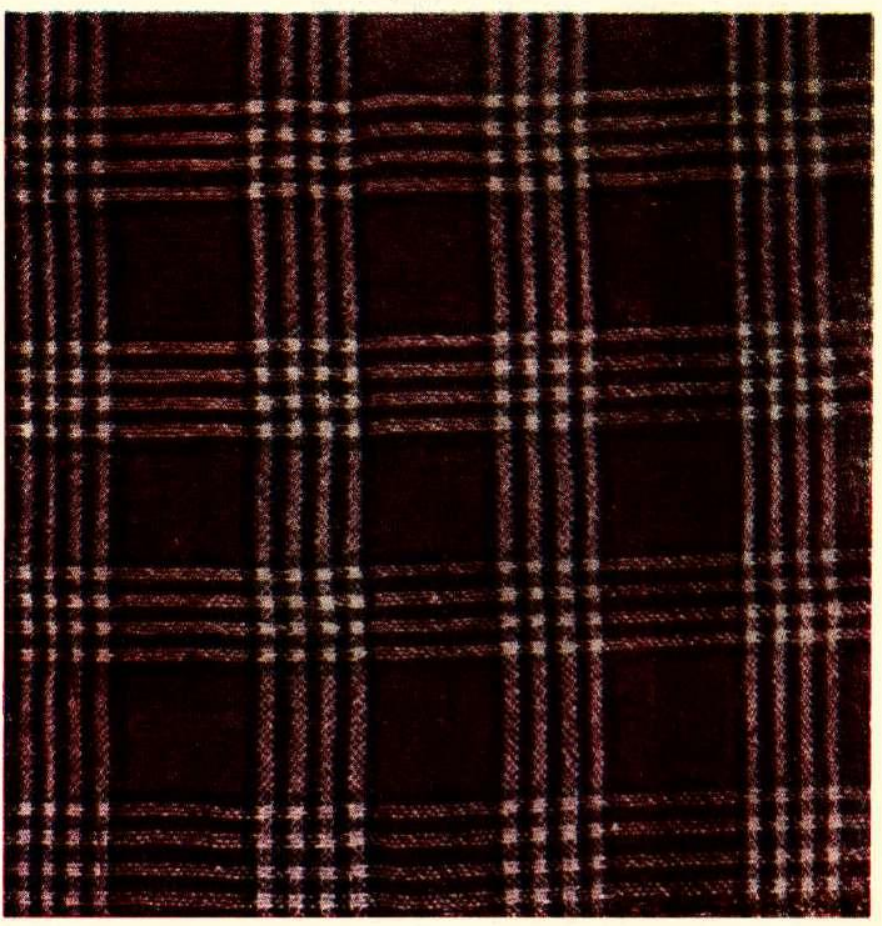
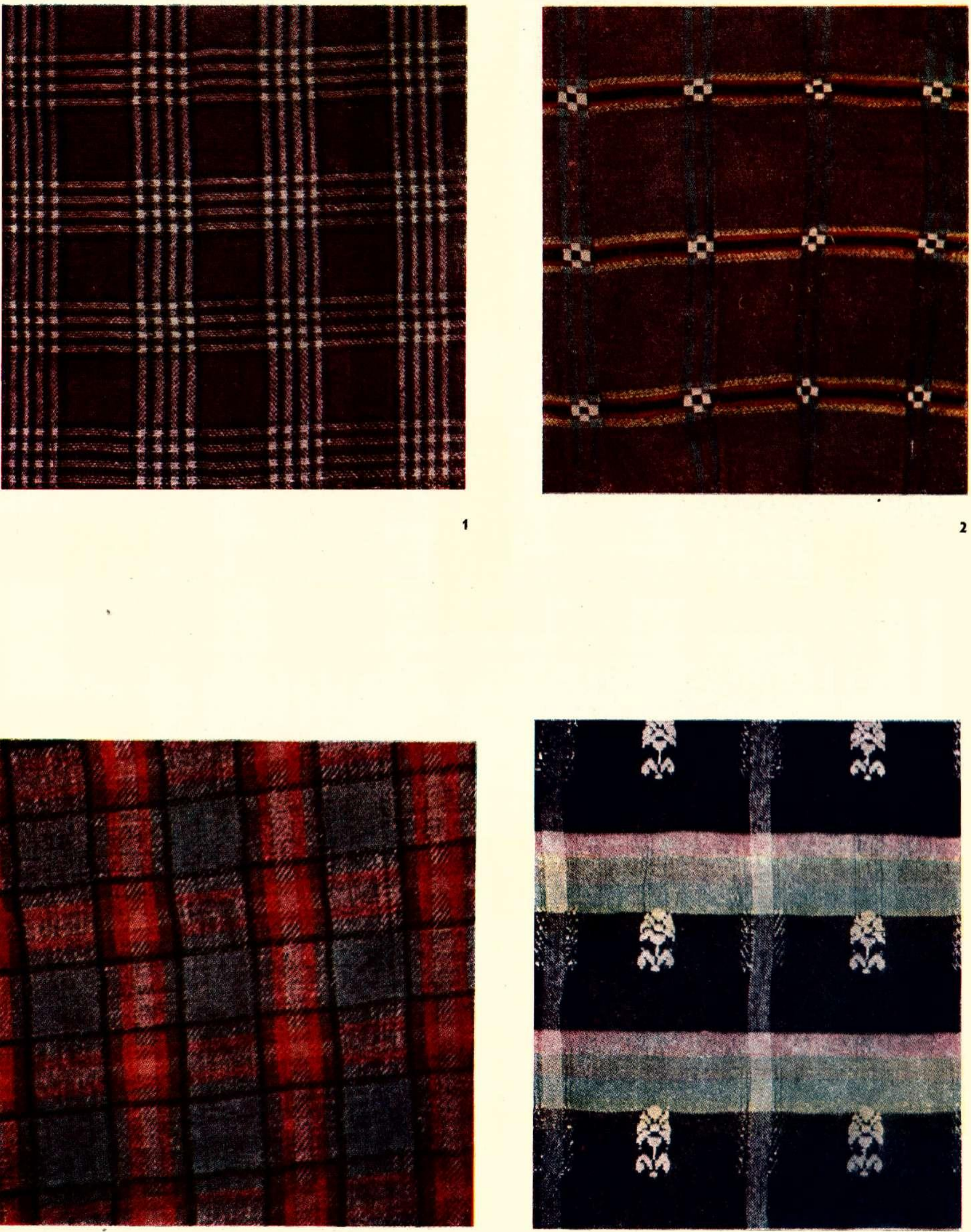

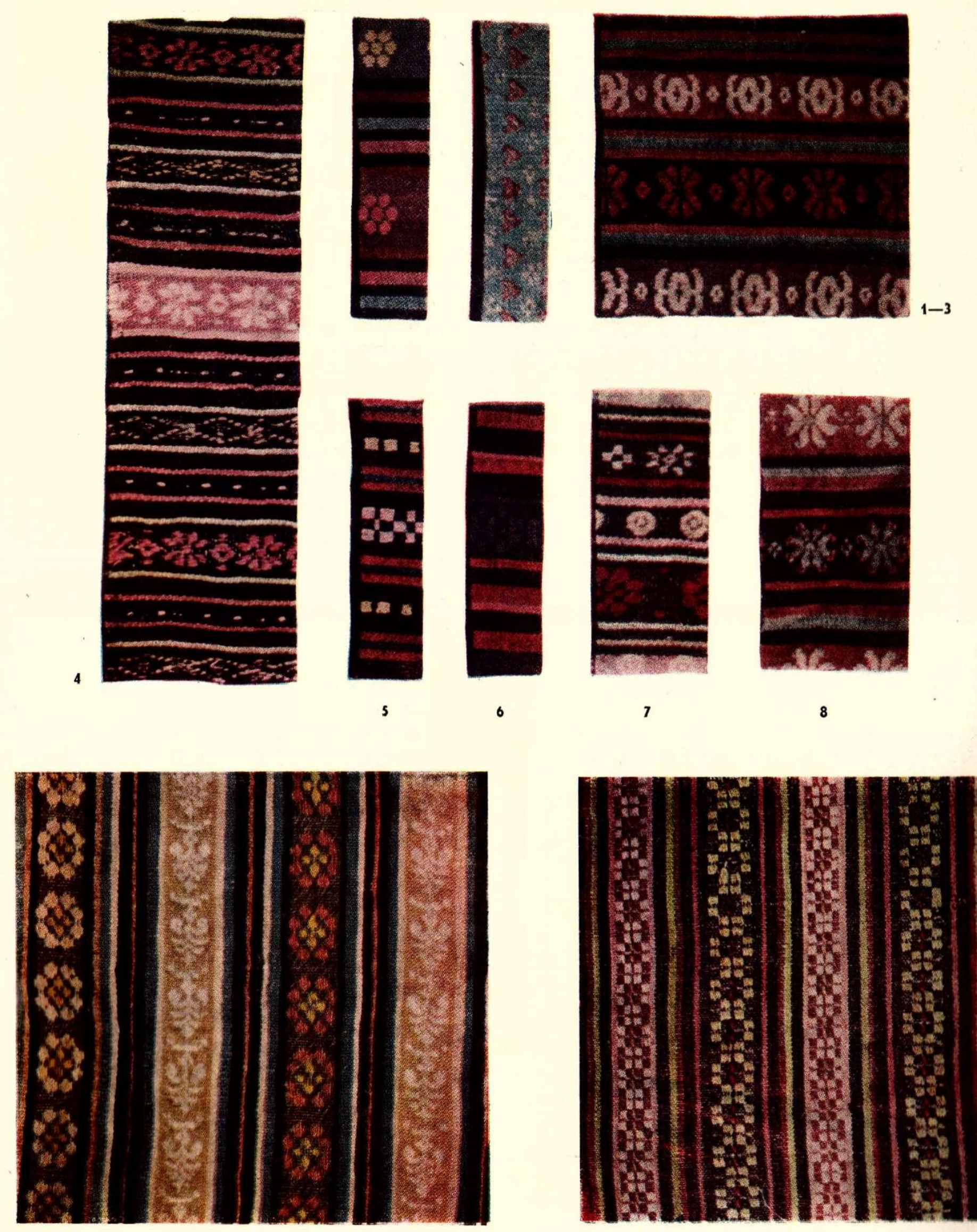
10. TABULA
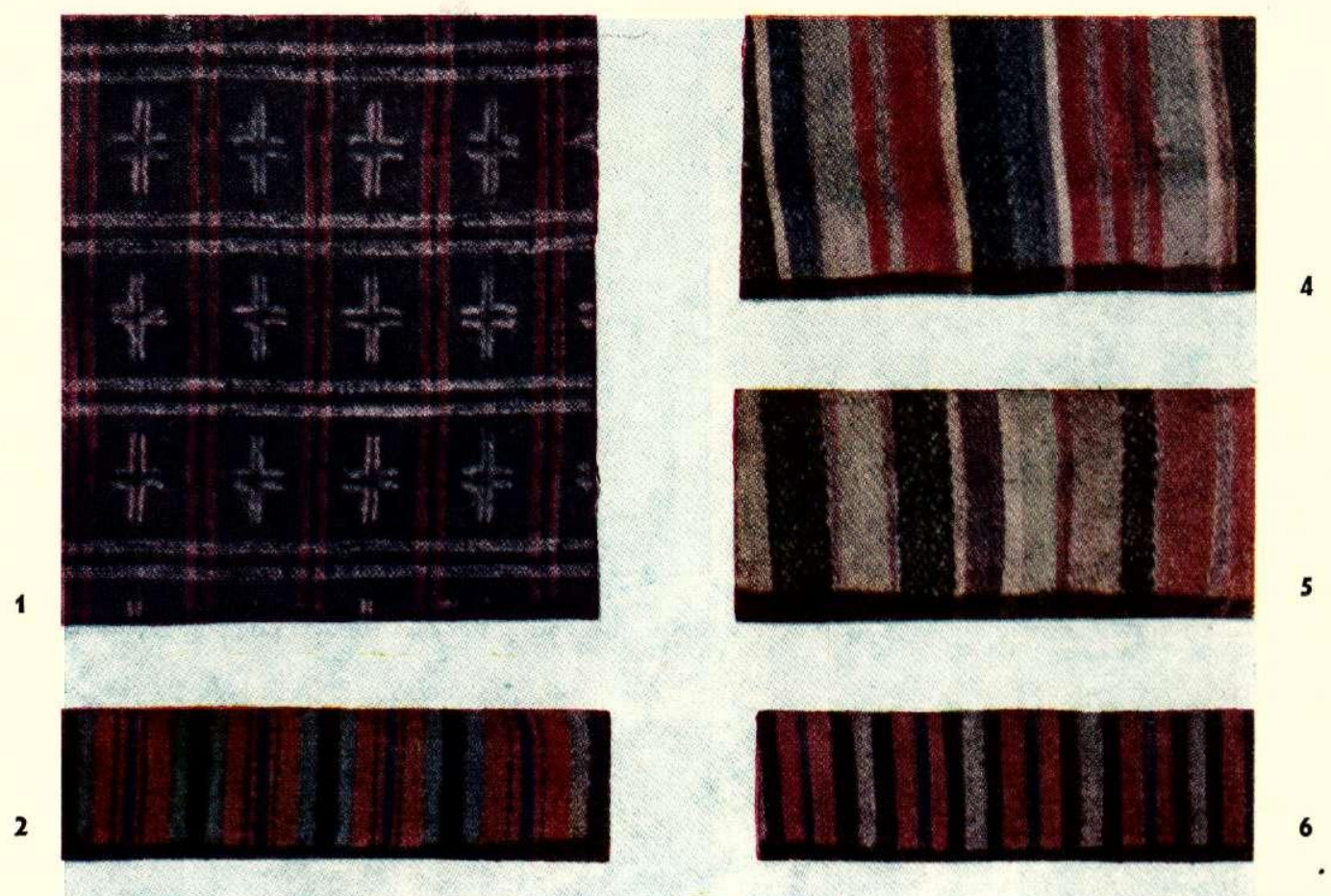

3
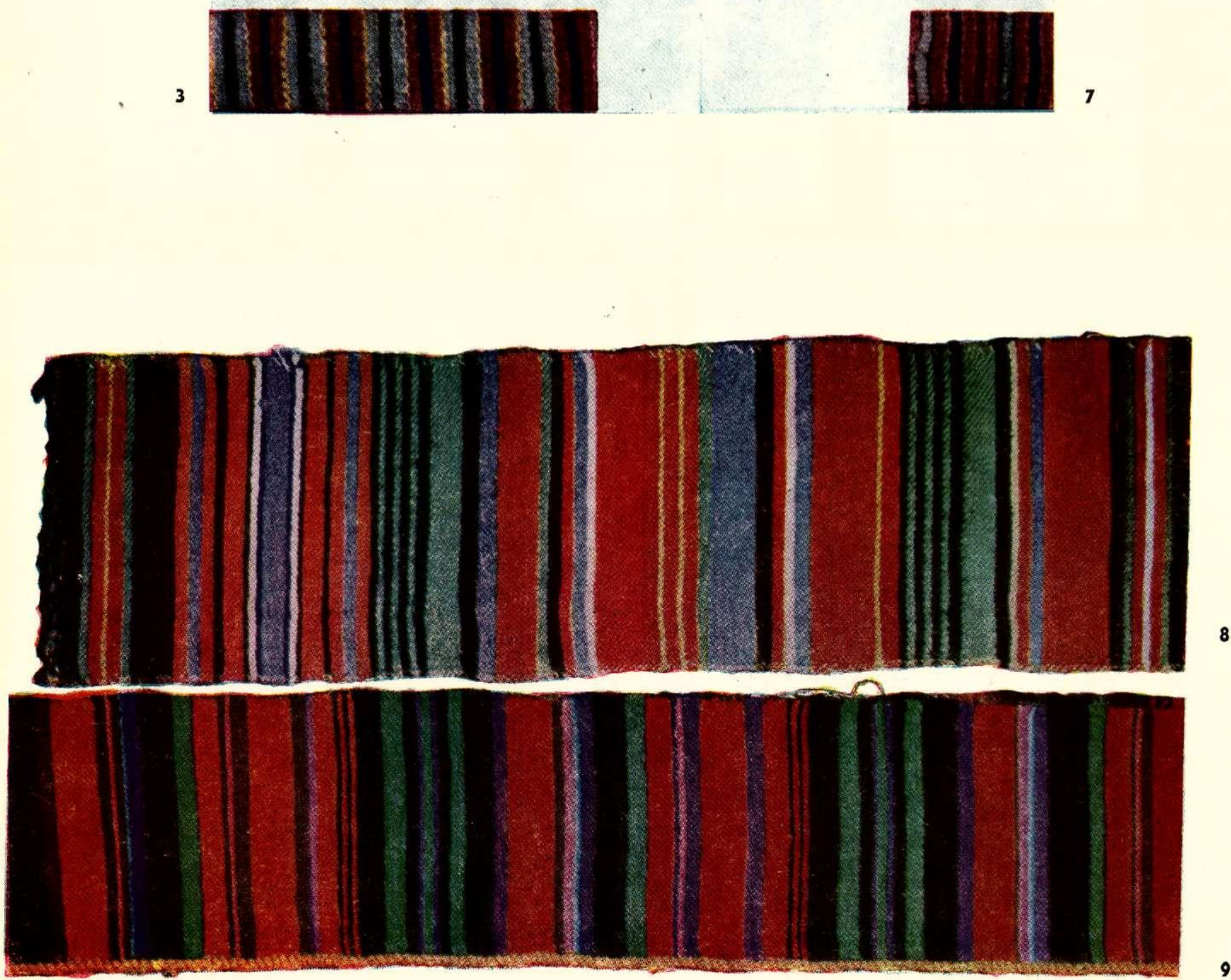

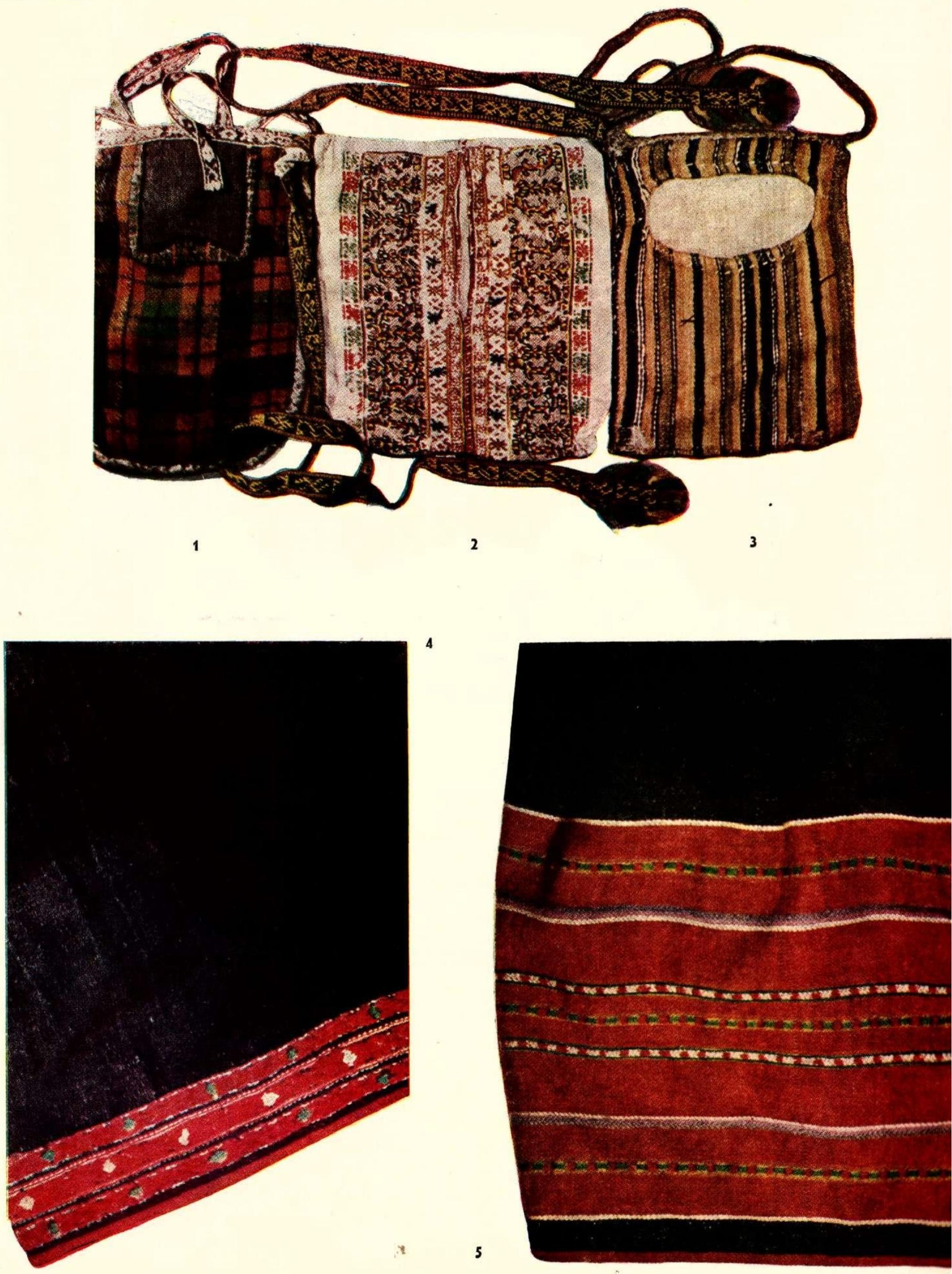

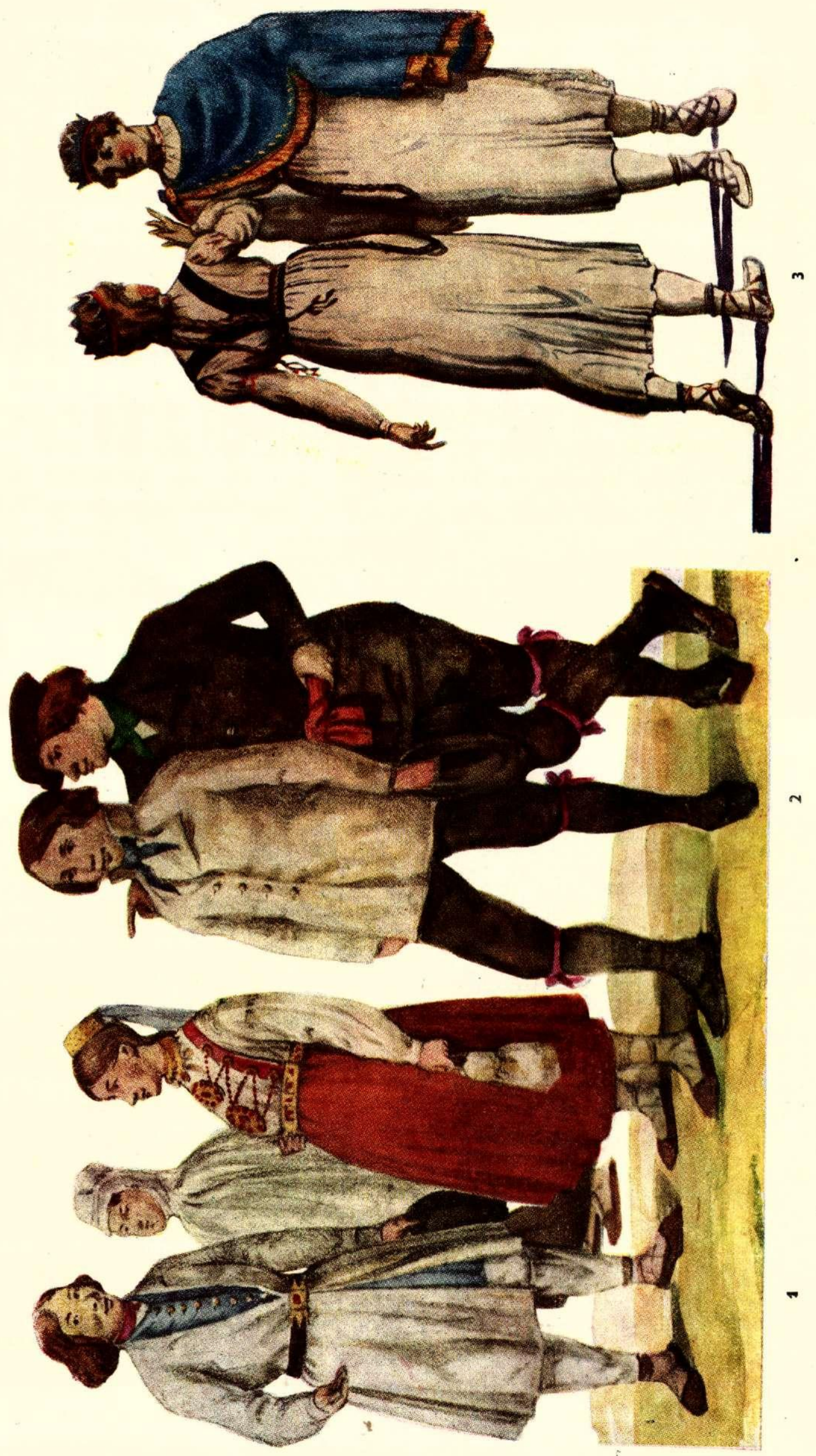

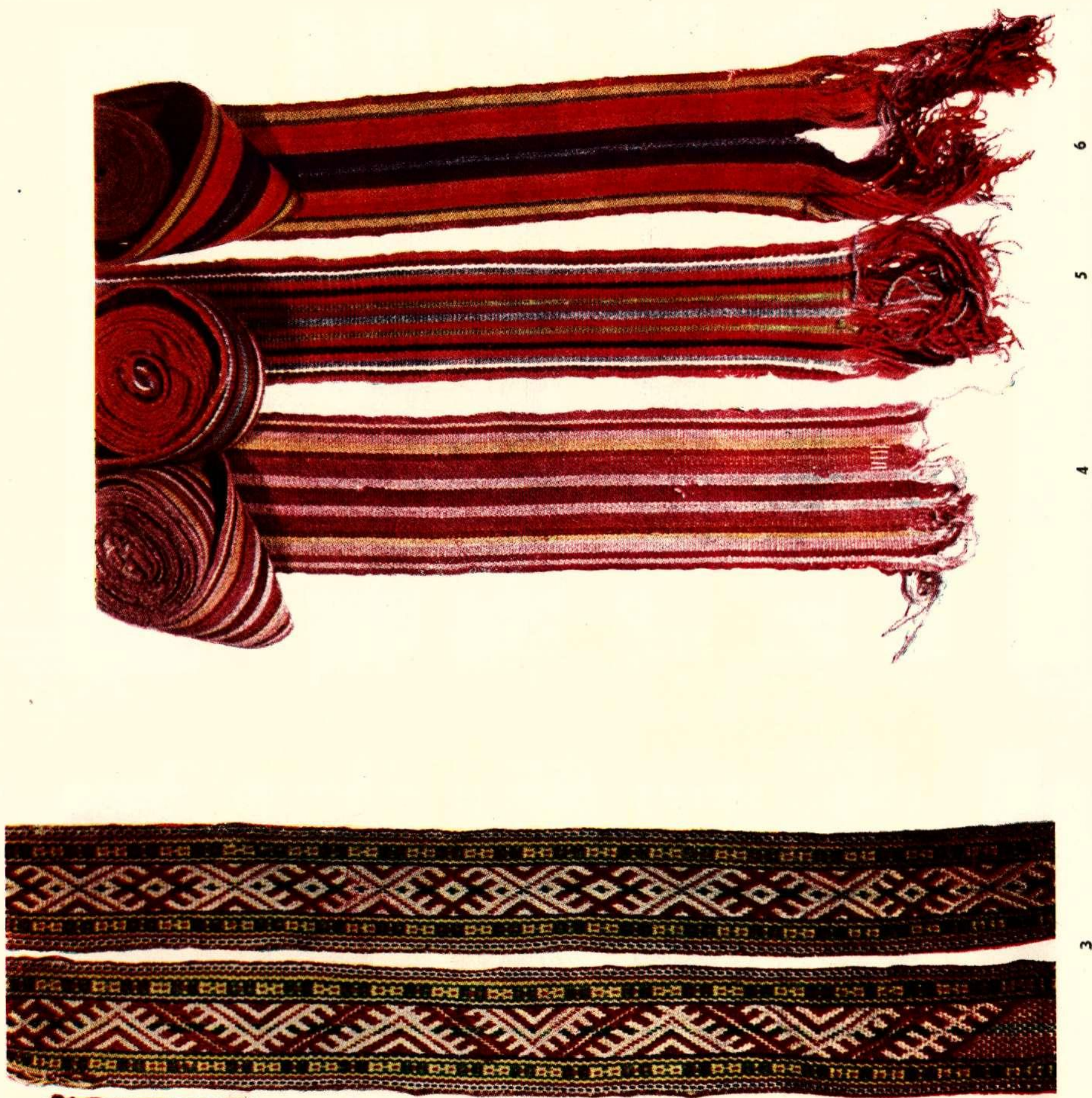

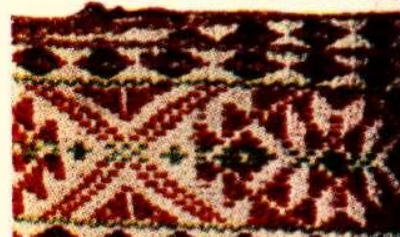

$x+2,2 x+2$
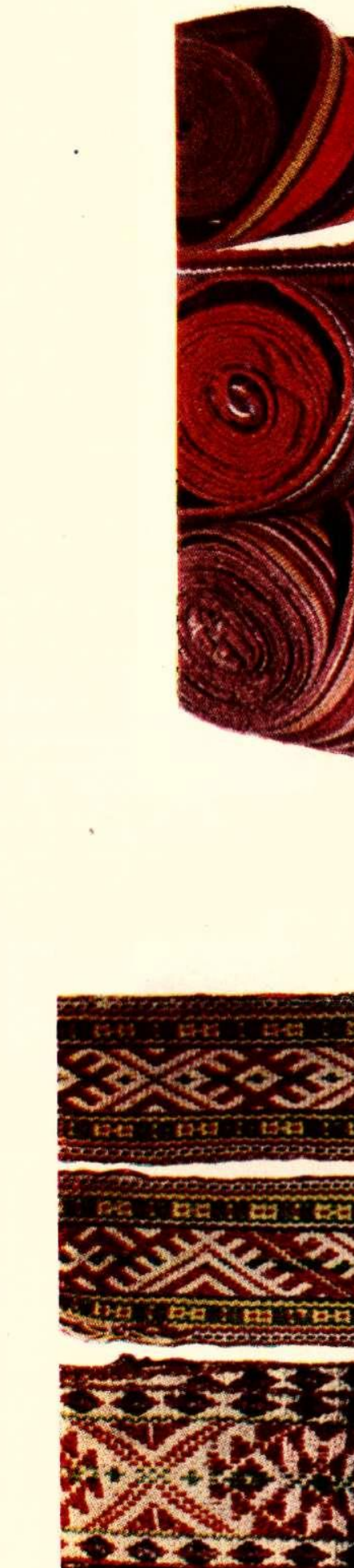

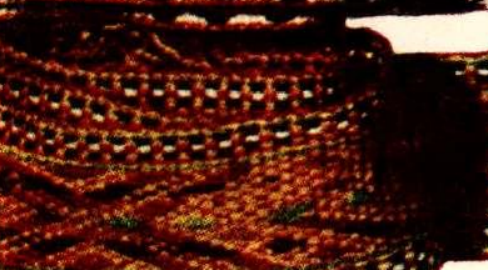

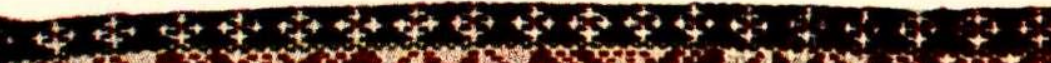

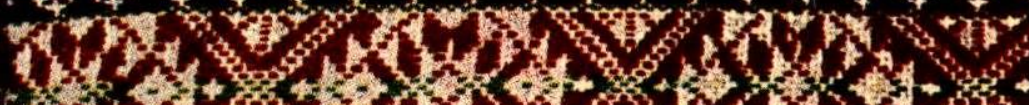

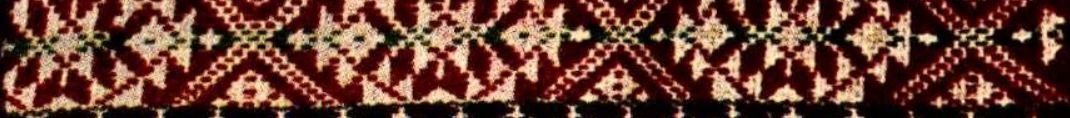

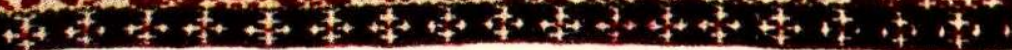
$-\cos x+25+20$ 

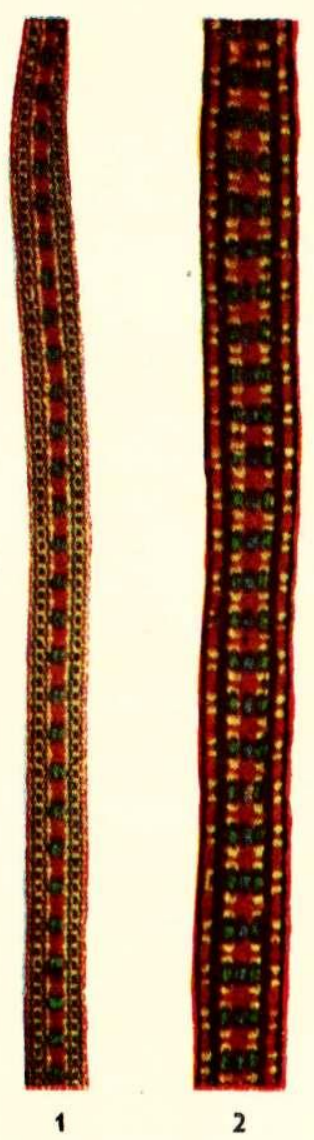
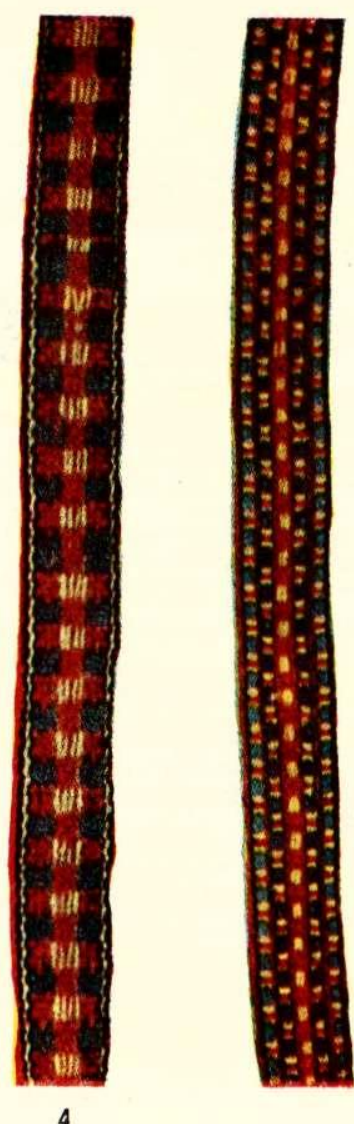
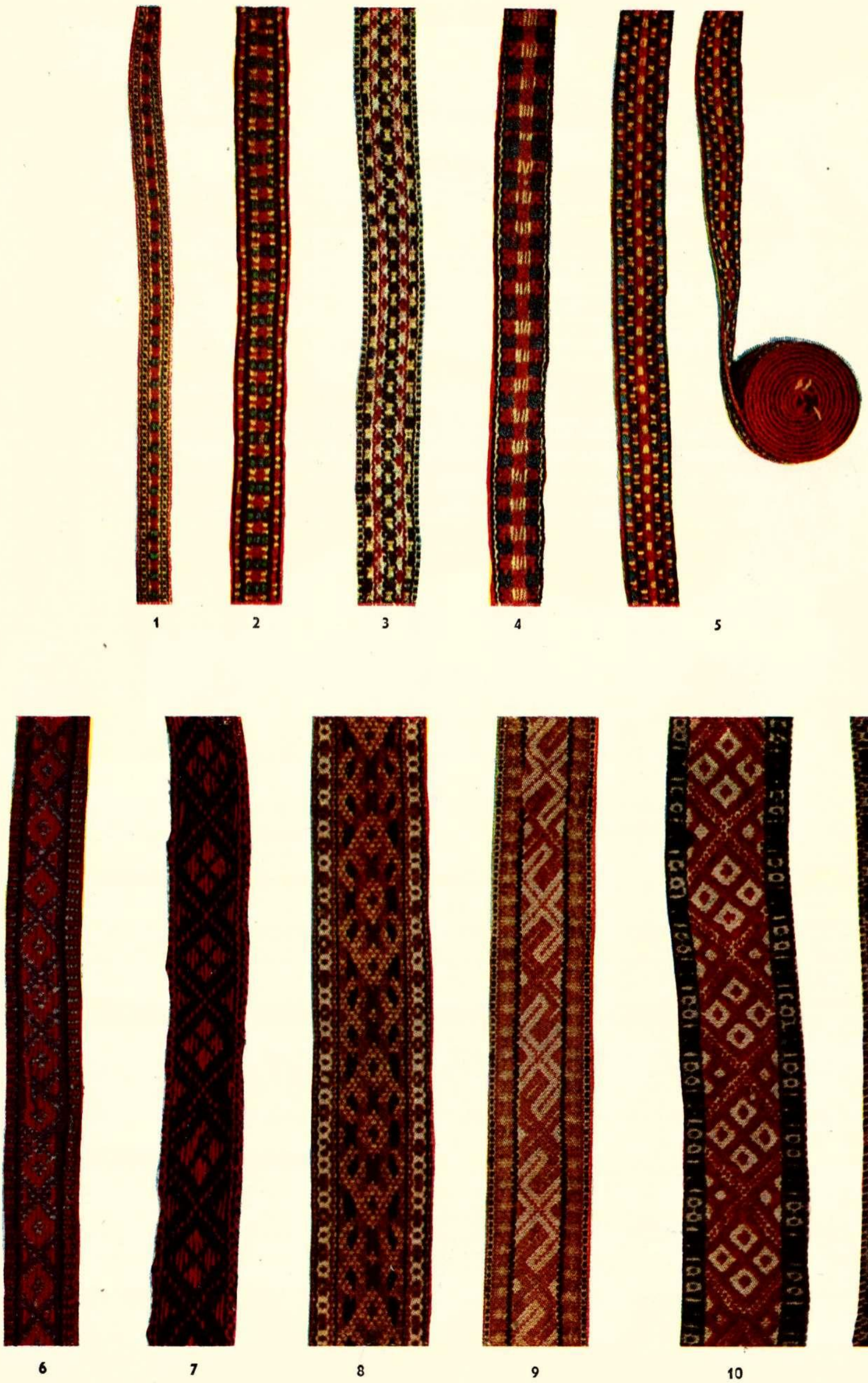

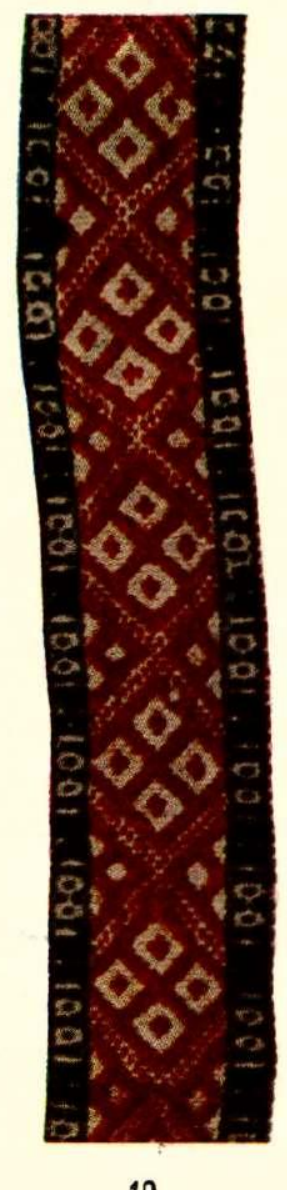

10

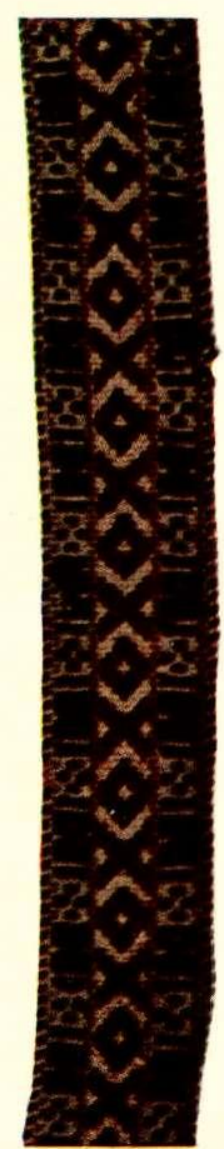

11 
15. TABULA
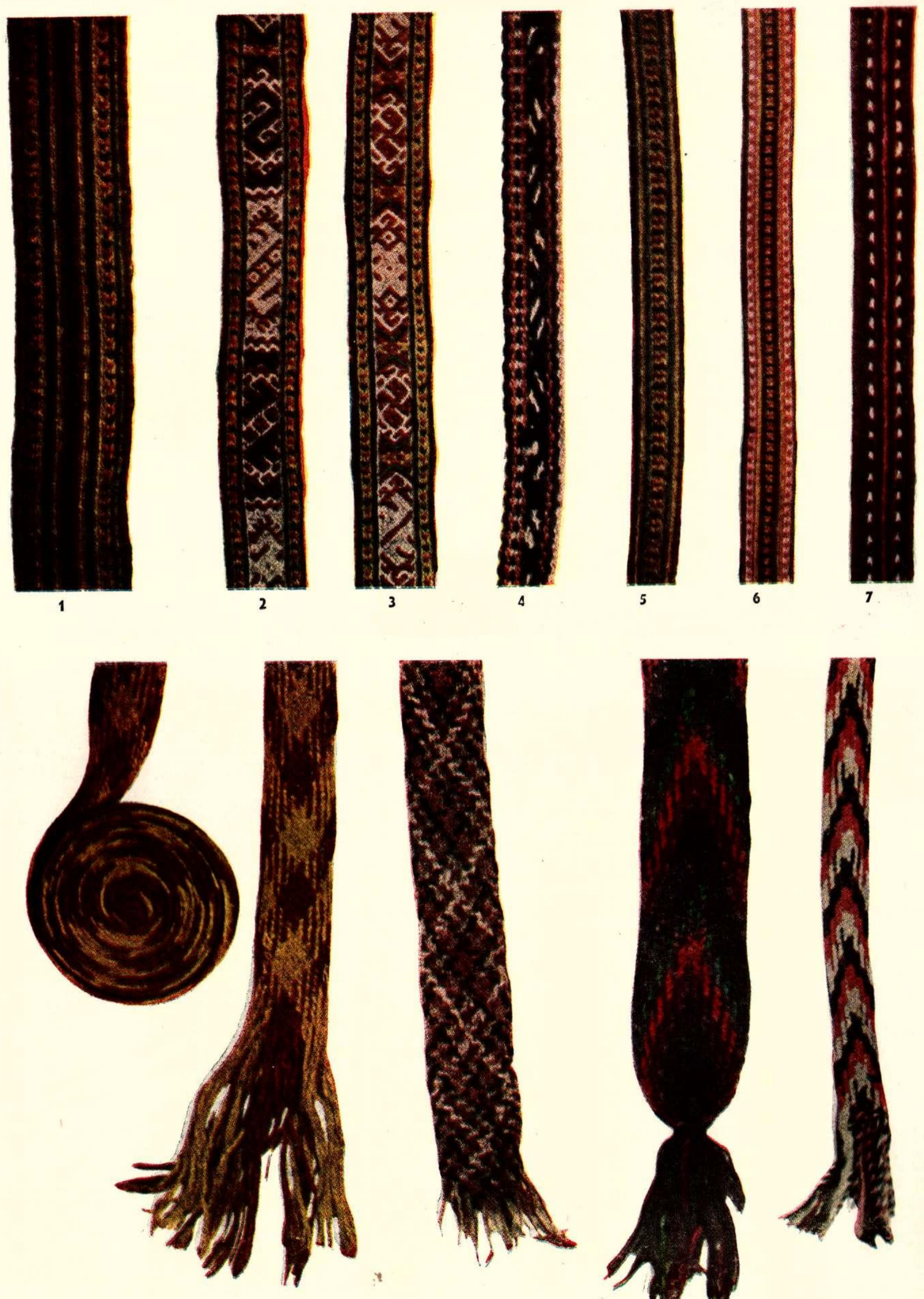

8

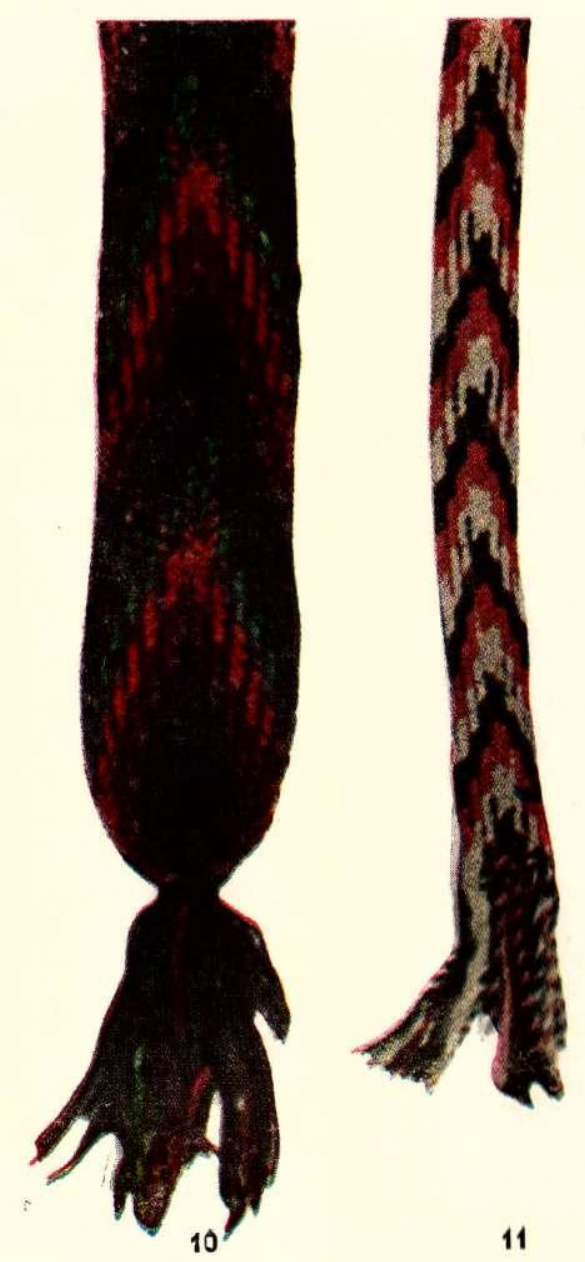




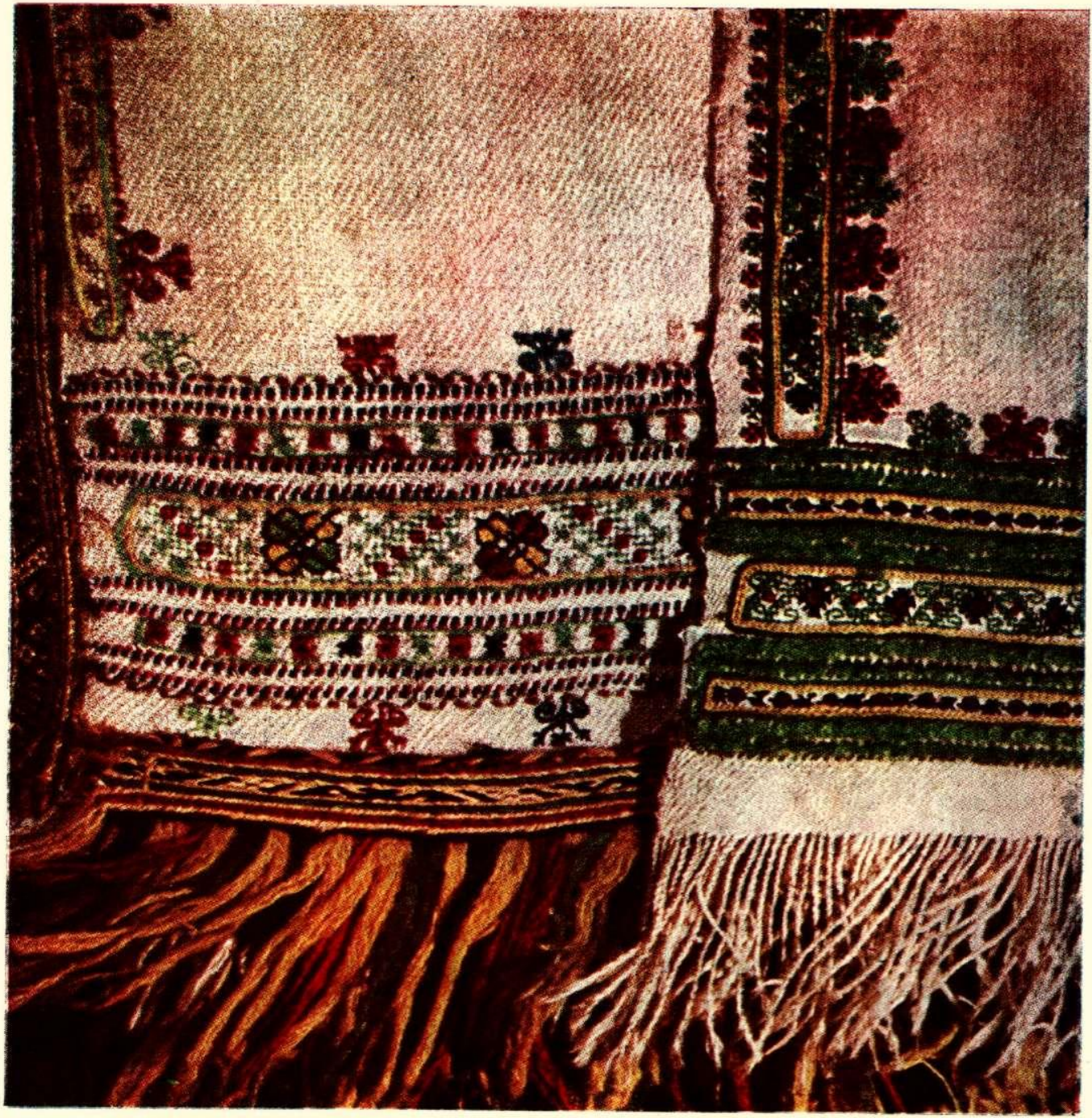

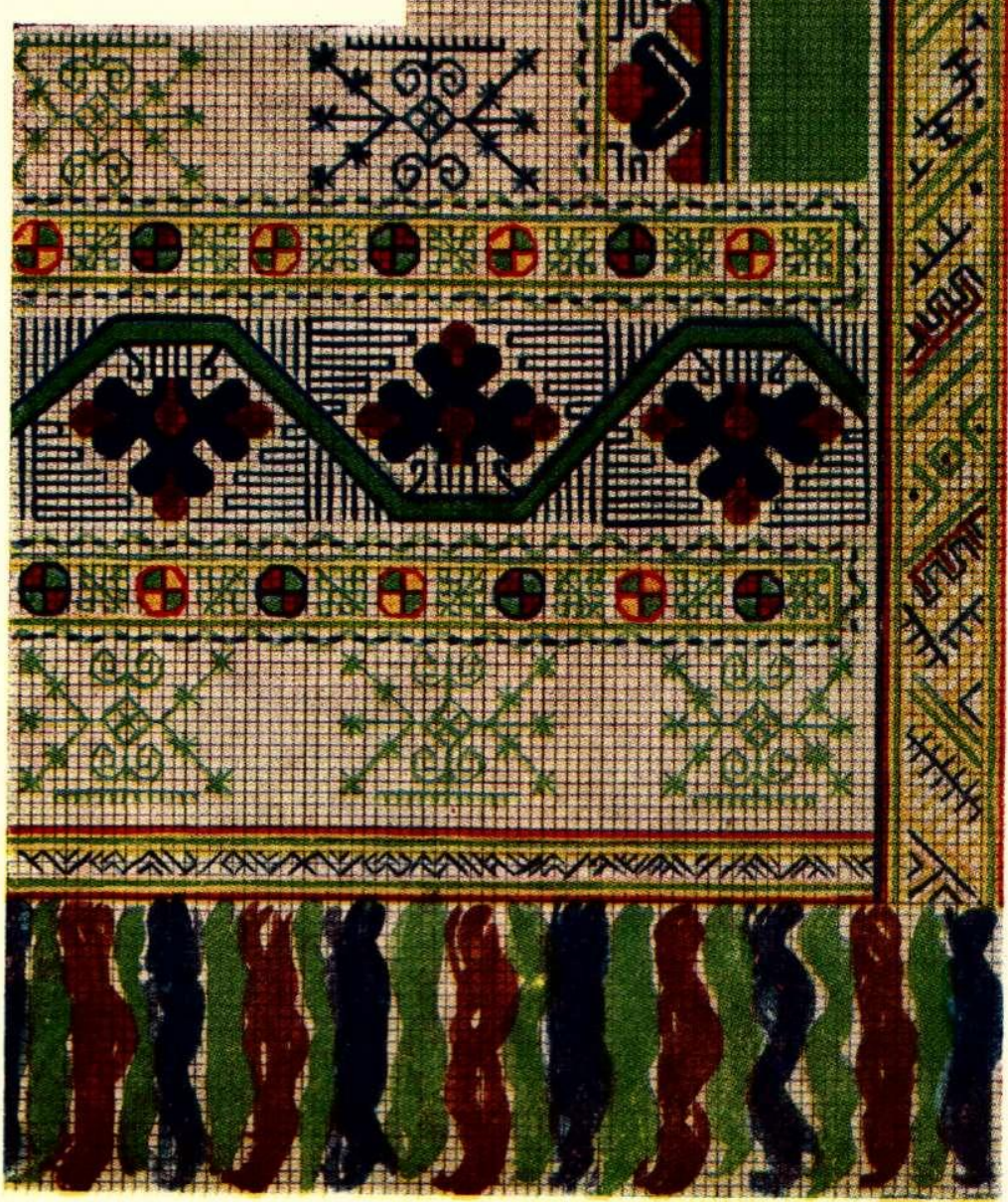



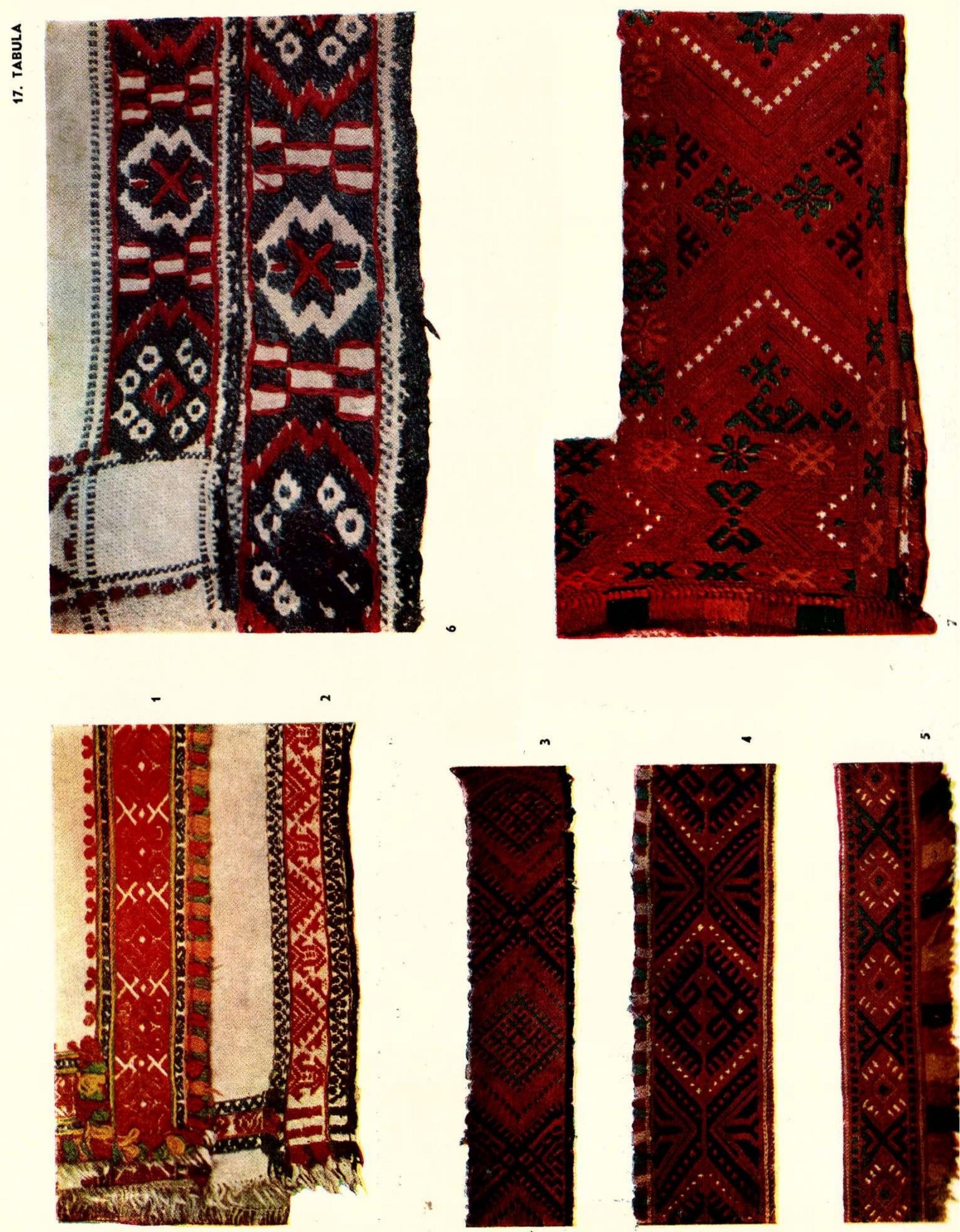
19. TABULA
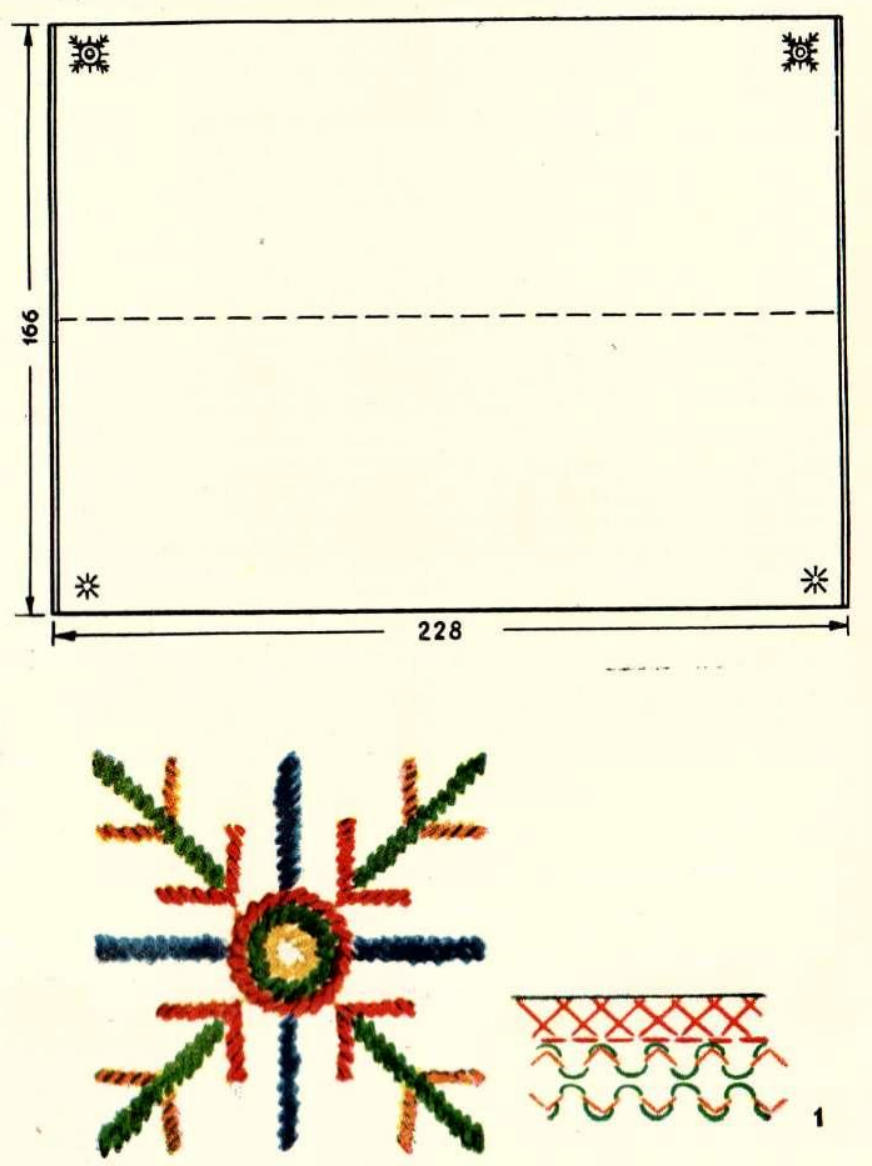
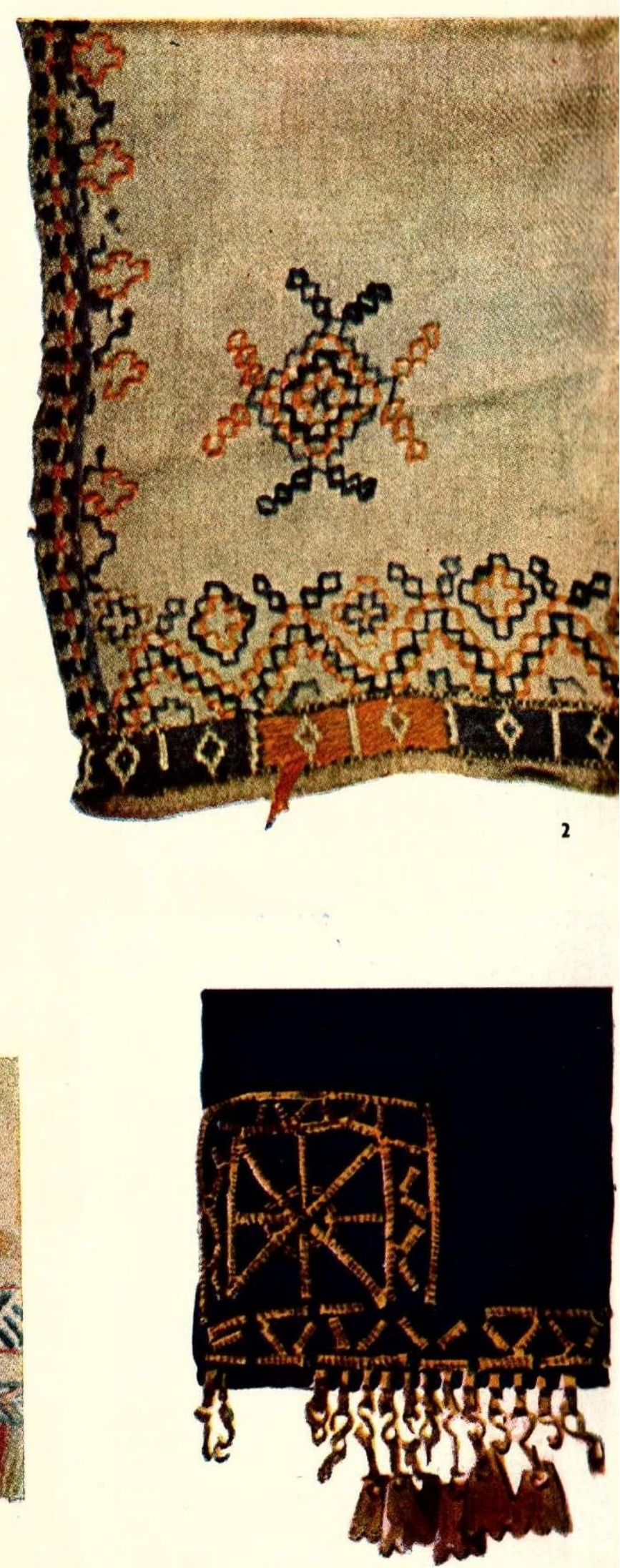

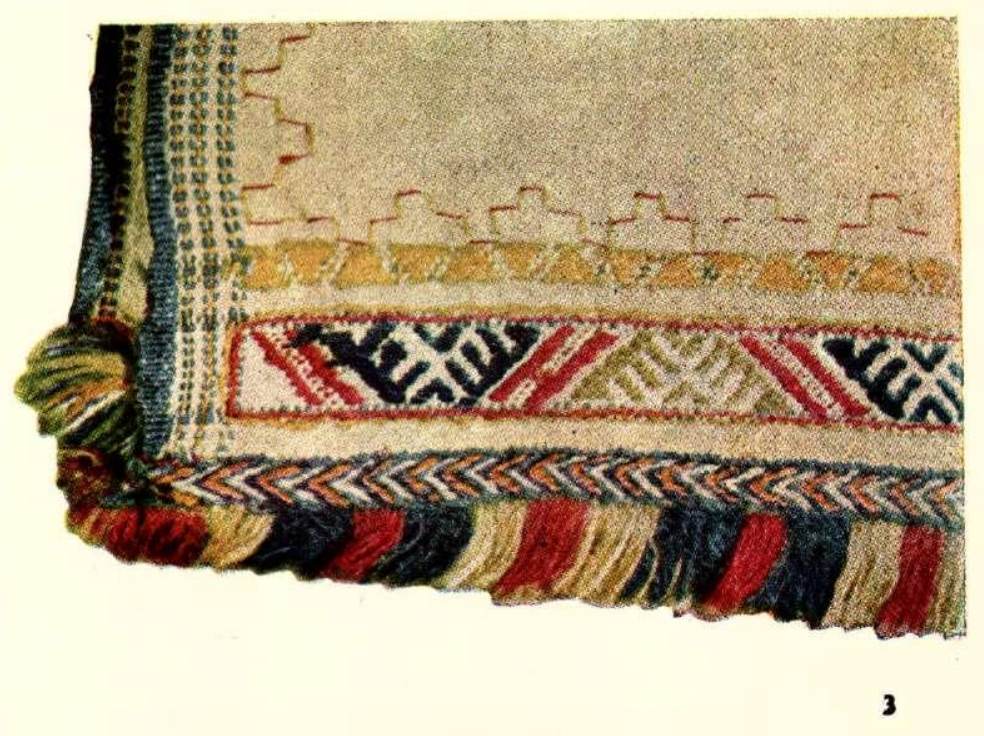




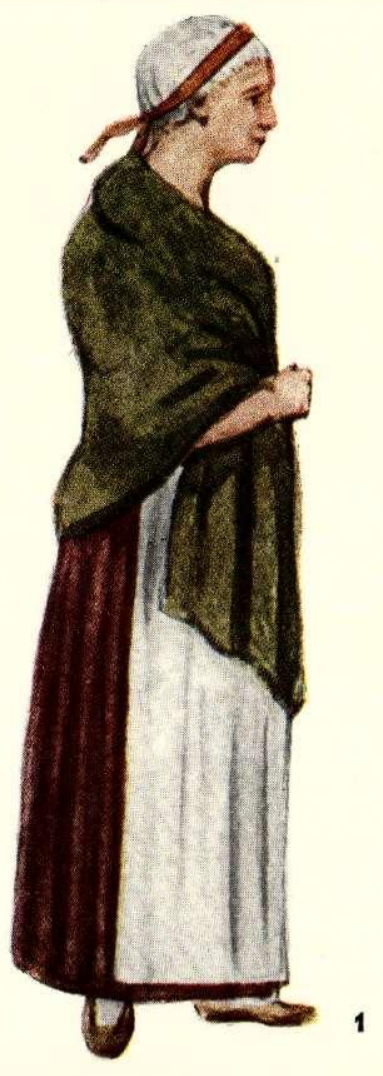

2
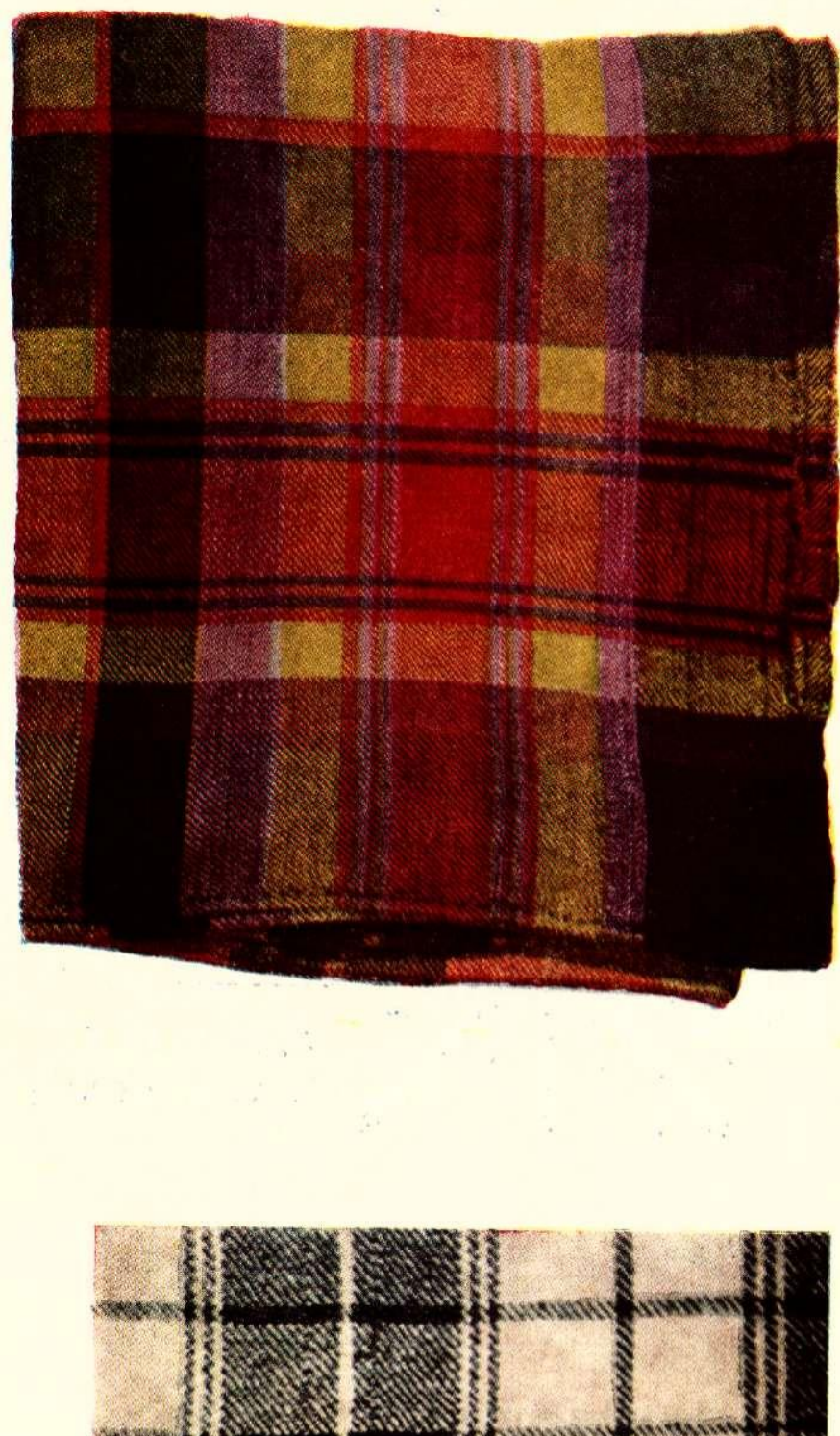

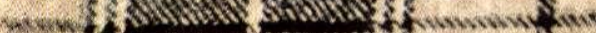

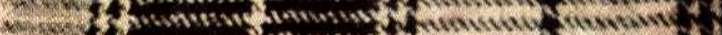

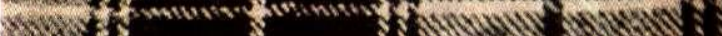
M 1 S

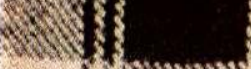

E Fum

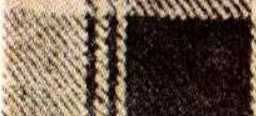

and 1

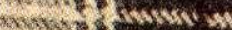

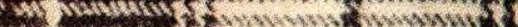

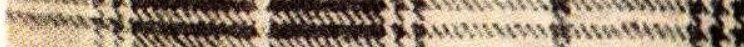

4
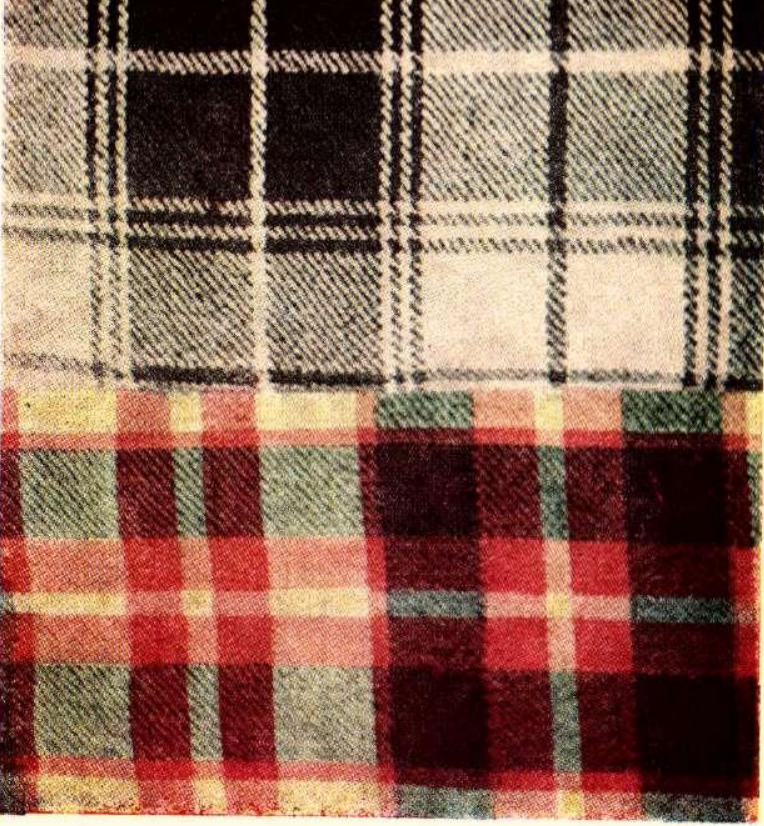

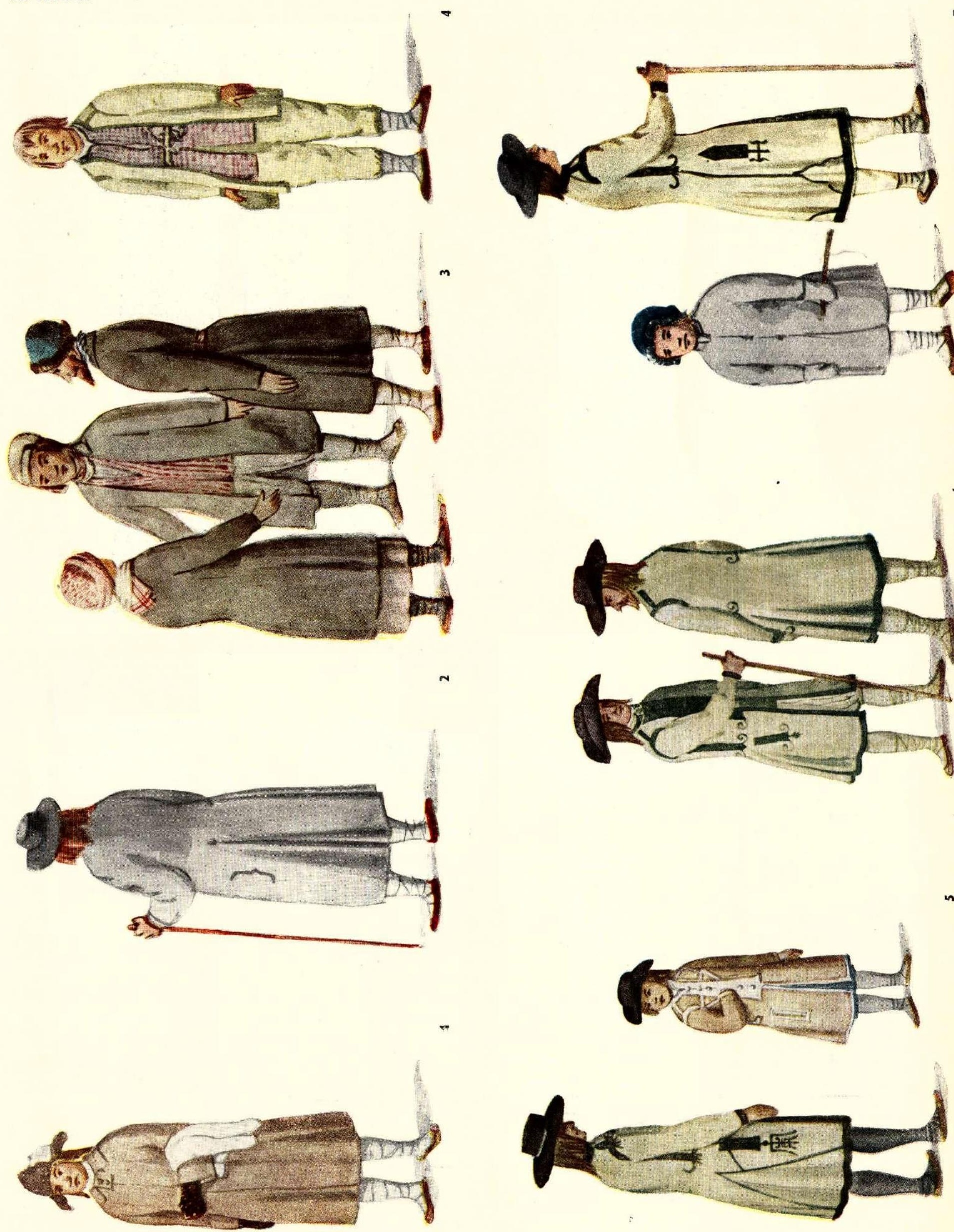

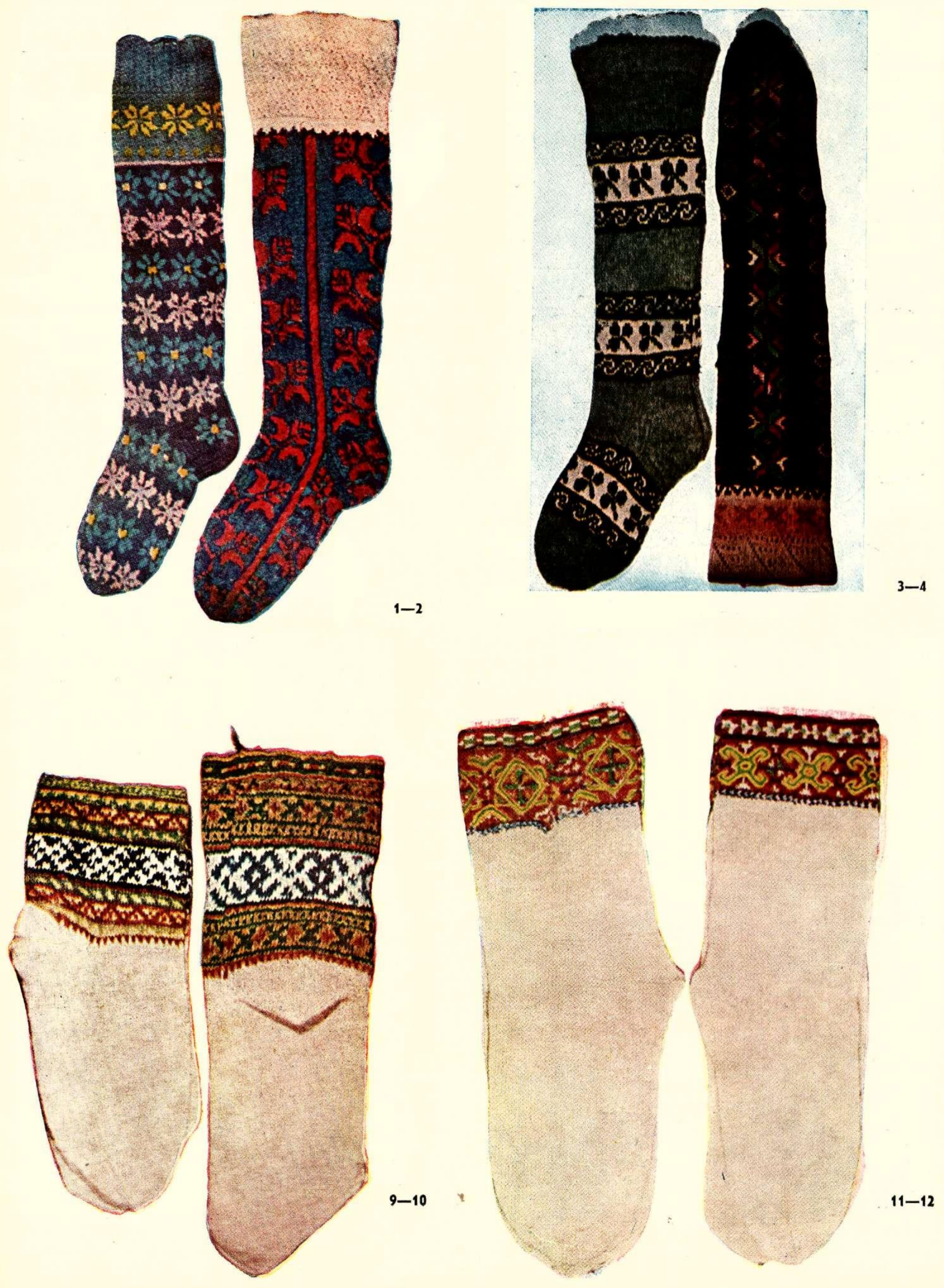


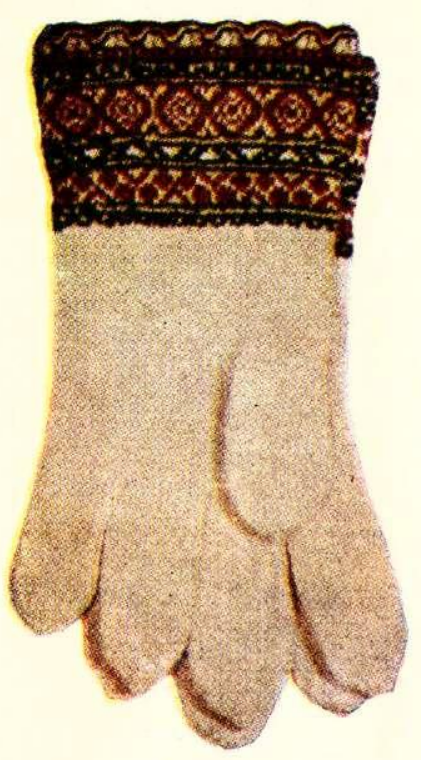

1
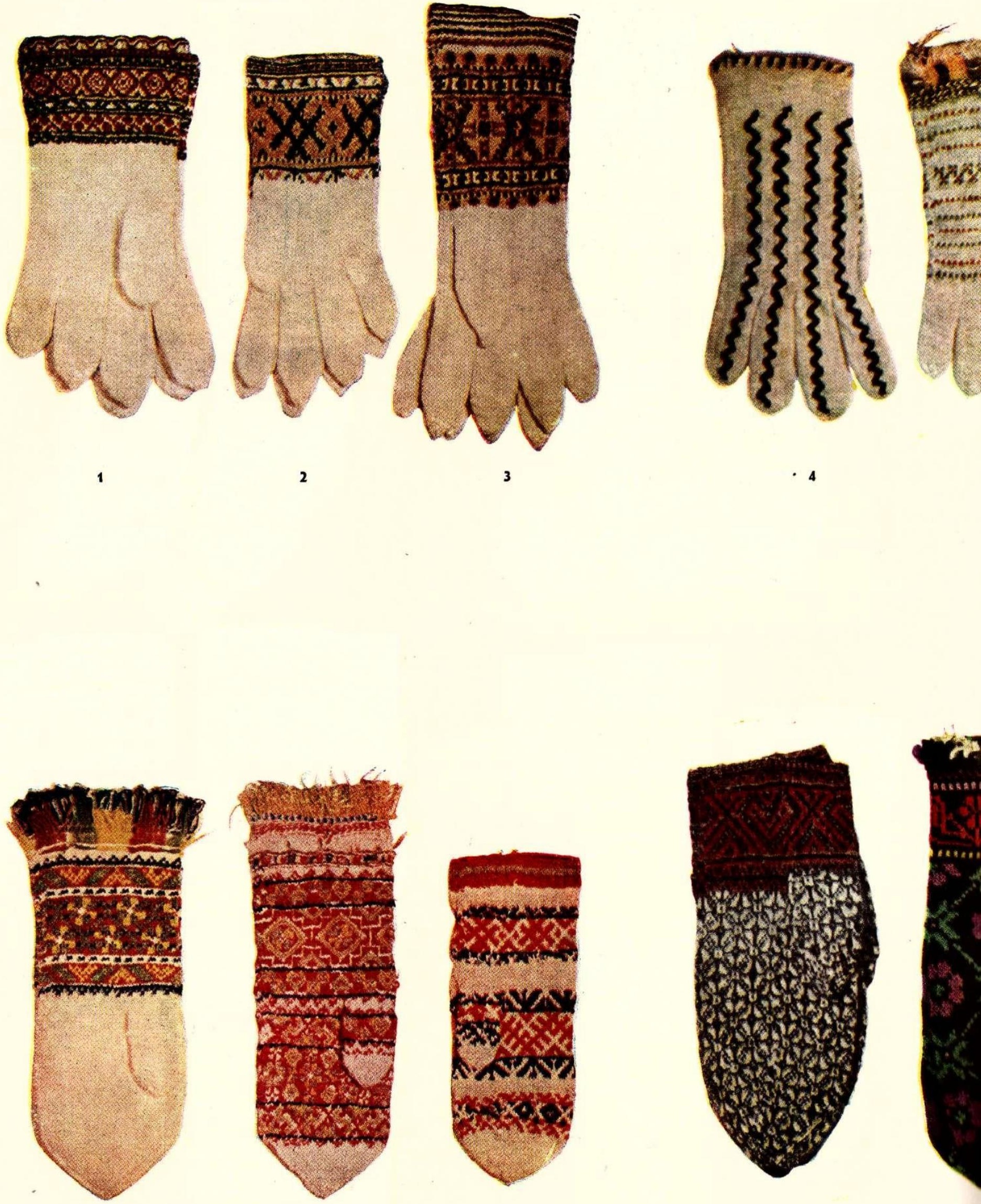


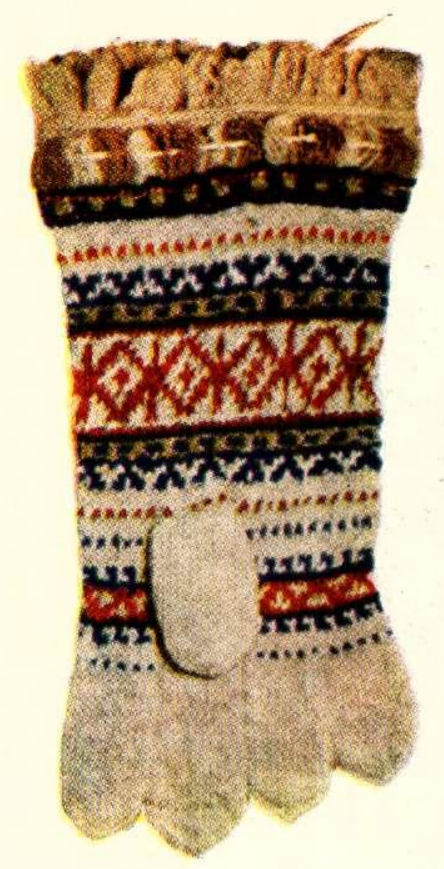

6

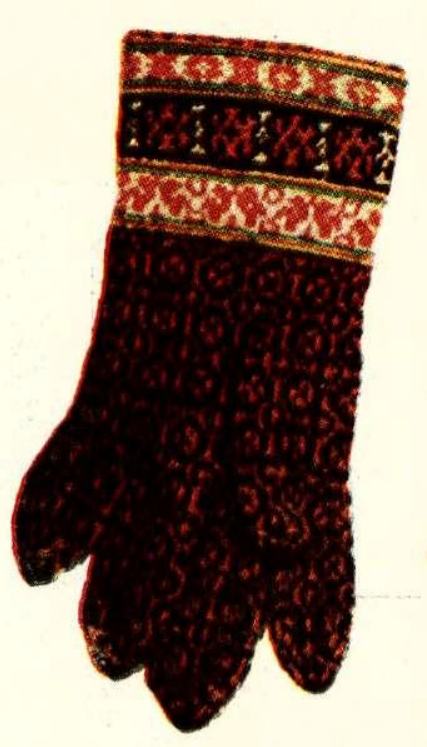

7

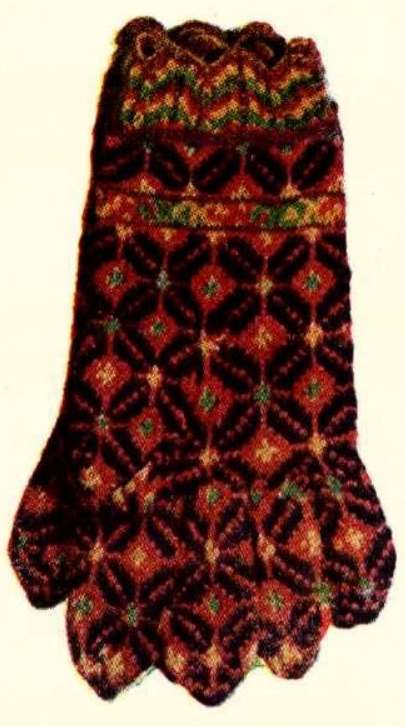

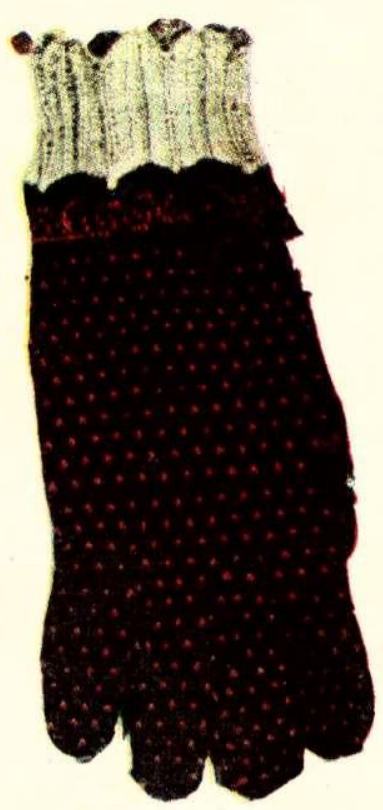

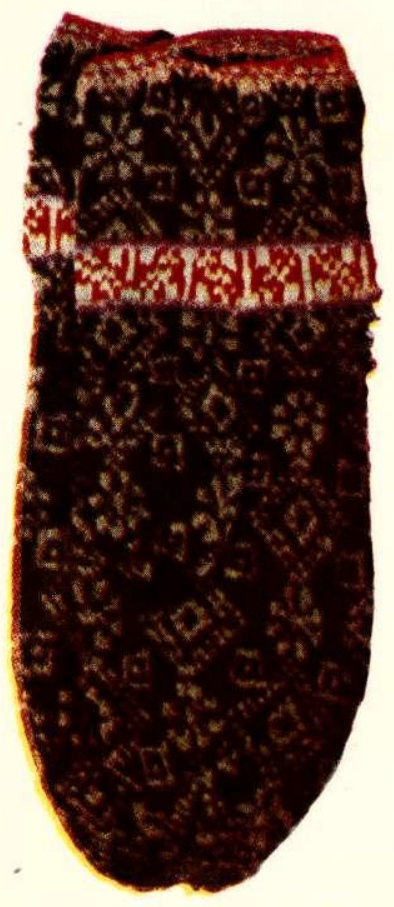

15
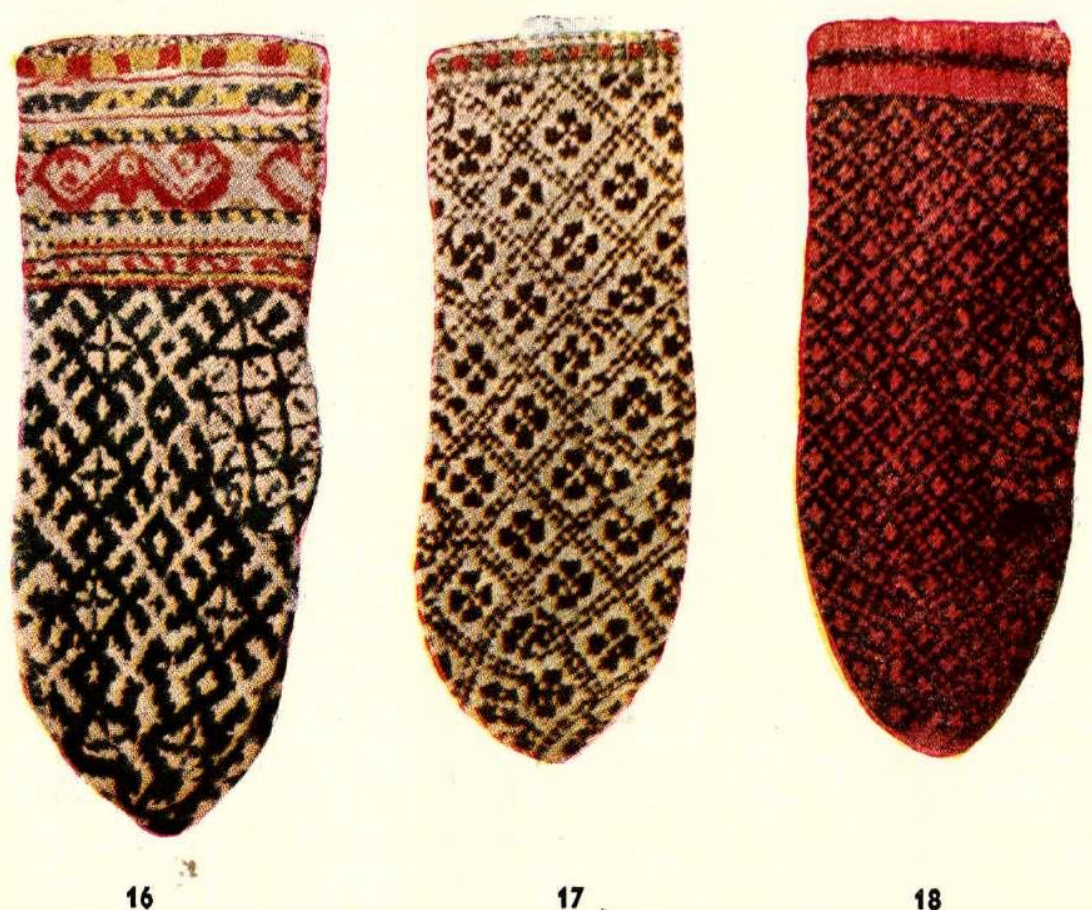

17 

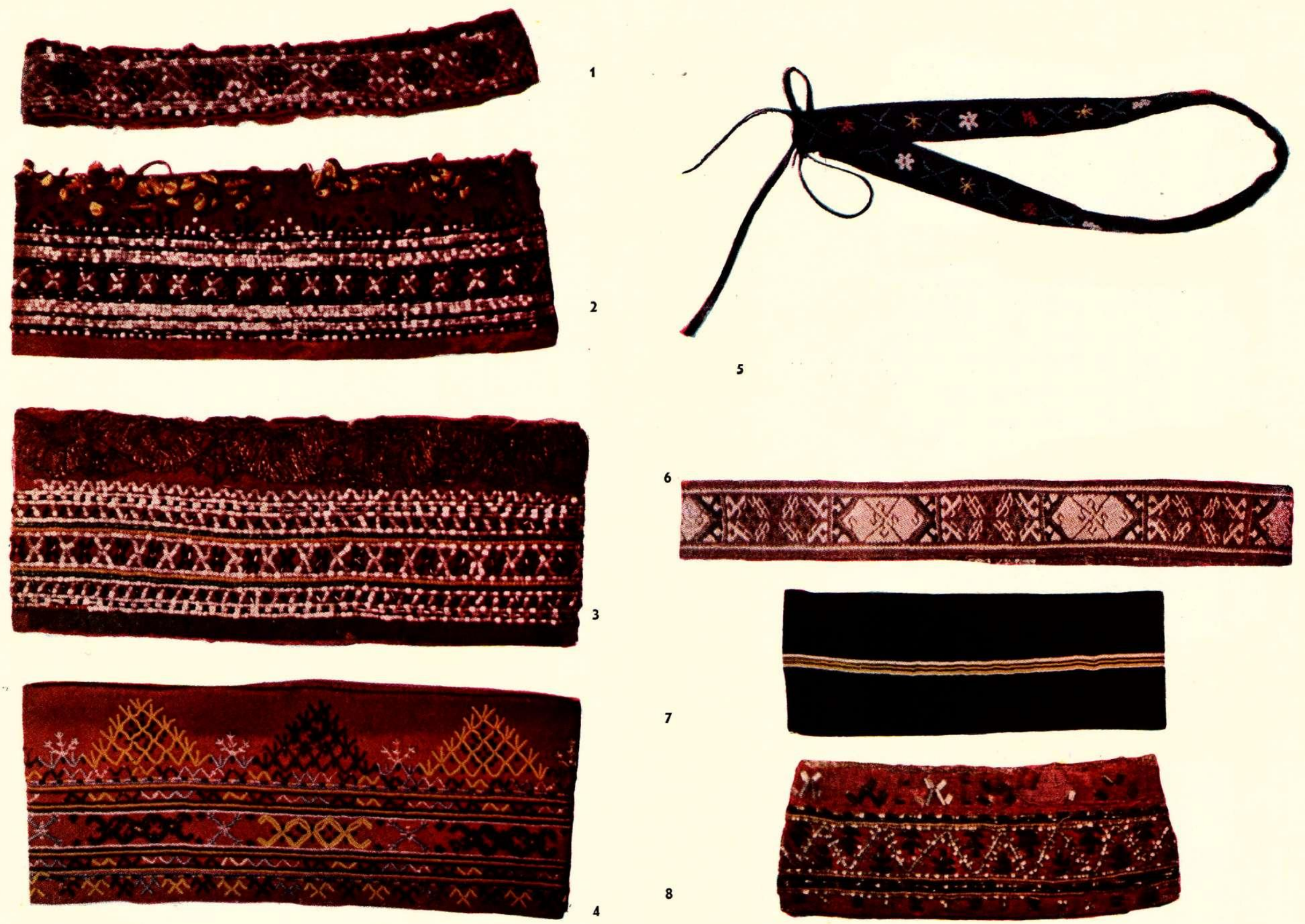

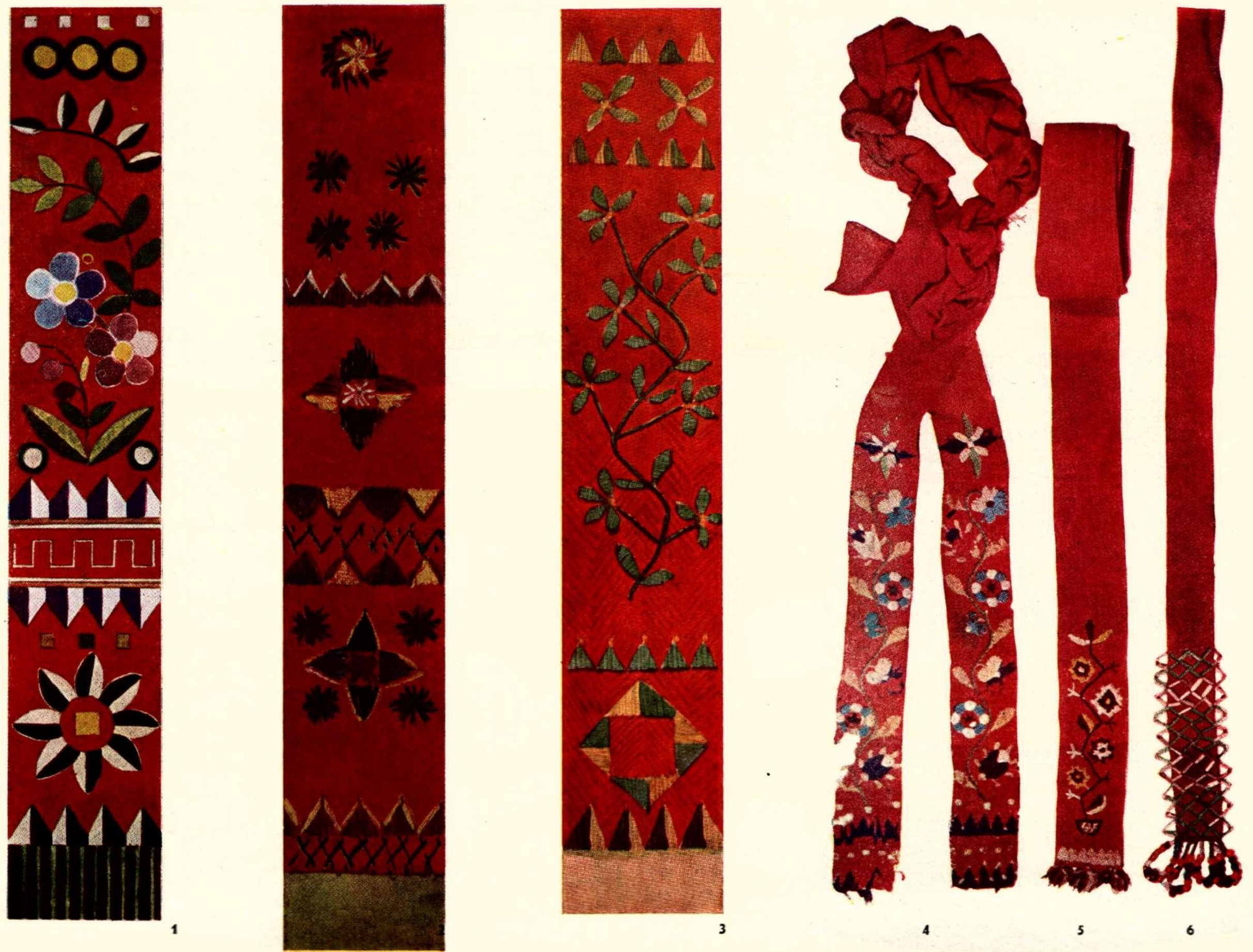

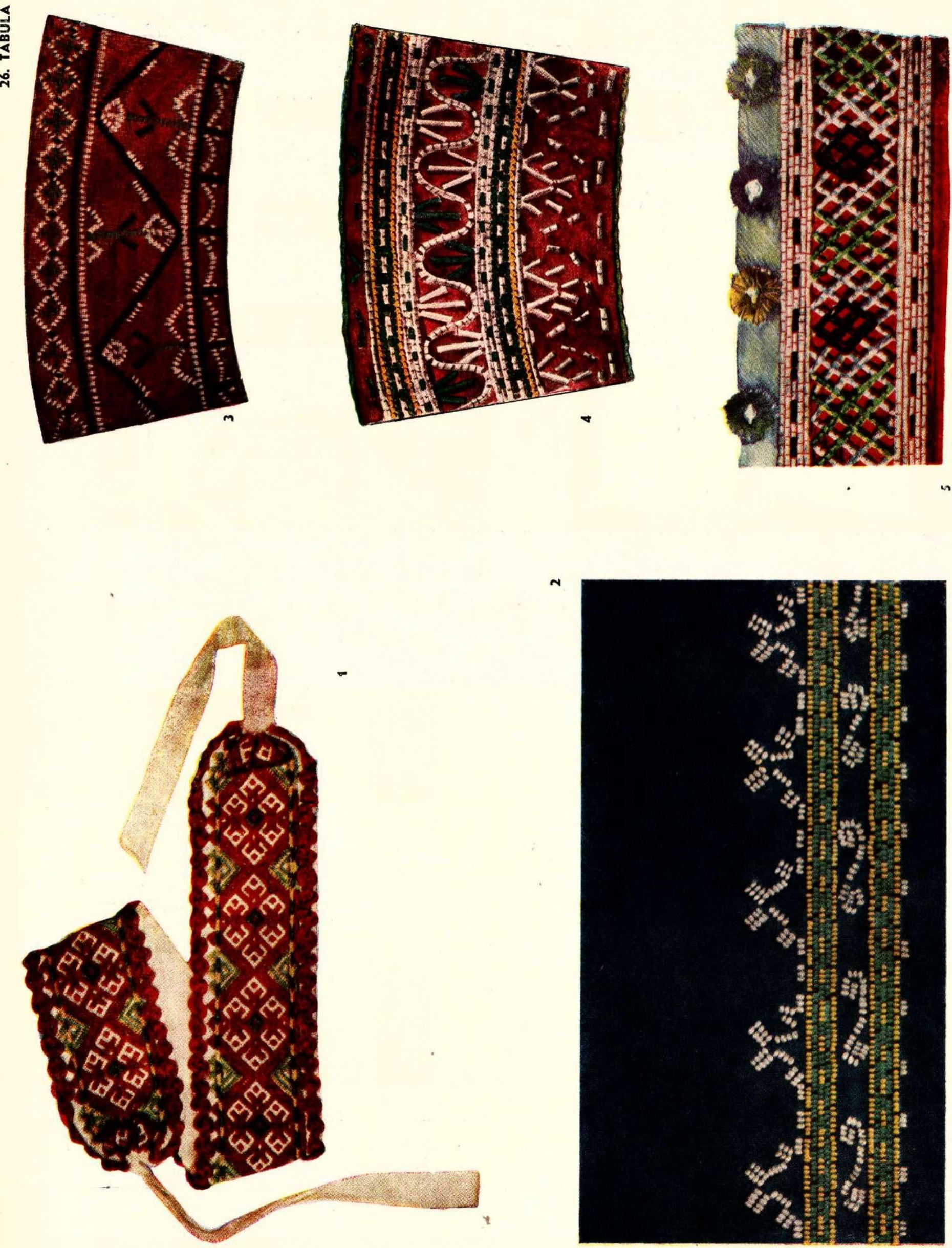

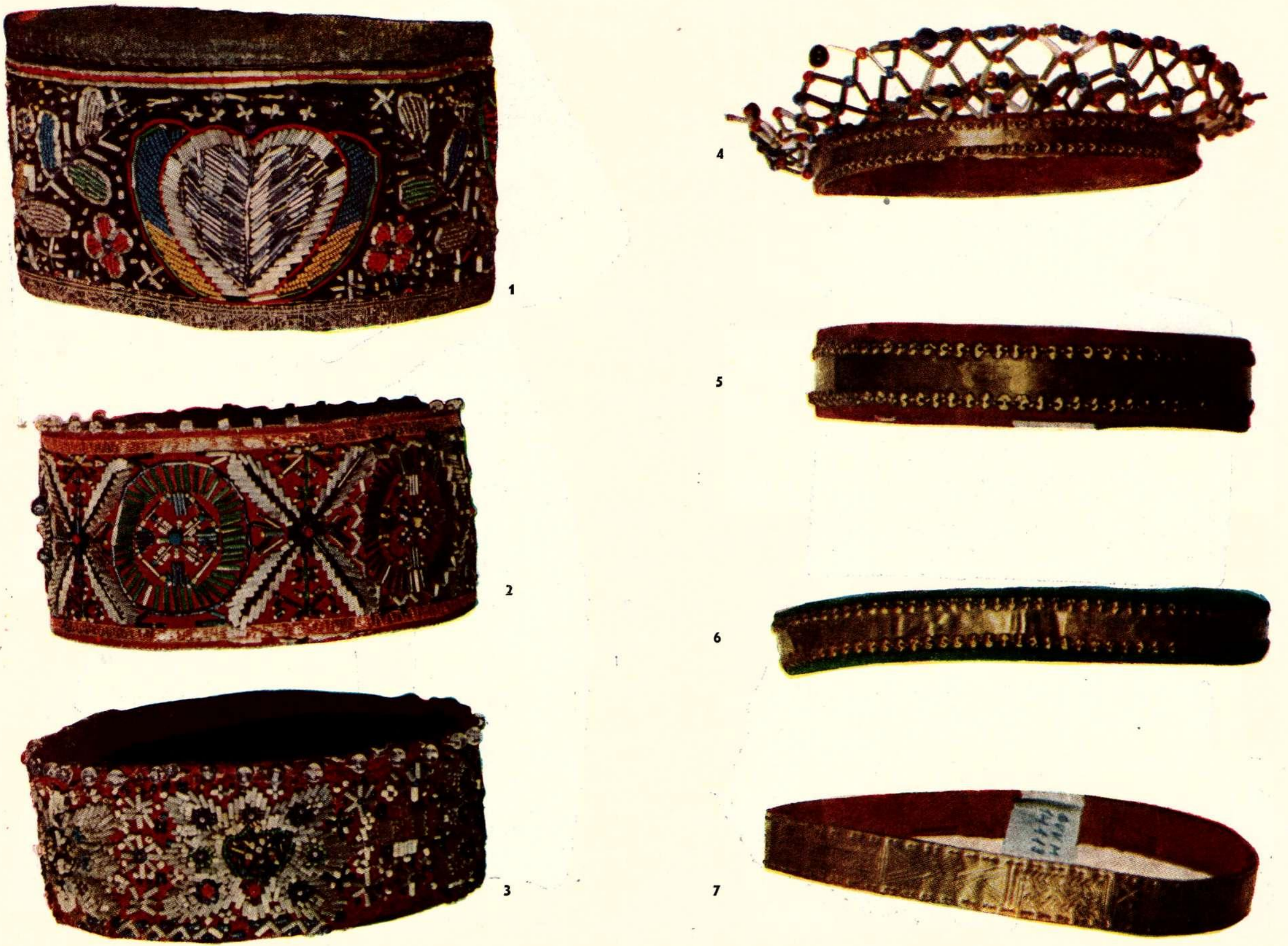

7

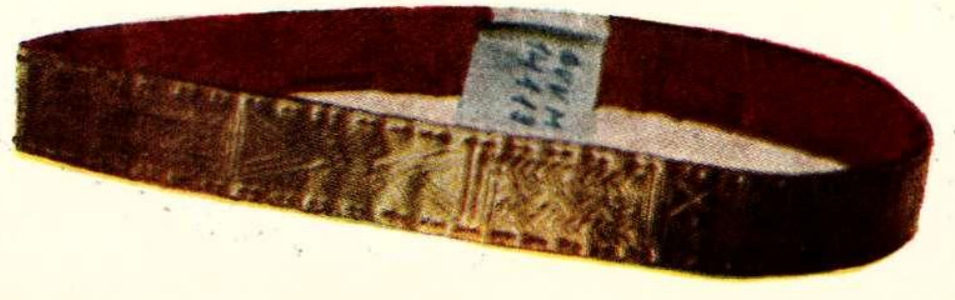


28. TABULA

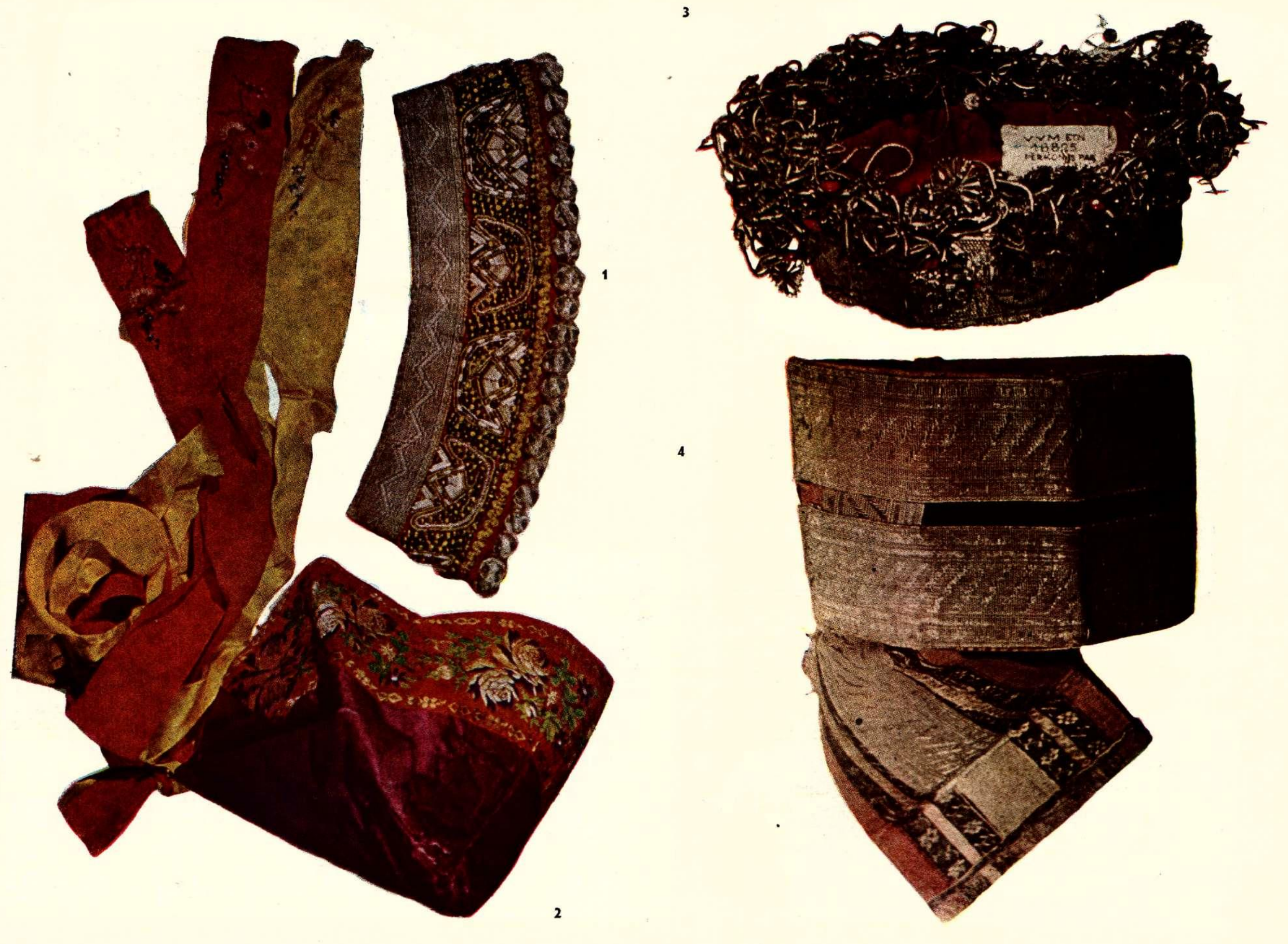



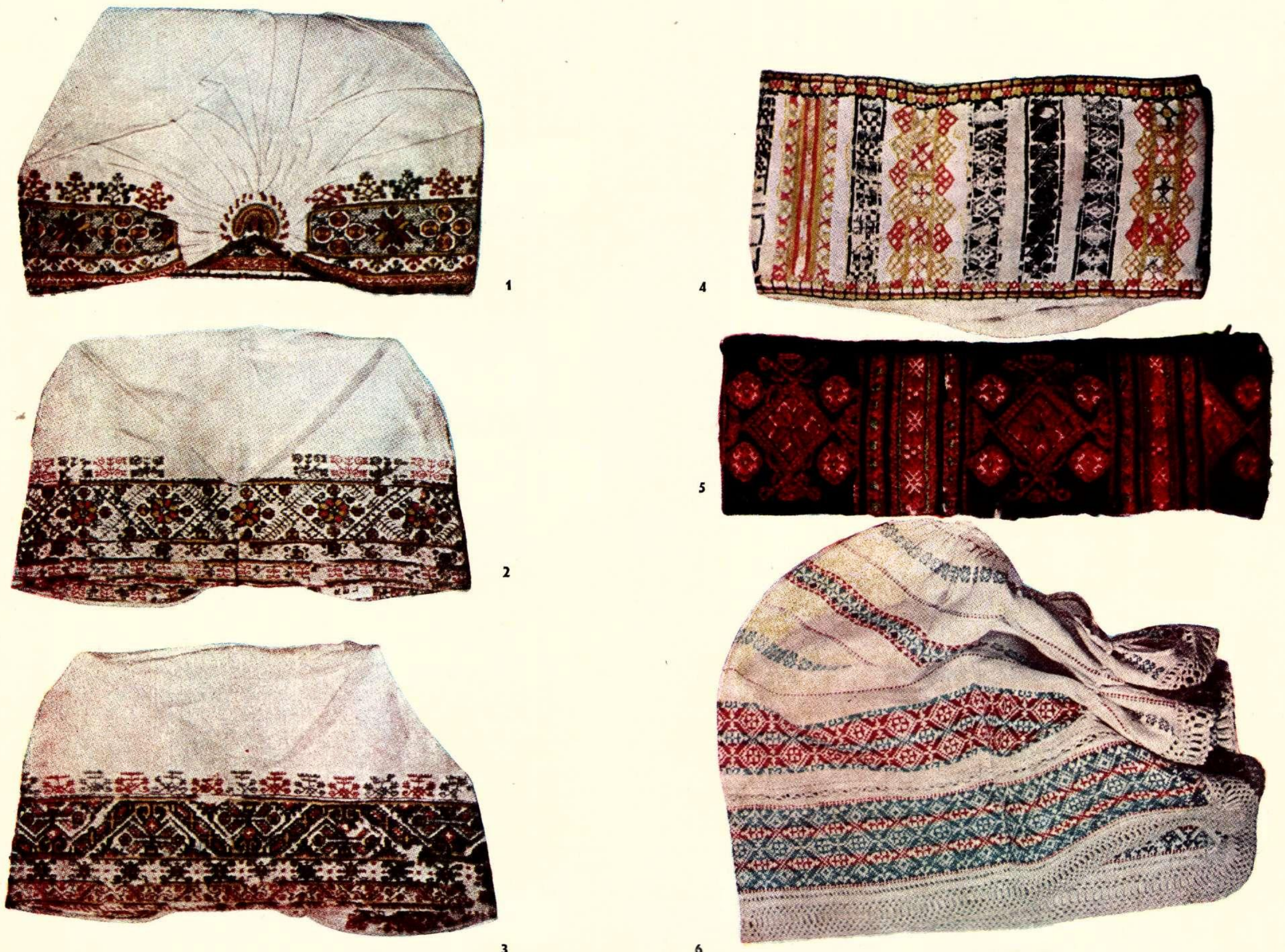


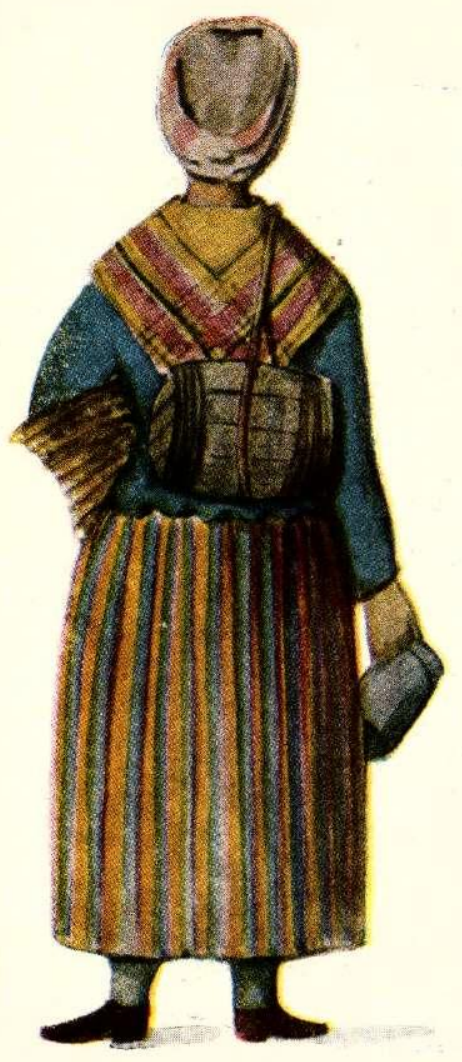

, 1

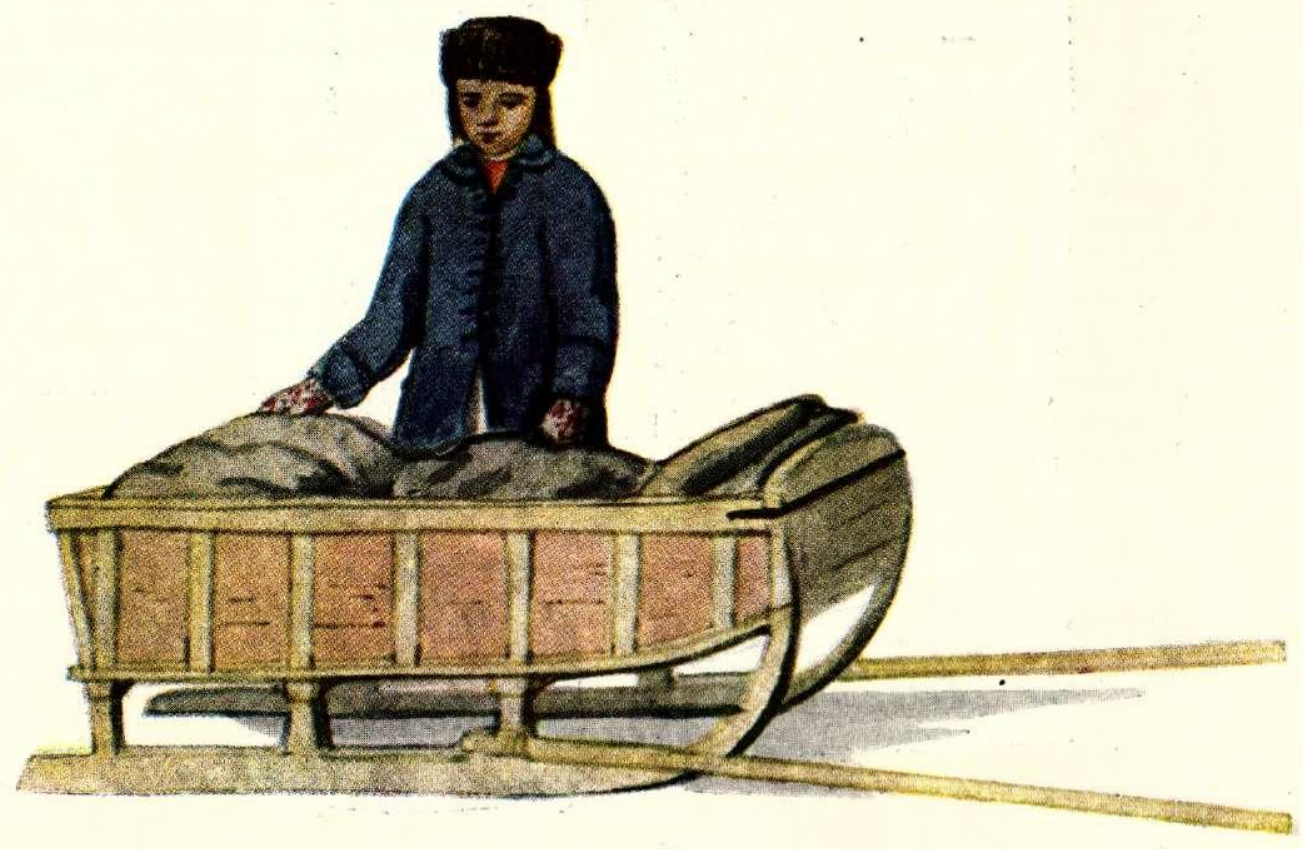

2

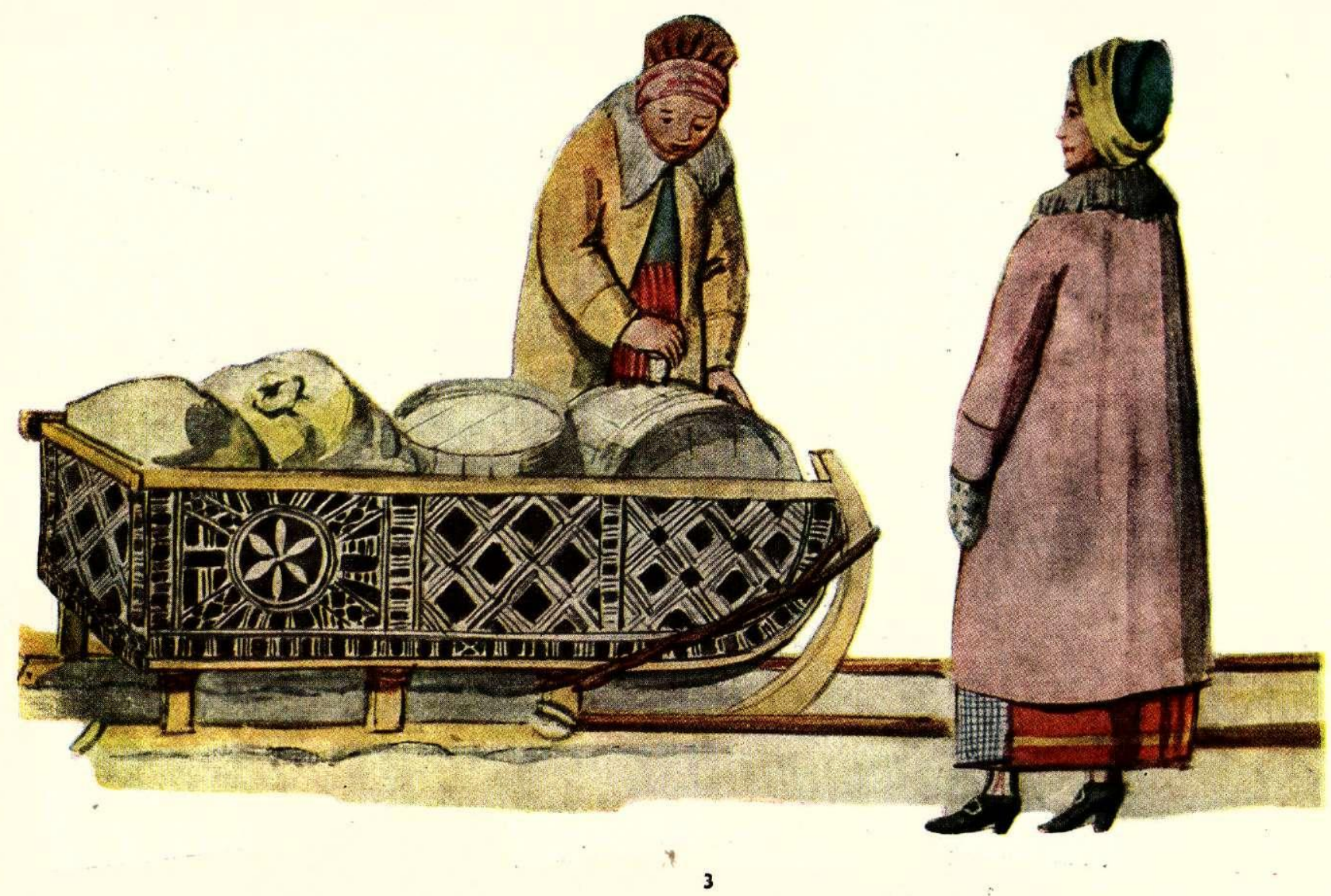



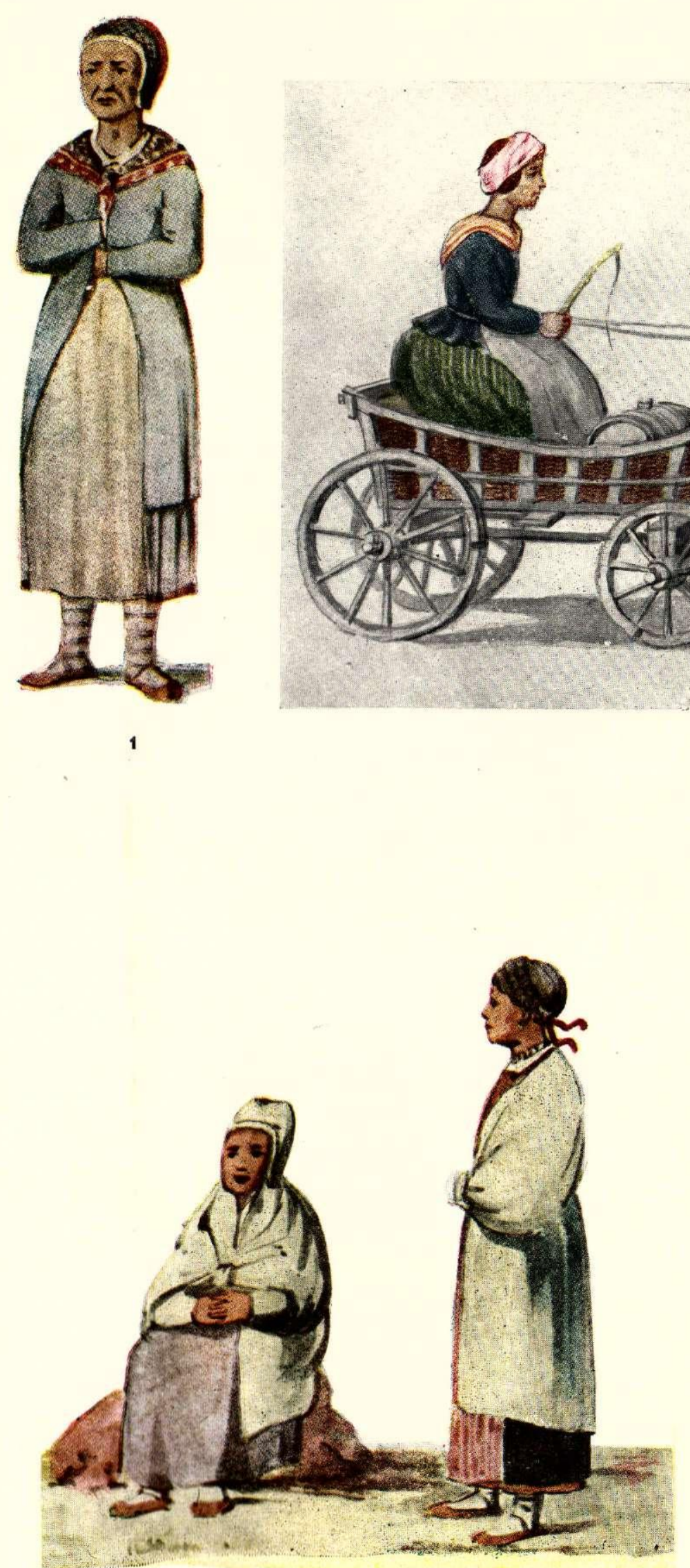

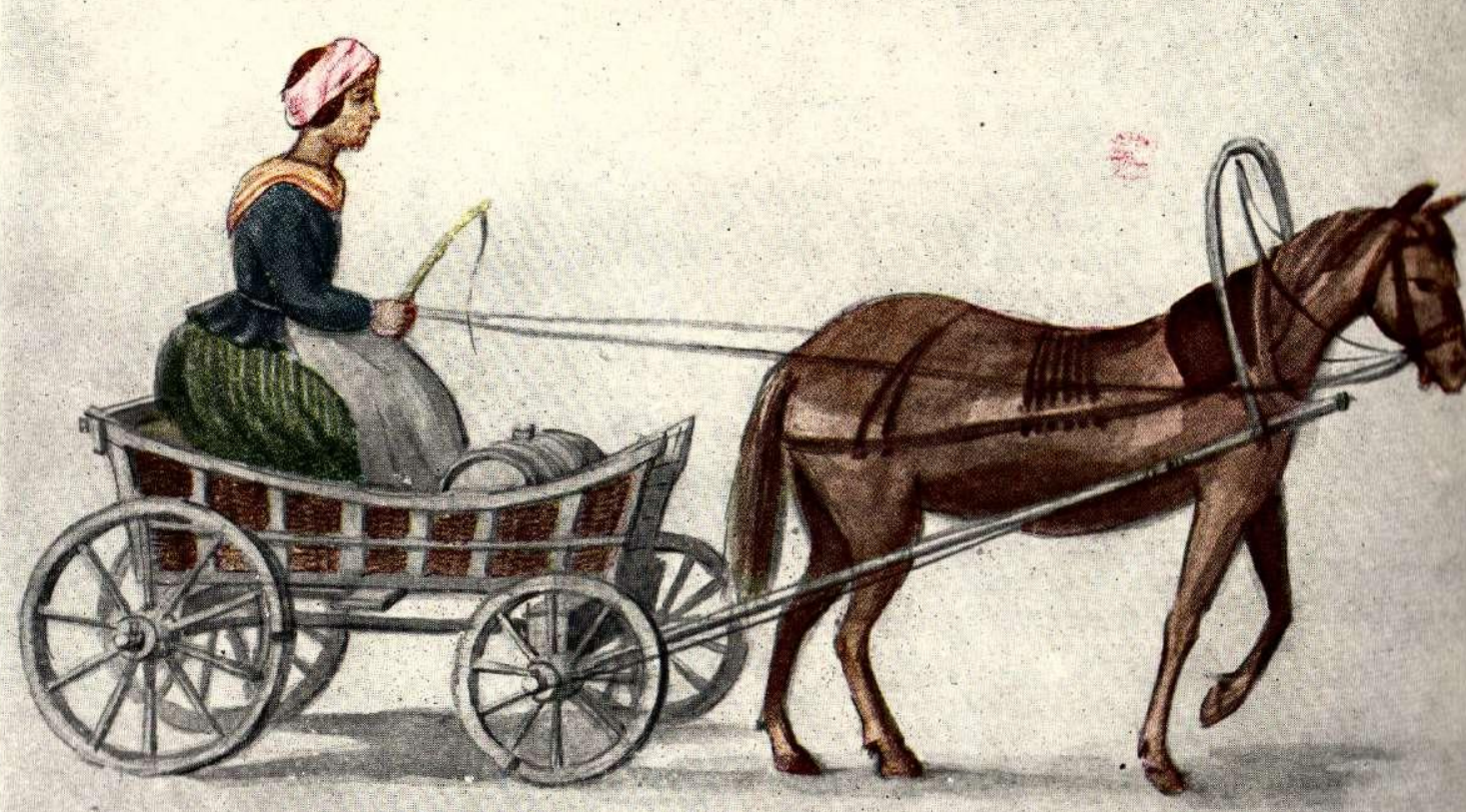

2

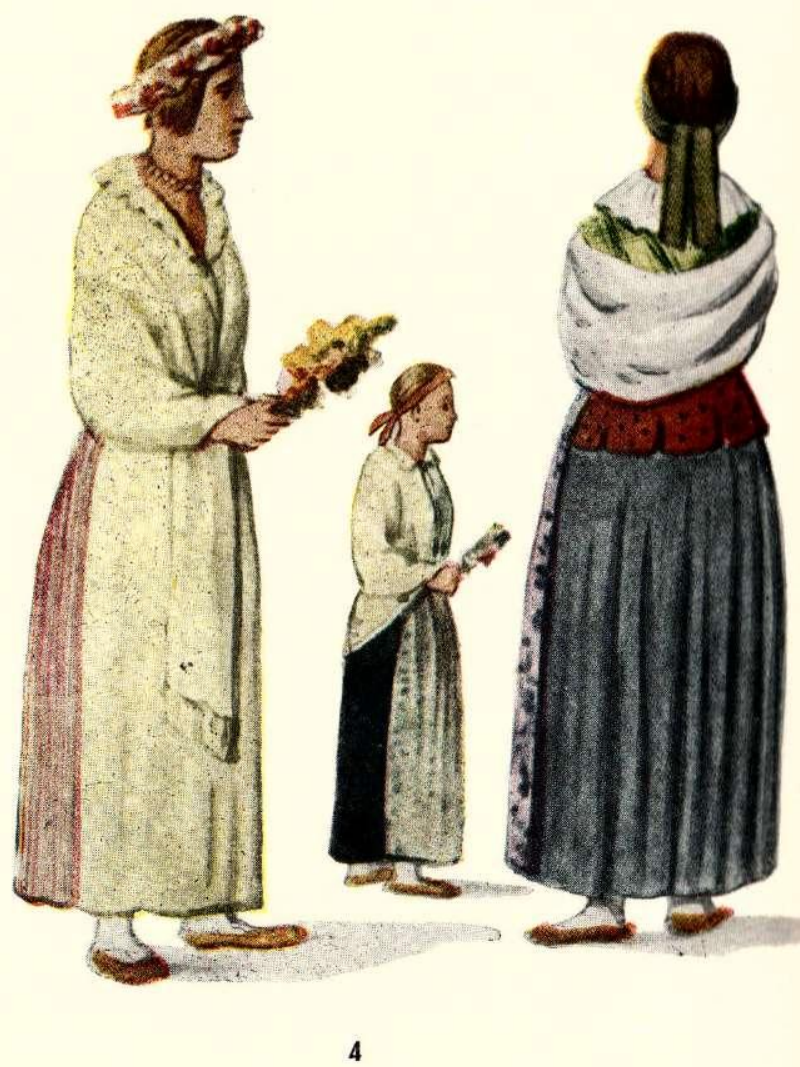



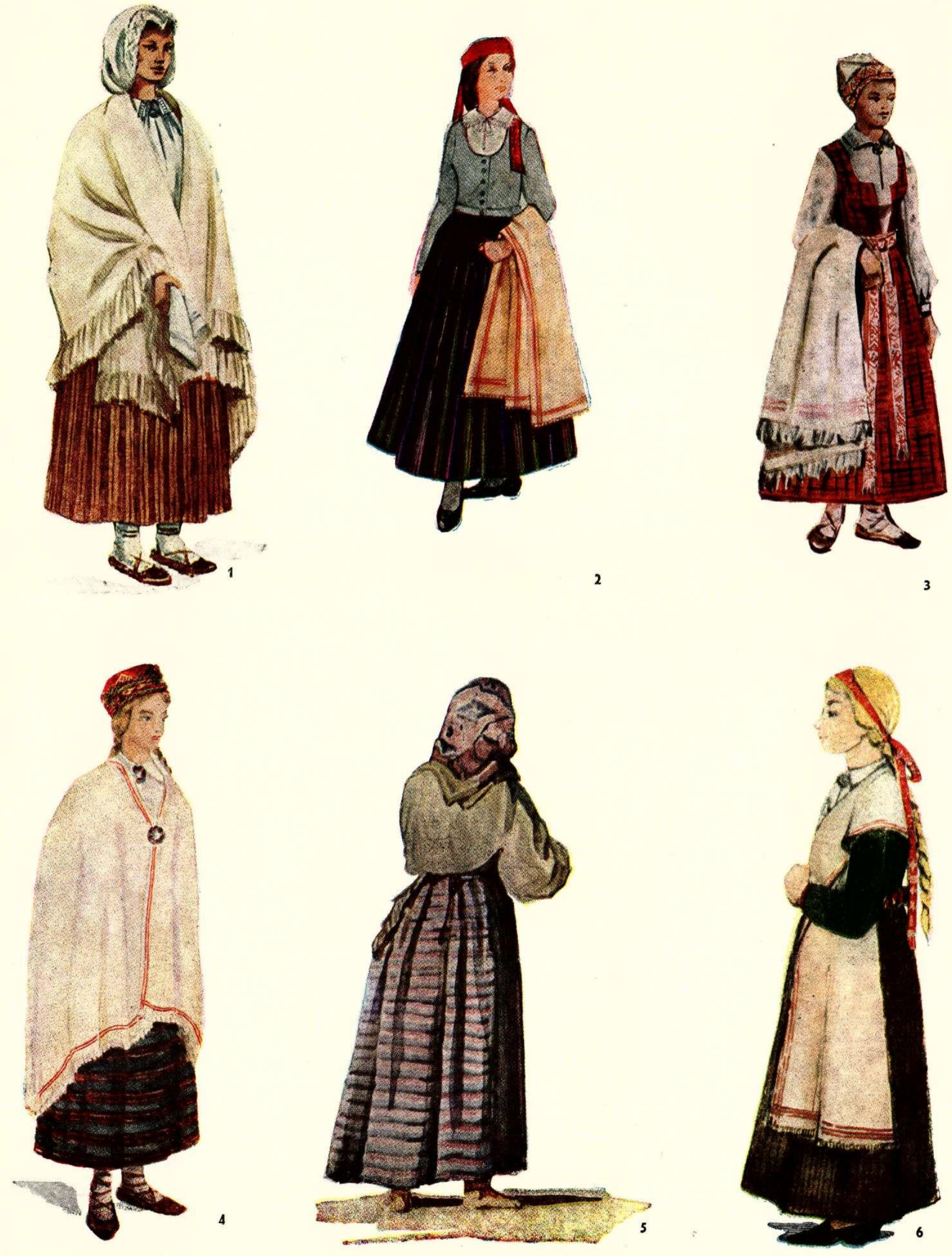

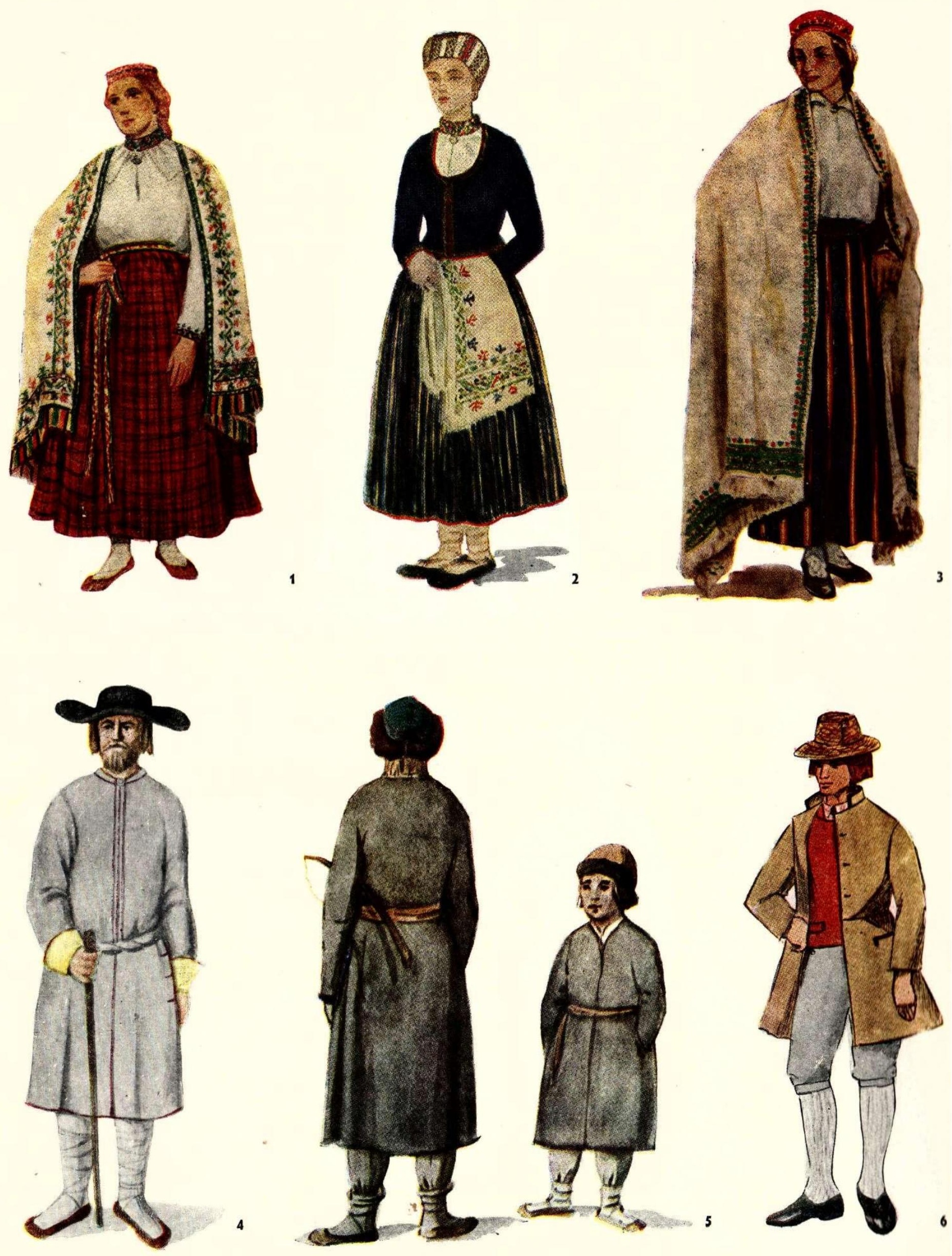

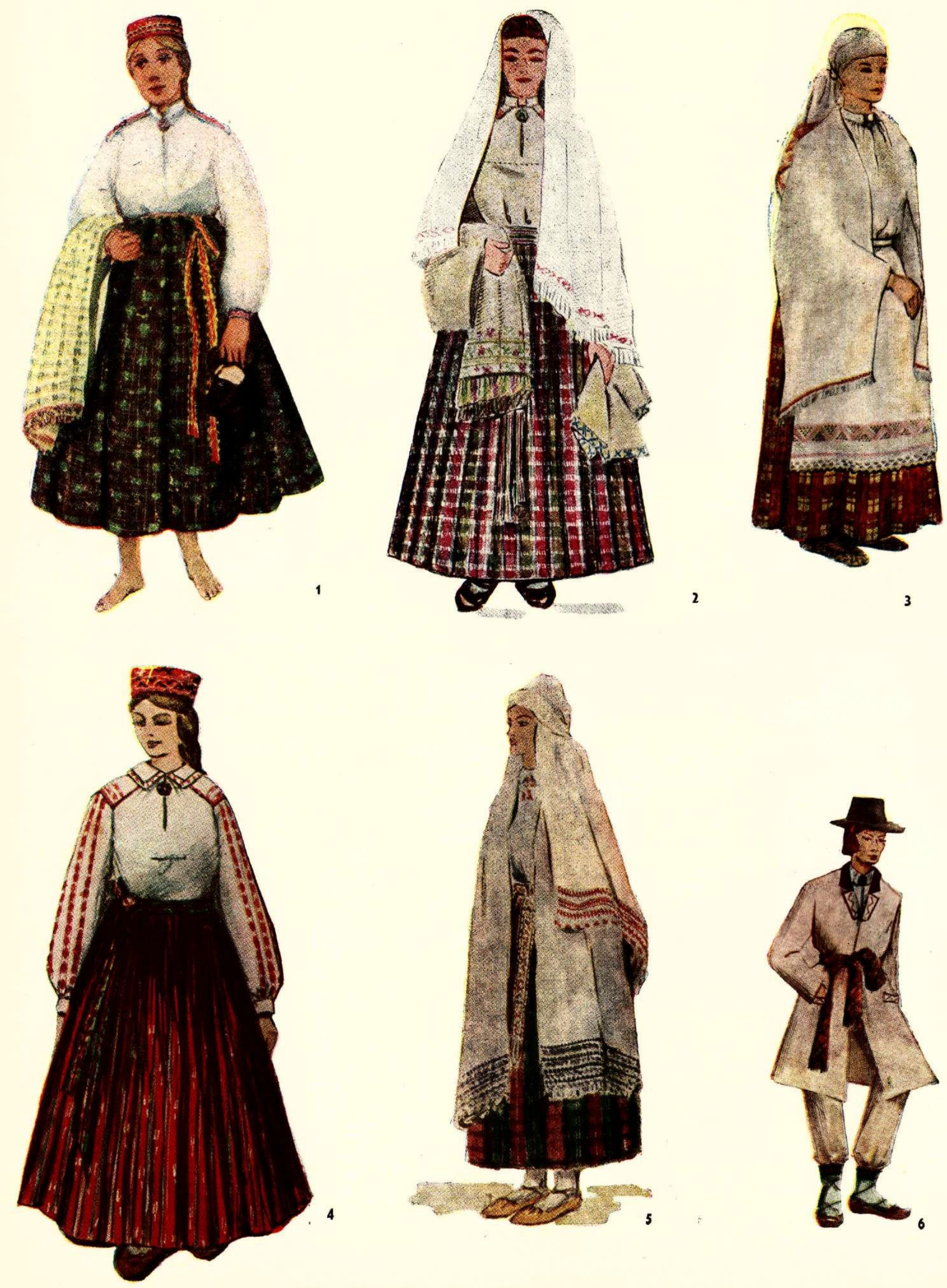

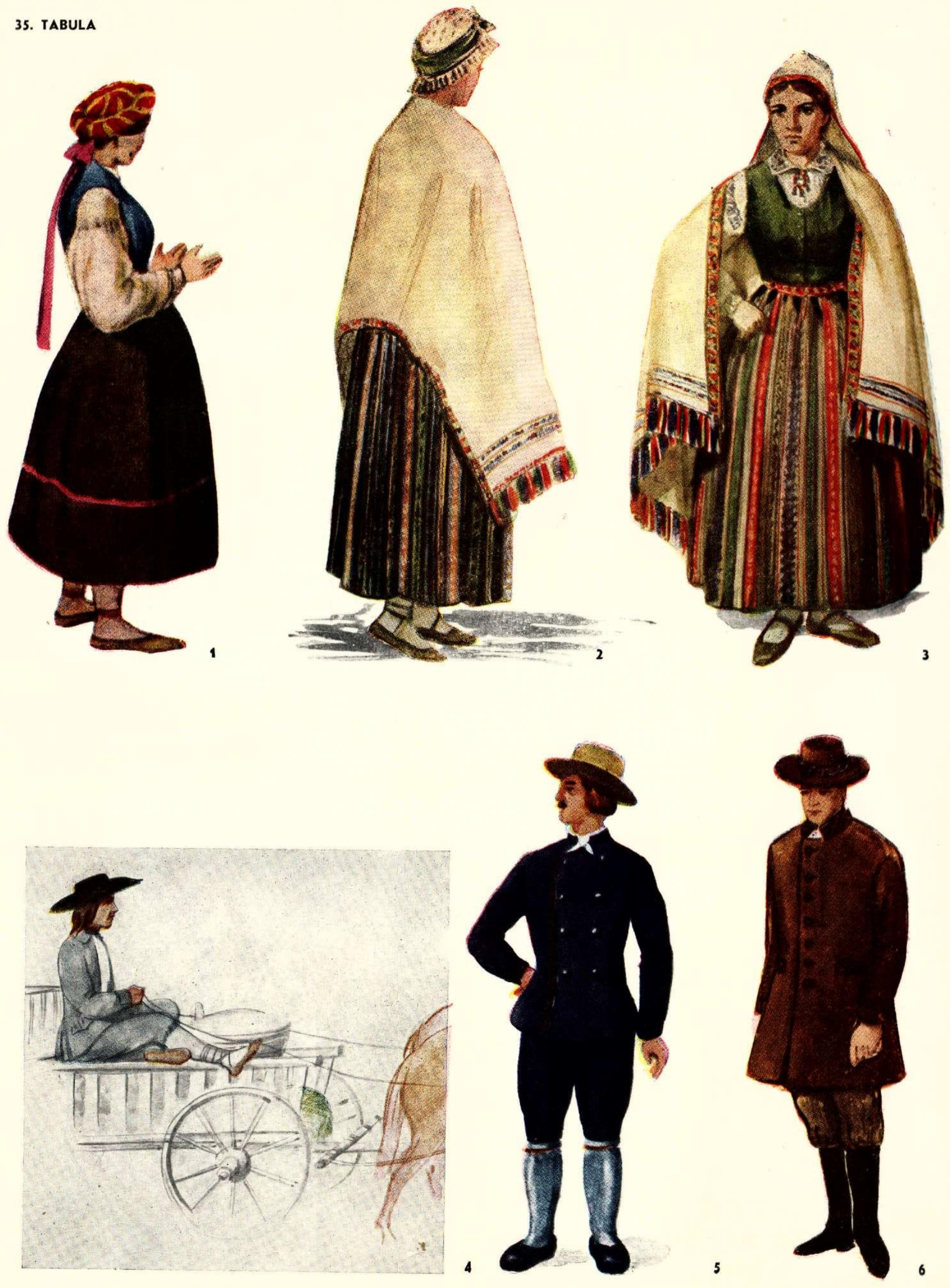
36. TABULA
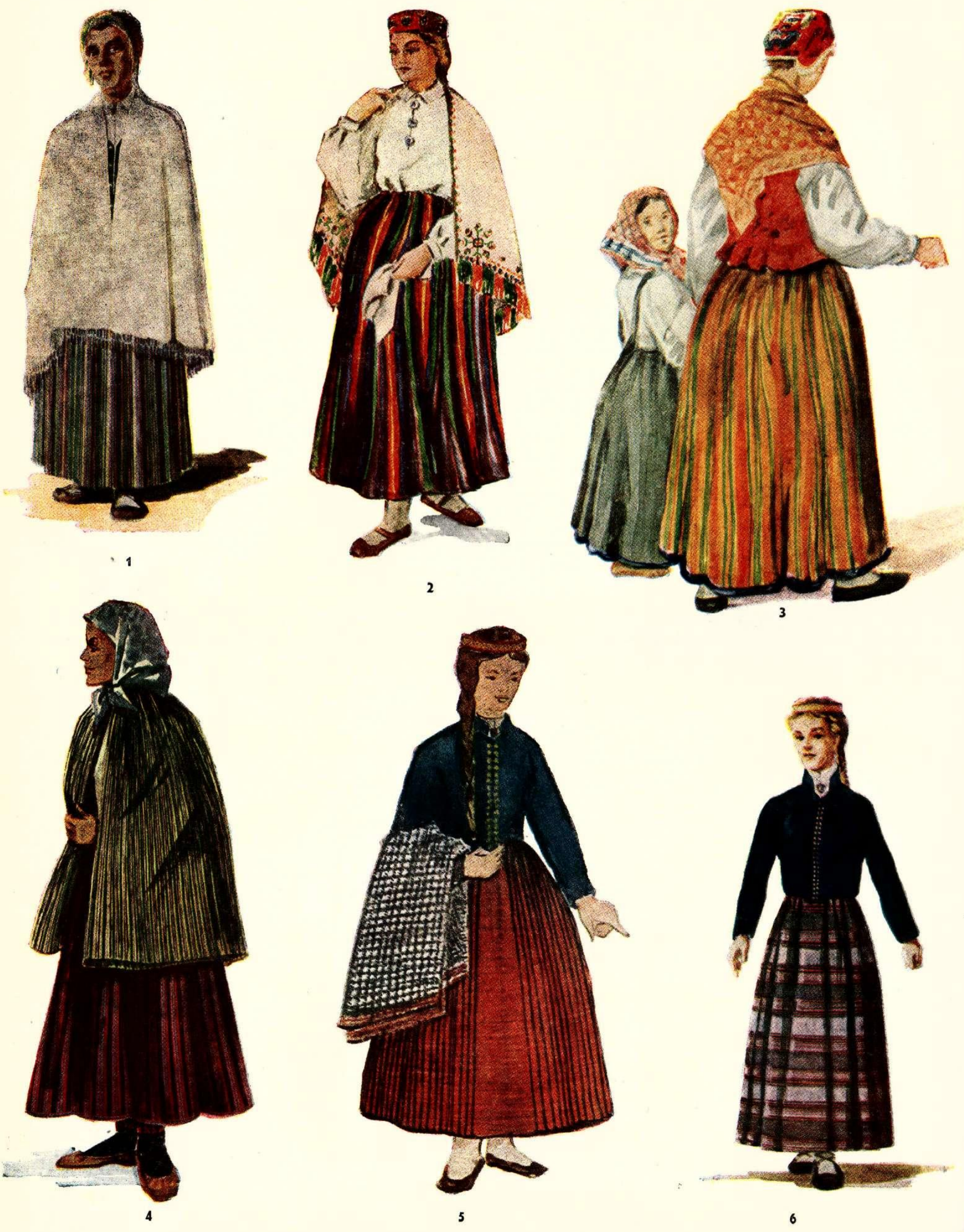

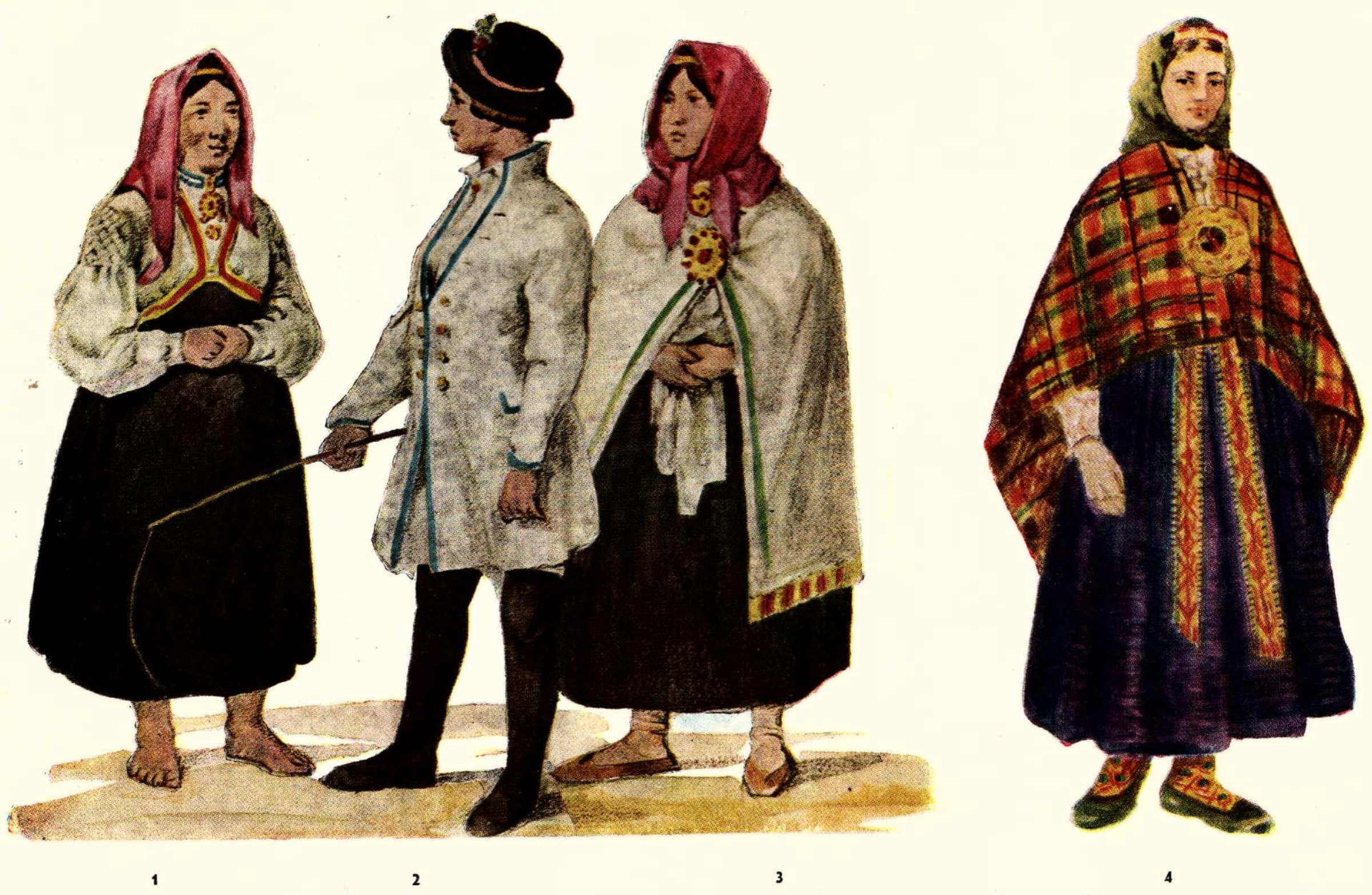

4 

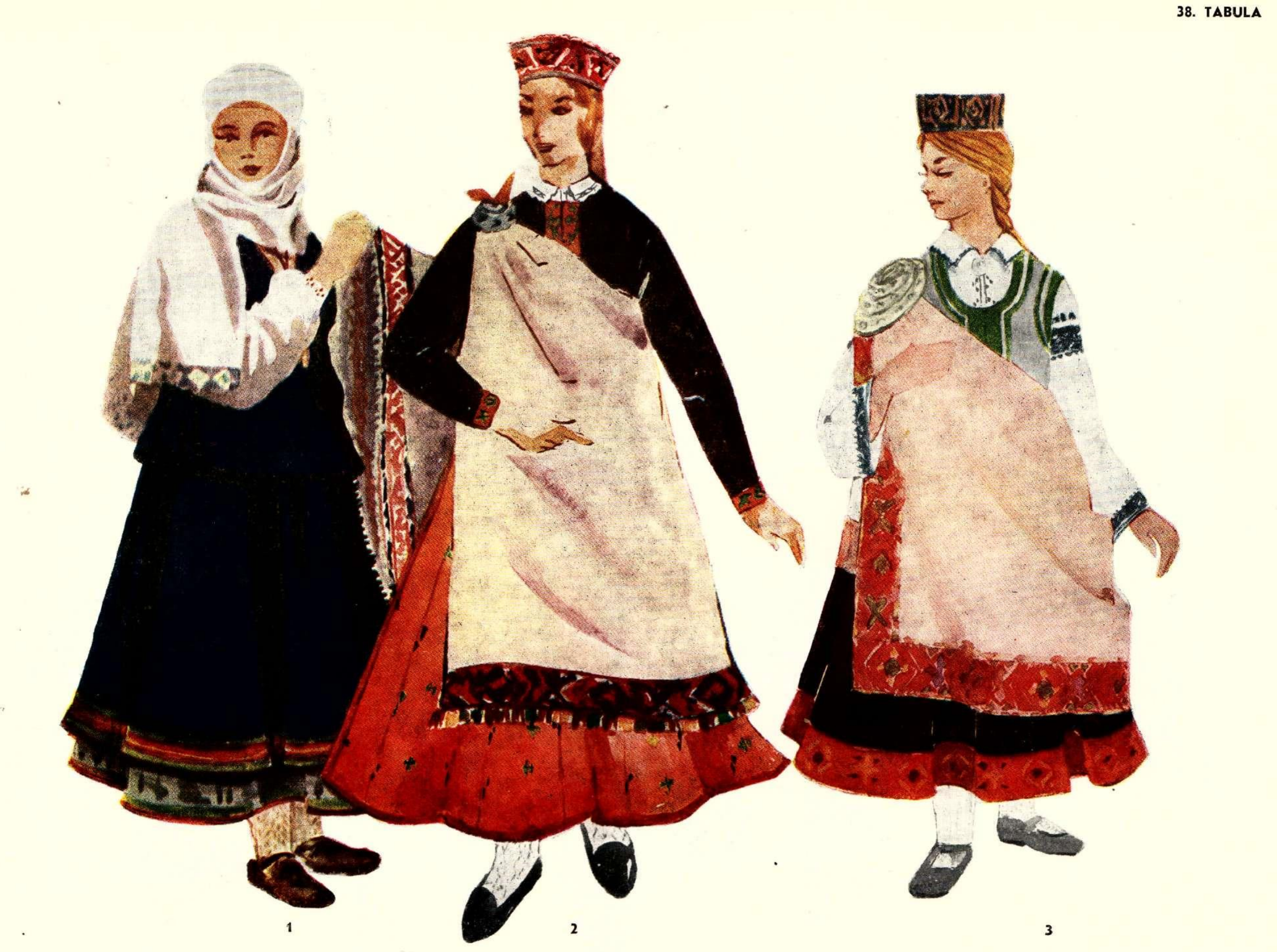


\section{SATURS}

Priekšvărds . . . . . . . . . . . . . . . . . . . . . . 5

levads

Avotu un literatūras apskats

Apgèrea materiāls, veidi un valkăs. vidum tradicijas

Audumu darināšana un apstrādāšana ... . . . . . . . . . . . . . . 25

Audumi . . . . . . . . . . . . . . 25

Linu balināšana un vilnas velšana . . . . 27

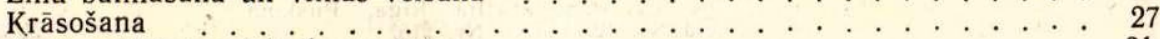

Apgēerba rotāšanas tehnika un šǔšana

Apḡērbs kā valkātāja vecuma, ğimenes un sociālā stāvoḳla atspogulotājs . . . 40

Apgèrba sastāvdalas ..................... . . . 44

Krekli

Brunči . . . . . . . . . . . . 48

Bikses . . . . . . . . . . . . . . . . . . . . . . 52

Jostas un prievites ..................... 54

Priekšauti . . . . . . . . . . 57

Villaines . . . . . . . . . . . . . . 58

Sieviešu jakas, nieburi, mềteli un kažoki . . . . . . . . . . . . . . . 68

Vïriešu svārki, mēteli un kažoki _. . . . . . . . . . . . . . . . . . 71

Matu kārtojums un galvassegas . . . . . . . . . . . . . . . . . . . . . . . . 76

Apavi, zekes, cimdi . . . . . . . . . . . . . . . . . 87

Rotaslietas . . . . . . . . . . . . . . 95

Latviešu tautas tērpa kompleksu lokālie varianti $\ldots \ldots a n$

Kultūrvēsturisko sakaru atspogulojums latviešu tautas tềrpā . . . . . . . . . . . . . 120

Latviešu tautas tērpa izveide lỉdz mūsu dienām . . . . . . . . . . . . . . . . . 125

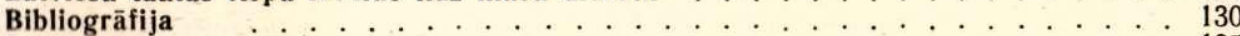

Parindes . . . . . . . . . . . . . . . . . . . . . 135

Латышская народная одежда (краткое изложение) . . . . . . . . . . . . 153

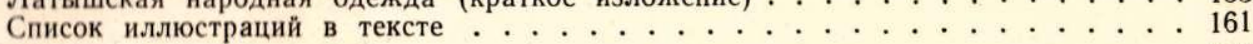

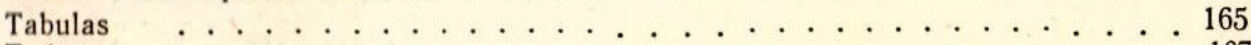

Таблицы . . . . . . . . . . . . . . . . . . 
ARHEOLOĢIJA UN ETNOGRAFIJA, VII M. Slava

LATVIESU TAUTAS TERPI

Redaktore A. Feldhũne. Tehn. redaktore E. Poča. Korektore A. Ava.

Nodota salikšanai 1965. g. 15. maijā. Parakstîta iespiešanai 1966. g. 16. augustā. Papĩra formāts $60 \times 90 / 8.27$ fiz. iespiedl.; 27 uzsk. iespiedl.; 28,83 izdevn. 1. Metiens 3000 eks. JT 22087. Maksā 3 rbl. 21. kap. Izdevniecība *Zinātne» Rigā, Turgeneva ielā 19. lespiesta Latvijas PSR Ministru Padomes Preses komitejas Poligrāfiskās rūpniecíbas pārvaldes Paraugtipogrāfijā Rīgā, Puškina

ielā Nr. 12 . Pasūt. Nr. 2167
$902.7+7 S .01$ 
АРХЕОЛОГИЯ И ЭТНОГРАФИЯ

VII

M. Слава

ЛАТЫШСКАЯ НАРОДНАЯ ОДЕЖДА

Издательство «Зинатне»

На латышском языке 
Pamanìtās k|ūdas

\begin{tabular}{|c|c|c|c|c|}
\hline Lpp. & Sleja & Rinda & Iespiests & Jābūt \\
\hline 24. & pa labi & 4. no apakšas & 30 gados & 30. gados \\
\hline 47. & pa kreisi & $13 . \quad$, & kriekliem & krekliem \\
\hline 60. & pa labi & $4 . \quad "$ & $\begin{array}{l}\text { Skaista, balta, } \\
\text { lieli raksti, }\end{array}$ & $\begin{array}{l}\text { Skaista, balta, } \\
\text { sīki raksti, }\end{array}$ \\
\hline 119. & pa kreisi & $9 . / 10 . \quad$, & $\begin{array}{l}\text { brunčiem (skat. } \\
\text { 38. tab., 4). }\end{array}$ & brunčiem. \\
\hline
\end{tabular}

Arheolog̣ija un etnogrãfija, VII. 
